DEPARTMENT OF THE INTERIOR

JoHn Barton PAyne, Secretary

United States Geological Survey.

George OtIS Smith, Director

Bulletin 697

\title{
GYPSUM DEPOSITS OF THE UNITED STATES
}

BY

R. W. STONE AND OTHERS

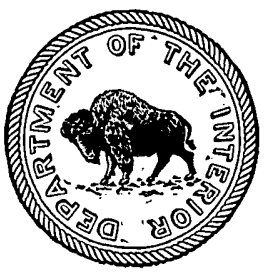

WASHINGTON

GOVERNMENT, PRINTING OFEICE 
ADDITIONAI COPIES

OF THIS PUBLICATION MAY BE PROCURED FROM THE SUPERINTENDENT OF DOCUMENTS GOVERNMENT PRINTING OFFICE WASHINGTON, D. C.

AT

50 CENTS PER COPY

$\nabla$ 


\section{CONTENTS.}

Part I. General discussion. Page.

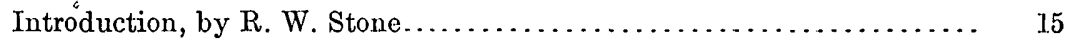

Mineralogy and geology of gypsum, by R. W. Stone............... 16

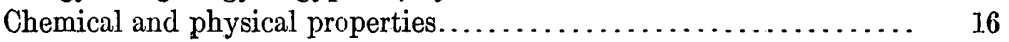

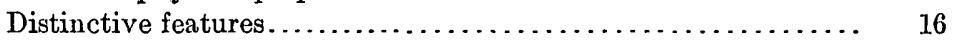

Chemical composition................................... 16

Hardness and specific gravity $\ldots \ldots \ldots \ldots \ldots \ldots \ldots \ldots \ldots \ldots . \quad 16$

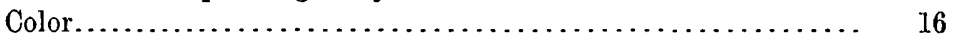

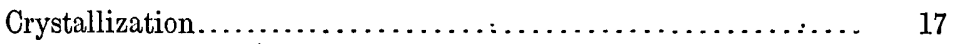

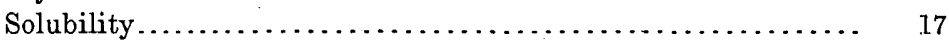

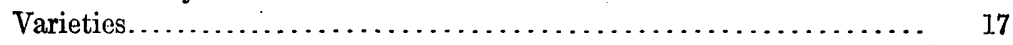

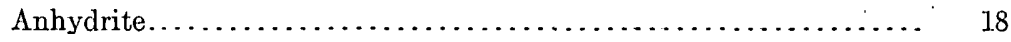

General features.................................. 18

Occurrence ...................................... 19

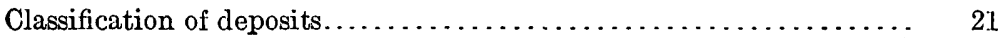

General discussion ................................ 21

Deposition from solutions............................ 22

Deposition from sea water ......................... 22

Deposition from ground water..................... 22

Deposits produced by alteration........................ $\quad 25$

Deposits produced by disintegration and mechanical reaccumulation ........................................... 25

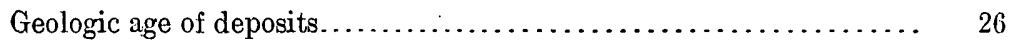

Analyses of gypsum, by R. W. Stone...................... 27

Errors in the chemical analysis of gypsum, by George Steiger.......... 30

The gypsum industry, by $\mathrm{R}$. W. Stone....................... 33

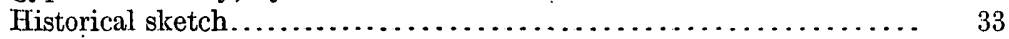

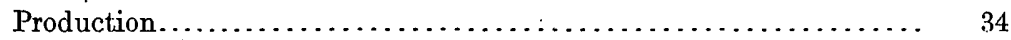

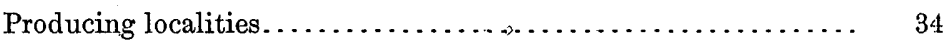

Production by States................................ $\quad 35$

Production by uses.................................. $\quad 36$

Imports.............................................. 38

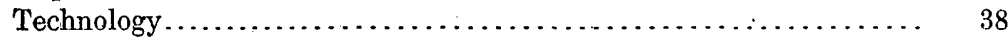

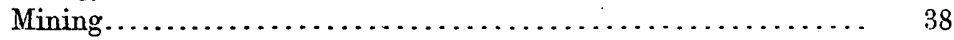

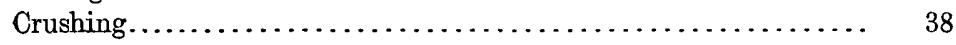

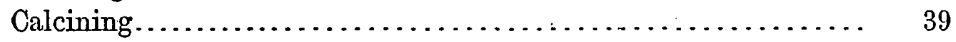

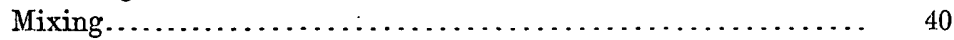

Arrangement and cost of plaster mills................... 40

Cost of gypsum plaster..................................... 41

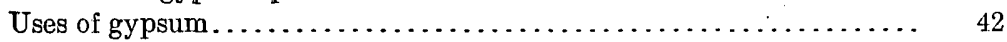

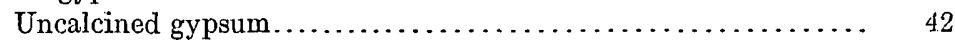

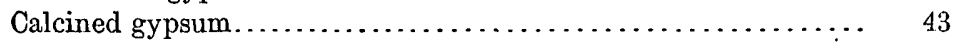

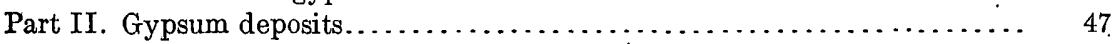

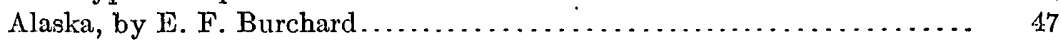

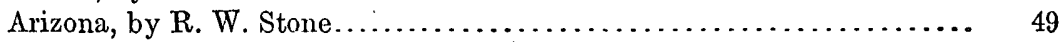

Development and character........................... 49

Localities ....................................... 49 
Part II. Gypsum deposits-Continued.

Arizona-Continued.

Localities-Continued.

Cochise County ........................... 49

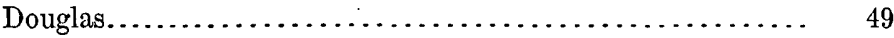

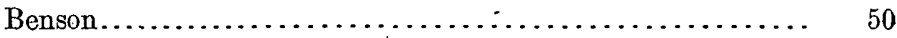

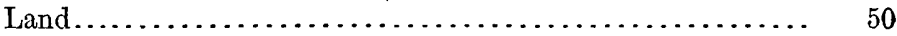

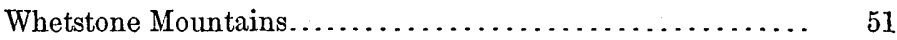

Mohave County............................ 51

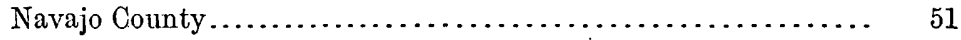

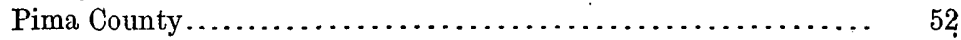

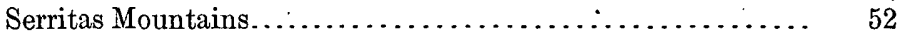

Santa Rita Mountains........................ 52

Empire Mountains............................ 52

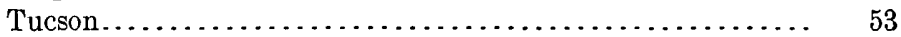

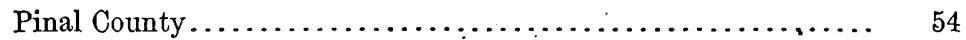

Area along San Pedro River................... 54

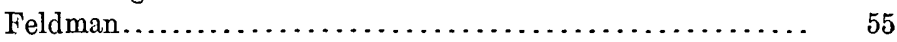

Arkansas, by H. D. Miser................................. 57

California, by F. L. Hess. . . . . . . . . . . . . . . . . . . . . . 58

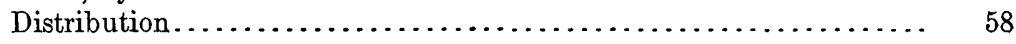

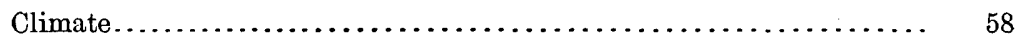

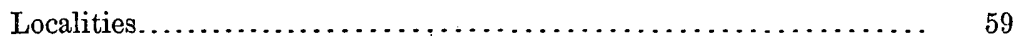

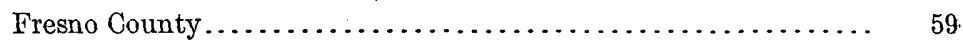

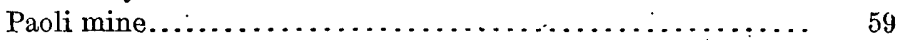

Deposits near the Paoli mine...................... 61

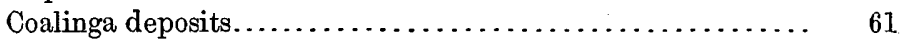

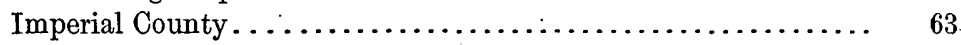

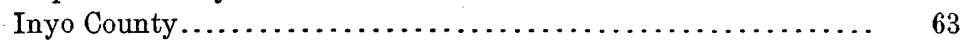

Kern County ............................... 64

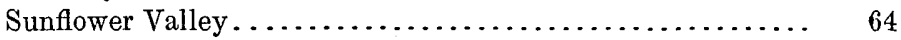

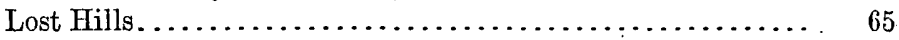

Deposits near McKittrick...................... 67

California Gypsum \& Mineral Co.............. 67

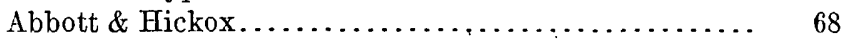

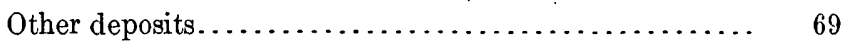

Deposits near Maricopa........................ 70

Deposits near Bakersfield ...................... 70

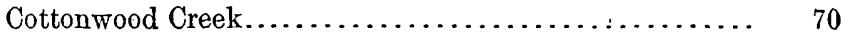

Kern Lake gypsite deposit. . . ................... 71

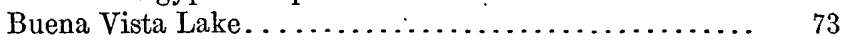

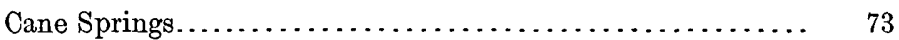

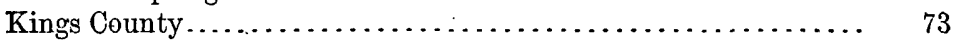

Kettleman Plains........................... 73

Los Angeles County . . . . . . . . . . . . . . . . . . . . . $\quad 75$

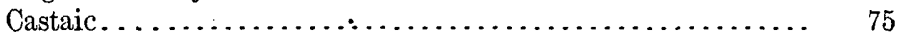

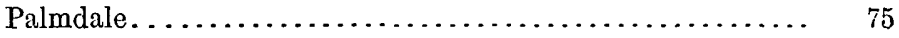

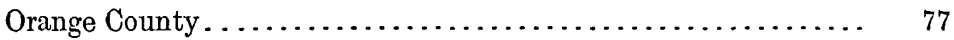

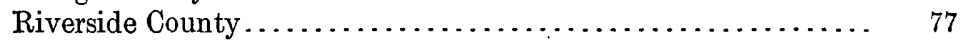

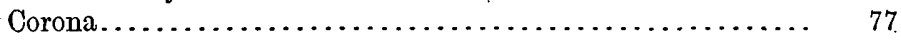

Palen Mountains............................... 78

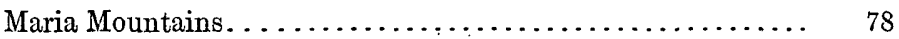

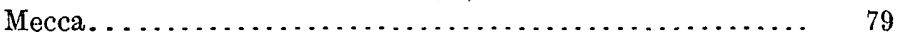

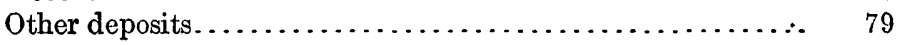

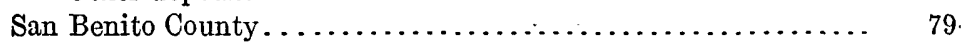


Part II. Gypsum deposits-Continued.

California-Continued.

Localities-Continued.

Page.

San Bernardino County . . . . . . . . . . . . . . . . . 81

Amboy ............................... 81

Avawatz Mountains........................... 82

San Luis Obispo County . . . . . . . . . . . . . . . . . . 83

Carrizo Plain .......................... 83

Alamo Creek. ............................ 84

Santa Barbara County......................... 84

Santa Barbara Creek. . . . . . . . . . . . . . . . . . . . 84

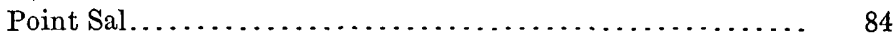

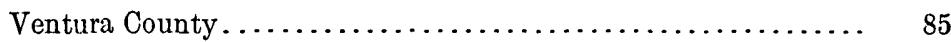

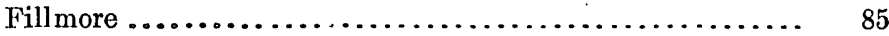

South Mountain ............................ 85

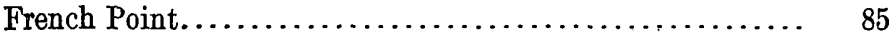

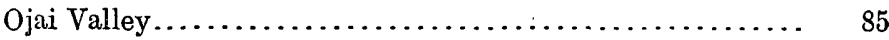

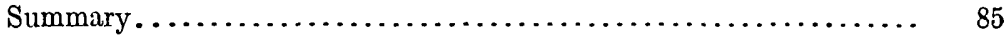

Colorado, by R. D. George.......................... 87

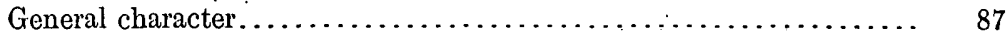

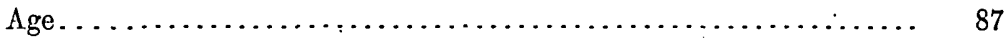

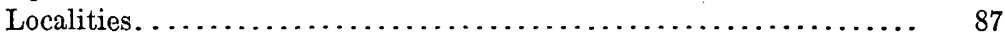

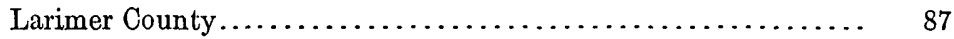

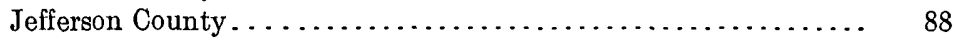

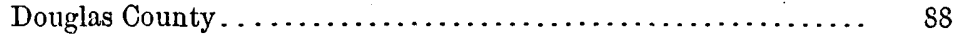

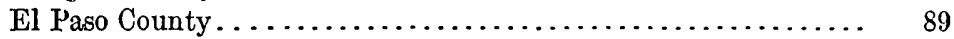

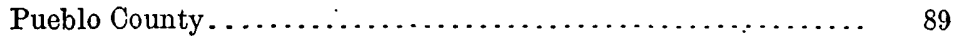

Fremont, Custer, Huerfano, and Chaffee counties............ 90

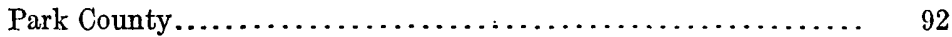

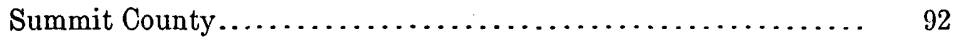

Rio Blanco, Garfield, Eagle, and Pitkin counties. .......... 92

Gunnison County............................. 93

Delta, Montrose, San Miguel, and Dolores counties.......... 93

Florida, by R. W. Stone.............................. 95

Idaho, by R. W. Stone. . . . . . . . . . . . . . . . . . . . . . . . 99

Iowa, by R. W. Stone and G. F: Kay ....................... 101

Gypsum at Fort Dodge, by R. W. Stone.................... 101

Character and extent............................ 101

Economic development. . . . . . . . . . . . . . . . . . . . 103

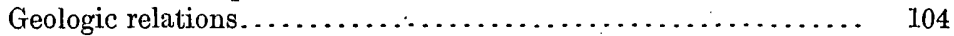

Gypsum at Centerville, by G. F. Kay ................... 107

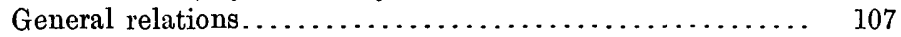

Development. . . . . . . . . . . 107

Character................................ 109

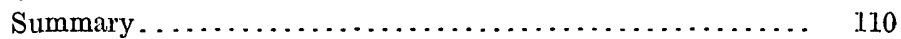

Kansas, by Erasmus Haworth. . . . . . . . . . . . . . . . . . . . 111

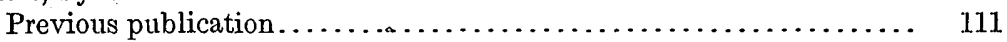

Geography . . . . . . . . . . . . . . . . . . 111

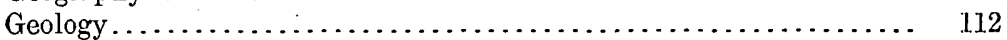

Localities.................................... 112

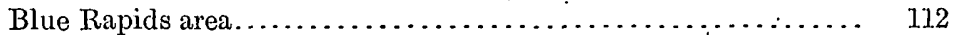

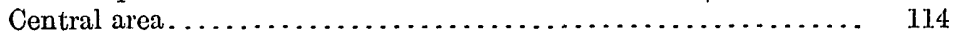

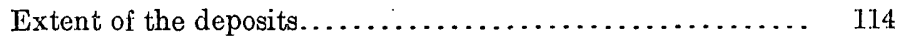

Solomon mine............................. 114

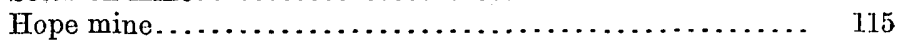

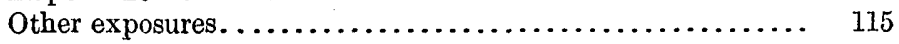


Part II. Gypsum deposits-Continued.

Kansas-Continued.

Localities-Continued.

Page.

Medicine Lodge area.............................. 117

Gypsum crystals............................. $\quad 118$

Pennsylvanian shales. ....................... 118

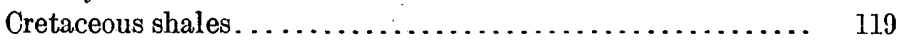

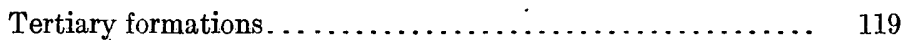

The gypsum industry in Kansas......................... 119

Origin of the gypsum of Kansas........................ 120

Louisiana, by R. W. Stone........................... 121

Michigan, by R. A. Smith........................... 122

Geologic occurrence................................ 122

Character and extent.............................. 122

Economic development, by R. A. Smith and R. W. Stone....... 124

Grand Rapids-Grandville district. . . . . . . . . . . . . . . . 124

Alabaster........................................ 127

Turner...................................... 127

St. Ignace................................. 128

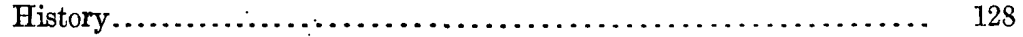

Mississippi, by R. W. Stone. .......................... 130

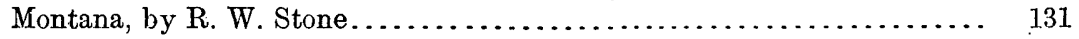

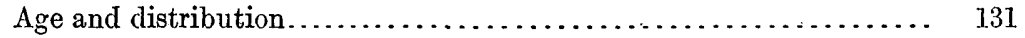

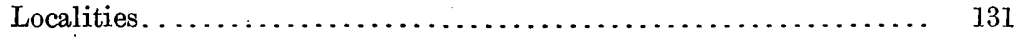

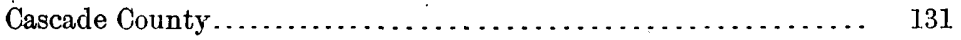

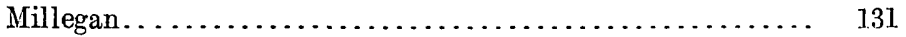

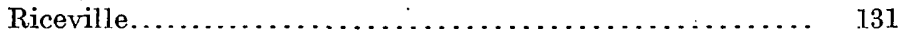

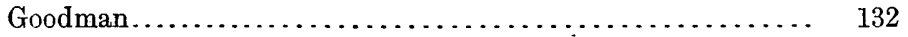

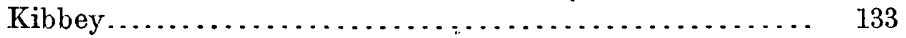

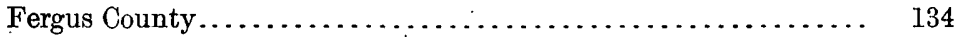

Big Snowy Mountains........................ 134

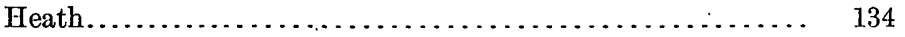

Hanover. . . . . . . . . . . . . . . . . . . . . . . 135

Jefferson County .................................. 136

Carbon County.................................. 137

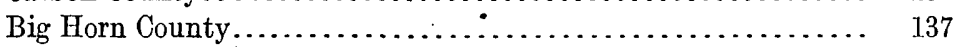

Madison County............................... 138

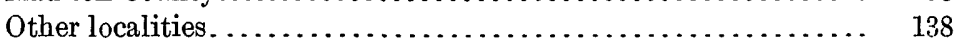

Nevada, by J. C. Jones.................................. 139

Character, extent, and development..................... 139

Geology . . . . . . . . . . . . . . . . . . . . . . . . . . . . . . 142

Deposits in western Nevada. . . . . . . . . . . . . . . . . . . 142

Deposits in southern Nevada....................... 144

Origin of the deposits. . . . . . . . . . . . . . . . . . . . . . . 144

Localities. ....................................... 146

Western Nevada............................... 146

Lovelock.............................. 146

Table Mountain............................ 150

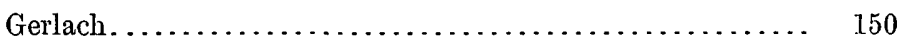

Mound House................................. 150

Gypsite near Mound House. . . . . . . . . . . . . . . . . . 152

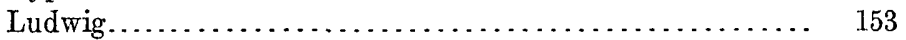

Hawthorne....................................... 155

Deposits in southern Nevada, by J. C. Jones and R. W. Stone.. 155

Arden..................................... 155 
Part II. Gypsum deposits-Continued.

Nevada-Continued.

Localities-Continued.

Deposits in southern Nevada-Continued.

Galt.

Page.

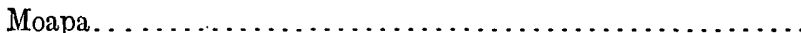

Las Vegas. . . . . . . . . . . . . . . . . . . . . . . .

Virgin River.

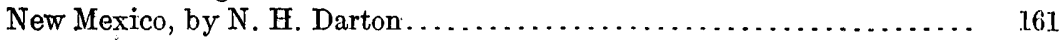

Distribution....................................... 161

General geologic relations.............................. 161

Manzano group.................................. 161

Gypsum above Wingate sandstone.................. 162

Gypsum of Quaternary age....................... 163

Localities.

Gypsum in Manzäo group....................... 163

Mesa Lncero............................... 164

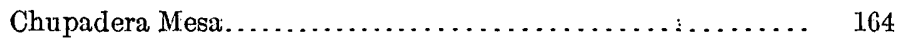

East of Socorro.............................. 166

Phillips Hills................................ 168

Sacramento Mountains......................... 169

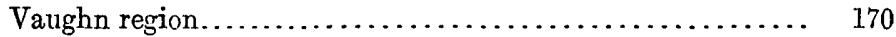

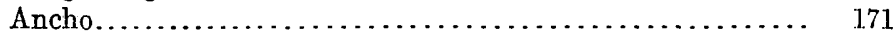

San Andres Mountains........................... 171

Caballos Mountains............................. 172

Sierra Fra Cristobal................................ 172

Rincon Colorado to Lamy......................... 173

Pecos Valley.................................. 173

Gypsum overlying the Wingate sandstone............. 177

Los Cerrillos ................................. 177

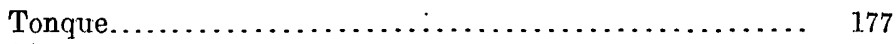

Tijeras Canyon.............................. 179

Rio Chama-Gallina region. . . . . . . . . . . . . . . 179

Nacimiento uplift. . . ........................ 181

Jemez region. . . . . . . . . . . . . . . . . . . . . . . . . . . . 182

San Jose Valley................................ 184

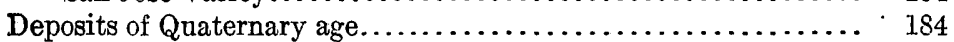

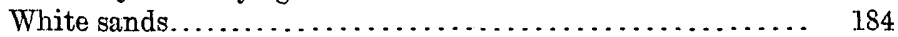

Pinos Wells................................... 186

New York, by D. H. Newland and Henry Leighton................ 187

History of the gypsum industry in New York................. 187

Method of mining ......................................... 188

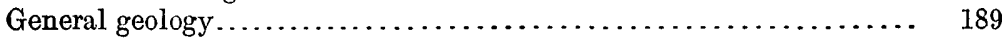

Age and distribution of the gypsum deposits............... 189

Stratigraphy of the Salina formation................... 191

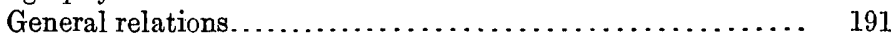

Bertie limestone member......................... 192

Camillus shale member....................... 192

Syracuse salt member........................... 193

Vernon shale member.......................... 193

Pittsford shale member........................ 193

General structure of the Salina formation . . . . . . . . . . . . . 193

Nature of the gypsum deposits. . . . . . . . . . . . . . . . . . . 194

Localities............................................ 194

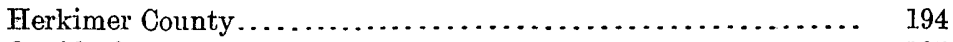

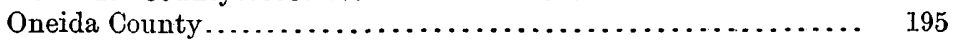

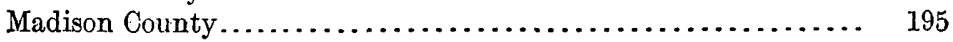

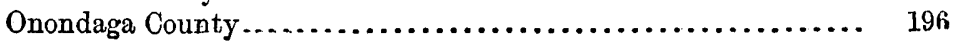


Part II. Gypsum deposits-Continued.

New York-Continued.

Localities-Continued.

Onondaga County-Continued.

Page.

Geology ................................. 196

Clifford Miller quarry .......................... 196

Quarry of the National Wall Plaster Co............... 197

Quarries at Jamesville.......................... 197

Other quarries in Onondaga County................. 199

Cayuga County .................................. 200

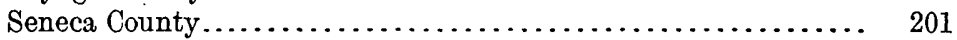

Wayne County.................................. 201

Ontario County.................................. 202

Livingston County.............................. 203

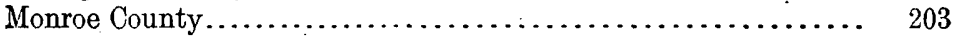

Distribution and general character of the gypsum deposits... 203

Empire Gypsum Co......................... 204

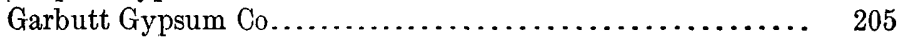

Lycoming Calcining Co......................... 206

Monarch Plaster Co.......................... 206

Consolidated Wheatland Plaster Co................ 206

Possible occurrences of gypsum elsewhere in Monroe County. 207

Genesee County.............................. 207

Distribution and development.................... 207

United States Gypsum Co....................... 207

Niagara Gypsum Co.......................... 208

Other occurrences in Genesee County ................ 209

Erie County .................................... 209

Distribution of the gypsum deposits................. 209

American Gypsum Co.......................... 211

American Cement Plaster Co...................... 211

Physical and chemical characters of the gypsum ............... 213

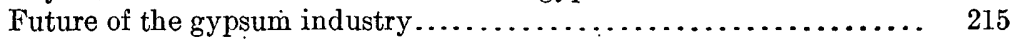

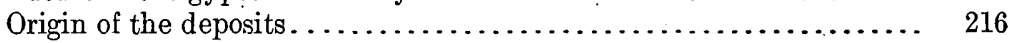

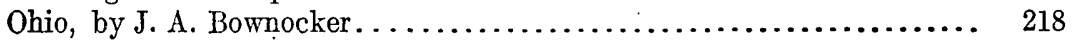

Location and thickness of deposits $\ldots \ldots \ldots \ldots \ldots \ldots \ldots \ldots \ldots \ldots \ldots \ldots \ldots$

History of development............................ 221

Development in 1918 , by R. W. Stone................... 222

Oklahoma, by L. C. Snider. . . ......................... 224

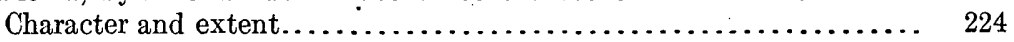

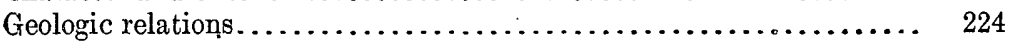

Localities.................................... 225

Main line of gypsum hills....................... 225

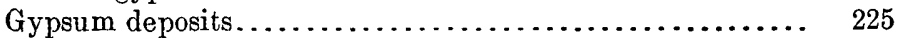

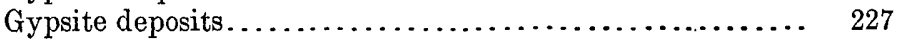

Second line of gypsum hills . . . . . . . . . . . . . . . . . 227

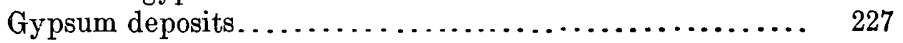

Gypsite deposits............................. 228

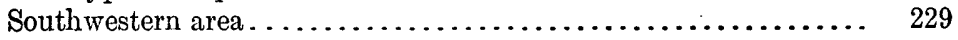

Gypsum deposits. . . . . . . . . . . . . . ............ 229

Gypsite deposits............................. 232

Economic development............................ 232

General condition of the gypsum industry ............... 232

Mills and quarries............................. 233

Oregon, by R. W. Stone................................. 236

Location and character.......................... 236

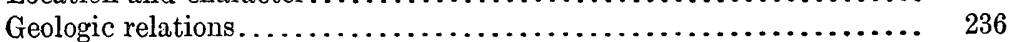

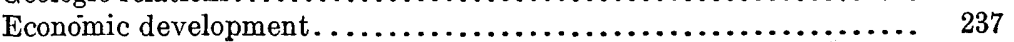


Part II. Gypsum deposits-Continued.

South Dakota, by J. G. Hutton.

Structure and stratigraphy............................... 239

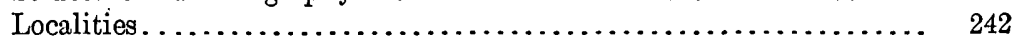

West of Minnekahta ................................... 242

Minnekahta to Hot Springs....................... 244

Rapid City to Sturgis. ........................... 245

Sturgis to Spearfish............................ 246

Chemical composition of shale and gypsum of Spearfish formation..... 248

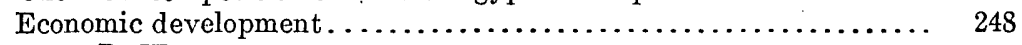

Texas, by R. W. Stone................................ 250

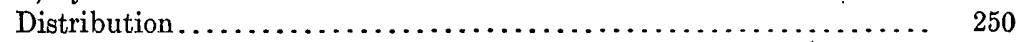

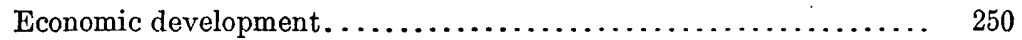

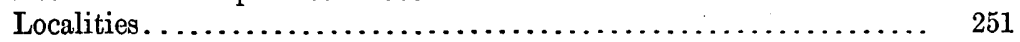

North-central Texas............................... 251

Character and general relations of the gypsum deposits,..... 251

Geologic relations of the gypsum beds, by W. E. Wrather..... 255

Culberson and Hudspeth counties..................... 257

Southeastern Texas............................... 258

Deeply buried deposits........................ 258

Brooks County, by C. L. Baker................... 259

Other localities, by B. F. Hill....................... 260

Utah, by R. W. Stone and C. T. Lupton .................... 261

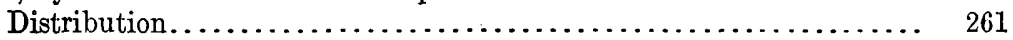

Localities in central and southern Utah, by R. W. Stone...... 261

Nephi, Juab County. ......................... 261

Levan, Juab County.......................... 265

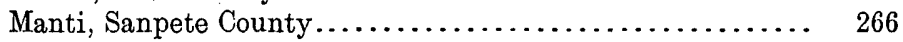

Mayfield, Sanpete County....................... 266

Salina, Sevier County........................ 267

Sigurd, Sevier County...................... 267

White Mountain, Millard County................. 268

Cedar City, Iron County, to Glendale, Kane County........ 270

St. George, Washington County................... 271

South Wash, Wayne and Garfield counties ............. 272

Moab, Grand County, by F. L. Hess................ 273

Gypsum along the west flank of the San Rafael Swell, by C. T.

Lupton.................................... 273

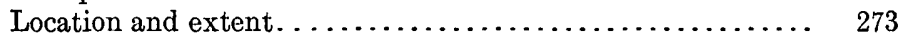

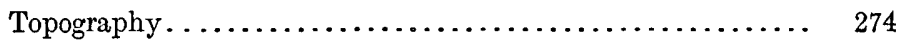

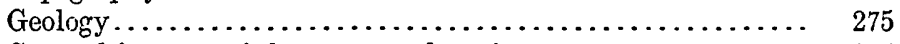

General features of the gypsum deposits............... 275

Localities. . ................................ $\quad 276$

South of Cedar Mountain..................... 276

San Rafael Valley.......................... 276

Horn Silver Gulch........................ $\quad 277$

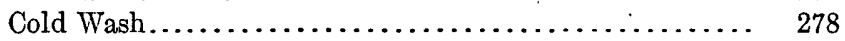

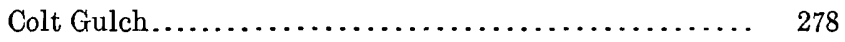

Muddy Creek.............................. 279

Last Chance Creek......................... 280

Caineville............................... 280

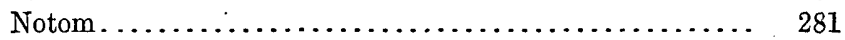

Other exposures.......................... 281

Character of the gypsum....................... 281

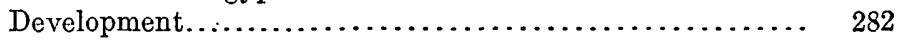

Virginia, py G. W. Stose.............................. 283

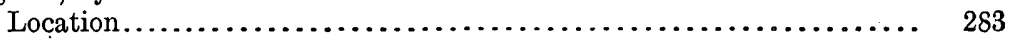

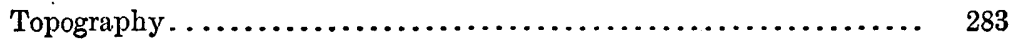


Part II. Gypsum deposits-Continued.

Virginia-Continued. Page.

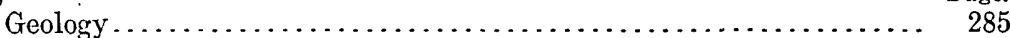

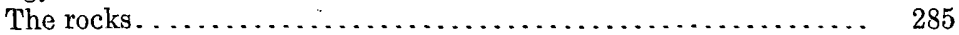

Structure..................................... 286

Origin of the deposits. . . . . . . . . . . . . . . . . . . . . $\quad 289$

Gypsum industry . ................................ 292

Earlier development........................... 292

Present operating mines............................ 293

Wyoming, by R. W. Stone............................... 295

Character and extent................................. 295

Economic development. .............................. 296

Localities........................................ 297

Black Hills..................................... 297

Big Horn Mountains. . . . . . . . . . . . . . . . . . . . . 299

Distribution.................................. 299

East slope...................................... 299

Sheridan County ............................. 299

Buffalo................................... 299

Crazy Woman Creek....................... 300

Powder River............................ $\quad 300$

West slope................................. 300

Shell. . . . . . . . . .

Hyattville............................... 301

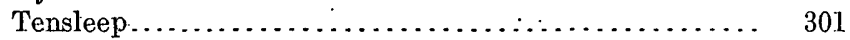

Bigtrails...................................... 301

Redbank.................................. 301

No Wood ................................... 302

Big Horn Basin ................................. 302

Stucco....................................... 302

Greybull...................................... 302

Cody ...................................... 302

Thermopolis................................... 303

Owl Creek Mountains............................. 303

Gros Ventre Range.............................. 303

Salt River Range............................... 304

Wind River Range and vicinity...................... 304

Fort Washakie................................... 304

Lander........................................ 304

Hailey . . . . . . . . . . . . . . . . . . . . . . . . . . 304

Central Wyoming...................................... 304

Conant Creek. ................................ 304

Rattlesnake, Green, and Ferris mountains............. 305

Alcova..................................... 305

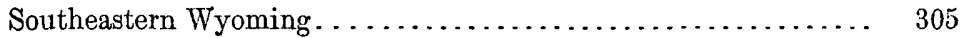

Casper-Douglas area........................... 305

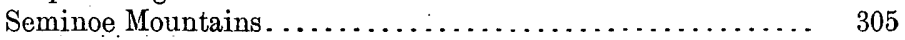

Shirley Mountains and Freezeout Hills.............. 306

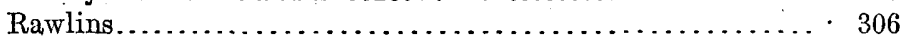

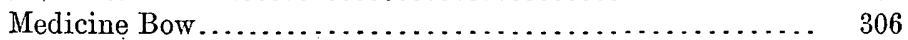

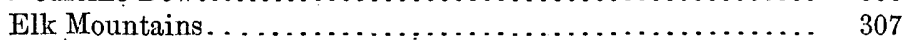

Laramie Basin . . . . . . . . . . . . . 307

Laramie Mountains. ............................. 308

Part III. Bibliography .................................. 309

General references......................................... 309

References by States................................... 309

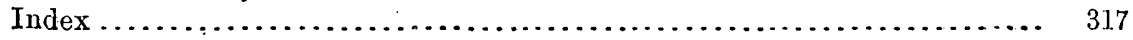




\section{ILLUSTRATIONS.}

Plate I. $A$, Selenite which has been split and bent to show cleavage and

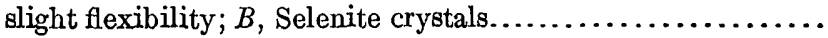

II. $A$, Gypsum having serrate surface due to erosion by rain; $B$, Rock gypsum that shows effects of solution...............

III. $A$, Massive gypsum showing mottled structure; $B$, Massive gypsum showing banded structure.....................

IV. $A$, Fibrous gypsum or satin spar from a fissure in clay; $B$, Slab of selenite an inch thick, illustrating transparency and incipient

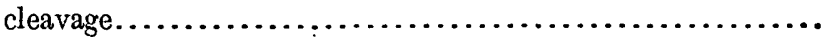

V. $A$, Aggregate of impure gypsum crystals from marl bed; $B$, Spongy gypsum formed as a secondary deposit. ..................

VI. Map of the United States showing localities which produce

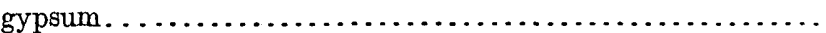

VII. $A$, Gypsite deposit, Douglas, Ariz.; $B$, Mill of Arizona Gypsum Plaster Co., at Douglas, Ariz.........................

VIII. $A$, Gypsum quarry 3 miles west of Winslow, Ariz.; $B$, Gypsum bed at Plaster Bluff, on Little Missouri River 3 miles south-

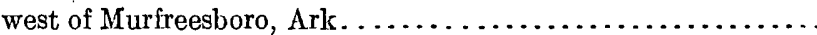

IX. Map showing distribution of gypsum deposits in California.......

X. $A$, Mound of gypsum in the Lost Hills, south of Tulare Lake, Calif., made by the evaporation of water seeping from the rocks below; $B$, Gypsum deposit 4 miles northwest of Coalinga, Calif .

XI. A. Gypsite workings in sec. 7, T. 32 S., R. 22 E., on the Carrizo Plain, Calif.; $B$, Gypsum interbedded with clay shales $1 \frac{1}{2}$ miles

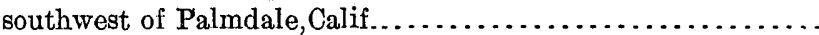

XII. $A$, Gypsum deposit in the bed of a periodic lake at Amboy, Calif.; $B$, Gypsite deposit 9 feet thick on the brow of a hill $1 \frac{1}{2}$ miles southwest of Palmdale, Calif...........................

XIII. $A$, Bed of gypsum on mesa 15 miles north of King City, Calif.; $B$, Gypsum outcrop on Fort Dodge, Des Moines \& Southern Railroad half a mile south of Des Moines River near Fort Dodge,

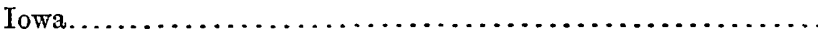

XIV. $A$, Gypsum quarry in Lykins formation, Loveland, Colo.; $B$, Thick bed of gypsum in Perry Park, Colo................

XV. Thick bed of gypsum at entrance to Garden of the Gods, Colorado

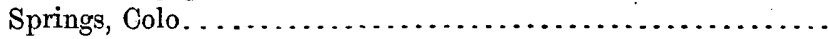

XVI. $A$, Mining gypsum, Fort Dodge, Iowa; $B$, Rock gypsum as it comes from the mine, Fort Dodge, Iowa..................

Page.

XVII. Map showing gypsum deposits and approximate limits of the Permian series in Kansas . ..............................

XVIIT. $A$, Gypsum bed in Best Bros. quarry, Kling, Kans.; $B$, Gypsum quarry of United States Gypsum Co. at Alabaster, Mich ........

XIX. Map of New Mexico showing distribution of gypsum deposits....

XX. $A$, Gypsum in north wall of Rincon Colorado east of Pedernal Peak, Torrance County, N. Mex.; $B$, Outcrop of gypsum near Rosario siding, west of Los Cerrillos, N. Mex................... 
Plate XXI. A, Gypsum on Wingate sandstone on bank of Gallina River, 14 miles north-northeast of Gallina, N. Mex.; $B$, Gypsum capping Cerro Blanco, 1 mile northwest of plaza of Gallina, N. Mex...

Page.

XXII. $A$, Cliffs of gypsum at edge of mesa 3 miles southwest of San Ysidro, N. Mex.; B, Outcrop of bed of gypsum 50 feet thick on north bank of San Jose River opposite pueblo of El Rito, on Atchison, Topeka \& Santa Fe Railway, 63 miles west of

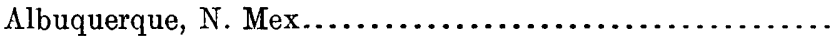

XXIII. The white sands, wind-blown gypsum in desert west of Tularosa,

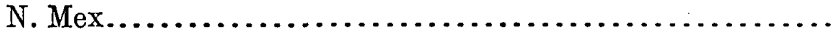

XXIV. $A$, Rock gypsum showing banding and selenite crystals, Akron, N. Y.; $B$, Gypsum quarry near Lyndon, Onondaga County, N. Y.

XXV. Map showing location of gypsum deposits in Ohio.............

XXVI. $A$, Mine of United States Gypsum Co. at Gypsum, Ohio; $B$, Rock gypsum quarry of American Cement Plaster Co., Watonga, Okla. XXVII. Map showing location of gypsum deposits in Oklahoma......... XXVIII. $A$, Glass Mountain, Woods County, Okla., capped with massive gypsum; $B$, Escarpment capped with gypsum ledges, Red River valley, Greer County, Okla....................

XXIX. $A$, Gypsum quarry and loading platform of aerial tramway, Gypsum, Oreg.; $B$, Gypsum outcrop 4 miles northwest of Minne-

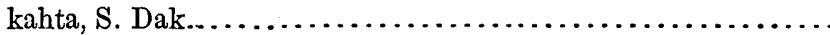

XXX. $A$, Bluff showing gypsum bed 1 mile northwest of Hot Springs, S. Dak.; $B$, Three gypsum beds in Hell Canyon, 20 miles southwest of Custer, S. Dak.

XXXI. A, Gypsum in Spearfish formation on east side of Spearfish Valley, S. Dak.; $B$, Close view of gypsum bed at Spearfish, S. Dak.....

XXXII. $A$, Gypsum at Spearfish, S. Dak.; $B$, Gypsum quarry 2 miles east

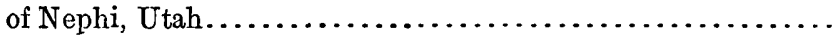

XXXIII. $A$, Polished block of gypsum from Nephi, Utah, showing mottled character of the rock; $B$, Polished block of gypsum from North Holston, Va., showing granular character and selenite phenocrysts........................................

XXXIV. $A$, Gypsum quarry $1_{2}^{1}$ miles east of Levan, Utah; $B$, Gypsum bed in Horn Silver Gulch, southeast of Ferron, Utạh............

XXXV. Map showing distribution of gypsum deposits on west flank of San Rafael Swell, Utah..............................

XXXVI. Map of Wyoming showing areas known to contain gypsum....... XXXVII. $A$, Butte of red beds of Spearfish formation capped with a 30-foot bed of gypsum east-northeast of Cambria, Wyo.; $B$, Method of mining gypsite, Laramie, Wyo.

Figure 1. Diagram showing faulted gypsum bed near Tucson, Ariz........

2. Diagram showing edge of gypsum bed near Tucson, Ariz........

3. Idealized section through gypsite deposit 4 miles northwest of

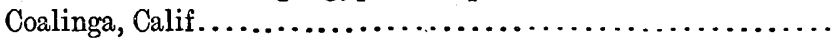

4. Idealized section across hills $1 \frac{1}{2}$ miles southwest of Palmdale, Calif., showing relations of gypsite and gypsum to the country rock..

5. Map showing location of gypsum and gypsum mills near Fort

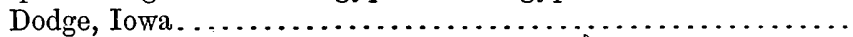

6. Section at Great Western gypsum mine, Blue Rapids, Kans......

7. Section at gypsum mine near Solomon, Kans.................

8. Outline map of Michigan showing gypsum deposits ............ 
Fraure 9. Map showing location of gypsum deposits in Nevada.

10. Map showing geology of T. 27 N., R. 32 E., and location of old gypsum quarries near Lovelock, Nev....................

11. Diagram of gypsum bed at entries of mine at Arden, Nev ........

12. Diagram showing relation of shale and gypsum in mine at Arden,

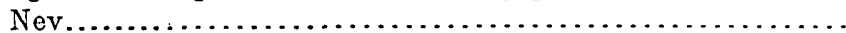

-13. Gypsum and anhydrite from Arden, Nev., as seen under petro-

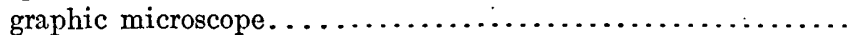

14. Generalized columnar section showing stratigraphic relations of gypsum deposits in New Mexico. ......................

15. Section of east slope of Mesa Lucero, in Socorro County, 25 miles

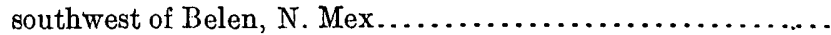

16. Section across Chupadera Mesa, 35 miles east of Socorro, N. Mex...

17. Map of part of central New Mexico showing gypsum deposits......

18. Section of strata in west face of Chupadera Mesa, 25 miles east of Carthage, N. Mex...............................

19. Section of gypsum and associated strata near Abo siding in the northwest face of Chupadera Mesa, N. Mex

20. Columnar section of gypsum and associated beds in Arroyo de las Cañas east of the spring, 7 miles east-southeast of Socorro, N. Mex.

21. Columnar section showing relation of gypsum and associated beds in Phillips Hills, 6 miles southwest of Oscuro, N. Mex..........

22. Columnar section of gypsum and associated strata about 2 miles southeast of Salinas siding, 10 miles north of Tularosa, N. Mex...

23. Columnar section of gypsum and associated strata east of Tularosa, N. Mex......................................

24. Approximate $\cdot$ section across Sacramento Mountains east from Alamogordo, N. Mex.

25. Columnar section showing relation of gypsum deposits in Rhodes Canyon, San Andres Mountains, 25 miles east-southeast of

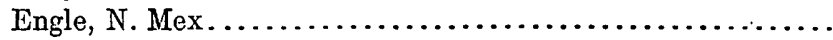

26. Section across San Andres Mountains, 18 miles northeast of Engle,

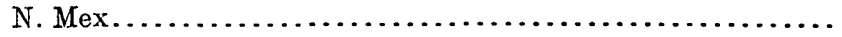

27. Columnar section showing relations of gypsum and associated beds in Caballos Mountains 15 miles southwest of Engle, N:Mex.

28. Section across Caballos Mountains 15 miles southwest of Engle, N. Mex., showing structural relations of gypsum . .............

29. Record of boring in NE. $\frac{1}{4}$ sec. 4 , T. 22 S., R. 28 E., east of Carlsbad,

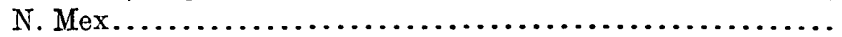

30. Section showing relations of gypsum deposit east of Rosario siding,

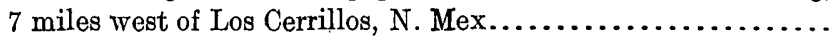

31. Columnar section showing relations of gypsum deposit on east bank of Tonque Creek, 2 miles below the brick works, Sandoval

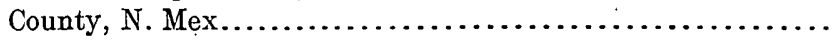

32. Cross sections showing relations of gypsum in Tijeras Canyon

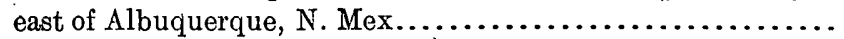

33. Outline map and section of part of the valley of Rio Chama, in Rio Arriba County, N. Mex., showing outcrop and relations of

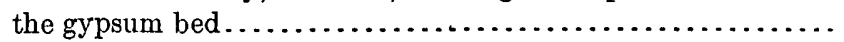

34. Columnar section of rocks in Rio Chama-Gallina region, N. Mex...

35. Map showing outcrop of gypsum bed along the west side of the Nacimiento uplift from Rio Gallina to Rio Salado, Sandoval County, N. Mex................................. 
Figure 36. Sketch section at Senorito, N. Mex., showing relations of gypsum bed.

37. Map and sections of the south end of the Nacimiento uplift southwest of Jemez, showing outcrop and relations of gypsum bed....

38. Section showing relations of gypsum bed southwest of Jemez, N. Mex.

39. Section of rocks associated with gypsum bed at El Rito, N. Mex...:

40. Section along north side of San Jose Valley near Suwanee, N. Mex., showing relations of great gypsum bed in faulted blocks. . . ......

41. Map showing outcrop of gypsum in San Jose Valley, N. Mex.......

42. Map of New York showing distribution of Salina formation........

43. Diagram showing relative position and linear extent of the Silurian strata in New York....................................

44. Map showing Jamesville-Fayetteville district, Onondaga County,

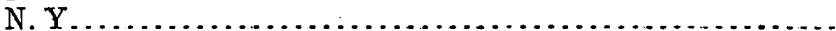

45. Map showing Wheatland district, Monroe County, N. Y.........

46. Map showing Oakfield and Akron districts, Genesee and Erie

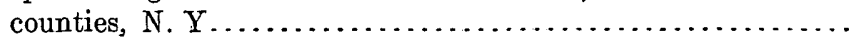

47. Map showing the area that contains the gypsum-bearing formation in the Black Hills, S. Dak.......................... 241

48. Map of Texas showing location of principal.deposits of rock gypsum.. 251

49. Columnar section showing strata exposed along Double Mountain Fork of Brazos River, from Flattop Mountain, Haskell County, to top of Double Mountain, Stonewall County, Tex.............

50. Map showing distribution of principal gypsum deposits in Utah...

51. Diagram showing geologic structure at gypsum quarry, Nephi, Utah........................................

52. Cross section of strata that lie between gypsum mill and quarry,

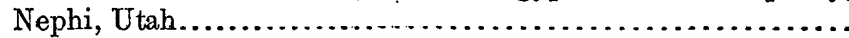

53. Map showing extent of gypsum deposit at White Mountain, Utah.

54 . Index map of southwestern Virginia .......................

55. Geologic map of Holston Valley, in the vicinity of Saltville, Va...

56. Structure sections across Holston Valley, Va, along lines indicated by letters on the margins of the geologic map...............

57. Structure sections across Holston Valley, Va., along lines indicated by letters on the margins of the geologic map ............. 


\section{GYPSUM DEPOSITS OF THE UNITED STATES.}

By R. W. Stone and others.

\section{PART I. GENERAL DISCUSSION.}

\section{INTRODUCTION.}

By R. W. Stone.

This report has been prepared to take the place of the Survey's Bulletin 223, "Gypsum deposits in the United States," which was published in 1904. The total value of crude and calcined gypsum produced in the United States increased from $\$ 2,750,000$ in 1904 to more than $\$ 11,000,000$ in 1918 , or over 300 per cent. Since Bulletin 223 was published much information has been obtained as to the quantity and the distribution of the gypsum deposits of the country. A large part of this new information is contained in State and Federal reports and in technical and scientific journals; but some of that which is given here has not previously been published.

The sections of this report relating to the deposits in the individual States considered have been prepared by State geologists, by members of the United States Geological Survey, or by others who are familiar with the subject. For this reason the method of treatment is not uniform throughout the report. Other variations are due to differences in the conditions of the development of the gypsum industry from State to State. In the sections on States such as Florida and Oregon, practically all that is known about the deposits is given; in those on others such as Iowa, New York, and Oklahoma, the information given is condensed from detailed reports.

Some of the material in the introductory chapter on the mineralogy and geology of gypsum is quoted almost literally from publications to which credit need not everywhere be given, because the material has been published many times in text books, encyclopedias, and State and Federal reports, with only slight changes in form, so that the original authorship is hard to determine.

The description of the processes of mining and milling gypsum is brief, because the discussion of technologic matter of this kind is thought to be outside the province of the United States Geological Survey. A paper on this subject, ${ }^{1}$ published by the Bureau of

1 Stone, R. W., Gypsum products, their preparation and uses: Bur. Mines Tech. Paper $155,1917$. 
Mines of the Department of the Interior in 1917, can be had on remitting 20 cents to the Superintendent of Documents, Government Printing Office, Washington, D. C.

\section{MINERALOGY AND GEOLOGY OF GYPSUM.}

By R. W. S'rone.

\section{CHEMICAL AND PHYSICAL PROPERTIES.}

Distinctive features. -Gypsum is a common mineral, which occurs in both massive and crystalline form, and is widely distributed in the United States. Crystalline gypsum, known as selenite, can be split into layers, sheets, or plates much like mica (see Pl. I, $A$ ), and any kind of gypsum is so soft that it can be scratched with the finger nail. Unlike the plates of mica, however, the plates of gypsum are not elastic. Gypsum is of commercial value chiefly because, after it is calcined and then mixed with water, it will set or harden and can be used as wall plaster. It was used in this way by the Egyptians 4,000 years ago.

Chemical composition.-Gypsum is a hydrous calcium sulphate, having the chemical formula $\mathrm{CaSO}_{4} \cdot 2 \mathrm{H}_{2} \mathrm{O}$. This formula, reduced to its final components, is:

Gypsum, $\mathrm{CaSO}_{4} .2 \mathrm{H}_{2} \mathrm{O}\left\{\begin{array}{c}\text { Calcium sulphate }\left(\mathrm{CaSO}_{4}\right), \\ 79.1 \text { per cent. } \\ \text { Water }\left(\mathrm{H}_{2} \mathrm{O}\right), 20.9 \text { per cent. }\end{array}\left\{\begin{array}{c}\text { Lime }(\mathrm{CaO}), 32.5 \text { per cent. } \\ \text { Sulphur trioxide }\left(\mathrm{SO}_{3}\right), 46.6 \\ \text { per cent. }\end{array}\right.\right.$

Pure gypsum, the sulphate of lime with water of crystallization, is seldom found in nature, for nearly all gypsum deposits contain oxides of iron and aluminum, carbonates of calcium and magnesium, and other impurities. The anhydrous calcium sulphate, anhydrite, which has the formula $\mathrm{CaSO}_{4}$, is often associated with gypsum, either disseminated through it or occurring with or in it in separate masses.

Hardness and specific gravity.--The crystalline form of gypsum, selenite, is the standard for the second degree (hardness 2) in the Mohs scale of hardness. Gypsum is so soft that it can be scratched with the finger nail, and it can thus easily be distinguished from other minerals that have a similar appearance. The specific gravity of the pure mineral ranges from 2.30 to 2.33-that is, 1 cubic foot of gypsum is 2.3 times as heavy as 1 cubic foot of water.

Color.-Pure rock gypsum is white and selenite is colorless and transparent or translucent. Owing to impurities, however, gypsum ranges through gray to black, from flesh pink to red and brown, and some is yellow or pale blue. Pure powdered gypsum is white. 


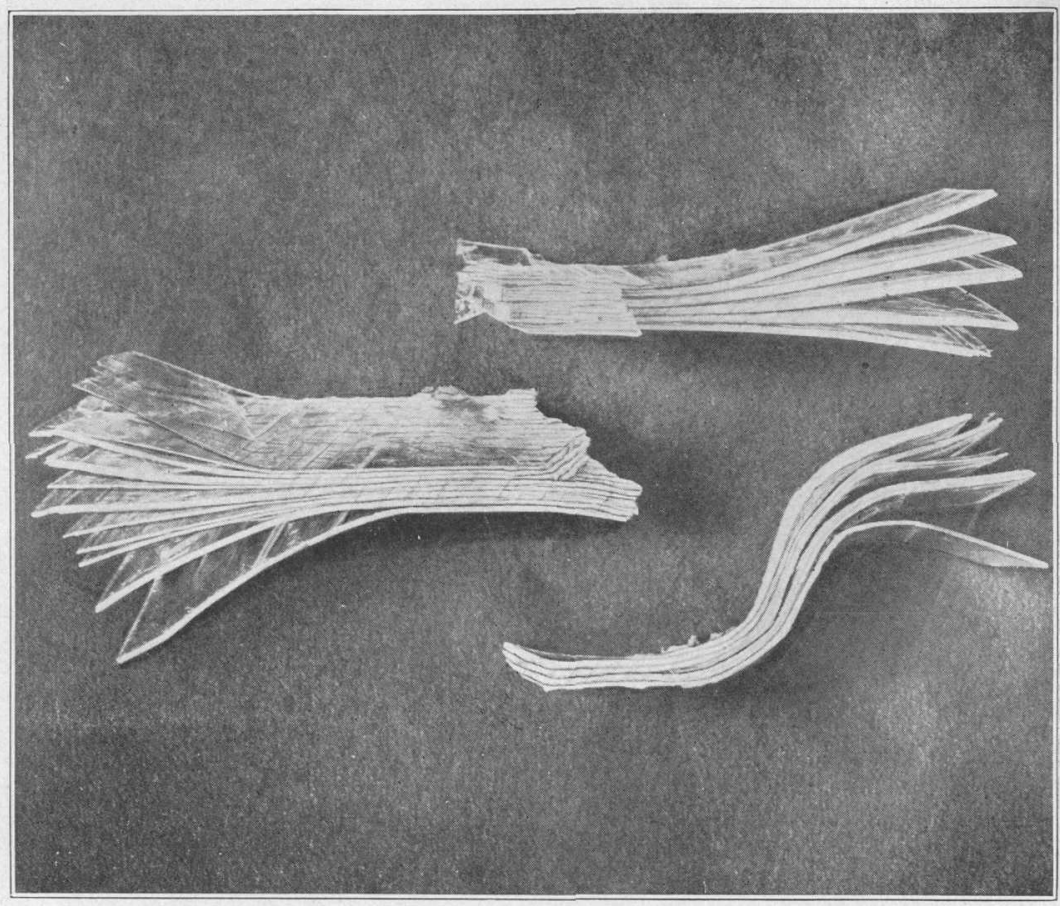

A. SELENITE WHICH HAS BEEN SPLIT AND BENT TO SHOW CLEAVAGE AND SLIGHT FLEXIBILITY.

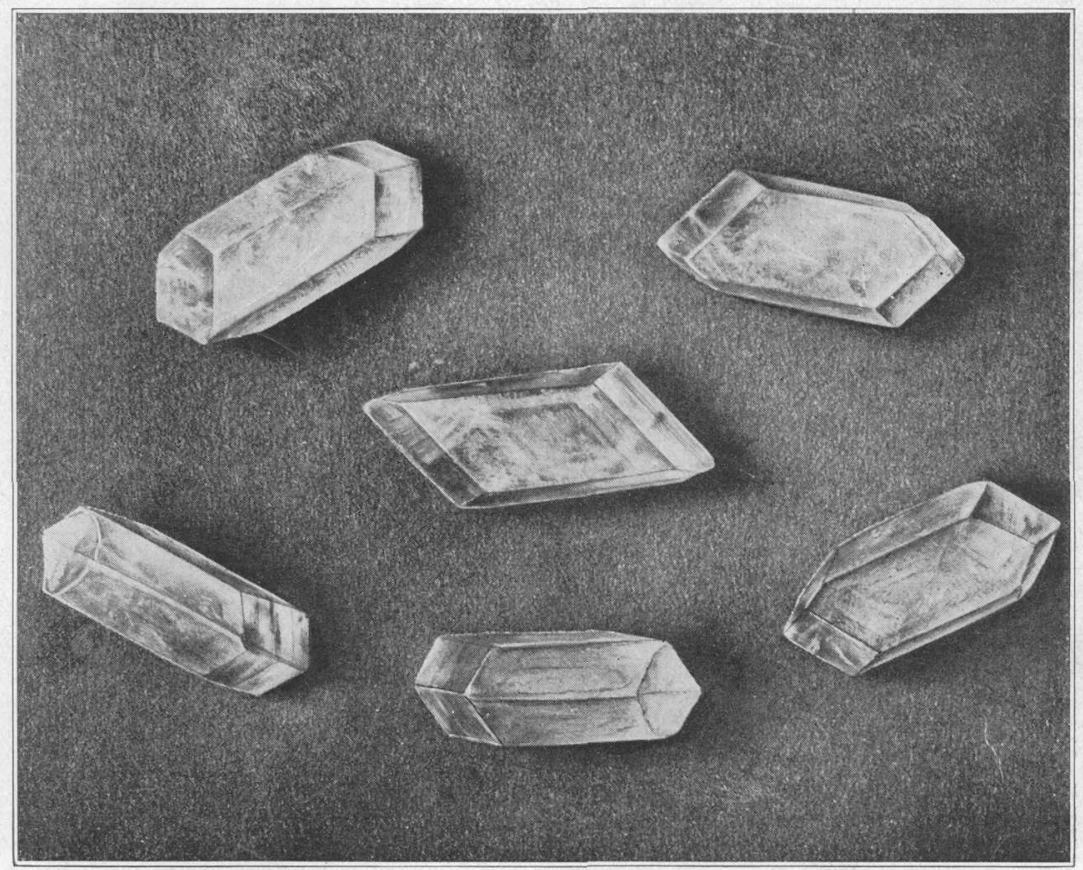

B. SELENITE CRYSTALS. 


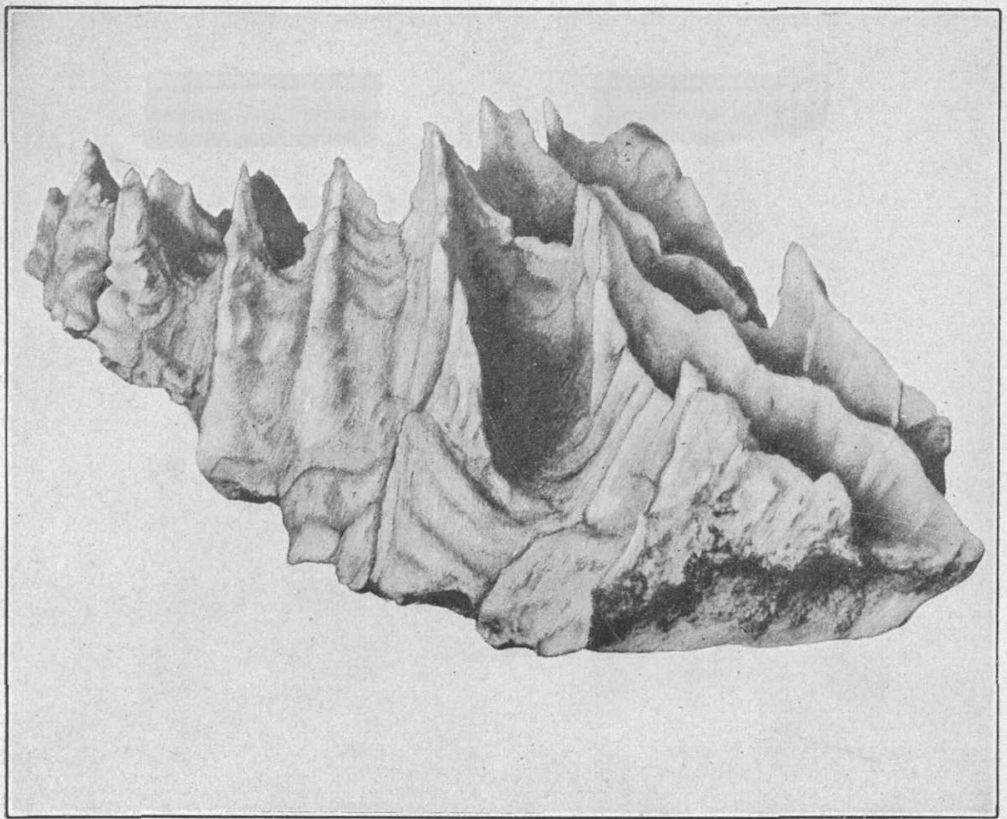

A. GYPSUM HAVING SERRATE SURFACE DUE TO EROSION BY RAIN.

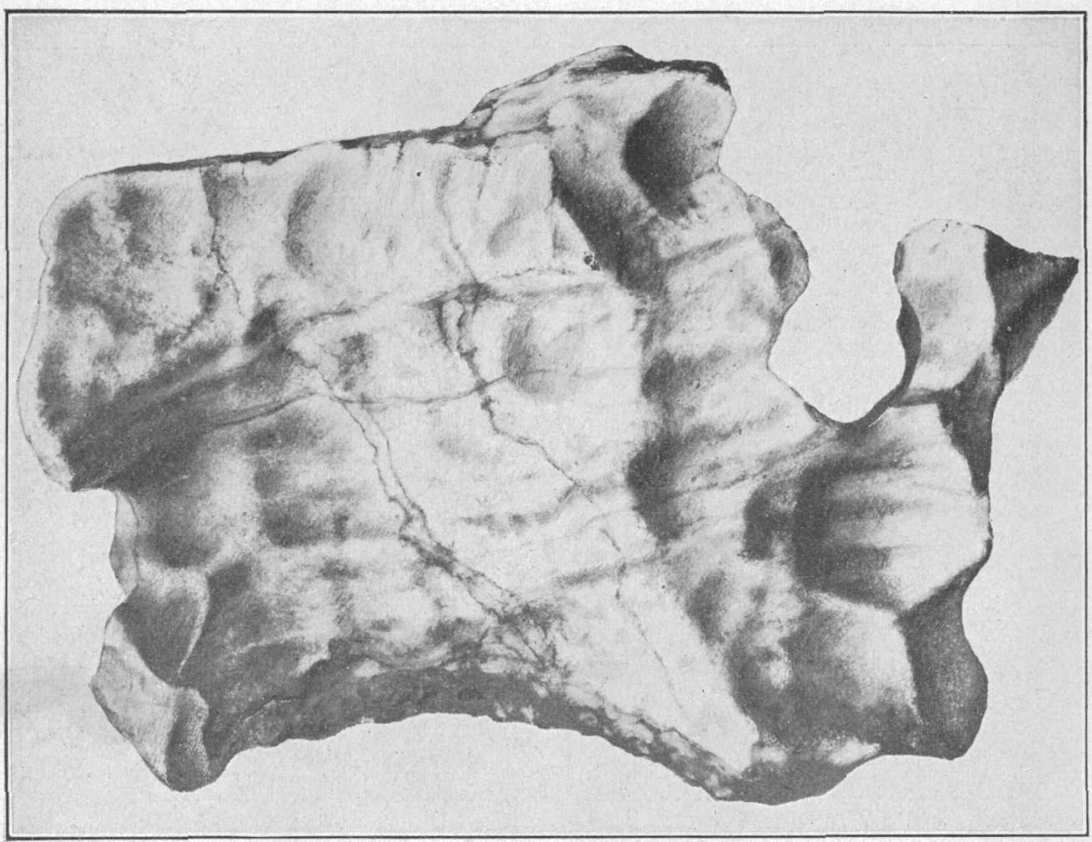

B. ROCK GYPSUM THAT SHOWS EFFECTS OF SOLUTION. 


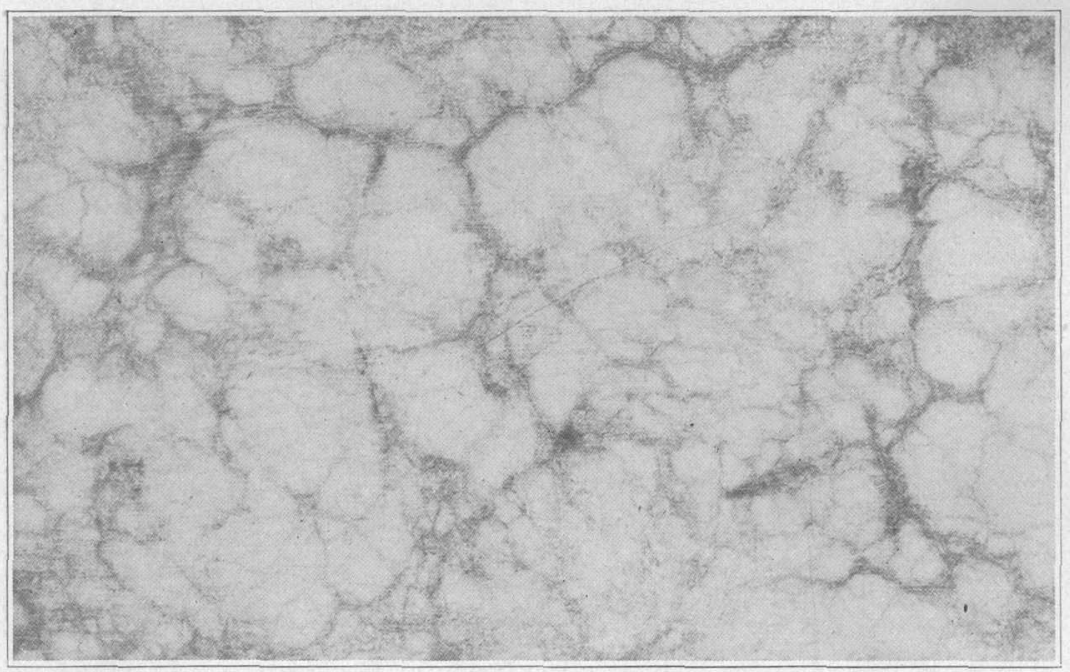

A. MASSIVE GYPSUM SHOWING MOTTLED STRUCTURE.

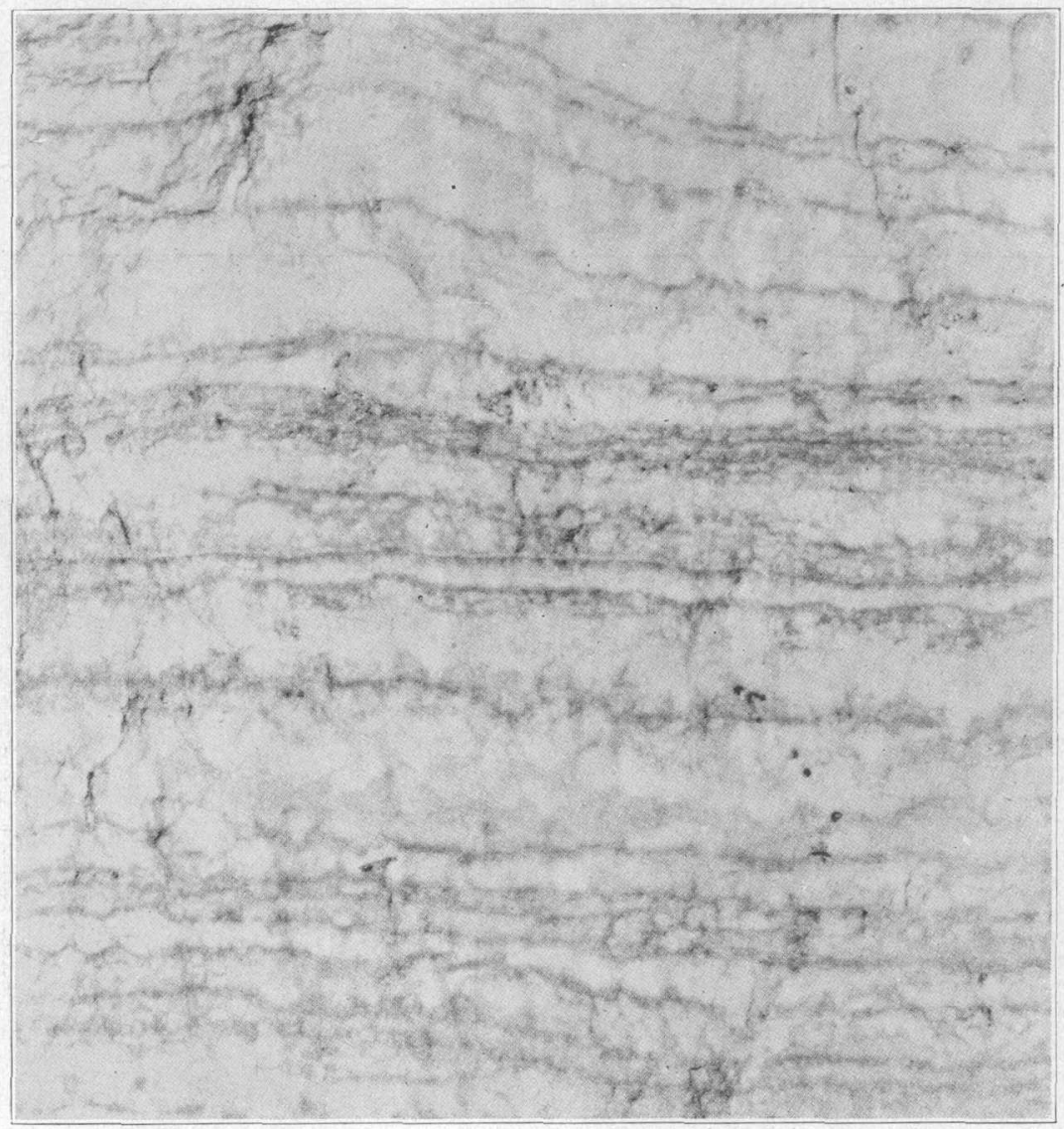

B. MASSIVE GYPSUM SHOWING BANDED STRUCTURE. 


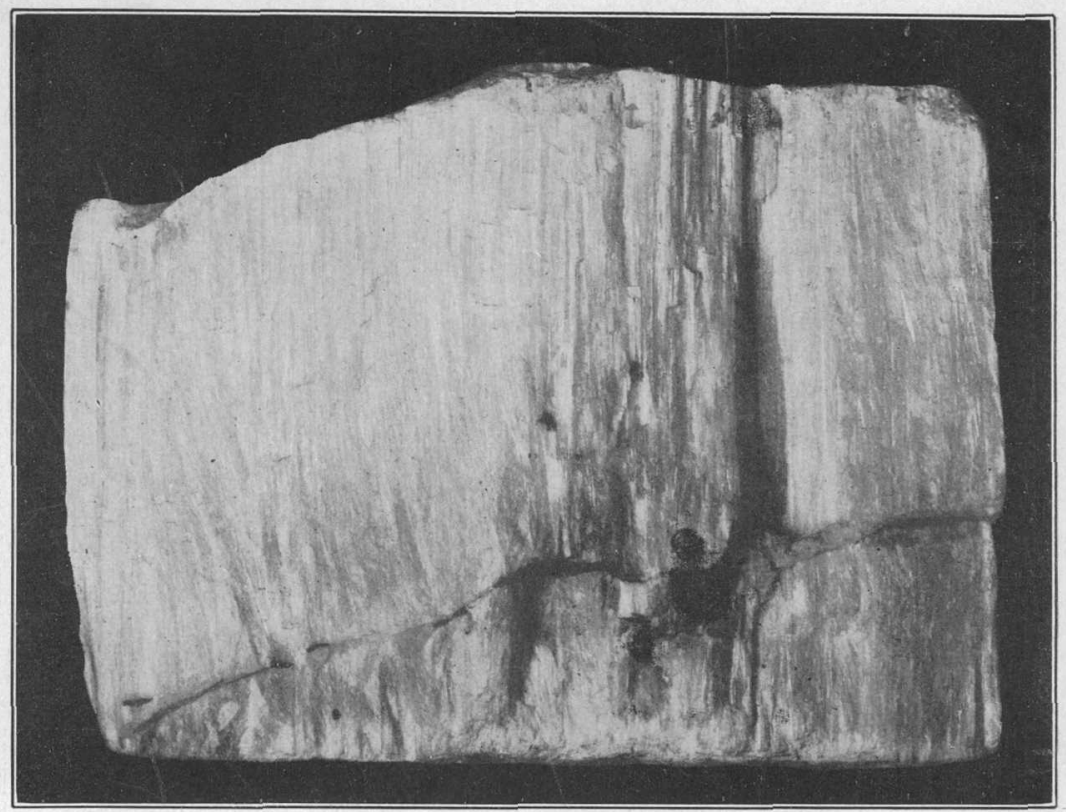

A. FIBROUS GYPSUM OR SATIN SPAR FROM A FISSURE IN CLAY.

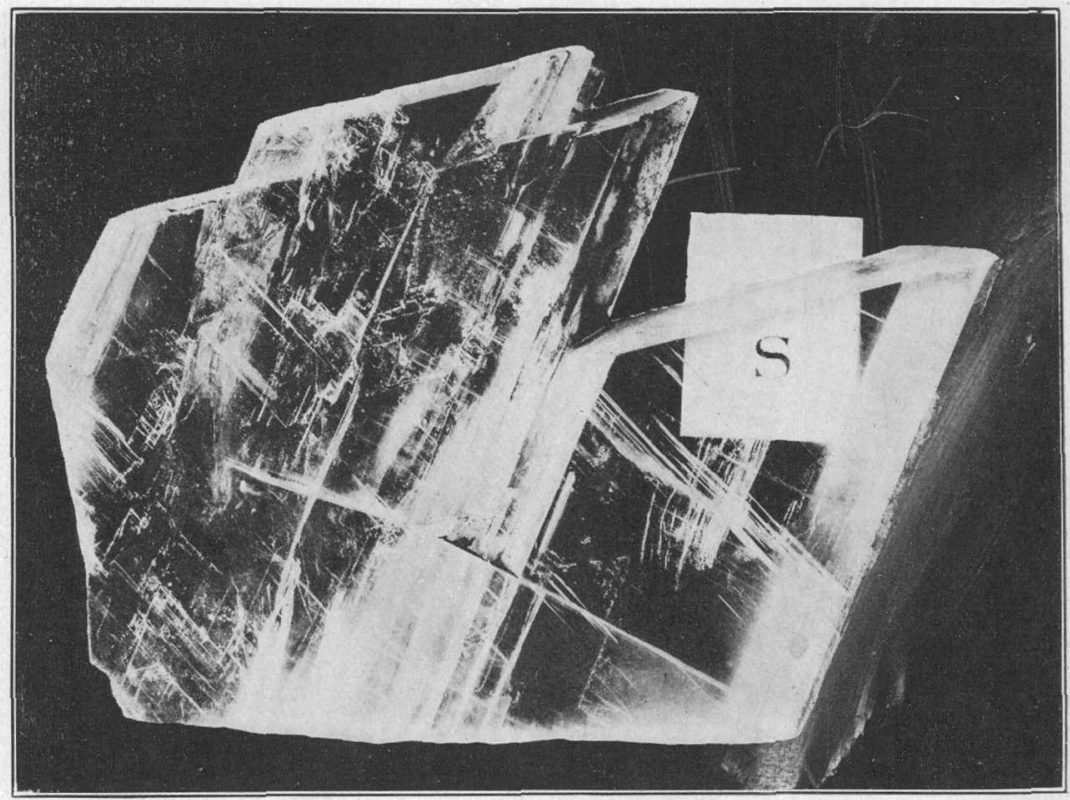

B. SLAB OF SELENITE AN INCH THICK, ILLUSTRATING TRANSPARENCY AND INCIPIENT CLEAVAGE. 
Crystallization.-Gypsum, as selenite, crystallizes in the forms peculiar to the monoclinic system. Typical gypsum crystals are shown in Plate I, $B$. Selenite has a perfect cleavage parallel to the principal plane. It separates into thin plates along the cleavage planes, but these plates, although thin as paper, are only slightly flexible, not elastic. A very common form of the crystal is an elongated irregular diamond or oblique parallelogram. Single crystals. differ greatly in size, but most crystals observed are less than 6 inches long. Crystals from 1 foot to 5 feet long have been found. Crystal aggregates occur in a variety of shapes, ranging from formless masses to beautiful rosettes.

Solubility.-Gypsum is soluble in hydrochloric acid but does not effervesce or gelatinize. It does not dissolve in sulphuric acid. It is slightly soluble in water. At $32^{\circ} \mathrm{F} .\left(0^{\circ} \mathrm{C}\right.$. $)$ one part of gypsum dissolves in 415 parts of water and at $75.2^{\circ} \mathrm{F}$. $\left(24^{\circ} \mathrm{C}\right.$.) one part of gypsum dissolves in 378 parts of water. In time, however, rain and ground water have a marked effect on gypsum, eating deeply into its outcrops, as shown in Plate II, and causing the formation of sinks and caves, in places of considerable extent.

\section{VARIETIES.}

Gypsum occurs as rock gypsum, gypsite, selenite, and satin spar. Rock gypsum, or massive gypsum, the form in which the mineral is most commonly found, is the form, that is of the greatest economic value. This variety occurs interbedded with sedimentary rocks and is composed of minute, even microscopic crystals, which make a generally opaque rock. When pure it is white; thick beds of gypsum in the Central and Western States are almost snow-white. Commonly, however, it contains impurities and may be pink, blue, green, gray, or brown. The color may be evenly distributed, banded, or mottled in the rock, as shown in Plate III, $A$ and $B$. Rock gypsum that is very fine grained, white, slightly translucent, and suitable for carving and sculpturing is known as alabaster. Rock gypsum occurs in beds ranging from thin layers covering small areas to deposits 60 feet or more thick and extending for many miles.

Gypsite, or earthy gypsum, is soft, incoherent, impure gypsum formed at the surface by the evaporation of gypsiferous water. It is an efflorescent deposit and ranges from material so powdery that it resembles wood ashes through sandy and earthy phases to a form that is slightly consolidated. In color gypsite is gray, mottled with white, buff or creamy, rusty, pink, or, where it contains much iron, red. The color is due largely to the clay and fine sand mixed in the deposit. Few deposits of gypsite are over 20 feet thick, and the largest cover only a few acres.

$124567^{\circ}-20-2$ 
Selenite is a variety of gypsum which occurs in distinct crystals or in broad folia. The largest crystals known are over 4 feet long, but these are rare. Pure selenite is colorless and transparent. Selenite splits easily into sheets, and therefore, as it is transparent, it is often mistaken for mica, but sheets of selenite are not elastic like mica. The cleavage, slight flexibility, and transparency of selenite are shown in Plates $\mathbb{I}, A$, and $I V, B$, and an aggregate of gypsum crystals is shown in Plate V, $A$.

Satin spar is a crystalline variety of gypsum made up of needlelike fibers. (See Pl. IV, A.) It occurs in narrow veins or seams, rarely over 3 or 4 inches thick, either in massive gypsum deposits or in the wall rocks near these deposits. It is nowhere sufficiently abundant to be commercially valuable. Satin spar is usually white or pink, and the fibers are perpendicular to the walls of the vein. It is deposited by the evaporation of gypsiferous waters and usually lies below a bed of gypsum.

\section{ANHYDRITE.}

\section{GENERAL FEATURES.}

Deposits of the mineral anhydrite are found at many places in the United States in close association with deposits of gypsum. Anhydrite is calcium sulphate, the formula for which is $\mathrm{CaSO}_{4}$, the same formula as that of dead-burned gypsum. In other words, it is of the same chemical composition as gypsum except that it contains no water of crystallization. By the absorption of two parts of water it turns to gypsum. This process actually takes place in nature and in some places has doubtless resulted in the alteration of beds of anhydrite to beds of gypsum.

Anhydrite may be formed from solutions of gypsurn at various temperatures when the solutions contain sufficient quantities of certain other salts. In a saturated solution of sodium chloride gypsium changes to anhydrite at a temperature of $30^{\circ}$ C. $\left(86^{\circ}\right.$ F.), a temperature commonly reached in summer. This fact satisfactorily accounts for the formation of anhydrite in nature from concentrated sea water or lake brines.

The similarity of anhydrite to gypsum and limestone is so marked that doubtless it has been wrongly identified many times. The simplest tests to distinguish them are those for hardness and specific gravity, for anhydrite is harder and heavier than gypsun. Some compact gypsum is so hard that it can not easily be scratched with the finger nail, but even if the two minerals can not be readily distinguished by the difference in the ease of scratching they can be distinguished by the sound of scratching. ' The difference in specific gravity is very considerable. When heated in a closed tube, gypsum gives off water abundantly, but anhydrite yields little or none. 


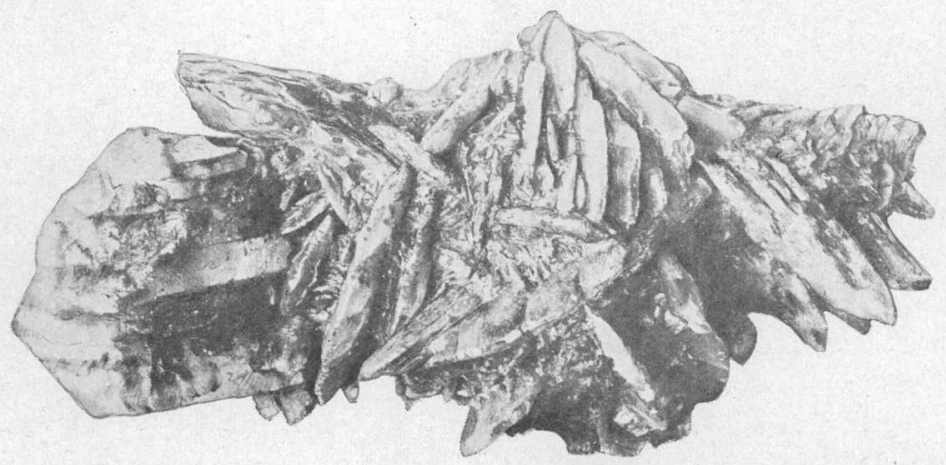

A. AGGREGATE OF IMPURE GYPSUM CRYSTALS FROM MARL BED.

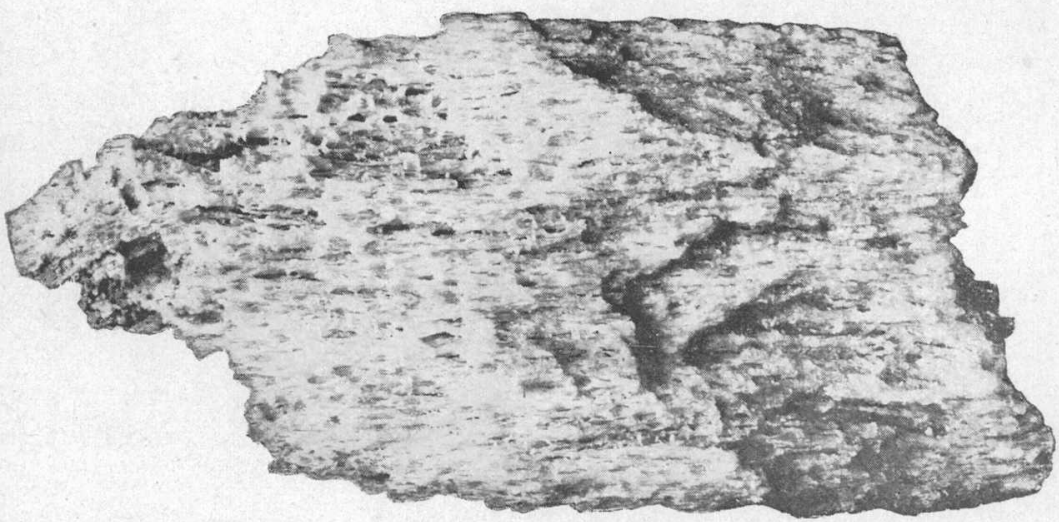

B. SPONGY GYPSUM FORMED AS A SECONDARY DEPOSIT. 
Anhydrite may be distinguished from gypsum by its crystalline cleavage, the planes of which intersect almost rectangularly in three directions, giving it a pseudocubic aspect. In the following table by Rogers ${ }^{1}$ the differences between the two minerals are contrasted:

Anhydrite, CaSOA.

Orthorhombic.

Cleavage, psendocubic.

Specific gravity, about 2.9.

Hardness, 3 to $3 \frac{1}{2}$.

Fragments are square or rectangular, with parallel extinction.

High relief in clove oil or balsam $(a=1.571 ; \gamma=1.614)$.

Double refraction, rather strong; maximum value, 0.043 .

Soluble with difficulty in dilute $\mathrm{HCl}$.

Little or no water in closed tube.
Gypsum, $\mathrm{CaSO} \mathrm{S}_{4} 2 \mathrm{H}_{2} \mathrm{O}$.

Monoclinic.

Cleavage, perfect in one direction.

Specific gravity, about 2.3 .

Hardness, $1 \frac{1}{2}$ to $2 \frac{1}{2}$.

Fragments are platy with oblique extinction, or have aggregate polarization.

Low relief in clove oil or balsam $(a=1.520 ; \gamma=1.529)$.

Double refraction, rather weak; maximum value, 0.009 .

Easily soluble in dilute $\mathrm{HCl}$.

Abundant water (20.9 per cent) in closed tube.

The optical tests implied above may be made with crushed fragments as well as with thin sections.

The weathering of anhydrite is very different from that of selenite or of fine-grained gypsum, for it remains hard and white instead of breaking down to a soft incoherent powder as gypsum does. The surface of a weathered block of anhydrite is usually rough, being covered with innumerable pits separated by thin sharp ridges.

\section{OCCURRENCE.}

According to Rogers, ${ }^{2}$ the modes of occurrence of anhydrite are as follows: As a sedimentary rock, often associated with salt in inland-sea deposits; as a vein mineral or an associate of ores; as the metamorphic equivalent of sedimentary anhydrite; as a cavity filling in igneous rocks; as a cavity filling in limestones; as a replacement of limestone along with dolomite; as the dehydration product of gypsum. Numerous localities where anhydrite occurs in the United States are mentioned by Rogers in the paper cited above. Of these the ones where anhydrite is found in considerable quantity, together with others known to the present writer, are given below.

California.-In the Palen Mountains, Riverside County, interbedded anhydrite and crystalline gypsum alternate with layers of limestone. The differentiation of the gypsum and the anhydrite is thought to be due to original differences in composition.

Colorado.-In the region around Gypsum, Eagle County, where gypsum is abundant, anhydrite has been found near the Iron Nellie

${ }^{1}$ Rogers, A. F., Notes on the occurrence of anhydrite in the United States: School of Mines Quart., vol. 36, p. 124, 1915.

2 Idem, p. 138. 
mine. Rogers thinks it probable that all the gypsum in this region is a hydration product of the anhydrite.

Iowa.-At a depth of 542 feet in a drill hole at Centerville, Appanoose County, there is a bed of anhydrite 5 feet thick, which is underlain by 5 feet of crystalline gypsum.

Louisiana.-Beds of anhydrite several feet thick have been found at different depths in deep wells at Belle Isle and near Vinton.

Michigan.-At a number of places in the southern peninsula anhydrite has been found in deep wells in beds from a few feet to 45 feet thick at depths ranging from 200 to 2,350 feet.

Nevada.-At the Ludwig mine, in Lyon County, anhydrite with a little gypsum occurs on the 400 -foot level, and on the surface its place is taken by gypsum. Rogers believes that the anhydrite was formed by the metamorphism of an original sedimentary bed of anhydrite.

At Mound House, Lyon County, anhydrite occurs on the lowest levels of the main gypsum quarry, and Rogers says that the formation of gypsum at the expense of anhydrite is unmistakable.

At Arden, Clark County, the present writer observed masses of anhydrite in the thick bed of gypsum and came to the conclusion that the deposit is the result of the hydration of an original anhydrite deposit.

New Mcxico.-Anhydrite in thick beds is not uncommonly associated with massive gypsum at a number of widely separated localities. The two different mineral deposits are thought to be original and to be due to changes in temperature of the concentrated sea water from which the deposits were formed.

Ohio.-Massive rock gypsum is found at the surface near Sandusky, but a deep well near Cleveland encountered anhydrite below rock salt at depths of 2,154 and 2,300 feet. Here, as in Michigan, the occurrence of gypsum at or near the surface and of anhydrite at considerable depths is suggestive that the gypsum deposits are original beds of anhydrite altered by meteoric or ground water.

Oklahoma.-A considerable bed of anhydrite occurs in the Medicine Lodge gypsum for 50 miles or more, with gypsum above and below it. L. C. Snider, of the Oklahoma Geological Survey, believes this anhydrite is the result of original deposition and not of alteration.

Texas.-In a deep well at Spur, Dickens County, seven beds of gypsum, from 1 to 15 feet thick, occur in the upper 285 feet of the boring. Anhydrite is first found at 298 feet and occurs at intervals down to 4,105 feet in beds from a few feet to 73 feet thick. It is intimately associated with dolomite and is partly original and partly secondary. Udden believes that the anhydrite has formed in connection with the dolomitization of limestone by a reaction be- 
tween magnesium sulphate and calcium carbonate. The fact that all the beds of calcium sulphate within about 300 feet of the surface are gypsum suggests that they may be due to the hydration of deposits originally laid down as anhydrite. They do not seem to be derived even indirectly from limestone, for the inclosing beds are shale and sandstone.

Utah.-At Nephi, in the middle of the upper part of the great quarry face, there is a large body of anhydrite surrounded by gypsum. As the geologic structure of the gypsum has not been determined definitely, there is some objection to the suggestion that the orginal deposit of anhydrite has been hydrated except the core.

Virginia mixed with the gypsum and the two minerals grade into each other. In one and perhaps in both of the mines the quantity of anhydrite seems to increase with depth, a condition which suggests the idea that the main deposit is anhydrite that has been altered to gypsum near the surface by hydration. This process may have been aided by circulation of water along a fault plane which cuts the bed of anhydrite and reduced part of it to a breccia of anhydrite and shale.

\section{CLASSIFICATION OF DEPOSITS.}

GENERAL DISCUSSION.

Gypsum deposits may be classified by their origin, mode of occurrence, position with relation to the earth's surface, and in other ways. Gypsite and gypsum dunes are accumulations on the surface, whereas satin spar and rock gypsum, occur within other rocks. Differentiation by mode of occurrence makes the following separation: Interbedded, efflorescent, and periodic-lake deposits, veins, dunes, and isolated crystals. This classification ${ }^{1}$ is simple and needs but a few explanatory paragraphs.

Interbedded deposits are those bodies of gypsum interstratified with shales, sandstones, and limestones which have been laid down in seas or lakes. The study of the broader stratigraphic relations of the gypsum series usually shows that they were formed in local basins, and lack or scarcity of fossil remains indicates sea water which had reached a degree of concentration unfavorable to life.

Efflorescent deposits are formed on the surface by the evaporation of water that has percolated through massive gypsum or gypsiferous strata. The gypsum thus formed is the variety known as gypsite or earthy gypsum. It is made of microscopic plates of crystalline gypsum.

Periodic-lake deposits are formed by the crystallization of gypsum from the waters of intermittent shallow lakes. The material of such a deposit is generally granular and crystalline, the particles

\footnotetext{
${ }^{1}$ Hess, F. L., A reconnaissance of the gypsum deposits of California: U. S. Geol. Survey Bull. 413, p. $7,1910$.
} 
ranging from minute specks to grains one-quarter of an inch in breadth, and thin in proportion. As it is derived largely from shallow water near the shore, where evaporation would be most rapid and the water would therefore be more highly saturated with gypsum, the gypsite deposited by a periodic lake will be found around the old medial shore of the lake.

Veins of gypsum are generally composed of satin spar or selenite. They are formed of gypsum dissolved by water circulating through gypsum-bearing strata and redeposited in fissures, cracks, and bedding planes.

Dunes of gypsum sand occur in some regions. The sand is the product of wind erosion and is derived from the disintegration of: massive crystalline gypsum or from surface deposits of small gypsum crystals produced by evaporation of gypsiferous waters. This sand, for instance, may be swept up by the wind from playa lakes during: drought. Soluble salts swept up with the gypsum by the wind are subsequently dissolved out of the dunes, leaving the less soluble material.

Isolated crystals and small flakes of gypsum, such as occur in many shale and clay deposits throughout the country, are supposed to have been formed by the decomposing of small quantities of pyrite and the resultant acid acting on calcium carbonate in the form of fossil shells. Iron sulphide yields sulphuric acid, which in contact with calcium carbonate gives calcium sulphate or gypsum.

Separation by origin gives the following classification: Deposition from solution in (a) sea water, $(b)$ ground water; produced by alteration; produced by disintegration and reaccumulation.

DEPOSITION FROM SOLUTIONS.

Deposition from sea water.-It is generally believed that most of the important deposits of rock gypsum of the world have been formed by the evaporation of sea water. This method of formation is inferred from the fact that the beds are usually interbedded with shales, sandstones, and limestones which have been deposited in seas or lakes. A scarcity or total absence of fossils in the gypsum-bearing rocks shows that the water in which they were deposited had reached a degree of concentration that was unfavorable to life. Sea water contains 3.5 per cent of mineral salts in solution. The most abundant salt is sodium chloride, which constitutes more than 77 per cent of the total solids, whereas calcium sulphate is only 3.6 per cent. Calcium sulphate is not precipitated until about 80 per cent of the water has been evaporated. With these facts in mind, it is difficult to account for the great thickness of some gypsum beds. The quantity of water of normal salinity which would have to be evaporated to make a gypsum deposit 30 or 60 feet or more thick is so great that 
no known ocean basin would hold it. From 1,000 feet of normal sea water about 0.7 foot of gypsum would be precipitated before the point of saturation for sodium chloride would be reached; to precipitate 30 feet of gypsum would require about 43,000 feet of water. Beds of gypsum 40 to 50 feet thick are not uncommon, requiring for their deposition continental depressions much greater than any now known. These thick deposits, which are not of great extent and grade laterally into much thinner deposits covering wide areas, are accounted for by Branson's modified bar hypothesis. 'This hypothesis is stated as follows:

In the drying up of a large interior sea the waters might come to lie in separate basins if the bottom were uneven. Evaporation over the full expanse of the interior sea might be rapid enough to decrease the depth and area in spite of the inflow of some stream, but when considerable areas of bottom had become exposed the total evaporation would have become less and the inflow nearer to the amount of evaporation. Assuming that isolated basins would be formed, separated by low barriers, and that the main streams would empty into the marginal basins, the inflow might be sufficient to cause these basins to overflow and supply the minor basins that had no direct stream connections with highly charged waters as fast as their own waters evaporated.

A part of this modified bar hypothesis is the assumption that when the isolated seas were formed the sea water had already reached a considerable degree of concentration, and so the interior receiving basins would be supplied with highly concentrated waters instead of normal sea water. The greater thickness of a gypsum bed may also have resulted, too, from currents shifting the unconsolidated gypsum along the bottom.

Deposition from solution in ground water.-Water making its way through joints, fissures, and bedding planes of gypsum-bearing strata may take up calcium sulphate in solution. This water may come to rest in passageways in the gypsum beds or in the adjacent wall rock and there by evaporation deposit the gypsum as selenite or satin spar.. These crystallizations in seams and veins are clearly secondary deposits and of later origin, for they not uncommonly cut beds of gypsum. Gypsum beds and rocks adjacent to them are in many places reined and seamed by such secondary deposits. The passages thus filled may have been very narrow at first but became enlarged gradually by solution and possibly by the expansive force of the growing crystals.

Gypsite or gypsum earth is found in many places in the western States, usually in regions where beds of rock gypsum occur. Gypsite probably is derived from primary deposits through the circulation of ground water. The spring theory of origin is generally accepted for deposits of this class, for water percolating through gypsum beds

1 Branson, E. B., Thick gypsum and salt deposits: Geol. Soc. America Bull., vol: 26, pp. 235-237, 1915. 
dissolves a portion of the rock and on issuing at a lower point as a spring redeposits the gypsum by evaporation, aided perhaps by the action of organic matter of decaying vegetation; also water may come up through beds of rock gypsum and form gypsite at the surface directly over the primary deposit. In either event a crust of minute gypsum crystals would be formed on the surface and increase gradvally in thickness.

Microscopic examination shows that gypsite consists of small irregular crystals and plates of gypsum. The deposits are so soft as to be easily worked with a spade, and some of the gypsite is very light and powdery. Gypsite deposits are thin and of little area-that is, they are rarely more than 15 feet thick and cover only a few acres. They are rather impure also, owing to the presence of sand, clay, lime carbonate, and organic matter, brought in by surface agencies.

Deposition from ground water is thought to be the mode of accumulation of certain other gypsum deposits. It has been found that some low dome-shaped mounds in Louisiana on the Gulf Coastal Plain are underlain by beds of salt and gypsum. Harris ${ }^{1}$ maintains that the domes are not due apparently to differential erosion but have been actually uplifted. Although uplift has been ascribed to gas pressure, water under great head, and igneous masses approaching the surface, Harris offers an entirely different explanation. He finds that the domes occur at the intersections of master faults and thinks the faults have served as channels along, which saline solutions have ascended from great depths. Theoretically warm waters rising through the faulted strata would precipitate their salts as they cooled. The solvent power of water for sodium chloride decreases rapidly at a high temperature, so the main precipitation of this salt would be at considerable depth. There would be a tendency for the salt to form a cone with point up, and this cone as it grew broader and donger, by the expansive force of crystallization, might force the overlying mass upward. The solution from which the sodium chloride had been precipitated would become cooler as it approached the surface and lose its calcium sulphate. Gypsum would therefore be found above the salt and near the surface. This relation has been noted in Louisiana and Texas.

Another idea of the origin of the domes of salt and gypsum on the Gulf Coastal Plain is that of G. S. Rogers, ${ }^{2}$ who believes

that the salt plugs are offshoots of deeply buried bedded deposits which have been subjected to great pressure or thrust and have been partially squeezed upward in a semiplastic condition along lines of weakness. As the region lies along a heavily loaded seacoast; the nature of the lateral thrust is not difficult to understand. The fact that the surface beds are undisturbed, except im-

\footnotetext{
${ }^{1}$ Harris, G. D., Econ. Geology, vol. 4, pp. 12-34, 1909.

2 Rogers, G. S., Intrusive origin of the Gulf coast salt domes: Econ. Geology, vol. 13, pp. $447-485,1918$.
} 
mediately around the salt plugs, is explained by the nature of the section-a series of indurated and rigid formations overlain by a great thickness of relatively yielding and plastic sediments.

The origin of the gypsum and anhydrite that cap most of the domes is obscure. Rogers suggests that anhydrite overlies the bedded salt deposit from which the salt plugs were derived, and that when the salt was squeezed up a portion of an overlying anhydrite bed was brought up with it. Later action of circulating waters may have changed the shape of the mass considerably and converted part of the anhydrite into gypsum. The capping gypsum and anhydrite may also reasonably be ascribed to the action of ground water that percolated down through any one bed toward the sea and, finding its progress arrested by the salt plug and the uplifted sediments around it, rapidly ascended to a cooler zone where some of its dissolved salts would be precipitated.

\section{DEPOSITS PRODUCED BY ALTERATION.}

Theorigin of gypsum may be explained in a number of ways, each applicable to a particular kind of deposit and all based on the fact that gypsum is produced by the chemical action of sulphuric acid on calcium carbonate. Gypsum may thus be formed in the laboratory, the reaction stated in its simple form being

$$
\mathrm{H}_{2} \mathrm{SO}_{4}+\mathrm{CaCO}_{3}=\mathrm{CaSO}_{4}+\mathrm{H}_{2} \mathrm{O}+\mathrm{CO}_{2} \text {. }
$$

Sulphuric acid dissolved in the water of thermal springs may produce gypsum by acting on travertine. The acid is formed from sulphurous vapors which have been oxidized, and the materials acted upon are principally calcium and magnesium carbonates. The thermal waters on evaporating at the surface deposit the gypsum as liayers of fine crystals.

The origin of some gypsum has been attributed to the alteration of limestone by the action of sulphuric acid in water from sulphur springs. The acid may be accounted for by the oxidation of sulphureted hydrogen, and this acid, working through cracks, joints, and bedding planes in the limestone, reacts with calcium carbonate and forms calcium sulphate.

Gypsum is formed likewise by sulphurous acid, which escapes around the fumaroles of volcanoes and which, when it is converted into sulphuric acid, attacks rocks which contain lime.

Limestone may also be converted to gypsum by sulphuric acid derived by ground water from pyritic shales. A more or less constant supply of acid in the ground water might in time change bedded limestone to apparently bedded gypsum. This origin has been ascribed by some to the gypsum deposits in New York.

Indiviclual crystals or small groups of crystals or plates of selenite are common in some clay and shale deposits but so scattered as to be 
of no economic importance. These disseminated gypsum crystals may be formed by the decomposition of pyrite, which gives rise to sulphuric acid and soluble sulphates that act upon any. lime present, as in fossil shells, and convert it into gypsum.

Anhydrite alters to gypsum by taking up water and recrystallizing. In this reaction great pressure is developed, for there is an increase of $33 \mathrm{per}$ cent in volume. The force of the expansion is sufficient to lift a considerable thickness of overlying strata and has been considered to be the cause of the hummocky surface over some gypsum deposits.

Anhydrite generally occurs in sedimentary beds, but it is not commonly found at the surface. Outcrops of anhydrite in Oklahoma and New Mexico are exceptions to this rule. Most of the known occurrences of massive anhydrite are in mines or deep wells. In a number of mines the large irregular masses of anhydrite completely surrounded by gypsum and the increasing abundance of anhydrite with depth suggest that it was the original mineral of the deposit. That the gypsum in a number of mines is dẻrived from anhydrite is proved conclusively by the microscopic structure of thin sections of the roek.

DEPOSITS PRODUCED BY DISINTEGRATION AND MECHANICAL REACCUMULATION.

Dunes of gypsum sand are found in a number of places where wind erosion is active. A large deposit of this sort is formed by the white sands in Tularosa Basin, New Mexico, which cover about 270 square miles. The sand is derived in part from the disintegration of gypsum exposed at the surface. Furthermore, the surface waters are highly impregnated with various salts. Evaporation is rapid and produces an efflorescence or crust which is disintegrated and blown by the wind into drifts. The sand derived from these two sources contains soluble salts, which are subsequently redissolved, leaving the dunes composed of practically pure gypsum.

\section{GEOLOGIC AGE OF DEPOSITS.}

The commercial deposits of gypsum that are being exploited in the United States range in age from Silurian to Quaternary. The age of some deposits, like that at Fort Dodge, Iowa, is so much in doubt that they are omitted from the subjoined table. Others, like the deposits near Bridger, Mont., and Empire Mountains, Ariz., are classified tentatively.

Age of gypsum deposits.

Quaternary______Arizona, Douglas, Tueson; New Mexico, County of Otero, white sands.

Tertiary _-_-_-_-_-_California; Nevada, lacustrine deposits.

Cretaceous Arkansas. 


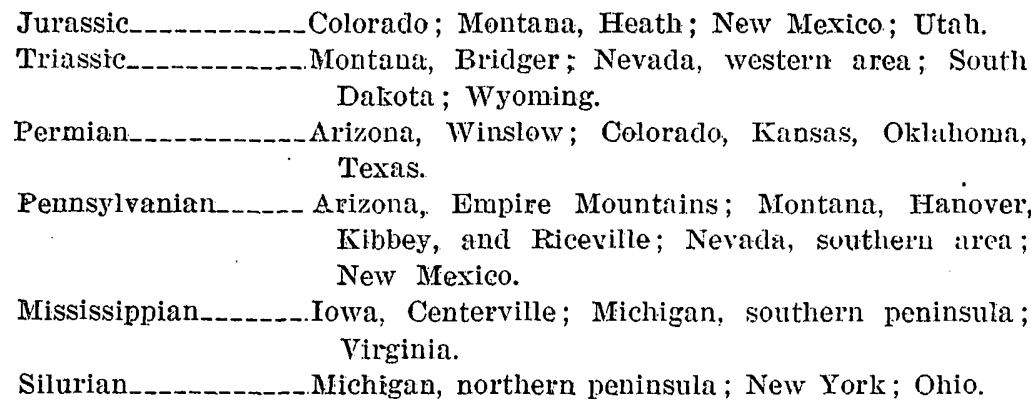

It is noticeable that the most extensive gypsum deposits in the f country, those in the western United States, oceur only in the Pennsylvanian, Triassic, and Jurassic rocks. In several places the gypsum is closely associated with beds of salt, and the fact that both I minerals occur in massive and extensive beds is indicative of wideispread aridity. Paleogeography shows that from Pennsylvanian t to late Jurassic time the sedimentary history of much of the western part of the United States ran an uneventful course with no physical changes of great moment. During much of the time the sea was shut out and its place taken in part by inland seas or lakes. There were occasional invasions of the sea, so that the estuaries and inland water bodies were sometimes salt, sometimes brackish, and sometimes fresh. That the sea did come in is shown by beds of limestone with marine fossils, and exclusion of the sea and arid conditions are shown by the widespread deposits of salt and gypsum. Deposition took place in these bodies of water and in dry basins; and in large part the material was derived so extensively from deeply weathered surfaces that the sedimentary strata are prevailingly red. Hence the name "Red Beds," which is closely associated with many of the western gypsum deposits.

\section{ANALYSES OF* GYPSUM.}

By R. W. STone.

The following analyses are compiled from various sources. Some were made in the laboratory of the United States Geological Survey from samples collected by members of the Survey. Some are taken from publications of State geological surveys. Others have been furnished by gypsum companies without information as to the analyst. The total calcium sulphate in each analysis has been computed by the writer from the ${ }^{\circ}$ sulphur trioxide. The significance of each analysis depends on the method af taking the sample, the method of. preparing it for analysis, and other methods employed. As these are not known, a discussion of the analyses is not attempted. 


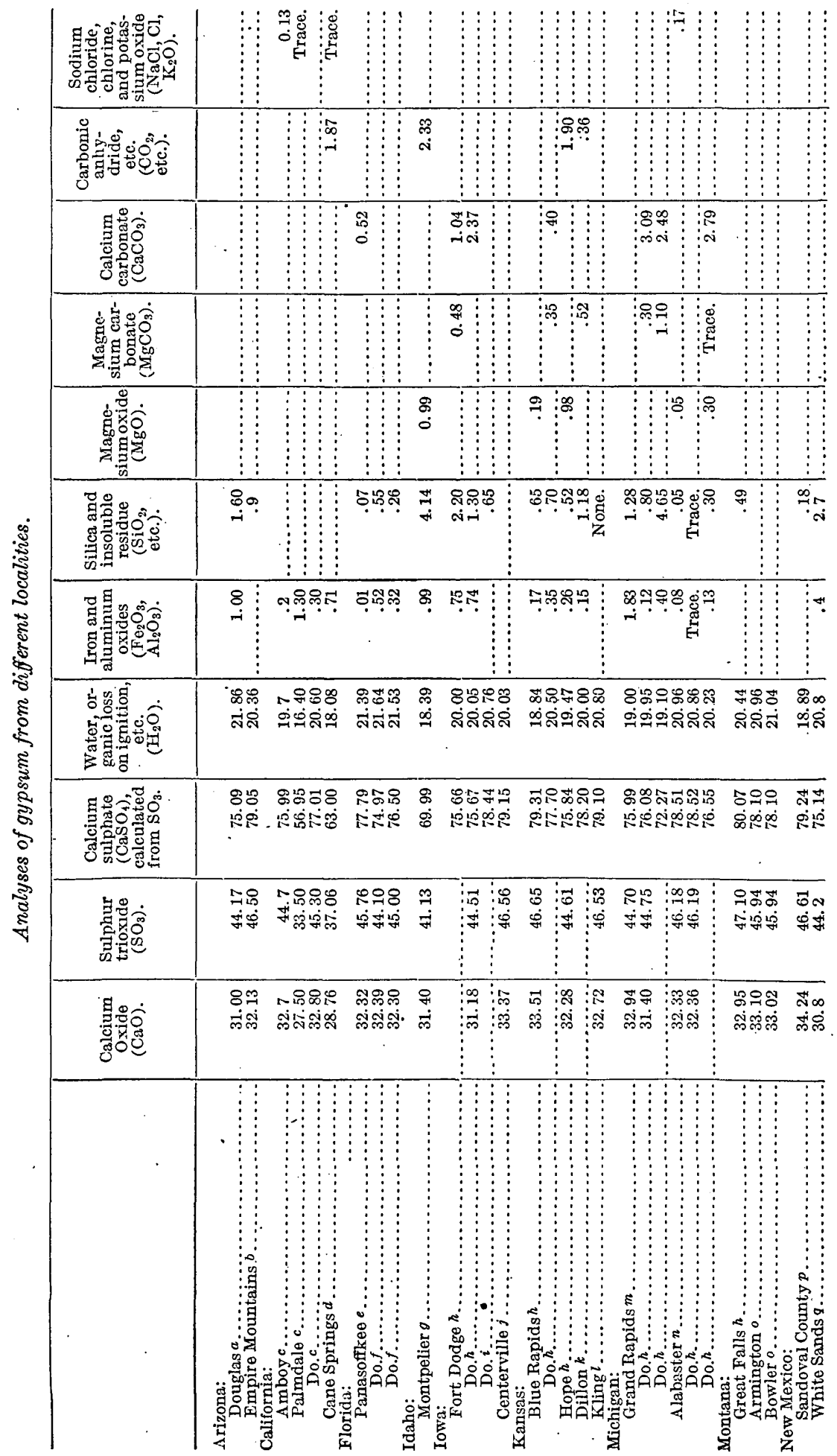




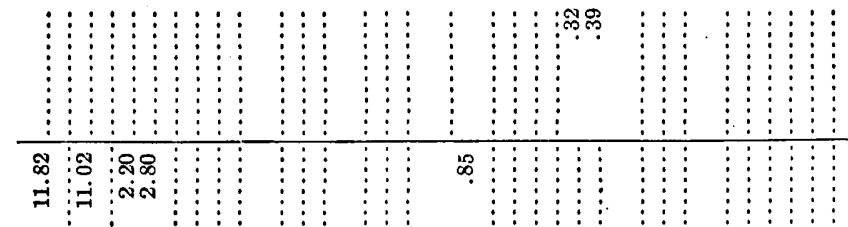

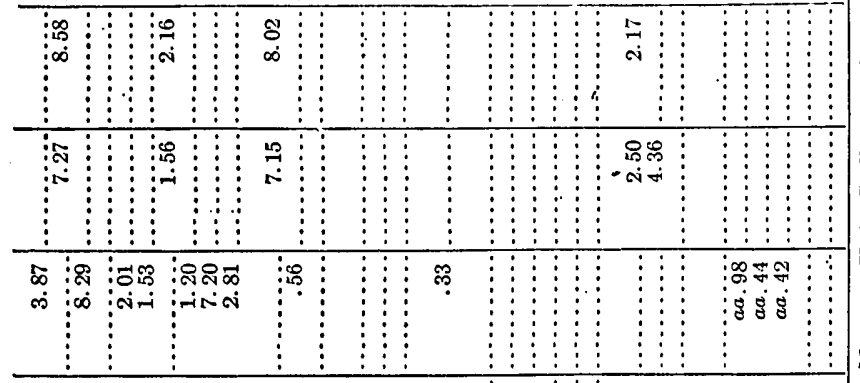

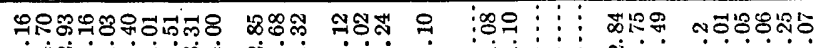

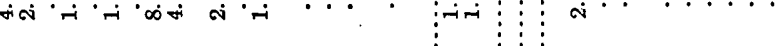

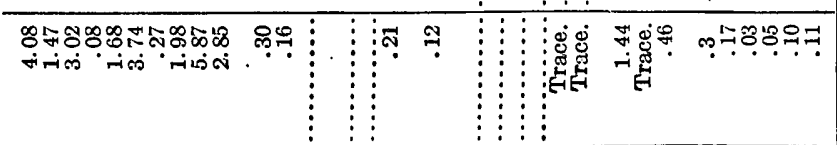

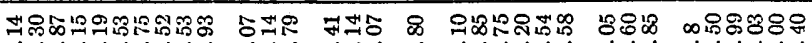

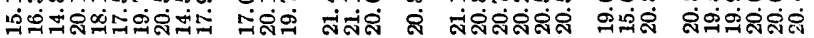

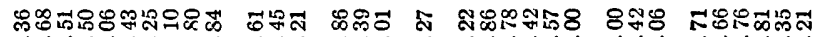

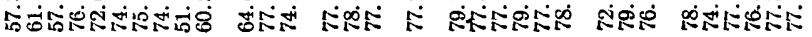

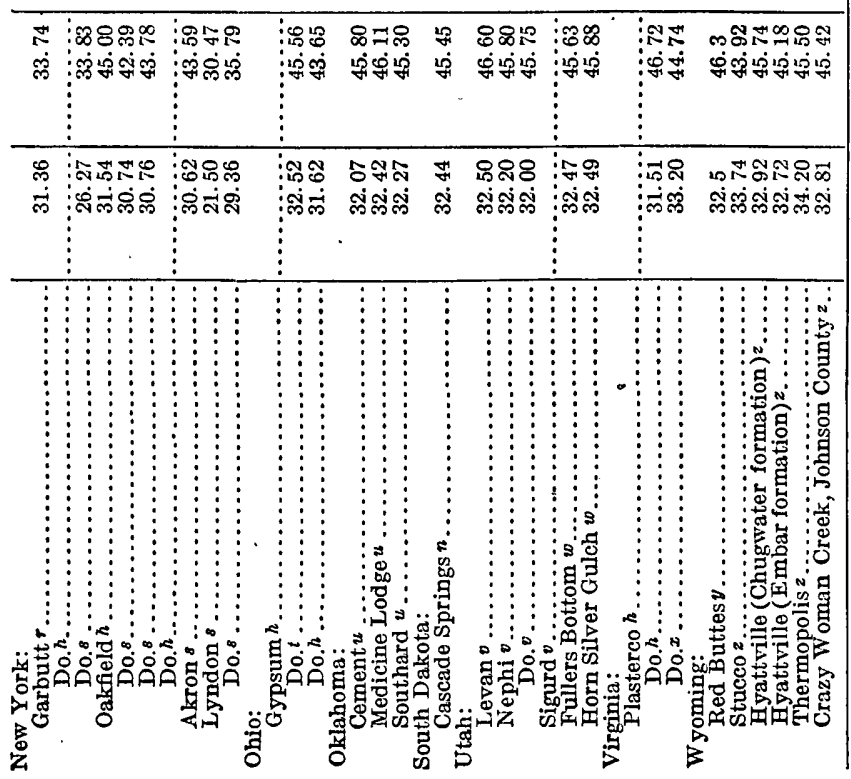

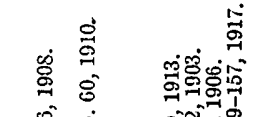

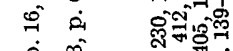

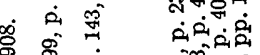 ถึ่ำ 点

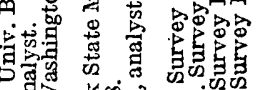

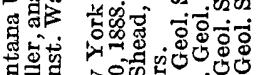

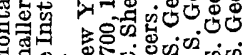

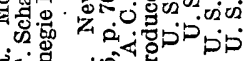 क्षित

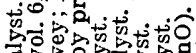 药 ino

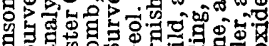

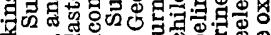 - a. O. 17 .

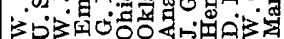

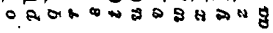

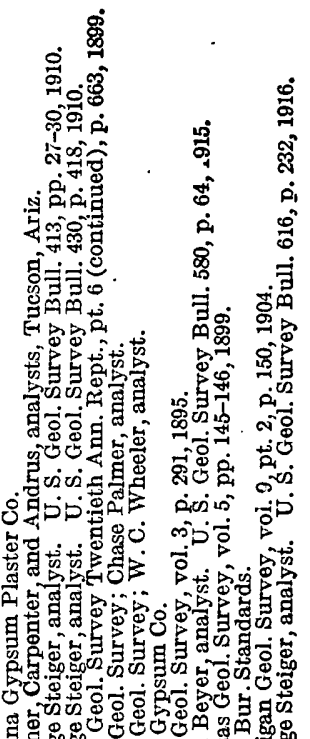
心

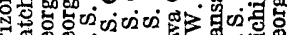

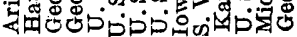

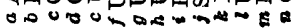




\section{ERRORS IN THE CHEMICAL ANALYSIS OF GYPSUM.}

By George Steigei.

Some difficulty was experienced with the determinations of water in the chemical analyses of gypsum made in connection with a report on gypsum in California. ${ }^{1}$

As is the custom in the chemical laboratory of the United States Geological Survey, the specimens were prepared for analysis by long grinding, to bring the materials to a very fine state of division. The water content in several specimens was so low as to throw doubt on the determinations; consequently', the figures were checked by the estimation of water on the unground material. The new. figures were several per cent higher than those previously found.

Some experiments were then made on a sample of pure selenite, and on one of very pure massive gypsum, each of which contained the theoretical percentage of water. The results proved to be of sufficient interest to warrant their being noted in connection with the present paper, as they go to show the totally fallacious results which might be reported in an analysis of gypsum if proper attention is not paid to the preparation of the sample. Fine grinding of any rock in preparing the sample for chemical analysis is liable to cause serious error in the determination of water, though usually not to the extent of the one in question. ${ }^{2}$

The selenite was ground in a mechanical grinder and the water content was determined from time to time by heating a gram portion to a temperature of $300^{\circ}$ or $400^{\circ} \mathrm{C}$. The extent of rehydration of this material which had been ground and heated was then determined by allowing it to stand in a loosely covered crucible for various lengths of time. For lack of time the rehydration of the ground material before heating was, unfortunately, not determined.

Extent of rehydration of ground and heated gypsum by exposure to air.

\begin{tabular}{|c|c|c|c|}
\hline $\begin{array}{c}\text { Time } \\
\text { ground. }\end{array}$ & $\begin{array}{c}\text { Content of } \\
\text { water. }\end{array}$ & $\underset{\text { slacked. }}{\text { Air }}$ & $\begin{array}{l}\text { Water re- } \\
\text { absorbed. }\end{array}$ \\
\hline Hours. & Per cent. & Days. & Per cent. \\
\hline 10 & $\begin{array}{l}16.65 \\
12.57\end{array}$ & 2 & 1.53 \\
\hline & & & $\begin{array}{r}1.47 \\
.1 .47\end{array}$ \\
\hline 15 & 10.25 & $\begin{array}{r}3 \\
3 \\
6\end{array}$ & $\begin{array}{l}1.79 \\
1.70 \\
1.74\end{array}$ \\
\hline 20 & 7.74 & $\begin{array}{r}14 \\
-\quad 3\end{array}$ & $\begin{array}{l}1.62 \\
2.15 \\
1.96\end{array}$ \\
\hline & & 13 & 2.02 \\
\hline 30 & 6.95 & 8 & 1.91 \\
\hline 49 & 4.11 & & \\
\hline
\end{tabular}

1 Hess, F. L., A reconnaissance of the gypsum deposits of California : U. S. Geol. Survey Bull. $413,1910$.

2 Hillebrand, W. F., The influence of fine grinding on the water and ferrous-iron content of minerals and rocks: Am. Chem. Soc. Jour., vol. 30, p. 1120, 1908. 
Potilitzin and Van't Hoff hold that "soluble anhydrite" will unite with water when exposed to ordinary air in such quantity as to form the half hydrate $\left(\mathrm{CaSO}_{4} \cdot \frac{1}{2} \mathrm{H}_{2} \mathrm{O}\right)$ and that at this point the hydration will cease. Cloez determined the quantity of water absorbed by soluble anhydrite to be 8 per cent, which is slightly in excess of the amount required to form the half hydrate-that is, 6.2 per cent.

W. A. Davis ${ }^{1}$ has shown the work of Cloez to be correct, but if the product is then exposed to dry air it will lose water to such an extent as to leave a resulting material containing water closely approximating the amount required for the half hydrate. From these data it may be concluded that for every 1 per cent of rehydration which has taken place, as shown in column headed "Water reabsorbed," 15.1 per cent of "soluble anhydrite" was present, the remainder having been there in the nonsetting condition.

Results of the same order were obtained from the sample of massive gypsum, though this was not ground so long as the selenite.

The following table is given to show the extent to which the dehydration due to grinding might affect the results of the chemical analysis of a commercial gypsum:

Extent to which dehydration due to grinding may affect analyses of gypsum.

\begin{tabular}{|c|r|r|}
\hline $\begin{array}{c}\text { Water in } \\
\text { coarse } \\
\text { ground. }\end{array}$ & $\begin{array}{c}\text { Water in } \\
\text { fine } \\
\text { ground. }\end{array}$ & Difference. \\
\hline 15.60 & 9.78 & 5.82 \\
20.45 & 16.12 & 4.33 \\
15.15 & 9.90 & 5.25 \\
19.48 & 19.90 & -.42 \\
17.80 & 9.19 & 8.61 \\
19.73 & 19.86 & .13 \\
\hline
\end{tabular}

The material used for the determinations contained in the first column was crushed in a mortar only to a rather coarse powder; no grinding motion was used. These figures represent the true percentages of water held by the impure gypsums. In the second column will be found the percentages of water retained after continued.grinding of fresh portions of the same specimens, and in the third column the errors caused by the long grinding.

Standard methods were used for the determination of $\mathrm{CaO}, \mathrm{SO}_{3}$, etc., with the usual precautions. No difficulties were experienced.

As stated by Van't Hoff, if the dehydration of gypsum takes place below $107^{\circ} \mathrm{C}$. anhydrite is formed without going through the half-hydrate stage. If the crude gypsums referred to in the earlier part of Bulletin 413 were formed by the dehydration of the dihy. 
drate by the action of the desert sun, and if Van't Hoff's conclusions are to be accepted, we might expect to find no half hydrate, but only the original dihydrate and anhydrite. W. A. Davis, however, shows by experiments that dehydration takes place in two stages, the half hydrate being an intermediate product. If this theory is accepted, all three forms may be present.

Le Chatelier ${ }^{1}$.showed that at $155^{\circ} \mathrm{C}$. the dehydration is incomplete, the half hydrate only being formed at this temperature. He states that the reduction to anhydrite requires a temperature of at least $163^{\circ}$ C. Lacroix ${ }^{2}$ claims that gypsum can be completely dehydrated at $80^{\circ} \mathrm{C}$, and Shenstone and Cundall ${ }^{2}$ observed that the water may be entirely driven off at $70^{\circ} \mathrm{C}$.

The allotropic forms in which these compounds may occur, tneir relations one with another, and the contradictory results obtained by numerous experimenters, together with the unknown conditions under which the dehydration or deposition of the crude gypsums referred to took place, throw doubt on any conclusions that would be drawn from an ordinary chemical analysis as to the amount of plaster a particular specimen might yield.

In crude gypsums that have been produced by natural processes under circumstances which are not fully known, either by the dehydration of the dihydrate or by direct deposition in the partly hycrated state, we would expect to find mixtures containing the dihydrate, the half hydrate, and the anhydrate, the last being partly in the soluble and partly in the nonsetting form From the bulk analysis of such material it is not possible to calculate the proportions of these compounds. All that can be done is to indicate the minimum quantity of plaster that might be produced by combining the entire amount of water (about $100^{\circ} \mathrm{C}$.) $)^{3}$ to the dihydrate, providing the material contains sufficient calcium sulphate.

Here again false conclusions may sometimes be drawn, for many, crude gypsums contain admixed clay or other hydrated materials. If impurities of this character are present the amount of plaster the sample will yield, as shown by the above calculation, will appear too high. On the other hand, if the partly dehydrated material contains a quantity of the half hydrate or soluble anhydrite, the figures will. be too low, as both of these forms are capable of producing plaster.

\footnotetext{
1 Experimental records on the constitution of hydraulic mortar.

2 Soc. Chem. Ind. Jour., vol. 26, p. 735, 1907.

${ }^{3}$ See Clarke, F. W., The data of geochemistry, 4th ed. : U. S. Geol. Survey Bull. 695, pp. $218,242,578,1920$.
} 


\section{THE GYPSUM INDUSTRY.}

By R. W. Stone.

\section{HISTORICAL SKETCH.}

Man has known the value of gypsum for certain purposes so long that the date of the discovery of its peculiar properties is unrecorded. The ancient Assyrians used alabaster for sculpture, and the Egyptians 4,000 years ago made plaster from calcined gypsum, the same as the plaster of Paris of the present time. Some of their plaster work done within the pyramids is hard and durable to-day. That the Greeks were familiar with gypsum is shown by the writings of Theophrastus (born 372 B. C.), and Pliny the Elder (23-79 A. D.) spealss of it in his Historia naturalis.

The white rock gypsum known as alabaster has been used in Europe for centuries in the ornamentation of buildings, particularly those devoted to religious purposes, and continues to the present, large quantities being used in Italy for sculpture. Calcined gypsum has had no extensive use until within the past half century, although for several centuries it has been utilized for plaster and for making casts.

Gypsum has been quarried and used in the United States for somewhat more than a century. The advancing tide of settlers found and first used the easternmost deposits - those in central New York-then those in Virginia, Michigan, Ohio, and Iowa. Gypsum was discovered in New York as early as 1792, and a stock company was organized in 1808 to quarry the rock for land plaster, but not until 1892 was the first production of plaster in New York reported. The utilization of the gypsum of Virginia for land plaster.was advocated in 1835. About 1840 the deposits near Grand Rapids, Mich., were discovered, and before 1850 gypsum was being obtained near Sandusky, Ohio. Iowa began to produce gypsum in 1872 and California in 1875 . In 1895 the production of 265,503 tons of crude gypsum was reported from 13 States, and in 1915 eighteen States and Alaska were yielding nearly ten times as much crude gypsum as in 1895 , the amounts ranging from a few thousand tons in some of the States to more than one-half million tons in New York. The output of crude gypsum mined in the United States in 1918 was $2,057,015$ short tons, and the total value of the crude and calcined gypsum sold was $\$ 11,470,854$.

The most rapid development of the industry was between 1898 and 1903, when the increase in production was more than 350 per cent. At that time gypsum wall plaster began to be used extensively. Since its introduction as a building material the increase in use of gypsum for this purpose has been rapid and the industry has grown from $\$ 750,000$ in 1898 to approximately $\$ 11,000.000$ in 1918 . There 
were 57 gypsum mills in the United States in 1918. The largest producers are the United States Gypsum Co., Chicago, Ill., the Acme Cement Plaster Co., St. Louis, Mo., and the American Cement Plaster Co., Chicago, Ill., each operating several mills and quarries in a number of States.

Two gypsum products of recent development, plaster board and gypsum tile, are adding impetus to modern sanitary fire-resistant or protective construction and seem to augur an appreciable increase in the gypsum industry.

\section{PRODUCTION.}

The following table shows the development of the industry:

Crude gypsum mined in the United States, 1880-1918.

\begin{tabular}{|c|c|c|c|c|c|}
\hline \multirow{2}{*}{\multicolumn{2}{|c|}{$\begin{array}{r}\text { Short tons. } \\
\quad 90,000\end{array}$}} & \multicolumn{2}{|r|}{ Short tons. } & \multicolumn{2}{|r|}{ Short tons. } \\
\hline & & 1893 & 253,615 & 1906 & 1, \\
\hline 1881 & 85,000 & 1894 & 239,312 & 1907 & $1,751,748$ \\
\hline 1882 & 100,000 & $1895_{---}$ & 265,503 & 1908 & 1., 721.829 \\
\hline 1883 & 90,000 & 1896 & 224,254 & $1909_{-}$ & , 785 \\
\hline 1884 & 90,000 & $1897 \ldots$ & 288,982 & $1910_{-}$ & $2,379,057$ \\
\hline $18985_{--}$ & 90,405 & $1898_{--}$ & 291,638 & 1911 & 2,3 \\
\hline $1886_{-}$ & 95,250 & 1899 & 486,235 & 1912 & 757 \\
\hline 1887 & 95,000 & $1900_{-}$ & 594,462 & $1913_{-}$ & $2,599,508$ \\
\hline 1888 & $-110,000$ & 1901 & 633,791 & 1914 & $2,476,465$ \\
\hline $1889 \ldots$ & 267,769 & 1902 & 816,478 & 1915 & $2,447,611$ \\
\hline 1890 & 182,995 & 1903 & $1,041,704$ & 1916 & $2,757,730$ \\
\hline 1891 & 208,126 & 1904 & 940,917 & 1917 & $2,696,226$ \\
\hline $1892_{--}$ & 256,259 & 1905 & $1,043,202$ & 1918 & $2,057,015$ \\
\hline
\end{tabular}

PRODUCING LOCALITIES.

Gypsum was mined and calcined in 1919 at plants located in the following places:

Arizona: Douglas.

California: Amboy.

Colorado: Loveland, Portland.

Iowa: Centerville, Fort Dodge.

Kansas: Blue Rapids, Medicine Lodge.

Michigan: Alabaster, Grand Rapids,

Grandville.

Montana: Hanover.

Nevada: Arden, Mound House.

New Mexico: Acme, Oriental.

New York: Akron, Garbutt, Oakfield. Ohio: Castalia, Gypsum, Port Clinton.
Oklahoma: Acme, Eldorado, Okeene, Southard.

Oregon: Gypsum.

South Dakota: Black Hawk, Piedmont.

Texas: Acme, Plasterco.

Utah: Nephi, Sigurd.

Virginia: North Holston, Plasterco.

Washington: Tacoma (using Alaska gypsum).

Wyoming: Kane, Laramie, Red Buttes.

Gypsum from Nova Scotia is calcined at Brooklyn, New Brighton, Newburgh, and New York City, N. Y.; at New Haven, Conn.; and at Chester, $\mathrm{Pa}$.

Twelve plants report the manufacture of Keenes cement, and 28 plants operated by the original producers of the gypsum report making gypsum block, tile, or board. 


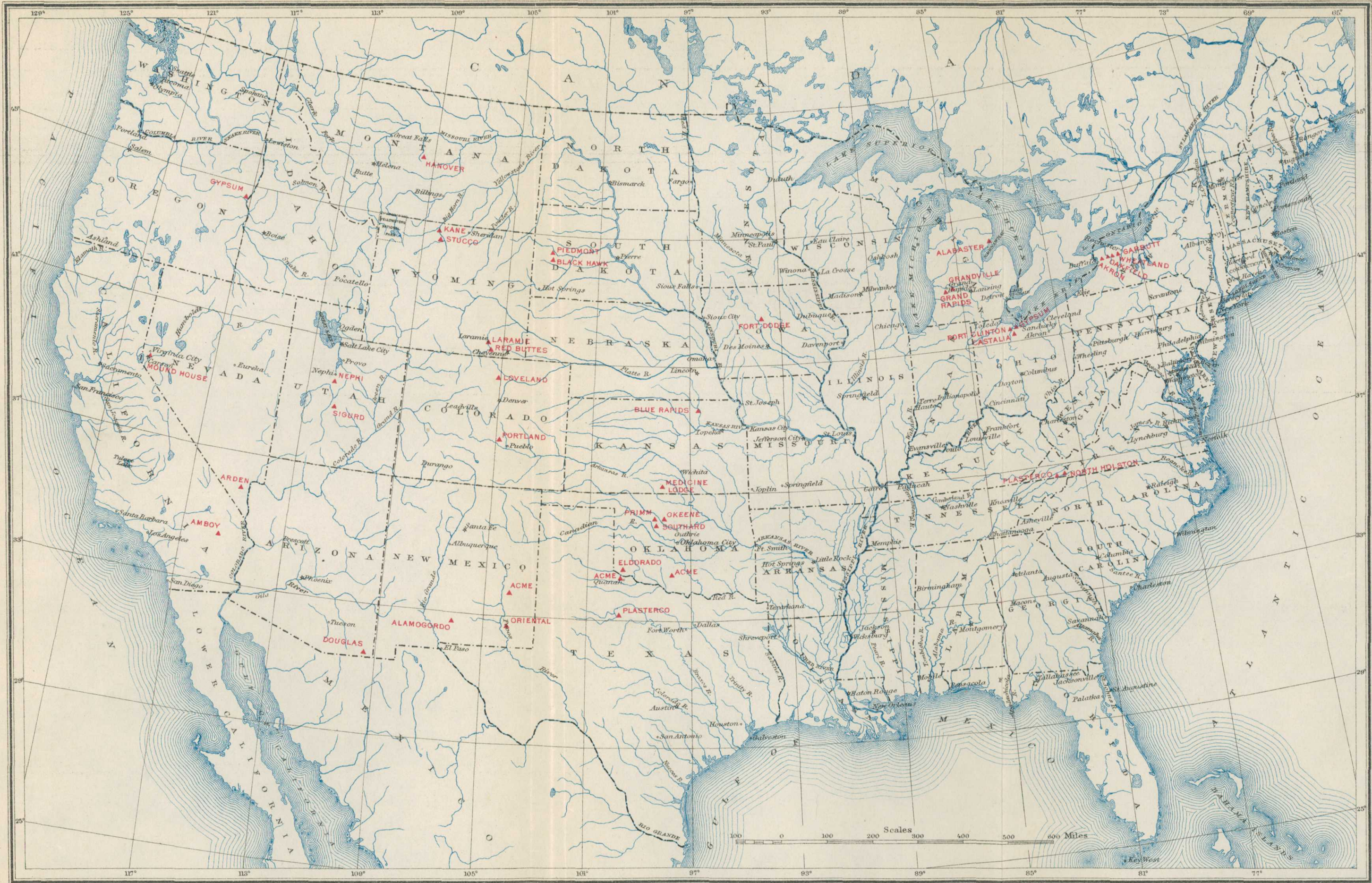


The producing localities are shown on the accompanying map of the United States (Pl. VI). This map shows graphically that the industry is distributed, except in the southeastern part of the United States. South of Ohio River and east of the Mississippi there is only one locality, near Saltville, Va., where gypsum is mined:

At some of the localities listed above the deposits have been worked for many years; at others the development is recent. There are other localities in the United States where gypsum has been mined and calcined but which have been abandoned because of the exhaustion of easily available raw material, burning of the mill, or lack of markets.

\section{PRODUCTION BY STATES.}

Gypsum was produced in 18 States and in Alaska in 1918. New York was the largest producer of raw gypsum, Iowa ranked second, and Michigan was third. Sales of gypsum products are credited to Illinois, Minnesoti, Washington, and Wisconsin, although these States are not producers. This is the necessary result of the trend of the gypsum industry toward assembling calcined gypsum, retarder, fiber, and sand, and preparing plasters for the market at local mixing mills, from which they may be more readily and econumically distributed to the trade territory. Sales reported to the Survey from mixing plants and warehouses are credited to the State in which the plants are located.

Gypsum produced and marketed in the United States, 1918.

\begin{tabular}{|c|c|c|c|c|c|c|c|c|c|}
\hline \multirow{3}{*}{ State. } & \multirow{3}{*}{$\begin{array}{l}\text { Num- } \\
\text { ber of } \\
\text { plants } \\
\text { report- } \\
\text { ing. }\end{array}$} & \multirow{3}{*}{$\begin{array}{c}\text { Total } \\
\text { quantity } \\
\text { mined } \\
\text { (short. } \\
\text { tons). }\end{array}$} & \multicolumn{4}{|c|}{ Sold without calcining. } & \multicolumn{2}{|c|}{$\begin{array}{l}\text { Sold as calcined } \\
\text { plaster. }\end{array}$} & \multirow{3}{*}{$\begin{array}{l}\text { Total } \\
\text { value. }\end{array}$} \\
\hline & & & \multicolumn{2}{|c|}{$\begin{array}{l}\text { Ground for } \\
\text { land plaster. }\end{array}$} & \multicolumn{2}{|c|}{$\begin{array}{l}\text { For Portland } \\
\text { cement, paint, } \\
\text { and other } \\
\text { purposes. }\end{array}$} & \multirow{2}{*}{$\begin{array}{c}\text { Quantity } \\
\text { (short } \\
\text { tons). }\end{array}$} & \multirow{2}{*}{ Value. } & \\
\hline & & & $\begin{array}{c}\text { Quan- } \\
\text { tity } \\
\text { (short } \\
\text { tons). }\end{array}$ & Value. & $\begin{array}{l}\text { Quan- } \\
\text { tity } \\
\text { (short } \\
\text { tons). }\end{array}$ & Value. & & & \\
\hline \multirow{7}{*}{ 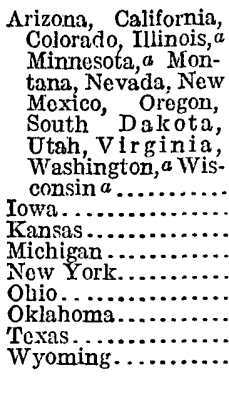 } & \multirow{6}{*}{$\begin{array}{r}18 \\
5 \\
3 \\
8 \\
6 \\
4 \\
4 \\
5 \\
4\end{array}$} & \multirow{6}{*}{\begin{tabular}{r|}
331,395 \\
327,927 \\
54,958 \\
286,768 \\
531,038 \\
199,456 \\
126,208 \\
157,388 \\
41,877
\end{tabular}} & \multirow{5}{*}{$\begin{array}{c}40,428 \\
10,546 \\
(b) \\
5,892 \\
3,139 \\
4,391 \\
\ldots \ldots \ldots\end{array}$} & \multirow{5}{*}{$\begin{array}{c}\$ 159,215 \\
37,823 \\
(b) \\
23,876 \\
14,552 \\
19,277\end{array}$} & \multirow{6}{*}{$\begin{array}{c}71,596 \\
47,173 \\
(b) \\
40,716 \\
179,968 \\
9,614 \\
35,211 \\
(b) \\
(b)\end{array}$} & \multirow{6}{*}{$\begin{array}{c}\$ 168,082 \\
122,325 \\
(b) \\
107,562 \\
442,087 \\
29,295 \\
70,437 \\
(b) \\
(b)\end{array}$} & \multirow{6}{*}{$\begin{array}{r}208,763 \\
218,178 \\
46,710 \\
207,059 \\
275,333 \\
162,626 \\
72,271 \\
129,034 \\
29,813\end{array}$} & \multirow{6}{*}{$\begin{array}{r}81,515,150 \\
1,786,266 \\
343,749 \\
1,629,711 \\
2,213,460 \\
1,191,077 \\
567,207 \\
834,560 \\
195,143\end{array}$} & \multirow{6}{*}{$\begin{array}{r}81,842,447 \\
1,946,414 \\
343,749 \\
1,761,149 \\
2,670,099 \\
1,239,649 \\
837,644 \\
834,560 \\
195,1.13\end{array}$} \\
\hline & & & & & & & & & \\
\hline & & & & & & & & & \\
\hline & & & & & & & & & \\
\hline & & & & & & & & & \\
\hline & & & $\begin{array}{l}(b) \\
(b)\end{array}$ & $\left(\begin{array}{l}b \\
b\end{array}\right)$ & & & & & \\
\hline & 57 & $2,057,015$ & 64,571 & 255,716 & 405,621 & 980,836 & $1,328,269$ & $10,234,302$ & $11,470,854$ \\
\hline
\end{tabular}

$a$ No crude gypsum is produced in the State.

$b$ Somo crude gypsum is included with calcined plaster. 
The sum of the quantity sold without calcining and sold as calcined plaster does not equal the total quantity mined, principally because there is a loss of about 15 per cent by weight in calcining.

In the following table is given by States the quantity of gypsum mined from 1908 to 1918. It shows that New York has been the principal producer since 1909, and Iowa has ranked second since 1911.

Crude gypsum produced in the United States, 1908-191S, in short tons.

\begin{tabular}{|c|c|c|c|c|c|c|}
\hline & & 1908 & 1909 & 1910 & 1911 & 1912 \\
\hline 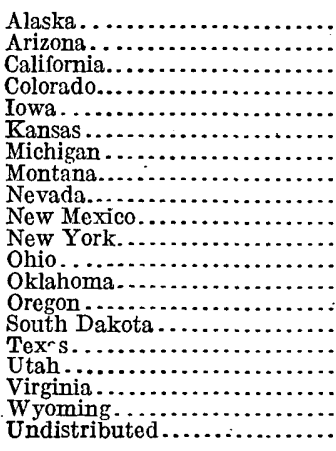 & 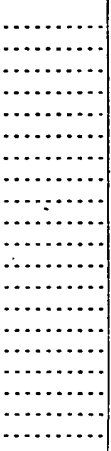 & $\begin{array}{l}(a) \\
(a) \\
(a) \\
(a) \\
240,270 \\
130,184 \\
327,810 \\
\cdots(a) \\
(a) \\
318,046 \\
(a) \\
(a) \\
(a) \\
(a) \\
(a) \\
(a) \\
(a) \\
31,188 \\
674,331\end{array}$ & $\begin{array}{l}(a) \\
(a) \\
(a) \\
(a) \\
319,577 \\
137,697 \\
394,907 \\
(n) \\
(a) \\
(a) \\
403,929 \\
(a) \\
(a) \\
(a) \\
(a) \\
(a) \\
(a) \\
(a) \\
43,745 \\
952,930\end{array}$ & $\begin{array}{l}(a) \\
(a) \\
45,901 \\
45,820 \\
322,713 \\
135,088 \\
357,174 \\
(a) \\
(a) \\
(a) \\
467,339 \\
(a) \\
162,788 \\
(a) \\
(a) \\
188,559 \\
46,279 \\
(a) \\
(a) \\
607,396\end{array}$ & $\begin{array}{c}(a) \\
(a) \\
43,855 \\
26,226 \\
354,204 \\
122,579 \\
347,296 \\
(a) \\
(a) \\
(a) \\
472,834 \\
(a), \\
108,653 \\
(a) \cdots \\
179,625 \\
(a) \\
(a) \\
44,687 \\
624,011\end{array}$ & \begin{tabular}{l}
$(a)$ \\
$(a)$ \\
47,741 \\
$(a)$ \\
411,186 \\
131,031 \\
384,297 \\
$(a)$ \\
122,408 \\
$(a)$ \\
506,996 \\
262,551 \\
135,074 \\
\hdashline$(a)=\cdot$ \\
160,863 \\
$(a)$ \\
$(a)$ \\
36,581 \\
302,029
\end{tabular} \\
\hline & & 829 & $2,252,785$ & 379,057 & $2,323,970$ & $2,500,757$ \\
\hline State. & 1913 & 1914 & 1915 & 1916 & 1917 & 1918 \\
\hline 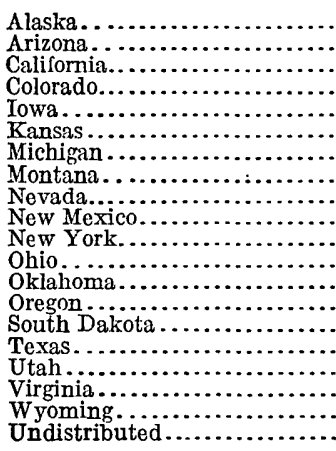 & 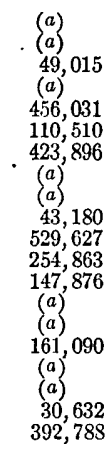 & $\begin{array}{l}(a) \\
(a) \\
27,376 \\
(a) \\
480,404 \\
80 ; 774 \\
393,006 \\
(a) \\
(a) \\
(a) \\
523,368 \\
265,091 \\
113,103 \\
(a) \\
(a) \\
158,814 \\
44,950 \\
(a), \\
31,216 \\
358,363\end{array}$ & 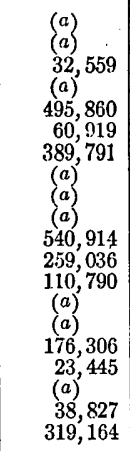 & $\begin{array}{l}(a) \\
(a) \\
32,575 \\
(a) \\
522,293 \\
78,257 \\
457,375 \\
(a) \\
(a) \\
(a) \\
579,527 \\
286,678 \\
161,661 \\
(a) \\
(a) \\
197,785 \\
\cdots(a) \ldots \\
46,964 \\
394,315\end{array}$ & $\begin{array}{l}(a) \\
(a) \\
30,552 \\
(a) \\
461,864 \\
79,331 \\
375,803 \\
(a) \\
(a) \\
(a) \\
606,268 \\
270,538 \\
158,017 \\
(a) \\
(a) \\
257,328 \\
(a) \\
(a) \\
55,844 \\
400,681\end{array}$ & $\begin{array}{l}\left(\begin{array}{l}a \\
a\end{array}\right) \\
(a) \\
(a) \\
327,927 \\
54,958 \\
286,768 \\
(a) \\
(a) \\
(a) \\
531,038 \\
199,456 \\
126,208 \\
(a) \\
(a) \\
157,388 \\
(a) \\
(a) \\
41,877 \\
331,395\end{array}$ \\
\hline & $2,599,508$ & $2,476,465$ & $2,447,611$ & $2,757,730$ & $2,696,226$ & $2,057,01$ \\
\hline
\end{tabular}

a Toavoid giving the production of individual plants, the figures are included under "Undistributed.".

\section{PRODUCTION BY USES.}

The quantity and value of gypsum marketed for different purposes is shown in the following table: 
THE GYPSUM INDUSTRY.

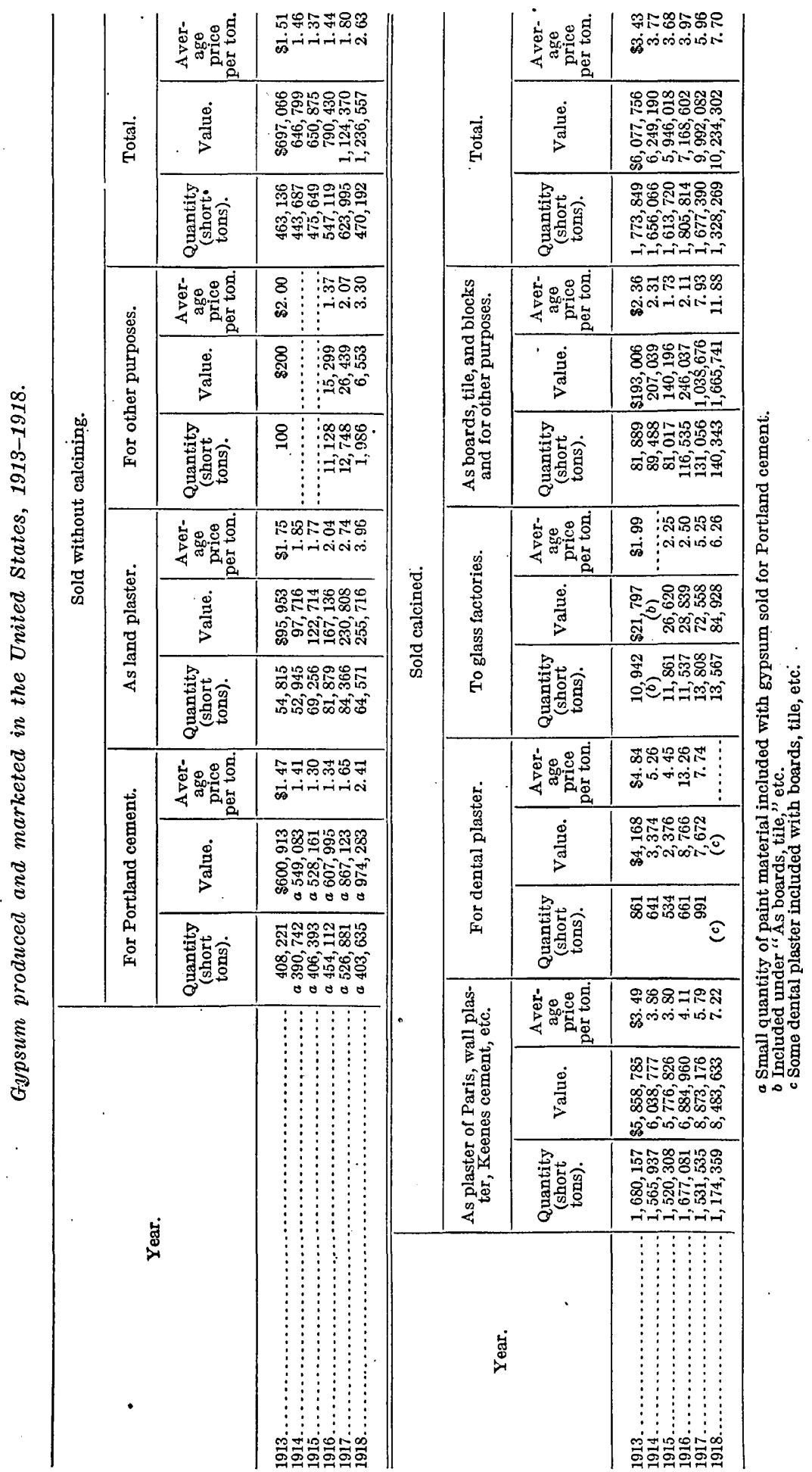




\section{IIMPORTS.}

Gypsum imported into the United States eomes almost wholly from Nova Seotia and New Brunswick and enters the ports of the New England and North Atlantic States, over one-half of it entering the port of New York. The value of imports from 1889 to 1898 averaged about one-third of the value of domestic production, but since 1899 the proportionate value of imports has become very small and seems to be steadily decreasing. It amounted to less than one-twelfth of the value of domestic production in 1913, about one-fifteenth in 1914, and one seventy-ninth in 1918.

Gypsum imported and entered for consumption in the United States, 1913-1919..

\begin{tabular}{|c|c|c|c|c|c|c|}
\hline \multirow[b]{2}{*}{ Year. } & \multicolumn{2}{|c|}{ Unground. } & \multicolumn{2}{|c|}{ Ground or calcined. } & \multirow{2}{*}{$\begin{array}{l}\text { Value of } \\
\text { manufac- } \\
\text { tured } \\
\text { plaster of } \\
\text { Paris. }\end{array}$} & \multirow{2}{*}{$\begin{array}{l}\text { Total } \\
\text { value. }\end{array}$} \\
\hline & $\begin{array}{l}\text { Quantity } \\
\text { (short } \\
\text { tons). }\end{array}$ & Value. & $\begin{array}{c}\text { Quantity } \\
\text { (short } \\
\text { tons). }\end{array}$ & Value. & & \\
\hline 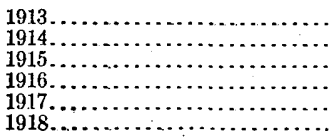 & $\begin{array}{r}447,383 \\
369,214 \\
336,856 \\
254,131 \\
240,269 \\
50,653\end{array}$ & $\begin{array}{r}\$ 473,594 \\
392,118 \\
356,791 \\
275,043 \\
265,504 \\
55,004\end{array}$ & $\begin{array}{r}4,542 \\
3,559 \\
5,749 \\
11,706 \\
16,533 \\
6,117\end{array}$ & $\begin{array}{r}\$ 31,277 \\
27,931 \\
22,873 \\
72,345 \\
109,732 \\
70,028\end{array}$ & $\begin{array}{r}\$ 52,051 \\
24,792 \\
10,095 \\
9,085 \\
6,016 \\
1,765\end{array}$ & $\begin{array}{r}\$ 556,922 \\
444,841 \\
389,759 \\
356,473 \\
381,252 \\
126,797\end{array}$ \\
\hline
\end{tabular}

a Figures compiled from records of the Bureau of Foreign and Domestic Commerce, Department of Commerce.

\section{TECHNOLOGY.}

Mining.-The variety of gypsum commonly used is massive or rock gypsum, which is mined where it occurs in beds several feet thick. The first operation at all properties is quarrying from the outcrop. In some places a flat-lying bed is close to the surface, and quarrying is continued by stripping the overburden; in other places the overburden becomes excessive a short distance from the outcrop, and quarrying gives place to mining, either from adits driven in the quarry face or from shafts. Flat-lying beds are mined by the room and pillar system. Where the gypsum beds dip strongly a sloping shaft follows the bed underground, drifts are run out from it, and the rock is taken by stoping.

Rock gypsum is drilled and shot down with powder, broken into lumps that can be lifted by one man, and loaded into tram cars for delivery to the crusher.

At a number of places in the Western States gypsite or gypsum earth is used instead of rock gypsum. This soft pulverulent material is dug by hand, with horse scrapers, or with gasoline shovel, and hauled to the mill by wagon or tram.

Crusking.-Gypsite is dumped into storage bins and sent to the kettles without further treatment, grinding being unnecessary. Rock 
gypsum is broken in a jaw crusher or nipper, from which it falls into a gyratory crusher. When reduced to pieces the size of coarse corn, it is carried by belt conveyer to a dryer, a large rotating cylinder, slightly inclined from the horizontal. Crushed rock is fed into the upper end and dried by hot gases entering at the lower end. The dry rock is then pulverized in burr, emery, or roller mills or in disintegrators and elevated to storage bins in the top of the building.

Calcining.-In nearly all gypsum mills the pulverized rock is calcined in kettles. A calcining kettle is a hollow cylinder of boiler plate, having a diameter of 8 to 14 feet and a depth of 6 to 10 feet. It has a convex iron or steel bottom. The kettle rests on a masonry fire box and is surrounded by a shell of brick. The gypsum is stirred by an agitator consisting of a gear-driven vertical shaft, to the bottom of which is attached a curved cross arm bearing several stirring paddles. A sheet-iron lid with loading doors covers the kettle.

The gypsum, whether ground rock gypsum or gypsite, is fed slowly into the kettle, which is heated to $212^{\circ} \mathrm{F}$. The temperature is raised gradually and the heat drives off the water of crystallization of the gypsum in the form of steam. The steam passing through the material floats it up and gives it the appearance of boiling. This stage is reached at $230^{\circ} \mathrm{F}$. At about $10^{\circ}$ higher the mass settles down, and if "first settle plaster" is desired, the contents of the kettle are drawn off at once through a gate near the bottom. For "second settle plaster" the temperature is raised, and at $270^{\circ} \mathrm{F}$. the mass begins to boil violently again. At a temperature of about $\$ 50^{\circ} \mathrm{F}$. the material is discharged through a gate into a fireproof bin or on to a floor, where it cools.

At a few mills gypsum is calcined in rotary kilns by the Cummer process. The rock ground by the gyratory crusher to pieces threefourths of an inch in diameter is fed mechanically in regular quantity into a long, nearly horizontal, rotating cylinder, where it is partly calcined by hot gases from a fire box built beneath. Most of the free water is eliminated and some of the water of crystallization. It requires about 10 minutes for the gypsum to pass through the rotary calciner, and during this time it is constantly agitated by falling from lifting blades or shelves. As it leaves the calciner, it is steaming and heated uniformly to the desired temperature, which ranges from $400^{\circ}$ to $600^{\circ} \mathrm{F}$.

The hot steaming rock is elevated to brick or brick-lined calcining bins, which are so constructed that the material in process of calcination is thoroughly ventilated, though the outside air is excluded. The heat carried to these bins by the material from the rotary calciner rapidly disseminates itself through the mass and 
completes the calcining process. To make the process continuous, four bins are required for each plant, the capacity of a single bin being equal to the daily output of the plant. While calcination is being completed in two bins, the third one is being discharged and the fourth is being filled. Plaster made by this process is pulverized after calcination.

In some very large and modern plants, calcining is completed in the rotary kiln, and the plaster goes direct to a cooling bin.

Calcined plaster is screened or bolted, and the oversize is reground in burr mills or pulverizers of other types. After screening and regrinding, the material is elevated to storage bins in the upper part of the mill over the mixing machines.

Mixing.-If pure material has been used this calcined gypsum or plaster of Paris will consist of calcium sulphate plus a residue of about one-fourth of the water in the gypsum. The ideal composition of plaster of Paris is represented by the formula $\mathrm{CaSO}_{4} \cdot \frac{1}{2} \mathrm{H}_{2} \mathrm{O}$, which calls for 93.8 per cent of calcium sulphate and 6.2 per cent of water. Plaster of Paris when mixed with water will set or harden. This is the principal characteristic from which gypsum derives its economic importance. Pure plaster of Paris of normal fineness ( 80 per cent passing 100 mesh) starts to set in about 6 minutes. Therefore in preparing gypsum plaster for the market for most uses a retarder must be added. The retarder commonly used in the United States is composed of hair, caustic soda, and lime. This retarder, together with other materials, such as sand and wood fiber, which may be added to the plaster for various purposes, is usually mixed with the plaster at the mill.

The mixing machine, which as a rule is installed on the first or shipping floor, consists of three parts-at the top a hopper that opens into the floor above, in the middle a mixing chamber in which are paddles that revolve in opposite directions, and below this a sacking chamber with several chutes for filling a number of sacks or bags simultaneously.

From the storage bins the cool calcined plaster is drawn by gravity through chutes to the hopper of the mixing machine. The other ingredients are carefully weighed and are added in the proper proportions, and the contents of the hopper are discharged into the mixing chamber. After mechanical mixing for a few minutes the plaster is dropped into the sacking chamber, from which it is fed into containers. It is then ready for use..

Arrangement and cost of plaster mills.-As plaster mills are generally arranged the rock is received at one end of the mill, where the power plant is located and the crushing is done. The grinding and 
calcining department is in the middle of the building, and the mixing, sacking, and storage space is in the opposite end from the crusher. Local conditions vary the details of arrangement. In some mills the crusher is on the ground floor at the end of the mill nearest the quarry, and the cracker is in an excavation directly below the crusher. In other mills, especially those at a lower elevation than the quarry, the crusher is on the second floor and the cracker below it on the first floor. The kettles, hot pit, power plant, and sacking and storage rooms are also on the ground floor. The second floor is occupied by the tops of the kettles; by the burr mills, and by the charging hopper of the mixing machine. Storage bins for the burr mills, kettles, and mixer occupy the third floor.

Several factors make considerable variation in the cost of $a$ gypsum mill of given capacity. These factors include type of mill, availability and kind of building material, labor, and location with respect to transportation. Estimates of approximate cost of plaster mills, when constructed of wood, including necessary mills, kettles, conveyors, building, and bins complete, ranged in 1916 from $\$ 7,000$ to $\$ 10,000$ for a capacity of 25 tons in 24 hours and a 60 -horsepower steam plant and from $\$ 27,000$ to $\$ 30,000$ for a capacity of 100 tons in 24 hours and a 150-horsepower steam plant. A mill of steel construction, fireproof throughout, having a capacity of 200 tons in 24 hours and requiring a 300-horsepower plant, would cost complete $\$ 75,000$ or more. In 1919 the cost of similar construction would be about double the estimated cost in 1916.

Cost of gypsum plaster.-The cost of producing and marketing gypsum plaster varies considerably, even in different plants operated by the same company: Local conditions affect cost of mining, fuel, and selling, and the season of the year is a large factor as well. Figures given by large producing companies and verified by the writer from their cost sheets are the basis for the following statements.

One company having a single plant reports that for the years 1911-1915 the average cost of production per ton of calcined plaster was \$2.64. This company has cheap power, but the selling cost of the product was at times very high. With large production and low selling cost it has made plaster for $\$ 1.78$, and with these conditions reversed it has cost $\$ 3.43$ a ton.

Two of the largest gypsum companies in the United States furnished the following figures of cost for 1915. The first company gave its average costs and the second its maximum and minimum costs per ton. 
Cost of producing and selling neat gypsum plaster in 1915.

\begin{tabular}{|c|c|c|c|}
\hline & \multirow{2}{*}{\begin{tabular}{c|} 
First \\
company. \\
Average.
\end{tabular}} & \multicolumn{2}{|c|}{ Second company. } \\
\hline & & Minimum. & Maximụm. \\
\hline 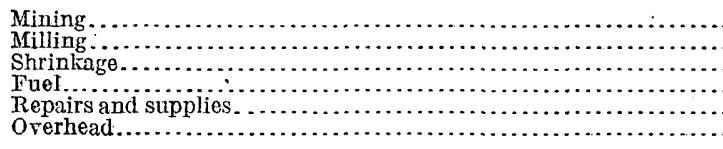 & $\begin{array}{r}\$ 0.65 \\
.85 \\
.15 \\
.50 \\
.25 \\
.60\end{array}$ & $\begin{array}{r}\$ 0.52 \\
.80 \\
.13 \\
.25 \\
.30 \\
.95\end{array}$ & $\begin{array}{r}\$ 1.10 \\
1.25 \\
.22 \\
.35 \\
.40 \\
1.25\end{array}$ \\
\hline & 3.00 & 2.95 & 4.57 \\
\hline
\end{tabular}

On account of the increased cost of labor and of all supplies entering into the manufacture of gypsum plaster, the cost since 1915 has increased more than 80 per cent, but detailed figures are not a railable.

\section{USES OF GYPSUM.}

Uncalcined gypsum.-Nearly half a million tons of gypsum is sold annually without calcining. The bulk of this material is used as retarder for Portland cement. Raw gypsum crushed to pass through a half-inch ring is added to the cement clinker as it comes from the roaster in the proportion of 2 per cent of gypsum to the total quantity of cement. The next largest use of raw gypsum and one of the earliest in this country is as land plaster or fertilizer. It has a very beneficial effect with some crops, especially clover and other legumes. The action of gypsum as a fertilizer is indirect, and not as a plant food itself. It is supposed to act on the double silicate of magnesia and potash, setting those substances free to act as plant food. Land in the Western States which contains black alkali or which upon being irrigated develops it in excess, to the detriment of crops, is made usable by the application of gypsum. The carbonates of soda, potash, and magnesia, which form black alkali, are changed to sulphates, which are less injurious to plants.

Raw ground gypsum or land plaster, if applied freely on manure piles and stable litter, acts as a disinfectant and also retains the ammonia, which is the valuable product of the barnyard manure heap. Cypsum reacts with the ammonia of the manure to form ammonium sulphate. This easily available plant food thereby is not given off into the air nor is it readily washed from the heap by rain, but it is saved until the manure is spread on the land.

Raw ground gypsum is used in making the common blackboard crayon, as base for paints, as a filler for cotton and in nearly all the finer grades of paper, and as a base for mixing with Paris green or other insecticides. It is sometimes added to water used for brewing. 
Raw gypsum and gypsite are used successfully at a few places in arid sections of the Western States as road metal, and gypsum has been quarried in blocks for building material. Fine-grained semitranslucent rock gypsum or alabaster is used by sculptors and artists for statuary and other forms of decoration, but so far as the writei is aware it is not quarried in this country for this purpose.

Calcined gypsum.-The principal use of calcined gypsum, amounting to about a million and a half tons annually, is as wall plaster. All gypsum wall plasters have other materials added to the calcined gypsum either before sacking or just before wetting for use. These plasters, of which there are many brands, commonly known as hard wall plaster, may be grouped in four classes: Cement plaster-calcined gypsum, retarder, with or without hair. Wood fiber plastercalcined gypsum, retarder, wood fiber. Prepared plaster-calcined gypsum, retarder, sand, hair or wood fiber. Finishing plastercalcined gypsum, with or without retarder, with or without hydrated lime.

These plasters are used in the ordinary manner for covering walli; and ceilings, being spread on wood or metal lath, plaster board, tile, concrete, or other masonry. Because it is a poor conductor of heat: and cold gypsum plaster is used as an insulating medium in coldstorage buildings, around steel frames of buildings. and as a covering for heating plants and water pipes.

An industry of recent development which is growing rapidly is the making of gypsum plaster board, tile, and blocks.

Gypsum plaster boards are of various types, mainly consisting of gypsum plaster mixed with fibrous binding material to give strength 'and toughness for effective nailing. A type of plaster board in common use consists of four alternate layers of paper or felt with three intermediate layers of gypsum. Other boards contain but two layers lof felt with a gypsum layer between. In order to meet the joist and stud spacing of standard construction, plaster boards are usually 32 by 36 inches ( 8 square feet) and are made one-fourth, threeeighths, and one-half inch in thickness. The fibrous binding material forming the outside surface of the plaster boards is an excellent bonding surface for gypsum plaster. Plaster boards are used in place of wood or metal lath on surfaces that are to be plastered. and where high fire-jesistive construction is required. In fireproof: construction the plaster boards are fastened to metal studs or hangers by metal clips. Plaster boards are used for deadening sound by being laid between rough and finished floors; as sheathing boards by being nailed to the studding and behind the clapboards; as outsicle shenthing, which is waterproofed before application of outside stucco cov- 
ering; as insulation and fire resistance under wood shingles, in air ducts, and in dumb-waiter shafts.

Gypsum floor screeds are used as a nailing sleeper for floors. They are 2 by 3 inches and 8 feet long and weigh 2 pounds per linear foot. They do not rot or burn.

Gypsum tile is made for partitions, floors, roofs, and furring. Partition tile, solid or hollow, is 12 by 30 inches wide and 2 to 8 inches thick. These tiles, laid with gypsum plaster, are used in the highest type of fireproof building for dividing and corridor partitions, in elevator and stairway inclosures, and in dumb-waiter shafts; they are light in weight, can be laid very rapidly, can be cut with a handsaw, and, when plastered with gypsum, make partitions of high heat-resistive value.

Gypsum floor tile is a hollow box or dome of reinforced gypsum plaster, used as a filler between concrete joist construction. These tiles are 19 inches wide and 24 inches long, 7, 9, 11, and 13 inches high, and weigh $24,27,30$, and 33 pounds per linear foot; they afford a saving in dead weight of construction and provide a smooth, allgypsum ceiling to plaster upon.

Gypsum roof tile is made 24 and 30 inches long, 12 inches wide, and 3 inches thick and is laid between supporting subpurlin $T$ irons. Larger gypsum roof tile, reinforced and made of especially hard gypsum, are made to span 4 feet and are laid upon the main roof purlins. In 1916 a long-span beam in $T$ and $I$ section and as much as 10 feet in length was introduced and used. In 1917 an improved long-span gypsum tile with channel( $\sqcap$ ) section was introduced, gained favor, and is being used on factory roofs of large area and on large Government buildings, including naval gun shops, ammunition warehouses, and docks. The tile are made with reinforcing metal fabric on the broad face and reinforcing rods looped at the ends embedded in the sides. The tile are 15 to 22 inches wide, 6 to 10 feet long, 4 to 7 inches thick, and weigh 16 to 20 pounds per square foot. They require less supporting steel than concrete roof decks and are quickly put in place at a low cost of erection. Common practice is to mold 6 -foot tile at the mill, and to mold longer tile where the building is to be erected. For field molding, however, an order of at least 50,000 square feet may be required.

Another type of gypsum roof deck is that which is cast in place, in the same manner as concrete. A roof cast in place is best poured in strips about 3 feet wide. One side of the strip must be bulkheaded and to the proper height, so that a screed moved along it will true the gypsum to the proper surface. Metal reinforcing rods may be placed in each T-beam stem and a 3-foot strip of wire mesh over the top. The finished deck is monolithic and can be corered with 
any type of roofing. The low heat conductivity of gypsum is an especially valuable quality in a roof deck. Slate or any other roof covering can be nailed or otherwise secured to the smooth decks of gypsum roof tile.

Gypsum furring tile are of the same character and general dimensions as the partition tile, are hollow or solid, and are 2 inches thick. They are fastened to the wall by nailing and are used for sound absorption and soundproofing, fire protection, insulation from heat or cold, and damp proofing.

Other uses for calcined gypsum which have been in practice longer than those just described are in making statuary and other art work, relief maps and models, molds for rubber stamps, molds for pottery and terra cotta, in bedding plate glass for polishing, in foundry molds for special castings, and in making surgical casts. Calcined gypsum enters into the composition of match heads, hat blocks, relief decorations for walls and ceilings, and asbestos pipe covering, and it is used for various other purposes. 



\section{PART II. GYPSUM DEPOSITȘ.}

\section{ALASKA}

- By E. F. Burchard.

The only known extensive deposit of gypsum in southeastern Alaska is operated by the Pacific Coast Gypsim Co. and is situated in the eastern part of Chichagof Island, about a mile from Iyoukeen Cove. Carboniferous rocks are exposed along the southeastern shore of the cove and form the divide on the southwest side of the valley. The gypsum beds apparently overlie these rocks and are tentatively assigned to late Carboniferous (Permian) formations. In the immediate vicinity of the gypsum beds cherty limestone strikes northwest and dips northeast, and in the mine the gypsum beds strike east and $\operatorname{dip} 20^{\circ}-60^{\circ}$ N. The mountain to the north is a granite mass intruding the limestone beds. The gypsum occurs in the bottom of a valley, but as the valley is deeply filled with gravel deposits the limits of the gypsum have not been ascertained. The deposit is covered by gravel, except near the shaft house, and no footwall nor hanging wall has been encountered in the mine workings. Several solution channels, filled with gravel that is more or less cemented, have been penetrated in mining. The gravel is of the same character as that in the bed of Gypsum Creek. The gravel-filled channels extend below the 160 -foot level. One channel has been tunneled for 35 feet without being cut through. Thin dikes of basaltic rock cut the gypsum beds, and a vein of anhydrite ranging in thickness from 6 inches to more than 10 feet has been found on the second level. This anhydrite is much harder than the inclosing gypsum, and it is left in the mine. Some of the gypsum is white, but most of it in the upper part of the mine is of a light bluish-gray color. It occurs in massive beds, which $\operatorname{dip} 30^{\circ}-60^{\circ} \mathrm{NE}$. The main body of gypsum has a high degree of purity.

The mine shaft is 315 feet deep. The first level is at 75 feet, the second is at 160 feet, the third at 300 feet, and there is a 15-foot sump. For 11 years the company mined on the second level and developed extensive galleries. Early in 1917 the shaft was sunk to a depth of 315 feet and mining begun on the 300 -foot level. Mr. W. R. Nichols, president of the company, and D. C. Stapleton, su- 
perintendent of the mine, report that the new workings have developed an extensive massive body of pure-white rock gypsum of superior quality. The general trend of the gypsum deposit is slightly north of west. Mining is by overhand stoping, and considerable broken gypsum rock is stored in the stopes.

The gypsum is hoisted to rock bins of 1,200 and 2,500 tons capacity. . The larger bin was completed in 1917. From the bins it is dumped into tramcars and drawn by steam locomotive to the wharf, where there is bunker capacity of 2,000 tons. The production of gypsum from this mine began in 1906. Shipments of crude gypsum are made by barges to Tacoma, Wash., where the material is calcined and manufactured into wall plaster of various grades and into plaster board and plaster blocks.

Other claims which have been located on reported deposits of gypsum adjoin on the east the claims now being worked for gypsum by the Pacific Coast Gypsum Co. and extend to the shore of Chatham Strait. 


\section{ARIZONA.}

By R. W. Stone.

\section{DEVELOPIVENT AND CHARACTER.}

Gypsum deposits in Arizona have been worked but little because of small demand within the State and because of an abundance of gypsum in adjoining States to meet the local needs. Most of the readily accessible deposits in Arizona were visited by the writer in September, 1916. At that time Douglas was the only place where gypsum was being mined and milled. The deposits visited includa gypsite, selenite plates, and massive gypsum, and widely differ in origin.

Most of the known gypsum localities are in the southeastern part of the State. Their description is arranged by counties.

\section{IOCALITIES:}

\section{COCHISE COUNTY.}

Douglas.-A deposit of gypsite in sec. 11, T. 24 S., R. 28 E., which is 5 miles east of Douglas and $1 \frac{1}{2}$ miles north of the international boundary, is the source of raw material for the Arizona Gypsum Plaster Co. The gypsite lies on a gently sloping plain on the north side of a low hill. The area of workable deposit is estimated at 100 acres, and the thickness is in places nearly 6 feet. The gypsite is underlain by reddish clay containing selenite crystals one-fourth inch long and in places by a limy rock (caliche).

The gypsite is light buff and is free from impurities except at the surface, where there is soil and vegetable matter. The top is therefore plowed up and scraped off into old workings. Horse scrapers are used for digging the gypsite and moving it to traps through which it is dumped to wagons below. (See Pl. VII, A.) It is hauled by team 5 miles over a good road down grade to the mill at Donglas for 3 cents a cubic foot. A small body of gypsite is reported in the southern part of sec. 14 and another between secs. 14 and 15, T. 24 S., R. 28 E. There is said to be a large deposit just over the line in Mexico.

The preparation of plaster at the mill of the Arizona Gypsum Plaster Co. is particularly simple. Loaded wagons are dumped directly into storage bins from an overhead trestle (Pl. VII, $B$ ). Screw and bucket conveyers move the material to bins over two 8 -foot kettles. These kettles and the engine boiler are fired with oil. After calcining, which takes about four hours, the plaster is elevated by bucket conveyer to a bin in the top of the mill. From this bin 
it flows to a revolving tubular fine wire screen, which removes foreign material and lumps of gypsum. From this screen the plaster flows directly to a bin over the mixer and sacker. There is no grinding machinery; the raw material is dumped directly into the calcining kettle, and the plaster is sacked after screening only.

Besides wall plaster this company makes solid and hollow gypsum plaster tile and blocks. The tile are used for partitions, roofing, and backing brick veneer; the blocks are used for walls, both interior and exterior. Blocks are made with either smooth, corrugated, or imitation rough stone face, and have been used for a number of years in Douglas as the main structural material in some houses, warehouses, and stores. The arid climate of southern Arizona makes possible the successful use of gypsum for exterior construction. A gypsumblock structure is estimated to cost 25 per cent less than brick, because cheaper labor can be used and the large size of the blocks makes walls go up faster. Blocks are made as large as 8 by 12 by 24 inches.

The Douglas Gypsum Block \& Plaster Co., beginning in August, 1918, made gypsum products, mostly in the form of cast building blocks. Gypsite from a deposit 5 miles east of Douglas was used. Operations began with one kettle.

Benson.-Reports of extensive gypsum deposits at Benson were not confirmed by a visit to this railroad junction in the valley of San Pedro River. Two miles south of Benson and one-third of a mile west of the Benson-St. David highway there is a place in the bluff forming the valley rim where gypsum crystals are abundant. The locality may be recognized by boulders of grit 2 to 3 feet in diameter near the top of the bluff. The crystals, which are for the most part aggregates of platy selenite smaller than a man's hand, occur in red clay, which at this point underlies a grit that outcrops in the boulders already mentioned. Where the crystals have weathered out in greatest number not more than a few bushels could be raked up. In other words, the deposit has no value.

There is, however, a deposit about 9 miles south of Benson, which is similar to others in this river valley.

Land.-About 9 miles south of Benson and 1 mile west of Land, a station on a branch of the El Paso \& Southwestern Railroad, there is a deposit of gypsum on which mining claims have been located. A company was formed and stock sold in it, but the writer failed to find any development work other than a little prospecting. The mesa is composed of clay, caliche, soft sandstone, and gravel, and in the bluff which forms its edge gypsum is exposed. Likewise the small outlying knobs and knolls are underlain by gypsum. These deposits are probably of Pliocene or post-Pliocene age. The plaster rock, however, is so deeply weathered, and partly concealed by wash from the overlying soft strata, that without digging the character 


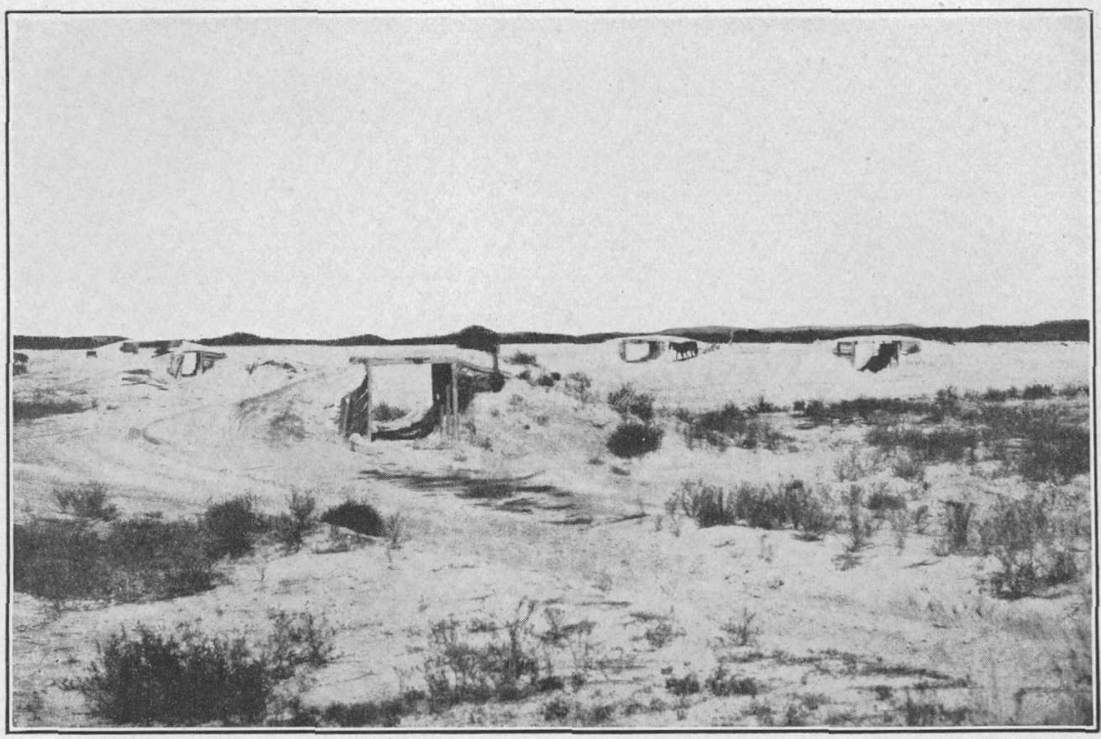

A. GYPSITE DEPOSIT, DOUGLAS, ARIZ.

Loading is done by horse scrapers that dump through platform to wagon below. Photograph by R. W. Stone.

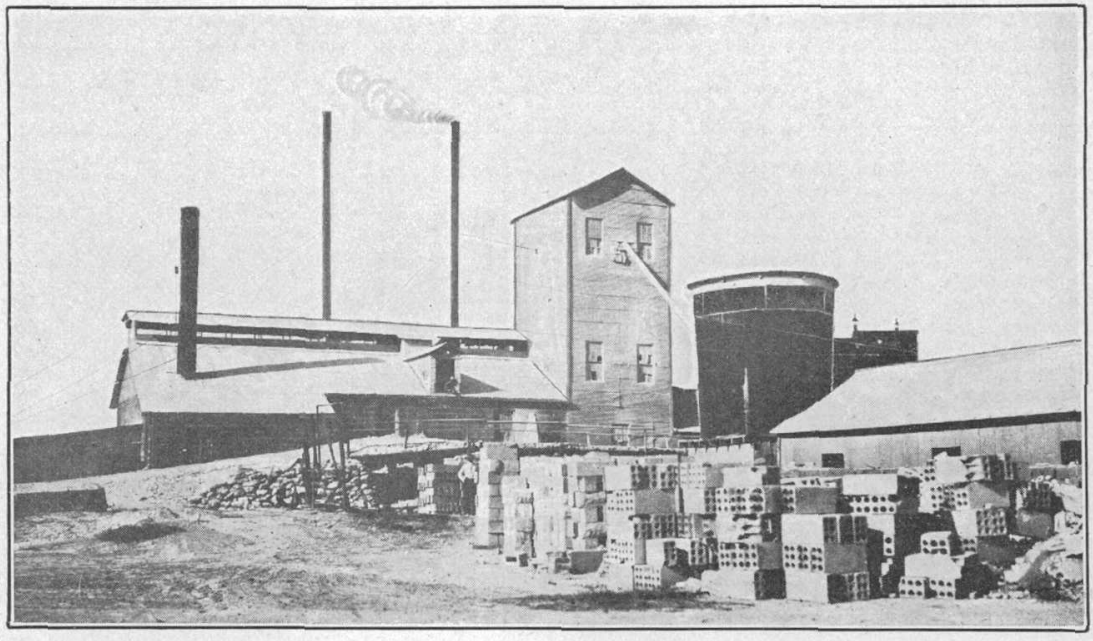

B. MILL OF ARIZONA GYPSUM PLASTER CO. AT DOUGLAS, ARIZ.

Gypsum block and tile yard in foreground. Photograph by R. W. Stone. 


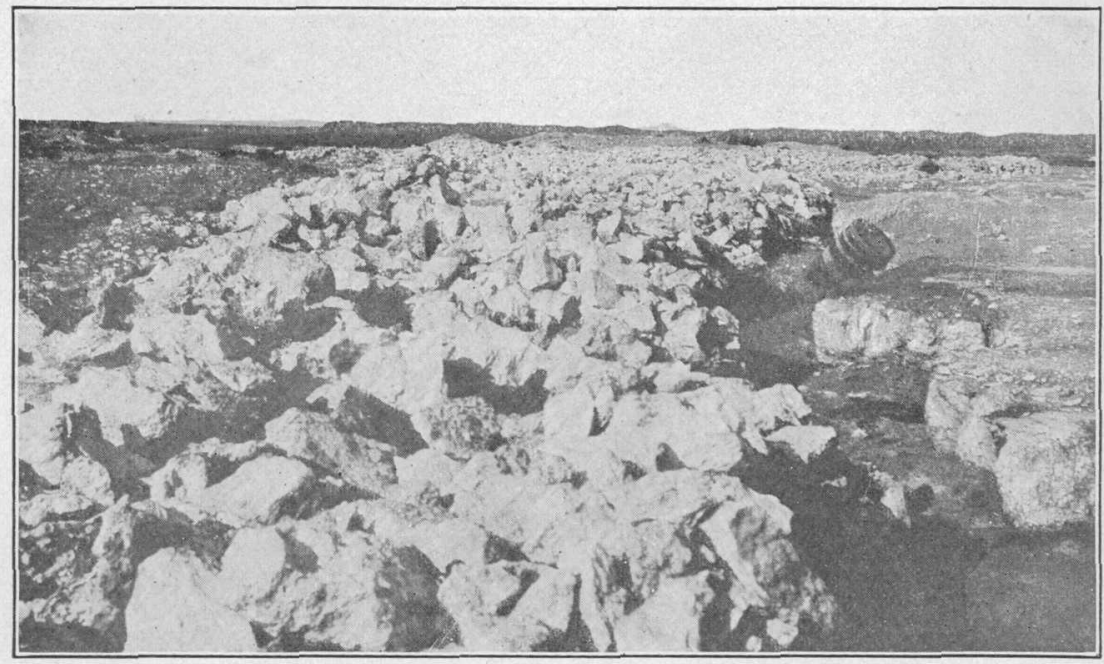

A. GYPSUM QUARRY 3 MILES WEST OF WINSLOW, ARIZ.

At this quarry very little stripping is required. Ledge from which gypsum is blasted is shown on left. Photograph by R. W. Stone.

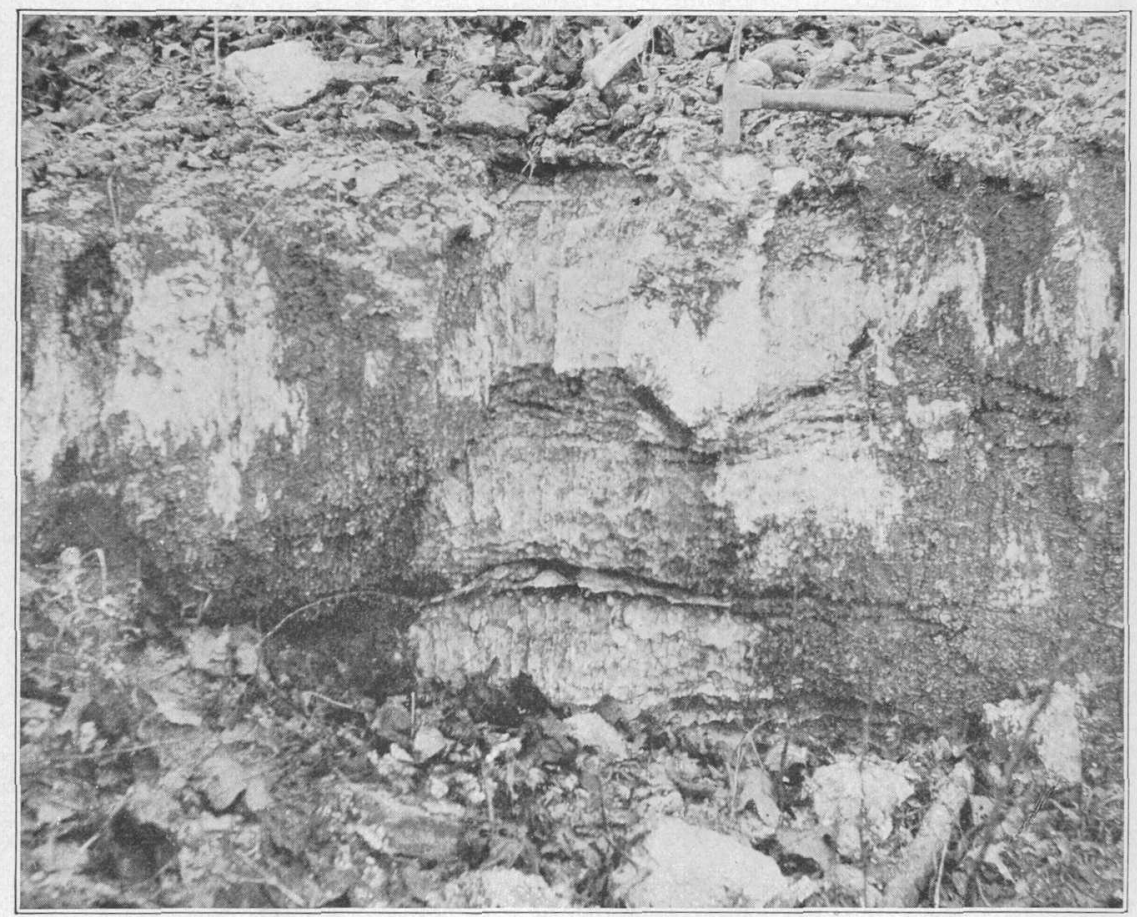

B. GYPSUM BED AT PLASTER BLUFF, ON LITTLE MISSOURI RIVER 3 MILES SOUTHSOUTHWEST OF MURFREESBORO, ARK.

Photograph by J. A. Taff. 
and thickness of the deposit could not be determined. General indications point to a bed about 10 feet thick. The outlying knobs containing gypsum have very little overburden and small acreage. Recovering gypsum from the main borly under the mesa would seem impracticable by reason of the overburden, which probably would increase in thickness back from the outcrop. Small selenite crystals: are abundant in the soil in this vicinity.

Whetstone Mountains:-In discussing the agriculture of the bottom land of San Pedro River near Santa Catarina and the application of gypsum to the soil Oscar Loew ${ }^{1}$ says: "This useful mineral is found in the neighboring Wheatstone Mountains." This reference probably is to the Whetstone Mountains, a few miles south of Benson, but no information has been obtained in regard to the deposits.

\section{MOHAVE COUNTY.}

W. T. Lee observed an abundance of gypsum in Virgin Valley and mentions ${ }^{2}$ it as follows:

The filling of this old valley is apparently composed of two distinct formations, but their relation was not satisfactorily determined. The older one consists of alternating layers of sand and clay and contains extensive beds of gypsum. * * * The gypsum and gypsiferous clay are conspicuously exposed along the river, where they are deeply dissected over a large area locally known as the badlands of the Virgin.

While at St. George, Utah, the writer was informed that thick ledges of massive gypsum are extensively exposed in South Mountain and in Quail Canyøn, 15 to 20 miles south of St. George. This locality is in the extreme northern part of Mohave County and west of Hurricane Cliff.

\section{NAVAJO COUNTT.}

Gypsum occurs in the form of selenite in plates of considerable size on the Fort Apache Reservation, in Navajo County. It is said to occur at three places in such quantity that it might be used in the construction of houses for the Indians.

Winslow, on the Atchison, Topeka \& Santa Fe Railway, in Navajo* County, was for a number of years the shipping point for gypsum quarried in the vicinity. The raw rock was used at the Portland cement plant at Riverside, Calif., and some was calcined at Los Angeles. Shipments were discontinued in 1914, owing, it is said, to an increased freight rate. The deposit lies on both sides of the railroad $3 \frac{1}{2}$ miles west of town. Holdings of the Acme Cement Plaster Co. in sec. 15, T. 19 N., R. 15 E., are said and appear to be worked out. A much larger tract in secs. 16 and 21 and neighboring

\footnotetext{
1 U. S. Geog; and Geol. Surveys W. 100th Mer. Final. Rept., vol. 3, p. 591, 1875.

${ }^{2}$ Lee, W. T., Geologic reconnaissance of a part of western Arizona: U. S. Geol. Survey Bull. 352, p. 36, 1908.
} 
sections of the same township is held by the Navajo Gypsum \& Fertilizer Co. It is reported that this deposit extends nearly 5 miles south from the railroad in a belt that is in places more than a mile wide. The gypsum is flat lying and close to the surface and needs only a little stripping. Both companies when operating obtained their rock by the same method. Large blocks of gypsum were blasted from the ledge (as shown on Pl. VIII, $A$ ), broken with sledges to lumps that could be lifted by hand, and loaded on tram cars for delivery at the loading platform on the railroad siding. The Navajo company used steel cars, which were hauled on the half mile of track. between the quarry and the railroad by gasoline engine.

The bed, which lies flat, is from 4 inches to 4 feet thick and averages about 18 inches. It rests on red shale and is overlain in places by green shale in which there are many veinlets of satin spar. Much of the gypsum seen at Winslow by the writer has a slight greenish tinge due to mottling by some green claylike. mineral scattered through the white gypsum. The rock approaches alabaster in fineness of grain. It occurs in red shale and sandstone of the Moencopie. formation, probably of Permian age.

Deposits of gypsum are reported to have been slightly developed. in the vicinity of Woodruff and Snowflake, but they are not now operated and no description can be given of the occurrences.

\section{PIMA COUNTY.}

Serritas Mountains.-It has been reported that in the Serritas. Mountains south of Tucson gypsum occurs with the copper ore deposits of the Azurite group. Inquiry of several mining men, including Mr. Ray, owner of the Mineral Hill mines (Azurite group), and the mineralogist at San Xavier mine, failed to substantiate. this report.

Santa Rita Mountains.- $\dot{A}_{\text {; }}$ gypsum locality described as in the. Santa Rita Mountains "not far from Rosemont" probably is the. locality in which gypsum occurs near the Total Wreck mine on the east side of the Empire Mountains and 10 miles south of Pantano, a station on the Southern Pacific Railroad. Mr. Carl Schofield, forest ranger, at Rosemont, and mining men familiar with the region have no knowledge of gypsum in the Santa Rita Mountains.

Empire Mountains.-According to Hatcher, Carpenter, and Andrus, mining engineers of Tucson, there is a deposit of gypsum in the Empire Mountains, 10 miles by road from Pantano, and at an elevation of about 1,000 feet above that station. In a limestone ridge parallel with a northeast wash, there are two gypsum beds, each about 50 feet thick and separated by a thin bed of limestone. These beds outcrop for about a mile and are composed of soft granular gypsum, mostly white but some cream-colored. The soft 
gypsum contains layers of alabaster 6 to 8 inches thick. The beds strike northeast with the ridge and dip southeast at a high angle. An analysis of this gypsum, made by Hatcher, Carpenter, and Andrus, is given in the takle on page 28 . The age of the gypsum beds is believed to be late Carboniferous.

.Tucson.-In the earlier report on gypsum in Arizona W. P. Blake ${ }^{1}$ says:

The locality north of. Tucson, in the foothills at the western end of the Santa Catalina Range, has afforded a supply for the production at Tucson of: plaster of Paris of good quality, which has been used locally in construction. A considerable quantity of the product was used in making the interior decorations of the cathedral. The crude rock is brought in from the quarry by Mexican teamsters, and little is known in regard to the geologic position of the deposit. It is probable that it occurs in strata of Triassic age, flanking the ancient gneiss of the mountains.

The writer made diligent inquiry at Tucson regarding this locality without success. Doubtless there was such a quarry years ago, but its existence is not known to the present mining men. There is a locality on the west side of the Santa Catalina Range where E. L. and Ralph. Wetmore of Tucson have discovered and sunk prospect pits on a bed of gypsum. This locality, however, does not seem to be the one mentioned by Blake, because it is not at the end of the range nor did the Wetmore brothers find evidences of former quarrying.

The Wetmore deposit is in sec. 3, T. 13 S., R. 14 E., about 8 miles northeast of Tucson and three-quarters of a mile south of Alamo Spring, which is shown on the topographic map of the Tucson quadrangle. The place is reached by a road which crosses Rillito Creek at the University farm. Gypsum is exposed on the east side of a wash and close under the north end of a low ridge which terminates in a 50 -foot bluff. Two pits have been sunk 8 to 10 feet and a third one 5 feet. Some of the rock was hauled to the experiment farm of the University of Arizona for use on a patch of black alkali soil.

In one of these pits there is $4 \frac{1}{2}$ feet of gypsum in a deposit a little over 6 feet thick. The top of the bed is at the surface and the pit passes into red clay below.

Section of gypsum bed 9 miles northeast of Tucson.

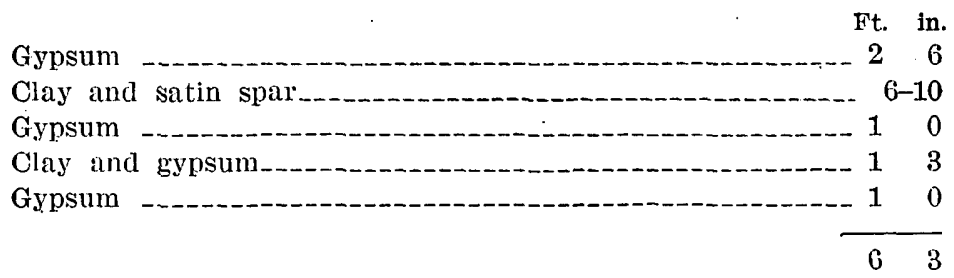

1 Blqke, W. P., Gypsum deposits in Arizona: U. S. Geol. Survey Bull. 223, pp. 100-101, 1904. 
The gypsum is massive, light-brown to: white, slightly porous, and contains veinlets of satin spar. Veins of satin spar in the clay are pure white. A nearly vertical fault, passing through this pit, has a throw of about 10 inches. One side of the shaft is shown in the accompanying diagram (fig. 1).

Only a few feet away is a pit about 5 feet deep, which discloses the edge of the deposit. The layers terminate with rounded edges, and each is shorter than the next above, producing a bevel underneath. The under surface of the lowest layer is irregular with hollows, cups, and small downward-projecting knobs, as if it had been attacked from below by a solvent. The accompanying diagram (fig. 2) shows these features.

Beneath and along the edge of the deposit is red clay with faint

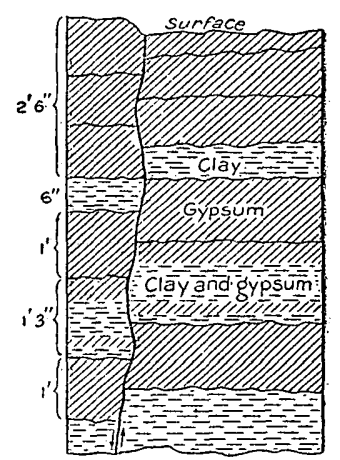

Figure 1.-Diagram showing faulted gypsum bed near Tucson, Ariz.

lines of bedding which follow roughly the curves of the beveled edge. Veinlets of satin spar in the clay have a similar trend. The conditions suggest undercutting and solution by running water and subsequent burial in mud.

If this deposit of gypsum extends back under the adjacent low ridge on the south, it underlies an area of several acres. No prospecting has been done, however, to determine its lateral extent. Several small hummocks in the wash consist of highly gypsiferous earth or red clay with abundant satin spar in minute irregular veins.

The formation in which the gypsum oecurs is red clay and semiconsolidated beds of sand and gravel. It forms a long, gently sloping apron at the base of the Santa Catalina Range, from which the material doubtless was derived. Arroyos and gulches dissect this apron, and in one of these the gypsum is exposed. The age of the deposit is supposed to be Quaternary.

PINAL COUNTY.

Areas along San Pedro River.-Concerning gypsum in one of the main valleys of southeast Arizona, W. P. Blake ${ }^{1}$ said:

The gypsum along San Pedro River- occurs in horizontal beds, probably of Pliocene or post-Pliocene age. The strata are soft, unconsolidated gray sandstones and clays and appear to be the lower members of the same series in which the beds of diatomite and volcanic ash are found. The gypsum is interstratified conformably in comparatively thin layers or seams, rarely more than a few inches in thickness. These layers appear to have been formed

${ }^{1}$ U. S. Geol. Survey: Bull. 223, p. 100, 1904. 
subsequent to the deposition of the strata by crystallization from the infiltration of gypseous solutions. The mineral occurs as selenite and also in the fibrous form, as satin spar.

This description seems to fit the occurrence of selenite crystals near Benson, already described (p. 50), and is applicable to other cleposits which doubtless occur at many places along the bluff of San Pedro River valley in Cochise and Pinal counties. There are, however, other deposits of gypsum along this river which are much more worthy of mention.

Prof. G. E. P. Smith, of the University of Arizona, at Tucson, told the writer that gypsum occurs in thick beds in a high bluff along San Pedro River in the extreme southeast corner of Pinal County, a few miles north of Redington. The writer did not visit the locality, and Prof. Smith's observation was only a casual one, so no details of the occurrence are at hand. It is as- . sumed from its location and from the occurrence of gypsum at Feldman, about 25 miles farther down the river, that the deposits near Redington are massive white, finely granular gypsum in semiconsolidated Quater nary sediments and possibly several square miles in area.

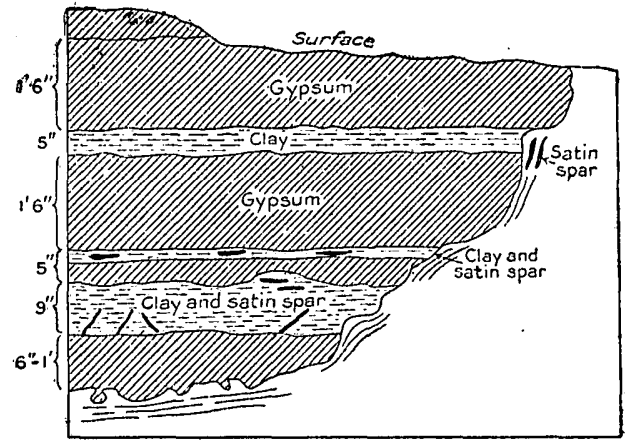

Figure 2.-Diagram showing edge of gypsum bed near Tucson, Ariz.

Feldman.-At the solitary ranch and post office of Feldman, 10 miles south of Winkelman, in sec. 33, T. 6 S., R. 16 E., there is a deposit of gypsum on both sides of San Pedro River. The attention of the writer was called to it by the following statement of Frank $\mathrm{L}$. Culin, jr., ${ }^{1}$ in a bulletin of the University of Arizona :

Another deposit has lately been discovered near Winkelman, Pinal County. United States Geological Survey men say that this deposit is the largest and most extensive deposit of high-grade grpsum in the United States. This deposit will probably be worked in the near future.

The United States Geological Survey was then unaware of this occurrence, and far more extensive deposits of high-grade gypsum have long been known in several States.

Mr. W. E. Duffy, mining engineer, Phoenix, Ariz., is authority for the statement made orally to the writer that gypsum occurs on the west side of San Pedro River at Feldman but in much less quantity than on the east side of the river.

${ }^{1}$ Culin, F. L., jr., Gypsum : Arizona Univ. Bull. 19, Mineral Technology Ser. 10, p. 7, 1.916. 
The deposit on the east side of San Pedro River at Feldman was seen by the writer in September, 1916. It outcrops in the low bluff that separates the valley bottom from the bench land and in the gullies which dissect the bench. The gypsum is soft and deeply weathered at the surface, so that it makes only a faint rim in the sides of the washes. Because of this weathered condition and for lack of complete exposures, either natural or artificial, the thickness of the deposit was not measured; that part of it which lies nearest to Feldman appears, however, to be 30 feet thick. It is reported that a shaft sunk 20 feet in the gypsum did not reach the bottom of the deposit. Through failure to find the shaft, the whereabouts of which is not known to the local residents, this statement was not verified.

From an elevation several feet above the gypsum a gray outcrop, believed to be the continuation of the deposit, was seen 2 or 3 miles to the east. It was reported by $\mathrm{Mr}$. Feldman that it extends along the road 3 miles, beginning nearly 2 miles north of Feldman post office and fully 3 miles east of the road. In other words, a considerable part of the southeast quarter of the township was once underlain by gypsum. Much of the original deposit has been removed by the cutting of gullies which dissect the bench land.

Near the road, and apparently farther east also, the deposit is overlain by unconsolidated gravel. For the most part the overburden is only a few feet thick. The underlying beds were not seen. The deposit is believed to be of Quaternary age.

It is reported that a company was formed and stock sold for the commercial development of this gypsum. The rock was to be hauled by wagon to Winkelman and shipped by train to a mill 5 miles east of Phoenix for grinding, but although some gypsum was hauled to the railroad it was never shipped. The likelihood of the successful commercial development of this gypsum deposit under present conditions, several miles from a railroad and far from a market, seems remote, although the gypsum, as shown by float specimens found in the gully bottoms, is massive, pure white, and apparently of good quality. 


\section{ARKANSAS.}

By H. D. Miser.

Gypsum crops out in Arkansas, so far as known, only in Pike and Howard counties, in the southwestern part of the State. Within these counties it is confined to the De Queen limestone member, in the upper part of the Trinity formation, which is of Lower Cretaceous age. This limestone, as well as the rest of the Cretaceous rocks in this region, dips at a low angle to the south and is exposed in a narrow belt extending westward from Plaster Bluff, on Little Missouri River, 3 miles south-southwest of Murfreesboro, through De Queen in Sevier County, and thence into Oklahoma.

The thickest exposure is in Plaster Bluff, where the gypsum forms a single bed ranging from 10 to 14 feet in thickness. This bed, an outcrop of which is shown in Plate VIII, $B$, consists of pure saccharoidal gypsum, though there are some thin seams of satin spar and as much as 3 feet of interbedded clay in its lower part. The thickest layer of gypsum is 4 feet thick and lies at the top. The gypsum at this locality.is 65 feet above Little Missouri River. Overlying it is 55 feet of interbedded clay and limestone, and in addition there are several feet of gravel on the top of the hill. This gypsum has been mined on a small scale, but so far no attempt has been made to develop it extensively.

To the west as far as Messers Creek, in Howard County, there are a few outcrops and reported occurrences of gypsum, but it is not everywhere pure, and at no place does its reported or observed thickness exceed 3 feet.

Gypsum is reported ${ }^{1} 100$ feet below the surface in a well at Augusta, Woodruff County, in the eastern part of the State. The bed is about 10 feet thick, is probably of Eocene age, and underlies deposits of sand and clay.

Gypsum has not been produced in Arkansas, and there is little call for the development of the deposits. as the demand is supplied by other States near by.

1 Purdue, A. H., Water resources of the contact region between the Paleozoic and Mississippian embayment deposits in northern Arkansas : U. S. Geol. Survey Water-Supply Paper 145 , p. $95,1905$. 


\section{CALIFORNIA.}

By F. L. Hess.

\section{DISTRIBUTION.}

The gypsum deposits in California that give promise of possible commercial importance are south of San Francisco Bay (see Pl. IX), and most of them are associated with Tertiary strata; a few occur in Pleistocene beds. Many deposits are found in the Coast Range, from San Benito County southward into Los Angeles County. These deposits are generally shallow, are covered thinly by soil, or lie on the surfaces of knobs or ridges, with here and there one on a hill slope or in a ravine, and are of the variety known as gypsite.

At Point Sal, Santa Barbara County, and at Palmdale, Lang, and Castaic, Los Angeles County, gypsiferous strata interbedided with clayey material have been worked. Beds that seem, from the descriptions obtainable, to have the same general characteristics as these occur at several points in the Colorado Desert.

In San Joaquin Valley, in the Mohave Desert, and probably in the Colorado Desert are many playas that become lake beds during wet seasons, and some of these beds carry considerable deposits of gypsum. Such deposits do not exist in all the periodic-lake beds, and whether they form or not depends on the nature of the rocks drained by the streams feeding the lakes. In the Palen Mountains and Maria Mountains, between the Colorado and the Mohave deserts, and in the Avawatz Mountains, there are large deposits of rock gypsum which appear to be the only extensive beds of the kind in the State.

\section{CIIMATE:}

The climate of the portion of California which contains the gypsum deposits described in this report is so dry that the most moist of the lands are semiarid and the less favored portions are arid. Along the west side of San Joaquin Valley, in the lower hills of the Coast Range, temperatures of $110^{\circ}$ to $125^{\circ} \mathrm{F}$. are frequently recorded in summer and in the Mohave Desert, according to common report, these temperatures are exceeded.

The seasons are often spoken of as wet and dry, because nearly all the rain that falls in that region comes during the late autumn, the winter, and the early spring. However, the wettest winters are probably not so damp as the summer season in the eastern portion of the United States. Naturally, with such heat and such dearth of rain 


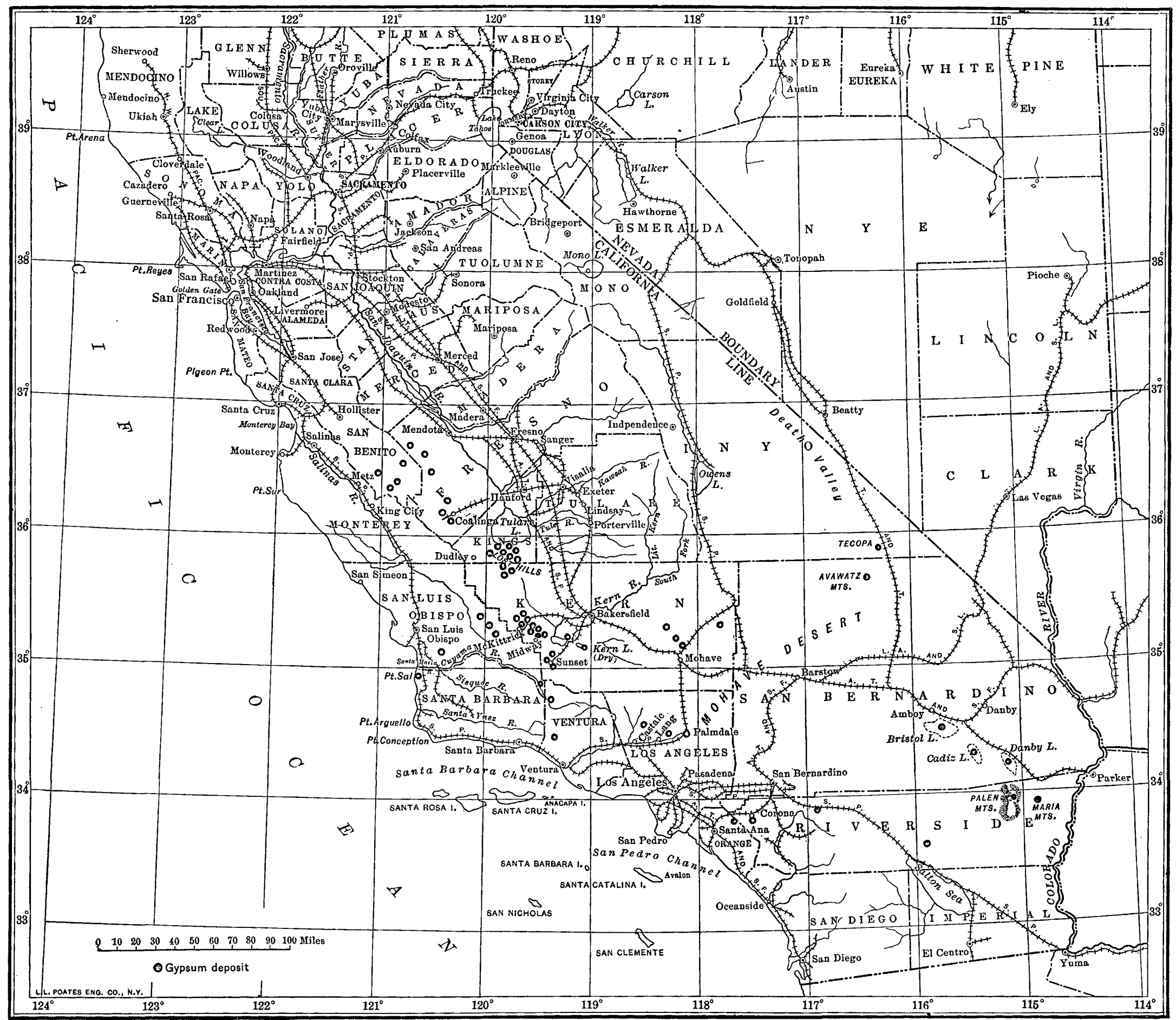

MAP SHOWING DISTRIBUTION OF GYPSUM DEPOSITS IN CALIFORNIA. 
the humidity is low in summer, so that water evaporates very rapidly and the rocks are quickly dried, the water being drawn ont of them to great depths. These climatic conditions have much to do with the formation of gypsum deposits and will be referred to in the descriptions of the deposits.

\section{LOCALITIES.}

The deposits of economic importance occur in three forms according to their origin-efflorescent, periodic-lake, and interbedded deposits.

The efflorescent deposits lie along the Coast Range, extending southward from San Benito County to Los Angeles County, in an area that is nearly coincident with the Tertiary sandstones and shales throughiout this region.

The periodic-lake deposits lie in San Joaquin Valley, Mohave Desert, and probably also in Colorado Desert, and the interbedded deposits occur principally in the mountains in the deserts of Riverside County.

Localities where gypsum is known to occur are here described by counties, which are arranged: in alphabetic order:

\section{TRESNO COUNTY.}

PAOLI MINE.

An efflorescent deposit has been worked at the Paoli mine, in Fresno County, on a ridge on the north side of Tomey Creek, 18 miles southwest of Mendota, in the SW. 1 sec. 1, T. 16 S., R. 12 E., Mount Diablo base and meridian, and adjacent lands. It lies from 400 to

$k$. 800 feet (barometric measurement) above the floor of the valley. Tomey Creek, which is at the foot of the hill, flows only during wet seasons and empties on the plain a mile or two farther east.

The outcrops of gypsite begin on a low hill less than 100 feet above the creek bed, and occur over a large part of the crest of a gradually rising ridge for nearly a mile. The rocks are soft and clayey, containing fine sand with interspersed pebbles of chert, igneous rocks, and glaucophane schists. Locally there are thin beds of diatomaceous shales and beds of sandstone containing large numbers of Tertiary barnacles. The dip is about northeast, at angles ranging from $15^{\circ}$ to $30^{\circ}$. The hills here are largely structural, with abrupt faces on the southwest and gentler slopes on the northeast. The gypsite occurs on the edges of the softer layers in irregular deposits whose distribution is due almost entirely to the strike and width of the outcrops. From the main ridge following Tomey Creek four other ridges extend - like fingers to the north; and gypsite deposits are found on these at a 
number of places. Gypsite is fourd also at several points in the intervening gulches beneath a thin layer of soil. The thickness of the deposits is hard to determine, as they had been cut through at only a few points, but it appears to range from 3 to possibly 15 feet. The latter depth, however, if reached at any place is exceptional, and the average depth probably does not much exceed 3 feet.

On the theory that the deposits were interbedded, a short tunnel was run into the hill 30 or 40 feet below one of the deposits, but it. encountered only a friable sandstone.

The gypsite is of a creamy or buff color and can be worked with a pick and shovel-at many places with a shovel alone. At some points it has been partly dissolved and reprecipitated, so that it is: considerably hardened, but the hardened part is not more than a few inches thick and can be readily worked with a pick. The gypsite is easily crushed and most of it could be handled by screening without crushing. Ordinarily the gypsite is covered by a few inches. of soil, below which for a few inches it is very free from foreign

- matter, containing a few pebbles of the same sort as those found in the sandstone. These pebbles increase in number downward. At a depth of 2 or 3 feet they become abundant, and at a greater depth. the gypsite forms the smaller part of the mass, the larger part being the sandstone of the underlying rock. In the gulches there are places to which the gypsite has been washed from the ridges by freshets and in which it now forms deposits several feet thick, though sufficient prospecting has not been done to show their exact dimensions. There is almost no gypsite on the sides of the hills, its absence. being due probably to its solution and washing away by rain water. The gypsite remains on the tops of the hills, but on their sides, which receive not only the falling rain but the run-off from the upper parts. of the hills, it is dissolved and carried away. Occasional torrential rains carry the gypsite from above and deposit it in the ralleys so quickly that it is not dissolved but is moved like so much earth or sand. Deposits in the gulches are rare and are generally mixed with considerable earth.

A specimen of the purer material from the Mendota No. 1 claim was analyzed by E. C. Sullivan, of the United States Geological Survey, with the following result:

Partial analysis of gypsite from north side of Tomey Creek, Fresno Count.y, Calif.

Lime $(\mathrm{CaO})$

28.3

Sulphur trioxide $\left(\mathrm{SO}_{3}\right)$

39.5

Water clriven off at $60^{\circ} \mathrm{C}$

.3

Water driven off at $300^{\circ} \mathrm{C}$

18. 6

Chlorine $(\mathrm{Cl})$

Trace.

Iron oxide $\left(\mathrm{Fe}_{2} \mathrm{O}_{3}\right)$

.6 
This is equivalent to 85 per cent of gypsum. In 1894 E. W. Hilgard ${ }^{1}$ published the following analyses of specimens from these deposits :

Analyses of gypsite from Tomey Creek, Fresno County, Calif.

\begin{tabular}{|c|c|c|c|c|}
\hline No. & Locality. & Gypsum. & Clay. & $\begin{array}{c}\text { Sand, } \\
\text { moisture, } \\
\text { carbonate } \\
\text { of lime, } \\
\text { etc. }\end{array}$ \\
\hline $\begin{array}{l}1 \\
5 \\
6 \\
7\end{array}$ & 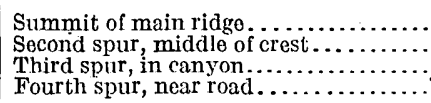 & $\begin{array}{l}95.24 \\
94.74 \\
92.90 \\
82.20\end{array}$ & $\begin{array}{l}1.98 \\
1.52 \\
2.60 \\
8.21\end{array}$ & $\begin{array}{l}2.78 \\
3.74 \\
4.50 \\
9.59\end{array}$ \\
\hline
\end{tabular}

Some gypsite was mined from these deposits several years ago, when a cabin and a small amount of machinery were erected. The gypsite was mined for land plaster and used on the ranches of San Joaquin Valley as an antidote for alkali. No work, except assessment work, has been done on the claims for a number of years. Water is very scarce and what is to be had is not fit for drinking. Drinking water must be brought from Mendota, 18 miles away. The plain is almost as flat as a floor and the soil makes good roads, so that teaming is easy and, for such a distance, hauling is very cheap.

On the south side of Tomey Creek similar deposits occur and have been prospected to some extent.

\section{DEPOSITS NEAR THE PAOLI MINE.}

A few miles south of Tomey Creek, along Cantua Creek, like beds were once worked in a small way for land plaster, and similar deposits may be found wherever the same rocks outcrop along the foothills.

\section{COALINGA DEPOSITS.}

In the NE. $\frac{1}{4}$ sec. 22 , T. 20 S., R. 14 E., Mount Diablo base and meridian, about 4 miles northwest of Coalinga, is an efflorescent deposit which was worked to a small extent for land plaster a number of years ago. The gypsite overlies a sandstone that lies next to a coarser fossiliferous stratum having a dip of about $30^{\circ} \mathrm{NE}$., occupying the top of a small hill, and may be followed for about 200 feet along the strike of the rocks. This sandstone was determined by Ralph Arnold and Robert Anderson, ${ }^{2}$ of the United States Geological Survey, to be near the base of the Tejon formation of the Eocene. The general relations of the gypsite and the country rock 
are shown in figure 3 . At a depth of 2 or 3 feet pebbles begin to appear in the gypsite, and below that they form so much of the mass that the material would have to be screened for use. (See Pl. X, B.) The gypsite is light buff, very soft and friable, and could be largely shoveled from the face. A few small stringers are harder, but all could be worked with a pick. The gypsite is so soft that small animals and insects burrow through it.

A partial analysis of a specimen of gypsite from this deposit, made for Arnold and Anderson by R. C. Wells, of the United States Geological Survey, gave $\mathrm{CaSO}_{4}, 71.6 ; \mathrm{SiO}_{2}, 0.8$.

About 7 miles northeast of Coalinga, on the top of a hill half a mile S. $20^{\circ}$ E. of the Home Oil Co.'s wells, is a gypsum claim, on which a small area about 20 by 50 feet has been stripped to a depth of 1 or 2 feet. The gypsite below this is very impure, containing many fragments of fine-grained shale.

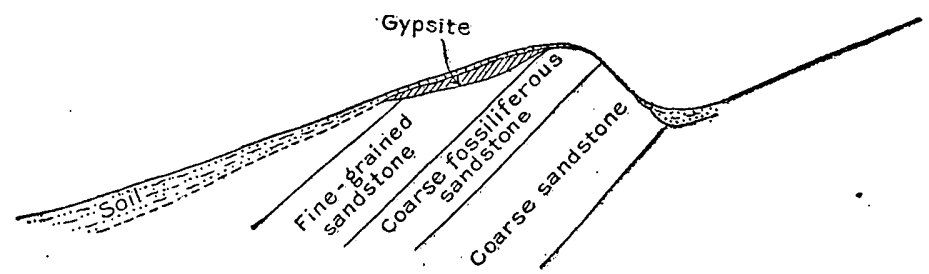

FIGURE 3.-Idealized section through gypsite deposit 4 miles northwest of Coalinga, Calif. Not drawn to scale.

An old gypsum mine 9 miles north of Coalinga, on the foothills of the Coast Range, was once worked by open cuts. In one cut the gypsum was 10 feet thick and in another cut it occurred in two beds interstratified with clay and sandy ealcareous shales. The strata dip $20^{\circ} \mathrm{SE}$. The gypsum was ground in a mill at Coalinga and used as a fertilizer.

Three miles west of Coalinga, on the east side of a hill in the S. $\frac{1}{2}$ sec. 35 , T. 20 S., R. 14 E., gypsite crops out at a number of places through a distance of about a quarter of a mile. Prospect holes have been sunk at a number of points and shallow excavations have been made. The deposits are very similar to those just described as occurring northwest of Coalinga but are somewhat larger. There is apparently from $2 \frac{1}{2}$ to 3 feet of fairly good gypsite, but below that the foreign matter forms too great a proportion of the material to allow profitable working. The deposit is overlain by about a foot of soil. The stratum covered by the gypsite is a soft sandstone, which is in many places very pebbly. The weathering of the sandstone leaves a layer of loose pebbles on the surface, and where gypsite has formed these pebbles are contained in it. 
A specimen collected by the writer from this deposit was partially analyzed by E. C. Sullivan, of the United States Geological Survey's chemical laboratory, with results as follows:

I'artial analysis of gypsite from S. $\frac{1}{2}$ sec. $35, T .20$ S., R. $14 \mathrm{E}$.

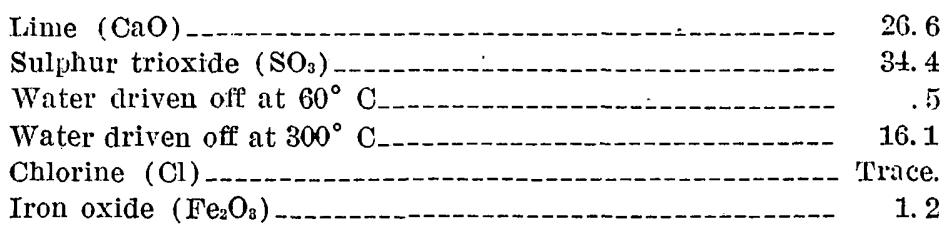

This analysis gives an equivalent of 74.1 per cent gypsum. A tunnel near the summit of the hill on the west side shows many narrow veins of crystalline gypsum cutting the sandstone. There are small nodules of kaolin from one-half to $2 \frac{1}{2}$ inches in diameter along one of the bedding planes of the sandstone. These nodules have probably not been formed by the kaolinization of granitic pebbles, as they contain no visible quartz grains. It seems possible that they may have been pellets of clay rolled on an ancient shore line.

Mr. N. L. Palmer, of Coalinga, stated that gypsum is to be found also in sec. 34, T. 20 S., R. 16 E., about 1 mile south of Stanley station on the Southern Pacific Railroad; in secs. 32 and 33, T. 21 S., R. 16 E., 6 or 7 miles southeast of Coalinga; and in sec. 34, T. 20 S., R. 14 E., 3 miles west of Coalinga.

\section{IMPERIAL COUNTY.}

A deposit of gypsum occurs in the hills 30 miles west of Brawley, close to the San Diego County line. It is in the W. $\frac{1}{2} \mathrm{NW}$. $\frac{1}{4}$ sec. 18, T. 13 S., R. 9 E., and the E. $\frac{1}{2}$ NE. $\frac{1}{4}$ sec. 13 , T. 13 S., R. 8 E. The gypsum is closely related to an occurrence of celestite and is said to be very thick. Reports indicate a massive rock gypsum, of good quality, 200 feet or more thick, making a narrow ridge onearly 1 mile long. The location of this deposit 25 miles from a railroad prevents its development at present.

INYO COUNTY.

In southeastern Inyo County, near Acme, south of Tecopa, there are several beds of pure-white gypsum from 6 to 10 feet thick, outcropping within a mile or two of the Tonopah \& Tidewater Railroad. A bed of massive crystalline gypsum reported to be about 8 feet thick and to dip about $40^{\circ}$ has been mined by tunnels and open cut by the Acme Cement Plaster Co. and the material shipped to Los Angeles for milling. 
KERN COUNTY.

SUNFLOWER VALLEY.

About 6 miles southeast of Dudley, Kings County, in the McLure Valley, or, as it is generally known, Sunflower Valley, Kern County, some thin deposits of buff gypsite, from 1 foot to 2 feet thick, over'lying soft, siliceous Tertiary shales, have been prospected to a small extent, and have been shown to cover possibly an acre on a low mound in the NW. $\frac{1}{4}$ sec. 15, T. 25 S., R. 18 E. The gypsite is covered with 8 to 16 inches of soil and is much mixed with shale.

Across a low range of hills of what is known locally as "porcelain shale" gypsite is found on many of the hilltops and ridges. A deposit on the property of the Visalia Oil Co., near the middle of the W. $\frac{1}{2}$ sec. 22, T. 25 S., R. 18 E., about 7 miles southeast of Dudley, may be taken as an example of the deposits common to this locality. It occupies the upper part of the east side of a northsouth hill through a distance of about a quarter of a mile, and its width reaches 300 feet as an extreme, probably averaging somewhat over 100 feet. It lies on fine-grained sandstone and shales, on both sides of a fossiliferous, limy sandstone carrying Ostrea vespertina and Pecten coalingaensis.

The gypsite is buff in color and is hardened for 2 or 3 inches on the top, so that when dug it breaks in slabs a foot or more across. Below the crust it is so soft that it may be screened to get rid of pebbles and fragments of sandstone or shale without crushing. The deposit is 2 to 3 feet thick, the purer material generally being contained in the upper 2 feet. Sandstone or shale forms a large portion of the lower part of the mass, the proportion becoming greater with increase of depth and making up the bulk of the lowest part of the deposit. Gypsite occurs also on the hills in other parts of the same section.

Mr. Orlando Barton, who lived near by in 1907 and who had spent much time in examining the rocks of this region, stated that deposits of gypsite occur on the following bodies of land in T. 25 S., R. 18 E., of which only those described were examined by the writer:

Gypsite deposits in T. 25 S., R. 18 R., near Dudley, Kings County, Calif.

Sec. 14 , small bed in SE. $\frac{1}{4}$.

Sec. 20 , about one-quarter acre in SE. $\frac{1}{4}$.

Sec. 21,10 acres in SE. $\frac{1}{2}$.

Sec. 22,20 acres in SW. $\frac{1}{4}$, NW. $\frac{1}{4}$, and SE. $\frac{1}{4}$.

Sec. 23 , thin; various parts.

Sec. 25,3 acres in SW. $\frac{1}{4}$.

Sec. 26 , small amount in NE. $\frac{1}{4}$ and NW. $\frac{1}{4}$.

Sec. 27,4 acres in NE. $\frac{1}{4}$.

Sec. 28,30 to 150 feet wide, runs north-south in E. $\frac{1}{2}$ E. $\frac{1}{2}$, the whole length. 
Sec. 29, small amount in SW. $\frac{1}{4}$; several acres of good gypsum in SE. 7 , renches thickness of 4 feet.

Sec. 30 , small bed of good gypsum in southeast corner.

Sec. 34, small bed of good gypsum in northwest corner.

Sec. 35 , good bed 100 feet wide in SE. $\frac{1}{4}$, one-fourth mile long; small bed in NE. 1.

Sec. 36, small beds in all but NE. $\frac{z}{4}$.

Mr. William Taylor, of Dudley, stated to the writer that gypsite deposits also occur in the NE $\frac{1}{4}$ sec. 3, T. 26 S., R. 18 E., in Antelope Valley, the next large valley south of McLure Valley.

\section{IOST HILLS.}

In San Joaquin Valley a few miles south of Tulare Lake and about $2 \dot{5}$ miles west of Wasco, on the Santa Fe Railway, is a low range of hills, running northwest and southeast, probably a continuation of a range somewhat higher and broader, known as the Kettleman Hills, which separates the Kettleman Plains from San Joaquin Valley. The Kettleman Hills are said by Arnold and Anderson ${ }^{1}$ to be of anticlinal structure, and it is probable that the Lost Hills are formed by the southern extension of the anticline, which here disappears under the floor of the valley. The rocks in place in the Lost Hills are probably a part of the Etchegoin formation, of upper Mioeene age.

This section of the valley is exceedingly dry, having an average annual rainfall of probably not more than 2 or 3 inches, and is even drier than the adjacent foothills, the nearest of which are 8 or $10^{\circ}$ miles to the west.

A county road from Wasco, the nearest shipping station, to Antelope Valley passes about 2 miles south of the Lost Hills. A traveler approaching the country from this road, when within half a mile or more of the hills, may notice gypsite in the piles of dirt thrown from holes dug by kangaroo rats and other rodents. In the W. $\frac{1}{2}$ sec. 30 , T. 26 S., R. 21 E., many such places were seen, and also in the western part of sec. 19. At a number of points the writer dug through the soil, which was 6 to $2 \pm$ inches thick. Below this cover of earth the gypsite is generally soft and powdery and of a creamy buff color, though at one or two places. it was brownish and granular. It was not practicable with the tools at hand to dig to any considerable depth, so that the thickness of the gypsite was not determined. Mr. Orlando Barton stated that he had at a number of places dug into the gypsite to a depth of 4 feet without passing through it. 
On the tops of the hills there is also a coating of gypsite, at many places without the usual covering of soil, which has probably been blown off, as the ground is dry and powdery and easily moved by the winds, which during a day sometimes pile it in drifts several feet deep. At one place in sec. 19, where a northeast-southwest draw cuts through the hill, the gypsum appeared to be from 6 to 8 feet thick.

On the south side of the draw, standing on a rather abrupt northern slope, is a mound known as "The Oil Bubble." (See Pl. $\mathrm{X}, A$.) The mound, which is 10 to 15 feet high and about 65 feet in diameter, is composed of small crystals of gypsum, most of them less than one-quarter inch in length, mixed with enough clay to permit the mass to be easily kneaded. This mound also contains a small amount of material resembling greatly oxidized asphalt, stained slightly with native sulphur. At the time it was visited the mound was wet and sticky, and it is said to remain moist throughout the summer. It is reported to give off some gas, the asphalt and the form suggesting the name "Oil Bubble." The mound is formed by the evaporation of water carrying gypsum in solution, the clay probably being brought to the place by winds. The excessive dryness of the surrounding country makes it seem probable that the water comes from a considerable depth, rising through the Tertiary gypsiferous sandstones.

On the north side of the draw is a dark, fine-grained sandstone cemented by gypsum, of which it carries a considerable quantity. It clips toward the northeast at a low angle, closely following the contour of the hill, and that it is of Pleistocene age, formed by the cenenting of wind-blown sand by gyjpsum, is suggested, though there is a strong possibility that it is a phase of the Pliocene sandstones met in the Kettleman Hills farther to the northwest.

Above the sandstone lies about 2 feet of gypsite, and this is said to extend 6 or 7 miles northwestward along the hills. If the Lost Hills are to be regarded as an extension of the Kettleman Hills anticline from which the upper, nongypsiferous beds have been eroded, it seems probable not only that the hills contain other such beds of gypsite, but that alongside them, for their whole length, such deposits as were noted in sec. 30 will be found. It is not to be supposed that these beds will be equally thick or good in. all places, and in spots the gypsite may be entirely lacking.

The beds in this locality are the most extensive that were seen by the writer in California. Whether they will be workable is problematic. At present the nearest shipping point is Wasco, on the Atchison, Topeka \& Santa Fe Railway, 25 miles to the east. Water could probably be obtained by boring deep enough almost. anywhere in the region. The deposits would need careful prospecting to ascertain 


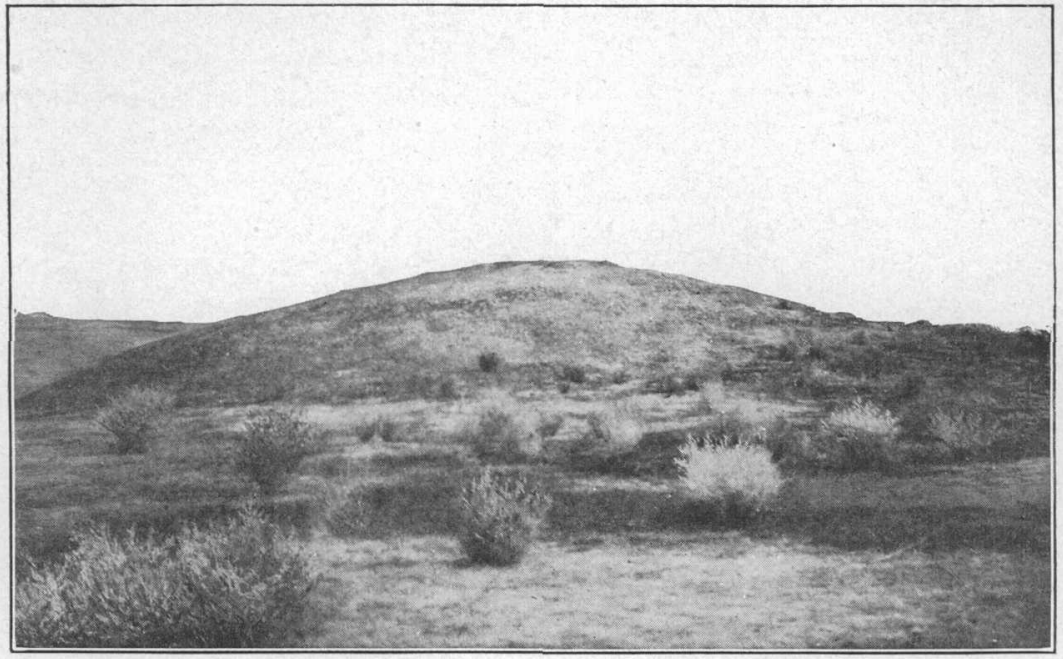

A. MOUND OF GYPSUM IN THE LOST HILLS, SOUTH OF TULARE LAKE, CALIF., MADE BY THE EVAPORATION OF WATER SEEPING FROM THE ROCKS BELOW.

Photograph by F. L. Hess.

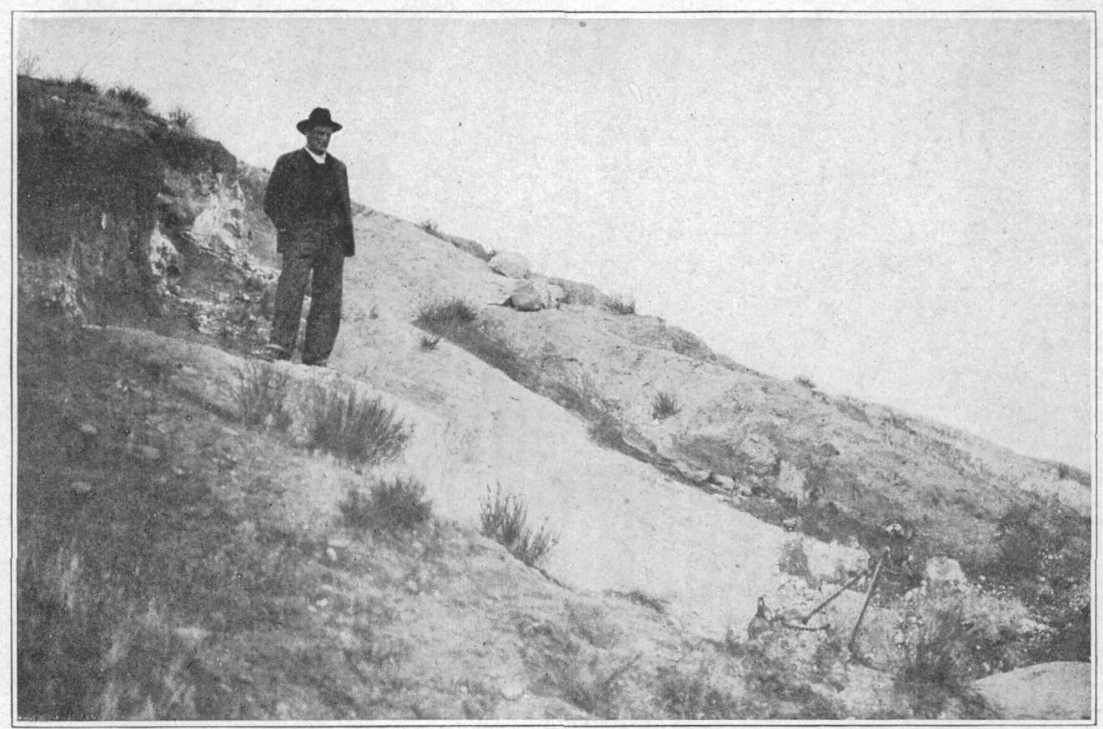

B. GYPSUM DEPOSIT 4 MILES NORTHWEST OF COALINGA, CALIF.

Photograph by F. L. Hess. 
their thickness and area, but this would not be difficult, as it could all be done with a shovel or a shovel and mattock. The ground could be easily stripped with teams and scrapers and the gypsite loaded into wagons directly from the scrapers by erecting a platform under which the wagons could be driven.

If a railroad should be built along the base of the foothills of the Coast Range, transportation would not be a serious matter, and if the deposits proved to be of sufficient extent the manufacture of gypsum plaster might then be undertaken.

Analyses of gypsum from sec. 30 , made by E. C. Sullivan and R. C. Wells, of the United States Geological Survey, are as follows:

Analyses of gypsite from south side of the Lost Hills, Kern County, Calif.

[Ground quickly to 40-mesl.]

\begin{tabular}{|c|c|c|c|c|}
\hline & 1 & 2 & 3 & 4 \\
\hline 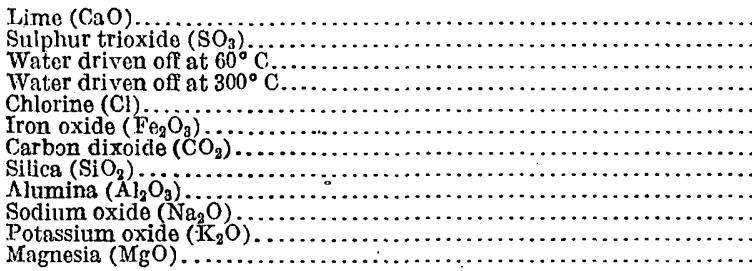 & $\begin{array}{r}25.3 \\
35.1 \\
.9 \\
16.9 \\
\text { None. } \\
1.1 \\
\cdots \ldots . . . \\
\cdots . . .\end{array}$ & $\begin{array}{r}29.9 \\
42.8 \\
19.2 \\
\text { Trace. } \\
.3 \\
\cdots \cdots \\
\cdots \cdots \\
\cdots \cdots \\
\cdots \cdots \\
\cdots\end{array}$ & $\begin{array}{r}29.5 \\
40.7 \\
10.1 \\
\text { None. } \\
.4 \\
.7 \\
5.3 \\
1.7 \\
1.2 \\
.6 \\
\text { None. }\end{array}$ & $\begin{array}{r}29.9 \\
40.8 \\
19.4 \\
\text { None. } \\
.3 \\
\text { None. } \\
6.1 \\
1.4 \\
2.0 \\
.5 \\
\text { None. }\end{array}$ \\
\hline
\end{tabular}

Analyses 1 and 2 by I. C. Sullivan; 3 and 4 by R. C. Wells.

The first analysis shows an equivalent of 75.5 per cent of gypsum, so that about one-fourth of the material is foreign matter; the second sample contains the equivalent of 91.2 per cent of gypsum. The analysis shows a slight excess $(0.6$ per cent) of calcium sulphate, which may indicate the presence of either anhydrite ('calcium sulphate not combined with water) or partly dehydrated gypsum. The third and fourth analyses are more detailed and show the character of the impurities better. The amount of gypsum indicated is nearer the amount shown by the second analysis than the first.

\section{DEPOSITS NEAR MCKITTRICK.}

The same Tertiairy sandstones and shales that are so prominent in the southern part of the Coast Range are also the prevailing rocks near McKittrick, and as would therefore be expected gypsite deposits are found in many places in this neighborhood.

California Gypsum \& Mineral Co.-The property of the California Gypsum \& Mineral Co. is located on the north slope of a rather low hill in the S. $\frac{1}{2}$ sec. 20, T. 30 S., R. 22 E., about one-half mile from McKittrick railroad station. The gypsite is overlain by 
6 . inches to 21 feet of soil and is of a buff color. It has been mined at a number of places to a depth of about 2 feet, below which it contains too much of the country rock to be profitably, worked. The rock beneath the gypsite is a fine-grained shale. In places the gypsite is somewhat hardened for 2 or 3 inches on the top, but the mineral below that can be easily handled with a shovel. Altogether perhaps 3 or 4 acres had been exposed.

A partial analysis by George Steiger in the chemical laboratory of the United States Geological Survey of a specimen collected by the writer was as follows:

Partial analysis of gypsite from deposit one-half mile southeast of McKittrick; Calif.

$\begin{array}{lr}\text { Lime }(\mathrm{CaO}) & 31.05 \\ \text { Sulphur trioxide }\left(\mathrm{SO}_{3}\right) & \\ \text { Water driven off. at } 60^{\circ} \mathrm{C}^{\circ} & \\ \text { Water driven off at } 300^{\circ} \mathrm{C}-49 \\ \text { Chlorine }(\mathrm{Cl}) \\ \text { Iron oxide }\left(\mathrm{Fe}_{2} \mathrm{O}_{s}\right)\end{array}$

This analysis gives an apparent equivalent of 85.2 per cent of gypsum. Several hundred tons of gypsite for use as land plaster had been shipped from the deposit, and there was a small plant on the property for the preparation of the material.

Abbott de Hickox.-A gypsite claim in the NE. $\frac{1}{4}$ SW. $\frac{1}{4}$ sec. 30, T. 30 S., R. 22 E., held by Messrs. Abbott \& Hickox, is about $2 \frac{1}{2}$ miles southwest of McKittrick. The deposit most worked is on the summit of a hill between 50 and 75 feet high. It is about 500 feet long by 200 feet wide at the widest point and is oval in shape. . The gypsite is from 2 to 4 feet thick and is overlain by soil that is in places 2 feet thick, although in other places gypsite forms the surface. The average covering is probably 10 to 12 inches thick. About 4,000 tons are said to have been shipped from the spot.

A partial analysis by George Steiger of gypsum from this deposit is given below:

Partial analysis of gypsite from deposit near McKittrick, Calif.

Lime $(\mathrm{CaO})$ 30.32

Sulphur trioxide $\left(\mathrm{SO}_{3}\right)$

Water driven off at $60^{\circ} \mathrm{C}$

Water driven off at $300^{\circ} \mathrm{C}$

Chlorine $(\mathrm{Cl})$

Iron oxide $\left(\mathrm{Fe}_{2} \mathrm{O}_{3}\right)$

This gives an equivalent of 92.5 per cent of gypsum. On several of the hilltops near at hand the gypsite outcrops were accompanied by carbonate of lime, which seemed to be a replacement of the gypsite, and the two are in places more or less mixed. 
Other deposits.-Considerable gypsite of character similar to that described above occurs in the SE. $\frac{1}{4}$ sec. 30 , T. 30 S., R. 22 E., and some has been shipped. In places it reaches a thickness of $3 \frac{1}{2}$ feet.

About 1 mile south of the locality just mentioned, on the north side of a small gulch, is a deposit which is 9 feet thick and considerably hardened but which does not seem to be of great extent. Parts of it are bleached almost white. This deposit also overlies a finegrained shale which is in places much colored by iron oxide. The shale is yellowish gray, of low specific gravity, and contains many casts of foraminifers. Borings made about 100 feet from the gulch are said to have shown the gypsite to be about 2 feet thick. A number of other deposits exist in secs. 28 and 29, T. 30 S. The gypsite and the underlying shales are at some places almost of the same color, so that it is not easy to tell where one leaves off and the other begins, as the gypsite is powdery and sifts down, disguising the appearance of the underlying rock. It was reported that on one claim the gypsite was 90 to 100 feet thick, but it is probable that the soft underlying shale has been supposed to be gypsite, for it does not seem possible, from the mode of formation of the gypsite, that it could have been so thick.

At the time of the writer's visit (1907) Mr. H. F. Brinkman, of Pasadena, Calif., was examining the deposits to determine their commercial value. Mr. Brinkman made the following estimate of the area and thickness of gypsite deposits in the neighborhood. The writer had no opportunity of verifying the figures outside of the areas mentioned above.

Gypsite in the McKittrick district.

\begin{tabular}{|c|c|c|c|c|c|}
\hline No. & Section. & Range. & Township. & Acres. & Thickness. \\
\hline $\begin{array}{r}1 \\
2 \\
3 \\
4 \\
5 \\
6 \\
7 \\
8 \\
9 \\
10 \\
11 \\
12 \\
13 \\
14 \\
15 \\
16\end{array}$ & 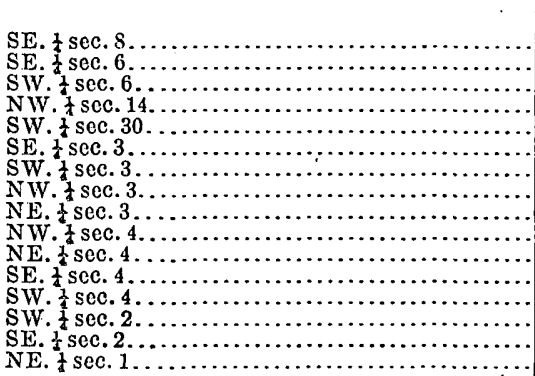 & $\begin{array}{l}22 \mathrm{E} . \\
22 \mathrm{E} . \\
22 \mathrm{E} . \\
21 \mathrm{E} . \\
22 \mathrm{E} . \\
21 \mathrm{E} . \\
21 \mathrm{E} . \\
21 \mathrm{E} . \\
21 \mathrm{E} . \\
21 \mathrm{E} . \\
21 \mathrm{E} . \\
21 \mathrm{E} . \\
21 \mathrm{E} . \\
21 \mathrm{E} \\
21 \\
21 \\
\mathrm{E}\end{array}$ & 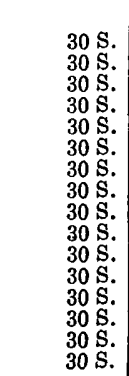 & $\begin{array}{r}2 \\
2 \\
10 \\
2 \\
3 \\
8 \\
10 \\
20 \\
10 \\
10 \\
10 \\
10 \\
10 \\
4 \\
10 \\
10\end{array}$ & $\begin{array}{rr}\text { Feet. } & \\
2 \\
2 \\
2 \\
2 \\
2 \\
2 \\
2-4 \\
3 \\
3 \\
2 \\
2 \\
2 \\
2 \\
2 \\
2 \\
2 \\
2 \\
2-3 \\
2-3\end{array}$ \\
\hline
\end{tabular}

According to Mr. Brinkman, deposits Nos. 1 and 2 contain about 4,000 tons and deposit No. 3 about 20,000 tons. Deposit No. 5 consists of powdery gypsite. No estimate was made of the extent of the deposits in secs. 30,31 , and 32, T. 30 S., R. 22 E., or in sec. 
29. A deposit in sec. 5, T. 31 S., R. 22 E., contains about 5 acres, and there is a little in sec. 4, T. 31 S., R. 22 E.

Samples of plaster of Paris made by Mr. Brinkman from gypsite from different localities in the neighborhood were all of a creamy to buff color, varying somewhat in shade, and a number of the shades would make attractive tints for wall coverings. The gypsite deposits follow the Tertiary sandstones and shales to the southwest, and many patches are reported to occur between McKittrick and Midway.

Mr. E. H. Andrews, of Midway, reported gypsite in the following sections in the area between McKittrick and Midway:

T. 30 S.. R. 22 F., secs. $29,30,31,32,33,34$, and 35.

T. 31 S., R. 22 E., secs. $4,5,8,9,10,11,17,18,19,20,21,22,26,27$, $28,34,35$.

T. 32 S., R. 22 E., secs. $2,3,6,7,11,12,17,18,20,21,22,23,26,27,34$.

T. 32 S., R. 24 E., running diagonally from northwest to southeast.

Owing to lack of time the writer was unable to visit these localities.

\section{DEPOSITS, NEAR MARICOPA.}

In the country closely adjacent to Maricopa, known as the Sunset district, are a number of small areas carrying thin deposits of gypsite; associated with shales like those found farther north along the Coast Range. None are known that seem to be of value.

\section{DEPOSITS INEAR BAKERSFIELD.}

C'ottonwood Creek.-Deposits of gypsite occur on both sides of Cottonwood Creek, 16 miles east of Bakersfield. They are reached from Edison, on the Southern Pacific Railroad, by following the main road $4 \frac{1}{2}$ miles to the creek and then traveling up the creek for $3 \frac{1}{2}$ miles. The deposits may also be reached from-Pampa, from which they are about 5 miles distant. The deposits occur on the northeast side of the creek at the top of a steep slope, between 50 and 75 feet above the creek bed. A more gentle slope rises from the top of the steep bank, and on this slope gypsite may be found at a number of places, covering altogether several acres. At the edge of the slope the gypsite is 2 to 3 feet thick, grading into soft, earthy material below, probably the equivalent of the shales over which the gypsite lies in the McKittrick and other districts. The deposit is in the SE. $\frac{1}{4}$ SE. $\frac{1}{4}$ sec. 20 , T. 29 S., R. 30 E., Mount Diablo base and meridian. A small amount of gypsite was shipped from this deposit several years ago for use as a fertilizer.

A number of claims on the southwest side of the creek were held by Mr. William Harmon. One of these claims was in sec. 28, where deposits had been opened in a small way on the top of a hill about 200 feet above the creek. The deposits are small and of no great value. In the narrow gulch east of the hill there is a deposit of 
impure, soft, powdery gypsite 6 to 8 feet thick, which is exposed for several hundred feet along the gulch. Its width and its thickness away from the creek are unknown. On the top of the hill east of the gulch, in the NW. $\frac{1}{4}$ sec. 28 , there are other gypsite deposits similar to those on the west side.

A partial analysis by E. C. Sulliran of a specimen from this deposit is given below:

Partial analysis of gypsite from deposit near Pampa, Calif.

Lime $(\mathrm{CaO})$

Sulphur trioxide $\left(\mathrm{SO}_{3}\right)$ -

Water driven off at $60^{\circ} \mathrm{C}$

Water driven off at $300^{\circ} \mathrm{C}$

Chlorine $(\mathrm{Cl})$-_-

Iron oxide $\left(\mathrm{Fe}_{2} \mathrm{O}_{3}\right)$

The analysis shows an apparent equivalent of 74.8 per cent of gypsum. In another gulch in the southeast corner of the NE. $\frac{1}{4}$ sec. 28, about one-quarter of a mile east of Mr. Harmon's cabin, gypsite from 10 to 25 feet thick is exposed on both sides for a distance of 100 yards. The gypsite is of about the same quality as that in the gulch already mentioned.

These gulch deposits are probably formed by the washing down of the gypsite from the hills above and are mixed with considerable earth. The deposits are about one-quarter of a mile from the contact of the soft Tertiary rocks, with old crystalline rocks, which are here andalusite schists. Mr. Harmon stated that much better deposits of gypsite occur near Caliente.

Kern Lake gypsite deposit.-In what was once the bed of Kern Lake but is now a part of a large farm belonging to the Kern County Land Co. gypsite has been exposed in secs. 26 and 27, T. 32 S., R. 27 E., Mount Diablo base and meridian, by an irrigating ditch that runs through the deposit for about three-quarters of a mile along the line between the north and south halves of the sections. The deposit is about 20 miles southwest of Bakersfield but only 5 miles from the railroad station known as Conner. Gypsite is also reported from a point one-half mile farther south, but none has been found nearer the center of the old lake, west of this locality. The ditch is $2 \frac{1}{3}$ feet deep, and gypsite forms its bottom and sides for a large part of the distance mentioned. The soil covering the gypsite is thin and very light and porous when dry. Over a large part of the known area the gypsite is less than a foot below the surface. The gypsite is creamy in color, finely granular, and in places is very free from dirt and foreign matter. Water from the irrigating ditch has cut channels from 8 inches to more than a foot in diameter through the gypsite, and they can be followed more than 50 feet on each side by the caving 
of the earth. Near the ditch the gypsite is reported to be 4 feet thick. The composition of a picked sample is shown by the following analysis by E. C. Sullivan, of the United States Geological Survey:

Analysis of gypsum from old bed of Kern Lake.

Lime $(\mathrm{CaO})$

Sulphur trioxide $\left(\mathrm{SO}_{3}\right)$ -

Water driven off at $60^{\circ} \mathrm{C}_{-}$

Water driven off at $300^{\circ} \mathrm{C}$

Iron oxide $\left(\mathrm{Fe}_{2} \mathrm{O}_{3}\right)$

The lime and sulphuric anhydride are both too high for pure gypsum, which contains 32.6 and 46.5 per cent, respectively, and the water is low (20.9 per cent in pure gypsum). The analysis apparently shows the presence of nearly 6 per cent of anhydrite (anhydrous calcium sulphate), which would leave about 94.3 per cent of gypsum. It is possible, however, that instead of containing anhydrite the material may include some partly dehydrated gypsum which would in no way be hurtful to plaster manufactured from it. It is remarkably free from other impurities. At some other points the gypsite is more or less mixed with earth. The lake received its drainage from the Tehachapi Mountains, on the south, which are composed largely of Tertiary rocks, presumably similar to those along the Coast Range and also to the rocks a few miles farther east. These rocks are highly gypsiferous, so that considerable amounts of gypsum would be carried into the lake, which was of great periodic variation in size owing to the unequal distribution of rainfall from season to season and from year to year, though it was at all times shallow. The saturation point for gypsum would possibly never be reached by the lake, even when the level of the water was near or below the surface of the soil, which, owing to its great porosity, will hold large quantities of water.

The deposition of gypsum from such a lake is apparently much the same phenomenon as the deposition of gypsite from rocks by the evaporation of water drawn to the surface by capillarity. The shallow water near the shore line would be more highly saturated with gypsum than the deeper water, as the part evaporated would be a much larger proportion of the mass. The hot sun would at the same time evaporate great quantities of water from the shore itself, which is formed of fine porous silt. The water would come, at least in part, from the already somewhat concentrated water along the edge of the lake, and as the water evaporated gypsum would be left behind in crystalline form. The flow of water once established would continue until capillary attraction could no longer lift the water from the depth to which it had sunk. In the absence of definite data, it may be supposed that the longer established channels by which the 
water escaped into the atmosphere would act much more rapidly than the newer ones that were allowed to form by the retreating shore line; that there would therefore be a movement of the water toward the side; and that there would be deposits of gypsite under certain areas from which evaporation was greatest and near which the shore most often lay. In the middle of the lake, where water stood oftenest and longest, probably no considerable deposits would form, as they would be again dissolved by floods in succeeding years.

It is probable that gypsite will be found at a number of points around the old medial shore of the lake-that is, around the shore which was its normal edge between the highest and lowest stages. If the deposits are of sufficient extent they might form a basis for: the profitable manufacture of gypsum plaster, particularly as much of the land is not under cultivation.

Buena Vista Lake.-Buena Vista Lake lies 5 or 6 miles west of the Kern Lake gypsum deposit, in the same shallow depression. A cut for the Sunset Railroad as it turns to the southwest to follow the shore of the lake exposes gypsite similar in appearance to that of Kern Lake. Nothing is known of its extent or thickness. Gypsite is reported along the foothills for 150 miles but nowhere in quantity to have commercial value. The deposits are scattered and thin.

\section{CANE SPRINGS. ${ }^{2}$}

About 25 miles northeast of Mohave and $3 \frac{1}{2}$ miles southeast of Cane Springs and Cantil, on the line of the Southern Pacific Railroad joining Mohave and Randsburg, gypsite is exposed at the surface over an area covering nearly 1 square mile. The gypsite deposits are on the south edge of a playa about 5 by 8 miles in extent. The thickest beds lie in the SE. $\frac{1}{4}$ NW. $\frac{1}{4}$ sec. 28 , T. 30 S., R. 38 E., Mount Diablo base and meridian, and reach a depth of 10 feet. The gypsite is exceedingly fine grained and of a buff color.

A partial analysis of a specimen collected where prospect holes showed the gypsite to be thickest indicated an equivalent of about 79.5 per cent of gypsum.

A plaster mill was erected on this deposit in 1910 and operated intermittently.

\section{KINGS COUNTY.}

\section{KETTLEMAN PLAINS.}

The E. D. Jones gypsum deposit is in the Kettleman Plains, Kings County, 200 yards north of an old schoolhouse in the NW. $\frac{1}{4}$ sec. 13, T. 24 S., R. 18 E., Mount Diablo base and meridian, ${ }^{2} 5 \frac{1}{2}$ miles by road northeast of Dudley. It is in the flat floor of the valley,

\footnotetext{
1 For a somewhat fuller account see Hess, F. L., Gypsum deposits near Cane Springs, IN: 1 County. Calif.: U. S. Geol. Survey Bull. 430, pp. 145-146, 1910.

? California State Mineralogist Thipteenth Rept., p. 503, 1896.
} 
between half a mile and a mile from the nearest hills on the northeast and still farther away from those on the southwest. It presents some features that differentiate it so: sharply from the deposits in the neighborhood that it is placed tentatively among the periodiclake deposits.

An excavation abont 30 by 50 feet and 3 feet deep has been made. The bottom of the hole is covered with gypsum, so that the depth of the deposit can not be told. The gypsum is said to be found over an area of 80 acres, although it was seen by the writer only at the excavation. The gypsum, which is coarsely granular, is composed of an aggregate of small crystals, the largest one-half to threefourths of an inch broad, is rather firmly coherent, and is overlain by a few inches of soil. Between the crystals the spaces are fillen with material apparently less pure. The comparatively large size of the crystals indicates that the deposit was laid down in a periodic lake rather than by efflorescence. The presence of considerable quantities of water seems necessary for the formation of gypsum crystals of easily visible size. Robert Anderson, of the United States Geological Survey, has informed the writer that in the surrounding hills there seems to be evidence that this portion of the Kettleman Plains was at one time covered by a lake or an arm of Tulare Lake.

This deposit was worked for land plaster in the early nineties. A small mill for grinding was put up, but the wagon haul of nearly 40 miles to Furon, the nearest railroad point, makes production too expensive to be profitable. It is stated that selected samples from this deposit contained 94 per cent of gypsum. ${ }^{1}$ A partial analysis by E. C. Sullivan of a specimen collected by the writer was as follows:

Partial analysis of gypsum from Kettleman Plains, Calif.

Lime $(\mathrm{CaO})$

Sulphur trioxide $\left(\mathrm{SO}_{3}\right)$

Water driven off at $60^{\circ}$

Water driven off at $300^{\circ} \mathrm{C}$

Chlorine (Cl)

Iron oxide $\left(\mathrm{Fe}_{2} \mathrm{O}_{3}\right)$
19. 1

27. 3

.8

15.3

Trace.

1. 1

This analysis gives an equivalent of only 59.2 per cent of gypsum. The specimen collected was thought to be representative, but hand sampling is almost invariably uncertain, owing to the small size of the specimen and to the narrow area from which it is taken. In order to get reliable results a sample taken from such a deposit must be very large and must be collected so as to reach all available parts of the deposit, and it must then be carefully mixed and quartered to a convenient size for analysis. It is therefore entirely probable that 
either or both of the specimens analyzed may give a wrong impression of the deposit. They are both of value, howerer, in giving some idea of the purity of at least portions of the gypsum.

\section{LOS ANGELES COUNTY.}

CASTAIC.

Gypsum was mined during 1904 and 1905 by the Fire Pulp Plaster Co. from a deposit in Charley Canyon, 12 miles north of Castaic, a station on the Southern Pacific Railroad in Los Angeles County. It is said to occur in a vein, 2 to 4 feet wide, in a soft, much-jointed shale. The vein runs at about a right angle to the face of the hill but was found too expensive to work, as the road of the canyon washed out after heavy rains. The gypsum is said to be white or pink in color and of excellent quality.

\section{PALMDALE.}

At Palmdale, Los Angeles County, a station on the Southern Pacific Railroad 69 miles north of Los Angeles, both efflorescent and interbedded gypsum deposits are found, about $1 \frac{1}{2}$ miles southwest of the railroad, on a low ridge along which runs the Los Angeles aqueduct carrying water from Owens River to Los Angeles. Decomposed granite occupies a portion of the outer side of the ridge, and on it in places is a basal conglomerate containing large boulders of granite. Over this is a series of gypsiferous soft sandstones and shales. With the shales are interbedded thin strata of gypsum, half an inch in maximum thickness, and some lenses 4 to 6 feet in length, and on these sediments gypsite has formed in deposits similar to those farther north, along the Coast Range. The gypsum deposits occur through a length of about a mile or a mile and a half along the top and sides of the ridge. In places they have been washed down the sides of the hill, so that they cover the granite below. The accompanying sketch (fig. 4) shows the geologic relations. Two companies, the Fire Pulp Plaster Co. and the Alpine Plaster Co., formerly worked the deposits, and each had a plaster mill at Palmdale, but the mills have been dismantled and all operations ceased because of the inferior quality and the meager quantity of the rock.

The gypsite is 2 to 10 feet thick and is irregular in distribution and purity. At a number of places it occurs in small valleys in which it has been deposited by freshets that brought it down from the low hills above. In places it is much stained with iron, especially in watercourses through the gypsite. The gypsite is ordinarily overlain by 6 inches to 1 foot of dirt, and excavations from which it is removed cover from a few hundred square feet to an acre or more. 
The thickest deposits are on the brows of spurs of the main hill, where they reach a thickness of 9 feet. (See Pl. XII, B.) The gypsite is creamy white in color.

A partial analysis by George Steiger of a specimen from one of these deposits which was being worked February 1, 1907, gave the following result:

Partial analysis of gypsite from Alpine. Plaster Co.'s deposit, Palmale, Calif.

Lime $(\mathrm{CaO})$

Sulphur trioxide $\left(\mathrm{SO}_{3}\right)$

Water driven off àt $60^{\circ} \mathrm{C}$

Water driven off at $300^{\circ} \mathrm{C}$

Chlorine (Cl)

Iron oxide $\left(\mathrm{Fe}_{2} \mathrm{O}_{3}\right)$
32.8

45. 3

.1

20.5

.06

.30

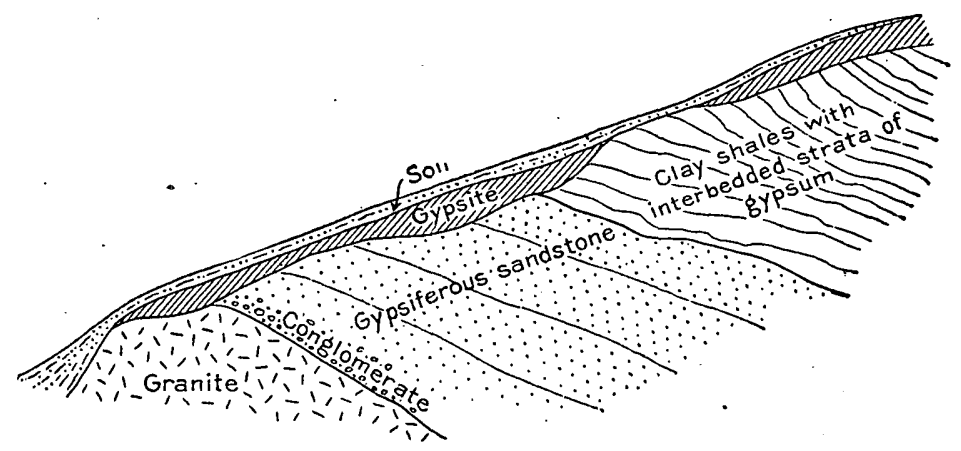

Figore 4.- Idealized section across hills $1 \frac{1}{2}$ miles southwest of Palmdale, Calif., showing relations of gypsite and gypsum to the country rock.

This is apparently equivalent to about 77.3 per cent gypsum. The interbedded gypsum deposits also were worked by the Fire Pulp Plaster Co. The beds are not at all uniform in the quantity of gypsum carried and can be worked only in places. The dip is uneven but is about $45^{\circ} \mathrm{W}$. The gypsum strata reach in places a thickness of 3 or 4 inches, and all contain more or less clay. (See Pl. XI, $B$.) The rock was shot down with dynamite and then handled with forks to separate the gypsum from the clay. Some hand picking was also necessary.

A piece of gypsum from one of the strata was partially analyzed by George Steiger, with the following result:

Partial analysis of rock gypsum from Palmale, Calif.

Lime $(\mathrm{CaO})$

27.5

Sulphur trioxide $\left(\mathrm{SO}_{3}\right)$.

33.5

Water driven off at $60^{\circ} \mathrm{C}$

.8

Water driven off at $300^{\circ} \mathrm{C}$

15.6

Chlorine $(\mathrm{Cl})$

Trace.

Iron oxide $\left(\mathrm{Fe}_{2} \mathrm{O}_{3}\right)$

1. 3

The specimen apparently carries 72.1 per cent of gypsum. 


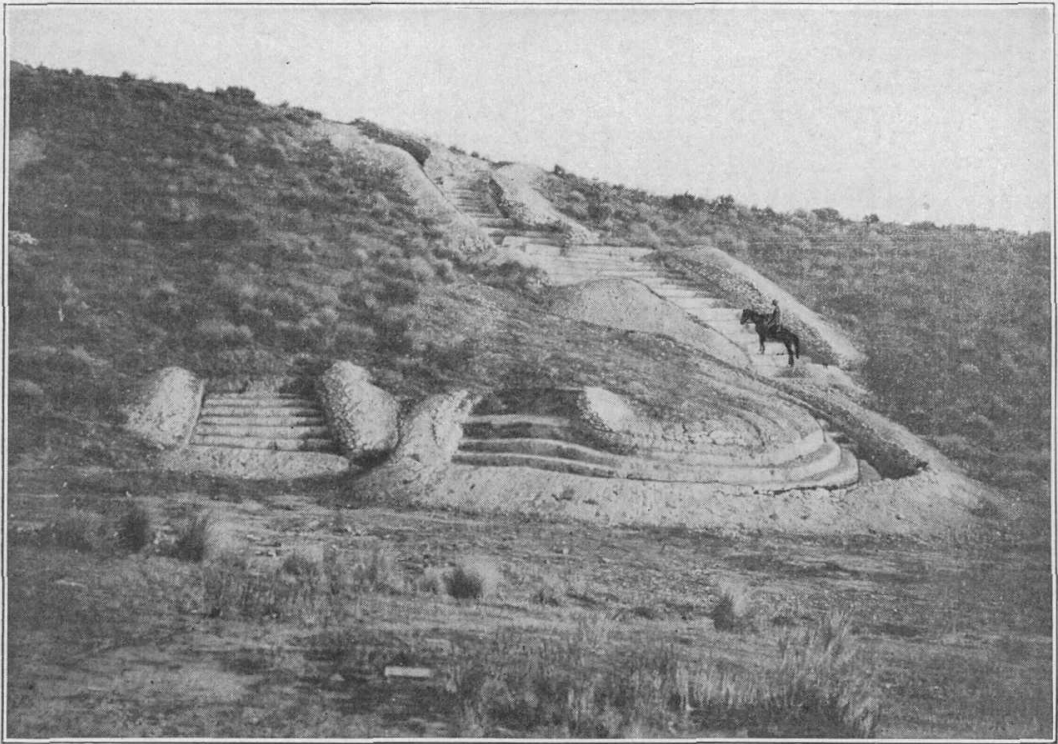

A. GYPSITE WORKINGS IN SEC. 7, T. 32 S., R. 22 E., ON THE CARRIZO PLAIN, CALIF.

This work was done to meet assessment requirements on supposed oil land. Photograph by Ralph Arnold.

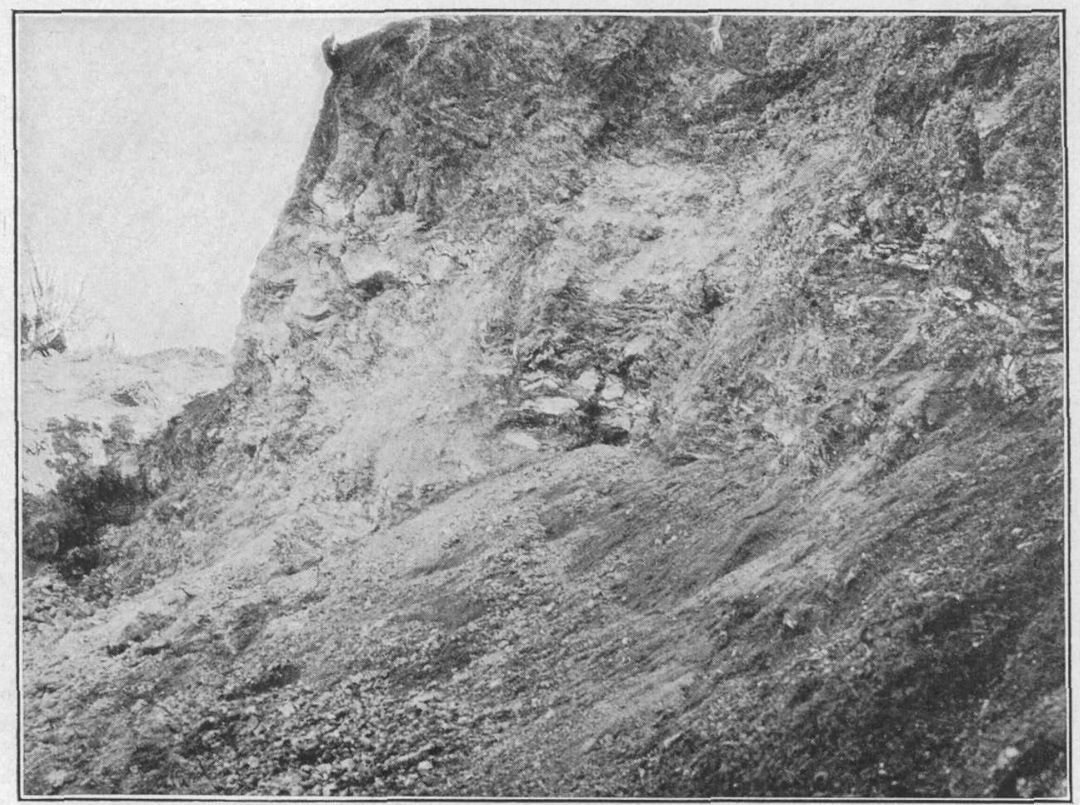

B. GYPSUM INTERBEDDED WITH CLAY SHALES $1 \frac{1}{2}$ MILES SOUTHWEST OF PALMDALE, CALIF.

The whiter strata are gypsum. Photograph by F. L. Hess. 


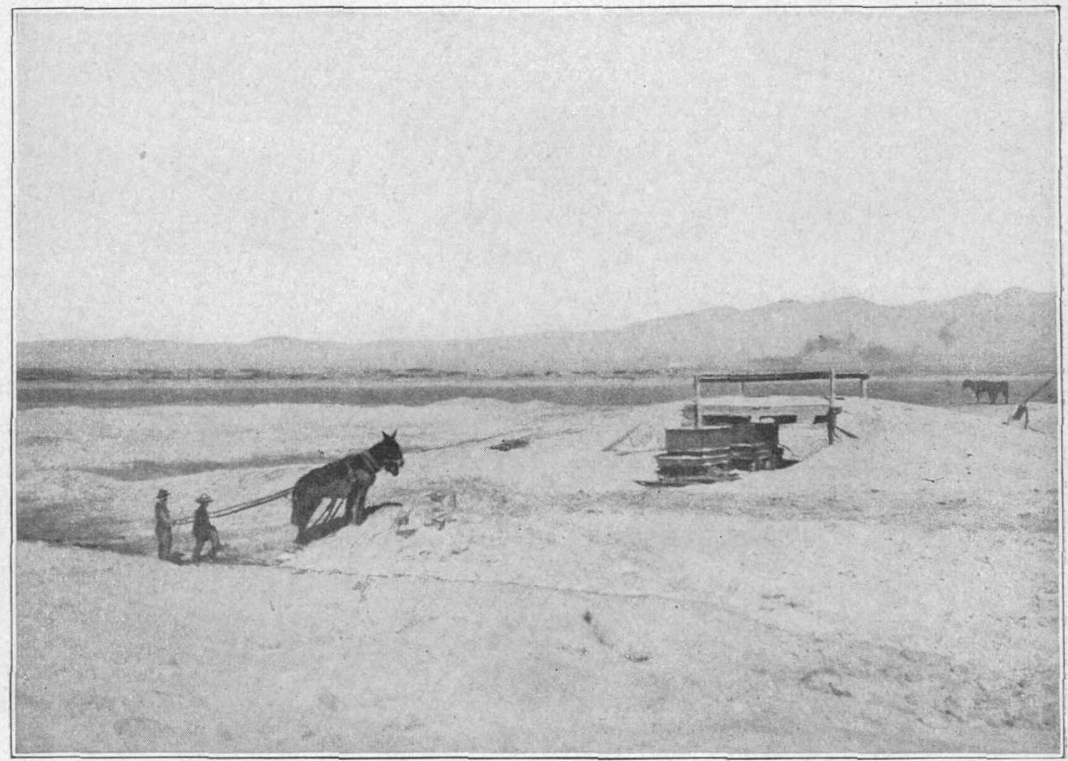

A. GYPSUM DEPOSIT IN THE BED OF A PERIODIC LAKE AT AMBOY, CALIF.

The gypsum, formerly dragged onto the platform by a horse scraper and dumped in the tramcars beneath, is now loaded by gasoline shovel. Photograph by F. L. Hess.

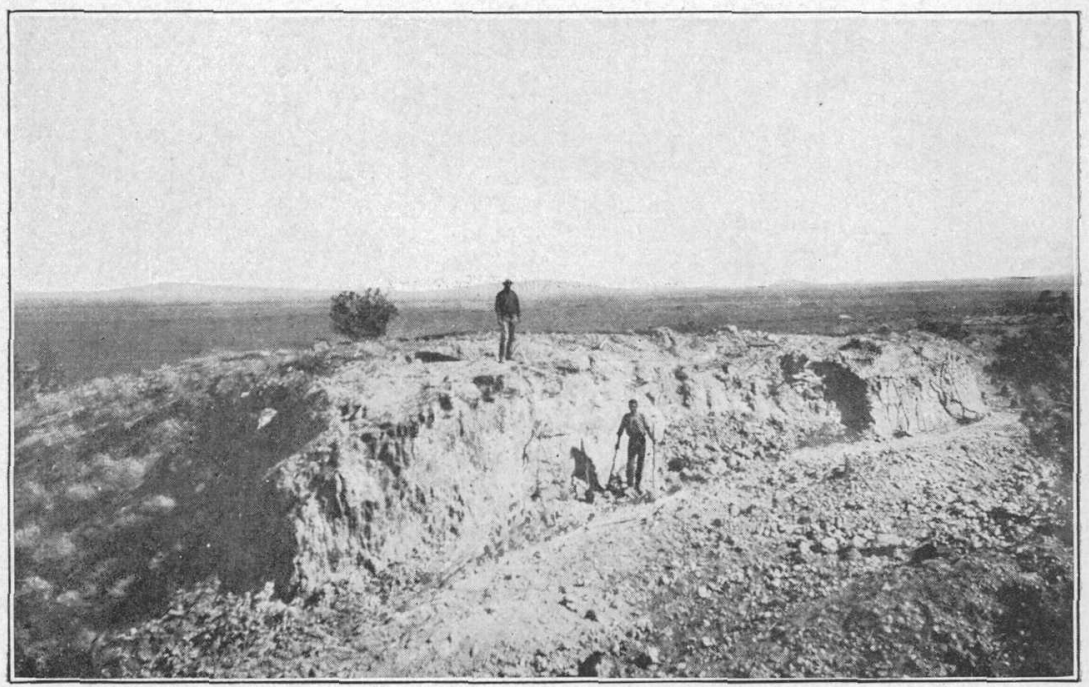

B. GYPSITE DEPOSIT 9 FEET THICK ON THE BROW OF A HILL $1 \frac{1}{2}$ MILES SOUTHWEST OF PALMDALE, CALIF.

Photograph by F. L. Hess. 
Similar beds outcrop at a point about $1 \frac{1}{2}$ miles northwest of the workings just described. 'A face 25 feet high and 50 feet broad is exposed in an excavation in the side of the hill: The beds here dip northeastward. Other deposits of gypsum are said to occur in the higher hills 6 or 7 miles south of Palmdile. Similar interbedded gypsum deposits are reported to occur at Lang, southwest of Palmdale, and the deposits at Castaic are said to be in the same rocks.

ORANGE COONTY.

A deposit in Gypsum Canyon, on the western slope of the Santa Ana Range, in Orange County, is in the form of a bunchy vein in rocks of probable Upper Cretaceous age. The strata are chiefly sandstone. The deposit, which has a thickness of 8 to 10 feet, is white and crystalline and almost as clear as alabaster. At one spot a mass of dolomite was found inclosed in it.

RIVERSIDE COUNTY.

CORONA.

Gypsite occurs in several small areas on both sides of Gypsum Canyon, about 2 miles south of Corona. The larger deposits, from which several hundred tons has been shipped, are on the east side of the canyon, a short distance from its mouth, in a small gulch that lies between 50 and 100 feet above the floor of the canyon. The gypsite is at most 4 feet thick and is overlain by 1 to 2 feet of soil. Its color is creamy, like that of the gypsite in the San Joaquin Valley, and it grades into the rock below in the same manner. 'The rock that it overlies is andesitic but is so badly decomposed that its nature can not readily be told. Its appearance in the field suggests that it may be a tuff. In thin sections it shows considerable iron pyrites, together with some calcite, and it is possible that the gypsum is derived directly from this rock through the interaction of weathering pyrite and plagioclase feldspars. However, close by, on the side nearer the mouth of the canyon, are soft sandstones from which the gypsite may have come. These sandstones may outcrop above the deposit on the hillside, and the gypsum may have been carried to its present place by the stream that flows in the gulch in wet weather. Near the mouth of the canyon a tunnel run into the west side has 4: to 5 inches of efflorescent salts on the floor, and on the walls there is an inch or more. The efflorescence is composed largely of iron sulphate. Other small gypsite deposits are said to occur in neighboring canyons west and southwest of Corona. This material is used in orchards as fertilizer and to prevent disease. 


\section{PALEN MOUNTAINS.}

Extensive deposits of gypsum occur in the Palen Mountains between the Colorado and Mohave deserts, northern Riverside County, Calif. The cut-off of the Atchison, Topeka \& Santa Fe Railway from Parker to Bengal passes within about 15 miles of the deposits.

The gypsum is very pure, occurring in extensive layers interbedded with limestone. Most of it is finely crystalline and compact and varies in color from transparent white to slightly reddish. A small percentage of the material is alabaster, finely granular, snow-white, and sufficiently compact for ornamental purposes.' This material occurs in layers and lenses in the crystalline gypsum.

The beds have a maximum thickness of several hundred feet, with little or no interbedded limestone; the entire series of limestone and gypsum is probably several thousand fcet in thickness. In places the gypsum is the predominant formation, but elsewhere the limestone is by far the most abundant.

The belt of gypsum and limestone is, roughly, about 3 miles long and from one-half mile to $1 \frac{1}{2}$ miles wide. It runs across the Palen Mountains in a general east-west direction and disappears under unconsolidated desert deposits on both sides. It is bounded on the north by a great mass of granite and on the south by quartzites and shales, with intrusive igneous rocks of several varieties. The gypsum beds are largest and most abundant in the southern part of the belt. The strike of the beds ranges from east to northeast, and the dip is to the north at different angles.

A dark igneous rock occurs extensively as an intrusive within the area of gypsum and limestone, being especially abundant in the northern half of the belt. It cuts the gypsum beds more commonly than the limestone because of their softer nature. On account of this fact many of the gypsum beds are locally so intricately intermixed with igneous rock as to render them almost valueless. However, large portions of the area are free from these intrusives.

\section{MARIA MOUNTAINS. ${ }^{2}$}

The series of gypsum and limestone beds of the Palen Mountains reappears to the east from under the desert deposits and occurs throughout the Maria Mountains. The main gypsum locality in the Maria Mountains is 17 miles in an air line south of Blythe Junction, a station on the Parker cut-off of the Atchison, Topeka \& Santa Fe Railway. The area underlain by gypsum is wedge-shaped, being above $2 \frac{1}{2}$ miles long, $2 \frac{3}{4}$ miles wide at the east end, and 1 mile wide

\footnotetext{
1 Harder, E. C., The gypsum deposits of the Palen Mountains, Riverside County, Callf. U. S. Geol. Survey Bull, 430, pp. 407-416, 1910.

¿ Surr, Gordon, Gypsum in the Maria Mountains of California : Min. World, vol, 34, pp. 787-790, 1911.
} 
at the west end. The country is flat and covered by mash both east and ivest. Gypsum beds again appear 5 miles east of the locality and the large gypsum deposits in the Palen Mountains, about 15 miles west of the west end of this district, are probably a continuation of the gypsum series here described.

The gypsum in the Maria Mountains occurs in beds that have a general east-west course and a northerly dip, which ranges at the cutcrop from $20^{\circ}$ to almost vertical. In places the formation is nearly flat, and so doubtless are the underlying gypsum deposits. Igneous rock, a quartz monzonite gneiss, bounds the gypsum area on the north and south. The gypsum beds range in thickness from 10 to more than 100 feet and are interbedded with limestone or shaly material. They occur in two bands of four beds each. The thickness of the limestone between the gypsum beds is from 100 to sereral hundred feet. Most of the gypsum is snowy white; some of it, however, has a grayish tint or shows grayish bands.

The openings in the gypsum are superficial with the exception of a shaft and numerous drill holes put down by the United States Gypsum Co. The shaft, which is in the eastern part of the district and near the northern limit of the gypsum belt, is vertical, 70 feet deep, and has a 50-foot crosscut at the bottom. A vertical hole was drilled. in the bottom of the shaft to a depth of 260 feet, but whether it was all in gypsum is not known.

The geologic age of the deposits is unknown but may be Paleozoic.

\section{MECCA.}

In the Colorado Desert, 12 miles east of Mecca, are deposits of rock gypsum about the extent and purity of which reports differ considerably. Specimens seen and information obtained from various sources indicate that the deposits are similar to those at Palmdale, and probably have no commercial value.

OTHER DEPOSITS. 1

At many places in the Colorado Desert the Miocene rocks carry interbedded strata of gypsum, which, however, are generally too thin to be of economic value.

\section{SAN BENITO COUNTY.}

Along the west side and middle of the Coast Range many deposits of gypsite that are in all essential respects similar to those on the eastern slopes have been reported. They are particularly numerous along the east side of Salinas Valley. 
The deposits east of Metz and King City, most of them in San Benito County but a few in Monterey County, have been briefly described in reports of the California State Mining Bureau.

A deposit on the southwest side of Bitterwater Valley, in San Benito County, 10 miles east of King City, at an elevation of 1,900 feet, crops out along the top of a series of ridges and dips gently westward. It is overlain by clayey soils and covers an area of several hundred acres. The upper portion of the deposit is composed of massive gray gypsum, which, according to analysis, is 90 per cent pure. The thickness of this deposit is from 3 to 7 feet. This stratum is underlain by another, less pure, which contains only 40 to 60 per cent gypsum, the impurities being lime, clay, and sand. The gypsum is soft and marly and can be advantageously used for fertilizing purposes. (See Pl. XIII, A.)

The following descriptions are taken from a report by Lewis $\mathrm{E}$. Aubury: ${ }^{1}$

In Bitterwater Creek canyon a number of detached gypsum deposits are found, running from Lewis Creek in sec. 5, T. 19 S., R.10 E. Mount Diablo meridian, to sec. 17 or 18 , T. 18 S., R. $9 . \mathrm{E}$. The quality of the gypsum differs materially in the various exposures.

F. Q. Alvarez, Bitterwater post office: In sec. 5, T. 19 S., R. 10 E., and sec. 32 , T. 18 S., R. 10 E., on the east side of the lower Bitterwater. The gypsum lies in or in close contact with a belt of serpentine which runs along the east rim of Bitterwater Valley. It is mixed with clay and often of a grayish color; some boulders of white gypsum are, however, found on the surface. Several years ago some was excavated and hauled to San Francisco, but in later years the deposit has been idle.

Mrs. S. Chambers, Bitterwater post office: In sec. 15, 'T. 18 S., R. 9 E., on the west side of Bitterwater Valley, some gypsum boulders were excavated some years ago. In a well dug near the house a bed of gypsum about 3 feet thick was passed through. Three hundred yards northeast of the house some open cuts have exposed two beds of a fair quality of gypsum. The country rock is shale, but the gypsum is accompanied by a light-gray sandstone containing inclusions of gypsum.

J. F. Dunn, Hollister: On the Topo ranch, in sec. 17 or 18, T. 18 S., R. 9 E., on the divide west of Bitterwater Valley, a deposit of gypsum lying in a horizontal bed 3 to 4 feet thick has been opened for about 100 feet. It has only a solid overburden of $2 \frac{1}{2}$ to 3 feet, and is underlain by shale. The gypsum is of fairly good quality. The deposit is 12 miles from railroad. ${ }^{2}$

J. C. Tully, Bitterwater post office: In sec. 32, T. 18 S., R. 10 E. [See Alvarez deposit, of which it forms part.]

R. R. Tully, Bitterwater post offce: In sec. 11, T. 18 S., R. 10 E. Some detached bodies of grayish-colored gypsum, somewhat mixed with clay.

Estate of T. Williams (deceased), 1003 First Street, San Jose: In the southwestern part of T. 19 S., R. 12 E., and the northwestern part of T. 17 S., R. 12 E. Mount Diablo meridian, on Silver Creek, indications of gypsum have been found.

1 The structural and industrial materials of California: California State Min. Bur. Bull. 38, pp. 286-287, 1906.

2 California State Mineralogist Thirteenth Ann. Rept., p. 504, 1896. 


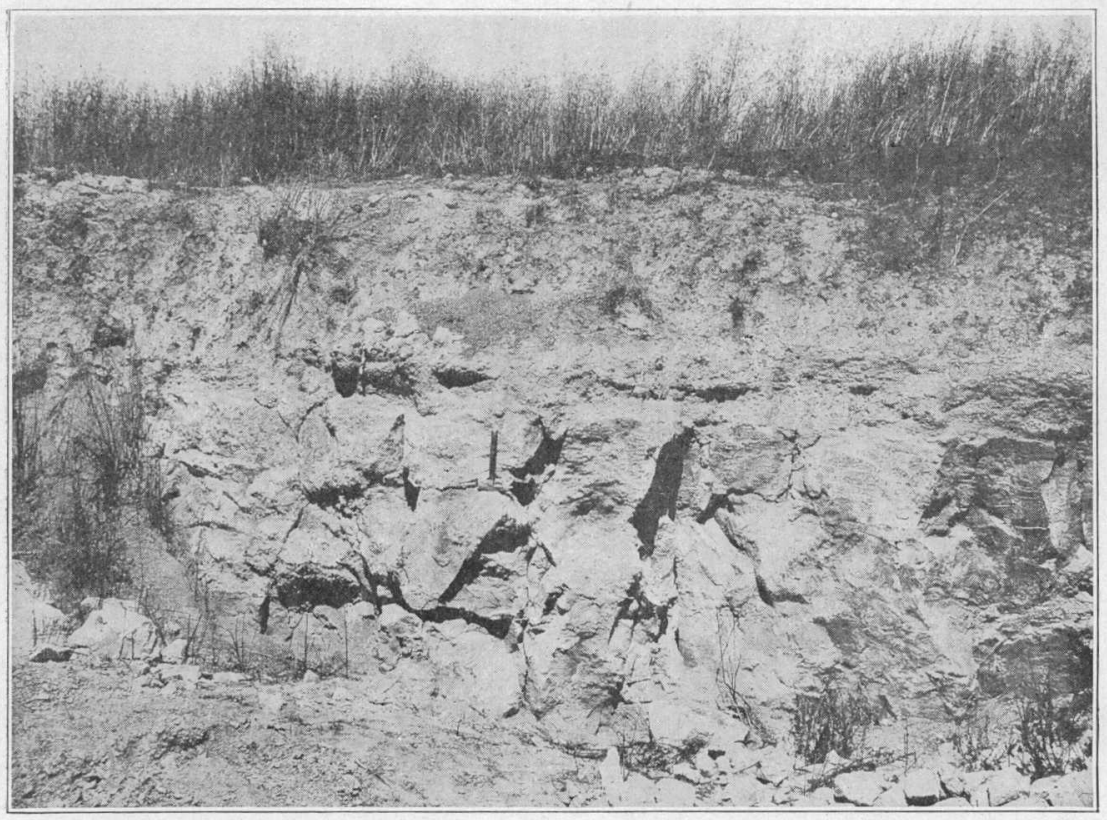

A. BED OF GYPSUM ON MESA 15 MILES NORTH OF KING CITY, CALIF.

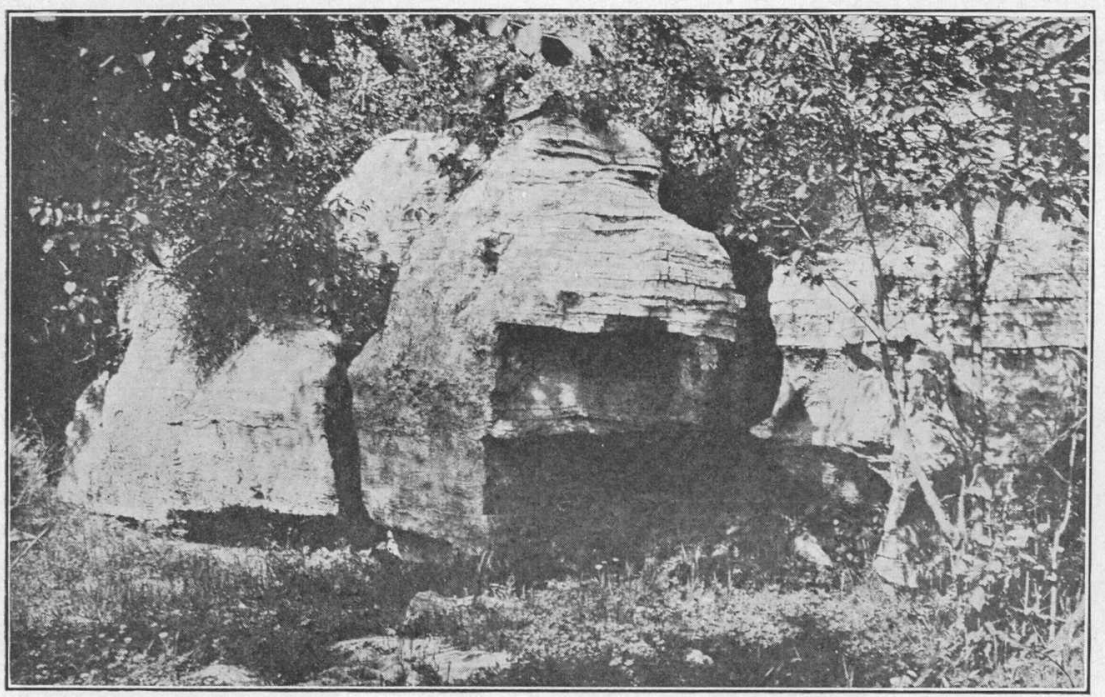

B. GYPSUM OUTCROP ON FORT DODGE, DES MOINES \& SOUTHERN RAILROAD HALF A MILE SOUTH OF DES MOINES RIVER, NEAR FORT DODGE, IOWA.

This outcrop shows bedding, solution channels, and durability under long exposure. Photograph by R. W. Stone. 
SAN BERNARDINO COUNTY.

AMBO.Y.

Amboy, a station on the Atchison, Topeka \& Santa Fe Railway in the Mohave Desert, San Bernardino County, about 225 miles from Los Angeles, is on the north shore of a periodic lake, along which the railway extends in an east-west direction for 6 or 8 miles. The gypsum deposits are in the lake bed, probably stretching nearly around it. This lake bed is of a type common in the Mohave Desert and is a number of miles in extent. The surface soil is salty, so that almost no vegetation grows on it. The lake receives drainage from mountains on both the north and the south, but the rainfall in the mountains is rarely sufficient to furnish the streams enough water to cover the surface of the dry bed.

A small volcano rises 3 miles west of the lake, and from this streams of basaltic lava have run over the lake bed. In the bays between these flows gypsum is found throughout the area, and the winds have blown it up into small drifts across the tongues of lava. Over a portion of the area a light volcanic ash forms the surface soil, a foot or more thick, and below this gypsum is found to a depth of 6 to 8 feet, at which point the water level is reached. It is not known how far the gypsum may extend below water level. Many prospect holes have been dug along the north and east shores of the lake and gypsum was found only within about half a mile or a mile of the shore line.

The gypsum varies considerably in character, both longitudinally and vertically. In many places the gypsum nearest the surface is rather dirty, but below it is a stratum, 14 inches to 2 feet thick; of clean, white granular gypsum. In places the gypsum is cemented into a clean, spongy mass, which has little solidity but can be broken out in chunks a foot or more in diameter. At other places the gypsum crystals reach an inch or more in breadth but are thin in proportion. There is also considerable variation in the amount of clirt present. It is reported that gypsum occurs on the south side of the lake bed, and it is probable that the deposits will be found along a considerable proportion of its circumference. The character of the rocks in the hills is unknown, but there are crystalline rocks on both sides and more than likely young sedimentary rocks also.

In a prospect hole 2 miles east of Amboy no water appeared at a depth of $9 \frac{1}{2}$ feet, and the gypsum does not have the salty taste which is common to the gypsum on the west side of the lake. Gypsum is found all the way to the bottom. The uppermost 2 feet is rather dirty. Below this material is 2 feet of much cleaner material, but the lower $4 \frac{1}{2}$ feet is iron stained and dirty. The gypsum is $124567^{\circ}-20-6$ 
coarse grained, the largest crystals being one-fourth inch across, and in general is loose but includes some hard layers and seams.

The Consolidated Pacific Cement Plaster Co. of Los Angeles is operating on the west side of the lake and has a mill at Amboy. This company draws its supply of gypsum from points between 2 and 3 miles southeast of the mill. The surface is stripped by horse scrapers to a depth of about 6 inches, and the gypsum is then loaded into tram cars by gasoline shorel. (See Pl. XII, A.) These cars are then hauled by steam locomotives to the mill. The deposit is worked down to water level, a depth at this point of somewhat less than 8 feet. The level will undoubtedly vary from time to time. At this depth the gypsum is apparently of as good or better quality than at points above.

A partial analysis of a selected sample by George Steiger is as follows:

Purtial analysis of gypsum from deposit a miles sonthivest of Amboy, Calif.

Lime $(\mathrm{CaO})$ 32. 7

Sulphur trioxide $\left(\mathrm{SO}_{3}\right)$ 44. 7

Water driven off at $60^{\circ} \mathrm{C}$ .2

Water driven off at $300^{\circ} \mathrm{C}_{-}$

Chlorine $(\mathrm{Cl})$ -

Iron oxide $\left(\mathrm{Fe}_{2} \mathrm{O}_{3}\right)$

The water driven off at $60^{\circ} \mathrm{C}$. is considered as hygroscopic. That driven off at $300^{\circ} \mathrm{C}$. (19.5 per cent) is sufficient to hydrate fully 92.8 per cent of gypsum. Nominally this would leave 2.7 per cent of anhydrite, but it is probable that this is partly hydrated calcium sulphate, and that a portion of the 92.8 per cent is also only partly hydrated, so that the sum of the two, 95.5 per cent, more nearly represents the amount available for plaster making. There is a small amount of lime present, probably as calcium carbonate, in which form it would amount to 2.5 per cent. The gypsum from the top to the bottom of the deposit would probably not be as pure as this analysis would indicate.

There is undoubtedly enough gypsum in sight to run several such mills as that now working for many years. Two salt works on the lake bed, a fer miles east of Amboy, make use of the heavy brine.

Similar periodic-lake deposits of gypsum are said to exist south of Danby, on the Atchison, Topeka \& Santa Fe Railway, and near Kelso, on the Los Angeles \& Salt Lake Railroad. Similar deposits are also reported in the Colorado Desert.

\section{AVAWATZ MOUNTAINS. ${ }^{1}$}

Not far from the northern boundary of San Bernardino County, on the northeast edge of the Avawatz Mountains, there are ex-

${ }^{1}$ Abstract from report made by F. R. Johnson for the Avawatz Salt \& Gypsum Co., July, 1911. 
tensive deposits of rock gypsum. The locality is at the extreme south end of Death Valley and about 10 miles west of the Tonopah \& Tidewater Railroad. The Avawatz Salt \& Gypsum Co. of Los Angeles has gypsum claims in secs. $15,22,23,25$, and 26, T. $18 \mathrm{~N}$., R. 5 E., San Bernardino base and meridian, and has done development work on the gypsum and associated beds of talc, salt, and celestite.

The gypsum-bearing strata range from 150 to about 400 feet thick, the average thickness being 250 feet. They outcrop over an area 9 miles long by 1 mile wide. These strata consist of greenish or reddish sands and clays, which carry large quantities of gypsum and beds of rock gypsum from 1 to 10 feet thick. The rock gypsum is massive, fine grained, and varies in color from white through shades of green, pink, and red to dull black. The green is due to flakes and seams of green clay, the red to iron, and the black to manganese. Weathered gypsum outcrops are generally cream or buff or show delicate tints of red or green. Satin spar occurs in seams from 1 inch to 4 inches wide. Plated selenite is comparatively rare.

Earth movements have been intense in these mountains, producing curved lines of strike and many prominent faults. The valuable nommetallic deposits lie mostly in troughs between parallel ridges and the main mountain mass. The gypsum in many places is in particularly advantageous positions for mining.

Analyses of a number of samples show from 74 to 97 per cent pure gypsum.

\section{SAN LUIS OBISPO COUNTY.}

CARRIZO PLAIN. ${ }^{1}$

Gypsite occurs at numerous places on the southwest flank of the Temblor Range, immediately east of the Carrizo Plain, from the vicinity of sec. 16, T. 31 S., R. 21 E., to the Kern and San Luis Obispo county line, near sec. 36, T. 32 S., R. 22 E. The deposits are of the efflorescent type, and most of them are of poor grade. They overlie the soft Miocene sandstones exposed on this flank of the range. Only assessment work had been done on these deposits. The gypsite is of so low a grade that under present costly methods of working and lack of adequate and cheap transportation facilities it is practically valueless. The locators made no secret of the fact that the work was done for the purpose of meeting the assessment requirements on oil claims, so that these occurrences could in no sense be considered as actual gypsite prospects.

Plate XI, $A$ (p. 76), a view taken in sec. 7, T. 32 S., R. 22 E., shows one of the many gypsite workings in the Carrizo Plain on which work had been done to meet assessment requirements. 


\section{ALAMO CREEK.}

Bunchy gypsum veins are scattered over 40 acres on Alamo Creek, 16 miles from Santa Maria. The veins occur in clay beds similar to those at Point Sal. Part of the gypsum is white and part grayish. Little development work has been done on the deposit.

\section{SANTA BARBARA COUNTY.}

\section{SANTA BARBARA CREEK.}

Deposits of alabaster described as 20 to 30 feet thick and traceable across the country for many miles were visited on the south side of an eastern branch of Santa Barbara Creek, 32 miles southwest of McKittrick. The location of the claim was given as the SE. $\frac{1}{4}$ sec. 34, T. 9 N., R. 25 W., San Bernardino base and meridian. The outcrop occupies the end of a low point and is about 50 to 75 feet long by 20 to 25 feet broad and probably somewhat less in thickness. It has an apparent strike along the face of the hill, but a prospect tunnel driven to a length of 40 feet failed to find gypsum in other than thin veins, the largest of which is about 4 inches thick. The outcrop is composed of finely crystalline material, some of which may be classed as alabaster. It is in irregular masses, the largest of which is probably not over 2 feet long, and the clear material is in still smaller pieces. There are small pieces of beautiful pink and clear white material, though only a part of it is hard enough to be useful as alabaster. It occurs in a soft. clayey sandstone, which is probably of Tertiary age.

\section{POINT SAL.}

On Point Sal, Santa Barbara County, gypsum was mined for several years previous to and including 1889, at a number of points 1 to 2 miles from the coast. Of the former workings there now remain only caved open cuts and tunnels. The rocks are clayey shales of Miocene age, only slightly consolidated, are overlain and underlain by harder rocks, and appear to be similar to those on Santa Barbara Creek, mentioned above. The gypsum in sight is similar to that described near Santa Barbara Canyon and is apparently not in continuous beds, as it can not be traced into the gulches. Almost none is to be seen on the surface, and the beds are probably of little or no economic value. From 10 to 20 carloads of gypsum remain unshipped on the seashore. The gypsum is well solidified and is of rather fine grain. Although it contains considerable clay a small part of it is white. 
VENTURA COUNTY.

FILLMORE.

A bed of massive white gypsum in secs. 12 and 13, T. 3 N., R. 20 W., t: miles by road south of Fillmore, was quarried from 1911 to 1914 . The gypsum is interbedded with diatomaceous shale that strikes east and dips north at a low angle. The rock was calcined and made into wall plaster at Fillmore. Operations were abandoned because of the impurity of the gypsum.

\section{SOUTH MOUNTAIN.}

On the south slope of South Mountain at an elevation. of 2,000 feet, about 4 miles south of Santa Paula, massive but soft granular gypsum occurs interbedded with diatomaceous shale. The beds strike east and $\operatorname{dip} 60^{\circ} \mathrm{N}$. The gypsum is between the two lines of the Southern Pacific Railroad, but it is impure, occurs on the top of the mountain, and does not wärant development.

\section{FRENCH POINT.}

'In sec. 16, T. 8 N., R. 24 W., San Bernardino base and meridian, on the east sicle of Cuyama River, 6 miles above the mouth of Santa Barbara Canyon, is a hill known as French Point, which is 200 to 250 feet above the river. A deposit of alabaster is reported to occur near the top of the hill, from which blocks a yard square and 10 inches thick are said to have been taken. An analysis shows that it contains over 90 per cent of gypsum. The locality is 25 miles south of Maricopa, Kern County.

\section{OJAI VALLEX.}

There is an undeveloped bed of gypsum on the hill below the grade that leads to the upper Ojai Valley in Ventura County about 3 miles east of Nordhoff. It is exposed for a width of 15 to 20 feet in a canyon on the south side of the road and dips slightly to the east. Another outcrop, perhaps the same bed, appears a mile distant, on the opposite side of the hill. The locality is so situated that it can be reached by the construction of a short road.

\section{SUMMARY.}

The gypsum deposits of California may be divided into four classes-(1) efflorescent deposits; (2) periodic-lake deposits; (3) interbedded deposits; (4) selenite, or crystallized gypsum veins. Of these all except the fourth class-the vein-may locally be of value.

The efflorescent deposits are widely spread over the Coast Range and Tehachapi Mountains from San Benito to Los Angeles counties. They overlie a variety of Tertiary sediments, fine and coarse sandstones and shales. In general they are of little or no value, but locally, where transportation is not too difficult, the deposits may be workable. 
At a number of places visited claims on such. deposits were nominally being held for the gypsum upon them. The gypsum at many deposits can be of no value until transportation is very much cheaper than it is now or is likely to be, and that at other deposits will never be of value: Many a claim owner freely admitted that he was really holding the claim for oil, but that under the then existing laws he believed there was no legal way of holding an oil claim against jumpers until it could be prospected, no matter what expenditure of time and money was made upon it, whereas if it were taken up as a gypsum claim it could be held until a patent was obtainable by doing the annual assessment work.

Effloresecnt deposits are formed by the evaporation of water which has percolated through porous gypsiferous rocks and dissolved gyfsum from them and which leaves its load of gypsum at the place where raporization has proceeded to a point at which gypsum is precipitated through supersaturation.

The periodic-lake deposits are found in San Joaquin Valley, the Mohave Desert, and probably in the Colorado Desert. The large deposit at Amboy is being mined, and prospecting may show others to be of value also. In this and other desert playas the waters are briny, but at Kern and Buena Vista lakes gypsum has been deposited from companatively fresh waters. In the desert lakes gypsum is probably precipitated through supersaturation brought about by evaporation, but in the fresh-water lakes the gypsum is deposited just outside the normal shore line by the evaporation of water from the soil, the deposit being formed similarly to the efflorescent deposits on rocks, the soil drawing its supply of water from the somewhat concentrated solution along the shore of the lake.

Practically all the efflorescent and lake deposits except those in the briny lakes are covered by soil. From those that are not thus covered the soil seems to have been remored by wind or other agencies. The soil is thought to be not necessarily of later deposition but to be older than or contemporary with the gypsite deposits. The summer heat is very great in all the localities, so that the moisture drawn from the rocks and soil by the sun is vaporized at a depth of several inches below the surface, the depth varying with the locality, or at least it is raporized sufficiently to precipitate the gypsum before it reaches the surface.

Interbedded deposits are found in Miocene clayey sediments at many places from the middle of Los Angeles County southward along the Colorado Desert, and at a few places northward. Locally these deposits may be workable, but they are generally lean. Interbedded deposits in the Palen, Maria, and Avawatz mountains are of unknown age and are reported to be of excellent quality and considerable size. - Large veins of selenite are not known at any place in the State. 


\section{COLORADO.}

By R. D. George.

\section{GENERAL CHARACTER.}

Gypsum is widely distributed in Colorado, though commercial deposits appear to be confined to a few geologic formations. The supply is almost unlimited, and unless very important new uses are found either for the raw mineral or the manufactured products there is enough to meet the demands for centuries. By far the larger part of the gypsum is of the granular rock variety and occurs interstratified with other sedimentary rocks. Here and there, however, through the weathering of the rock gypsum, considerable accumulations of gypsite have been formed.

Two deposits in the vicinity of Pueblo may be of Tertiary lake origin. One of them is firm gypsum, but the other is gypsite.

Of the vast volume of gypsum in the State a very large proportion is of excellent quality, and analyses show as high as 99 per cent of hydrous calcium sulphate. In places the deposits must be classed as gypsiferous shales, which are commercially useless.

There are only two deposits being worked for the manufacture of plaster at the present time. These are the United States Gypsum Co.'s property near Arkins, west of Loveland, in Larimer County, and the Colorado Portland Cement Co.'s deposit at Coaldale, with a mill at Portland, in Fremont County. Gypsum is quarried near Stone City, Pueblo County, for use in Portland cement.

\section{AGE.}

So far as our present knowledge goes the Carboniferous was by far the most important period of gypsum deposition. Probably 90 per cent of the gypsum of the State occurs in strata of Pennsylvanian and Permian age. The Morrison formation (of Cretaceous or Jurassic age) contains workable deposits near Pueblo and Colorado Springs. Gypsum, mainly in the form of selenite crystals, occurs in the Benton, Niobrara, and Pierre formations of Upper Cretaceous age. The large deposit of commercial gypsum near Stone City rests on Cretaceous strata and may be of Cretaceous age, but so far as the writer knows it is possible that it is of Tertiary lake origin.

\section{IOCALITIES.}

\section{LARIMER COUNTY.}

The gypsum near Arkins is near the base of the Lykins formation (probably of Permian age) and is revealed by the erosion of the crest of an anticlinal fold. The deposit as exposed ranges in thickness from 12 to 36 feet and arerages about 24 feet. 
Pl. XIV, A.) The gypsum lies between the hard basal sandstone member of the formation and the "crinkled" sandstone, which consists of a varying mixture of sand and lime carbonate. Exposures and test holes have shown a minable deposit exceeding $1,000,000$ tons.

The color ranges from gray to white, and the texture is fine granular. Analyses show slight variations in purity from place to place, but as a whole it is a remarkably uniform and clean body of gypsum. It is convenient to transportation, easily quarried, and makes excellent gypsum products. This deposit has been quarried for many years and is now worked by the United States Gypsum Co.

Gypsum occurs at about the same position in the Lykins formation at points between the Arkins deposits and the north line of the State. Some of the more important outcrops are at Owl Cányon, Deadman Butte, near Greenacre ranch, and on Boxelder and Sand creeks near Table Mountain. Between these points minor outcrops are known, and beyond Table Mountain others have been reported. The evidence at hand makes it appear possible that the deposit is fairly continuous for several miles between Owl Canyon and Greenacre ranch.

The Owl Canyon outcrop shows a clear-white granular gypsum of 99 per cent purity and apparently of great extent. West and southwest of.Greenacre ranch there are two beds separated by a considerable thickness of red shaly sandstones and shales. In places the western or lower deposit carries much beautiful selenite, but the upper deposit is weathered into gypsite over a considerable area. In the vicinity of Table Mountain the deposit is white massive granular gypsum, and forms a ridge of considerable extent. To the north of the mountain it occurs in several bands from 2 to 12 feet thick separated by thin red shales. ${ }^{1}$

\section{JEFFERSON COUN'TY.}

Near Morrison, on Bear and Deer creeks, gypsum occuirs as lenses and in bodies of considerable size in the Lykins formation. On Deer Creek a stratum 20 feet thick lies not fär from the top of the formation. As a rule the gypsum is associated with the variegated shales and earthy limestones, but on Deer Creek the deposit is associated with the limestones occurring below the capping sandstone. Shipments have been made from the vicinity of Morrison.

\section{DOUGLAS COUNTY'.}

The Perry Park gypsum deposits also occur in the Lykins formation, which there consists mainly of soft red shales. The "crinkled" sandstone forms two bands, the lower of which is calcareous and

${ }^{1}$ Butters, R. M., I'ermian or "Permo-Carboniferous" of the eastern foothills of the llocky Mountains in Colorado: Colorado Geol. Survey Bull. 5, pt. 2, p. 74, 1913. 


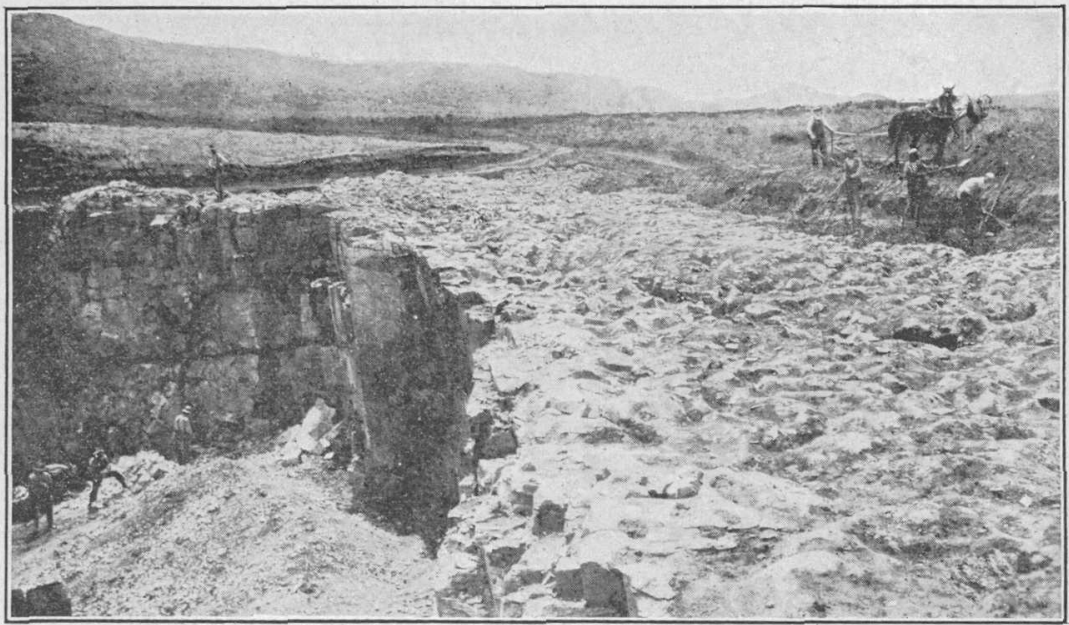

A. GYPSUM QUARRY IN LYKINS FORMATION, LOVELAND, COLO.

Photograph by W. T. Lee.

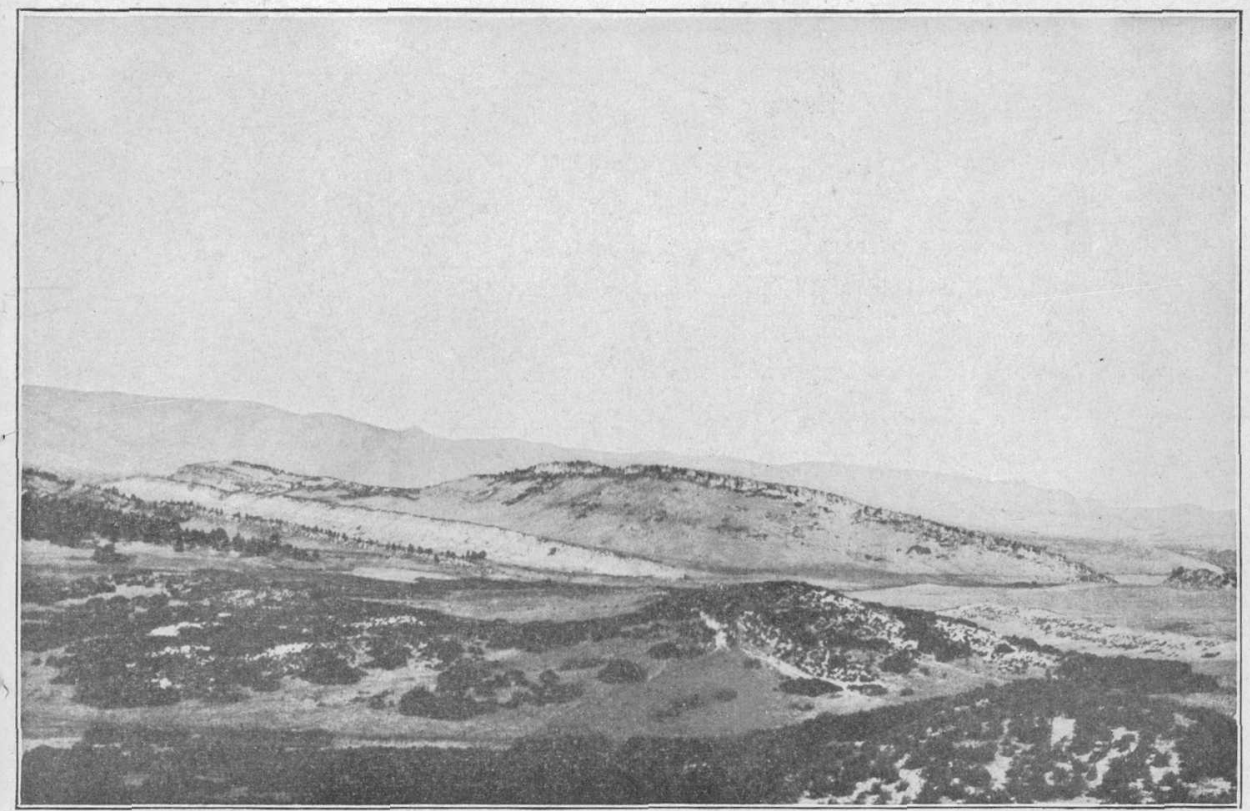

B. THICK BED OF GYPSUM IN PERRY PARK, COLO.

This deposit is west of Gove Creek and shows as a white band in the middle ground. Photograph by G. B. Richardson, 


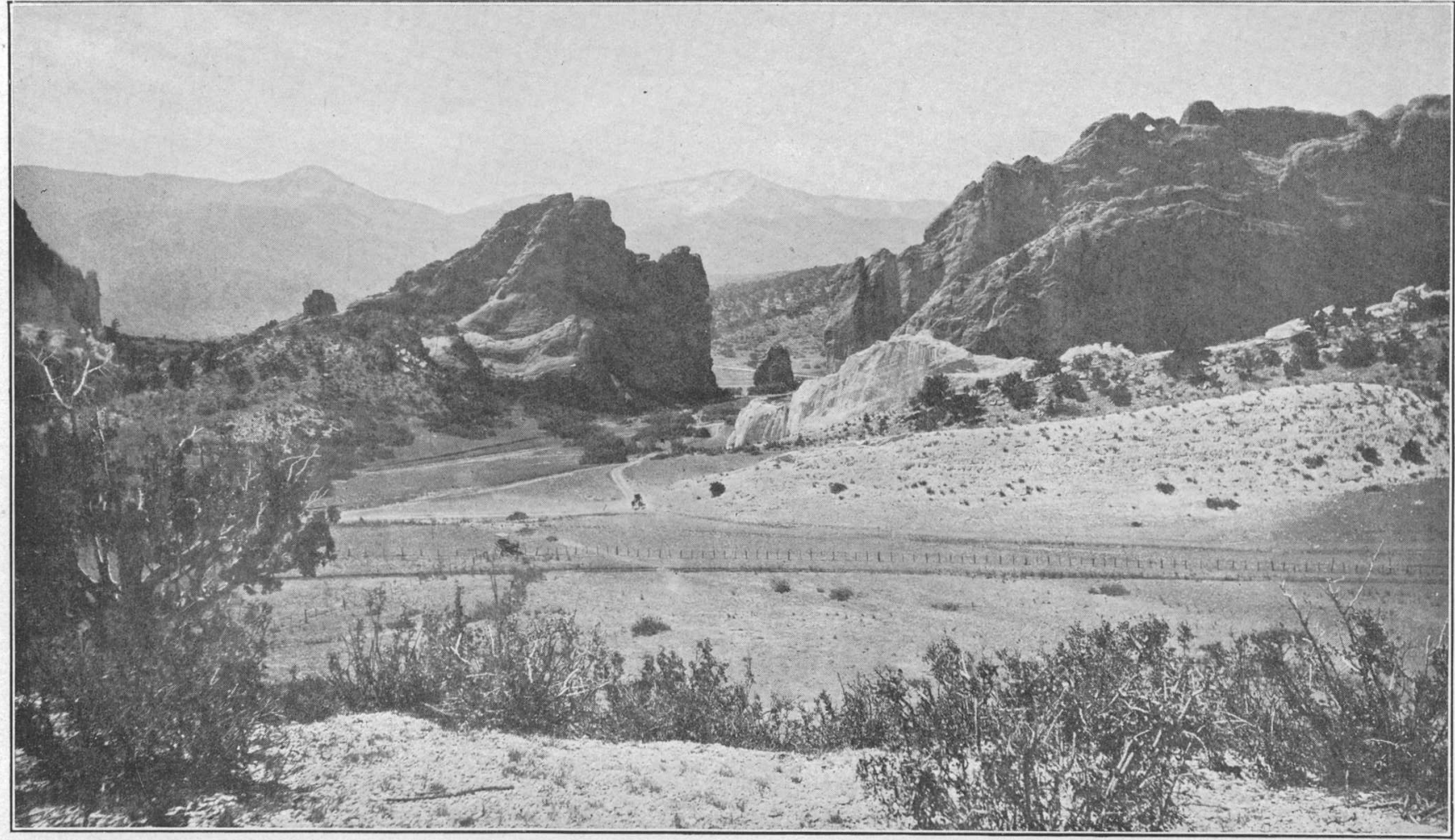

THICK BED OF GYPSUM AT ENTRANCE TO GARDEN OF THE GODS, COLORADO SPRINGS, COLO.

The gypsum is in the foreground between the fence and the white sandstone ledge. 
yields fossils regarded as of Permian age. Above the upper band - and apparently forming the top of the Lykins formation is an irregular band of gypsum averaging about 40 feet but reaching a maximum of 75 feet in thickness. ${ }^{1}$ 'This band of gypsum is overlain by a limestone which probably belongs to the Morrison formation. The gypsum can be traced for about 8 miles. (See Pl. XIV, B.) $A$ large part of the mineral is of excellent quality, and it has been quite.extensively worked.

\section{EL PASO COUNTY.}

In the Garden of the Gods, along Fountain Creek, Little Fountain Creek, and at Glen Eyrie extensive beds of fine white granular gypsum occur in the upper part of Hayden's Red Bed series, which is now called the Lykins formation. The deposits range in thickness from a few feet to 60 feet. Selenite and satin spar occur in appreciable quantity in some of the beds. In the Garden of the Gods the gypsum is interstratified with clays, and the white outcrop of this member is a conspicuous feature at this much frequented place. (See Pl. XV.) Near Glen Eyrie the bed is 57 feet thick. These beds have not been worked to any extent, but beds near Colorado City have been worked rather extensively. Stevenson ${ }^{2}$ reports a thickness of 120 feet of gypsum and shales on Little Fountain Creek.

Local occurrences of gypsum are reported as far south as Trinidad, but no descriptions are available.

\section{PUEBLO COUNTY.}

A short distance south of Stone City, about 20 miles northwest of - Pueblo, there is a considerable surface deposit of very pure gypsum which has been worked by the Turkey Creek Stone, Clay \& Gypsum Co. The product is used in the cement industry. The deposit is underlain by Upper Cretaceous rocks and, from the description at hand, would appear to be of comparatively recent lake origin.

Gypsum is reported in Sullivan Park, on SW. $\frac{1}{4}$ sec. 4, T. 18 S., R. $67 \mathrm{~W}$, or near the county line, a few miles north of Stone City. Nothing is known of the character and extent of the deposit.

Gilbert ${ }^{3}$ mentions two occurrences of gypsum in the Pueblo quadrangle. Of the first of these he says:

Near the northwestern corner of the quadrangle are two small areas of the Morrison formation. These are parts of a much larger area occurring in the Colcrado Springs quadrangle, adjacent at the north, so that they belong rather to that quadrangle than to the Pueblo. The formation contains an

1 Butters, R. M., op. cit., p. 82.

a stevenson, J. J., Report on the geology of a portion of Colorado examined in! 1873: U. S. Geog. and Geol. Surveys W. 1.00th Mer. Final Rept., vol. 3, p. 379, 1875.

${ }^{3}$ Gilbert, G. K., U. S. Geol. Survey Geol. Atlas, Pueblo follo (No. 36), p. 6, 1897. 
important series of gypsum beds, and a few of those beds were observed in the more easterly of the Pueblo areas. They are orerlooked from the south by a high cliff of Dakota sandstone and are accessible only from the Colorado springs sicle. The gypsum is massive and is mottled with gras and white.

The westernmost of these deposits lies in Fremont County and extends a considerable distance northward into the Colorado Springs quadrangle. Near the road between Canon City and Colorado Springs, about 3 or 4 miles northwest of the northwest corner of Pueblo County, the United States Portland Cement Co. has quarried gypsum for their cement plant at Concrete. This deposit is beliered to be a continuation of that near Stone City. It is not unlikely that the gypsum on Beaver Creek mentioned by Stevenson ${ }^{1}$ belongs to the same series, but it is hard to reconcile his statement that the thickness is 100 feet with the thickness recorded for the Stone City deposit.

The second occurrence mentioned by Gilbert is that of a deposit of earthy gypsum in an alluvial flat near Greenhorn station, on the Trinidad line of the Denver \& Rio Grande Railroad. The flat is probably along Greenhorn. Creek or its tributary from the south. In either case the flat must be underlain by beds of Niobrara age.

The gypsite is said to have been manufactured into plaster in Pueblo.

TREMONT, CUSTER, HUERFANO, AND CHAFTEE COUNTIES.

From Oro Junta to Cramer and beyond on the Florence \& Cripple Creek Railroad, in Fremont County, there is an extensive deposit of rock gypsum. Though the writer does not know the age of the inclosing strata, it would seem probable that they belong to the Lykins formation. The gypsum varies from massive granular to finely laminated, and in color from a pure white to a dark brownish gray. Selected rock proved on analysis to be almost entirely free from impurities, but the darker rock is evidently impure. The beds in places attain a thickness of 60 to 75 feet, and the outcrop is traceable at least $1 \frac{1}{2}$ miles. No attempt was made by the writer to determine the limits of the deposit. Several exploratory pits have been dug, but so far as known no commercial shipments have been made. This deposit is probably the one referred to by Stevenson. ${ }^{2}$ He says:

From Ute Creek (Eightmile) to Beaver Creek the gypsum bed is a wellmarked feature of the outer.wall of the park and seems to be in thin layers alternating with drab or lead-colored clays.

In the same connection he mentions the occurrence of gypsum along Turkey Creek farther east. Here he indicates that the beds 
are either Jurassic or Triassic and states that they vary but little from 100 feet at several exposures. Several low hills are covered by gypsum. These beds must be almost continuous with those of Little Fountain Creek.

The deposit at Coaldale is the most extensively worked deposit in the State. From this locality the Colorado Portland Cement Co. gets its supply of raw material for its plaster mill and its cement plant at Portland, Colo. The average quality of the rock is equal to that of any other found in the State, and the quantity is sufficient to meet the demand for many years.

The gypsum occurs in low hills extending for a distance of over 2 miles. At the places where the rock is quarried the only covering is a thin layer of alluvial gravel. The underlying rock is said. to be sandstone. Weathering has developed a considerable quantity of gypsite, which was once worked for plaster making.

At the principal workings the quarry face is over 100 feet high and 300 feet long. Bands and lenses of dolomite occur in the deposit, but they are not continuous and present no serious obstacle to the working of the quarry. There are four other openings on the company's holdings of 1,600 acres, all of which show commercial gypsum. The main body of the deposit is dark gray, but streaks of white are found. .

On the same line of Carboniferous outcrops, both to the southeast in Custer and Huerfano counties, and northwest in Fremont and Chaffee counties, gypsum deposits of commercial quantity' and quality occur, but no detailed description of the geology is available. From Stevenson's report it is evident that he regarded the containing strata as Carboniferous. The stratigraphic succession from the bottom is limestone, shales and sandstone, gypsum, reddish-gray sandstones, and shales. Between Howard and Swissvale the deposits occur irregularly on both sides of the river in a series of strata about 125 feet thick in which is one stratum of gypsum about 15 feet thick. Tests by the United States Portland Cement Co. showed that this band is of excellent quality. It has not yet been worked.

The United States Portland Cement Co., of Concrete, Colo., is mining gypsum for the cement plant at a point about 4 miles northwest of Stone City. The gypsum of this region occurs in comparatively thin masses interruptedly over an area 10 to 12 miles long from north to south and about 7 miles broad from east to west. The gypsum series is underlain by shale, and shale and red sandstones and sandy shales separate the gypsum strata, which range from 4 to 6 feet in thickness. The mineral is pink and of excellent quality. for the purposes of the cement industry. 
PARK COUNTY.

Near the old salt works in South Park impure gypsum occurs in large quantity in what Peale ${ }^{1}$. believed to be either Cretaceous or Jurassic strata. The outcrops are near the bases of several lava-capped buttes. The lower slopes of the buttes are so covered that the exact geologic relations are not clear. In one place, however, the gypsum is in laminated sandstones dipping north. It is very impure and ranges in color from gray to black. The surrounding country is occupied by Hayden's Upper Carboniferous, which includes in many places strata corresponding in character and position to the Permian. It is not unlikely that the gypsum belongs to this series.

In lake deposits, west and southwest of Fairplay, Stevenson ${ }^{2}$ found a fine soil containing much gypsum.

\section{SUMMIT COUNTY.}

Stevenson ${ }^{3}$ reports the occurrence of gypsiferous shales on Snake River, a tributary of Blue River, in Summit County.

RIO BLANCO, GARFIELD, EAGLE, AND PITKIN COUNTIES.

Along the valleys of White, Grand, and Eagle rivers, and their tributaries, such as Roaring Fork and Fryingpan, Brush, Gypsum, and Cottonwood creeks, extensive areas of Hayden's Upper Carboniferous formations are exposed. In many places along these streams the outcropping edges of the strata show large deposits of gypsum and gypsiferous shale varying in color from pure white to pink-gray and almost black. In some places the weathering of the gypsum has covered wide slopes with a soft flourlike gypsite that is more or less mingled with detritus from the higher strata. The general geologic relationships are such as to suggest an equivalence of age with the deposits along the eastern foothills of the range, though in places the gypsum is possibly in strata corresponding to the Hermosa formation of the San Juan country, and is thus of Pennsylvanian age.

At Ruedi, on Fryingpan Creek in Eagle County, a plaster mill was in operation for a few years, but it is now closed. A few carloads of gypsum have been shipped from Gypsum station to Portland, Colo., for use in the manufacture of cement.

Along the open valley of Eagle River, between the canyon and a point about 5 or 6 miles above the Grand, the bordering hills are formed of gypsiferous shales and gypsum, which break down into

1 Peale, A. C., U. S. Geol. and Geog. Surv. Terr. Seventh Ann. Rept., for 1873, p. 224, 1874 .

a stevenson, J. J., op. cit., p. 454.

3 Idem, p. 374. 
a soft powdery gray to white mass of impure gypsite and alluvium. In the lower canyon of Eagle River the gypsum beds dip from the river in both directions.

The peculiar erosion of these hills has developed a topography closely resembling that of the badlands. The section on Eagle River consists of about 1,500 feet of shales, sandstones, and limestones, with many transitions from one type to another. In color the rocks are white, gray, pink, red, brown, and black. Of the total thickness probably one-half is gypsum bearing. From fossil evidence Lesquereux determined the age to be Permian. Recent work supports this finding.

The same gypsiferous series continues from the Eagle to the Grand and follows it interruptedly almost to the canyon. It also appears on both sides of Spruce Creek and on both sides of Roaring Fork. In all these areas the strata and gypsum deposits are very similar to those just described.

The gypsum occurs in strata and lenses of irregular thickness. In length some are measurable in miles, others in yards, and the thickness ranges from a few inches to approximately 200 feet. In many places the beds are scattered rather uniformly throughout the gypsiferous series, and workable beds may number from two to six. In other places the bulk of the gypsum is massed within one-third or one-fourth the thickness of the series. At a point $2 \frac{1}{2}$ miles east of Gypsum, in a stratigraphic section 140 feet thick, the gypsum measures 90 feet. Here selenite and anhydrite are plentiful.

The gypsum deposits along Eagle and Grand rivers in Eagle County are so extensive that they could supply the entire United States for many years.

\section{GUNNISON COUNTY.}

Howell ${ }^{1}$ mentions the occurrence of gypsum on the east side of the river near Gunnison.

\section{DELTA, MONTROSE, SAN MIGUEL, AND DOLORES COUNTIES.}

Siebenthal ${ }^{2}$ describes the occurrence of gypsum along the Gunnison Canyon in Delta and Montrose counties. The gypsum occurs near the middle of a series of shales and sandstones of undetermined age but separated from what has been called Dakota sandstone in that area by 400 feet of "variegated but predominantly reddish shales with interbedded red and buff sandstones." The description

1 Howell, E. E., Report on the geology of portions of Utah, Nevada, Arizona, and New Mexico examined in the years 1872 and 1873 : U. S. Geog. and Geol. Surveys W. 100th Mer. Final Rept., vol. 3, p. 264, 1875.

2 Siebenthal, C. E., Gypsum of the Uncompahgre region: U. S. Geol. Survey Bull. 285, pp. 401-403, 1906. 
of the sandstone resting on the pre-Cambrian schists suggests the "crinkled" sandstone of the Lykins formation east of the range.

The gypsum-bearing rocks average 110 feet in thickness and outcrop interruptedly for 20 miles-from Smiths Fork to Red Rock Canyon. The gypsum beds range from 1 foot to nearly 60 feet thick. Some of the sandstones and shales are gypsiferous.

A thick bed of gypsum occupies the whole head of Big Gypsum Valley and extends along the north side of the valley to Dolores River. It reappears down the river at the mouth of Little Gypsum Valley and extends some distance up that valley, especially on the north side. The deposit is overlain by a crumpled limestone, and this is overlain unconformably by the sandstone and conglomerate of the Dolores formation. The unconformity may represent Cutler time. In places a rich Pennsylvanian fauna occurs some distance above the gypsum. The area covered by gypsum in the two valleys is probably between 20 and 30 square miles. The mineral occurs as massive white gypsum in beds from 5 to 10 feet thick throughout a series of strata between 200 and 300 feet thick. Weathering has formed impure gypsite.

In East Paradox Valley gypsum covers about 8 square miles and in West Paradox Valley about one-half square mile. In these valleys the gypsum is associated with limestone and shales and is overlain by red shales and shaly sandstone.

In Sinbad Valley gypsum covers about 7 square miles and is associated with limestone and shale. Cross and Howe ${ }^{1}$ believe the gypsiferous series to be the same as that which Peale regarded as probably Permian. They think the beds may be the Cutler formation. In later official publications the Cutler has been classed as Permian (?).

From the views expressed and from the field relations, it would seem probable that the beds in all this region are Permian or late Pennsylvanian.

In the Rico quadrangle gypsum occurs well down in the Hermosa formation, and in places reaches a thickness of 30 feet. It is underlain by black shales. In the Rico mining district gypsum occurs as a gangue, especially on Newman Hill.

On Hermosa Creek, north of Durango, a small exposure of gypsum appears to be well down in the Hermosa formation. Gypsum occurs in other parts of the State, particularly in the west and southwest.

\footnotetext{
1 Cross, Whitman, and Howe, Ernest, Red Beds of southwestern Colorado and their correlation: Geol. Soc. America Bull., vol. 16, pp. 447-498, 1905.
} 
By R. W. Stone.

Gypsum has been reported at only one locality in Florida, which is near Panasoffkee, Sumter County, 60 miles north of Tampa. This locality is not readily accessible, for it is a low-lying area of hummocky land, known as Bear Island, in the midst of a marsh about 6 miles west of Panasofflee. It was examined by D. T. Day about 20 years ago. At the time of his visit there was a logging road across the swamp, but that road has been torn up, and the place is now less easy to reach. The following description is quoted from Day's report: ${ }^{1}$

In the southern and southwestern portion of this so-called island the gypsum reaches the surface, with no covering whatever except an inch or two of vegetal mold. By striking a hoe into this the gypsum may be dug up in a soft state like clay, but it soon hardens on exposure to dry air. It is greenish while wet and turns white on drying. Where the gynsum is at the surface there are knolls from 10 to 50 feet square and 3 to 6 feet higher than the adjoining land, but the gypsum is found almost everywhere by slight excavation. The deposit is probably gypsite, or secondary gypsum.

Two pits sunk through it have shown it to be $6 \frac{1}{2}$ feet thick in one place and 7 feet thick in the other, with the usual light Florida sand underneath. Mixed through it are boulders of very impure limestone, with occasional hard, flinty ones. As a rule the topography of the country will admit of digging 6 or 8 feet through the gypsum without encountering any considerable amount of water, except in the wet season.

The quality of the gypsum is almost uniform in all the places from which specimens were taken. The quantity is evidently sufficient for a large supply. The only difficulty to be anticipated in the mining is the fact that the lumps of limestone would be encountered at irregular intervals; their character makes it evident that they are residual lumps from limestone which has been dissolved by the action of rain water, as in many other. parts of the State. It is probable that the floor of the deposit will frequently be a bed of limestone, very irregular in its surface, so that it will be difficult to dig all the gypsum from it by cheap means.

According to a description by. Prof. F. H. H. Calhoun, of Clemson。 College, S. C., there is at this locality a deposit of powdery to granular gypsum evidently formed from springs, and varying in composition from pure gypsum to $22 \frac{1}{2}$ per cent calcium carbonate. $\mathrm{He}$ describes it as in places from 3 to 7 feet thick with an overburden of

1 Day, D. 'T., Gypsum in Florida: U. S. Geol. Survey Twentieth Ann. Rept., pt. 6, pp. 662, 663, 1899; Gypsum deposits in Florida: U. S. Geol. Survey Bull. 223, p. 48, 1904. 
3 feet and elsewhere from 6 to 12 feet thick without overburclen. Thie following quotation is from Mineral Industry, 1917: ${ }^{1}$

This deposit is probably the same one visited by Dr. Day, but lie eviclently did not see the best exposures. The material appears in sec. $23, \mathrm{~T}$. $20, \mathbf{R}$. 21, as a huge mound from 6 to 10 feet thick. It has an average length of 150 yards and an average width of 60 yards.

North of this large deposit, which occurs on what is. known as Soapstone Island, the deposits become thinner and less continuous. It might be best described as a swell or saucer type.

This type continues for some 200 yards and then gradually gives place to the type of deposit described by Dr. Day on Bear Island. The deposits on Bear Island consist of isolated mounds of gypsum from 6 to 100 feet in diameter and probably average 3 or 4 feet in thickness. I estimate that the deposit on Soapstone Island contains about 35,000 tons, the adjacent deposit about 70,000 , and that on Bear Island probably as much, but so scattered as to make quarrying difficult. I found very little evidence that these mounds were connected under the surface.

Mr. Harry Houston, of Brooksville, Fla., has examined these deposits and finds that Bear and Soapstone islands are in the E. $\frac{1}{2}$ sec. 23 , T. 20 S., R. 21 E., and that the largest continuous deposit is on Soapstone Island, probably in the NE. $\frac{1}{4}$ SE. $\frac{1}{4}$ sec. 23 . He sunk many holes with a 2-inch auger and found the deposit from 6 to 10 feet thick with an average of 8 feet. North and west of the large deposit there are many more or less detached hummocks of gypsite. $\mathrm{He}$ reports one deposit " 3 acres wide and 6 acres long with an average thickness of 8 feet," or approximately 206,000 cubic yards, and another " 350 yards long and 140 yards wide with an average depth of $8 \frac{1}{8}$ feet," or a total of 131,800 cubic yards. This makes a total of 337,000 cubic yards or about the same number of tons. Mr. Houston's report is furnished by Messrs. A. J. Burnham and S. Stevens, of Bushnell, Fla., who have a lease on the gypsum land.

The writer visited this locality in March, 1919, and learned that gypsite occurs on Bear, Soapstone, and Burnt islands in the swamp west of Panasoffkee and also near Inverness. These islands are about 4 miles west of the Seaboard Air Line Railway at a point $3 \frac{1}{2}$ miles south of Panasoffkee. Pine land extends within about threequarters of a mile of the islands, but the remaining distance is swamp grown up with saw grass more than head high, so that access from this direction is difficult. The islands are easily reached by a small gasoline launch from Panasoffkee. It takes about three hours to make the trip across Panasoffkee Lake, up Withlacoochee River and Jumpers Lake, and thence by pole boat up Bear Island Creek to the islands.

The deposits are a soft, incoherent mass of fine gypsum crystals or particles having the character of gypsite. On Bear Island there

1 Mineral Industry for 1917 , p. $117,1918$. 
are many hummocks of gypsite from 3 to 6 feet high which are said to extend from northeast to southwest for nearly a mile in a belt a quarter of a mile wide. By these estimates this belt would cover approximately 160 acres, but as the hummocks are detached, with little or no gypsite between them, the available quantity probably is not over 200,000 tons and may be much less.

At the south end of Soapstone Island, which is half a mile long, there is an area of several acres in which gypsite forms a comparatively level-topped deposit rising about 10 feet above water level. Ijordering it on the west and north are several acres of gypsite hummocks as much as 10 feet high. The deposit at the south end of Soapstone Island is the largest compact body that has been discovcred. Drill holes sunk in it by Mr. Houston, are reported by him to show an average thickness of 8 feet of gypsite. Several holes showed $7 \frac{1}{2}$ to $9 \frac{1}{2}$ feet of gypsite, and two holes 14 and 15 feet deep did not reach the bottom of the deposit.

The overburden consists of 2 or 3 inches of vegetable deposit or woods mold. There is over the whole area a forest cover of palmetto, cabbage palm, cypress, live oak, and other trees. Overturned trees show a flat mass of roots but no tap roots, perhaps because the bottom of the gypsite deposit seems to be practically at the level of the surrounding swamp and the gypsite is probably always damp. It might not be difficult to strip off the forest and leave a clean surface of gypsite, but as the highest estimate of the quantity available is only about 330,000 tons a moderate-sized business of 50,000 tons annually would exhaust the deposit in six or seven years. A conservative estimate of 150,000 tons available to be worked by a small plant having a capacity of 20,000 tons a year gives the same result -exhaustion in a brief period. Although the deposits could be mined by steam shovel or floating dredge, they have not been developed because of their small size and location in an area of small market, which is easily supplied from gypsum producers in Virginia and those in the Atlantic Coast States using gypsum from Nova Scotia:

Samples of gypsite were taken by the writer for analysis:

Analyses of gypsite from Florida.

[Chase Palmer, analyst.]

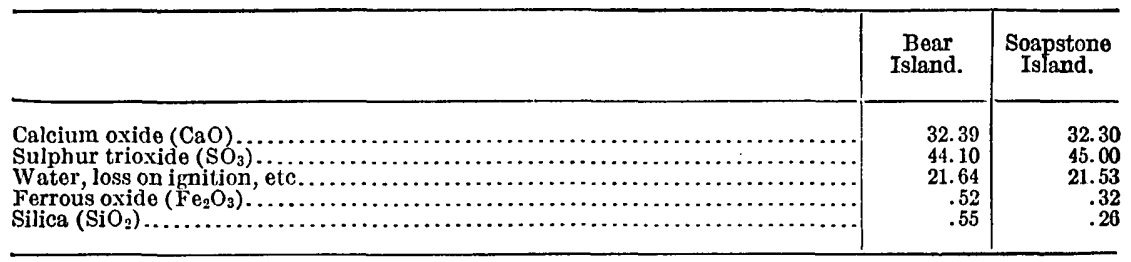


The sample from Bear Island was obtained by cleaning off a few inches from the face of an exposure to get unstained material free from vegetation. The sample from Soapstone Island was dug 2 feet below the surface in the side of a vertical wall of a natural hole in the deposit. These analyses are practically identical with that of the sample obtained by D. T. Day, as shown in the table of analyses on page 28.

According to geologic maps of Florida, the area west of Panasoffkee is occupied by rocks of the Vicksburg group, of Oligocene age. This group consists of soft, porous light-gray to white limestone, containing marl beds and layers of chert. The writer did not find limestone exposed near the gypsite deposits but did see nodules of fossiliferous chert between the hummocks of gypsite. The meager evidence suggests, as mentioned by Prof. Calhoun, that the gypsite has been derived from springs. It would seem that at some earlier geologic period the land stood at a slightly higher elevation and that gypsiferous waters rising under artesian head reached the surface here and, evaporating, made mounds of gypsite.

According to Mr. S. Stephens, of Bushnell, Fla., there is considerable gypsite on Burnt Island, which lies about 200 yards east of the north end of Soapstone Island, and also a few miles north of this locality, near Inverness. He reports that the deposit near Inverness is pockety, can be traced about $1 \frac{1}{2}$ miles, and does not contain more than 5,000 tons. Of this same deposit Prof. Calhoun says: ${ }^{1}$

Further north, about 5 miles east of Inverness, more deposits are found, but in these the type is different. It lies beneath the surface covered with an overburden from a few inches to several feet in thickness. The deposit itself, I believe, would not average more than 3 feet and is not continuous. This deposit extends south some 2 or 3 miles.

The writer concludes that the Florida gypsite would make plaster suitable for gypsum board, block, and tile and for base coats. Probably it would not make perfectly white plaster. The manner of occurrence and the size of the deposits do not encourage development. ${ }^{2}$

\footnotetext{
1 Mineral. Industry for 1917 , p. 117, 1918.

2 Stone, R. W., Florida gypsum deposit explored: Rock Products, vol, 23, No, 2, pp. $30-31,1920$.
} 


\section{IDAHO.}

By R. W. STONE.

Gypsum has been found in two localities in Idaho in quantity worthy of mention. The smaller but more accessible of these deposits is in Bear Lake County, 3 miles east of Montpelier, oii the south side of Montpelier Canyon. G. R. Mansfield, of the United States Geological Survey, who examined the deposit, has furnished the writer with the following data, previously unpublished. There is a prospect hole in the deposit in the SW. $\frac{1}{4}$ sec. 32 , T. 12 S., R. 45 E., where a small body of gypsum lies on and fills cracks in limestone apparently of Pennsylvanian age. The gypsum is fine grained, white, massive, and seemingly pure. It is not well exposed, but the bed is at least 4 feet thick. The lateral extent was not determined. An analysis made by W. C. Wheeler, of the United States Geological Survey, from a sample cut across 4 feet of the bed is as follows:

Analysis of gypsum from a deposit near Montpelier, Idaho.

[W. C. Whecler, analyst.]

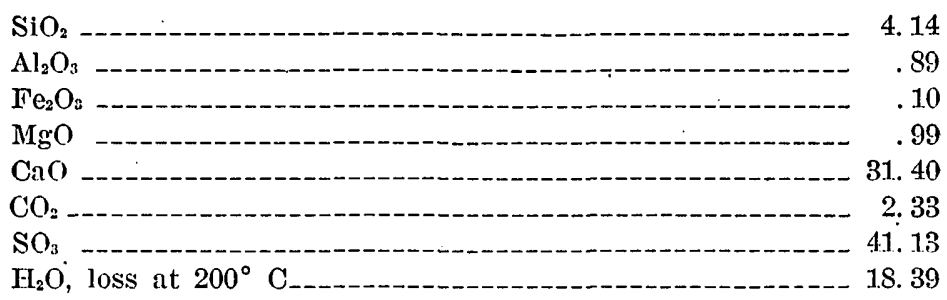

In the mountains in the northeastern part of Bear Lake County Mr. Mansfield found lenses and layers of gypsum in the Nugget sandstone, of Jurassic or Triassic age, but nowhere more than a few inches thick.

The second deposit was examined and described by E. F. Burchard. ${ }^{1}$ It is in Washington County and lies high in the blutf's overlooking Snake River, about 10 miles northeast of Huntington, Oreg., which is the nearest town. Rock gypsum as exposed in short adits and pits in secs. 7, 8,17, and 18, T. 13 N., R. 7 W., occurs in lenticular masses banded with grayish and greenish material, possibly chloritic. 'The lenses appear to range from 6 to 20 feet in thickness.

${ }^{1}$ Burchard, E. F., Gypsum industry in 1910: U. S. Geol. Survey Minoral Resources, 1910, pt. 2, p. 727, 1911. 
Some of the gypsum is pure white, massive, and spotted with small lumps of impure gypsum and dark country rock; some is yellowish, owing to lumps of foreign material; and some is so filled with laminae of a greenish chloritic (?) mineral and small rolls of impure limy material that it would seem to be worthless. Quarrying would require handling much overburden and waste gypsum, and underground mining would be uncertain because of the lenticular character of the deposit.

There is a branch of the Oregon Short Line Railroad on the Oregon side of Srake River within half a mile of the prospects.

The character of the deposit is similar to that a few miles farther south on the Oregon side of the river, and meager evidence suggests that the gypsum-bearing rocks are of the same series in both places and of Miocene age. 


\section{IOWA.}

By R. W. Stone and G. F. KaY.

The first gypsum mill built in the United States west of Mississippi River was located at Fort Dodge, Iowa, and the plaster industry of the State is over 45 years old. Gypsum, however, is known to occur in only two areas-the well-known one at Fort Dodge and the recently discovered one at Centerville. At Fort Dodge the gypsum outcrops, but at Centerville it lies 500 feet below the surface and was discovered in a drill hole. The two occurrences will be described separately.

GYPSUM AT FORT DODGE.

By R. W. Stone.

CHARACTER AND FATENT.

In the vicinity of Fort Dodge, Webster County, which is near the center of the State, there is an area of 60 or 70 square miles underlain by sedimentary strata carrying gypsum. This area is 3 to 6 miles wide and about 13 miles long. It extends in a northeast-southwest direction, and the greatest width is at Fort Dodge, where Des Moines River crosses it. Gypsum is exposed in the bluffs along the river. and its tributaries, Soldier Creek and Twomile Creek or Gypsum Hollow. Earlier reports ${ }^{1}$ have contained stratigraphic sections of the gypsum and adjacent strata exposed at a number of quarries and other localities in the vicinity of Fort Dodge, but in June, 1916, at the time of the writer's visit, none of these localities presented adequate exposures, for the rocks were buried in talus and overgrown with brush. In fact, no place was found where more than 15 feet of the beds near the gypsum horizon were exposed, and although it was intended to search for fossils in the pink shales, the possibility of finding traces of animal life was despaired of because of the soft clayey character of the shales at the outcrop and the friable, sugary character of the sandy layers.

The gypsum bed is fairly well exposed north of Fort Dodge, in the bank of Soldier Creek, just above creek level, $1 \frac{1}{2}$ miles above its mouth, near a railroad bridge at the cemetery. South of the city in Gypsum Hollow above the tracks of the Fort Dodge, Des Moines \& Southern Railroad, and directly across Des Moines River, in the 
hollow which that railroad follows south, gypsum outcrops conspicuously. (See Pl. XIII, B, p. 80.) All these localities contain abandoned quarries, where the gypsum was taken along the outcrop and back so far as the cover was not too great. At none of these places is the whole thickness of the gypsum clearly exposed, but it may be seen at the mouth of the drift mine of the Plymouth Gypsum Co. in the SE. $\frac{1}{4}$ sec. 31, T. 89 N., R. 29 W., which is on the west side of Des Moines River.

Extensive development by mines and drill holes has shown that the gypsum occurs in a single bed lying practically horizontal and ranging in thickness from 10 to 30 feet. In that part of the gypsum area now being mined the bed is commonly 22 to 25 feet thick and is reported to be fully 30 feet at one place in the property of the Wasem Plaster Co. in the SE. $\frac{1}{4}$ sec. 34, T. 89 N., R. 28 W.

The miners recognize the following divisions in the gypsum bed:

Section of gypsim, bed at Fort Dodge, Iowa.

9-foot ledge, all but upper part suitable for plaster, varying in thickness

Feet.

-foot ledge, fine plaster rock

$3-12$

Hard ledge

18-inch ledge inferior for plaster but sometimes used.

4

Bottom, or 2-foot ledge, not good for plaster

The bottom ledge is not of constant thiekness and is almost everywhere left in the floor, either because the rock below it is clay that would swell and make a bad floor, or is a sand that is not easily separated from the plaster rock and would be detrimental. The 18-inch ledge in some places is not so good as the best rock, and it' is not everywhere mined. The hard ledge is recognized by the miners in all the properties by the quality that gives the name. Above it is the ledge that furnishes most of the plaster rock and is removed except for what is left in pillars and roof. Only those thoroughly familiar with the deposit can pick out the various ledges, for the outward appearance is the same and the separation is only a line of parting and not marked by clay or other foreign material. The upper ledge, sometimes called the 9 -foot, is the most variable because this deposit was exposed to the preglacial erosion and its upper surface suffered thereby. One can easily imagine that when this gypsum bed was exposed over a wide area the streams carved channels in it and through it, and the margins of the troughs thus made were irregular by reason of the tributary gullies. So the upper ledge varies much in thickness. In places it is entirely cut away and in others the whole thickness of the gypsum deposit was eroded. An old watercourse of this sort, which cut clean through the gypsum in preglacial time and was subsequently filled by what the miners cail "sea mud," is fully 500 feet wide in one of the mines 
and means the loss of several acres of valuable deposit. Close to the old watercourse the gypsum is thin and poor. The upper part of the 9-foot ledge is always left to support the roof and is very uncertain working beeause of its great irregularity.

Vertical joints at intervals of 50 feet or less are common in the gypsum and make a clean parting from roof to floor. In some places they are an advantage in mining. Solution channels are present, and in the drift mine of the Plymouth Gypsum Co., on the west side of Des Moines River, a cavity said to have been 1.5 by 50 feet was penetrated. The water from the sumps in this mine is all pumped into and carried away by an underground channel in the mine.

Although in the mine now being worked the gypsum bed averages over 20 feet thick, it is reported that in a well in sec. $27, T .89 \mathrm{~N}$., R. $28 \mathrm{~W}$, only 1 foot of gypsum was found and in another well none. The gypsum lies only 40 to 60 feet below the surface of the prairie, and one of the wells was 90 feet deep. One of the old mines is said to have run into gypsum too thin to work.

The evidence of mines, wells, and drill holes shows, therefore, that although the gypsum deposit in a general way underlies 60 to 70 square miles, it is very possible that little more than 40 square miles of this area is what would be termed workable at the present time. If we consider 10 feet the average thickness of the gypsum actually mined, which would mean a yield of 30,000 tons to the acre, it is easily understood that there is a vast quantity of gypsum in the vicinity of Fort Dodge.

This massive gypsum, described above as divisible into ledges, is stratified in layers from 2 inches to 2 feet thick. The thin layers are called flags. Furthermore, all of the ledges and layers show marked horizontal banding of altẹrnate light and dark layers about half an inch thick. The small bands are for the most part regular and horizontal but in places are slightly wary.

That the gypsum is of fine quality is shown by the analyses in the table on page 28. Small bands of satin spar have been found, but large plates and crystals of selenite do not occur in the gypsum bed. Selenite crystals occur in the coal measures, however.

ECONOMIC DEVELOPAEENT.

The gypsum plaster industry began at Fort Dodge when a mill was erected in 1872 at the head of Gypsum Hollow, at that time 2 miles southeast of the village square. A second mill was built in 1882 near the mouth of Gypsum Hollow, and in 1885 the Blandon mill was erected on the east bank of Des Moines River due south of the town. This mill was followed by the Duncombe mill at the mouth of Gypsum Hollow. The mills were supplied with rock 
quarried along the outcrop by stripping the overburden of glacial material. Rock for the Duncombe mill was hauled across the river on a pontoon bridge.

Operations on the prairie began when the Cardiff mill, named in memory of the Cardiff giant, which was quarried from gypsum in Gypsum Hollow and shipped to New York State for burial and discovery, was erected in 1895, and a shaft was sunk to the gypsum. This mill was $4 \frac{1}{2}$ miles southeast of the city, and the mine was the easternmost development. Mining was done as in a flat-lying coal bed, by the room and pillar method. As the overlying deposits are glacial clays 40 to 60 feet thick, shafting to the gypsum bed is not expensive. The second mill on the prairie was the Crawford, completed in 1899. The Mineral City mill began operations in the spring of 1900, and the Waterloo mill was finished in the fall of 1901. Since that time mills have been built by the Acme, American, Plymouth, Wasem, and United States Gypsum companies. Of the 13 mills that have been built, 3 have burned, 5 have been dismantled, and 1, the Mineral City, was moved a few hundred feet and replaced by the present large Mineral City mill. Five mills are now in operation at Fort Dodge by the following companies: American Cement Plaster Co., Cardiff Gypsum Plaster. Co., Plymouth Gypsum Co., United States Gypsum Co., and Wasem Plaster Co. The method of mining is the same on all properties. (See Pl. XVI, A.) Hand and electric augers are used, the rock is blasted down, and cars loaded with gypsum blocks are moved by hand or by mules. In the larger mines, electric motors are used on main gangways. (See Pl. XVI, B.) Mill machinery is driven with electricity. All calcining is done in kettles with coal for fuel. Gypsum plasters are the principal product; gypsum plaster board is made by. one company and gypsum blocks by three companies.

The location of the mills and mines is shown on the accompanying map (fig. 5). All are ușing rock hoisted from a shaft at the mill, except the Plymouth Gypsum Co., which has worked out the gypsum. available at the mill and is operating a drift mine on the west side of Des Moines River. The rock is crushed at the mine and carried to the mill by cars running on overhead cables a distance of 7,000 feet.

Iowa is second only to New York in the production of gypsum. Most of the calcined gypsum is sold as wall plaster in a territory included mostly in the States of Iowa, Illinois, Wisconsin, Minnesota, Nebraska, and the Dakotas.

\section{GEOLOGIC RELATIONS.}

Fort Dodge and the gypsum mills are on the prairie. Gypsum is exposed in the vicinity along the bluffs of the river and its tributaries. There is a mantle of glacial material 20 to 60 feet thick over 


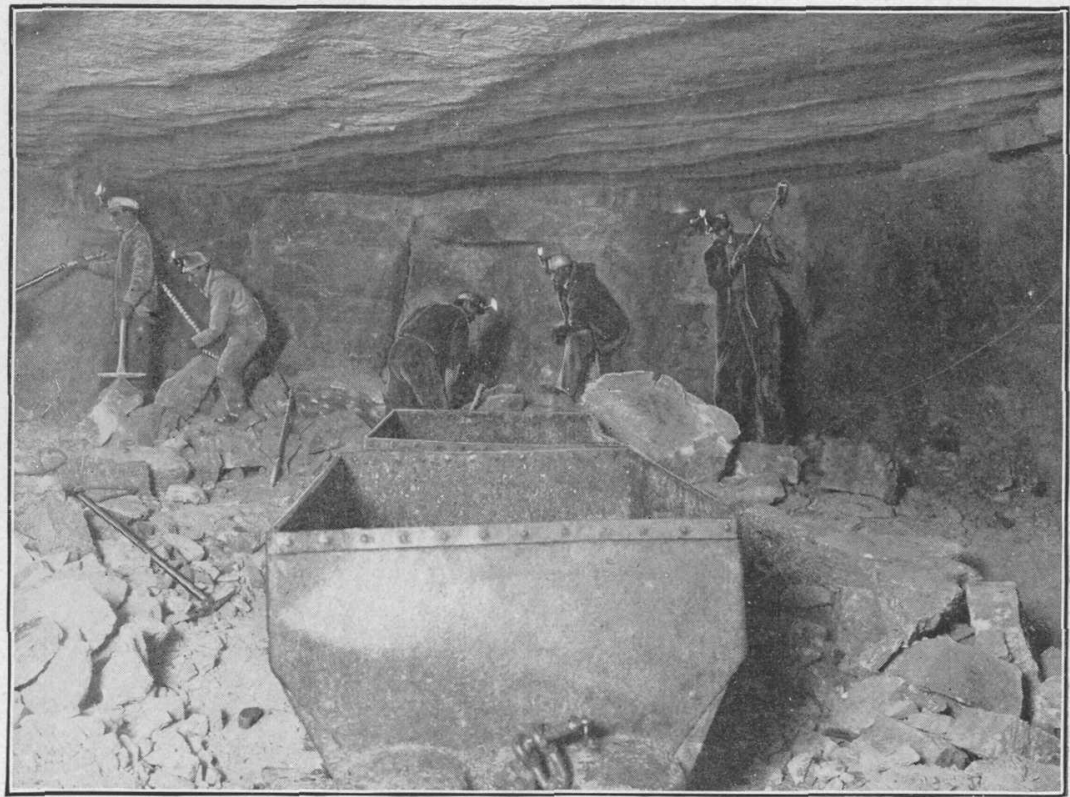

A. MINING GYPSUM, FORT DODGE, IOWA.

View showing general appearance of working face in underground gypsum mine, method of drilling, and method of loading. Photograph furnished by United States Gypsum Co.

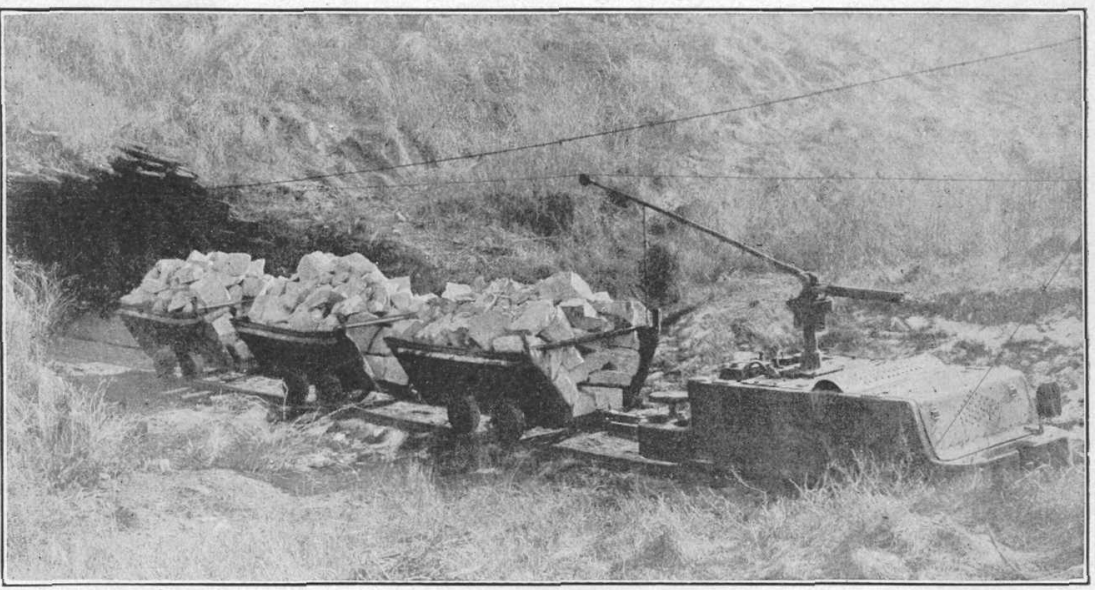

B. ROCK GYPSUM AS IT COMES FROM THE MINE, FORT DODGE, IOWA.

Only one mine at Fort Dodge is entered by an adit, the others being shaft mines. Electric motor and mine cars are shown. 
not be verified. No such exposures were found in 1916 at the localities mentioned.

The oldest bedrock exposed in the gypsum area is the St. Louis limestone of Mississippian (lower Carboniferous) age.

- Earlier study of field exposures and the records of wells and naines show that the surface of the St. Louis limestone was uneren at the time the coal measure shales were laid down unconformably upon it. It is probable that the younger Pennsylvanian or upper Carboniferous strata completely covered the limestone, but were subsequently partly removed, so that in places knobs and ridges sticking up many feet into the coal measures became exposed at the surface as islands in the midst of the shales. The gypsum was laid down on this fairly level surface and was deposited for the most part on the coal measure shales but in some places directly on the: limestone.

After the deposition of the gypsum mud was laid down in which there were layers of gypsum an inch or more thick. On top of this mud sand was laid down and more mud, making alternating strata of shale and sandstone. These beds above the gypsum, the original thickness of which is unknown, are soft, the shales clayey, and the sandstone friable. The color is gray and red, some of the exposures being very noticeably pink. Mottling of green and pink is seen in some of the shales, and some of the friable sandstone at the outcrop is pure white or cream with sharply outlined pink areas in it. Of these beds 20 to 30 feet remain in some places, but elsewhere the glacial drift lies directly on the gypsum.

The upper surface of the gypsum was widely exposed and eroded previous to the glacial epoch and was channeled by streams, as described earlier in this paper.

The gypsum deposit at Fort Dodge seems to be in a trough or basin. The gypsum bedis lie unconformably on strata of Pennsylvanian and Mississippian age, and the basin is completely surrounded by these older rocks. The gypsum and its closely related rocks in this area have yielded few fossils, so that there is little paleontologic evidence of the age of this deposit. The Permian of Kansas, Oklahoma, and Texas is highly gypsiferous, including some very thick pure deposits, and is so highly colored as to be known as the "Red Beds." The Fort Dodge gypsum is related to a pink formation, not red. Furthermore, in Kansas there is no unconformity between the Permian and the underlying coal measures. There is therefore no definite evidence for correlating these beds with the Permian 300 miles west, although there is some color of resemblance. The age of the Fort Dodge gypsum is therefore unknown but is believed to be Permian. 


\section{GYPSUM AT CENTERVILLE.1}

By Gronge F. KaT.

GENERAL RELATIONS.

A gypsum deposit was discorered in the southern part of the town of Centerville, Appanoose County, Iowa, in the fall of 1910. For many years the Scandinarian Coal Co. has been operating a coal mine at Centerville. This company, in prospecting for coal on its property by means of the diamond drill, discovered gypsum below the coal-bearing rocks.

The rocks below the Pennsylranian in Appanoose County are known only from drill records of artesian wells. At Centerville three deep wells have been sunk for water. The deepest of these weils and the one of which there is the most complete record gare a section as follows: ${ }^{2}$

Record of alcep well at Centervinle, Ionou.

Feet.

Quaternary: Drift _._._.

Carboniferous:

Pennsylvanian: Shales, conl and coaly shale, and a few

thin seams of limestone

Mississippian: Chiefly limestones and shales______-_-_-_ 574

Deronian: Limestone and shales._-_._-_-_._-_-_-_-_-_-_- 260

Silurian : Limestones, shales, and sandstones_-_-_-_-_._-_._- 180

Ordorician: Dolomites, limestones, sandstones, and shales_... 955

The depth of this well was 2,495 feet. Its bottom penetrated the Oneota dolomite, or lowest formation of the Ordovician in Iowa. This well wis sunk in 1893, and if gypsum was penetrated it was not so recorded by the drillers. However, in this connection, it is of interest to state that the log of one of the other deep wells, ${ }^{3}$ completed in 1904, contains a statement to the effect that at a depth of 600 feet below the surface the drill passed through 15 feet of "white sand." From the evidence that has been obtained from the holes recently drilled it is very probable that this material should have been recorded as gypsum. This well is more than half a mile northeast of the hole in which gypsum was first recognized.

The driller's log of the Scandinavian Coal Co.'s hole, in which the gypsum was first recognized, has been published in detail elsewhere. ${ }^{4}$

${ }^{1}$ A brief reference was made to this deposit in Iowa Geol. Survey Ann. Rept., vol. 21, p. 24, 1912.

2 Idem, p. 935 .

${ }^{3}$ Idem, p. 937.

« U. S. Geol. Survey BulL. 580, pp. 59-64, 1914. 
This log has been interpreted as follows:

Correlation of log of Scandinavian Coal Co.'s hole at Centerville, Ioura.

Feet.

Quaternary: Drift

31

Carboniferous :

Pennsylvanian: Des Moines group:

Henrietta formation: Limestones and soft blue shales_ 36

Cherokee shale: Blue, gray, and black shale, sandstone, several thin seams of coal, and some limestone

Mississippian: Chiefly limestone, lime shale, shaly limestone, some sandstone, gypsum, and anhydrite 111

The gypsum and anhydrite were penetrated between the depths of 537 and 547 feet below the surface. Analyses made under the direction of Dr. S. W. Beyer, of the Iowa State College, proved that the upper 5 feet of this 10 feet was anhydrite and the lower 5 feet gypsum. The gypsum was overlain by 14 feet of limestone and underlain by 2 to 3 feet of buff dolomitic limestone, beneath which was shale.

\section{DEVELOPMENT.}

Soon after gypsum had been found in Discovery hole some of the citizens of Centerville subscribed sufficient funds to drill two additional holes. One of these was located 1,200 feet southwest of Discovery hole at a lower elevation. The drill penetrated to a depth of 563 feet but found neither gypsum nor anhydrite. The Mississippian was pierced to a depth of 114 feet, the hole ending in shale, above which was 2 feet 6 inches of dolomite.

A third hole was then drilled about 1,700 feet northwest of Discovery hole. This hole gave a section upon which the following interpretation is placed:

Correlation of log of third hole at Centerville, Iowa.

Quaternary : Drift____ 20

Carboniferous :

Pennsylvanian: Gray, blue, and dark shale with seams of coal and limestone..._-_._-_._._._._. 456

Mississippian: Limestone, arenaceous limestone, some

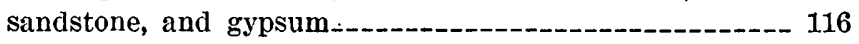

$\overline{592}$

The gypsum was entered at 572 feet below the surface. It proved to be 19 feet thick and of fine quality. Just beneath the gypsum was gray sandy shale, which was penetrated for only 1 foot.

The Centerville Gypsum Co. was then formed, with a capitalization of $\$ 25,000$, and decided to sink a shaft close to Discovery hole 
with the object of using it later for hoisting gypsum on a commercial scale. This shaft was started about July 1, 1912. The gypsum was reached about September 1, 1913, and the shaft has been sunk to the rock beneath the gypsum. The shaft is 16 by 6 feet and has three compartments. Gypsum, 13 feet in thickness, was reached at a depth of 533 feet. In the eastern part of the shaft the gypsum is free from anhydrite but in the western part anhydrite is associated with the gypsum.

When the shaft reached a depth of 528 feet, only a few feet above the gypsum, progress was greatly hampered by large quantities of artesian water that entered it. Some water had come in nearer the surface, but it was easily handled. The artesian water, about 3,300 gallons an hour, comes from a porous limestone about 4 feet thick which lies on the gypsum. It rises to a height of about 300 feet. The problem of handling this water was not solved and no further work was. done toward opening a mine until 1917, when the water was successfully sealed out. The mine and mill were operated for several months in 1919. The gypsum bed is 10 to 22 feet thick and is worked by the room and pillar system.

CHARAC'TER.

The gypsum that has been obtained from the 2-inch drill cores and from the shaft is of two fairly distinct varieties, rock gypsum and selenite. The rock gypsum breaks into irregular-shaped lumps, is white in color, and is composed of small, brightly shining elongated crystals. It is saccharoidal and distinctly friable, being easily crumbled to fragments resembling a pure-white granulated sugar. Much of the selenite is very clear and transparent and has the characteristic pinacoidal cleavage. It is possible to secure fairly large masses of selenite free from impurities. Some of it is gray to light brown in color.

Under the direction of Dr. S. W. Beyer, of the Iowa State College, five analyses were made, two of the gypsum and three of the anhydrite. The results ${ }^{1}$ were as follows:

Analyses of gypsum and anhydrite from Appanoose County, Iowa.

\begin{tabular}{|c|c|c|c|c|c|}
\hline \multirow{2}{*}{$\because$} & \multicolumn{2}{|c|}{ Gypsum. } & \multicolumn{3}{|c|}{ Anhydrite. } \\
\hline & 1 & 2 & 1 & 2 & 3 \\
\hline \multirow[t]{2}{*}{ 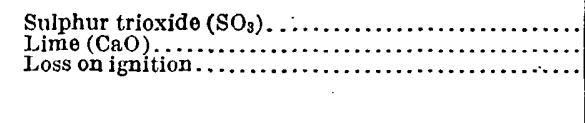 } & $\begin{array}{l}46.56 \\
33.37 \\
20.03\end{array}$ & $\begin{array}{l}45.65 \\
32.76 \\
20.75\end{array}$ & $\begin{array}{r}54.12 \\
40.20 \\
6.62\end{array}$ & $\begin{array}{r}55.29 \\
40.67 \\
4.66\end{array}$ & $\begin{array}{r}54.45 \\
39.58 \\
5.13\end{array}$ \\
\hline & 99.96 & 99.16 & 100.94 & 100.62 & 98.16 \\
\hline
\end{tabular}

1 Iowa Geol. Survey Ann. Rept., vol. 21, p. 24, 1912. 
SUMMARY.

The discovery of a deposit of gypsum in the Mississippian rocks of southern. Iowa is of scientific interest. The evidence indicates that the deposit may be extensive, and the gypsum is of good quality. The presence of anhydrite decreases the value of the deposit for making wall plaster and related products. The relation of the anhydrite to the gypsum and the relative amounts of the two minerals will have an important bearing on the commercial value of the deposit. Howerer, anhydrite is considered by some manufacturers of Portland cement to be practically as serviceable as gypsum.

The fact that the deposit is more than 500 feet below the surface and the presence of large amounts of artesian water are factors unfarorable to the mining of the gypsum. On the other hand, the deposit is well located with regard to fuel and transportation, and it is fair to assume that if gypsum products were made in this part of the State a good market for such products could soon be developed. 


\section{KANSAS.}

By Erasmus Haworth.

\section{PREVIOUS PUBLICATION.}

The Kiansas University Geological Surrey published in 1899 a report on gypsum and gypsum cement plasters. ${ }^{1}$ The rolume treated the subject with special reference to the State of Kansas. The changes that have occurred since 1899 have been in the manufacture of gypsum products, and nothing new regarding the origin of the gypsum or its geology has been brought to light.

This short review is little more than an abridgment of Grimsley and Bailey's report with some added notes regarding the present status of the industry.

\section{GEOGRAPHY.}

The accompanying map (Pl. XVII) shows the areas of the State throughout which rock gypsum can be had in sufficiently large quantities to supply gypsum industries. Hcre and there throughout this area are small patches of gypsum earth or gypsite. They were exhausted long ago as sources of material for the manufacture of wall plaster. The supply of rock gypsum, however, is sufficient to supply the world for centuries, and its quality is fully equal to that found elsewhere. Freight rates and demand determine the amount of it that is mined in Kansas from year to year and not the amount of material available.

It will be seen from the map that an area comprising many square miles in the vicinity of Blue Rapids is underlain with workable gypsum. South of Kansas Rirer gypsum is more abundant. In the area between Salina and Hope rock gypsum is very abundant.

The largest deposit of gypsum in Kansas is west of Medicine Isodge, in Barber County. It is 12 to 15 miles across in any direction. The gypsum, which is interbedded with the shale of the Permian Cimarron group ("Red Beds"), resists erosion and is left as a cap on the shale hills. In some places the gypsum beds are 40 to 50 feet thick, and in a large part of this area they are without cover. To the west and north the strata dip underneath the surface, and

${ }^{1}$ Grimsley, G. P.,. and Bailey, E. H. S., Special report on gypsum and gypsum cement plasters: Kansas Univ. Geol. Surrey, vol. 5, 1899. 
the gypsum beds for many miles are covered by overlying formations.

The three areas mentioned are the principal ones in Kansas. A number of others are very well known. Near Wellington and Mulvane, in Sumner and Sedgwick counties, rock gypsum occurs in large quantities, and here and there patches of gypsum earth have been found. Gypsite, near Mulvane, was manufactured into wall plaster years ago.

\section{GEOLOGY.}

In the vicinity of Blue Rapids and in the southern part of Dickinson County and also southeast of Wellington the lower Permian rocks, which lie at the surface, consist of beds of gypsum interbedded with limestone and shales that carry marine fossils, indicating the geologic age of the strata. All of the gypsum beds in these areas lie considerably above the Cottonwood limestone, which is at or close to the division line between the Permian and the Pennsylvanian.

The gypsum in Barber County is much later in age. It is in great layers, interbedded in red shale and sandstone, generally known as "Red Beds." It is not easy to determine the manner in which the gypsum and associated red beds were deposited. There is fairly good evidence that they were accumulated under ocean water, although some geologists attribute them to subaerial accumulation. It is now generally admitted that they are Permian in age.

\section{LOCAIITIES.}

BLUE RAPIDS AREA.

A vertical section showing the relations of limestone, shale, and gypsum beds to each other and to the Cottonwood limestone at the Great Western gypsum mines, Blue Rapids, is given in figure 6. The gypsum bed at this mine is $8 \frac{1}{2}$ feet thick and immediately overlies $2:$ feet of limestone, which is 26 feet above the Cottonwood limestone. In this locality the shales range from light to dark green in color, so characteristic of the Permian.

In the 143 feet of strata shown in the section above the Cottonwood limestone there is a total of $10 \frac{1}{2}$ feet of limestone in five beds. All these limestones, and in many places the shales just above and below them, are rich in marine fossils. Some of the more common forms of fossils are Fusulina cylindrica, Seminula argentea, Chonetes granulifera, Productus semireticulatus, and Derbya crassa.

Gypsum is reported in wells north, south, and west of Blue Rapids but appears to be absent in wells to the east of that town. 


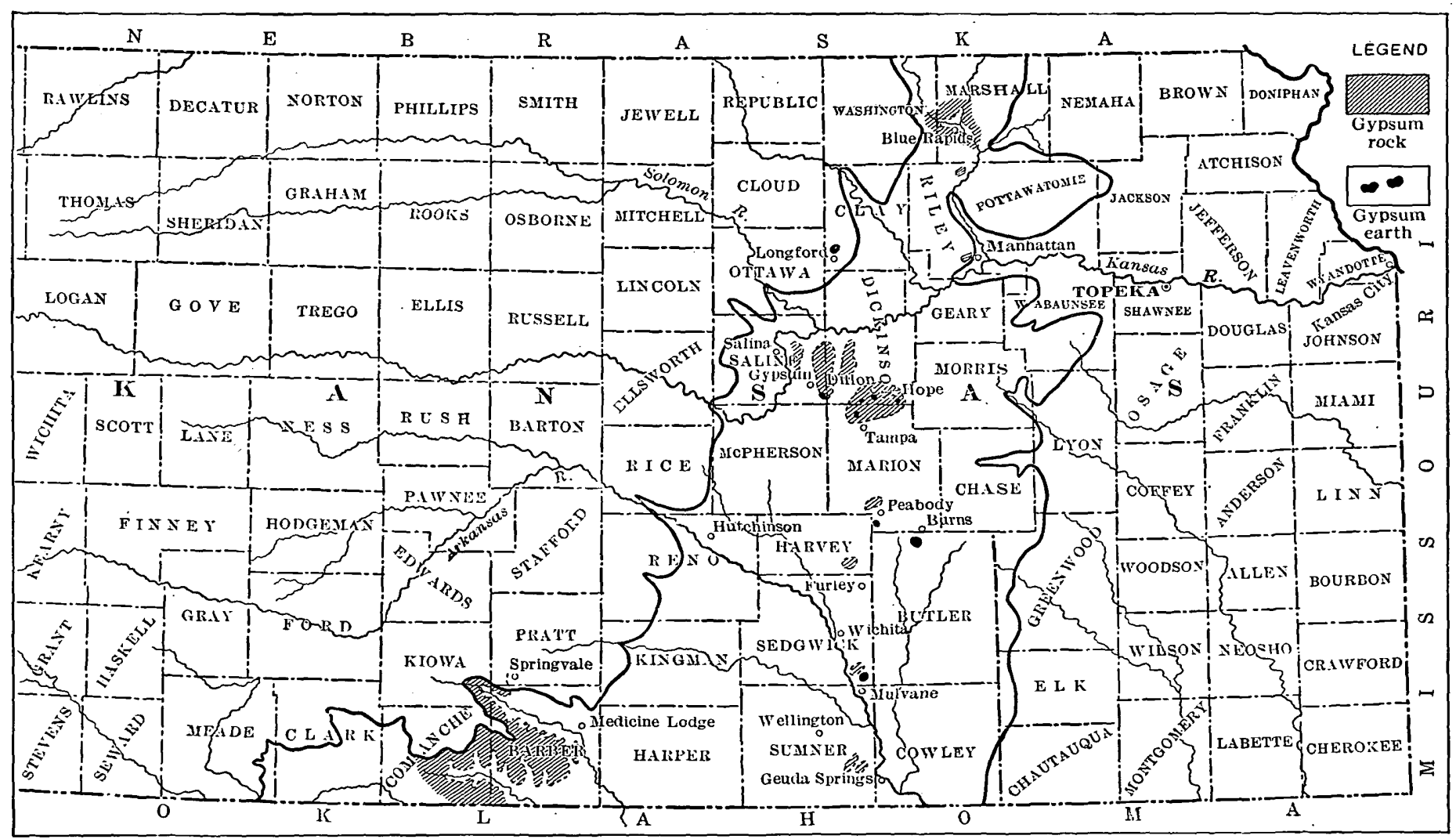

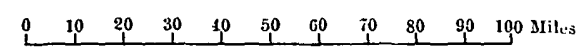

MAP SIONING GYPSUM DEPOSITS AND APPROXIMATE LIMITS OF THE PERMIAN SERIES IN KANSAS. 
The bed is probably continuous in a large area around Blue Rapids. It is reported in wells at Herkimer, west of Marysville, at 80 feet below the surface; on the Axtell farm, 3 miles north of the Great Western mine, at 90 feet below the surface; and on the Lee farm, west of Blue Rapids and three-fourths of a mile south of Winter's mill, at 60 feet below the surface. Gypsum is reported in many other wells, but these reports are unreliable, because many of them are based upon the peculiar taste of the water. . Ontcrops of the gypsurn near Blue Rapids are not extensive, owing to the soluble character of the gypsum, which is dissolved out and covered by débris from the crumbling rocks above.

A small amount of gypsum was obtained some years ago from a mine on the Yarrick farm, 1 mile south of Blue Rapids. The blocks, which are piled around the entry, are now bleached white and seamed with small fissures. The fresher specimens show that the gypsum is about the same as in the other mines. At this place it is 100 feet below the buff limestone.

Pink rounded gypsum nodules occur in the shales in many of the ravines west of Blue Rapids. Near Waterville the nodules are in black shale, of which 2 feet is exposed, overlain by 3 feet of blue shale and a 30 -inch bed of limestone. The buff limestone with flint nodules, which

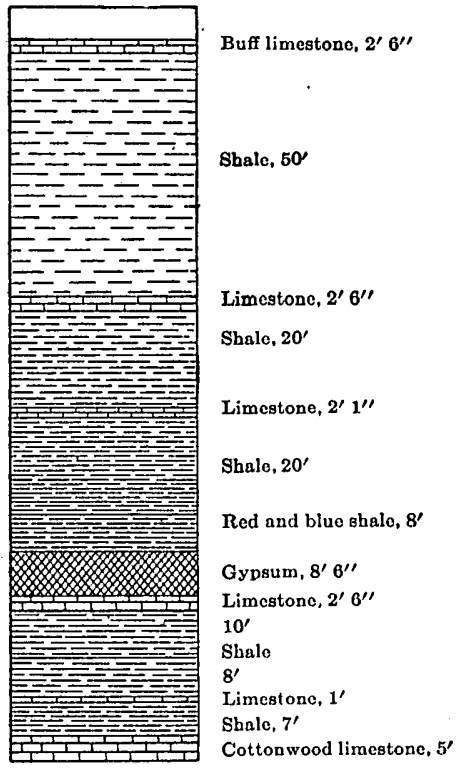

Figure 6.-Section at Great Western gypsum mine, Blue Rapids, Kans. may be traced across the country, lies 100 feet above this limestone. The gypsum lies about 10 feet above Blue River.

On the John Morrow farm, about 2 miles east of Waterville and 2 miles west of Blue Rapids, pink gyjpsum nodules are embedded in 12 feet of shale near the water's edge. Above the gypsiferous shale is 20 feet of red and blue shales and limestone.

The dip from Winter's mine to Fowler's mine, $1 \frac{1}{2}$ miles north, is 12 feet, or 8 feet to the mile; and from the Yarrick mine to the Great Western, a distance of $2 \frac{1}{2}$ miles a little east of north, the dip is 18 feet, or 7 feet to the mile. From the Great Western mine west to the exposure at Waterville the dip is between 8 and 10 feet to the mile. The dip of the gypsum, then, in the vicinity of Blue Rapids, is to the northwest, about 10 feet.to the mile. 


\section{CENTRAL AREA.}

Extent of the deposits.-There are two well-marked horizons at which rock gypsum occurs in the central Kansas area and indications of a third horizon. The lower and more extensive deposit extends over the central, northern, and western parts: of the area; the second one over the central and southern parts; and the third is found only in the southern part. The interval between the middle and lower deposits is 100 feet, and between the middle and upper it is 40 feet. The dip of the gypsum is nearly west, ranging from 6 to 12 feet to the mile.

Solomon mine.-In the northern part of the area, 6 miles southwest of Solomon, on the bank of Gypsum Creek, was located the mill and mine of the Crown Plaster Co. The mine entrance is 15 feet above the creek; the gypsum is 5 feet thick and is underlain by about 4 feet of shaly limestone. Be-

\begin{tabular}{|c|c|}
\hline W & Soil and gypsum, $4^{\prime}$ \\
\hline 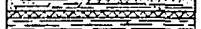 & Gypsum, 1' \\
\hline 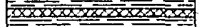 & Gypsum, $1^{\prime}$ \\
\hline कon & Gypsum, 10" \\
\hline$=5=5$ & \\
\hline$\alpha<x<x \times x<x$ & Gypsum, 2' \\
\hline . & Gypsum, $5^{\prime}$ \\
\hline 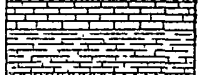 & \\
\hline $8 x<x$ & Gypsum, $3^{\prime}$ \\
\hline
\end{tabular}

Figure 7.-Section at gypsum mine near Solomon, Kans. low this limestone there is a series of shales. with a 3 -foot stratum of gypsum. The roof of the mine is a 2 -foot member of compact dark shale. The strata at the Solomen mine, including six beds of gypsum, are shown in the section (fig. 7).

The shales with the intercalated gypsum layers are folded and broken. The folds extend down into the mine, causing the shales of the roof to cut out the gypsum in many places. For this reason the mine was abandoned in 1898. Probably the dip of the gypsum is northwest.

The lower part of the thickest gypsum layer is very compact and is filled with oval crystals of yellowish-brown selenite, which have the greater length in the direction of the vertical crystal axis. The crystals are laminated by pronounced pinacoidal cleavage. The larger ones are about seven-eighths of an inch long and half an inch wide, and rock specimens from this portion of the stratum break with a conchoidal fracture. The upper part is white, less compact, contains no phenocrysts, and breaks more irregularly.

The occurrence of these selenite phenocrysts is of no little interest. It indicates that the ocean water at one time was evaporated very slowly and under the most favorable conditions for the production of individual crystals. Later there was a slight freshening of the water by surface drainage entering the-concentrated lake, so that the erystals were partly redissolved, as shown by their rounded edges. Still later the rapid evaporation of the water precipitated the massive gypsum, and afterward an agitation of the shallow water sufficiently vigorous to mix the crystails 
thoroughly with the newly precipitated gypsum formed the whole mass as it now appears. The deposit is therefore a record of rains. and winds not unlike those now common in the same locality.

Hope mine.-At Hope, 20 miles southeast of Solomon, the Kansas Cement Plaster Co. began operations in 1887. Calcining ceased here sereral years ago. This company first used the middle stratum of gypsum quarried near the top of the hill, 11. miles west of tormn. It is about 5 feet thick and lies 10 feet below a buff shaly limestone. It is white and compact in texture, except near the surface, where it is rendered granular and more or less colored as a result of weathering. The satin spar associated with it is clear white when viered from the side, but when viewed from above it possesses a cream-white tinge. Overlying the main gypsum bed is a thin dcposit of black, impure, shaly gypsum:

In 1894 this quarry was abandoned and an 80-foot shaft was sunk a quarter of a mile west, to the lower stratum, which is nearly 14 feet thick. In this shaft the gypsum is white, though much of it is traversed by wavy dark lines close together, giving it an appearance somewhat like granite or gneiss, so that plaster made from it was called by the company "granite cement plaster." The lower part of the stratum is" compact, and contains rounded crystals of selenite, with dark mottled surfaces. It thus bears a close resemblance to the gypsum near. Solomon, already described, although the crystals are ustally larger, averaging about 2 inches by 1 inch.

A study of the levels and the character of the rock indicates that the gypsum quarried below Solomon is the same as that in the shaft near Hope.

The gypsum in the quarry on the hill east of Hope lies below a buff soft shaly limestone, which accompanies all the gypsum outcrops to the south and southeast, at the Henquenet cave, German church, Rihodes mill, and Elmo. This gypsum lies 100 feet above the rock in the Hope shaft. The levels and dip would connect this upper layer with the outcrop near Saline, which was named by Cragin ${ }^{1}$ the Greeley gypsum, from the township in which it was found. $\mathrm{He}$ states that it was probably 100 feet higher than the so-called. Hope gypsum, but as two gypsum horizons occur at Hope it is doubtful to which one he refers.

Other exposures.-The lower gypsum, or the one near Solomon, outcrops a quarter of a mile sonth of the Diflon mill, where it is 5 feet thick and is covered with 5 feet of dirt. This locality is 2 miles west of the Hope shaft, and the gypsum is 10 feet lower. In a well near the Tinkler earth deposit at Gypsum, 15 miles west

${ }_{1}$ Cragin, F. W., The Permlan system. in Kansas: Colorado Coll. Studies, vol. 6, p. 10, 1.896 . 
of the outcrop at Dillon, rock gypsum is found 60 feet lower. This same rock gypsum outcrops along the east bank of Gypsum Creek, and exposes about 3 feet of white granular gypsum. It may be seen in places between Gypsum and Solomon, and at nearly the same level. Similar outcrops occur in the Holland Creek area. South and west of Gypsum no gypsum was found, either in outcrops or in wells. The upper gypsum, as exposed in the Hope quarry, outcrops at higher altitudes to the west and north. It occurs 7 miles southwest, at the gypsum cave on the Henquenet farm. The lower 8 feet of gypsum at this cave is veined and spotted, and polished slabs of it bear some resemblance to onyx. The upper 2 feet exposed is fine grained and compact, like alabaster. This layer is covered by 15 feet of shales and 10 feet of buff shaly limestone. The roof of the eastern end of the cave has fallen, making a ravine with gypsum walls. No other caves are found in this region, but there are a number of similar ravines which probably have had the same origin.

Two miles west of the cave, near the top of the hill, there is an exposure of 15 feet of white gypsum which, according to barometric measurement, is about 300 feet higher than the cave gypsum. One mile farther west a deposit of banded gypsum covered with buff shales was found in a well on the Wuthnow farm. The well was drilled 8. feet into the rock and then abandoned. On the hill onequarter of a mile to the north is an old gypsum quarry 35 feet higher than the gypsum in the well. The rock as exposed is 5 feet thick, dark colored and irregularly crystalline in the upper portion, and is covered with a layer of black gypsum. This deposit and the one on top of the hill mentioned above were the only outcrops noted of the third or upper gypsum.

In the well on the Rhodes farm, 3 miles west of the Wuthnow farm, the gypsum is 40 feet lower than it is at the cave 6 miles east, and 60 feet lower than in the Hope quarry, 8 miles northeast. This layer outcrops at the same level in the ravine below the well, and it is compact and banded. Above it is the buff shaly limestone as at the other places. The dip from Wuthnow to the Rhodes farm is nearly 12 feet to the mile.

One mile south of the exposure on the Rhodes farm the gypsum outcrops on the Banker farm and extends for some distance farther south. It also outcrops on the Tucker farm, 1 mile east and nearly 15 feet higher. One mile northeast of this exposure is a thick bed of gypsum 10 feet higher, close to the German church.

The deposits of gypsum rock in this central area have not attracted much attention. The lower bed, or the one near Solomon, seems to be more favorable for working than the so-called Hope gypsum, for it has good thickness and quality wherever found, whereas the upper bed differs in character from place to place. 
The southern area, which is in the vicinity of Medicine Lodge, is the largest area in Kansas, and, with its continuation in Oklahoma and Texas, it forms the largest area of gypsum in the United States. The gypsum extends from a point near the town of Medicine Lodge vestward through Barber County into Comanche County and southward into Oklahoma and Texas and passes under the Tertiary gravels to the north. The outcrop of the deposit trends northeast and southwest.

The gypsum of the Medicine Lodge area is massive, and the lower portion of the stratum is very compact. This portion is used at the Medicine Lodge mill for the manufacture of terra alba, and the ripper portion, which has a sugary texture, is used in the manufacture of wall plaster. The satin spar, which is found throughout the "Red Beds" below the gypsum, forms wavy plates, made up of an aggregate of perpendicular needles. Some pieces of it are soft and readily crumble, but other pieces are compact and glassy in appearance.

The easternmost occurrence of gypsum in this area is 6 miles southwest of Medicine Lodge, in an isolated range of hills 3 miles long, which is separated by a narrow valley from a second hill 1 mile in length. The valleys of East Cedar and West Cedar creeks, 2 miles wide, separate these hills from the next series, in which the gypsum plateau is continuous to the west. Medicine Lodge River cuts out the gypsum in a valley 6 or 7 miles wide. The northern limit of the gypsum can not be determined, for it is covered with Tertiary deposits. Salt Fork and Sandy Creek cut out broad valleys to the south, and the streams in the eastern portion of Comanche County have removed much of the gypsum, but it is continuous over the great portion of western Barber and eastern Comanche counties. It lies about 1,800 feet above sea level.

In the eastern part of Comanche County, on Cave Creek, a gypsum. bed 15 feet thick is found 15 feet above the Medicine Lodge bed. This upper layer, called the Shimer gypsum by Cragin, ${ }^{1}$ appears to be a local deposit.

West of Medicine Lodge the Gypsum Hills, with sloping sides and level tops, are composed of the red clays and shales of the Permian "Red Beds." The cap rock is a ledge of solid gypsum, which has protected to a considerable extent the underlying soft strata. The base of the hills is a massive red sandstone. A second red sandstone is found 125 feet higher, and 100 feet still higher is the ledge of gypsum that forms the top of the hills. This gypsum layer ranges from 3 to 20 feet in thickness, depending upon 
the amount of erosion. Forty feet below the gypsum is a green gypseous sandstone $2 \frac{1}{2}$ feet thick, which stands out as a prominent ledge through the hills. The red clays and shales below the gypsum contain an interlacing network composed of layers of selenite and satin spar of variable thickness, redeposited from downward-moving surface waters which have dissolved portions of the gypsum bed.

At Kling, in the northwest corner of Barber County, is the quarry from which Best Bros. produce gypsum for their mill at Medicine Lodge. The gypsum bed is 20 to 25 feet thick, and the orerburden is 30 feet thick. About 20 feet of gypsum is quarried, and the bottom of the bed, consisting of 3 feet of hard, darker gypsum, is not remored.

In the western part of Barber and the eastern part of Comanche counties the solvent effects of water on the gypsum are well shown by caves, sinks, bridges, and underground watercourses. On Cave Creek, 4 miles west of Evansville, is the Big Gypsum Cave in the Medicine Lodge gypsum. A stream of considerable size flows into the west entrance and out of the east one, making the cave an underground watercourse for at least 100 feet. The roof at the east entrance is 15 feet above the water level, but in a short distance it lowers to 3 feet. The floor is strewn with large slabs of white gypsum. At the center is an opening through the roof. This nearly circular hole is a few feet in diameter in the cave and 30 feet on the surface. The section near this cave shows 30 feet of the Medicine Lodge gypsum separated by 15 feet of red shale from the Shimer gypsum, which is 15 feet in thickness. This exposure is the typical one of the Cave Creek formation of Cragin.

The natural bridges found here are remnants of old cares, or underground water channels, whose roofs have partly fallen in. One of the best of these natural bridges is on Bear Creek, south of Sun City. It is about 40 feet high and 35 feet wide.

\section{GYPSUAI CRYSTALS.}

Pennsylvanian shales.-In numerous places in the Pennsylvanian shales of southeastern Kansas, gypsum crystals are found in comparative abundance but not in sufficient quantities to be of any economic importance. They occur ustally in the soil and clay near the surface. The size of the crystals ranges from microscopic dimensions to almost an inch in diameter, but most of them range from one-eighth to three-eighths of an inch.

The occurrence of selenite crystals is interesting principally from theoretic considerations, as it illustrates in a beautiful manner or $\partial$ of the modes by which gypsum may be formed. 
They probably have orginated principally through the action of soluble iron sulphate on calcium carbonate, the iron sulphate having been produced by the oxidation of pyrite. The shales in the vicinity of a gypsum deposit are usually quite heavily charged with pyrite. As weathering decomposes the shales the pyrite changes to iron sulphate, which may come in contact with limestone and thus form calcium sulphate. One of the noticeable features of such localities is the iron sulphate present in the water of wells which penetrate the undecomposed shales.

Cretaceous shales.-In many parts of Kansas, where Cretaceous shales outcrop, fine crystals of gypsum are common. Along Smoky Hill River for many miles such crystals are particularly numerous. Some of them measure more than a foot in length and are magnificent museum specimens. Nowhere in Kansas is the Cretaceous gypsum abundant enough to be of any importance for manufacturing purposes.

Tertiary formations.-In the southwestern part of the State, where the Tertiary formations are in contact with the Cimarron group ("Red Beds"), the lowermost portions of the Tertiary sands in many places contain well-formed gypsum crystals, particularly in the southwestern part of Meade County and in different places in Seward County. From 50 to 100 feet above the contact line between the "Red Beds" and the Tertiary gypsum crystals are abundant and as perfectly formed as any others in the State.

It is probable that these crystals originated from an upward morement of water through the "Red Beds," which served as a source of the gypsum, and that the crystallization was produced by surface evaporation at or near the present position of the gypsum. The deposits of gypsum crystals have no economic importance.

\section{THE GYPSUM INDUSTRY IN KANSAS.}

At the present time the gypsum industry in Kansas is in successful operation. A number of the smaller companies have sold out to the larger ones, so that fewer companies are now operating.

The gypsum industry at present is confined to the Blue Rapids and Medicine Lodge districts, where there are four mills or plants. At Blue Rapids the American Cement Plaster Co. is operating two mills, and the United States Gypsum Co. is operating one. The mills south of Kansas River in Dickinson County have been abandoned. A mill at Hope, operated occasionally, has for a number of years produced only crude gypsum to be sold to Portland cement factories throughout the State. At Medicine Lodge the Best Bros.' Keenes cement plant is very active. 
The plants at Blue Rapids use rock gypsum. They make wall plaster of different kinds and during recent years have made hollow tile and blocks for interior walls. Partition tile and blocks are made $1 \frac{1}{2}$ to 12 inches thick. The light weight of gypsum tile walls permits the use of much lighter structure to sustain the load.

The factory at Medicine Lodge, which has been in operation more than 25 years, makes Keenes cement equal in quality to the English product. This material sets harder than ordinary gypsum wall plaster, and sells at higher prices. It is used as wall plaster, for making imitation marbles, as a backing for marble slabs, and in ornamental plaster work. Best Bros.' quarry is at Kling. Plate XVIII, $A$, shows the character of the bed and the overburden.

\section{ORIGIN OF THE GYPSUM OF KANSAS.}

Space does not permit a lengthy discussion here of the ideas which have been expressed regarding the origin of gypsum. From their complete interbedding with stratified rocks the conclusion is reached that the gypsum beds are of sedimentary origin. In all the areas in Kansas to the east and northeast of Barber County gypsum occurs very closely associated with limestones and shales, which are doubtless of marine origin, as is abundantly shown by the large number of marine fossils in them, and therefore the gypsum must have been of marine origin also.

We may, therefore, say that the gypsum around Blue Rapids and in Dickinson County, and other points to the south outside of Barber County, was laid down in a body of ocean water sufficiently concentrated to allow the deposition of gypsum but not enough to precipitate salt. Deposition of gypsum begins after evaporation of 37 per cent of the water, whereas 93 per cent of the original water must be evaporated in order to deposit salt.

It seems probable that here and there in the Kansas gypsum belt there were small bodies of ocean water. which for a time were concentrated and later rediluted, either by an influx of ocean water or by an extra amount of fresh water due to increased rainfall.

The origin of gypsum in the "Red Beds" in Barber County may have been a little different, although the burden of evidence at the present time.indicates that here also as with the other Kansas deposits the gypsum was mainly derived by a concentration of ocean water. 


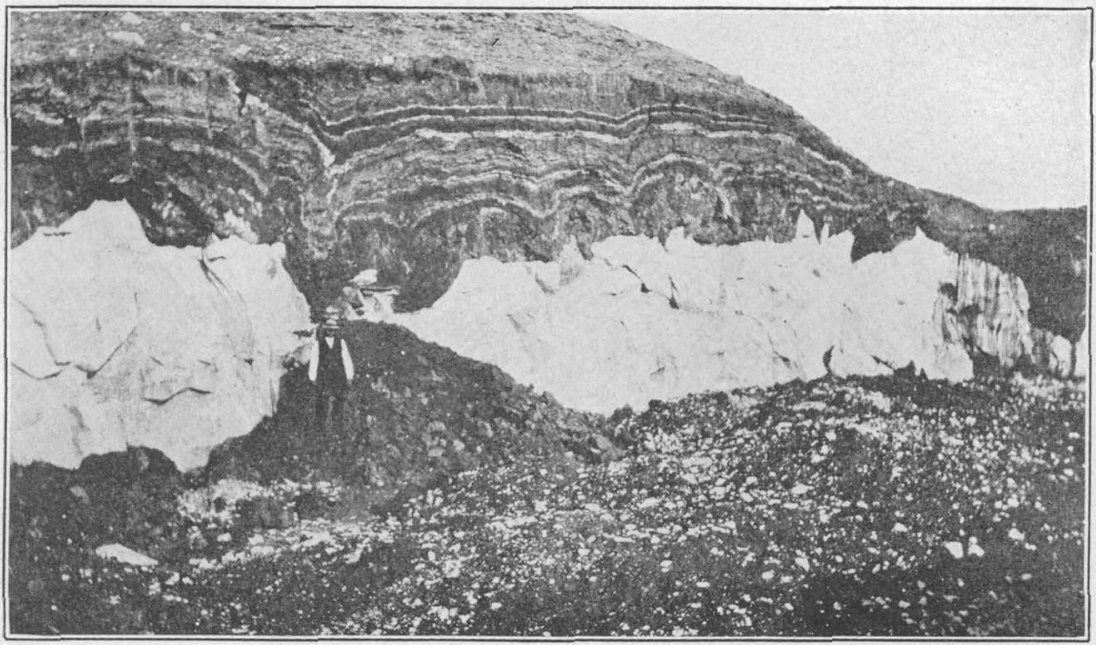

A. GYPSUM BED IN BEST BROS.' QUARRY, KLING, KANS.

Photograph by E. F. Burchard.

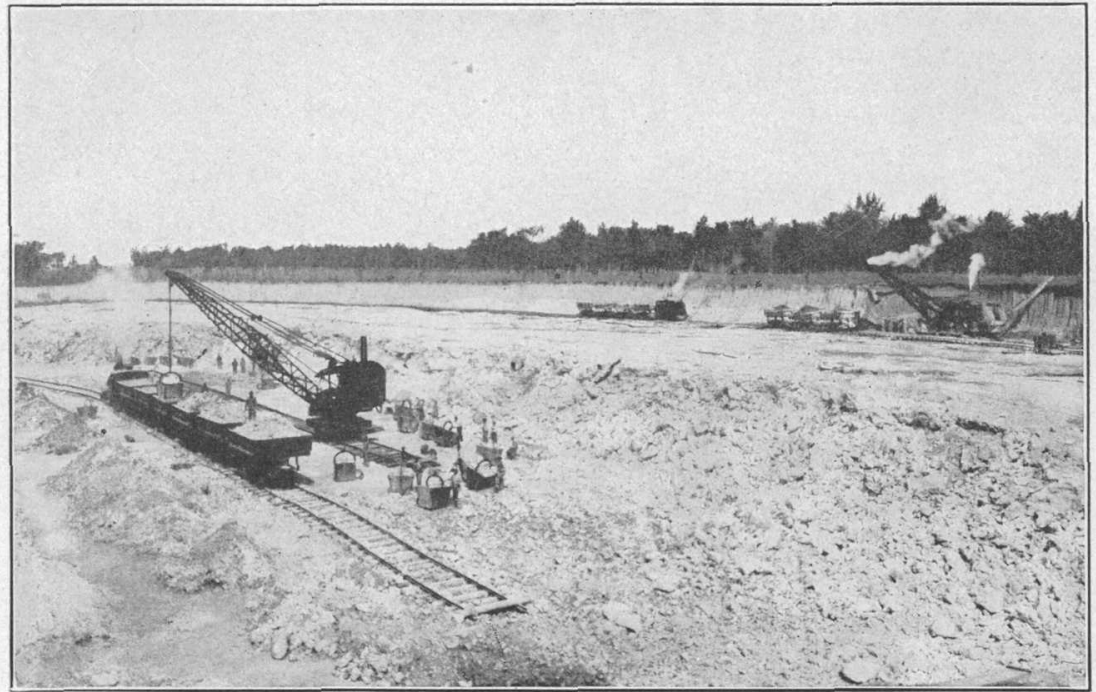

B. GYPSUM QUARRY OF UNITED STATES GYPSUM CO. AT ALABASTER, MICH.

View shows method of removing overburden and of loading rock blasted from ledge. Photograph furnished by United States Gypsum Co. 


\section{LOUISIANA.}

By R. W. STone.

Deep drilling for oil has disclosed the fact that rock gypsum occurs several hundred feet below the surface at a number of places in the western and southern parts of Louisiana. Conspicuous among these localities is the Sulphur mine, 3 miles west of Sulphur City, Calcasieu Parish, where a well sunk by the Louisiana. Petroleum Co. to a depth of 1,230 feet was in "pure gypsum, dense, granular, and coarsely crystalline, grayish or white" ${ }_{1}$ for 540 feet, from 690 to 1,230 feet below the surface.

In Calcasieu Parish, 4 or 5 miles southwest of Vinton, 1.50 feet of gypsum was recorded at a depth of 950 feet, and on Hackberry Island, in Cameron Parish, 33 miles southwest of Lake Charles, a well at a depth of 1,620 feet reached 210 feet of gypsum. Likewise in Winn Parish, a well at Goldonna penetrated 22 feet of gypsum but did not pass through the formation at the bottom of the hole about 2,240 feet deep.

On the Gulf coast, a well sunk at Belle Isle, three-quarters of a mile north of Atchafalaya Bay passed through 100 feet of gypsum and sulphur rock from 290 to 390 feet below the surface, and the next 490 feet was in very porous sulphur, gypsum, and anhydrite.

Smaller quantities of gypsum have been reported in other wells. Where selenite crystals have been obtained from the sand pumpings the identification of gypsum may be considered as authentic, but elsewhere, in the absence of satisfactory samples, there is some question whether the rock reported as gypsum may not be partly consolidated marl or some other rock. These thick deposits of rock gypsum near the Gulf of Mexico may eventually be developed by deep shafts. Besides supplying the local market, Louisiana gypsum products might be used for some of the trade of Central and South America.

${ }^{1}$ Harris, G. D., Otl and gas in Louisiana, with a brief summary of their occurrence in adjacent States: U. S. Geol. Survey Bull, 429, p. 100, 1910. 


\section{MICHIGAN.}

By R. A. SMIrhH.

A more detailed report on the gypsum deposits of Michigan by Grimsley ${ }^{1}$ was published by the Michigan Geological Survey in 1904.

\section{GEOLOGIC OCCURRENCE.}

Gypsum in Michigan occurs chiefly in the Michigan formation (lower formation of Grand Rapids group) of the Mississippian, in the Bass Islands dolomite (lower formation of Monroe group, Silurian), and in the Salina formation of the Silurian. More or less gypsum occurs locally in the Detroit River dolomite, the upper formation of the Monroe group. The Grand Rapids group immediately underlies the Michigan coal basin and is exposed in many places in a nearly continuous belt around it. On the southeastern side of the coal basin the Bayport limestone (upper formation of Grand Rapids group) and the gypsum-bearing series beneath it locally have been wholly or partly removed by erosion. The-Monroe group outcrops only in the extreme southeastern portion of the State and in the St. Ignace Peninsula and adjacent islands. The Salina formation does not come to the surface in southern Michigan and has not been certainly differentiated from the Monroe group in the St. Ignace Peninsula. (See fig. 8.)

\section{CHARACTER AND EXTENT.}

Large deposits of gypsum occur at many places in a nearly continuous belt of gypsum-bearing rocks around the coal basin which occupies the central part of the Southern Peninsula. Gypsum deposits also occur in the St. Ignace Peninsula and on the St. Martin Islands in Lake Huron. Surface indications point to the probable occurrence of gypsum deposits in the northern part of the Beaver Island group in the northern part of Lake Michigan. Thick beds of anhydrite, in part altered to gypsum, are known in Monroe County and in the vicinity of Detroit and St. Clair rivers, but at considerable depth. Borings within the central coal basin show that locally thick beds of gypsum are present beneath the coal measures.

${ }^{1}$ Grimsley, G. P., The gypsum of Michigan: Michigan Geol. Survey, vol. 9, pt. 2, 1904. 
The gypsum of Michigan belongs to the massive rock variety and occurs in lenticular deposits embedded in shale and shaly limestones. In some places the beds of gypsum are rery numerous. The beds range in thickness from a fraction of an inch to 25 feet ol more.

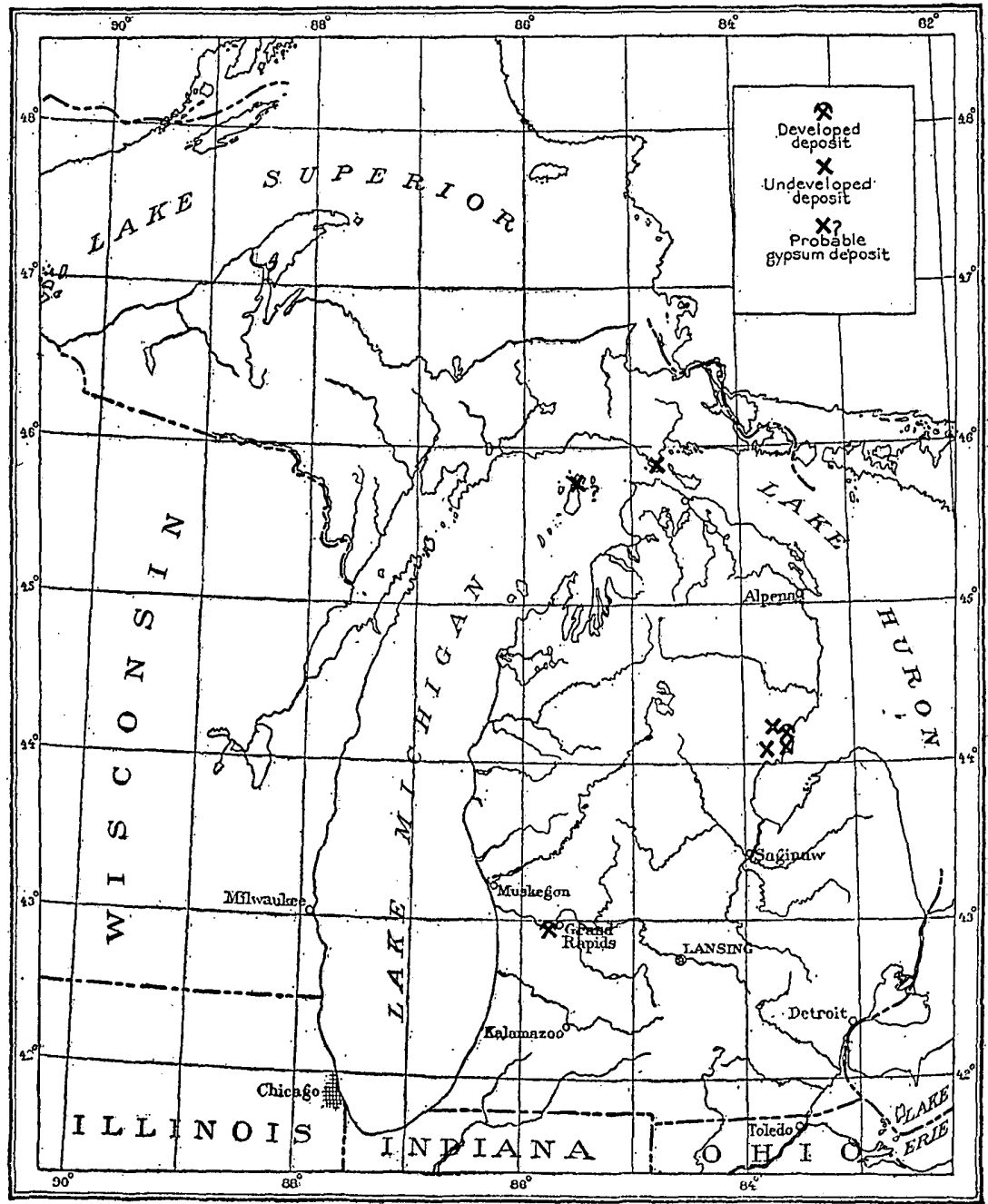

FIGURA 8.-Outline map of Michigan showing gypsum deposits.

The thinner beds are generally small in area, but some of the thicker. ones have been traced over large areas. The easily mined deposits of gypsum in Michigan are practically inexhaustible. In addition less easily accessible deposits underlie an area hundreds and probably thousands of square miles in extent. 
The rock gypsum is generally very pure. Commonly its color is white or reddish, but the upper portions of some beds which lie near the surface are stained yellow by iron oxide and are more or less mixed with clay, sand, and gravel. The texture in most places is finely to coarsely crystalline. At Alabaster, Iosco County, some of the rock of a very fine and uniform grain is the variety known as alabaster.

\section{ECONOMIC DEVELOPIMENT.}

By R. A. Smith and R. W. Stone.

The gypsum deposits are, or have been, mined in three localitiesGrand Rapids and Grandville in Kent County, Alabaster in southeastern Iosco County, and St. Ignace in Mackinac County, but operations ceased at St. Ignace many years ago. Large undeveloped deposits occur in western Iosco, southeastern Ogemaw, and southern Arenac counties. Beds from 5 to 30 feet thick occur at comparatively shallow depths at Ionia, Ionia County, and in Saginaw County. Beds from 6 to 12 feet thick were penetrated in shallow wells at Bellevue and Eaton Rapids in Eaton County.

Grand Rapids-Grandville district.-The Grand Rapids-Grandville district, as developed, extends in a belt 3 or 4 miles in width along the valley of Grand River from the northern part of Grand Rapids southwest through Grandville into eastern Ottawa County, a distance of 10 miles or more. The valley of the Grand ranges in width from 1 mile at Grand Rapids to 4 miles at Grandville. The bluffs along the valley are composed of drift material and rise 100 to 150 feet above the river flats. Exploration and development have been confined to the Grand River valley, where the rock is covered by only a few feet of river silt or sand and gravel. Further exploration in the creek valleys northwest and southeast along the strike of the beds will probably show that the gypsum has a much greater extent in these directions than now known.

There are several beds of minable thickness in this area, and a number of others under 5 feet thick. At Grand Rapids, the first workable bed, 6 feet in thickness, has been quarried; the second, a 12foot bed, is both quarried and mined; and the third, a 22 -foot bed, about 30 to 60 feet below the second, is mined. The upper bed is absent in many places, having been removed by erosion, and the second is locally very thin, or even absent. Where the 12 -foot bed is mined the 6 -foot bed is generally left untouched. The 22 -foot bed is divided near the middle by a shale parting 1 foot or more in thickness. Until about 1900 only the two upper beds at Grand Rapids were worked, for it was supposed that water would be very troublesome 
in mining the third bed, but when a shaft was sunk to it mining conditions were found to be ideal, the mine entries being perfectly dry.

North of the river near Grand Rapids the mine adits enter the bluffs at the level of the mills. South of the river near Plaster Creek the bottom of the lowest bed quarried is about 10 feet above the river. At Grandville the quarries are about a mile south of the river and only slightly above it.

The overburden in the vicinity of the quarries ranges from a few feet to more than 20 feet of sand and gravel. Near the Plaster Creek quarries surface materials are relatively thin, but there is 12 to 15 feet of shale above the 6-foot bed of gypsum. The heavy cost of removing the overburden and pumping water has caused the gradual abandonment of quarries and the opening of mines. ${ }^{1}$

The gypsum mills and mines nearest to Grand Rapids are just outside the west city limits on the north side of the river. At the first two mills, those of the Grand Rapids Plaster. Co., the geologic section is as follows:

Section at Eagle Mills, Grand Rapids, Mich.

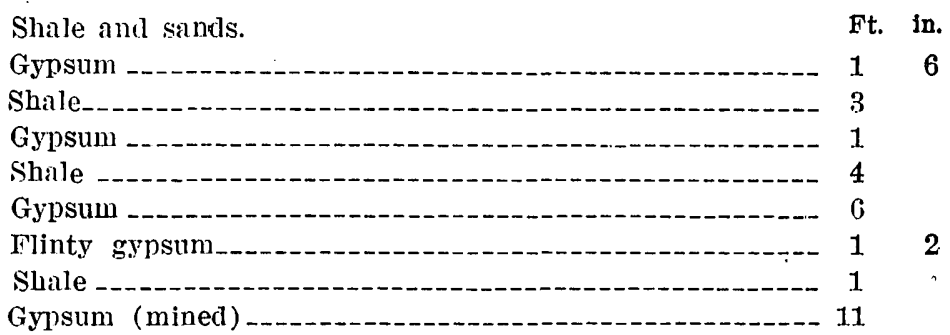

The so-called 12-foot bed, which at this locality is 11 feet thick, is being mined from two short slopes, 1,100 feet apart, one at each mill. The 6-foot bed just above it, which used to be quarried, is left in the mine roof.

At the Midland mill of the United States Gypsum Co., a short distance farther west, the 12-foot bed has been worked out and a thicker bed, 36 feet below it, is being mined from a vertical shaft. This deeper bed is about 20 feet thick. Another bed of gypsum, called the "salt vein," lying a few feet above the big bed, has been mined to a small extent from this shaft.

That these deeper beds are present under the mines first mentioned is shown by drill holes and shafts in sec. 34, T. 7 N., R. 12 W., of which a composite $\log$ has been furnished by Mr. A. H. Apted, of the Grand Rapids Plaster Co.

1 The remainder of the description of the Grand Rapids-Grandville district was written by R. W. Stone. 
Composite log of drill holes and shafts in sec.. 3., T. r N., R. 12 W., Grand Rapids, Mich.

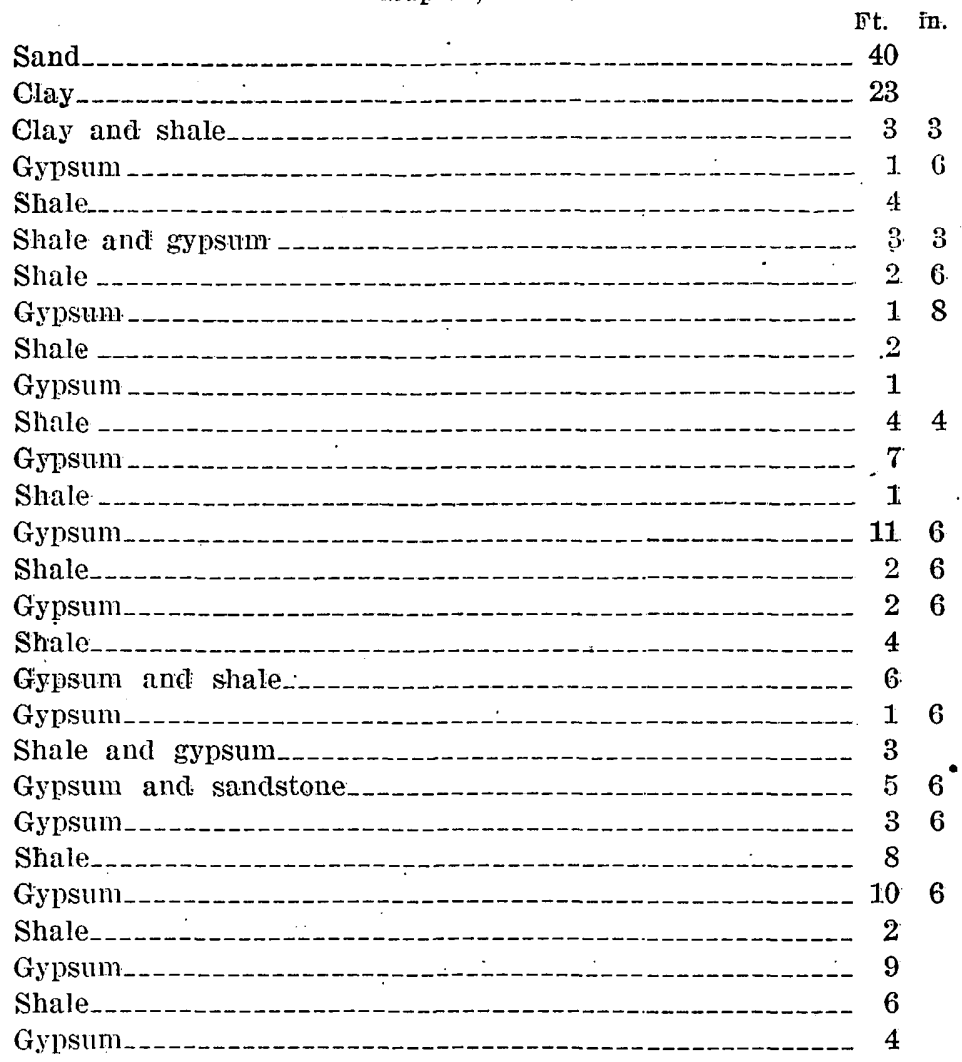

At the mine of the Michigan Gypsum Co., on the south side of the river, the upper bed was quarried out and the excavations are now full of water. The lower or 22 -foot bed is being mined from a vertical shaft 90 feet deep.

At Grandville an 11-foot bed lying under a considerable eover of unconsolidated sand and gravel is being quarried by the Grand Rapids Plaster Co. It is reported that 4 feet below it there is a 14-foot bed and that an abandoneek shaft of the United States. Gypsum. Co. about 2,000 feet from this quarry reached a still lower bed-the 22-foot bed of the Grand Rapids mines.

Correlation of these beds seems simple, for they lie practically horizontal. Furthermore, it is asserted by men long familiar with these gypsum keposits that rock from the upper and lower beds can be distinguished by physical characteristics. The apper beds are said to be whiter, softer, more massive, and to contain fewer small selenite plates than the lower beds.

It is believed by some that the mines of the Grand Rapids Plaster Co. at Grand Rapids are working in the same bed that makes the. 
floor of the quarry of that company at Grandville; in other words, that the 6-foot and 12-foot beds at Grand Rapids are respectirely the 11-foot and 14-foot beds at Grandville. Others believe that the 6-foot bed of the Grand Rapids area is absent near Grandville, and that the 11-foot bed in the Grandville quarries is the 12-foot bed at Grand Rapids. If this is so, then the 14-foot bed at Grandville is represented at Grand Rapids by beds of gypsum and shale shomn in the log of test holes on page 126 as lying just below the 12-foot bed. There seems to be no question that the bed 20 to 22 feet thick in the drill holes in sec. 34 , in the shafts of the United States Gypsum Co., and of the Michigan Gypsum Co. is one and the same bed. No matter which correlation is correct, the quantity of gypsum in the Grand Rapids-Grandville area is sufficient to meet the demands of the entire United States for many years. Alabaster.-The Alabaster quarry and mill are located in the southeastern part of Iosco County, 6 miles south and west of Tawas City, and three-fourths of a mile from the shore of Saginaw Bay. The gypsum bed is from 18 to 23 feet in thickness. Near the bay it was originally covered by 5 to 8 feet of gravel. Farther west the overburden is tough boulder clay 9 to 14 feet or more in thickness, which is removed by steam shovels as quarrying progresses. (See Pl. $\mathrm{XVIII}, B$.) The base of the bed is about 15 feet above the level of the bay. A large area has been morked out; the face of the quarry is now in the form of a horseshoe and is nearly a mile long. This quarry is the largest in Michigan and one of the largest in the United States. It is owned and operated by the United States Gypsum Co.

The bed of gypsum at the Alabaster quarry is of commercial thickness over an area of at least 25 to 30 square miles in southeastern Iosco County and northwestern Arenac County. The bed dips gently to the southwest under other strata. In the western part of Iosco County and southern Ogemaw County gypsum outcrops in many places and is only lightly covered over a large area. Drillings north and west of Alabaster show at least five workable beds below the Alabaster quarry bed ranging from 4 to 22 feet thick.

Turner.-In the vicinity of Turner, Arenac County, and in the northeastern part of the county, a persistent bed of gypsum occurs 50 to 100 feet above the Alabaster quarry bed. This bed is locally known as the Turner bed. ${ }^{1}$ There are two areas in the county in which this bed is thick enough for mining-one in the vicinity of Turner and the other in the northeastern part of the county. The combined extent of the two areas is 20 to 25 square miles, but further exploration will probably increase rery greatly the minable area of the bed.

' Gregory, W. M., Geology of Arenac Cọnty : Michigan Geol. and Biol. Surrey Prb. 11, Geol. Ser. 8, pp. 54-58, 1911. 
St. Ignace.-Gypsum occurs at different places in the St. Ignace Peninsula ${ }^{1}$ and on adjacent islands. In 1850 a quarry was opened near Point Aux Chenes, 7 miles west of St. Ignace. A dock was built and gypsum was shipped to mills in Chicago. Owing to various troubles, chief of which were water in the quarry and a scourge of smallpox, the quarry was operated only intermittently for a number of years. Finally an ice floe carried away the dock, and the enterprise was abandoned. In 1894 some test holes were put down 2 miles west of the old quarry. According to reports 3 holes penetrated a ledge of gypsum a few feet in aggregate thickness. In a deep well 2 miles south of St. Ignace, some gypsum was struck at 35 feet, 13 feet of gypsum at 174 feet, and 5 . feet at 255 feet. Drillings on a bench at the foot of Rabbits Back Point, a high limestone spur projecting into the lake 4 miles north of St. Ignace, showed some gypsum a few feet below the surface, a 21-foot bed at about 30 feet, and a 9 -foot bed at 57 feet. The surface of the land on which the drillings were made is only 10 to 15 feet above the lake. In some places gypsum was found under only about 14 inches of soil, and near the extremity of Rabbits Back Point a bed outcrops close to the water's edge and can be seen beneath the water near the shore. Gypsum was found on adjoining tracts of land and at Grosse Pointe, 4 miles farther north. From this point eastward gypsum outcrops along the shore for several miles. On the southern part of St. Martin İsland, directly east of Grosse Pointe, gypsum is struck in shallow wells over a large area of the island and may be seen in the water along the shore. The top ledge, said to be 3 feet thick, is near the surface, and other beds occur lower down. According to analysis, the rock is very pure, containing over 98 per cent of gypsum.

Present evidence indicates seven easily accessible heavy beds of gypsum in St. Ignace Peninsula and adjacent islands, but whether water would be generally troublesome in quarrying or mining is uncertain.

According to Lane there are many signs of gypsum deposits in the northern part of the Beaver Island group in Lake Michigan.

\section{HISTORY. 2}

In 1827 gypsum was discovered on Plaster Creek, in the southwestern part of Grand Rapids. It was calcined some years later by James Clark, who used an old Indian corn mill for grinding and a caldron kettle for calcining. The first mill was built on

1 Grimsley, G. P., The gypsum of Michigan: Michigan Geol. Survey, vol. 9, pt. 2, p. 83, 1904 .

2 Idem, p. 42. 
Plaster Creek in 1841 near the crossing of the Grandville road. The machinery consisted of one run of millstones and a thick-bottomed two-barrel caldron kettle. Most of the gypsum was ground into land plaster, and 10 years later 60 tons were produced daily. In 1843 gypsum was discovered on the north side of Grand River, and in 1849 a mill was built near the site of the present Eagle Mill No. 1 of the Grand Rapids Plaster Co. A second mill, now the Eagle Mill No. 2 of this company, was erected on neighboring property in 1869 .

In the early sixties gypsum was discovered south of Grandville, 6 miles southwest of Grand Rapids, through the overturning of an old tree by a high wind, and two mills were built, one in 1873 and the other in 1874. Other mills were built and quarries opened later at different times, but owing to the keen competition and faulty methods of calcining many of the ventures were unsuccessful. About 1901 consolidation of the interests began, and at present the seven mines and quarries and eight mills in the Grand Rapids-Grandville district are owned or controlled by four companies.

Gypsum had been discovered by the Indian traders at Alabaster before 1841, but it was not until 1862 that a quarry was opened, supplying small mills at Winona, Bay City, and Monroe with gypsum for the manufacture of land plaster. Later a mill was built, and at present this quarry, operated by the United States Gypsum Co., is one of the largest in the United States. Another quarry was opened in 1870 about 3 miles south of Alabaster, but trouble with water caused its abandonment.

In 1823 Dr. J. J. Bigsby made the first discovery of gypsum in Michigan, on St. Martin Island. In the fifties a gypsum quarry was opened near Point Aux Chenes, 7 miles west of St. Ignace, Mackinac County, but its operation was abandoned after a few years. $124567^{\circ}-20-9$ 


\section{MISSISSIPPI.}

By R. W. STone.

So far as has yet been discovered gypsum does not occur in commercial quantities in the State of Mississippi. Gypsiferous marls occur in Attala, Carroll, Hinds, Holmes, Leake, Madison, Rankin, and Scott counties, and gypsum crystals are found with clayey material in a broad area. This crystalline gypsum occurs usually in plates, rosettes, or lenticular masses less than 2 inches thick. The largest mass ${ }^{1}$ of pure gypsum found in the State was 10 to 12 inches thick. It was embedded in clays in a well near Cato, Rankin County. Another occurrence was a crystalline mass 1 to 2 inches thick that had a surface equal to 1 square foot. Gypsum crystals from Canton, Madison County, in the writer's possession are in lumps 2 to 3 inches across and 1 inch thick. The material is colorless, glassy, and transparent, but flaws are numerous and partly filled with clay. These gypsum crystals are sometimes mistaken for mica but can be readily distinguished from it by reason of the fact that they can be scratched easily with the finger nail, and the thin plates into which they can be split are only slightly flexible and are not elastic.

Plaster of Paris can be made from gypsum crystals, but they are not used for this purpose commercially. Exceptionally fine, clear crystals are used to a very small extent for certain optical purposes. The gypsum crystals found in Mississippi have no value.

1 Hilgard, E. H., Report on the geology and agriculture of the State of Mississippi, 1860. 


\section{MONTANA.}

By R. W. STONe.1

\section{AGE AND DISTRIBUTION.}

Cascade, Fergus, and Carbon counties contain all the developed gypsum deposits and, so far as is known, most of the workable beds in Montana. The gypsum beds are in rocks of Carboniferous age overlying the Madison limestone and in the Ellis formation of Jurassic age. These formations occur in the eastern part of the mountain belt and are exposed in five principal areas-(1) from Missouri River eastward along the flanks of the Belt Mountains through Riceville and Kibbey, thence southeast toward Judith Gap, and around the Little Belt Mountains to the head of Musselshell River; (2) encircling the Big Snowy Mountains and structural domes in Judith Basin; (3) from Livingston east to Boulder River; (4) around north end of Big Horn Mountains; (5) in the Jefferson and Madison ranges.

There seems to be no published record of gypsum in the Jefferson. and Madison ranges and none in the Livingston area in these formations. Of some other deposits but little is known beyond the location. It is possible that commercially workable deposits of gypsum occur $\checkmark$ elsewhere in the general areas described than at the few places here mentioned, but if so they are not known to the writer.

\section{IOCALITIES.}

\section{CASCADE COUNTY.}

Millegan.-The presence of gypsum near Millegan, in T. $15 \mathrm{~N}$., R. $3 \mathrm{E}$., and in the hills 4 miles north of this place and 2 miles west of Smith River, is reported by Mr. J. R. Villars, a surveyor, of Great Falls, Mont. The upper part of the Carboniferous is exposed in this area, and it is presumed that the gypsum is the massive variety occurring in a bed or beds several feet thick, as at Riceville.

Riceville.-Gypsum has been mined intermittently for a number of years at Riceville, on the Neihart branch of the Great Northern Railway. For seven years the rock was calcined at Great Falls; both mine and mills discontinued operation in 1915.

The gypsum is in the upper part of the Carboniferous section and outcrops about 700 feet above the creek. Mining developments of the

\footnotetext{
1 Based on field notes of C. F. Bowen, of the U. S. Geological Survey; on data furnished by the United States Gypsum Co., of Chicago; by J. R. Villars, of Great Falls; by D. C. Bard, of Seattle; and on notes in earlier publications of the U. S. Geological Survey and other sources.
} 
past few years show that the gypsum deposit near Riceville is variable in thickness and not continuous; the workable part is a bed 3 to 6 feet thick. In places it pinches out entirely. At one place the bed is 15 feet thick without a parting, but an adit shows that this thick bed pinches out in 100 feet. The deposit, as a rule, has a number of clay and sandstone partings. The following section of the deposit is obtained by combining measurements in a shaft and an adjacent drill hole:

\section{Section of gypsum deposit at Riceville, Mont.}

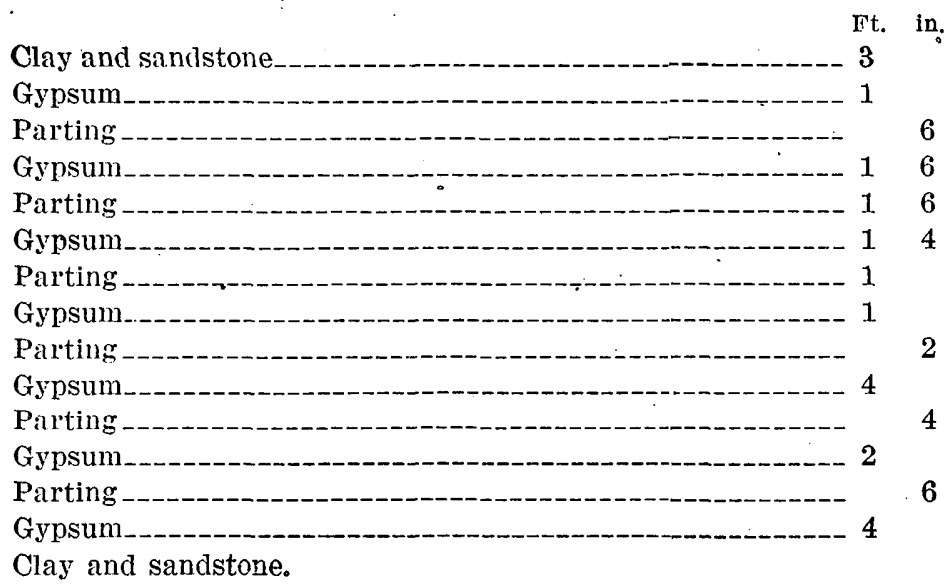

The partings are either clay or sandstone, or both. The lower 4 feet of gypsum is said to be left unmined on account of impurities mixed with it.

The mine consists of a devious branching adit, from the sides of which many rooms have been driven. At the mouth the adit is in red clay, which may not be in place. Gypsum first appears about 50 feet from the portal and is about $4 \frac{1}{2}$ feet thick. The roof is shale and gypsum and the floor sandstone. About 115 feet from the entry gypsum disappears, and the adit passes through red shale, which shows many slickensided surfaces and appears to be a roll. Fifty feet farther the gypsum reappears and forms the walls of the adit to the end, which is about 1,000 feet from the entry. Throughout most of the mine the bed has a northeast dip of about $5^{\circ}$, but at the end of the adit the dip increases rapidly.

The bed is exposed about 1 mile northeast of Riceville on the east side of Belt Creek, but the position soems abnormal. It appears to be in a landslide or small fault block, for it strikes directly into a hill of sandstone underlain by red shale, the shale butting against the gypsum on the east.

Goodman.-At Goodman siding, 3 miles north of Riceville, an attempt to mine gypsum was unsuccessful. A small gypsum mill was 
erected in 1900, evidently before thorough prospecting of the deposit. An adit on the east side of Belt Creek, driven several hundred feet into the hill, encountered only lenticular masses and thin seams of gypsum embedded in red clay. Judged by its relation to the overlying thick sandstone this bed is slightly higher in the geologic section than the one which has been mined at Riceville. If this correlation is correct the main bed has not been found.

An effort to develop the bed on the west side of Belt Creek about 1 mile north of Goodman siding, at Sieglung's place, had the same result as the work at Goodman. Two adits 500 and 615 feet long passed through small bodies of gypsum but were mostly in wash.

Kibbey.-In the northern part of T. 16 N., R. 8 E., 10 miles east of Riceville, is Kibbey, a small settlement near which gypsum was mnined about 1899. The mine was near Charles Beckstrom's farm. A section measured by C. F. Bowen at this place is as follows:

Section of gypsum at Kibbey, Mont.

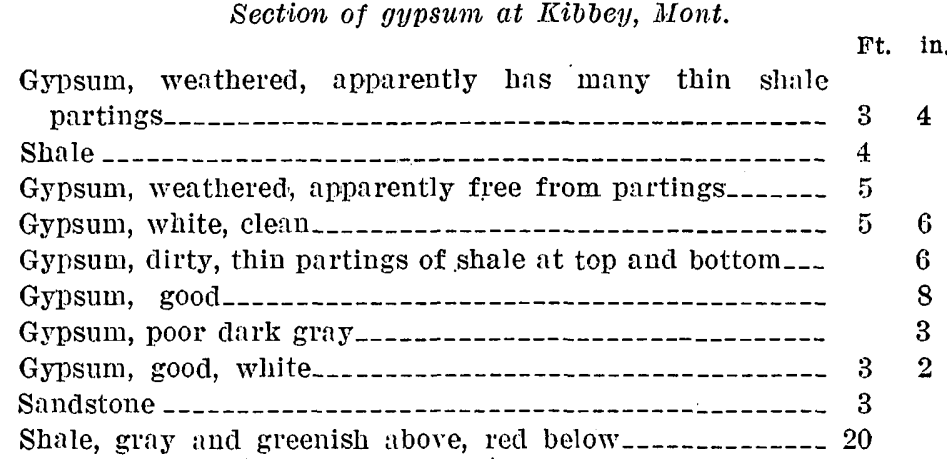

About 1,000 feet southwest of this mine the upper beds of the Madison limestone are exposed, striking east and dipping $5^{\circ}$ north. The gypsum, which is 100 feet stratigraphically above the limestone, is exposed for at least half a mile to the east.

In 1898-99 gypsum was quarried about a mile west of Kibbey and milled at Monarch, but the plant was burned in 1900 and operations were discontinued.

There is undoubtedly a large body of good gypsum in the vicinity of Kibbey, but it is several miles from a railroad. It occurs a short distance above the top of the Madison limestone, and 500 to 700 feet stratigraphically below the bed at Riceville, popular belief to the contrary notwithstanding.

The next reported occurrence of gypsum is 12 miles east of Kibbey and 7 miles south of Geyser, on Tree Creek. No data are at hand concerning the thickness and correlation of the bed, and it is presumed that this is only one of the many exposures of gypsum along the north side of the Little Belt Mountains. 
FERGUS COUNTY.

Gypsum occurs in Fergus County alongt the north side of the Little Belt Mountains, around the Big Snowy Mountains, encircling a small dome at Hanover and probably in other structural domes. No information is at hand concerning deposits west of the Great Northern Railway in this county.

Big Snowy Mountains.-The gypsum-bearing formations completely encircle the Big Snowy Mountains and the gypsum is said to be pure and in a thick bed. Several places are reported by O. W. Freeman, as follows: ${ }^{1}$

Pure beds of gypsum over 20 feet in thickness occur in the foothills of the Big Snowy Mountains, as on the East Fork of Spring Creek and near Irene, on the south side of the Snowies. A small amount of pure-white gypsum has been produced in the foothills southeast of Moore. The gypsum found on the southwest side of the Snowies is exceptionally white and pure and, being found only a few miles from the railroad, might be utilized at a profit. Quantities of excellent gypsum in beds 20 to 30 feet thick occur on Alaska bench, east of the Snowies and near the $\mathrm{N}$ ranch, northwest of Tyler.

It is reported that a thick bed of gypsum outcrops extensively 2 miles south of Forest Grove, which is on a branch of the Chicago, Milwaukee \& St. Paul Railway east of Lewistown.

Heath.-C. F. Bowen, of the United States Geological Survey, in 1916 examined a bed which outcrops near Heath, a post office 8 miles southeast of Lewistown, in a coulee in the SW. $\frac{1}{4}$ sec. 1, T. 14 N., R. 19 E., and in a railroad cut in the NW. $\frac{1}{4}$ sec. 12 . (See Pl. XVIII, C.) He reports that the United States Gypsum Co. has prospected the bed by eight drill holes, six of which penetrated 13 to 14 feet of gypsum. At two holes on a slope where a thinner deposit was found the top of the bed probably is eroded. The lower 2 feet of the bed, as seen by Mr. Bowen at a prospect, is pebbly or crushed and interlàminated with thin films of clayey and sandy material. This stratum is overlain by 3 or 4 inches of shale, above which is the main gypsum ledge, about 8 feet thick, consisting of clean white gypsum, apparently of good quality. As it has been proved to underlie several hundred acres, and is directly on the railroad, it should furnish ample material for commercial development. The remainder or upper part of the deposit is apparently somewhat dirty, but prospecting had not gone far enough to determine whether the impurity is inherent in the gypsum or is due to weathering and infiltration of sandy material. Near the top of the deposit there is a shale parting about 1 foot thick.

The United States Gypsum Co. has leased 300 acres of land in secs. 1 and 2, T. 14 N., R. 19 E., near Heath, and is preparing to

${ }^{1}$ Freeman, 0. W., Gypsum and lime industry in central Montana : Min. and Eng. World, vol. 45, pp. 663-664, 1916. 
erect a plant for mining gypsum and making wall plaster and other gypsum products.

Mr. W. V. Shoemaker, superintendent for the company, furnished the accompanying sections, which were measured on adjacent property.

Sections of gypsum at Heath, Mont.

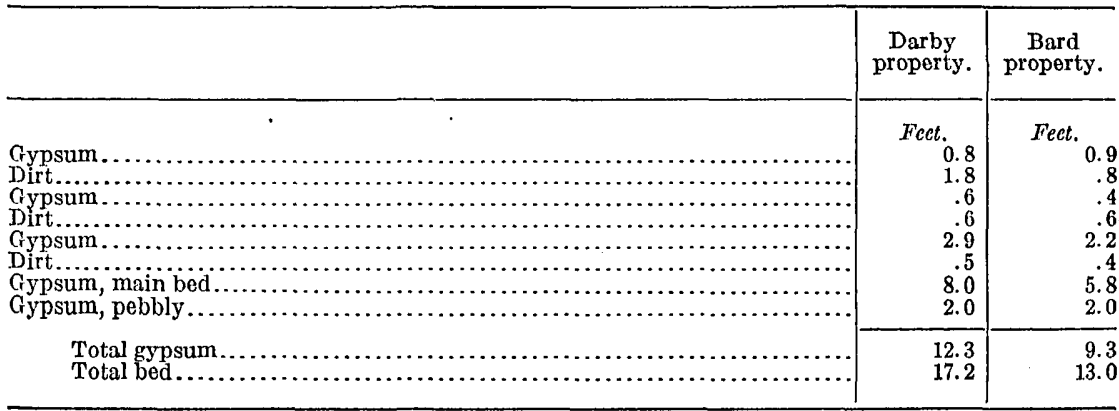

The bed dips to the northwest at a low angle except along the county road, where the dip is $15^{\circ}$. 'This gypsum bed is in the Ellis formation of Jurassic age, and it is believed that the other occurrences of gypsum around the Big Snowy Mountains are of the same age.

Hanover.-On the north side of Big Snowy Creek, in the foothills of South Moccasin Mountains, 8 miles northwest of Lewistown, there is a physiographic eminence more or less detached from the main mountain uplift. It is located in secs. 22 and 27, T. 16 N., R. 17 E., at a railroad siding called Hanover. This topographic feature is a structural dome, as shown by Calvert's map ${ }^{1}$ of the Lewistown coal field or Judith Basin, as the area commonly is called. Rocks of the Morrison (Cretaceous?) and Ellis formations encircle the dome and dip away from it in all directions. The Carboniferous rocks are exposed in the middle. Gypsum occurs at the top of the Carboniferous section and makes a roughly cireular outcrop. It is exposed at several places around the margin of the dome and at each exposure dips a way from the dome. At the south side of the dome near the railroad the strike curves strongly to the north, both east and west of the quarry that has been opened recently. The dip at the quarry is $21^{\circ} \mathrm{S}$. At a prospect on the northwest flank of the dome, where the strike is northeast, the dip is $18^{\circ} \mathrm{NW}$. The center of the dome, therefore, is not underlain by gypsum but is surrounded by gypsum. that dips away from it. There is some suggestion of faulting about 1,000 feet northwest of the quarry.

${ }^{1}$ Calvert, W. R., Geology of the Lewistown coal fleld, Mont. : U. S. Geol. Survey Bull. 390, pl. 1, 1909 . 
The Hanover Gypsum Co., which owned several hundred acres on this dome, opened a mine and quarry and built a mill. The making of plaster was begun in the summer of 1916. After a few days' operation the property was sold to the Three Forks Portland Cement Co., which has continued to operate it.

Mr. C. F. Bowen visited Hanover in September, 1916, and reports that the gypsum bed seems to be constant in thickness. Two exposures about half a mile northwest of the mine show 6 feet of good clean gypsum. He measured the following section at the quarry and tunnel northeast of the mill:

Section of gypsum deposit at Hanover, Mont.

Gypsum, with lenses of shattered limestome---_---.-.---

Limestone, thin bedded, dark

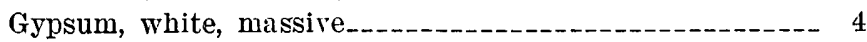

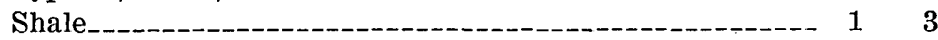

Gypsum_-_. 9

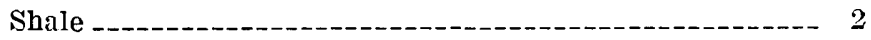

Gypsum, white; variable thickness_._._._._......-.- 1

Shale, gray, streaked with gypsum; variable thickness_-_- 1

Gypsum, white to gray, massive

Shale, black, indurated, seamed with gypsum_...--_-_-- 2

Gypsum, thickness not known.

The bottom bed has not been explored. As the upper bed is either at the surface or under light cover it can be quarried. The 7 -foot bed will be mined. Under these conditions rock can be taken from the quarry in summer and from the mine in winter or inclement weather. The quarry and mine are about 1,000 feet from the mill. Rock is moved to the mill by gravity on a small tramroad. It is broken by jaw and gyratory crushers in a building separated from the main mill. An underground conveyor carries the crushed gypsum from storage bins in the crusher building to a rotary drier in the mill. After passing over this drier, it goes through the usual revolving cylindrical drier, about 40 feet long. The dry rock is pulverized in a Raymond mill before calcining.

\section{JEFFERSON COUNTY.}

A small deposit of rock gypsum has been developed in Jefferson Canyon at Cavern, just east of Lime Spur, in a gulch a few hundred yards north of Jefferson River. The area is very small and much faulted. The gypsum is quarried and hauled down grade to loading bins at a railroad siding. The Three Forks Portland Cement Co. uses the gypsum quarried here in making cement at Trident. Because of the excessive folding and faulting the stratigraphic position of the deposit is difficult to determine, and the age of the gypsum is not known definitely. 


\section{CARBON COUNTY.}

A gypsum field that has been little explored extends from Bridger Canyon in a southeasterly direction into Wyoming. A plaster mill 8 miles southeast of Bridger operated on a gypsum bed 10 to 12 feet thick, but this mill has been idle for 10 years or more. The following data are furnished by J. P. Rowe, ${ }^{1}$ of the University of Montana:

A gypsum bed 15 to 20 feet thick outcrops $1 \frac{1}{2}$ miles from Bowler and is exposed for more than a mile. Another locality is east of Bridger and 4 to 5 miles north of Bowler. Here a 20 -foot bed increases to 50 feet farther north and 3 miles north of the first outcrop has thinned to 15 feet. This place is $4 \frac{1}{2}$ miles from Crockett and may be over the line in Big Horn County. The bed strikes north and dips west. The gypsum is of Triassic age (Chugwater formation).

BIG HORN COUNTT.

In the Red Valley, west of Lodge Grass Creek, in the Crow Indian Reservation, the following section was measured by C. A. Fisher ${ }^{2}$

Section of Chugwater formation west of Lodge Grass Creek, Mont.

Feet.

Red sandstone (overlain by Sundance formation) _-_.-.-.-.-- 60

Gypsum - -

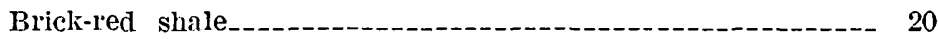

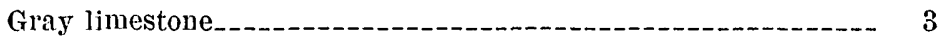

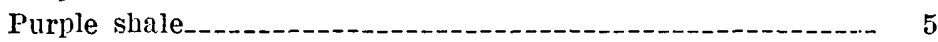

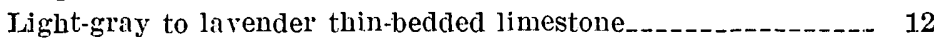

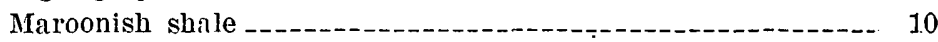

White limestone, thin bedded at base, massive above_......-.- 16

Purplish shale _-

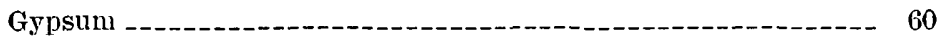

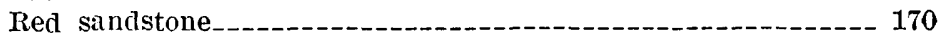

Gray and red laminated sandstone, 6 to 10 inches_...-_...-..- 6

Red sandstone._._.-.-_- 150

Gypsum_-_._-_._- 50

Porous purple limestone-_-_- 4

Red shale -..--- 30

Purple thin-bedded limestone (Minneliahta) -.---.-- 2

Concealed (probably red shale)

652

These three beds of gypsum, 6, 60, and 50 feet thick, are at the north end of the Big Horn Mountains and illustrate the abundance of gypsum that encircles the range. They are 15 to 20 miles from a railiroad and have not been developed.

\footnotetext{
${ }^{1}$ Rowe, J. P., Montana gypsum deposits: Mines and Mincrals, vol. 28, i. 59, 1907.

2 Darton, N. H., Geology of the Big Horn Mountains : U. S. Geol. Survey Prof. Paper 51, p. $38,1906$.
} 


\section{MADISON COUNTY.}

The following notes are furnished by D. D. Condit, of the United States Geological Survey. Between Cabin and Beaver creeks, small tributaries of Madison River, in or near sec. 10, T. 11 S., R. 3 E., which is about 10 miles east of Lyon, there is about 10 feet of gypsum in the Dinwoody formation. The geologic position of this deposit is just below the "Red Beds" (Chugwater formation) and just over the Phosphoria formation.

About 12 miles west of Lyon in the NW. $\frac{1}{4}$ sec. 27, T. 10 S.; R. 2 W., a bed of gypsum 10 to 20 feet thick is exposed along a wood road. This locality is on the head of Trail Creek at the summit of the Gravelly Range, which is the southern continuation of the Tobaccoroot Mountains. The gypsum is above the "Red Beds" and is thought to be in the Ellis formation.

\section{OTHER LOCALITIES.}

At Hunters Hot Springs, on the north bank of Yellowstone River, about 20 miles east of Livingston, the hot waters are depositing gypsum, and the old hot spring fissures are filled with a mass of gypsum and stilbite. Weed ${ }^{1}$ says that the gypsum occurs in veins from 1 to 5 feet wide. The material has not been utilized.

Besides the occurrences described above, gypsum is found in the form of selenite crystals in certain Cretaceous strata in the counties east of the Rockies. The crystals occur singly, in clusters and rosettes, and on weathering out from the shale in which they originate are found scattered on the surface. They are not known to be sufficiently abundant at any locality to be of commercial value.

1 Weed, W. H., Gypsum veins and waters of Hunters Hot Springs, Mont. : U. S. Geol. Survey Bull. 260, pp. 601-604, 1905. 


\section{NEVADA.}

By J. C. Jones.

\section{CHARACTER, EXTENT, AND DEVELOPMENT.}

Four types of gypsum deposits are known to occur in Nevada(1) beds or lenses of rock gypsum interstratified with sedimentary rocks of marine origin ranging in age from Pennsylvanian to Triassic; (2) thin beds and seams in lacustrine deposits of Tertiary age; (3) small seams and replacements in mineralized areas chiefly in the altered andesites of Tertiary age; and (4) surface or gypsito deposits resulting from the erosion and solution of the other types. Excepting a single gypsite deposit, only the deposits of rock gypsum are extensive enough to be utilized.

The deposits of rock gypsum occur in two widely separated areas or provinces, in western Nevada and in the extreme southern portion of the State. The western province includes the deposits near Lovelock and Table Mountain, in southern Humboldt County; near: Gerlach, in central. Washoe County; at Mound Houses in Ormsby County; at Ludwig, in Lyon County; and near Hawthorne, in Mineral County. These deposits are all of Triassic age and are large masses or beds of coarsely crystalline rock gypsum, usually dazzling white in color, most of which have been more or less metamorphosed and recrystallized by a later intrusion of granodiorite.

The southern group is confined to Clark and southern Lincoln counties and includes the deposits near Arden and those in the mountains in the vicinity of Moapa and Logan. The Arden and Galt deposits are Pennsylvanian in age, but the others in the group inay be somewhat younger. The gypsum is massive and granular and varies in color from white to red. Aside from such segregation and recrystallization as was developed incident to the folding and faulting during the formation of the mountain ranges the gypsum has not been materially altered since its deposition.

In recent years considerable search for suitable deposits of gypsum has been made throughout the State, but as far as known none has been found outside of the two general areas mentioned. Though rocks of Carboniferous age are widely distributed in the eastern, central, and southern parts of the State gypsum occurs in them only at the extreme south. The Triassic rocks are mainly found in the western part of the State and to some extent in the extreme south. Gypsum in large masses or lenses is commonly associated with them. 


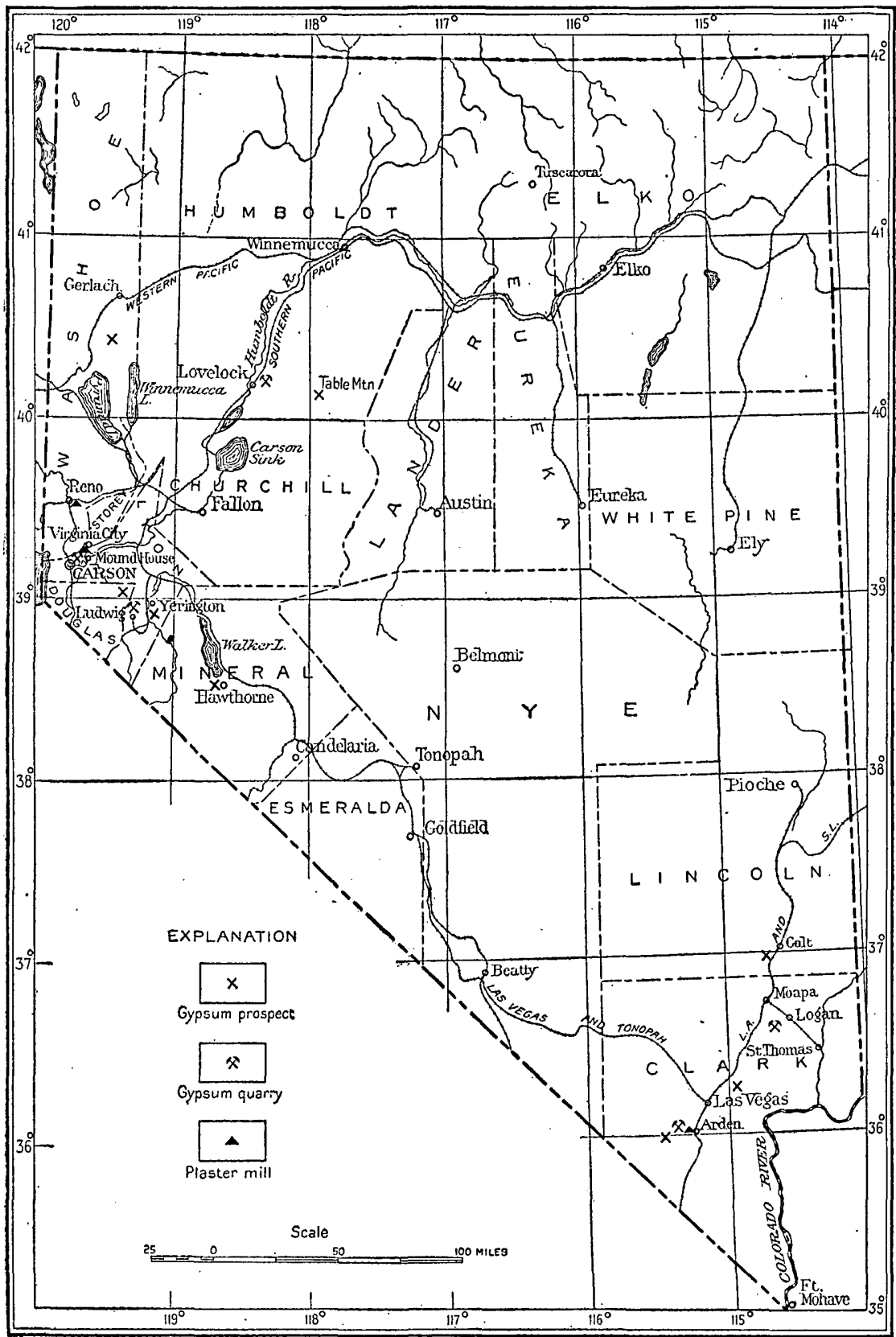

Figure 9.-Map showing location of gypsum deposits in Nevada. 
Scattered throughout Nevada, generally in the foothills and lower ranges, are large areas of unconsolidated clays, tuffs, and other lacustrine sediments characterized by an abundance of diatomaceous earth. These sediments are largely of Miocene age and in a former report ${ }^{1}$ on the gypsum deposits of Nevada are said to contain beds of gypsum, both as`white granular layers and as selenite. None of these deposits has been worked, and many of the reported gypsum deposits have proved to be diatomaceous earth or volcanic tuff locally bearing thin stringers of selenite.

Widely distributed through the State are large areas of mineral-. ized and altered rocks in which sulphides are very abundant. Through the action of the atmosphere and surface waters the sulphides are oxidized, forming sulphates and sulphuric acid, which are carried in solution through the rocks. These react with the calcium minerals, in particular calcite, that may be present and form calcium sulphate. Gypsum thus formed may occur as isolated crystals, thin seams or veins of selenite, or in the limestones it may form fairly large masses through replacement. The veins and disseminated crystals are especially common in the altered andesites that are abundant in most of the mining camps in Nevada. Owing to the small size, deposits of gypsum formed in this way are of no value at present.

During the weathering of gypsum deposits more or less of the gypsum is removed, chiefly in solution. Owing to the generally dry climate of Nevada, the surface waters carrying the gypsum in solution usually evaporate near the original deposits and form gypsum earth or gypsite. Some of these secondary deposits are large enough for profitable working, and for' a number of years such deposits have been utilized near Mound House. Elsewhere the deposits are too small or contain too much foreign material to be of value.

At the time when the previous report was published, in 1904, two quarries, located at Lovelocks and Mound House, had been opened, and one mill, located at Empire, near Carson, was in operation. ${ }^{2}$ Since then quarries have been opened at Ludwig, Arden, near Overton, and Dike, and mills have been established at Reno, Arden, and two at Mound House. In addition several other deposits have been prospected in the southern part of the State and near Gerlach. In 1918 only the mills at Mound House and at Arden were in operation. Considerable gypsum is shipped direct from the quarries to mills in California. The combined capacity of the mills in operation is approximately 500 tons of plaster daily. By its high quality the manu-

${ }^{1}$ Louderback, G. D., Gypsum deposits in Nevada: U. S. Geol. Survey Bull. 223, p. 113, 1904.

Idem, pp. 112-118. 
factured product reaches a wide market. A large quantity of Nevada plaster was used at the Panama-Pacific International Exposition in San Francisco for making the staff with which the buildings were surfaced.

Owing to the comparatively small local demand and the expense of transportation and fuel, only those deposits which are favorably located near the railroads can be profitably developed under present conditions. The high quality of the products offsets to a large degree the higher cost of production and enables the Nevada mills to compete successfully in the markets along the Pacific coast. There is an opportunity for the Nevada quarries in the small but growing demand for gypsum to apply to the thousands of acres of lands high in alkali. Gypsum neutralizes the alkali and makes the land cultivable.

In the present study of the gypsum deposits the quarries at Lovelock, Mound House, Ludwig, and Arden were visited, and information regarding the deposits near Gerlach, Overton, Dike, and elsewhere was given by Gov. Emmett D. Boyle, E. Duryee, and others. The writer gratefully acknowledges the courteous aid given him by Mr. Gorin, superintendent of the Arden Plaster Co.; Mr. McKenzie, foreman of the Pacific Portland Cement Co., whose quarries are at Mound House; and Mr. Orem, superintendent of the Nevada Douglas Copper Co., which owns the deposit at Ludwig.

The known deposits of gypsum in Nevada are large, some are of exceptional purity, and the supply is so abundant that it will suffice for many years to come.

\section{GEOLOGY.}

\section{DEPOSITS IN WESTERN NEVADA.}

The gypsum deposits in western Nevada have many features in common that indicate a similar origin. All are in the form of large lenses or beds intercalated in massive limestones of Triassic age; all have been intruded by or are in close proximity to the late Mesozoic granodiorite; and where the development has been extensive they are seen to grade into masses of coarsely crystalline anhydrite, from which they have been derived through hydration.

The Triassic rocks of this province lie in an area roughly defined as lying west of a line extending south from Battle Mountain through Austin and Silver Peak and south of an east and west line running a few miles north of Winnemucca and Gerlach. The typical geologic section of the area is in the West Humboldt Mountains near Star Peak. J. P. Smith ${ }^{1}$ has recently described this section as follows :

1 Smith, J. P., The Middle Triassic marine Invertebrate faunas of North America: U. S. Geol. Survey Prof. Paper 83, p. 8, 1914. 
Geologic section of the West Humboldt Range, Nev.

\begin{tabular}{|c|c|c|}
\hline \multicolumn{2}{|l|}{$\begin{array}{l}\text { Lower Jurassic } \\
\text { (Lias). }\end{array}$} & Carries Arietites. \\
\hline \multirow{4}{*}{ Upper Triassic. } & \multirow{5}{*}{ 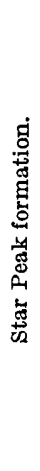 } & $\begin{array}{l}\text { Pseudomonotis subcircularis zone (slates, with Rhabdoceras and Halorites). } \\
\text { Thickness about } 900 \text { feet. }\end{array}$ \\
\hline & & Siliceous and tuffaceous beds, without fossils. Thickness unknown. \\
\hline & & $\begin{array}{l}\text { Massive limestones, probably corresporiding to the Hosselkus (Upper Triassic) } \\
\text { limestone of the California section. Thickness about } 2,000 \text { feet. }\end{array}$ \\
\hline & & $\begin{array}{l}\text { Siliceous and tuffaceous beds without fossils, partly rhyolites, and other vol- } \\
\text { canic flows. Thickness } 1,000 \text { to } 2,000 \text { feot. }\end{array}$ \\
\hline Middle Triassic. & & $\begin{array}{l}\text { Daonella zono. Slaty limestones and tuff beds, hard at the top and grading over } \\
\text { into shaly limestones and calcareous shales at the bottom. Thickness } 1,000 \\
\text { to } 1,500 \text { feet. The lower } 200 \text { feet contain nearly all the fossils, which belong to } \\
\text { the fauna of Ceratites trinodosus. }\end{array}$ \\
\hline \multicolumn{2}{|c|}{ Koipato formation. } & $\begin{array}{l}\text { Slliceous beds, tuffs, graywackes, and igneous rocks of unknown thickness. } \\
\text { Without fossils. }\end{array}$ \\
\hline
\end{tabular}

Though this general succession probably holds good throughout the province, the local sections are so meager and complicated by faulting and so little detailed work has been done that the correlation of the different gypsum deposits can only be suggested. The deposits near Lovelock are in the southern end of the West Humboldt Range, where the Triassic rocks seem to be confined to the upper half of the Star Peak formation. Louderback ${ }^{1}$ says that the fossils found at Muttleberry Canyon belong to the Pseudomonotis zone and that the overlying Jurassic rocks appear at the summit. The gypsum outcrops only a short distance from the summit but is separated from it by a westward-dipping normal fault. Knowledge of the general structure of the range suggests that the throw of the fault is not over 1,500 feet and that the gypsum lies in the massive limestone below the Pseudomonotis zone.

Fossils were not found in the series containing the gypsum at Ludwig, though the rocks resemble those in the Star Peak section just below the Pseudomonotis zone. On the other side of the Smith Valley Range, near the Mason Valley mine, two imperfectly preserved fossils belonging. to the Daonella zone of the Star Peak formation were found in a slaty limestone. Here a number of faults interrupt the section, and the Triassic rocks are mainly massive white and black limestones and meta-anclesite. As these rocks are quite different from those exposed at Ludwig, the suggestion can merely be made that the gypsum is contemporaneous with that near Lovelock.

${ }^{1}$ Louderback, G. D., Basin-range structure of the Fumboldt region: Geol. Soc. America Bull,, vol. 15, p. 295, 1904. 
The sections exposed in the other areas are too incomplete to make any definite correlation, but if the constant occurrence of the gypsum immediately below the dark brecciated limestone in all the localities in this province can be safely used for correlation, the deposits are contemporaneous and are Upper Triassic in age.

\section{DEPOSITS IN SOUTHERN NEVADA.}

In the absence of fossils no definite statement as to the age of these deposits can be made. Spurr ${ }^{1}$ in describing the geology of the Muddy Range says that in the vicinity of the gypsum deposits the Carboniferous limestone is brought by faulting into contact with red Mesozoic sandstones, although in places they are apparently conformable. From the fossils collected Stanton thought the red beds might be as old as the Pèrmian and certainly not younger than the Triassic. The limestone is Pennsylvanian in age. If, as appears probable, the gypsum belongs with the limestones rather than the sandstone, it is doubtless of the same age as the gypsum in the Spring Mountain Range. As the gypsum in the Galt deposit, to the north, is also in the Pennsylvanian series ${ }^{2}$ it would seem probable that all the deposits in the southern province are of the same age, although there is a possibility that those in the Muddy Range are somewhat younger.

\section{ORIGIN OF THE DEPOSITS.}

The deposits of rock gypsum in Nevada, as has been shown, occur as lenses and irregular masses interbedded with limestone and shale of marine origin. In all the deposits that have been extensively developed more or less anhydrite is present, and in the deposits of the western province the gypsum has had its immediate origin through the hydration of massive anhydrite by the action of surface waters. Further, all the deposits in this province have been intruded by or are in close proximity to granodiorite later in age than the gypsum. In at least one deposit, that at Mound House, typical contact-metamorphic minerals are present in the gypsum.

Some years ago, before the presence of the anhydrite was known, the rather constant association of the gypsum with near-by deposits of sulphides in the western province led to the suggestion that the gypsum originated through the replacement of limestone by the action of acid waters formed in the oxidation of the sulphides in the neighboring ore bodies. This view was supported by the presence of limestone in the gypsum, by the rounded and corroded grains of calcite seen in thin sections of the gypsum, and by the irregular outlines of the deposits. That this action takes place in the vicinity of the

\footnotetext{
1 Spurr, J. E., Descriptive geology of Nevada south of the fortieth parallel and adjacent portions of California : U. S. Geol. Survey Bull. 208, p. 137, 1903.

2 Idem, pp. 148-151.
} 
ore bodies is shown by the beautiful crystals of selenite found in the Ludwig mine in the midst of the oxidized ore.

As many of the gypsum deposits are much larger than the ore deposits from which they were supposed to have originated; are conformable with the sedimentary series of which they are a part; are usually separated from the ore bodies by a hundred feet or more of limestone through which the solutions must pass and in which no trace of gypsum can be found; and as the gypsum contains no copper minerals that would have been deposited from the solutions and grades with depth into anhydrite, whose origin from cold surface solutions would be difficult to understand-this hypothesis is quite improbable.

From the constant association of the gypsum with marine sediments it is almost certain that the gypsum was formed by evaporation of the oceanic waters that deposited the limestones and shales found interbedded with it. In a study of the deposits at the Ludwig mine and at Mound House Rogers ${ }^{1}$ came to the conclusion that the original deposits were largely if not altogether anhydrite, which was recrystallized at the time of the intrusion of the granodiorite. In commenting on Rogers's paper Jones ${ }^{2}$ suggested that the original deposits were probably gypsum that had been dehydrated and metamorphosed into anhydrite through the action of the intruding granodiorite, citing the intimate interbedding of thin limestone and gyp' a sum layers and the known absence of saline deposits as indicating that the concentration of the water did not progress far enough to cause the deposition of anhydrite. Van't Hoff and his associates have shown that when sea water is evaporated at a temperature of $25^{\circ} \mathrm{C}$. the calcium sulphate is deposited as gypsum until the solution is saturated with sodium chloride and then is deposited as anhydrite'along with the salt. At $60^{\circ} \mathrm{C}$., however, only anhydrite is formed, and though this may seem to be a much higher temperature than is reached ordinarily in sea water, yet the saline waters of some inclosed basins have still higher temperatures in the layers near the surface. In many deposits elsewhere a layer of gypsum lies under anhydrite and. salt, suggesting that these deposits were formed at the lower temperature mentioned. On the other hand, deposits are common with anhydrite and gypsum intermingled as at Arden. The formation of these deposits is possibly explained by the work of Van't Hoff, who has shown that the hemihydrate may

\footnotetext{
1 Rogers, A. F., The occurrence and origin of gypsum and anhydrite at the Ludwig mine, Lyon County, Nev. : Econ. Geology, vol. 7, pp. 185-189, 1912. Notes on the occurrence of anhydrite in the United States: School of Mines Quart., vol. 36, pp. 123-142, 1915.

2 Jones, J. C., The origin of the anhydrite at the Ludwig mine, Lyon County, Nev.: Econ. Geology, vol. 7, pp. 400-402, 1912.
} 
be formed in saline solutions at somewhat lower temperatures than anhydrite. The hemihydrate, which is never found in nature, is very unstable and quickly changes to a mixture of gypsum and anhydrite.

The evidence disclosing the effect of intrusions on gypsum is meager. It is well known that when gypsum is heated it first loses part of its water, changing to the hemihydrate or plaster of Paris, and if the heating be continued all the water is lost, and the product has the same composition as anhydrite. There is some difference of opinion as to whether this product is the same as anhydrite, as it has been observed that the crystal form of the product is different from that of anhydrite. Van't Hoff has shown, however, that in dehydrating gypsum an intermediate form of the anhydrous sulphate, which he called "soluble anhydrite," is first produced which slowly changes over to anhydrite. As far as experiment can show, then, it is possible that the heat attendant upon the intrusion of the granodiorite, which was high enough to cause the development of tourmaline and phlogopite in the gypsum at Mound House, could have dehydrated whatever gypsum was present in the original deposits and changed it to anhydrite.

As the temperature and salinity of the waters that formed the original deposits are only conjectural, the question whether either gypsum or anhydrite alone or a mixture of the two composed the original masses must remain open. We can safely say, however, that the deposits of rock gypsum in Nevada were precipitated either in the form of gypsum or anhydrite or as a mixture of the two from evaporating sea waters along with the limestones and shales with which they are interbedded, and that in the western province they were metamorphosed and recrystallized and possibly dehydrated at the time of the intrusion of the granodiorite. Further, the intrusion of the granodiorite caused more or less segregation of the gypsum and partial replacement of the limestone layers in the gypsum. Faulting, which has continued to tho present time, has elevated certain blocks of the gypsum-bearing strata, and erosion has exposed them in the present mountain ranges. The solvent action of the surface waters has continued the replacement of the limestones in the gypsum and has hydrated the anhydrite to a depth of 200 to 400 feet.

\section{IOCALITIES.}

\section{WESTERN NEVADA.}

\section{LOVELOCE.}

The deposits of gypsum near Lovelock are in the West Humboldt Mountains east of the town. This range extends in a southerly direction from Imlay to the Carson Sink, a distance of over 60 miles. 
Near the center the range is divided into two parts by the deep transverse valley of Cole Canyon. The northern half of the range is sometimes known as the Star Peak Range and tho southern half as the Lake Range. About 10 miles south of Cole Canyon is Muttleberry Canyon, a steep-walled valley that crosses the Lake Range. Lovelock is 6 miles a little north of west of the mouth of Muttleberry Canyon. The gypsum outcrops at intervals in the area immediately to the north of the canyon.

In this area the Lake Range is largely composed of Triassic limestones, slates, and quartzites, and Lower Jurassic shales. These rocks are intruded by granodiorite, which is probably contemporaneous with the late Mesozoic batholith of the Sierra Nevada. Tertiary rhyolites, andesites, and basalts also are present, having flowed over the eroded surface of the older rocks.

The Mesozoic rocks are folded into a series of rather open anticlines and synclines, the axes of the folds striking a few degrees to the east of the trend of the range. As the Tertiary volcanic rocks are not warped the folding probably took place at about the time of the intrusion of the granodiorite. The present form of the mountain range is due to faulting, which has continued to the present time and has broken the mountain mass into a number of large blocks. The major fault lies along the western base of the range.

Louderback ${ }^{1}$ has thus described the structure of the mountain range in the vicinity of the gypsum deposits: At Muttleberry Canyon the sedimentary rocks are folded in an anticline, which, as the axes of the folds are oblique to the trend of the range, is succeeded to the north by a series of synclines and anticlines. Superimposed on these folds are several faults which strike both parallel and transverse to the trend of the range. As is shown by the outcrops of the gypsum, the general effect of the transverse faults has been to offset the strata progressively to the northwest.

The gypsum occurs as a large bed or lens intercalated in the Triassic limestone. It ranges in thickness from 100 to 200 feet, and its pure white outcrops are a striking feature that may be seen for many miles. The southern outcrop of the gypsum lies a short distance north of Muttleberry Canyon and a little east of the crest of the range. About 100 feet of gypsum is exposed in a massive gray limestone that dips $20^{\circ} \mathrm{E}$. The bed of gypsum strikes parallel to the crest of the range and may be followed for about half a mile. A large fault parallel to the crest of the range marks the western boundary of the gypsum, and transverse faults terminate it at both the north and south.

${ }^{1}$ Louderback, G. D., Basin-range structure of the Humboldt region: Geol. Soc. America Bull., vol. 15, pp. 296-297, 1904. 
The other gypsum outcrops are all on the western face of the range. Owing to the structure they are progressively offset to the northwest and 2 miles north of Muttleberry Canyon are at the base of the range. The old quarry is at this point and as shown by Louderback $^{1}$ is on the crest of an anticline that gives the deposit an appearance of being unusually thick. The axis of the anticline strikes a few degrees east of north and pitches both north and south from this point. The gypsum is carried below the surface about a quarter of a mile north of the quarry by the pitch of the

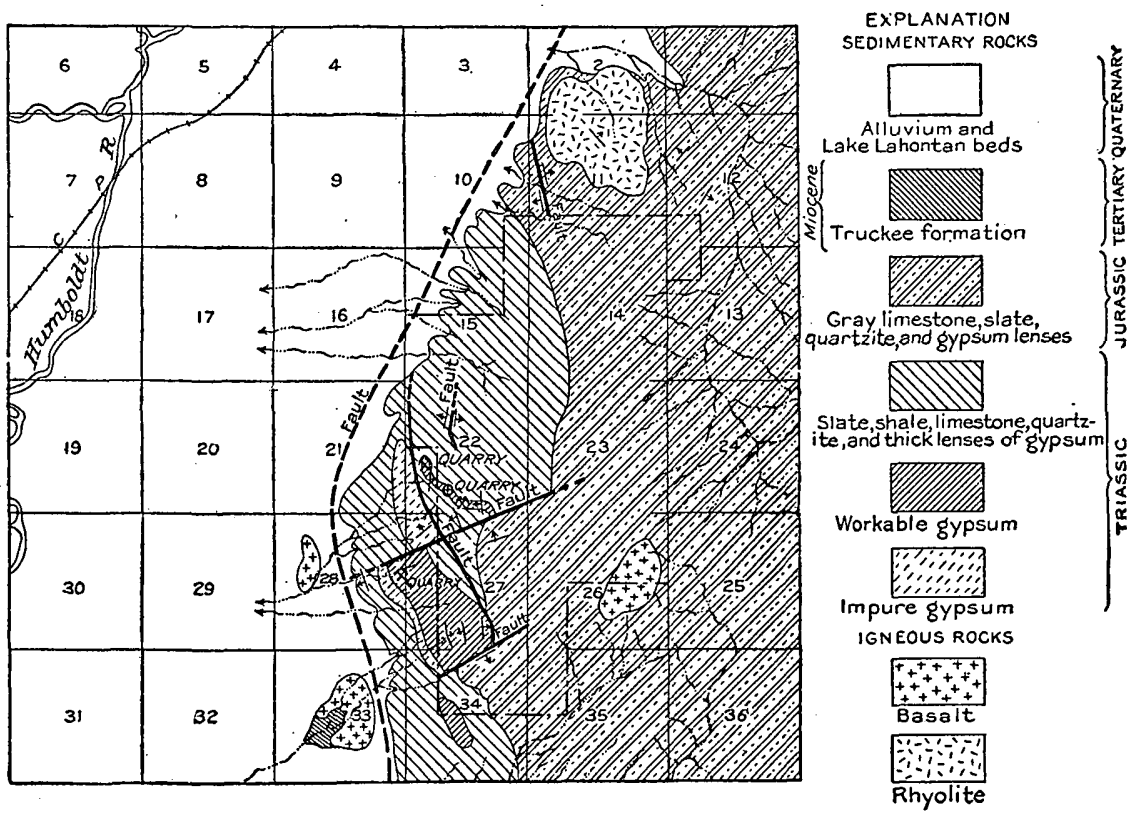

Figure 10.-Map showing geology of T. 27 N., R. 32 E., and location of old gypsum quarries near Lovelock, Nev. By L. J. Pepperberg. Furnished by courtesy of Southern Pacific Co.

axis of the anticline or is terminated by a transverse fault. Transverse faults have progressively. offset the gypsum so that the outcrops to the south appear to rise toward the crest of the range. 'See fig. 10.)

About two-thirds of a mile north of the quarry the gypsum again appears at the surface in a flat syncline that also pitches to the north. At the new quarry at the southern end of the syncline the gypsum outcrops on the side of a steep hill and runs northward, in two arms that finally disappear beneath the alluvial deposits of the valley at distances of half a mile and a mile, respectively.

The new quarry is a large open cut in the side of a steep buttress near the base of the range, about 6 miles east of Lovelock.

${ }^{1}$ Louderback, G. D., Gypsum deposits in Nevada: U. S. Geol. Survey Bull. 223, p. 115, 1904. 
The exposed face shows the gypsum to be intricately folded and plicated. This is well brought out by the many alternating thin white and bluish bands of the gypsum. Many of the bluish bands are thin beds of limestone intercalated in the gypsum. The limestone is usually broken into small angular blocks 2 to 3 inches in diameter separated by thin seams of pure-white granular calcite and gypsum 1 inch in greatest width. A short tunnel run into the face at the floor of the quarry intersects a limestone breccia, the contact with the gypsum above dipping $30^{\circ}$ toward the hill. Another tunnel 200 feet to the east starts at the contact of the gypsum and breccia, and the end of the tunnel, 50 feet from the portal, is entirely in the breccia. A 10 -foot raise at the end of the tunnel broke into a small cave lined with stalactites and rosettes of purewhite crystalline gypsum.

The gypsum was shipped for a time to the mill of the Western Gypsum Co. at Reno, but as the face of the quarry progressed into the hill the proportion of calcium carbonate became excessive, and the quarry has been idle for a number of years. The following section is exposed at the new quarry:

Section in gypsum quarry near Lovelock, Nev.

Limestone, hard, black, fine grained, and brecciated, with numerous transverse stringers of white calcite

Gypsum and limestone, white, thin-bedded in alternatiug layers, the limestone commonly fractured and recementerl by calcite and gypsum, most of the gypsum confined to the unper 200 feet

Limestone, gray to black, fine grained

Shales and sandstones, green and yellow, indurated, containing much pyrite in peifect small cubes; base covered 200

The gypsum contains many thin bands of bluish-white limestone which become more numerous toward the top and bottom until they form the greater part of the deposit. The gypsum has weathered to a white earthy deposit that has washed over the face of the hill and masks the limestone strata so that the outcrop appears to be a single thick bed of gypsum. As is shown at the quarry, the gypsum taken. into solution apparently replaces the calcite to some extent and assists in concealing the true nature of the deposit. Whether this is true of: all the gypsum in the vicinity can not be stated definitely, as there has been little development outside the two quarries, and it is possible that in the series there are thick beds of gypsum without an excess of limestone. As the gypsum taken into solution by the surface waters is largely deposited and concentrated as a network of veins and partial replacement of the limestone at the surface, the surface layers may be utilized in time. 
TABLE MOUNTAIN.

The deposit of gypsum at Table Mountain is located about 26 miles a little south of east of Lovelock, the mearest shipping point, and in the first mountain range east of the Lake Range. It is described by Louderback ${ }^{1}$ as a bed 100 to 200 feet thick about two-thirds of the way up the western slope of the mountain. The bed dips $40^{\circ} \mathrm{E}$. into the monntain, and its striking white outcrop extends for 2 miles along the face. It is underlain by a yellow to gray limestone and capped by a dark-colored brecciated limestone similar to that overlying the gypsum in the Lake Range. It is similar to the gypsum previously described and is of the same age, but it has never been dereloped because of its distance from the railroad and the high divide over which it must be hauled.

\section{GERLACH.}

At the western base of Luxor Peak, toward the northern end of the Truckee Range and about 10 miles south of Gerlach, in an area of a few square miles, limestones, schists, and gypsum of Triassic age are exposed in contact with granodiorite to the east. The beds are nearly vertieal and strike to the northeast somewhat obliquely to the trend of the range. The gypsum occurs in several large lenses, and as it is somewhat more resistant to weathering than the surrounding rocks, it forms low terraces 20 to 40 feet in height. On one of these terraces hot springs have built low cones of selenite as described by Hague. ${ }^{2}$ The gypsum lies between a white limestone and a dark calcareous schist. For the most part it is pure gypsum, containing beds of limestone and sandy layers. It is soft, massive, white, and crystalline. Drilling has shown that it passes into white coarsely crystalline anhydrite with depth, but more than a million tons of gypsum are available.

\section{MOUND HOUSE.}

South of Virginia City several irregular bodies of Triassic sedimentary rocks occur in the Virginia Range. Near Mound House one of these bodies, which is composed of limestones, gypsum, shales, and meta-andesites, forms an extended belt along the eastern slope near the crest of the range and extends southerly across Carson River into the ranges to the south. Fossils have not been found in this particular belt, but fragments of Daonella, a Triassic pelecypod characteristic of the lower part of the Star Peak formation, have been found in a similar belt south of Dayton, a few miles to the

${ }^{1}$ Louderback, G. D., Basin range structure of the Humboldt region: Geol. Soc: America Bull., vol. 15, p. 334, 1904.

2 Hague, Arnold, Descriptive geology : U. S. Geol. Expl. 40.th Par. Final Rept., vol. 2, pp. $808-809,1877$. 
east. At Mound House the sedimentary rocks have been intruded and somewhat metamorphosed by granodiorite, very similar to and probably of the same age as the late Mesozoic batholith of the Sierra Nevada, a few miles to the west.

About a mile west of Mound House there is a thick lens of gyp- sum that is interbedded with limestone. Quarries of the Pacific Portiand Cement Co. are located here, the gypsum being transported by aerial tram to the mill. on the Virginia \& Truckee Railway a short distance north of the station. There are several large open pits or quarries in the deposit, the largest being about 100 feet deep. About half a mile north is the Ragan quarry, located in a smaller deposit which has been developed but little. Several gypsite deposits formed from the rock gypsum lie to the east and furnish raw materiai for the Ragan mill, located a quarter of a mile east of the town on a branch of the Southern Pacific Railroad.

As described by Louderback ${ }^{1}$ the main deposit is a thick bed or lens approximately 350 feet.wide at the south end and thinning to only a few feet 700 feet north of the end. At the south the gypsum is abruptly cut off by granodiorite. On the east a nearly vertical fault brings the gypsum in contact with meta-andesite and on the west the gypsum lies on a yellowish soft granular limestone into which there is more or less gradation. About half a mile to the north, at the Ragan quarry, a thin bed of gypsum outcrops directly below a dark-bluish brecciated limestone cemented with white veins of calcite that has been replaced to some extent by gypsum. The gypsum and limestone dip at a high angle to the east at both quarries, and the sequence is the same as that near Lovelock.

In the southern quarries the gypsum is banded to some extent and the intricate plications and folds suggest the bedding of the deposits near Lovelock. The gypsum is massive, pure white, with bands somewhat darker and grayish, rather coarse grained and crystalline, the fractured surfaces showing many glistening cleavage faces. Small vertical slips with polished slickensided faces, parallel to the major fault on the east, are quite numerous in the upper parts of the deposit. These have been the channels of surface waters which have widened the fractures by solution and deposited more or less secondary selenite.

Many of the darker streaks and blotches owe their color to finely disseminated pyrite. In the lower levels of the main quarry there are a few darker masses that have the appearance of included boulders. The largest of these masses is 3 feet in diameter. They are somewhat harder than the surrounding gypsum, and thin sections show that they are composed of a fine-grained groundmass of

${ }^{1}$ Louderback, G. D., U. S. Geol. Survey Bull. 223, pp. 115-116, 1904. 
gypsum, containing crystals of a brown mica, probably phlogopite, tourmaline, rounded and corroded grains of pyrite, calcite, and anhydrite. As phlogopite and tourmaline are usually formed at high temperatures and in close relation to granitic intrusions, it is probable that these darker, harder masses were produced by sporadic replacement of the gypsum consequent upon the intrusion of the granodiorite.

Thin sections of the gypsum show that it is composed of gypsum crystals 1 to 5 millimeters in length.with perfect outlines embedded in a groundmass of smaller grains of gypsum with irregular interlocking outlines caused by the mutual interference of the individuals as they finished their growth. In both the larger crystals and the groundmass there are numerous minute elongated bubbles that are usually filled with a white claylike material that is so fine grained that it appears to be opaque. In places this impurity occurs in blotches in the groundmass. The bubbles are arranged parallel to the longer axes of the gypsum crystals, and as the best-developed cleavage is in the same direction many of the crystals resemble a grid. In addition to the gypsum there are fairly abundant rounded and corroded grains of calcite, suggesting a replacement of calcite by gypsum.

In gypsum from the lower levels of the main quarry there are fragments of anhydrite, the largest of them 2 or 3 millimeters in diameter. The development of gypsum along the cleavage cracks and about the rounded borders of the anhydrite indicates that much of the gypsum has originated from the hydration of the anhydrite. Drilling operations conducted some years ago are said to have determined that the gypsum graded into massive crystalline anhydrite within 200 feet from the bottom of the quarry.

\section{GYPSITE NEAR MOUND HOUSE.}

A broad alluvial apron slopes gently to the east from the ridge containing the massive gypsum. On this slope are six or more low concentric terraces spaced from a few hundred feet to a third of a mile apart. At the outer borders of the terraces and forming the greater part of their steep front are deposits of gypsite 5 to 15 feet in depth and several hundred feet in length. The main impurity in the gypsite consists of small pebbles that are easily removed by screening, leaving rather pure material that is used at the Ragan mill and was for a time shippèd to the mill at Reno.

The concentric arrangement of these deposits about the gypsum in the ridge back of them shows that they have been formed through the erosion and weathering of the gypsum. It is difficult to determine whether the gypsite has been carried in solution and de- 
posited through evaporation or has simply been washed down. It is probable that both processes have been effective. There is but little gypsite apparent in the intervals between the belts.

\section{IUDWIG.}

The deposit of gypsum at Ludwig is located at the base of the western slope of the Smith Valley Range. The range at this point is composed largely of limestone, slate, quartzite, and meta-andesite of Triassic age flanking on both sides the core of granodiorite which has intruded the sedimentary rocks. Tertiary rhyolites, tuff, and andesite occur in patches, and to the north and south these later volcanic rocks form much of the range. Although the Mesozoic rocks are folded, the present attitude of the range is due to a number of large faults both parallel and transverse to the range.

The sedimentary rocks strike a few degrees east of north at a slight angle with the course of the mountain range and dip about $55^{\circ}$ E. The section exposed in the immediate vicinity of the gypsum deposit of the Nevada Douglas Copper Co. is as follows:

Geologic section at Ludwig, Nev.

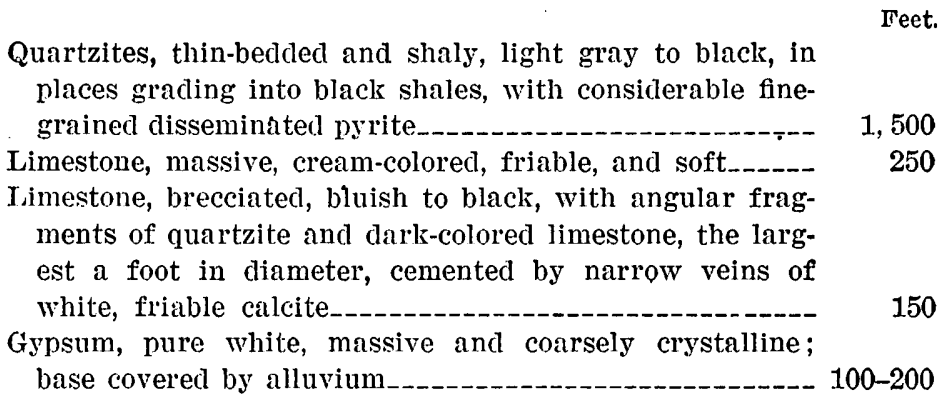

Although no fossils were found in the section measured, yet the finding of an imperfect ammonite and a Daonella in a shaly limestone near the Mason Valley mine, on the opposite side of the range, makes it quite probable that these beds are contemporaneous with the beds at Lovelock, as is suggested by the lithologic similarity.

The gypsum outcrops in an elongate area lying parallel to and 150 feet west of the gossan that marks the outcrop of the ore body of the Ludwig copper mine. The main gypsum outcrop extends several hundred feet beyond the northern end of the ore body and there turns somewhat to the east. - A second outcrop of the gypsum in the alluvium a couple of hundred feet to the south of the main outcrop indicates a total length of the gypsum body of 4,000 feet and a maximum width of 200 feet.

Near the center of the deposit and 100 yards northwest of the incline of the Ludwig mine is a quarry about 100 by 200 feet in 
area, with a maximum depth of 40 feet. This is the terminus of the Nevada Copper Belt Railroad, which connects with the Sorthern Pacific Railroad at Wabuska, 50 miles distant by rail. Until the purchase and closing down of the mill at Reno by the Pacific Portland Cement Co. the gypsum was shipped there for treatment.

The gypsum is a very pure, snow-white, coarsely crystalline rock gypsum, with many glistening cleavage faces showing on the fractured surfaces. There is no banding or other evidence of bedding. Where a few feet of alluvium covers the gypsum, the upper surface is undulatory and solution channels in the gypsum are filled with alluvium. .

On the 400-foot level of the Ludwig mine a 200 -foot crosscut has been driven west into the gypsum. The first 150 feet is in the brecciated limestone that forms the footwall of the ore body, the next 10 or 15 feet is in gypsum, and the remainder of the crosscut is in coarsely crystalline pare-white anhydrite. The boundary between gypsum and anhydrite is irregular and undulatory and dips abont $20^{\circ} \mathrm{E}$. At the contact the gypsum grades rather sharply into the anhydrite and has evidently been formed by the hydration of the anhydrite. The contact between the gypsum and the brecciated limestone is marked by a heavy gouge and fault breccia with slickensided walls. The breccia dips $55^{\circ} \mathrm{E}$., parallel to the general bedding of the overlying strata. The gouge probably marks a fault.along the bedding plane which has not materially altered the relative position of the gypsum and the limestone.

Thin sections show the anhydrite to be in large rectangular crystals with well-developed cleavage and with somewhat irregular outlines due to their mutual interference. Numerous minute inclusions of a translucent claylike material that is greenish by transmitted light are arranged parallel to the cleavage cracks and partly fill them. They occur also in irregular patches, giving the gypsum a cloudy appearance. The alteration to gypsum begins on the faces of the crystals and along the cleavage cracks. Under a high-power microscope exceedingly minute needles of gypsum may be seen penetrating the crystals of anhydrite.

Many of the gypsum crystals are 5 millimeters in diameter but do not show perfect outlines, as they are intimately intergrown along their borders. At Ludwig, as at Mound House, the gypsum contains many bubbles. The lack of any evidence of strain suggests that there has been little if any increase in volume during the change from anhydrite to gypsum.

Another deposit similar to the one at Ludwig is known just west of Buckskin, 4 miles west of Ludwig. Aside from sinking a few pits little has been done toward its development. 
About 5 miles southeast of Yerington a large lens of gypsum occurs in a white limestone that has been intruded by granodiorite. In appearance and mode of occurrence it is similar to the deposit at Iudwig and probably grades into anhydrite with depth.

\section{HAWTHORNE.}

Three miles west of Hawthorne a large body of interbedded gypsum and white limestone somewhat similar to the deposits at Lovelock outcrops on two steep rounded hills. It has been intruded by granodiorite and probably changes to anhydrite with depth.

\section{SOUTHERN NEVADA.}

By J. C. Jones and R. W. STone.

ARDEN.

The deposit near Arden is in the foothills of the Spring. Mountain Range about 15 miles southwest of. Las Vegas and about 5 miles west of the mill at Arden, a station on the Los Angeles \& Salt Lake Railroad. Gypsum is transported to the mill over a narrowgage railroad. The entire property was developed, owned, and operated by the Arden Plaster Co. until 1919, when it was purchased and its operation continued by the United States Gypsum Co., of Chicago, Ill.

An oval-shaped hill, approximately 500 feet high and three-quarters of a mile in length, the longer axis trending northwest, is underlain by gypsum. The following section is exposed at the southern end of the hill:

Geologic section exposed at Arden, Nev.

Feet.

Limestone, massive, dull gray, cherty, the chert in thin bands and lenses forming one-third of the mass; both chert and limestone with abundant poorly preserved fossils, the greater number being fragments of Productus and Athyris, bryozoans, and corals.

Shales, red and green, gypsiferous, with thin beds of gray limestone in places and including a bed of gypsum ranging from 25 to 80 feet in thickness

Limestone, gray massive with rare chert nodules; thickness unknown.

The strata dip gently to the east, and there probably is a fault along the eastern side of the hill. A transverse fault about a quarter of a mile northwest of the quarry apparently has cut off the gypsum.

The gypsum ranges from 20 to nearly 90 feet thick, the upper surface being very irregular, as shown in figure 11. 
The impression given is that an origival deposit about 90 feet thick was subjected to rapid and deep erosion, or solution, which cut channels across and in places nearly through it. This very irregular surface was engulfed in a mud flow which carried blocks of gypsum and partly consolidated mud beds. This mud filled the channels and worked down into narrow cracks in the gypsum. As the mud dried and hardened, water descending from it opened small solution cavities in the upper sur-

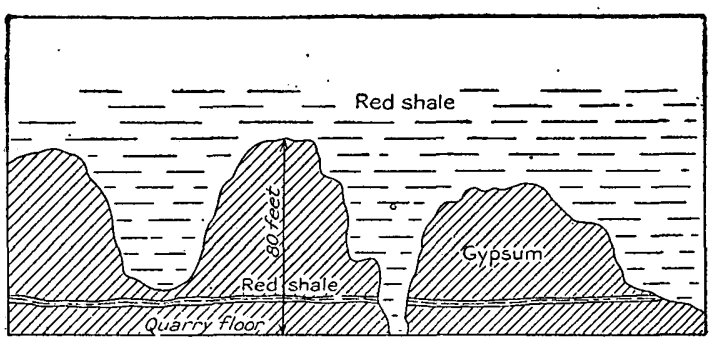

Figure 11.-Diagram of gypsum bed at entries of mine at Arden, Nev. face of the gypsum. The hardened mud or shale was strong enough to bridge the few inches of open space thus formed. The relation of the shale and gypsum near the east entry of the mine is shown in figure 12 .

In the face of the east quarry 3 feet of shale is interbedded in the gypsum. It contains numerous stringers of selenite of secondary origin.

After quarrying on the east and south side of the hill until the removal of overburden became excessive, the company drove several entries and opened large ochambers in the gypsum. Thousands of tons of gypsum were removed from an upper level, and work was begun and continued on a lower level as well. The whole body of gypsum is being removed except necessary pillars; but as the hard shale that fills the old channels penetrates nearly to the bottom of the gypsum and the bed contains here and there large masses of anhydrite, these impurities are left as pillars, thereby reducing the waste of gypsum. The pillars are 25 to 50 feet in diam-

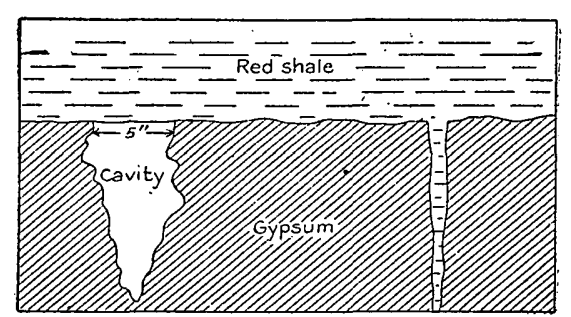

Figune 12.-Diagram showing relation of shale and gypsum in mine at Arden, Nev.

eter. The change from the masses of pure gypsum to the gypsiferous shale that fills the channels is abrupt, the boundary being nearly vertical and somewhat undulatory.

The gypsum is massive, pure, with a reddish tinge near the surface that changes to bluish underground, translucent, medium grained, and crystalline. Masses of anhydrite, the largest of which weigh 100 tons, are found in the midst of the gypsum. The anhydrite is similar in appearance to the gypsum and can be recognized by its greater hardness and tendency to break in rectangular blocks. 
Thin sections of the anhydrite show a network of slender crystals of anhydrite, the largest of which are 5 millimeters in length, and have a decided tendency to radiate from common centers. The interstices are filled with a mosaic of smaller rounded grains of anhydrite. The anhydrite is transparent and has well-developed rectangular cleavage, that parallel to the longer axes of the crystals being best. A few patches composed of very minute opaque dustlike particles of kaolin and iron oxide are arranged parallel to the longer axes of some of the larger crystals. In a few isolated areas gypsum has developed as single large crystals containing many elongate bubbles and inclusions arranged parallel to the principal cleavage. Minute fragments of anhydrite included in the gypsum crystals suggest that the gypsum has developed at the expense of the anhydrite. If this is so, the absence of veinlets of gypsum shows that the replacement is proceeding from isolated centers rather than along fractures.

Thin sections of the gypsum have little resemblance to the texture of the anhydrite from which it may have originated. Clear crystals of gypsum with very irregular outlines, intimately intergrown, are the chief constituent. The crystals contain numerous elongate bubbles, largely filled with a whitish pulverulent clay, which are usually ar-

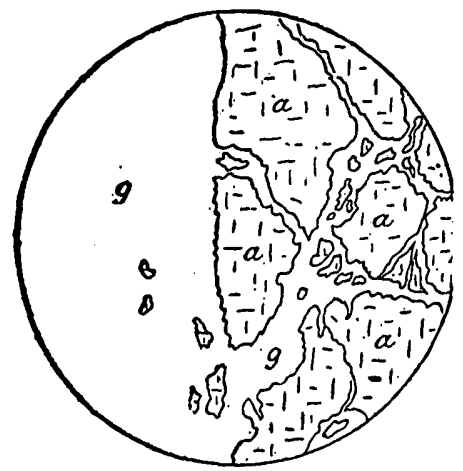

Eigure 13.-Gypsum and anhydrite from Arden, Nev., as scen under petrographic microscope. 's, Gypsum ; $a$, anbydrite. ranged parallel to the principal cleavage cracks. A few minute rounded fragments of anhydrite are scattered through the gypsum.

A hand specimen from this mine shows on the weathered face a sharp line between anhydrite on one side and gypsum on the other. Close examination reveals small stringers of gypsum penetrating the. anhydrite. A thin section cut from this specimen along the contact between the two minerals discloses only a few minute grains of anhydrite in the massive gypsum, but anastomosing veinlets of gypsum are abundant within the anhydrite on the other side of the contact. The width of the veinlets tends to become narrower as the distance from the contact increases. This evidence of the microscope and the shape and relation of the anhydrite masses to the gypsum bed are strongly conclusive that a large part of the gypsum at least is derived from the anhydrite. Fracturing of the anhydrite along the contact, as shown under the microscope, is evidently due to increase in volume by hydration. 
About a mile west of the quarry hill is a long ridge which shows a similar geologic section. The beds dip about $30^{\circ} \mathrm{SW}$. A quarry. was opened by the Arden Plaster Co. in this ridge, but work in it . has been discontinued. The gypsum thins down the dip and does not appear on the other side of the ridge. It is evidently the edge of a lens of gypsum, of which that in the detached hill is a part.

Gypsum occurs at several other points in the Spring Mountain Range near the Arden deposit, although none of the other deposits have been developed. Gilbert ${ }^{1}$ gives the following section, measured at Cottonwood Springs, 6 miles west of the Arden quarry:

Section of Carboniferous strata in the Spring Mountain Range, Nev.

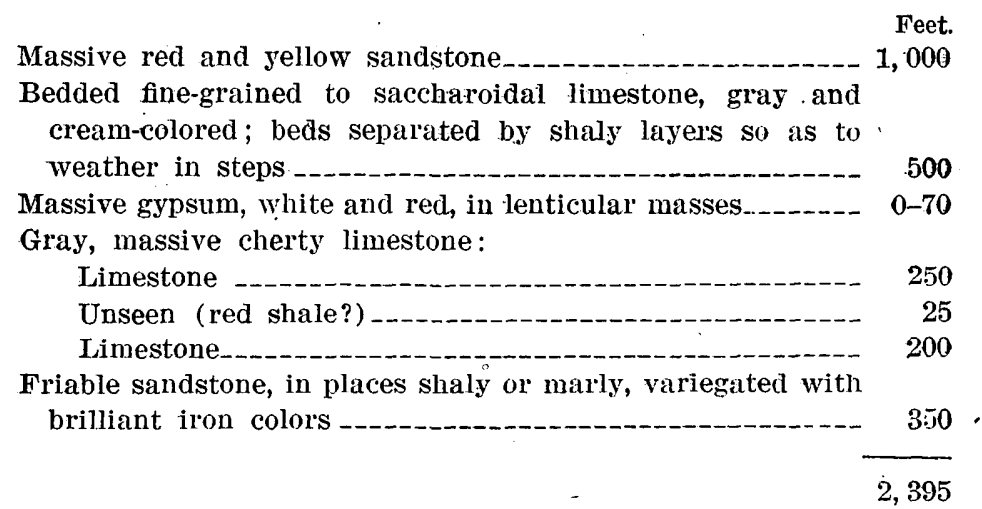

Both limestones contain Pennsylvanian fossils similar to those found above the gypsum at Arden. If the cherty limestone at Arden is the same as that in the above section the gypsum lies in the shale of the fourth member of the section and is somewhat older than the gypsum at Cottonwood Springs.

GAIT.

Several large deposits of gypsum occur in the Las Vegas, Muddy, and Meadow Valley ranges north and east of Las Vegas. The northernmost of these is the Galt deposit, which is in the Meadow Valley Range 27 miles north of Moapa, and about $1 \frac{1}{2}$ miles from the main line of the Los Angeles \& Salt Lake Railroad. The gypsum lies on the east slope of the range in an erosion basin which drains through a ravine to Mormon Canyon and finally to Colorado River. The range $^{2}$ is here composed of folded and faulted limestones, shales, and sandstones of Carboniferous age. The section $^{3}$ at the gypsum de-

1 Gilbert, G. K., Report on the geology of portions of Nevada, Utah, California, and Arizona examined in the jears 1871 and 1872: U. S. Geog. and Geol. Surveys W. 100th Mer. Final Rept., vol. 3, p. 166, 1875.

2 Spurr, J. E., Descriptive geology of Nerada south of the fortieth parallel and adjacent portions of California: U. S. Geol. Survey Bull. 208, pp. 148-151, 1903.

s Boyle, E. D., private report, 1913. 
posit includes a thick series of calcareous sandstones on which lies unconformably a thick series of alternating thin-bedded limestone and gypsum. Above the gypsum series is massive, red, siliceous limestone. The gypsum deposit is about 3,600 feet long and 1,000 feet wide. The strata dip about $60^{\circ} \mathrm{NW}$. and are more or less distorted. To the south the series grades into gypsiferous shale with thin beds of gypsum. The gypsum beds range in thickness from a few inches to 20 feet, and it is estimated that about 15 per cent of the deposit can be utilized.

MOAPA.

Another large deposit is located in the Muddy Range directly south of Moapa and about 5 miles from the nearest shipping point, which is 7 miles from Moapa on the St. Thomas branch of the Los Angeles \& Salt Lake Railroad. It is owned by the Rex Plaster Co., which formerly shipped the gypsum to its factory at Los Angeles. The property includes an area 2 miles long and half a mile wide, running north and south through the middle of T. 16 S., R. 66 E. Mount Diablo meridian. According to Mr. E. Duryee, superintendent of the Rex Plaster Co., a well-defined and massive body of pure white gypsum 100 to 300 feet thick runs through the property. It lies between gray limestone on the west and red sandstone on the east. The beds dip about $40^{\circ} \mathrm{E}$. at the southern end and gradually steepen to $70^{\circ}$. E. at the northern end. The mass of gypsum is exposed by numerous narrow vertical-walled gullies that cross the deposit at right angles. It is estimated that $5,000,000$ tons of gypsum are available above the bottoms of the gullies. The only overburden is a few feet of weathered-gypsum at the surface.

\section{LAS VEGAS.}

Dr. R. W. Martin, of Las Vegas, reports that 7 miles northeast of the town there is a solid ledge of rock gypsum, which is 100 to 125 feet thick and outcrops for nearly a mile. He says that the bed dips at a high angle at the outcrop but flattens under cover, for an adit driven under it 150 feet did not reach the gypsum. A raise at the end of the adit showed the presence of the bed. The gypsum is said to be like that at Arden, and a specimen on exhibition at the Chamber of Commerce of Las Vegas certainly is similar.

Dr. Martin also reports that just east of the above-described property, 9 miles northeast of Las Vegas, there is an area of several hundred acres underlain by gypsite, which has a maximum thickness of 15 feet, and that 15 miles east of Las Vegas there is a cave containing stalagmites and stalactites of gypsum and large plates of selenite. One of these plates of selenite, exhibited at the 
Chamber of Commerce at Las Vegas, measures about 10 by 24 inches.

Some of the streets in Las Vegas and a long stretch of the main road south from town have been surfaced with gypsum scraped from knolls in the desert. The result is very satisfactory.

VIRGIN RIVER.

In September, 1915, H. S. Gale, of the United States Geological Survey, visited the valley of Virgin River below St. Thomas. He found that the valley is narrow and bounded abruptly by cliffs and steep slopes. In these valley walls there is a great thickness of gypsum and gypsiferous shales associated with thick beds of rock salt. ' These mineral deposits are exposed at several places along both sides of the Virgin River valley between St. Thomas and the mouth of the Virgin at Colorado River. They are included in a series of characteristically red shales and sandstones usually referred to as "Red Beds," of Triassic or Permian age. The beds including the gypsum and salt have clearly been very much faulted and folded, so that the present outcrops represent disconnected parts of them. The gypsum is particularly well exposed in the walls of a canyon about 4 miles south of St. Thomas on the west side of Virgin River. 


\section{NEW MEXICO.}

By N: H. DARTON.

\section{DISTRIBUTION.}

A very large area in New Mexico is underlain by gypsum, and this mineral outcrops extensively in several districts. The beds are thick, and most of the material is exceptionally pure. Many deposits are interbedded with red and gray sandstones and limestones of later Carboniferous age, which extends through the south-central portion of the State, and a thick bed overlies a sandstone of Jurassic age in the northern part of the State. A large deposit of gypsum, constituting the white sands of the Tularosa Desert, is of Quaternary age.

The principal exposures of gypsum in workable deposits are in Bernalillo, Chaves, Dona Ana, Eddy, Guadalupe, McKinley, Otero, Quay, Rio Arriba, Roosevelt, Sandoval, San Juan, San Miguel, Santa Fe, Sierra, Socorro, Torrance, and Valencia counties.

Only a small amount of gypsum has been mined in New Mexico, mainly because of long distance to market, and because the local demand for plaster is small. Doubtless in future years, as settlement progresses, the deposits will be more extensively utilized.

On the map (Pl. XIX) are shown the principal areas in which gypsum or formations that contain gypsum are exposed. This map sets forth many facts not shown in the previous publications, ${ }^{1}$ but when further detailed studies of the geology of the State are made the boundaries will be modified in places, and probably some additional areas will be discovered.

\section{GENERAL GEOLOGIC RELATIONS.}

The accompanying columnar section (fig. 14) shows the principal stratigraphic relations of the more important gypsum deposits in New Mexico.

Manzano group.-The gypsum deposits in the Manzano group are associated with the Yeso formation and the San Andreas limestone of Lee. ${ }^{2}$ The Yeso formation consists of red shales with gypsum beds and the overlying San Andreas limestone when studied in detail proves to be an alternation of limestones, gray sandstones,

${ }^{1}$ Herrick, H. N., Gypsum deposits in New Mexico: U. S. Geol. Survey Bull. 223, pp. $89-99,1904$.

${ }^{2}$ Lee, W. T., The Manzano group of the Rio Grande valley: U. S. Geol. Survey Bull. 389 , p. 12,1909 . 
and gypsum beds, the latter ranging from a thin sheet to 100 feet or more thick. These two formations begin in north-central New Mexico and thicken in a short distance southward, finally attaining a thickness of 1,000 feet or more in the San Andres, Sacramento, and Caballos mountains. As shown in figure 14, the lowest formation of

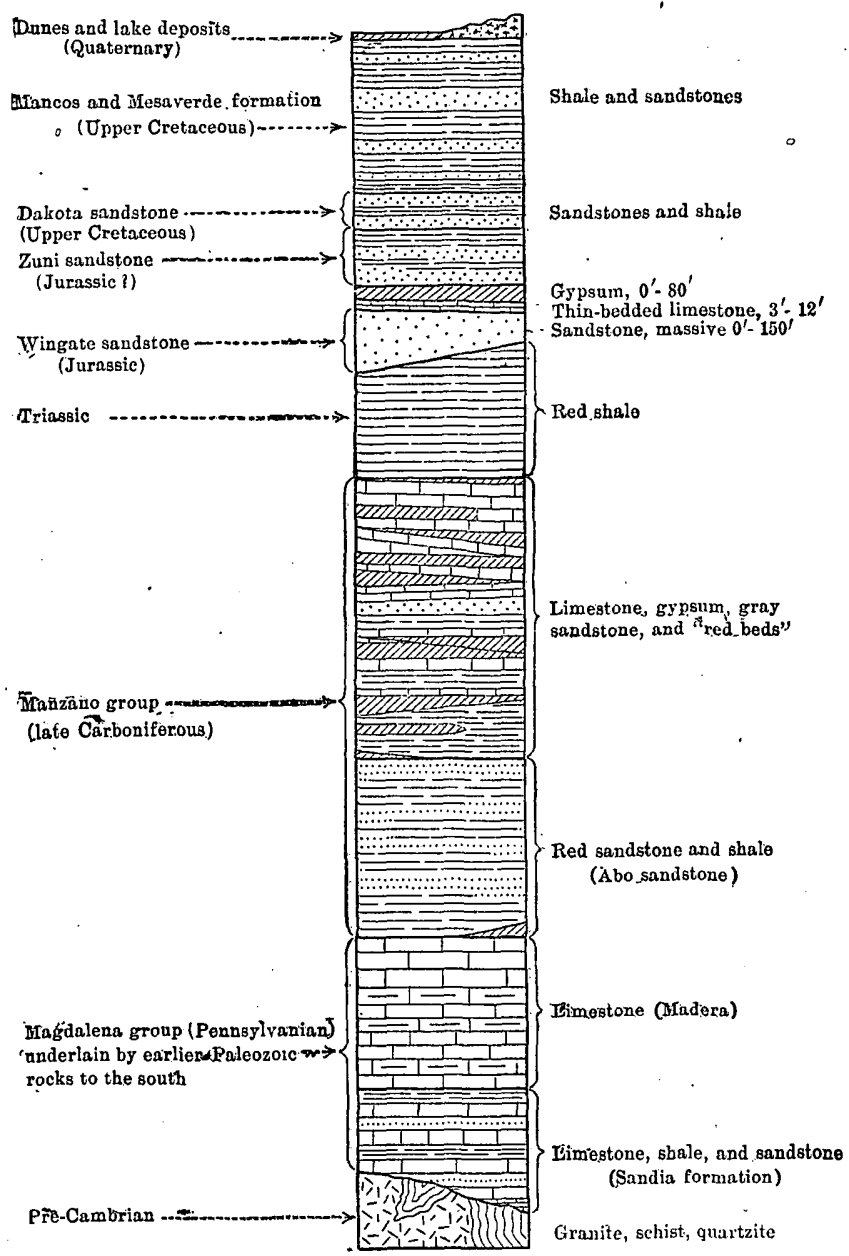

Figure 1. Weneralized columnar section showing stratigraphic relations of gypsum deposits in New Mexico.

the Manzano group is the Abo sandstone, which consists of dark-red sandstone and shale. In the southern part of Otero County there is a bed of gypsum apparently in the lower part of this formation.

Gypsum above Wingate sandstone.-The massive sandstone that extends across western New Mexico in the Zuni uplift, where it was named Wingate sandstone, appears also in the Rocky Mountain, Nacimiento Mountain, and Sandia Mountain uplifts, and is everywhere overlain by a distinctive thin-bedded limestone and locally, 


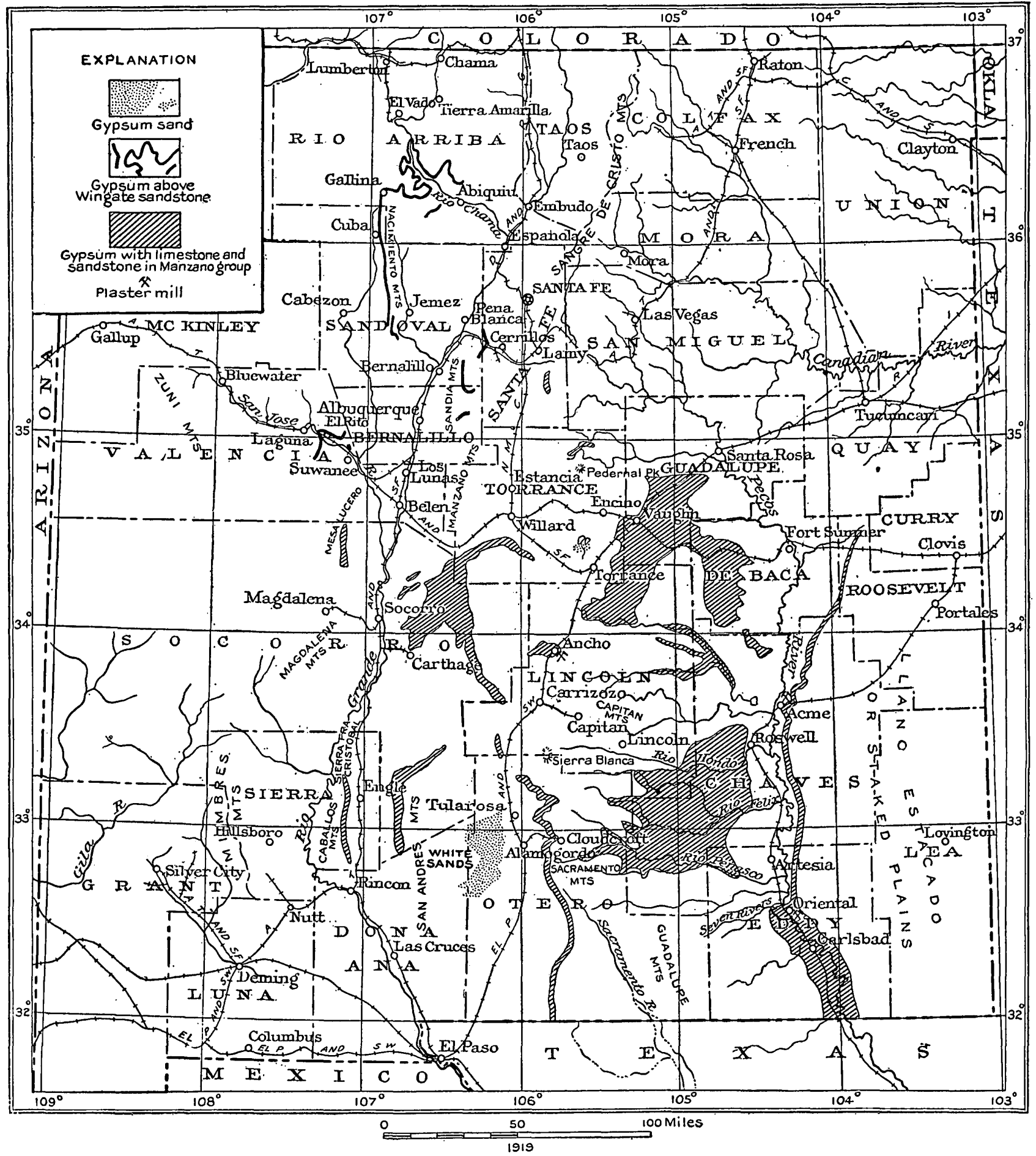

MAP OF NEW MEXICO SHOWING DISTRIBUTION OF GYPSUM DEPOSITS. 
by a thick bed of gypsum, which attains a thickness of 100 feet near Cuba, on the west side of the Nacimiento uplift, 65 feet on Chama River near Gallina, 80 feet at El Rito near Laguna, and 60 feet on Galisteo Creek west of Los Cerrillos. As shown in figure 14 , it is overlain by shales and sandstones of supposed Morrison age. To judge from relations in northwestern New Mexico, Arizona, and Utah it is of Jurassic age. The southernmost exposure of this succession is in the Sandia uplift not far northeast of Tijeras, east of Albuquerque, and it finally thins out and disappears in the central part of the State.

Gypsum of Quaternary age.-Calcium sulphate (or gypsum) is carried in solution" by surface waters in many places, especially in drainage from areas of shales or from "Red Beds" which contain gypsum deposited at the time of the accumulation of the red sediments. When these surface waters evaporate they leave crusts of gypsum and other minerals, which are observable in many places in the arid and semiarid regions. When the waters drain into basins the deposit may accumu! te to a considerable thickness. Such deposits occur in most of th desert basins in New Mexico. Water rising from below and seeping out at the surface also brings up calcium sulphate and other salts, hich gradually accumulate and in places build up mounds. These mi unds are conspicuous in those parts of the Tularosa Desert where the gr. und-water level is near the surface. The readily soluble salts wash out of these deposits, and so the gypsum of the mounds is nearly pur $\Rightarrow$ or mixed with blown sand. By these two agencies-evaporation in basins and in mounds-there has been a great accumulation of gypsum in the Tularosa Desert west of Alamogordo. The wind has blown much of this gypsum into sand and built up the extensive areas of the white sands described elsewhere (p. 184).

\section{IOCALITIES.}

\section{GYPSUM IN MANZANO GROUP.}

Gypsum deposits appear in the Manzano group a few miles southeast of Lamy in Santa Fe County and they thicken and increase in number southward and southeastward. The principal areas of outcrop are shown approximately on the map (Pl. XIX), but detailed descriptions can be given only for some representative exposures. Part of the region has not been examined in detail, and no data are available for the area between the Datil and Zuni mountains. There is a vast amount of the mineral so exposed conveniently for working; and most of it is of very high grade. It is worked at Ancho, Lincoln County; Acme. Chaves County; and Oriental, Eddy County. 
Mesa Lucero.-The slopes of the high lava-capped plateau southwest of Belen consist of thick beds of limestone, sandstone, and red shale, with several intercalated deposits of gypsum, as shown in figure 15. The beds dip west at a low angle.

The aggregate thickness of gypsum in this exposure is about 160 feet, and two of the beds exceed 80 feet in thickness.

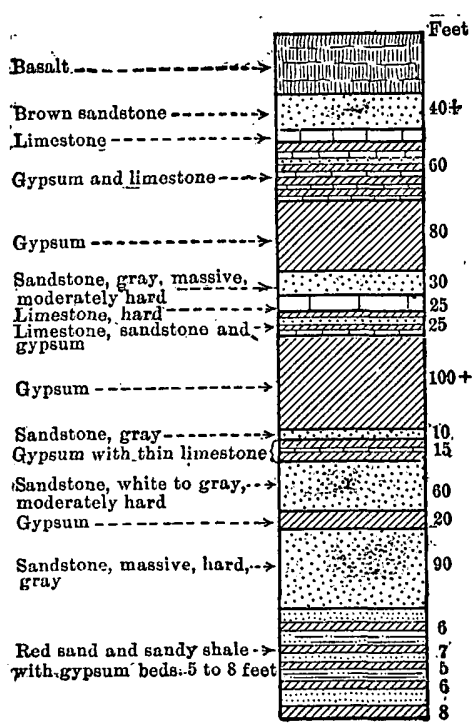

FIGURE 15.-Section of east slope of Mesa Lucero, in Socorro County, 25 miles southwest of IBelen, N. Mex.

A few miles farther south, at a point 5 miles east of Puertocito and 30 miles northeast of Socorro, the two principal gypsum beds are 65 and 60 feet thick and are separated by 90 feet of limestone. Under the hard massive sandstone member, in this locality 80 to 100 feet thick, are 200 feet of red shales with beds of limestone and gypsum. Next below there is about 1,500 feet of red sandstone (Abo sandstone), extending to the top of the limestone of the Magdalena group.

Chupadera Mesa.-The Chupadera Mesa (fig. 17) occupies a wide area in the eastern part of Socorro County and extends north into the southwestern corner of Torrance County, where its northern margin is known as Mesa Jumanes. The highland is capped by limestone of the upper part of the Manzano group in a broad sheet, dipping gently east, and at its southeast corner sloping down into the north end of the Tularosa desert west of Carrizozo. To the north, west, and southwest the mesa terminates in a line of high cliffs in which are exposed sandstones, gypsum, and red shale with interbedded limestones. The general structural relations are shown

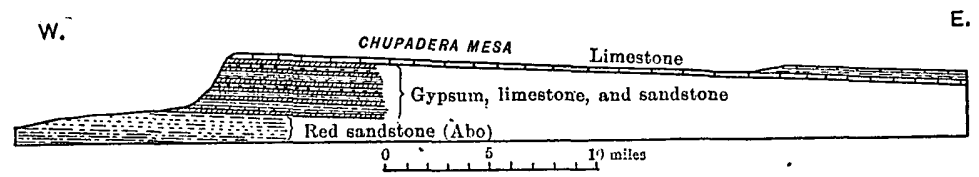

E.

Figure 16.-Section across Chupadera Mesa, 35 miles east of Socorro, N. M $2 x$.

in figure 16. The succession differs somewhat from place to place, but figure 18 shows a typical section of the strata overlying the Abo sandstone, which constitutes the slopes west and north of the foot of the mesa. It will be seen from this section that there are many thick beds of gypsum, aggregating more than 250 feet, not counting thin beds. Most of the gypsum is pure white and evidently of high grade. 


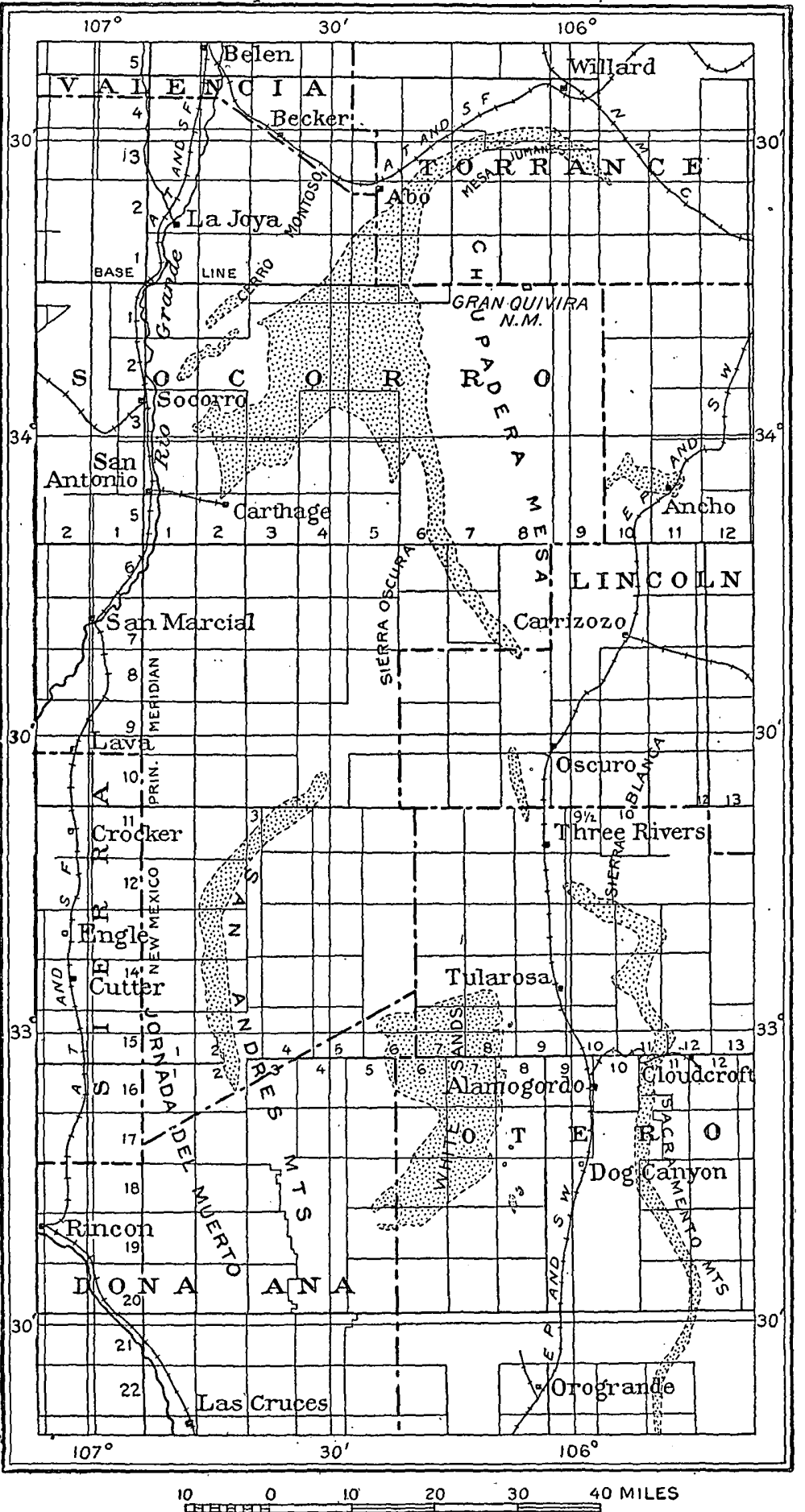

Figdre 17.-Map of part of central New Mexico showing gypsum deposits. The areas described in this report are indicated by the dotted sections. 
In sections east of Abo Pass the gypsum is exposed in the succession shown in figure 19.

In this locality the principal bed, 90 feet thick, is near the top, but there are several thin beds lower down.

In the north face of Mesa Jumanes, a short distance south of Williard (fig. 17), there is a

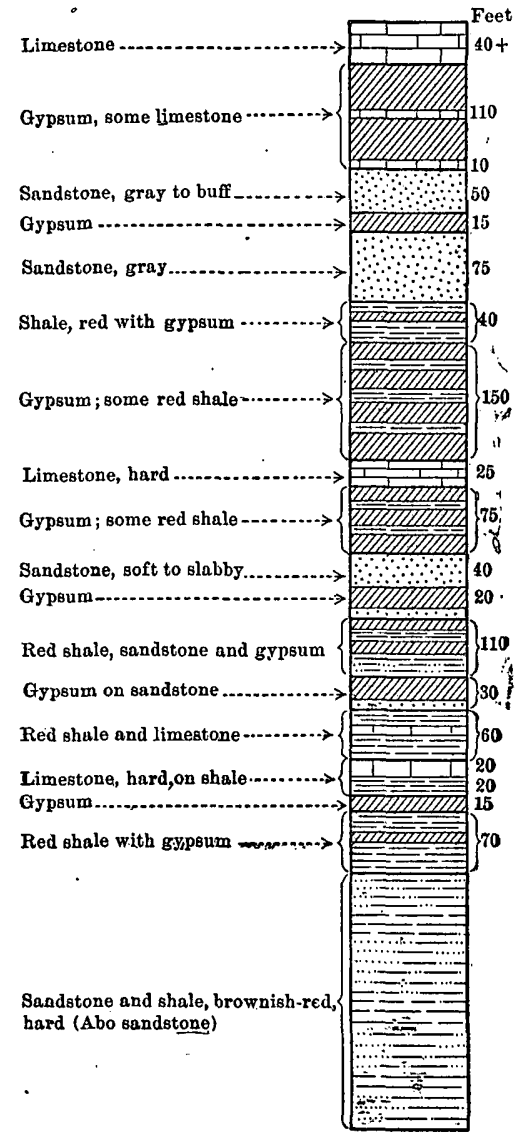

FraUre 18.-Section of strata in west face of Chupadera Mesa, 25 miles east of Carthage, N. Mex. similar succession, but the gypsum beds are much thinner.

East of Socorro.-In the many ridges of limestone and sandstone of the Manzano group east of Socorro there are numerous

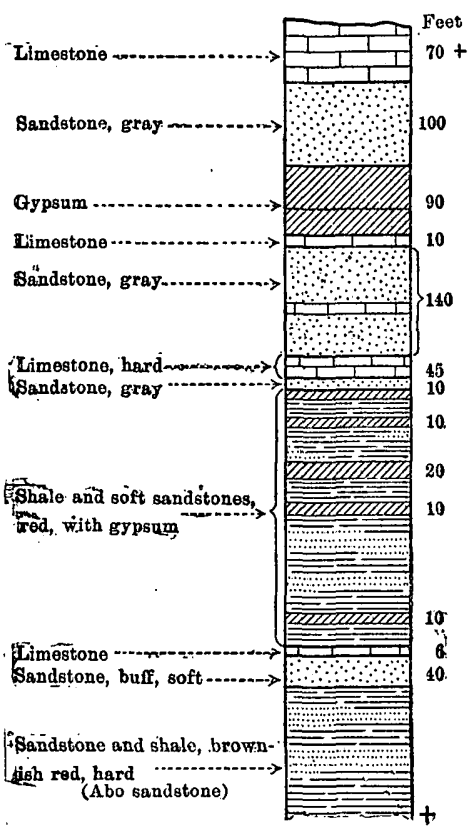

Frgure 19.-Section of gypsum and associated strata near Abo siding in the northwest face of Chupadera Mesa, N. Mex.

thick beds of gypsum similar in relations to those in Chupadera Mesa. These beds have an aggregate thickness of 200 feet in much of the area but are separated by sandstones and limestones. The thickness and stratigraphic relations vary greatly from place to place. The exposures are extensive, but many faults traverse the region and interrupt the continuity of outcrops. In general the width of the outcrop is from 8 to 10 miles. It extends from the ridges rising a few miles north of Carthage to the west side of Chupadera Mesa, 40 miles 
northeast of Socorro. There are many billions of tons of gypsum and anhydrite in this area, and practically pure selenite is abundant.

In Mesa del Yeso and vicinity, 12 miles northeast of Socorro, there is one principal bed of gypsum from 60 to 80 feet thick in a succession of soft red sandstones lying below gray sandstone and limestone. In the ridges east of Mesa del Yeso, 15 miles northeast of Socorro, are many deposits of gypsum with a large aggregate thickness. The succession and thickness of beds are variable. In the large butte 2 miles southeast of Mesa del Yeso the principal bed of gypsum is 60 feet thick. It lies between soft red sandstones. In the slopes of the high mesa 8 miles east of Mesa del Yeso there is, below the thick cap of limestone and gray sandstone, 250 feet of strata, largely composed of gypsum in thick beds but interbedded with red shale and many thin layers of limestone. In Cibola Pyramid, a conical: peak 4 miles east of Mesa del Yeso, there is a similar succession below the limestone and gray sandstone cap but apparently with thicker bodies of soft red sandstone between the gypsum deposits. Most of the beds of gypsum here are 10 to 25 feet thick.

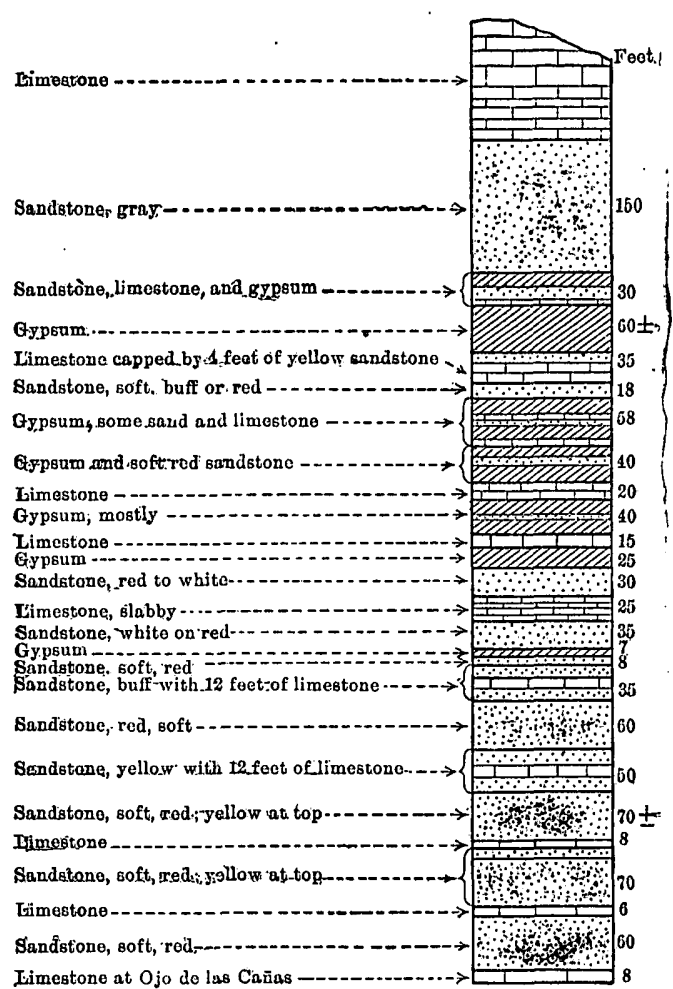

Figure 20.-Columnar section of gypsum and associated beds in Arroyo de las Caũas east of the spring, 7 miles east-southeast of Socorro, N. Mex.

In the long ridge 2 miles northeast of Mesa del Yeso the amount of gypsum in the upper part of the Manzano group increases greatly. There is at least 300 feet of thick gypsum beds separated by thin bodies of limestone and soft red sandstone.

In the Coyote Buttes, 10 miles northeast of Socorro, the gypsum beds are much thinner than in the adjoining regions, and they are broken by several faults.

In the Lomo de las Cañas, east-southeast of Socorro, the gypsum beds aggregate 200 feet thick. Their succession as exposed in an arroyo in this ridge is shown in figure 20. 
In the ridges 2 miles north of Prairie Spring, 12 miles northeast of Carthage, there is a similar succession in which the gypsum beds aggregate about 280 feet. The section is as follows:

Section of gypsum and associated beds 12 miles northeast of Carthage, N. Mex.

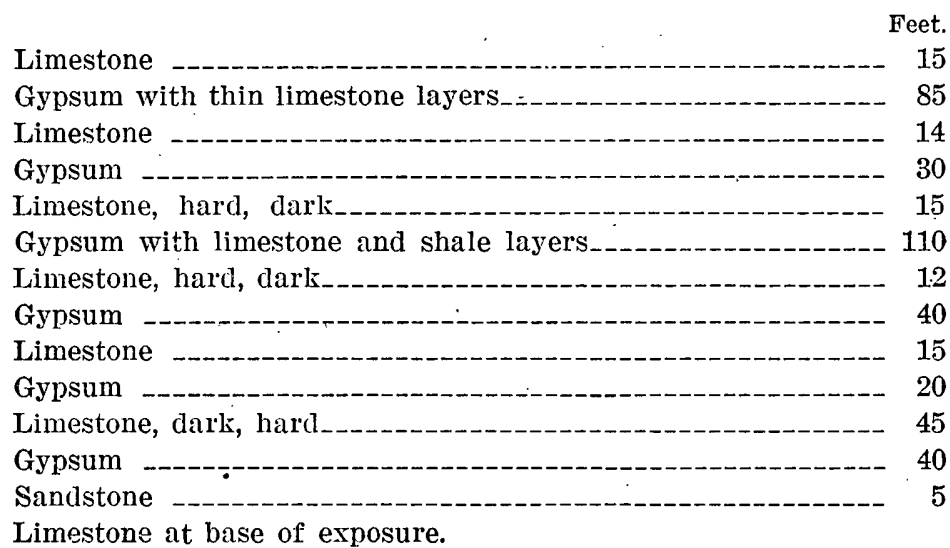

Phillips Hills.-The upper members of the Manzano group rise on the east side of Tularosa desert in Phillips Hills. These hills

form a ridge 7 miles long, lying
between the railroad and the Mal-
pais, southwest of Oscuro. The
beds dip at a small angle, gen-
erally about $10^{\circ}$ E., and pass be-
neath red beds, which, however,
are mostly concealed by the sand
and gravel of the bolson. Sand and
Gypsument...


Sacramento Mountains.-The great gypsum-bearing series of the Manzano group, which passes under the Tularosa desert southwest of Carrizozo and outcrops in the Phillips Hills, appears prominently in the ridges a short distance east of Tularosa. It also extends along the upper slopes of the east face of the Sacramento Range and thence south to Texas.

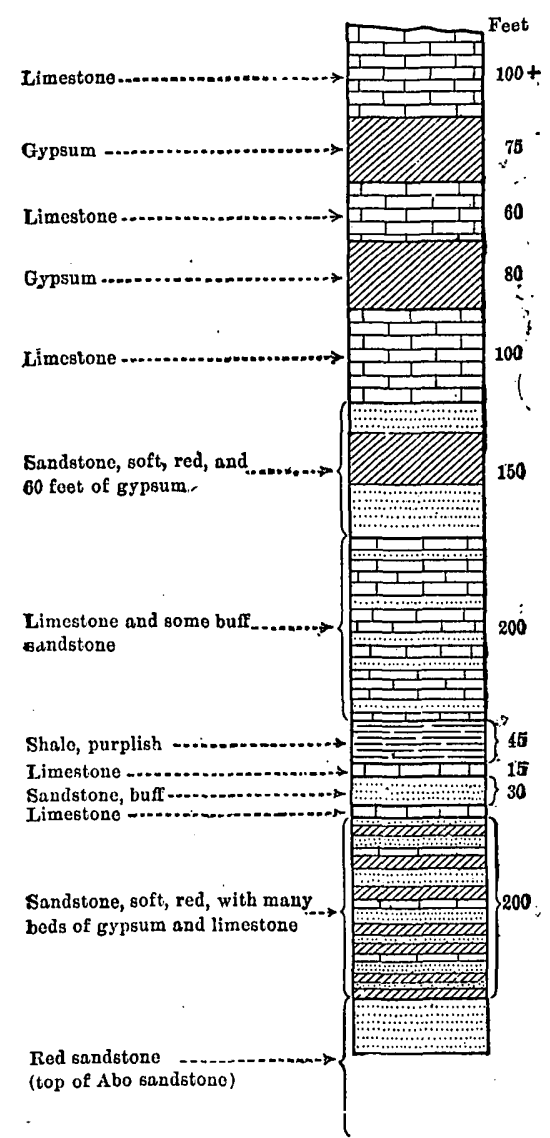

Figure 22.-Columnar section of gypsum and associated strata about 2 miles southeast of Salinas siäing, 10 miles north of Tularosa, N. Mex.

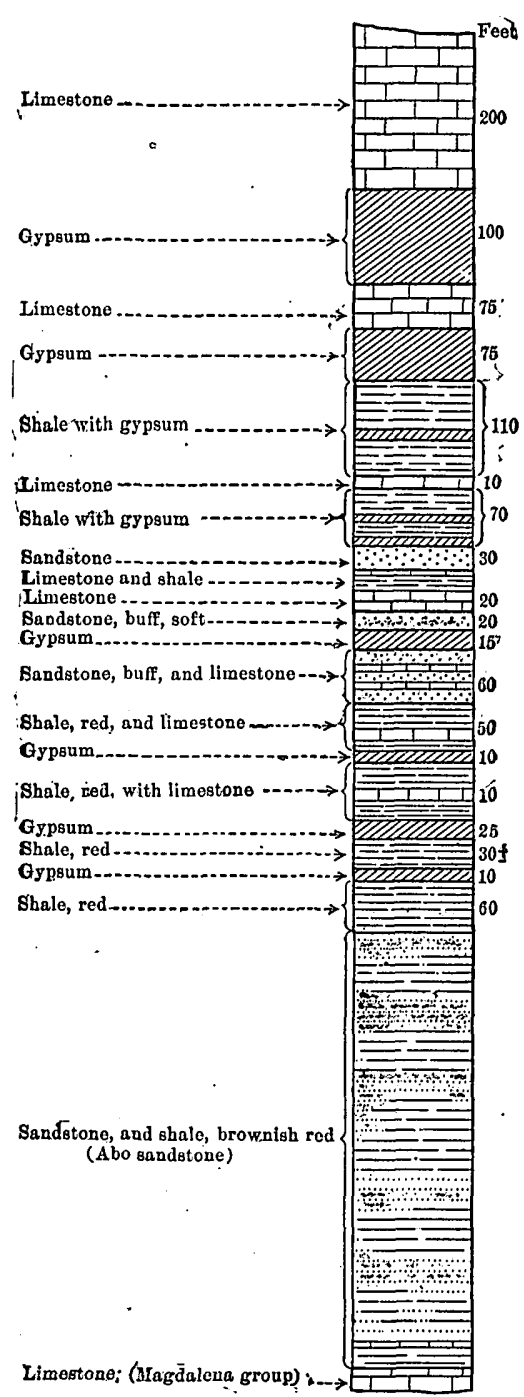

Figure 23.-Columnar section of gypsum and associated strata east of Tularosa. N. Mex.

In figure 22 is given a section in a bluff 10 miles north of Tularosa, in which the beds first rise above the bolson east of the railroad.

A similar succession appears in the slopes northeast and east of Tularosa, as shown in figure 23.

In the slopes west of Cloudcroft, on the higher part of the range, talus and landslides conceal the gypsum and limestone cliffs 
preponderate. Farther south, however, the gypsum appears again, so that doubtless the deposits are continuous under the Cloudcroft region. The structural relations are shown in figure 24 .

There are exposures of these beds in Grapevine Canyon and adjoining slopes 25 miles southeast of Alamogordo, but in this locality the gypsum is much thinner than in the exposures east of Tularosa. In the cliffs 15 miles northeast of Oro Grande the following section is exposed:

Section of beds of Manzano group 15 miles northeast of Oro Grande, $N$. Mex.

Limestone
Sandstone, slabby; mostly red, some buff
Gypsum, mostly pure
Shale, red -
Sandstone, red, slabby ; some shale (Abo sandstone)
Gspsum (not well exposed)
Limestone (probably of Magdalena group).

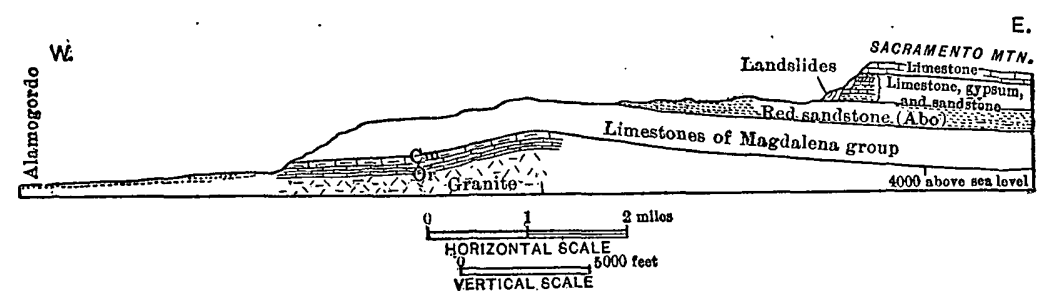

Frgurd 24.-Approximate section across Sacramento Mountains east from Alamogorao, N. Mex. Or, Ordovician limestones; Cm, Mississippian limestone.

These cliffs are along the west face of a southern continuation of the Sacramento Mountains, and the beds have the same low dip to the eastward as in that range. Just west of its foot, however, there is a low arch in which limestones, apparently of the Magdalena group, dip to the westward and present a long dip slope toward the bolson in that direction. The lower gypsum bed appears to be in the base of the Abo sandistone.

The westward-facing cliff continues far south, but its height gradually decreases. At a point 20 miles southeast of Oro Grande the limestone in the Magdalena group is overlain by a thick body of gypsum not well exposed. It is overlain by 30 feet of red shale, above which limestone 250 feet thick caps the ridge and extends east in a long dip slope. At the base of the limestone are some buff sandy layers.

Vaughn region.-Near Vaughn, in Guadalupe County, and in the wide ridge constituting the divide east of that place there are many thick beds of gypsum. In the old stone quarry half a mile north of Vaughn station, on the El Paso \& Southwestern Railroad, there is 
an extensive exposure of a bed of gypsum about 20 feet thick witli 15 feet of limestone above and below it.

The deep boring at Tony, near Vaughn, is reported to have penetrated 100 feet of gypsum, partly white and partly of red and yellow tints, and the 341 -foot well at Pastura passed through alternations of thick beds of limestone, sandstone, and gypsum, the gypsum aggregating more than 100 feet. In the plains east of Vaughn there are many sink holes which connect with underground passageways for water in the gypsum, on the edges of which the mineral is exposed. Ledges are exposed in the railroad cut at W.inkle and near Aragon and Pastura.

Gypsum undoubtedly underlies much of the plateau, which is capped by nearly horizontal limestone that extends southward from Vaughn beyond Corona, and the mineral was reported in borings at Varney and Duran. These beds appear at the surface at the foot of the south side of the plateau at Ancho.

Ancho.-At Ancho, in Lincoln County, there is a plaster mill where gypsum is ground and burned in moderate amounts. In the vicinity of the plaster mill the strata are considerably disturbed by flexures and cut by faults and igneous rocks.

The gypsum is extensively exposed in the slopes near the railroad, especially in the cuts east of the plaster mill, half a mile north of the railway station. There are several deposits interbedded with layers of limestone

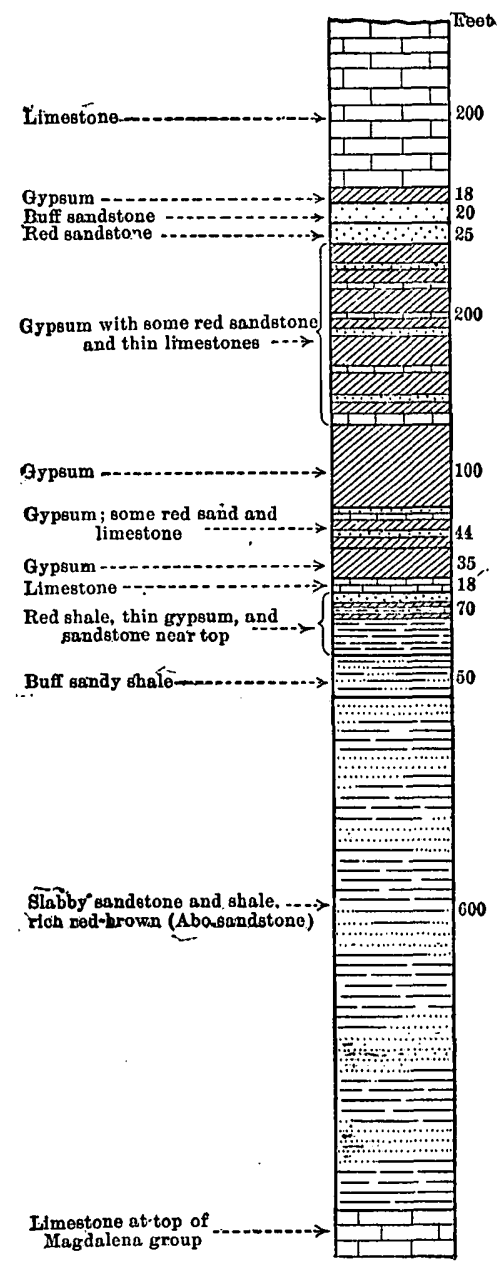

Figure 25.-Columnar section showing relation of gypsum deposits in Rhodes Canyon, San Andres Mountains, 25 miles east-southeast of Engle, N. Mex. and red sandy shale and clay. The most valuable bed is 35 feet thick, and others are 10 to 15 feet thick. The principal material used in making plaster here is gypsite or pulverulent material weathered or washed out of the main ledges: Some quarrying also has been clone.

San Andres Mountains.-The upper formations of the Manzano group, which extend for many miles along the west slope of the 
San Andres Mountains, contain numerous thick beds of gypsum. The stratigraphic relations are similar to those in Chupadera Mesa and Sacramento Mountains-namely, an alternation of red shale, sandstone, gypsum, and limestone, the limestone capping ridges of considerable prominence. (See fig. 25.)

In general the beds form a monocline that dips gently to the west, and most of the gypsum is on the steep east slopes of ridges capped by the harder limestone. The cross section (fig. 26) shows the structure which prevails. The geologic section in the center of the mountains shows a typical succession of beds, but the order and thickness differ greatly from place to place. The outcrop

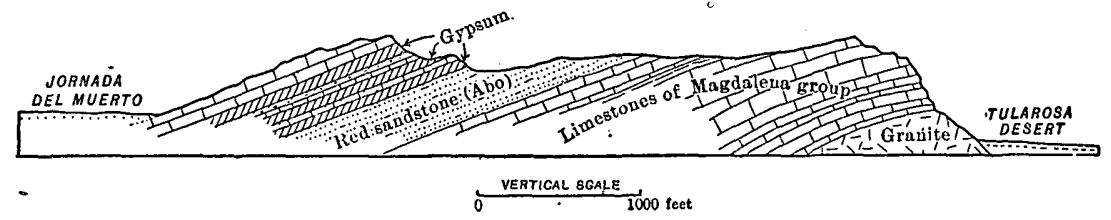

Figurm 26.-Section across San Andres Mountains 18 miles northeast of Engle, N. Mex.

ceases at the south end of the San Andres Mountains, northeast of Las Cruces, and near the north end of the range, at a point about 35 miles northeast of Engle.

4 Caballos Mountains.-The upper part of the Manzano group extending along the east slope of the Caballos Mountains consists of an alternation of limestone and gypsum, whose aggregate thickness is about 800 feet. Of these rock strata about 325 feet is gypsum in beds 10 to 40 feet thick. The bodies of limestone intervening are 5 to 40 feet thick, and there are also some thin beds of sandstone and sandy shale. The succession differs from place to place, but the section shown in figure 27 is fairly representative. Figure 28 shows the structural relations.

It will be seen from the cross section that the beds dip gently to the east and are cut off on the east by a fault by which sandstones of Cretaceous age are dropped against the limestones which overlie the gypsum.

The outcrop of the gypsum beds extends for several miles along the slopes, parallel to the railroad and about 12 miles west of it. The nearest stations are Cutter and Aleman.

Sierra Fra Cristobal.-The south end of the Fra Cristobal Range, northwest of Engle, Sierra County, has extensive outcrops of red beds, gypsum, and limestone of the Manzano group. No detailed examination was made of the beds exposed, but there is an alternation of about 700 feet of gypsum and limestone, with an aggregate of nearly 300 feet of gypsum in beds 10 to 40 feet thick. The stratigraphic and structural relations are clearly similar to those in the Caballos Mountains, of which this range is a detached continuation. 
Rincon Colorado to Lamy.-Several beds of gypsum are exposed in the cliffs of red beds on the east side of the plateau east of Pedernal Peak, in the northeastern part of Torrance County. These cliffs are on the slopes adjoining the headwaters of the middle branches of Pintada Canyon. A view of a portion of them is shown in Plate $\mathrm{XX}, A$. The principal bed of gypsum is 20 feet thick, and not far above it is another bed 5 feet thick. No detailed examination was made of this region, and therefore it is not known how far to the north and east these exposures extend. As the beds of gypsum at this horizon outcropping along the west side of the plateau northeast of Pedernal Peak and near Cuervo Butte are thin, there are probably no extensive deposits in the plateau extending north from Pedernal Peak to Glorieta Mesa. A thin bed of considerable value for local use outcrops in Jaspe Canyon 15 miles southẻast of Lamy.

Pecos Valley.-A large part of the Pecos Valley has been developed in "Red Beds" which contain deposits of gypsum at many places from the vicinity of Fort Sumner to the Texas State line. Some of these deposits are near the river, but most of them are in adjoin-

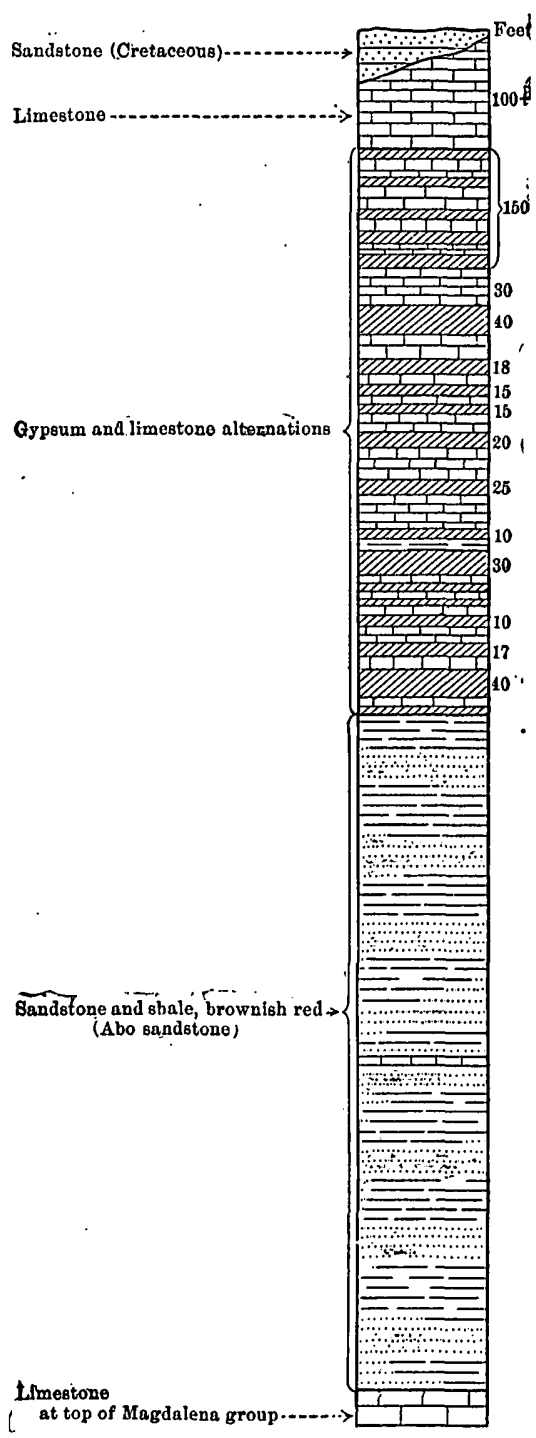

Figure 27.-Columnar section showing relations of gypsum and associated beds in Caballos Mountains, 15 miles southwest of Engle, N. Mex.

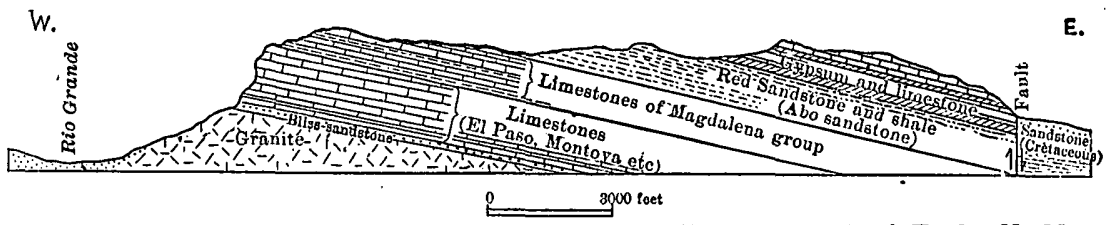

Figure 28.- Section across Caballos Mountains 15 mlles southwest of Engle, N. Mex., . showing structural relations of gypsum. 
ing slopes or in lateral valleys. Well records show also that there are thick beds intercalated among the limestones and other strata underlying the valley. Many features of the geology of the region have been -described by C. A. Fisher, ${ }^{1}$ and the following material is taken from his report:

The so-called Permian series of this [the Roswell] district consists of an upper red bed member of gypsum, red sand, limestone, and clay 600 to 800 feet thick, forming the high bluffs along the east side of Pecos River and underlying the recent deposits of Pecos Valley, and a lower member of massive limestone, clay, and gypsum of undetermined thickness, which constitutes high rugged slopes to the west. Overlying the red bed division east of Pecos River is a reddish-brown sandstone about 100 feet thick, which may be of Cretaceous age. No subdivisions have been made of the probably Permian rocks in this region in the present reconnaissance.

Red bed division.-These rocks consist of alternating beds of gypsum, red sand, and clay, with an occasional layer of dark-gray, compact limestone. The gypsum predominates and usually occurs in beds about 10 feet thick. It is often found, however, in thinner layers, interbedded with clay and limestone. The red beds are provisionally placed in the Permian, although no fossils have been found in them. $* * *$ The upper part $o_{i}^{2}$ the beds is well exposed in the bluffs along the east side of Pecos River, where a number of sections have been measured. These sections are as follows:

Sections of gypsum bluffs along the east side of Pecos River; N. Mex.

East of Roswell:

Feet.

A.ternating layers of gypsum and red sand, locally contain-

ing layers of limestone. $-50$

White gypsum -.-.-_- 6

Red sand -_-_- 6

White, thin-bedded gypsum

Red sandstone containing thin layers of limestone___._._. 24

White gypsum _-_._- 5

Red sand _._.

Gypsum - - 10

Red sand -..-_- 3

Gypsum -

Red sand _..... 8

Gypsum -._-_-_-

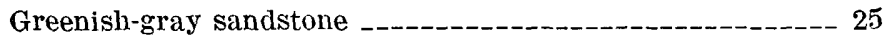

Gypsum - - 6

At Dimmit Lake:

Gray sandy limestone___- 20

Alternating layers of gypsum and red and green clay, locally containing beds of porous limestone_____._-_- 100

Gypsum_-_-_-_-_- 4

Red clay -

Gypsum

Alternating layers of gypsum and red clay_..._._._-_.- 6

Gypsum_-_____._._. 11

${ }^{1}$ U. S. Geol. Survey Water-Supply Paper 158, pp. 6-8, 1906. 
At Dimmit Lake-Continued.

Feet

Alternating layers of gypsum and red sandstone_-_-_-_-- 6

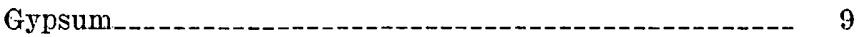

Red clay__._._. 1

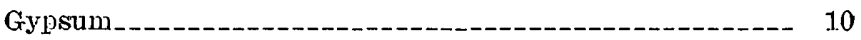

Alternating layers of gypsum and red clay_-_-_-_-_-_ 15

Gjpsum_-_-_-_. 5

Red clay

Gypsum -..- 10

Red clay -_.

Alteruating layers of gypsum and red clay_-_-_._-_-_-- 8

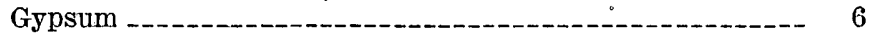

Red clay, with thin layers of gypsum

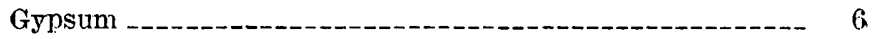

Gray compact limestone._-___._- 5

Gypsum and red sandy clay in alternate succession_...- 65

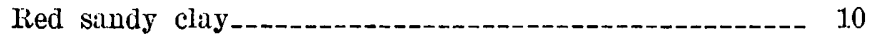

White massive gypsum_._-_._-_-_- 15

Red sandy clay

White gypsum-_._. 10

Gray limestone -.-_-_-_. 5

Gypsum _._-_-_. 18

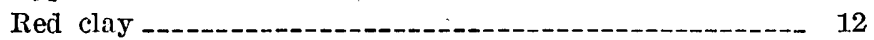

Gypsum _-_-

About 2 miles southeast of the mouth of South Fork of Seven Rivers :

Massive gray limestone

Gypsum and red sandstone in alternate layers, locally containing limestone ledges

Gypsum, thin-bedded porous limestone, and red sandstone arranged alternately, the gypsum. predominating-.--- 150

Gypsum, with thin layers of gray limestone-_._-_-_-_-- 50

Limestone division.-The massive limestone beds underlying the so-called Permian red beds of this region consist mainly of gray compact limestone, with layers of soft sandstone, clay, and gypsum. In the upper part the limestone is more or less thin bedded and porous and contains many sandy layers.

Much gypsum in this series of "Red Beds" has been quarried and made into gypsum plaster at Acme, a small village in Chaves County, 18 miles northeast of Roswell, and also at Oriental, a station in Eddy County halfway between Artesia and Carlsbad. The beds included in the foregoing sections are all in the series of red shales overlying: the thick succession of limestone, sandstone, and gypsum constituting. the great dip slope that extends continuously from the summit of the Sacramento and Guadalupe mountains to Pecos River. (See p. 169.) 


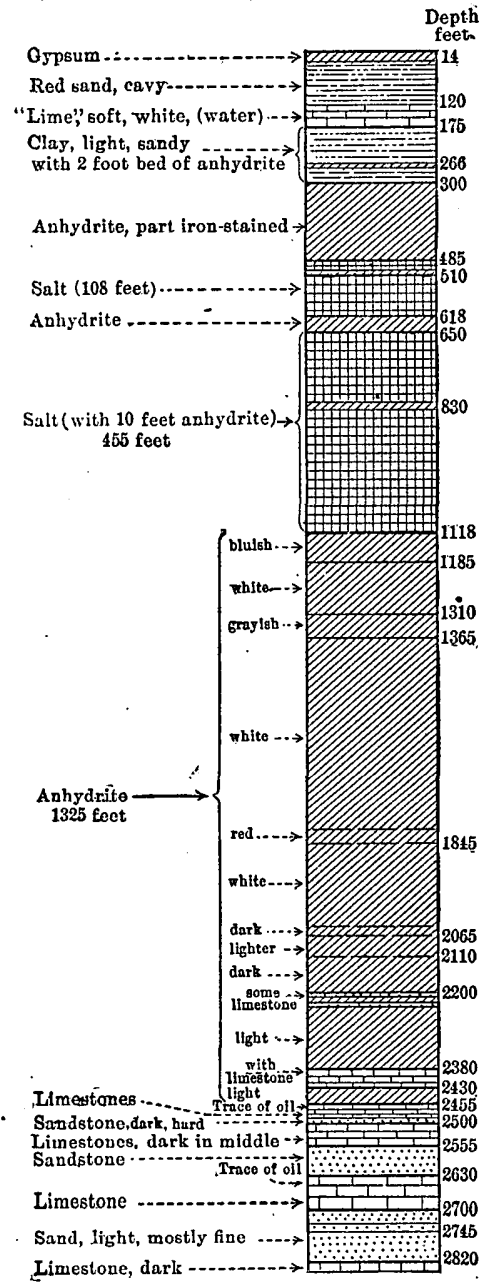

Figune 29.-Record of boring in NE. $\frac{1}{4}$ sec. 4 , T. 22 S., R. 28 E., east of Carlsbad, N. Mex.
Some of the many deep valleys and canyons on this slope cut through the limestone and expose beds of gypsum, but the area has not yet been examined in sufficient detail to show the places of occurrence and succession of beds. Some of the deep borings in the Pecos Valley penetrate this series of rocks and pass through very thick beds of gypsum and salt. The record of a well 2 miles east of Carlsbad is given in figure 29.

E. E. Lyder and W. A. Whittaker, of the University of Kansas, made many tests of samples as boring progressed. The presence of 1,327 feet of gypsum (anhydrite) from 1,118 to 2,455 feet and 563 feet of salt between 510 and 1,118 feet are the most remarkable features in this record.

A boring at McMillan, a few miles northwest of Oriental, penetrated gypsum in beds 5 to 6 feet thick from 49 to 80 feet; pure white, moderately hard gypsum, 135 to 200 feet; and very hard white gypsum, 200 to 450 feet. $^{1}$ In a record of a near-by well, however, through the same beds the continuity of the gypsum deposit is stated to be interrupted by much clay and sandstone.

w:

E.

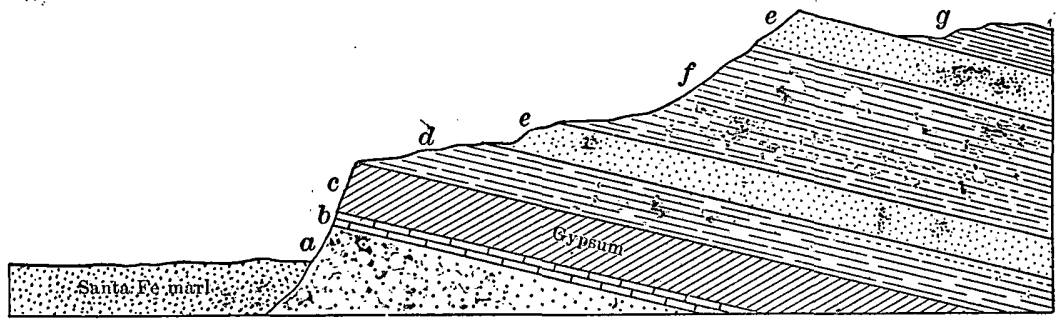

FrgURE 30.--Section showing relations of gypsum deposit enst of Rosario siding, 7 miles west of Los Cerrillos, N. Mex. a, Massive sandstone, buff above, red below (Wingate?) ; $b$, thin-bedded limestone; $c$, gypsun bed; $d$, purplish to chocolate clays; $e$, gray to buff sandstone; $f$, light clays, some sandstone; $g$, dark shale. 
GYPSUM OVERLYING THE WINGATE SANDSTONE.

Los Cerrillos.-The "Red Beds" that come to the surface in the great monocline west of Los Cerrillos in Santa Fe County contain a thick bed of gypsum, which outcrops very conspicuously along the bank of Galisteo Creek as shown in Plate XX, $B$ (p. 178). This locality is at a point about a mile east of Rosario siding; on the Atchison, Topelza \& Santa Fe Railway. The exposure extends along the sicle of the railroad for nearly half a mile and then trends off to the north, finally passing under the Santa Fe marl. The section exposed is presented in figure 30 .

The gypsum bed is 60 feet thick, but it appears to thicken locally; in one place this is due to faulting and slipping.

A small but apparently representative sample of gypsum from this outcrop was tested by A. A. Chambers in the laboratory of the United States Geological Survey and found to contain about 96.22 per cent of $\mathrm{CaSO}_{4} \cdot 2 \mathrm{H}_{2} \mathrm{O}$.

Tonque.-The same gypsum bed as that near Rosario reappears again near Tonque Creek, in the southeastern part of Sandoval County, 6 miles east of Bernalillo, and extends southward for about 10 miles. Its ends are covered by

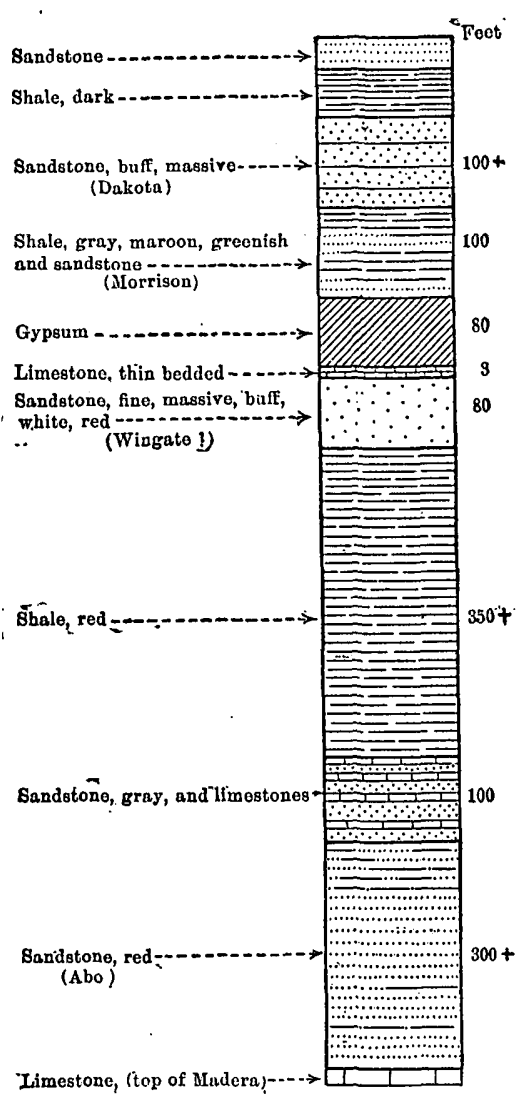

Figure 31.-Columnar section showing relations of gypsum deposit on east bank of Tonque Creek, 2 miles below the brick works, Sandoval County, N. Mex.

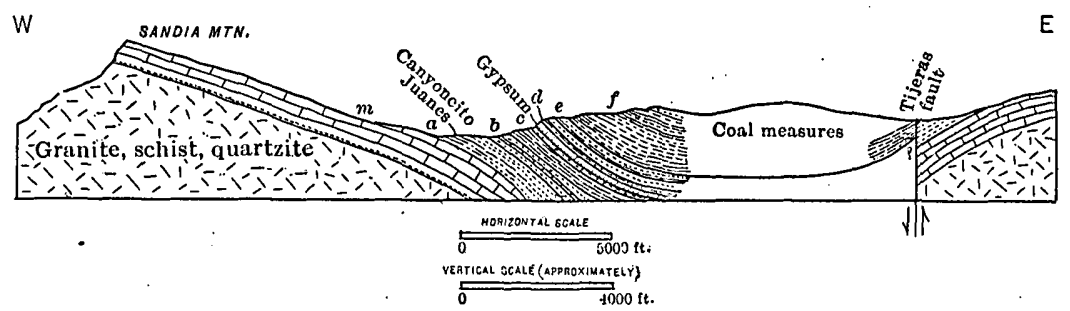

Figurv 32.-Cross section showing relations of gypsum in Tijeras Canyon east of Albuquerque, N. Mex. a, Red beds, with $b$, sandstone and limestone member ; $c$, Wingate (?) sandstone overlying gypsum; $d$, Morrison shale; $e$, Dakota (?) sandstone; $f$, Mancos shale and overlying coal measures - $m$, Madera limestone. 


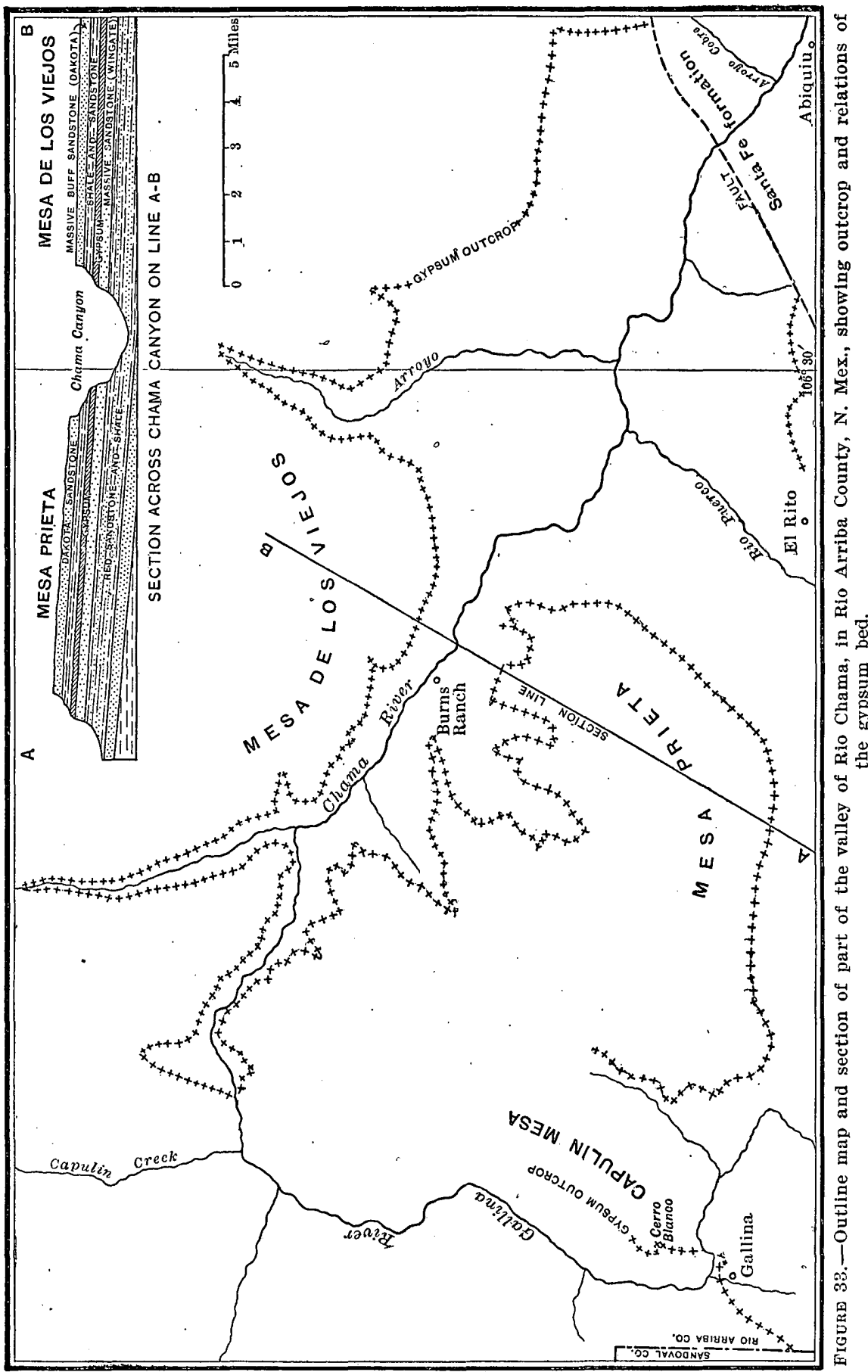

4

$\checkmark$ 


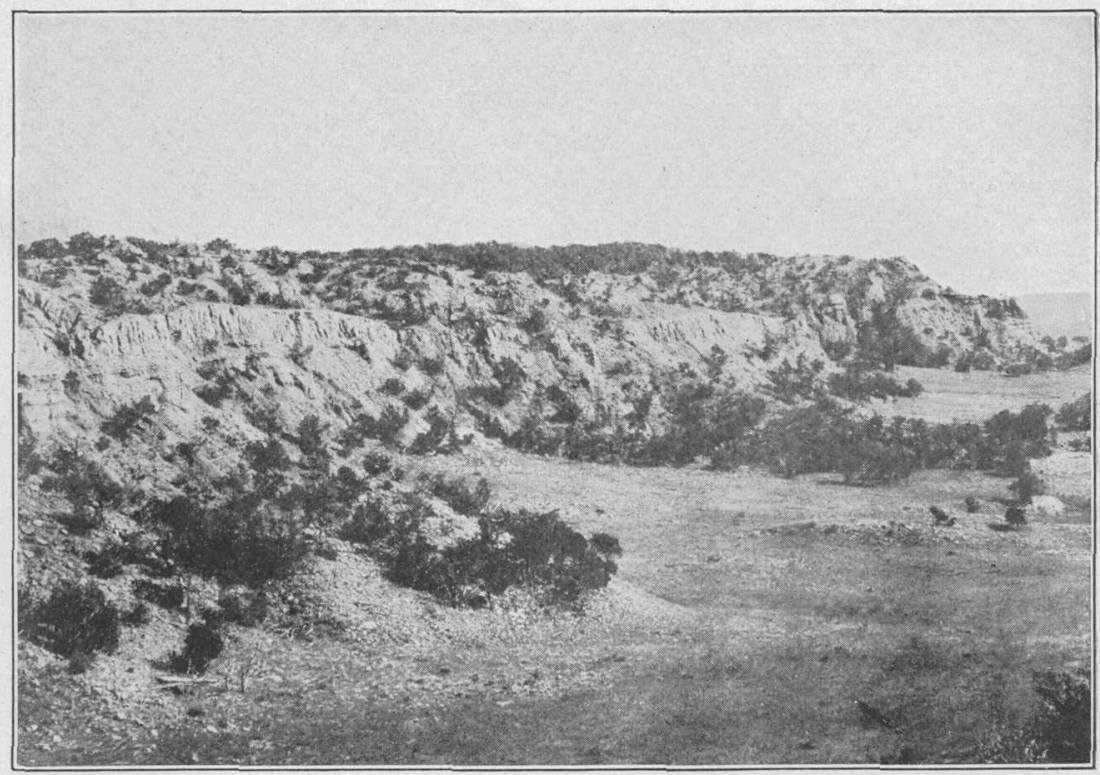

A. GYPSUM IN NORTH WALL OF RINCON COLORADO, EAST OF PEDERNAL PEAK, TORRANCE COUNTY, N. MEX., LOOKING NORTHEAST.

Photograph by N. H. Darton.

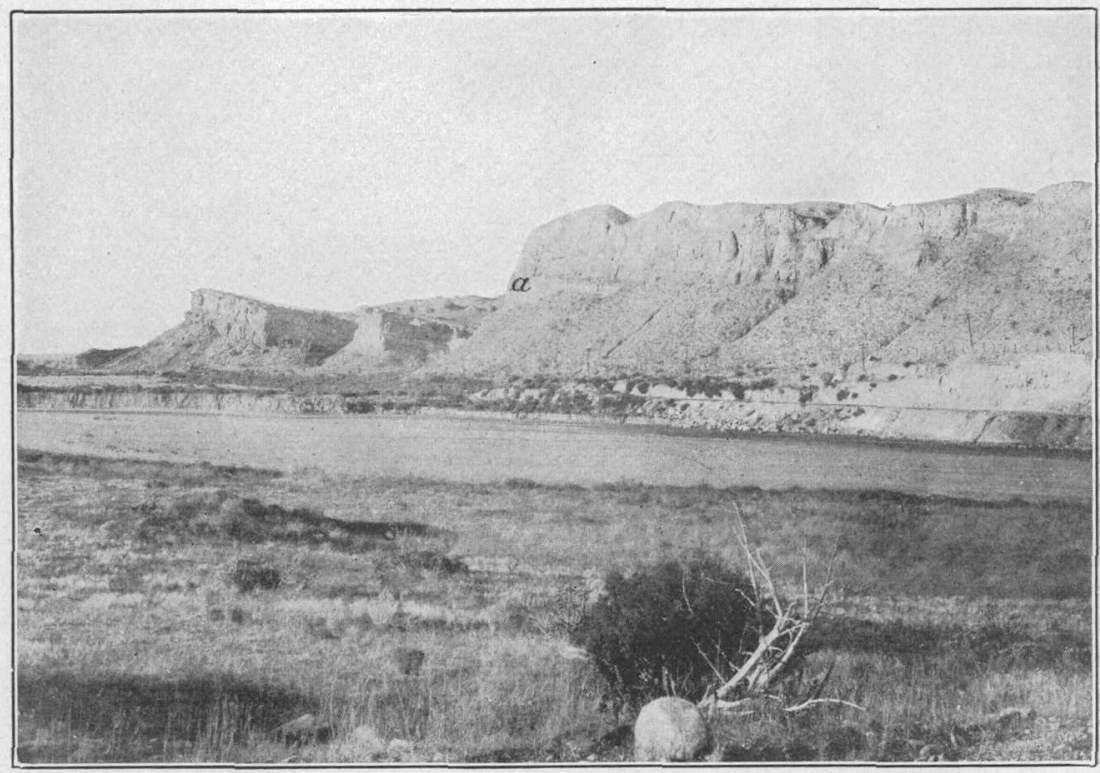

B. OUTCROP OF GYPSUM NEAR ROSARIO SIDING, WEST OF LOS CERRILLOS, N. MEX., LOOKING NORTH.

This great outcrop extends along the Atchison, Topeka \& Santa Fe Railway on the south bank of Galisteo Creek. The gypsum is underlain by the bedded limestone on Wingate (?) sandstone (a). Photograph by W. T. Lee. 


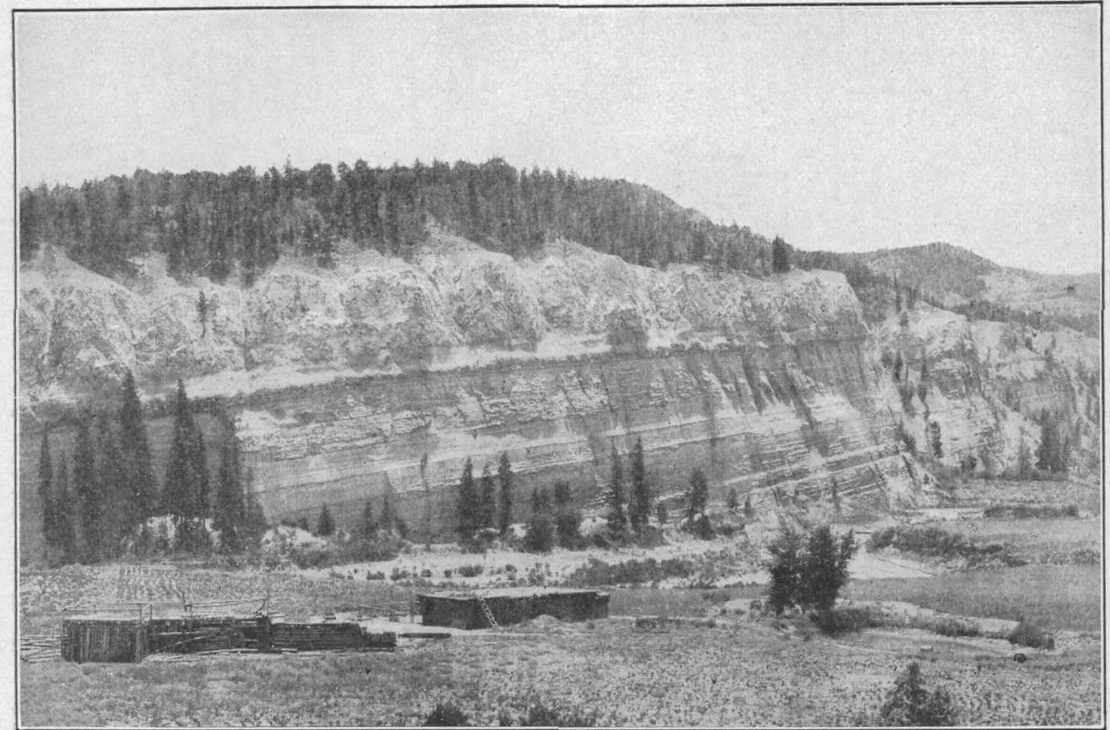

A. GYPSUM ON WINGATE SANDSTONE ON BANK OF GALLINA RIVER, 14 MILES NORTH-NORTHEAST OF GALLINA, N. MEX., LOOKING SOUTH-SOUTHWEST.

Photograph by N. H. Darton.

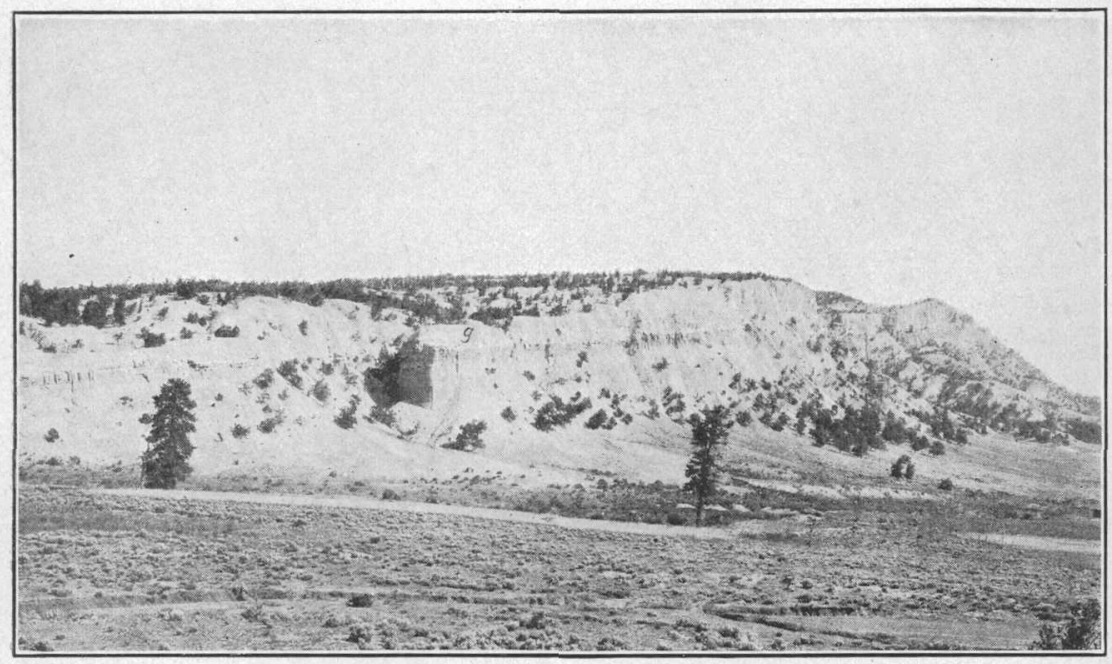

B. GYPSUM CAPPING CERRO BLANCO, 1 MILE NORTHWEST OF PLAZA OF GALLINA, N. MEX., LOOKING NORTH.

Photograph by N. H. Darton. 
Tertiary deposits. The thickness is about 80 feet, and although the beds dip eastward at moderate angles and the outcrop zone is narrow, there are many places where the deposit could be easily worked. At one or two places, notably at Tejon, the gypsum does not appear, probably on account of cover or a slight fault. The succession of rocks is shown in figure 31.

Tijeras Canyon.-The bed of gypsum described above reappears in the upper part of Tijeras Canyon, 15 miles east of Albuquerque,

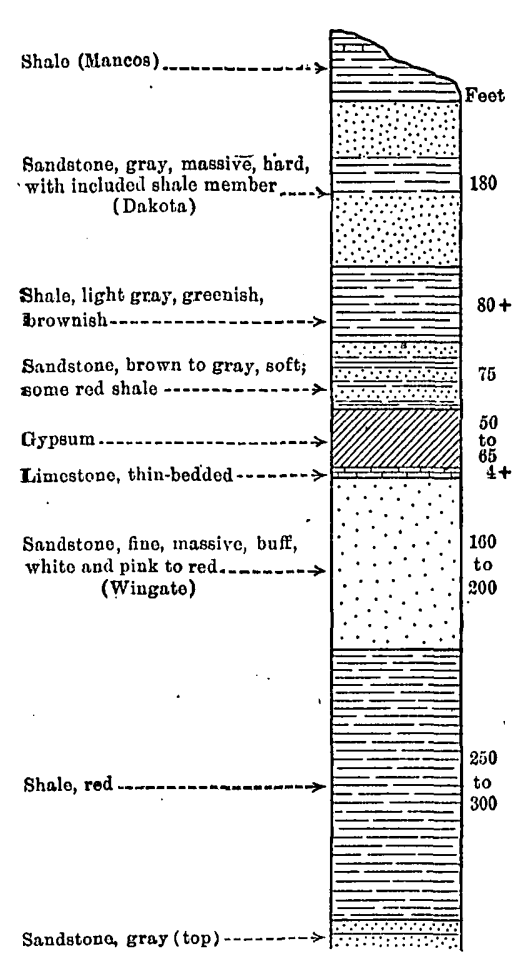

Figule 34.-Columnar section of rocks in Rio Chama-Gallinal region, N. Mex. where it is traceable for about 5 miles to faults, which cut it off at each end. Its structural relations in this area are shown in figure 32. The bed of gypsum is 60 feet thick. It lies on 3 feet of very thin bedded limestone, which caps massive finegrained sandstone (Wingate?) as in the region north and west. This exposure is the southernmost of these three beds.

Rio Chama-Gallina region--A thick bed of gypsum is exposed for many miles along the canyon of Chama River in Rio Arriba County and in the slopes of the high mesas extending north and south. To the west the exposures extend along the south side of Mesa Prieta to the Mexican plaza of Gallina and thence south along the west slope of the Sierra Nacimiento, as described on page 181. The outcrop is terminated to the east by the Santa $\dot{F}$ e marl, dropped by a great fault which crosses Rio Chama 4 miles northwest of Abiquiu. The outcrop and general structural relations are shown in figure 33 . The cross section shows that the gypsum bed passes laterally under the mesa and is revealed by the valleys cut below the old plateau surface. A typical exposure is shown in Plate XXI, $A$. In most of the area the beds lie nearly level, but on Gallina River, in the northwestern part of the outcrop, they present a sharp anticline, and west of Gallina they are upturned on the west slope of the Nacimiento uplift.

The success ion of rocks shown in the columnar section (fig. 34) is uniform throughout, but there are local variations in the thickness of the beds. The beds of gypsum, so far as observed, range 
in thickness from 50 to 65 feet. At Gallina the thickness is about 50 feet, but at most places it is 55 feet. The mineral is massive, pure white, and evidently of very high grade. Though most of

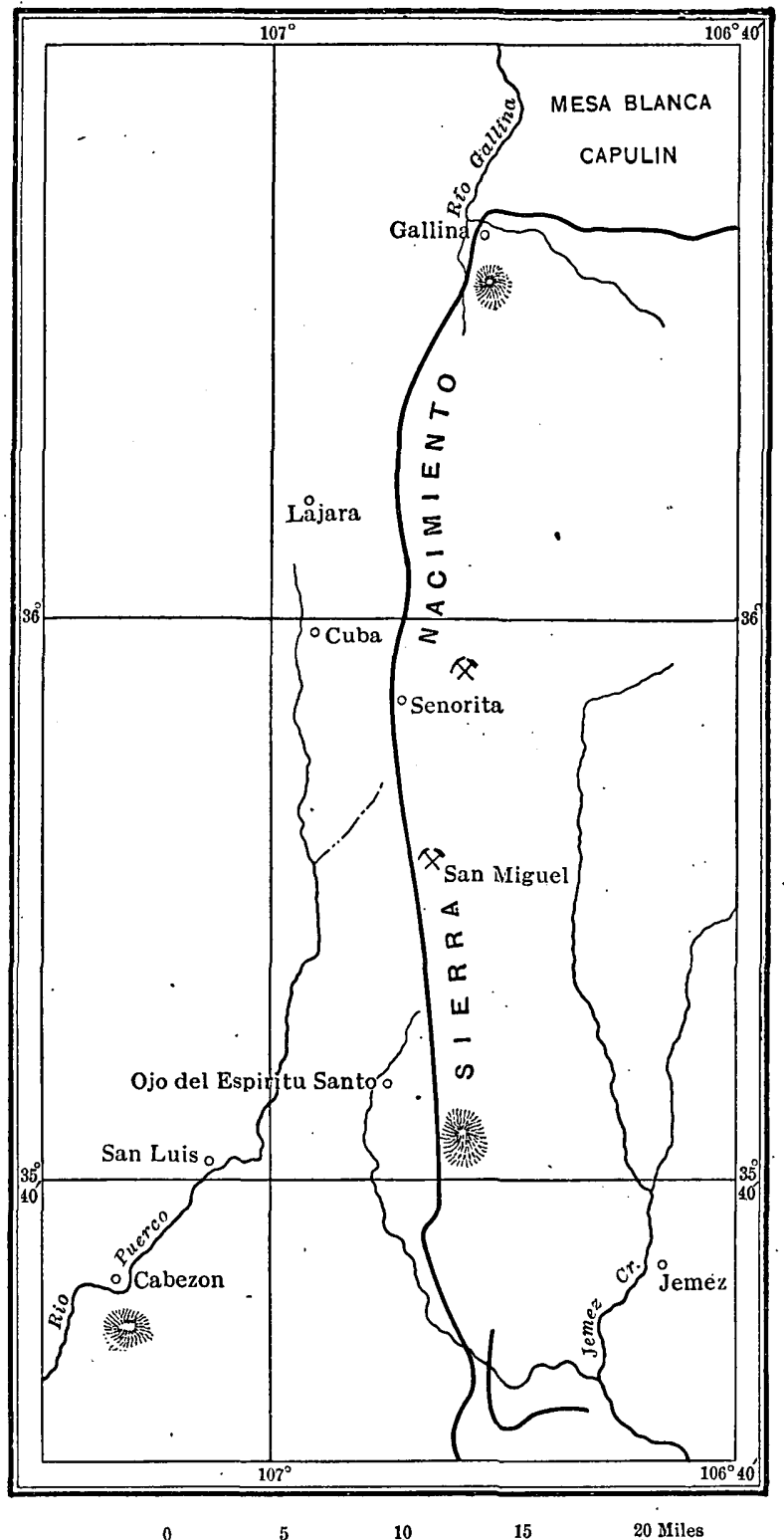

$2+1,5$

20 Miles

Figure 35.-Map showing outcrop of gypsum bed along the west side of the Nacimiento uplift from Rio Gallina to Rio Salado, Sandoval County, N. Mex. (After M. K. Shaler.)

the outcrops are in cliffs or steep slopes, in places the deposit spreads out in broad areas convenient for quarrying. The gypsum at Cerro Blanco (Pl. XXI, $B$ ) is an occurrence of this sort, the bed here hav- 
ing a long, gentle slope to the west. The gypsum has been worked in small amount for use at Gallina. Most of this region is in the Jemez and Carson forest reserves.

Nacimiento uplift.-From Gallina the outcrop of the great gypsum bed extends 45 miles nearly due south along the west slope of the Sierra Nacimiento. Its thickness ranges from 50 to 100 feet, the amount gradually increasing to the south. This area has been described by Shaler, 1 and the following facts are condensed from his statements. The beds dip steeply to the west and in places are vertical. The outcrop is almost continuous, but locally there is covering of talus or wash and Tertiary deposits. To the south the bed passes down the south side of the Rio Salado valley and is cut off by a fault as described on page 184. The map (fig. 35) shows the course of the outcrop and the section (fig. 36) shows the structure.

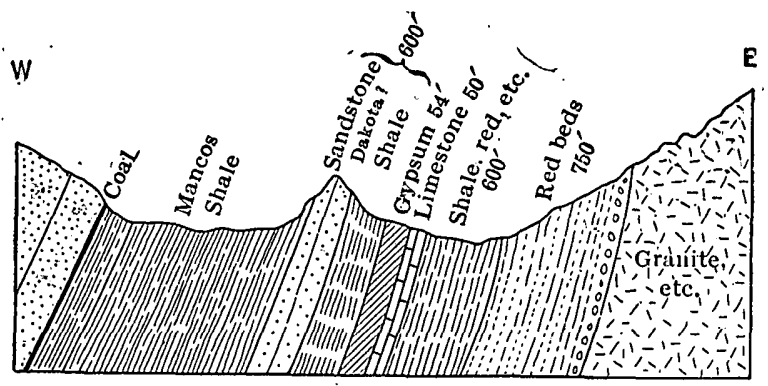

Frgure 36.--Sketch section at Senorito, N. Mex., showing relations of gypsum bed. (After data by Shaler.)

The sketch section (fig. 36) is at Senorito, where the gypsum bed is 54 feet thick and is underlain by 50 feet of white crystalline limestone which has been burned for lime. The gypsum outcrops extensively one-fourth of a mile west of the post office. Half a mile farther west the San Miguel Copper Co. has opened a 6-foot coal bed which parallels the gypsum outcrop for several miles, an association which may be important when the deposit is utilized.

In the slopes 3 miles west of the San Miguel mine the gypsum is 60 feet thick and dips nearly due west at an agle of $40^{\circ}$. The following section shows the succession of beds:

Section 3 miles west of San Mrigucl coppcr mine, Sandoval County, N. Mex.

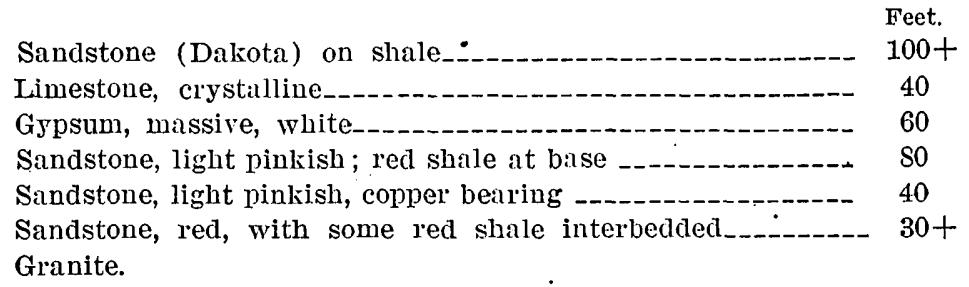

\footnotetext{
${ }^{-1}$ Shaler, M. K., Gypsum in northwestern New Mexico: U. S. Geol. Survey Bull. 315, pp. $260-265,1907$.
} 
This gypsum has been worked to a small extent at this place for local use.

A partial analysis of a surface sample of the gypsum from this locality by W. T. Schaller, of the U. S. Geological Survey, is as follows:

Analysis of gypsum from the deposit west of the San Miguel copper mine, Sandoval County, N. Mex.

Calcium oxide --.-- 34.24

Sulphur trioxide_-_-_-_-_-_-_-_-_-_- 46.61

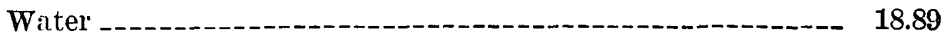

Insoluble residue_._.

Loss_._-

This analysis shows that the mineral is about 97 per cent pure, the remainder being mostly calcium carbonate.

South of the San Miguel mine the bed of gypsum continues to thicken gradually to a maximum of about 100 feet at a point about 3 miles southeast of Ojo del Espiritu Santo, or opposite Jemez Peak, beyond which it thins somewhat. At the place just mentioned the beds are tilted at an angle of $70^{\circ} \mathrm{W}$., but in a short distance from the foot of the mountain they flatten out, widening the outcrop greatly so that the gypsum is at or near the surface in an area of considerable extent. It is white and doubtless as pure as near San Miguel mine, described above. The gypsum is underlain by 250 feet of shales and soft sandstone not well exposed and 200 feet of red sandstone extending to the granite.

The gypsum outcrop extends south some distance along the valley of the Rio Salado to the Cabezon-Albuquerque wagon road, in the area shown on the west side of the map (fig. 37). At one locality there is a broad area in which the beds dip west-northwest at a low angle, and the gypsum is covered by shale which could be readily stripped. It is underlain by soft, massive yellow Wingate sandstone.

The gypsum in this region is too remote from transportation and nıarket to work, for it is 25 miles to Bernalillo, the nearest railroad station, and the long wagon haul is out of the question. If a railroad line goes through this region the deposit may be used if the demand is sufficient to pay freight. The great purity of the mineral and the presence of coal near by are advantageous.

Jemez region.-The outcrop of the bed of gypsum extends along the west side of the Nacimiento uplift and passes over the uplift where the axis of the fold pitches down at Rio Salado, a few miles southwest of Jemez Pueblo. The features at this place are shown on the map (fig. 37). The succession of rocks in this region is closely similar to the one presented in Gallina-Chama region, EI 
Rito, and Los Cerrillos. The gypsum lies on the massive Wingate sandstone and is overlain by shales of supposed Morrison age. Figure 38 shows the succession southwest of Jemez.

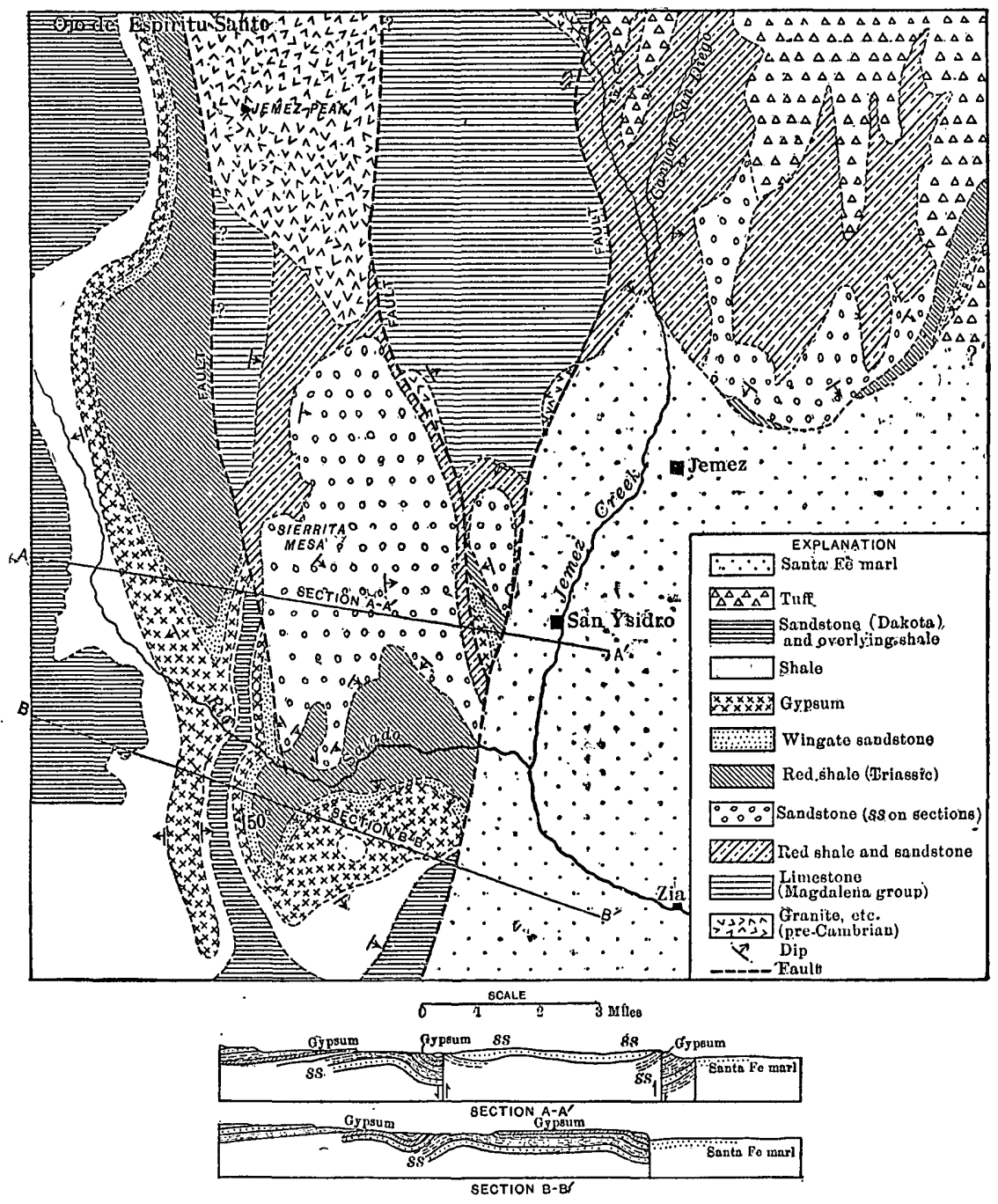

Figurn 37.-Map and sections of the south end of the Nacimiento uplift southwest of Jemez, N. Mex., showing outcrop and relations of gypsum bed.

In part of this area the gypsum extends along high slopes or caps buttes, as in the extensive area 3 or 4 miles southwest of San Ysidro (Pl. XXII, $A$ ), but farther up Rio Salado it extends down to lower lands and could be easily mined over a large area. Small wedge-shaped masses appear in slopes 4 miles northeast of Jemez and along the fault $1 \frac{1}{2}$ miles west of San Ysidro. The southern 
extension of this fault cuts off the gypsum 3 miles south-southwest of San Ysidro, and it does not appear again between that point and the San Jose Valley at Suwanee.

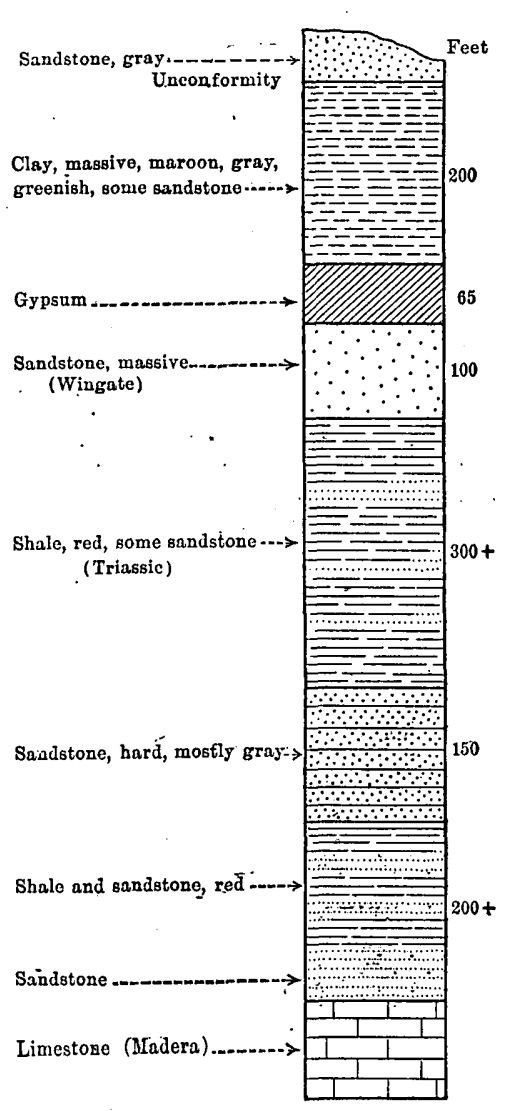

Figdre 38.-Section showing relations of gypsum bed southwest of Jemez, N. Mex.

the section (fig. 40) and the map (fig. 41 ), in which also are indicated other faults, along one of which the gypsum is uplifted for a short distance in the slope a half mile northeast of Suwanee.

DEPOSITS OF QUATERNARY AGE.

White sands.-In the bolson of Tularosa Desert, between the San Andres and Sacramento mountains, there are extensive deposits of wind-blown gypsum sand known as the white sands. These sands lie mainly in Otero County but extend a short distance into the east side of Dona Ana County. They extend 28 miles from north to south and range from
San Jose Valley.-A high cliff of gypsum extends along the north slope of the San Jose Valley in the vicinity of El Rito Pueblo near Rito siding on the Atchison, Topeka \& Santa Fe Railway. As shown in Plate XXII, $B$, it extends along the north side of the railroad track for some distance. The relations of this bed of gypsum to adjoining rocks are represented in the section (fig. 39).

This bed of gypsum crosses the San Jose Valley a short distance west of the pueblo but thins out a. few miles south of El Rito. On the north slope of the valley it gradually rises to the east and outcrops for 16 miles to a point 5 miles north of Suwanee, where a great northside, cuts off all the beds. The relations in this vicinity are shown in

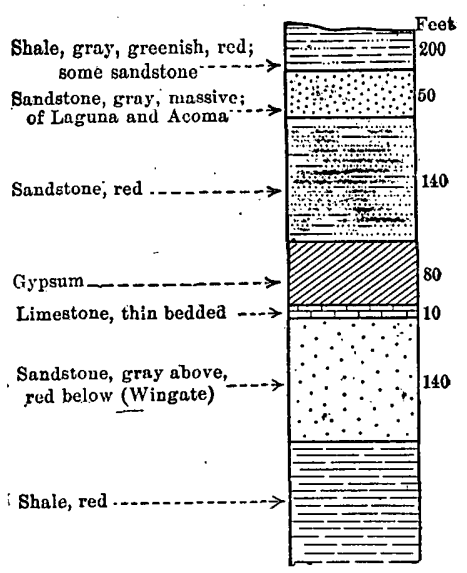

FIgdRE 39.-Section of rocks associated with gypsum bed at El Rito, N. Mex. south fault, which drops on the east 


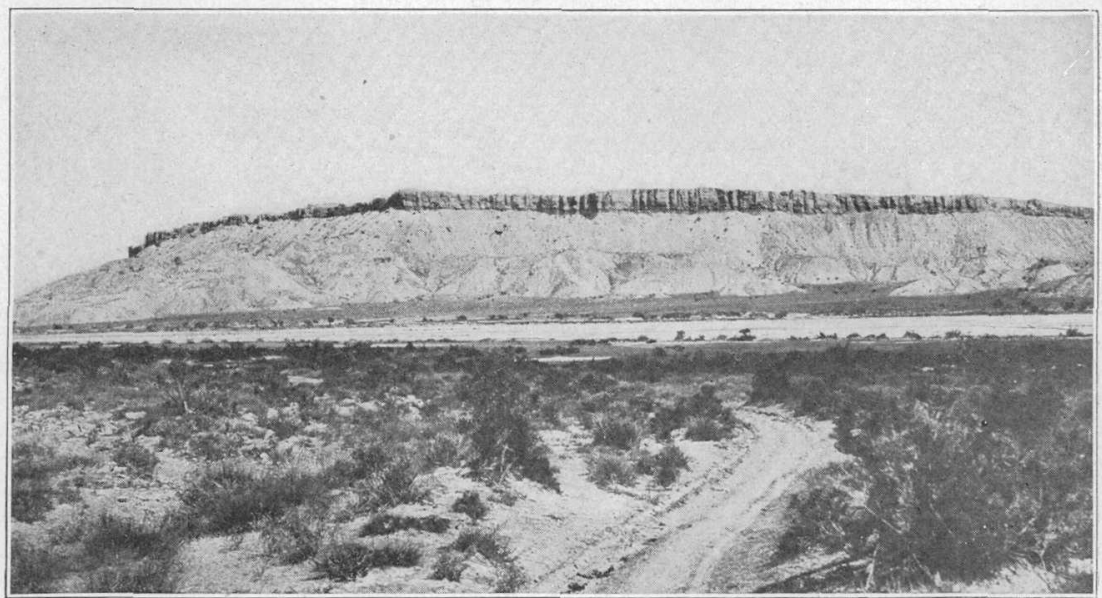

A. CLIFFS OF GYPSUM AT EDGE OF MESA 3 MILES SOUTHWEST OF SAN YSIDRO, N. MEX., LOOKING SOUTH, RIO SALADO IN MIDDLE GROUND.

The gypsum is underlain by soft massive sandstone (Wingate). Photograph by W. T. Lee.

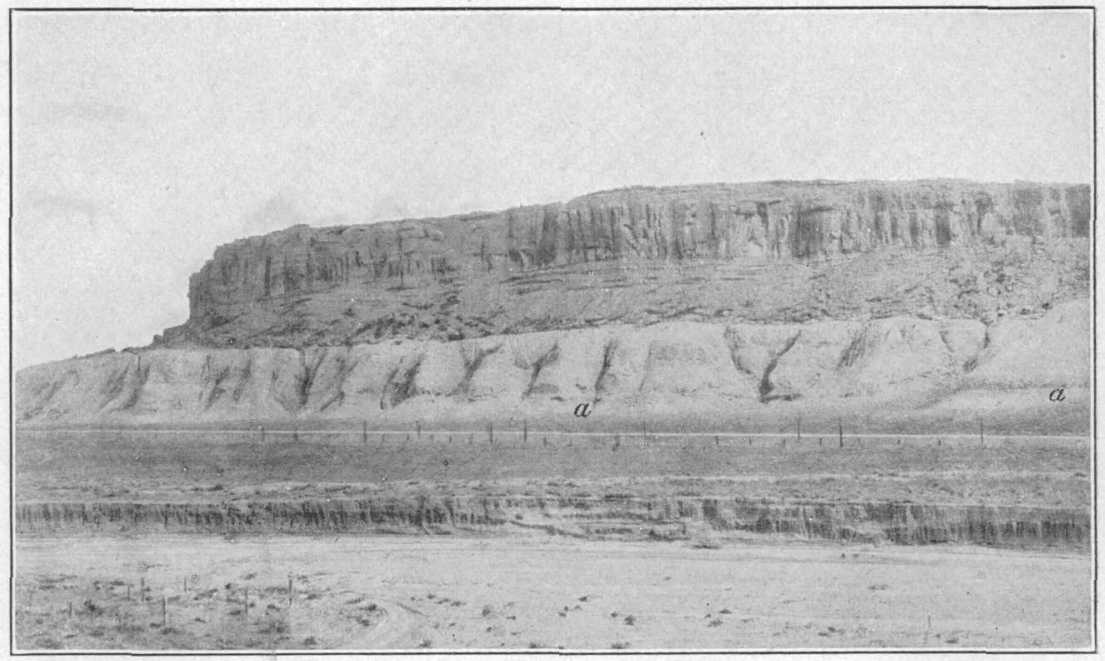

B. OUTCROP OF BED OF GYPSUM 50 FEET THICK ON NORTH BANK OF SAN JOSE RIVER OPPOSITE PUEBLO OF EL RITO, ON ATCHISON, TOPEKA \& SANTA FE RAILWAY, 63 MILES WEST OF ALBUQUERQUE, N. MEX., LOOKING NORTH.

Gypsum is overlain by bed of sandstone and underlain by thin limestone $(a-a)$. Photograph by N. H. Darton. 


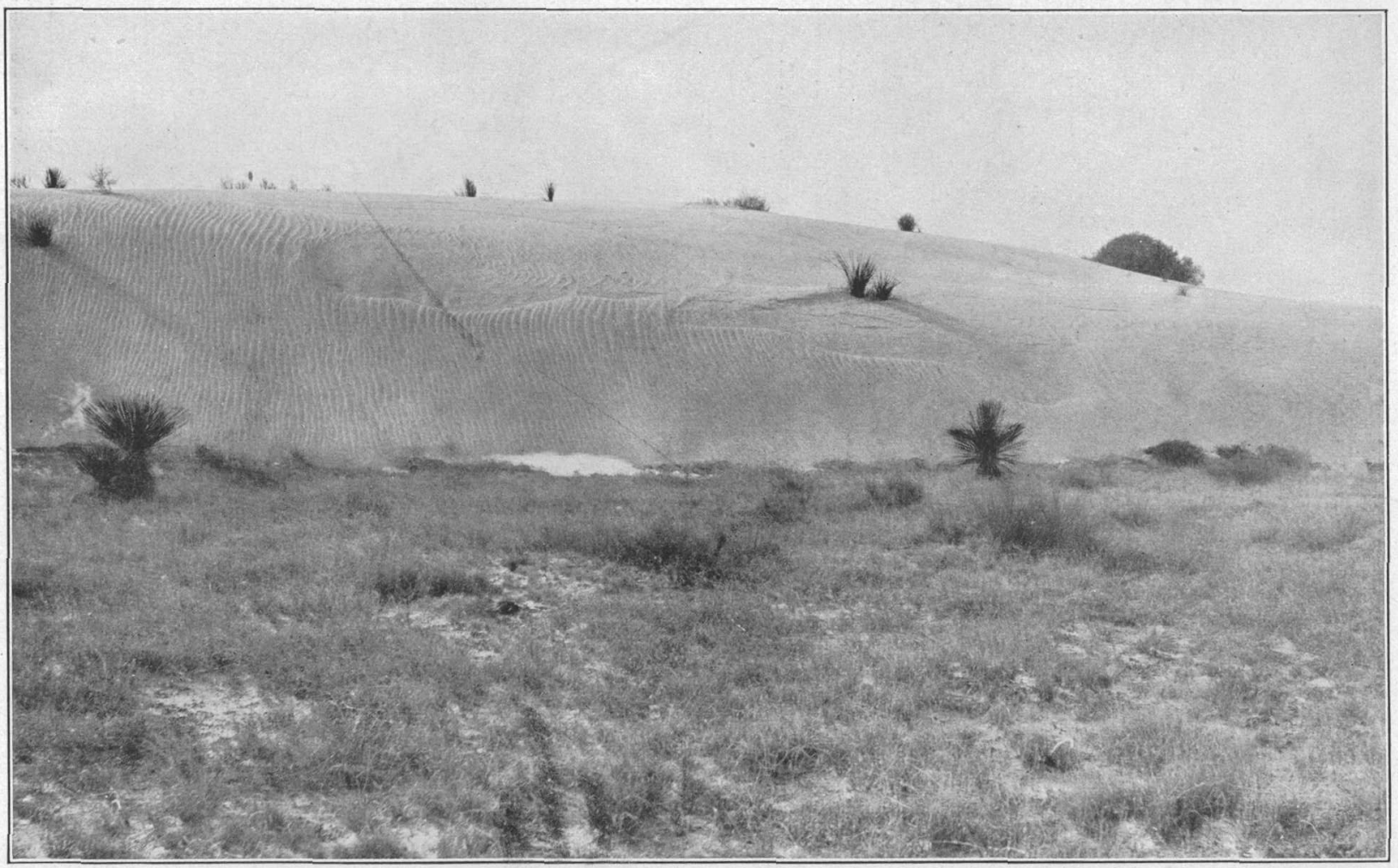

THE WHITE SANDS, WIND-BLOWN GYPSUM IN DESERT WEST OF TULAROSA, N. MEX. 
6 to 15 miles in width; they cover an area of about 270 square miles. Their eastern edge lies $11 \frac{1}{4}$ miles west of Alamogordo station. Most of the deposit is in dunes 10 to 30 feet high, the average thickness

W

$E$

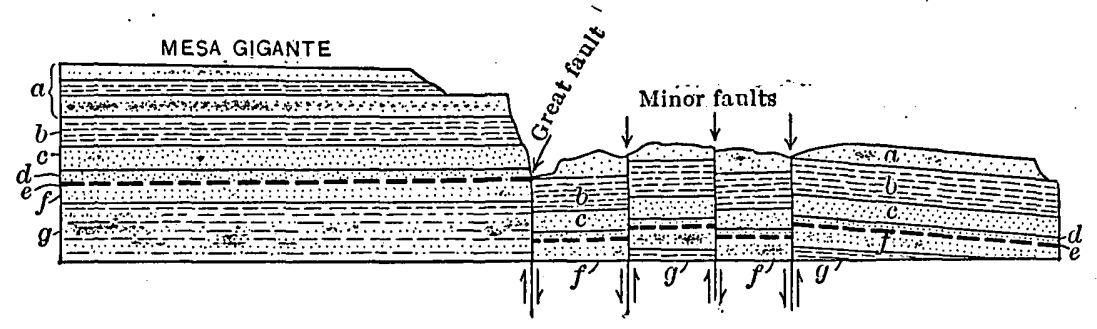

Figure 40.-Section along north side of San Jose Valley near Suwanee, N. Mex., showing relations of great gypsum bed in faulted blocks. Looking north. $a$, Dakota sandstone and overlying beds; $b$, shale; $c$, buff massive sandstone; $d$, red sandstone; $e$, gypsum on thin-bedded limestone; $f$, Massive pink sandstone (Wingate); $g$, red stale and sandstone (Triassic).

probably being nearly 20 feet. A large part of the material is snowwhite, resembling snowdrifts. In places a small amount of quartz sand is included. A typical view is given in Plate XXIII. The

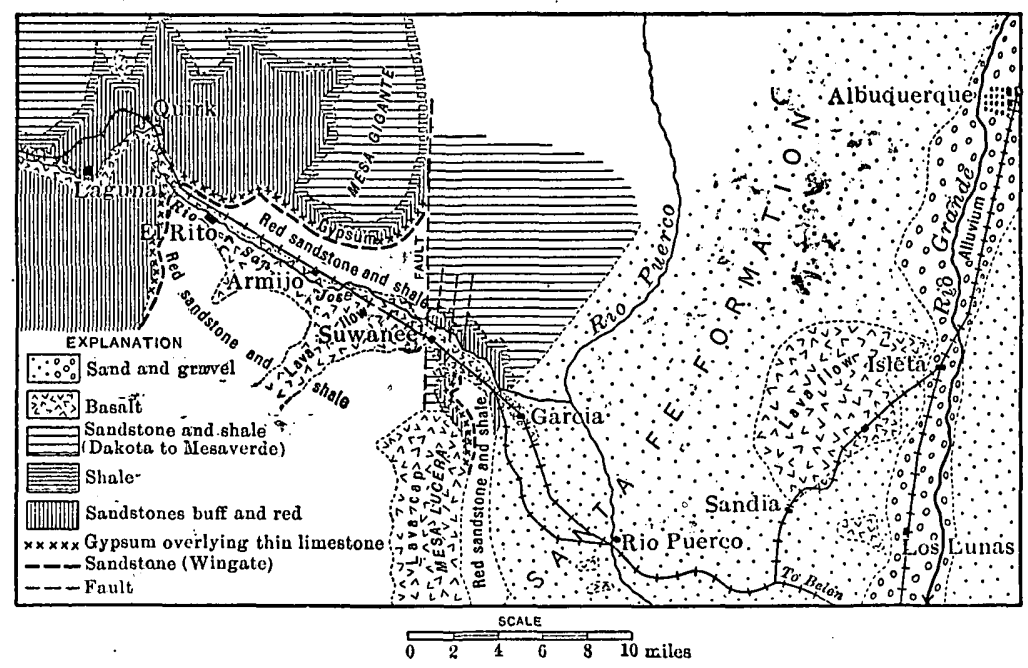

Figdre 41.-Map showing outcrop of gypsum bed in the San Jose Valley, N. Mex.

extent of the deposit in relation to county and township lines and other features is shown on the map (fig. 17, p. 165).

Some of this gypsum sand has been hauled to Alamogordo from time to time, but owing to the slight demand and the distance to the larger markets the industry is very small and intermittent.

The following two analyses of these sands have been published. 
Analyses of gypsum of the white sands, Otero County, N. Mex.

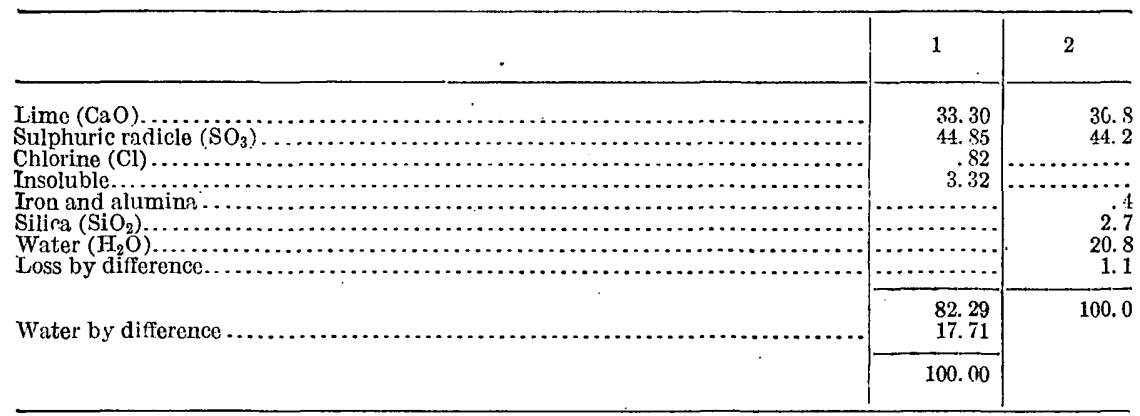

1. Arthur Gross, State chemist of Indiana, analyst. Brady, F. W., Mines and Minerals, vol. 25, pp. 529-530, 1905.

2. W. J. Gies, analyst. Mac.Dougal, D. T., Botanical features of North American deserts: Carnegie Inst. of Washington Pub. 99, p. 16, 1908.

Analysis No. 1 is believed to indicate that 96.43 per cent of gypsum is present, and No. 2, 95.8 per cent.

In a report on the Tularosa Basin, Meinzer says:

Gypsum underlies the southern part of the large alkali flat, all of the white sands area, and a section of the low desert plain extending southward to T. 22 S., Rs. 5 and 6 E., eastward to Dog Canyon and within a few miles of Alamogordo and Tularosa and northward to a point beyond Malpais Spring. It outcrops along most of the alkali flats in the outliers that project above the flats, in erosion remnants of the white sands, in the banks of the miclslope and low-level arroyos, in many open wells, in sink holes, and in the knolls and hummocks produced by sink holes and wind work throughout the gypseous portion of the desert plain. Its distribution is shown not only by outcrops and well sections but also by the existence of sink holes and hummocky topography. ${ }^{1}$

Some of the benches and low outlying buttes show gypsum horizontally bedded, "indicating deposition from concentrated waters of an ancient lake." Crystals more than a foot long are found at one locality.

Pinos Wells.-According to Meinzer ${ }^{2}$ there are deposits of gypsum sand in the Pinos Wells basin, in the southeastern part of Torrance County. They are similar to the white sands but of much less extent, and though in places the sand is pure, much of it is mixed with fine clay. No facts are available as to its extent or availability for plaster manufacture. The locality is about 10 miles west of Duran, on the Chicago, Rock Island \& Pacific Railway, and 15 miles southwest of Encino, on the cut-off of the Atchison, Topeka \& Santa Fe Railway.

1 Meinzer, O. I., Geology and water resources of Tularosa, N. Mex.: U. S. Geol. Survey Water-Supply Paper 343, p. 69, 1915.

2 Meinzer, O. E., Geology and water resources of the Estancia Valley, N. Mex., with notes on adjacent portions of central New Mexico: U. S. Geol. Survey Water-Supply Paper 275, p. 83, 1911. 


\section{NEW YORK.}

By D. H. Newland and Henty Ietghton.

\section{HISTORY OF THE GYPSUM INDUSTRY IN NEW YORK.}

Gypsum has been mined in New York for more than a century. The present development of the industry dates back, however, about two decades. During this period the production has grown to many times its former proportions, and from a relatively insignificant position the State has advanced into prominence with regard to both the mining and manufacture of gypsum. The basis of this progress is supplied by great natural resources combined with unexcelled market advantages.

The discovery of the gypsum deposits must have been practically coincident with the first permanent settlement of central and western New York, which followed close upon the termination of the War of the Revolution. The earliest mention that is still a matter of record relates to an occurrence on lot 9.0, Camillus Township, Onondaga County, said to have been discovered by W. Lyndsay in 1792 . In 1808 a stock company was organized to exploit this deposit for land plaster. The beds in Sullivan Township, Madison County, were worked during the War of 1812, and the output was shipped to Hudson River and as far away as Philadelphia. It appears that gypsum was quarried at Union Springs as early as 1811, and by 1822 several thousand tons are reported to have been shipped each year from that place to Pennsylvania. The sole use of the product was for agricultural plaster.

At the time of the first geologic survey (1836-1841) the quarrying of gypsum was actively pursued along the belt of Salina strata from Madison to Genesee counties. The reports of that survey mention operative quarries in the towns of Wheatland, Leroy, Seneca Falls, Union Springs, Phelps, Manlius, Camillus, and Sullivan; and their output was then nearly as large probably as at any time in the succeeding 50 years.

Though the deposits were under active exploitation long before those of Michigan, Ohio, and the Central States had become productive, they have played little part in the development of the trade in calcined plasters or their technology. It was only after this branch of the industry had become firmly established in other parts of the country and American practice had become fairly perfected that the local deposits began to receive attention as a source of material for calcined plaster. The first production of plaster of Paris was reported in 1892 and amounted to 75 tons. With the successful issue of the early undertakings the natural advantages of 
the State for manufacture and marketing contributed a powerful impetus to this branch of the business, which is now the most important of all.

Though the production for the years previous to 1889 can not be stated definitely, it is estimated that the aggregate output since the beginning of the industry in the State has been more than $9,000,000$ tons: The production probably did not average over 10,000 tons a year previous to the opening of the Erie Canal, for until then the facilities for shipment were small. From the year of its opening (1826) until 1889 the average was probably about 35,000 tons. For the period 1810-1888 the production may be estimated accordingly at 2,400,000 tons, and the actual output in the period 1889-1918 has been $7,226,135$ tons. The combined total in round numbers is $9,626,000$ tons

\section{METHOD OF MINING.}

The extraction of gypsum by open cutting is necessarily confined to the eastern and central areas. The pocket deposits are worked only in a small way after the simple methods of early days. More systematic operations are carried on in connection with the rock gypsum of Onondaga and Cayuga counties. The beds are exposed along the sides of hills with a thickness of 20 to 60 feet. The quarries at Lyndon, Jamesville, and Union Springs are opened on such natural exposures. The overlying limestones and drift are stripped off or allowed to fall into the excavation left by the removal of the gypsum. As the work advances into the hill an increasing amount of overburden is encountered and in the course of time this becomes a serious problem, necessitating a change to underground mining or the abandonment of work altogether. There are many abandoned quarries around Fayetteville. At Union Springs the drift covering is stripped by steam shovels, and the material is loaded on cars for removal to a dump. The breaking of the gypsum rock is effected by drilling and blasting with black powder or dynamite.

In the western area the gypsum is mined underground, and this practice has also been introduced recently in some of the quarries around Fayetteville to obviate the handling of the overburden. Entrance to the workings is through an adit where the gypsum approaches sufficiently near the surface; otherwise a vertical shaft is used.

The main adits which serve for haulage are driven from 5 to 8 feet high and from 6 to 10 feet wide. The larger dimensions refer to the mines near Jamesville, where the gypsum is excavated in large rooms and removed by two-horse wagons that are loaded directly at the working face. In thin beds the rock is hauled 
out on mine cars attached to a cable. A foot or so of the floor rock may be removed to provide the necessary head room, but this is generally unnecessary. The maximum size of the rooms is 30 feet square. The overlying limestone makes a firm roof, and little support is needed in addition to that given by the pillars; timbering or backing is only. rarely necessary.

The mines at Akron and Oakfield, as well as those of the Consolidated Wheatland Co. at Wheatland, and the Garbutt Gypsum Co., at Garbutt are entered through vertical shafts from 50 to 70 feet deep. The shafts have either two or three compartments, one of which serves for a ladder and airway. The underground workings follow the room and pillar system but are more regularly planned than those of the adit mines and are based on accurate surveys. The mines are electrically lighted, ventilated by forced draft, and when necessary are drained by pumps, which raise the water from a sump at the shaft bottom. Electricity and steam are used for power. Electric locomotives have been introduced in one or two mines for underground haulage, but in others the cars are either pushed by hand or drawn by mules. The hoisting is accomplished in different ways. At the Garbutt mine a derrick and boom raised the rock, which was loaded into a metal scoop. The American Gypsum Co. has installed at Akron a bucket elevator. Single and balanced platform hoists, which raise the gypsum in the mine cars, are most generally employed.

The rock is broken by drilling and blasting. Auger drills are used in some mines and percussion drills in others, the former being employed where the rock is sufficiently soft. With hard or tough rock they are apt to become heated and to bind in the holes. Some companies prefer to let the mining on contract, but others maintain the wage system. The miners represent many nationalities but are mainly from southern Europe. A few Indians from the New York reservations are employed in the western district.

The mines are usually connected with the milling plants by tracks. In the Fayetteville district, however, the rock is hauled in wagons. Much of the output of this section is shipped in lumps or ground form to cement and plaster mills outside the district.

\section{GENERAI GEOLOGY.}

AGE AND DISTRIBUTION OF THE GYPSUM DEPOSITS.

The workable gypsum deposits occur only in the Salina formation of the Silurian system. The Salina includes also the rock-salt beds of the State and is the equivalent practically of the "Onondaga salt group," as described in the early reports by Hall and Vanuxem. 
The Salina strata occupy two main areas within the State. The. larger area, and the more important one economically, is represented by a belt that extends uninterruptedly from Albany County on the east through central and western New York to Niagara River and thence into the Province of Ontario. Its approximate limits are shown on the map (fig. 42).

The belt terminates within or near the town of Knox, Albany County, by the thinning out of the strata; which in this part consist of only a few feet of shale. From Albany County westward the Salina beds follow the range of hills that borders the Mohawk Valley

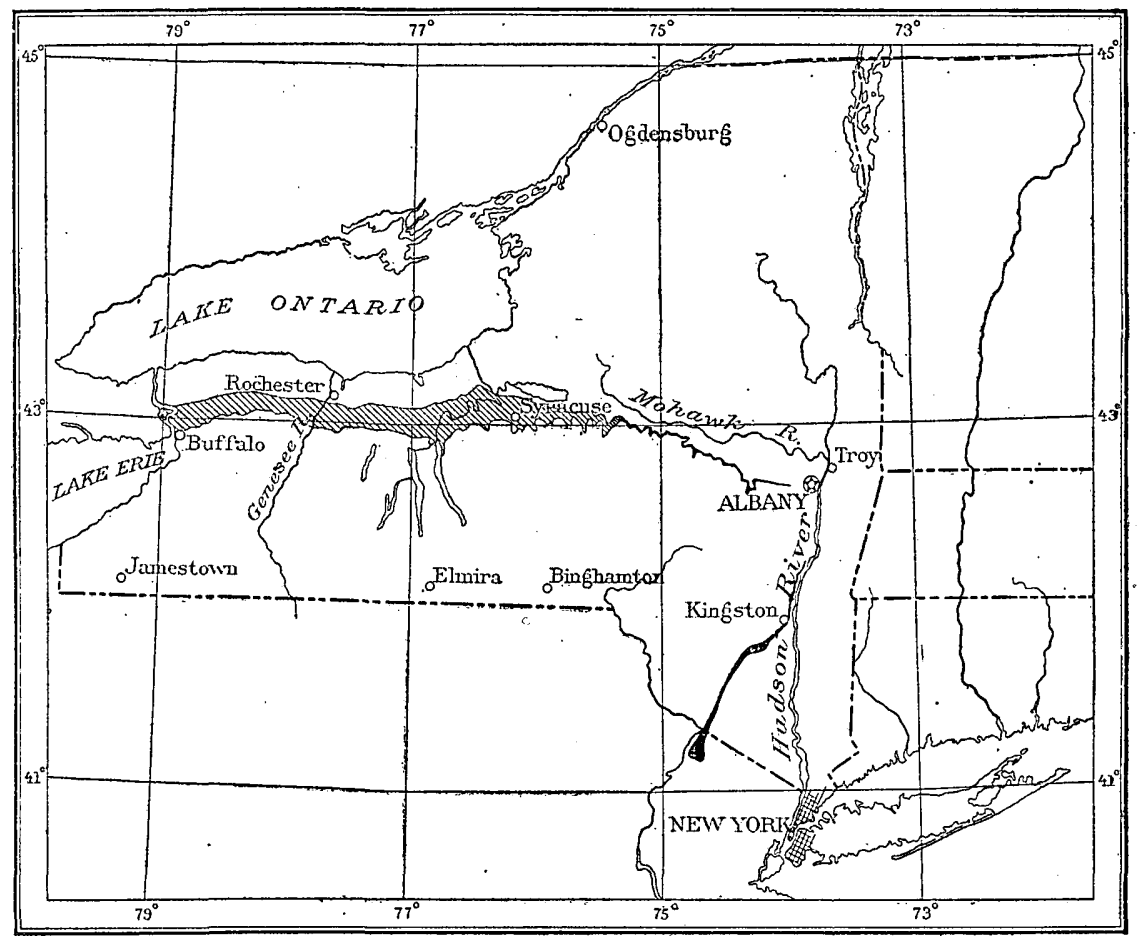

FIGURE 42.-Map of New York showing distribution of Salina formation. The area described in this report is indicated by the shaded section.

on the south, their outcrop being at first well up the slopes and at a distance of about 15 miles from the river itself. They parallel the Mohawk as far as Oneida County, where, owing to increased thickness of the members and the flatter topography, they begin to spread out so as to occupy a surface from 1 to 3 miles wide. Their course thus far is sinuous, owing to the numerous deep north and south valleys tributary to the Mohawk, which produce long upstream deflections. Beyond Oneida County their outcrop broadens greatly in a short distance; it is about 12 miles wide at the west end of Oneida Lake and fully 20 miles on the line of Cayuga Lake, where it attains 
the maximum width for the State. The outcrop in western New York is more regular, maintaining an average of 7 to 10 miles and running almost in a straight line parallel to the shore of Lake Ontario.

The Salina of this area is mainly a shale formation. The other elements are gypsum, which occurs in the upper shale beds; salt, near the middle of the section; and an impure limestone, which forms a thin capping to the shale in the central and western parts and discontinuous bands within the shale itself. The great mass of shale, except for a few feet at the base, is devoid of fossils.

The second area within which the Salina beds appear is in southeastern New York, and here they show a quite different development. They are found in two principal belts, one of which begins in Ulster County near the Hudson and follows the Shawangunk Mountain uplift in a southwesterly direction across the State line into New Jersey; the other is in Orange County, beginning near Cornwall and running parallel to the first along the Skunnemunk Ridge.

The main members of the Salina here are conglomerate at the base, overlain by shale and sandstone, with some limestone at the top. The shales have a thickness of several hundreds of feet, so as to predominate over the other members. They are reddish and pyritic and in places graduate upward into sandstone. With their exception, the strata of the region present a coarser phase of sedimentation than that inherent in the Salina of central and western New York.

It is highly improbable that any valuable deposits of gypsum occur in Ulster County, where conglomerates and sandstones are the prevailing strata. If present at all, they will be found in the extreme southern part near the New Jersey border, in association with the shales, which are here much thicker and even become the predominant member of the series. None, however, has been discovered.

STRATIGRAPHY OF THE SALINA TORMATION.

General relations.-The Salina formation as developed in central New York is divisible into five members. These members are in few places sharply delimited by physical features, and owing to the scarcity of fossils throughout the beds their demarcation on the map is possible only in a general way. They are usually connected by zones of gradation, though in some places the transition from one member to another is marked by a sequence of alternating layers. The alternating layers, for example, occur in the passage from the water lime that caps the formation to the underlying shale.

The full series is found only in the part of the belt that lies west of Madison County. To the east they overlap upon the lower for- 


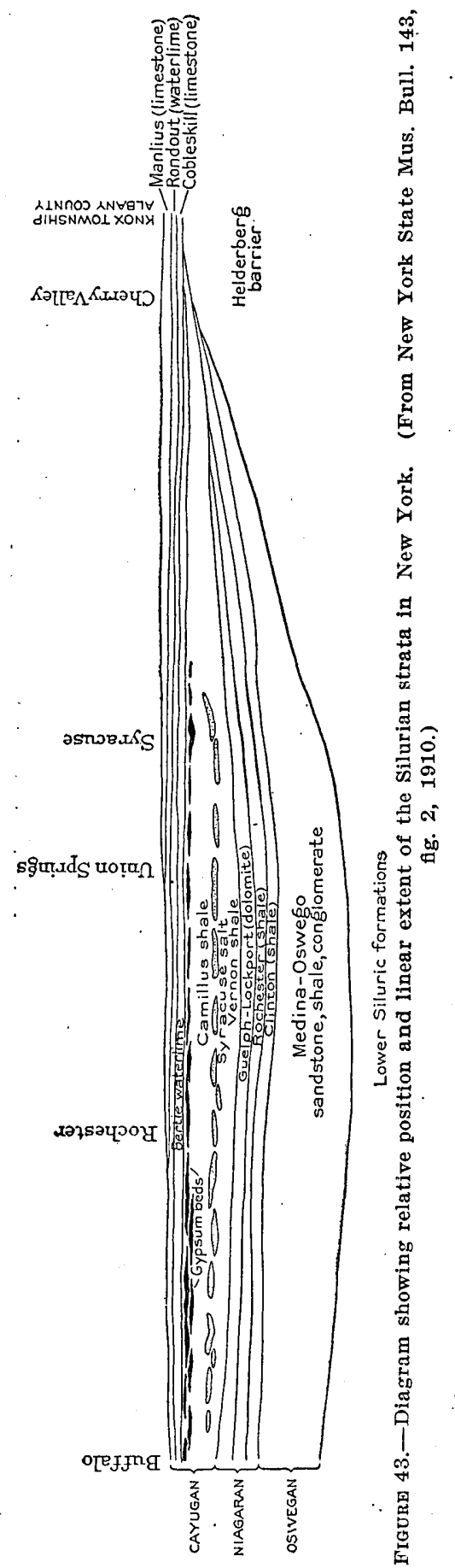

mations and gradually thin out and disappear. The general relations of the members are shown in figure 43.

Bertie limestone member.-The Bertie limestone member is an argillaceous, more or less magnesian limestone which forms the top member of the Salina formation. It is a persistent division of quite uniform character. It extends from the Province of . Ontario, where the type locality is found, eastward as far as Schoharie County. In field exploration it serves as a very useful indicator, for the main gypsum beds are usually not far below it in the shales.

As a rule the limestone contains numerous small cavities, which may so abound as to lend the appearance of a porous lava or slag. The cavities or cells are rounded or irregular in shape; some of them are elongated like worm tubes; and many are lined with a calcareous deposit.

The limestone possesses hydraulic properties and has been burned for hydraulic cement. Its thickness ranges from 60 feet in Canada and 50 feet in Erie County to 10 feet or less in eastern New York.

Camillus shale member.-Underneath the Bertie limestone occurs the Camillus shale, which includes a considerable thickness of soft shale, containing intercalated layers of magnesian limestone. The workable gypsum beds are found in this shale at different horizons,

but mainly near the top. The color of the shales is commonly drab or gray but it varies to olive-green and in places to red. 
The thickness of the shale, together with the gypsum beds, averages perhaps 300 feet in the central part of the State.

The gypsum deposits are seamed more or less with shale which divides them into separate beds, though there is little regularity in. the number or thickness of the beds from place to place. The shale intercalations range all the way from mere films to layers several feet thick. Though the main body of gypsum is usually found near the top of the Camillus shale, in some places directly beneath the water lime there are nodules, veins, and layers of gypsum distributed all through the mass.

Syracuse salt member.-The Syracuse salt member is a variable body of alternating beds of rock salt and shale, which occupies a position between the Camillus and the Vernon shales.

From the records of deep wells, the salt horizon is recognizable in the Salina from Madison County westward to Erie County.

Vernon shale member.-The thickest member of the Salina formation is the Vernon shale. It is a soft shale which, as a rule, can be distinguished by its deep-red color from the shales above the salt horizon. The strong ferric-oxide color is particularly prevalent in the eastern section, where the beds can be traced across the country by the red greasy clays that result from their decomposition. In the western part they are banded with greenish and grayish layers and bear some resemblance to the shales of the Medinal. group. They are exposed from Herkimer County westward across Oneida, Madison, Onondaga, and Cayuga counties but beyond Genesee River are generally buried under the drift, and as their color is no longer uniform their line of outcrop is not so readily determined in that part. Thin layers of limestone also appear in the western counties, as shown in well sections.

The thickness of the Vernon shale reaches a maximum in Onondaga and Cayuga counties, where it probably averages about 500 feet. At Syracuse the salt-well section shows 525 feet. Toward the east the shale thins rather abruptly and apparently disappears entirely in Herkimer County. Westward its thickness also diminishes, but from the information afforded by the few wells that have penetrated the Salina the shale seems to persist as far as Genesee County at least.

Pittsford shate member.-In a few localities the base of the Salina formation is marked by a bed of dark shale, the Pittsford shale, which rests upon the Lockport dolomite.

GENERAL STRUCTURE OF THE SALINA FORMATION.

The Salina strata, which outcrop from Albany County to Niagara River, have been little disturbed since their emergence from the sea. 
They are nowhere involved in local folds, and if at all faulted the displacement must be so slight as to escape general observation. They dip uniformly toward the soutla, the direction ranging from due south to a few degrees east or west of south.

Within the central and western parts their inclination averages about 40 or 50 feet to the mile, or roundly 1 foot in 100 feet. This dip is probably no more than the slope of the sea floor on which they were laid down. In the eastern section the dip is somewhat higher. The main part of the belt has the structure of a broad, shallow syncline with an axis running north and south and with its eastern wing rising well above the western.

\section{NATURE OF THE GYPSUM DEPOSITS.}

The gypsum forms regularly stratified beds, which are usually heavy and range from several inches to 5 feet or more in thickness. The impure argillaceous gypsum is, however, rather thinly bedded, the individual layers being separated by shale intercalations. The strata are not, of course, absolutely continuous along the Salina belt but have the shape of elongated lenses which succeed each other along the strike and dip, perhaps after intervals occupied only by the accompanying shale and limestone. The workable deposits are thus separated into more or less well-defined areas, on the borders of which the gypsum diminishes or entirely disappears, and considerable intervals may occur between adjacent areas that are barren of minable rock.

The lenticular form of the deposits is well illustrated by the area near Akron, which has been fairly well delimited by exploration underground and by numerous test holes. (See fig. 46.) The bed averages about 4 feet thick and extends for nearly 2 miles from east to west before it thins out. On the north or outcrop side it apparently diminishes very slightly and then terminates abruptly, a feature which is due probably to removal of the gypsum by erosion. The extension of the bed.on the dip has not been thoroughly explored, though the available evidences indicate a gradual thinning in that direction.

\section{LOCALITIES.}

FIERKIMER COUNTY.

The most easterly occurrence of gypsum that was ever worked commercially is a deposit in southeastern Herkimer County. It was discovered previous to 1837 in an adit run into the hillside on the James Crill farm in the western part of Starke Township. The gypsum is said to have been found in a roundish mass and to have had a white color. About 20 or 30 tons were removed by Mr. Crill. 
It seems probable that the deposit, which lies in a white sandstone of Clinton age, is of secondary character, derived from scattered inclusions of gypsum in the Camillus shale above.

\section{ONEIDA COUNTT.}

The shales of the Salina formation have a small areal distribution in Oneida County, and there are no records to show that gypsum has ever been worked within its limits, though the occurrence of small deposits seems very likely, especially toward the western boundary of the county, in Vernon, Augusta, and Kirkland townships.

\section{MADISON COUNTY.}

The gypsum beds of Madison County, so far as known, all lie near the upper or southern part of the Salina outcrop in a belt running east and west across the northern portion of the county.

The gypsum occurs in the form of lenses, pockets, or irregular masses in the shales of the upper part of the Salina, in many places immediately underlying beds of water lime. The pockets are rarely very extensive, few of them exceeding 25 feet in length and 10 or 20 feet in depth.

The gypsum consists of a mixture of clear selenite plates and a dark, loose, earthy mass, consisting of clay and organic material.

The quarrying and grinding of gypsum for agricultural uses have been carried on in the county from early times. In the first part of the nineteenth century it was a much more important industry than now. Quarries were then in operation along Cowaselon Creek in the town of Lincoln (formerly Lenox); on Clockville Creek; south of Chittenango, between Sullivan and Clockville; and the old Sullivan bed, to the east and north of Chittenango, which was worked during the Revolution and its plaster shipped as far as Philadelphia. In recent years pockets of gypsum have been quarried and milled intermittently at Hobokenville and about 1 mile south of Cottons.

The gypsum at Clockville is as favorably situated as any in the county for extraction and shipment. The bed, about 100 feet long and 5 to 7 feet thick, outcrops along the Lehigh Valley Railroad about one-fourth mile northeast of the Clockville station, 200 feet north of the railroad bridge crossing the creek. Another bed outcrops just south of the bridge, and the surrounding hills contain numerous other deposits. The gypsum is the typical friable admixture of selenite and impure gypseous clay. It is underlain by shales and overlain by clay. It averages about 70 to 75 per cent gypsum and can be easily and cheaply mined and loaded directly on cars. 
About 5 miles farther west are gypsum beds of similar character and also easily accessible. Other deposits are found near the Erie Canal, such as those between Chittenango and Sullivan. They are in many places very heavily topped with a shale and limestone cap, which must be stripped in quarrying, as it appears to be too badly broken up to allow tunneling.

Owing to their somewhat irregular character and to their relatively low percentage of gypsum, the more inaccessible deposits in this region have little present value, and even the more favorably situated and larger lenses are of little utility.

ONONDAGA COUNTY.

Geology.-The Salina outcrops in Onondaga County in an eastwest belt ranging in width from 10 to 12 miles. The gypsum-bearing Camillus shale occupies a belt $2 \frac{1}{2}$ to 3 miles in width and is bounded on the south by the ridge which is a prolongation of the Helderberg escarpment. It also extends in long tongues to the south through the escarpment in the valleys of Limestone, Butternut, Onondaga, Marcellus, and Skaneateles creeks. The gypsum series consists of gray, drab, or mottled shales with interstratified layers of finegrained dolomite and contains many thick beds of grayish to black gypsum and gypsiferous shale. The gypsum beds seem to be most persistent where overlain by the escarpment of the Bertie, Cobleskill, Manlius, and Onondaga limestones and for this reason are found mainly in the low hills capped by these limestones and along the stream valleys cutting through the escarpment.

The beds of massive gray gypsum occur beneath small hills between Fayetteville and Jamesville. (See fig. 44.) The first area is a group of wooded hills ranging in height from 40 to 100 feet. These lie 2 miles southwest of Fayetteville and 1 mile south of Lyndon, a station on the trolley line. They are capped by Helderberg limestone, and the gypsum outcrop forms a belt around each hill.

Clifford Miller quarmy.-This quarry is situated three-fourths of a mile directly south of Lyndon, to the east of the road. It has been worked from early times. The gypsum bed is about 60 feet thick and consists of a number of alternating layers, varying in purity, color, and grain, the individual layers having local names such as the "cap rock," the "9-foot," the "11-foot," etc. They range in color from very light drab in the cap rock to dark or almost black, and in places have a brownish color from the presence of iron. Despite its varied appearance the rock runs rather uniform in gypsum, and no attempt is made to sort the material in the quarry operations. (See Pl. XXIV, B.)

The gypsum here is overlain by 2 feet of marlite or weathered shale, followed by 5 feet of thinly bedded blue limestones (Bertie), 


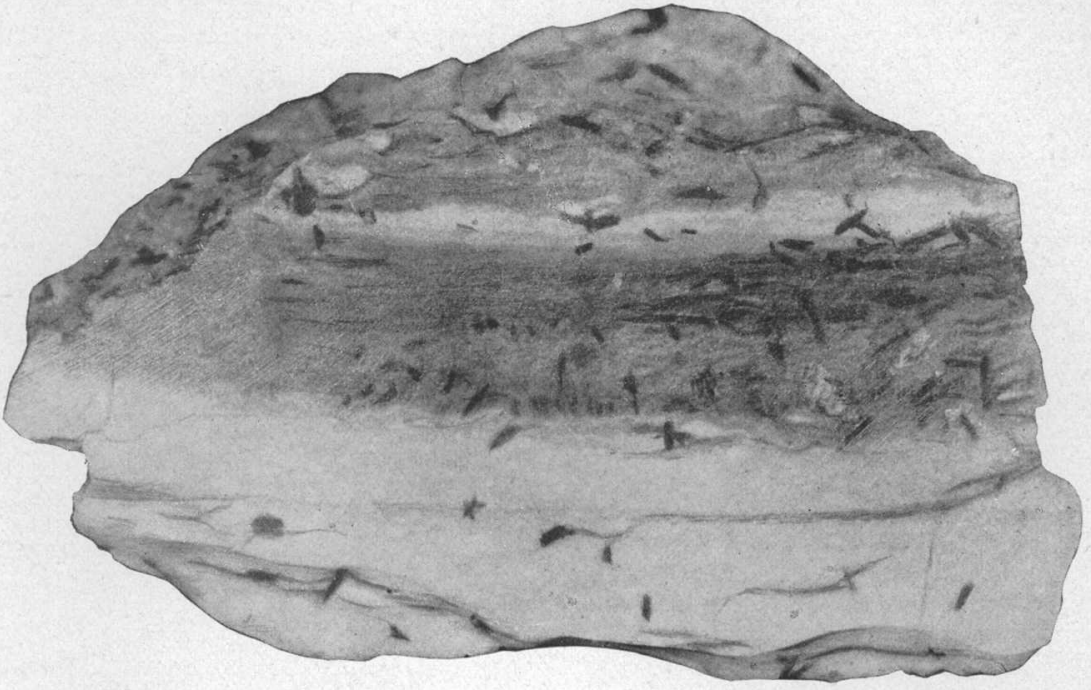

A. ROCK GYPSUM SHOWING BANDING AND SELENITE CRYSTALS, AKRON, N. Y.

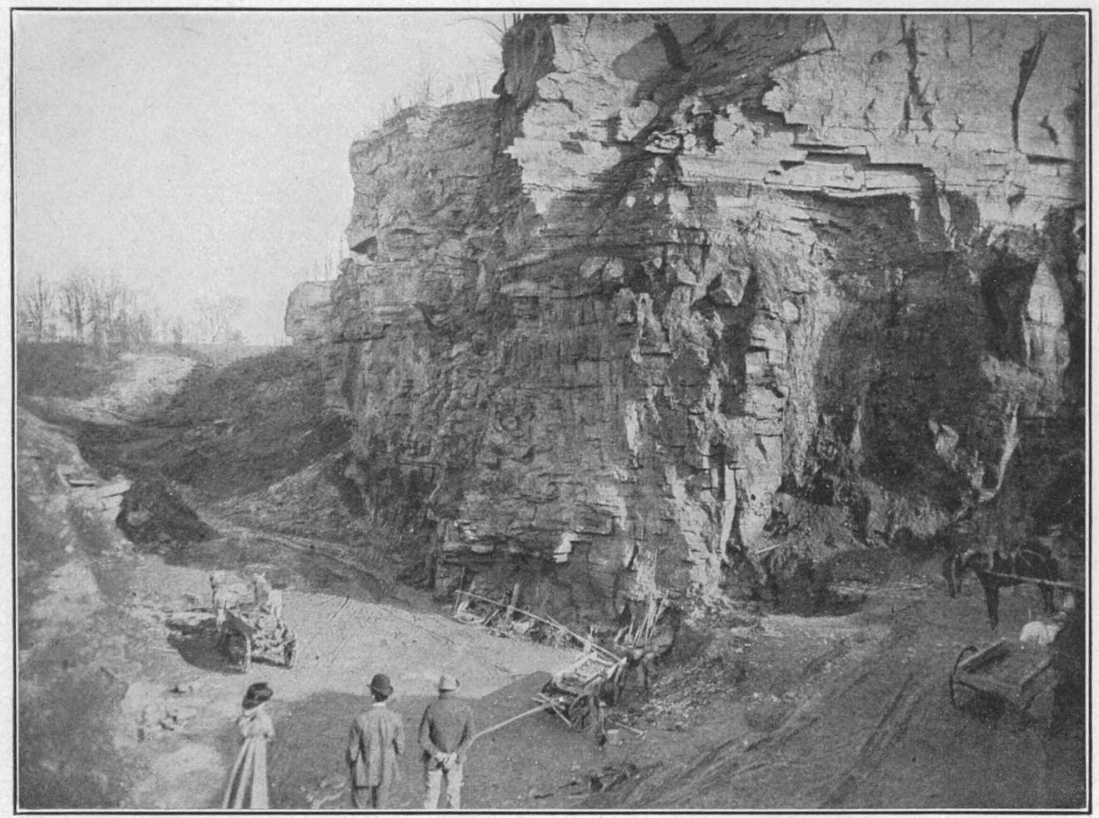

B. GYPSUM QUARRY NEAR LYNDON, ONONDAGA COUNTY, N. Y. 
then 15 or 20 feet of massive porous Cobleskill limestone with many small cavities. A varying thickness of glacial drift and soil caps the whole. The heavy mass of overburden becomes more troublesome as the quariry is carried farther into the hill, and stripping becomes difficult. The quarry has been idle a number of years, but when last in operation the gypsum was hauled in 20 -ton wagons by a traction engine to a dock on the Erie Canal $1 \frac{1}{2}$ miles north.

The gypsum was all shipped in crude state to Mr. Miller's plaster mill in New York City.

Quarry of the National Wall Plaster Co.-This quarry is situated south and west of the Miller quarry on the same knoll. The gypsum bed is continuous with that in the Miller quarry but is not so thick.

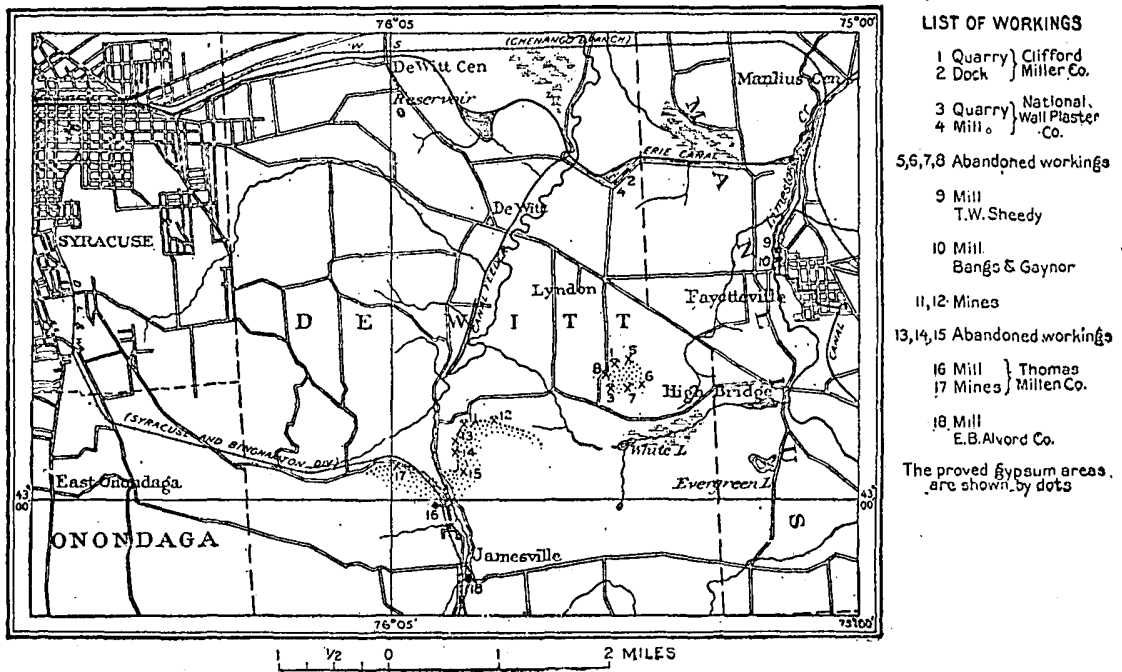

Frgune 44.- Map showing Jamesville-Fayetteville district, Onondaga County, N. Y.

Quarrying was carried on intermittently, and at present no work is being done: The overburden is similar to that of the other quarry, but stripping was accomplished by excavating the gypsum in such a way as to undercut the limestone beds, which are then allowed to fall into the vacant space. The rock was formerly hauled to the canal and to the mill on the canal bank, but the mill now stands idle.

There are several other idle quarries in this immediate vicinity.

At Fayetteville there were two gypsum mills. Each was equipped with jaw crusher, nipper, and burrstone mills. Their mineral was purchased from the neighboring quarries. The ground gypsum was sold as land plaster or to fertilizer companies.

Quarries at Jamesville.--The second area in which operations have been conducted is 1 mile north of Jamesville and enst of the road heading to De Witt. As in the quarries near Lyndon, the gypsum outcrops on the slope of a hill capped with Helderberg limestone. 
The north and west faces of this hill are abrupt slopes, of which the lower portion is composed of gypsum.

A quarry of the Thomas Millen Co. is about half a mile east of Reals station on the Jamesville trolley road. The gypsum is very similar to the Lyndon product and occurs in the sane manner. It averages about 30 feet in thickness and is overlain by 50 feet of limestone. Until about 1908 quarrying 'was carried on in the usual manner, but subsequently the gypsum was mined underground by means of a tunnel driven along a 6-foot layer of the best rock. About 2,000 feet of underground work was done before mining ceased at this opening. Much timbering is needed. The rock was quarried by electric drills, and the mine was equipped with electric lights. The broken rock was loaded into 1-ton side-dump metal cars, which were hauled by wire cable from the working face to the entrance and up an inclined trestle, the cable being operated by a small engine and drum. Owing to the grade of the tunnel, the cars returned to the face by gravity. From the cars the rock was dumped directly into 3 -ton wagons and hauled by a team to the mill. The mill is situated about half a mile north of Jamesville station, on the Delaware, Lackawanna \&. Western Railroad. No plaster of Paris is made, the rock being shipped.crude or after a preliminary crushing in a jaw crusher. This mill has lately been supplied from a quarry beside the Delaware, Lackawanna \& Western Railroad tracks 1 mile northwest of Jamesville.

Half a mile east of the Millen tunnel, on the same escarpment, is the mine of E. B. Alvord \& Co. The gypsum is overlain by a few feet of thin shale, 15 feet of massive limestone, and 20 feet of thinly bedded limestones. The company some years ago began mining the rock by means of a tunnel driven in an old quarry, but the mine was worked only a short time. A 5-foot layer was utilized. The mine was lighted by electricity and the drills were operated by the same power. No mine cars or track were used, but the wagons and horses were driven directly into the mine and to the working face, which necessitated wide gangways and large rooms, but no trouble was experienced with the roof. The mill of this company at Jamesville, across the river from the post office, is now supplied with raw material brought from other quarries. The power is furnished by a 70-horsepower turbine, and the equipment consists of a jaw crusher, cracker, and burrstone mill, as well as an unused kettle. The rock is sold with only preliminary crushing to cement factories or is ground in the burrstone mill and sold as land plaster.

The gypsum bed appears at several places around the western flank of the hill where there are abandoned quarries, and in an abandoned tunnel near Fiddlers Green, a station on the Jamesville trolley line. 
The close proximity of the railroad to this area is a feature that should bring about its greater development.

Other quarries in Onondaga County.-The deposits in other sections of the county are mainly of the pockety type and consist of mixtures of white gypsum, flakes and crystals of selenite, and fibrous gypsum veins with shale. Like those in Madison County few of them are over 10 feet in thickness and 25 feet in diameter.

In the eastern part of the county the deposits are quite numerous in the town of Manlius, particularly in the hilly area between Chittenango, Mycenae, and Fayetteville. Many of the knolls have been opened up from time to time and the gypsum worked for land plaster, but at present no production is made. Westward there are no beds, with the exception of those in De Witt Township, already discussed, until the Onondaga Valley is reached. The heavily glaciated area between Butternut Creek and Syracuse probably contains gypsum beds, but as yet they are undiscovered.

In the construction of the railroad from Syracuse to Auburn large quantities of gypsum were uncovered along the south side of Ninemile Creek between Camillus and Martisco (formerly Marcellus station). Thousands of tons of the material were taken out and the deposits attracted great attention. The gypsum bed consists of a mixture of limestone, shale, and selenite, or in places a whitish gypsum with wavy markings. At no part of the extensive cut was gypsum in pure masses observed, and if quarrying were undertaken the whole impure mass would need to be excarated and the percentage of gypsum would run low. The ease of mining and its accessibility to the railroad may render it of some value in the future. Other outcrops occur farther to the west, at Martisco. One outcrop is at the prominent point or hill northwest of the station, where a 10 -foot layer has been quarried. The material is similar to that already described. On a branch of Ninemile Creek another outcrop is seen just south of Martisco station, on the Marcellus \& Otisco Railroad. It is about 20 feet in thickness and extends for 150 feet along the road.

A few miles to the west the Auburn Railroad runs through a steepsided valley, and on either bank gypsum deposits are common. Probably the purest deposit of gypsum noted in the county was encountered in this ledge in an old quarry about midway between Halfway and Martisco. It is situated just off the road about onequarter of a mile south of the Auburn track on the face of an escarpment at an elevation of about 100 feet above the railroad. The quarry shows about 15 feet of gypsum in all, of which 4 feet is of much better grade than the average for Onondaga County. It is a grayish to white crystalline mass dotted with brown cleavable crystals and resembles the rock found at Oakfield, Akron, and Garbutt. It is overlain by 20 feet of limestone, and the expense of strip- 
ping is the probable cause of idleness. No other outcrops were found in the vicinity, so that no idea of the extent of this stratum could be formed.

The abundance of gypsum outcrops on the sides of the deep-cut valleys between Camillus and Halfway would seem to indicate the former presence of a persistent and continuous gypsum bed in that region, and it is probable that underlying the Helderberg limestones on most of the hills, gypsum beds would be found.

\section{CAYUGA COUNTY.}

The area underlain by Salina rocks in Cayuga County ranges from 14 to 20 miles in width.

The topography of the northern portion of the surface of the Salina permits but few outcrops. The area bordering Seneca River is low and marshy, and in other areas bedrock is completely obscured by a heavy covering of glacial drift. On this account very little is known of the gypsum deposits in that portion of the county. About $1_{2}^{1}$ miles north of Throopsville, along the river, pockets of gypsum were worked in 1837. Other impure deposits have been reported in the vicinity of Montezuma.

Along the southern border of the Salina and immediately underlying the Bertie and Cobleskill limestones are the extensive gypsum beds of the county, in early times the most valuable in the State. These beds are exposed at three localities: In the town of Springport north of Union Springs; at Cayuga Junction, one-half mile east of Crossroads station; and on the boundary of the township $1 \frac{1}{2}$ miles north of Crossroads. The gypsum in these localities ranges from 10 to 40 feet in thickness and is gray or bluish, firm, and massive, with plates and veins of selenite coating some of the blocks or mixed with the more impure material. In a few places it is overlain by water-lime rock but usually has an immediate covering of till from a few feet to 25 feet in thickness. The occurrence, as well as the character of the rock, is very similar to that at Jamesville and Lyndon.

In the early days many quarries were in operation in the Cayuga Junction area, 2 miles north of Union Springs (then Springport), and land plaster was shipped by canal all over the country. It is reported that plaster was used there as early as 1811, and by 1842 the quarries were producing 10,000 tons yearly, the price delivered by boat to Ithaca being $\$ 1.50$ to $\$ 2$ per ton. From Ithaca it was transported by the Ithaca-Oswego Railway and Susquehanna River to points in Pennsylvania.

Up to 1916 and for some years previously the only active quarry was that of the Cayuga Gypsum Co. The 'mill is situated along 
the Ithaca branch of the Lehigh Valley Railroad, about 2 miles north of Union Springs at Cayuga Junction. It is equipped with a cracker and nipper and five burrstone mills. The rock is sold in lump or ground form to cement factories and others; none is calcined. The quarry is about one-eighth of a mile back from the mill. The gypsum ranges from 20 to 30 feet thick and is overlain by as much as 25 feet of glacial drift that contains many water-lime boulders. Stripping is effected by means of a steam shovel, and the earth is carried to a convenient dumping place at one side. The gypsum is worked by quarry methods and by means of a tunnel driven into the lower course of the gypsum. Steam drills are used, and on the open face the rock is blasted off in benches.

Another gypsum deposit was formerly worked at Cayuga, the gypsum occurring both above and below the bridge. This deposit was in small pockets, however, and was soon abandoned for the better material south of it.

\section{SENECA COUNTY.}

The gypsum area in Seneca County is almost devoid of rock exposures. Where Seneca River has cut its channel through the Cobleskill and Bertie limestones, however, the Camillus shales have been uncovered and their gypsum masses exposed. These masses are small, at most a few rods in length, and although the plaster industry a half century or more ago on Seneca River had an output of 5,000 tons annually, it has long been abandoned, and there is little prospect of its resumption. The deposits are all, no doubt, of the impure "mixed" type, and any that may underlie the drift of Junius or Tyre townships would require shaft mining and that, too, under unfavorable conditions, such as wet ground.

WAYNE COUN'TY.

Only the northern or lower portion of the Salina formation outcrops in Wayne County and that portion only along the southern border in a belt averaging perhaps 6 miles wide. Gypsum is said to be exposed at various places along the line of the Erie Canal and the New York Central Railroad. At Clyde it is found in wells at a depth of 25 feet, at Lyons at 40 feet, and at Palmyra at the same depth. Gypsum was at one time quarried at a point 2 miles west of Newark, where the railroad and canal pass between two hills. North of the canal quarries were opened as early as 1832, and 2,000 to 3,000 tons had been extracted by 1839 . The gypsun is described by Hall ${ }^{1}$ as being "mostly lamellar, transparent, and of that variety which receives the local name of isinglass plaster." It was said

${ }^{1}$ New York Geol. Survey Second Ann. Rept., for 1837, p. 326, 1838. 
to occur with varicolored gypseous marl and to have the form of "large, round, irregular masses."

South of the canal was Blackmar's quarry, which was worked at the same time and contained plaster of similar quality. Gypsum has also been quarried around Port Gibson (see p. 203), and undoubtedly many similar pockets underlie the area northeast of Port Gibson in Wayne County. As they occur in the lower part of the Vernon shale, the deposits are not likely to prove of commercial value. The gypsum is all of the quality known as "mixed"-that is, it consists of selenite plates and reddish granular and fibrous gypsum interstratified and seamed with clay shales, marlites, impure shaly gypsum, and other materials-and it is found in small irregular deposits.

\section{ONTARIO COUNTY.}

The Camillus shale occupies the entire northern portion of Ontario County and ranges in width from 6 miles in the eastern portion to 2 miles in the western. In character it varies but little from its general type, a greenish or dark shale that becomes light gray on exposure. Where exposed it commonly contains the pockety beds of gypsum so characteristic of the beds to the east. In the greater portion of the area, however, actual exposures are rare, owing to the heavy mantle of drift.

Beginning in the eastern part of the county, the first exposures of gypsum are between Phelps and Gypsum. The best grade of rock is in the Empire Plaster Co.'s quarry, 1 mile north-northeast of Phelps Junction, near the bridge. The rock is a gray impure gypsum, heavily seamed with fibrous white gypsum in layers ranging from one-fourth to $1 \frac{1}{2}$ inches in width. The material is hauled by wagons to the mill, 1 mile to the west. This mill is equipped with a cracker, pipper, and burrstones and is run by water power. The mill has been idle for several years but formerly carried on an active business in land plaster.

Across the road from the mill is an abandoned quarry from which masses of gypsum from $2 \%$ to 3,000 tons in weight were formerly extracted. In early times a number of mills were in operation in and around Phelps and Gypsum, and the annual production of land plaster in the early forties was 6,000 tons:

From Manchester to Victor the Salina beds are heavily covered or swampy, and no gypsum has been reported, although well drilling may bring some to light. The cuts made by Ganargua Creek northeast of Victor have uncovered several gypsum masses of the pockety . type, and quarrying was at one time undertaken. A mill and quarry were operated on the Conover farm $1 \frac{1}{2}$ miles east of Victor on the north side of the creek. The gypsum, for its kind, was of good 
grade, 40 feet thick, and had a large sale for land plaster. The quarry has been idle for 25 years. In the later years of quarrying the stripping became such a troublesome feature, because of the 30 to 40 feet of drift, that a tunnel was driven at the base of the hill, with a breast of 14 feet. Gypsum was also quarried at one time in the Goose Egg, an oval hill about $1 \frac{1}{4}$ miles north of this locality.

On the Conover farm there have been found by core drilling two layers of gypsum resembling in appearance that seen at Garbutt. The drill holes were put down in the flat area near Ganargua Creek about 1908, after going through 19 feet of soil and 16 feet of water lime, the first gypsum bed, 8 feet thick, was encountered. At 104 feet a second bed, 6 feet thick, was struck. The cores were examined by the writers, and the gypsum appeared to be of fairly good quality. The lower bed is light colored and fine textured, resembling the gypsum at Oakfield, but the upper one is less pure and dark colored, though firm and massive, resembling the rock at Garbutt.

Irregular pockets of gypsum occur near Port Gibson and have been worked for land plaster for years but are no longer productive.

\section{LIVINGSTON COUNTY.}

No gypsum beds have been recorded in Livingston County, probably because they are heavily covered with limestone. The northern border of the county is occupied by the drab limestone of the Bertie member, which overlies the gypsum beds. The Garbutt and Wheatland gypsum bed lies at an elevation of about 570 feet above sea level. With an assumed dip of 40 feet to the mile, a fair average inclination, the bed on the border of the county would lie about 490 feet above sea level, so that at a surface elevation of 600 feet the bed would be pierced at 110 feet. There is reason to believe, however, that in the region between Caledonia and Mumford and in the area north and northeast of Maxwell, the horizon of the "gypsum approaches nearer to the surface. Though the prospect of finding gypsum within these regions seems good, it will require exploration with the drill to determine the matter definitely, for in all probability the beds are not absolutely continuous with the Camillus shale.

\section{MONROE COUNTY:}

Distribution and general character of the gypsum deposits.-The Camillus shale crosses Monroe County from east to west. 'Its northern limit is uncertain, owing to the heavy drift covering and to its merging gradually into the Vernon shale below. Its southern limit is the outcrop of Bertie limestone. 
The valuable gypsum deposits seem to be limited strictly to the town of Wheatland, in the southwestern corner of the county. Here the Bertie beds, underlain by gypseous shales and the gypsum layers, are exposed for a distance of several miles along Allen Creek, between Garbutt and Mumford, and small gypsum deposits have been exploited along its banks as far west as Fort Hill, in Genesee County. The deposits in Wheatland Township are among the most productive in the State. The area at present worked occupies about 3 square miles. (See fig. 45 .)

The gypsum at present developed occurs in two continuous layers below 40 feet or more of soil and water lime. The upper layer lies above the level of the stream; but the lower layer is probably at the stream's level. The upper layer ranges in thickness from 5 to 7 or 8 feet, but in few places can good rock be obtained with a thickness of more than $5 \frac{1}{2}$ feet. The second layer, or "second bottom," as it is locally termed, has been found in practically all the workings. It is separated from the upper layer by a hard bluish limestone, ranging in thickness from 6 to 12 feet. The gypsum in this layer also ranges from 5 to 7 or 8 feet in thickness and in some mines contains from 1 to 2 feet of whiter gypsum than that of the upper layer. At present the upper layer alone is being developed, although the lower layer has been exposed and its qualities are known. Descriptions of the individual properties follow.

Empire Gypsum Co.-This company owns the most eastern mill. of the group, situated southeast of Garbutt station. The gypsum, which is mined from a slightly inclined tunnel, averages 5 feet 5 inches in thickness. The middle 2 feet of the bed appears to be of the best quality, and the lower 2 feet is harder. The bed is overlain by a good limestone roof and underlain by 10 feet of limestone, below which is a second gypsum bed not yet developed.

The workings extend about one-fourth of a mile in a southwest direction and are based on the room and pillar method. Drilling is done with hand auger drills, and blasting with dynamite. The rock is loaded on wooden mine cars and hauled by mules to the surface. At the mill the rock is crushed with a jaw crusher and then by one of the usual nippers. It is then dried in a rotary cylinder and ground in a Universal pulverizer. After grinding the dust is collected by a fan, which saves screening the whole product. The remainder is screened on inclined shaking screens. The ground material is then calcined at a temperature of $280^{\circ}$ to $350^{\circ} \mathrm{F}$. in three 11-ton kettles with solid bottoms. Material calcined at this temperature is said to be "first settling" and is "greasier and smoother" than that calcined at a higher temperature. Some of the material is calcined at $450^{\circ} \mathrm{F}$, or second settling, and is sold for bedding plate 
glass. The mixing room is equipped with Broughton mixers, 12-tube bagging machines, and a fiber shredder of the type in which the log of wood is pivoted and the knives revolve against it. This machine is capable of grinding 2,500 pounds a day. The fiber is blown by a blast of air into the bins, the aeration also separating the dust from the fibers and loosening the mass. The wood used is mainly willow and basswood. Some of the crude rock is shipped directly, being - dumped from the mine cars on the trestle into the gondolas below; a

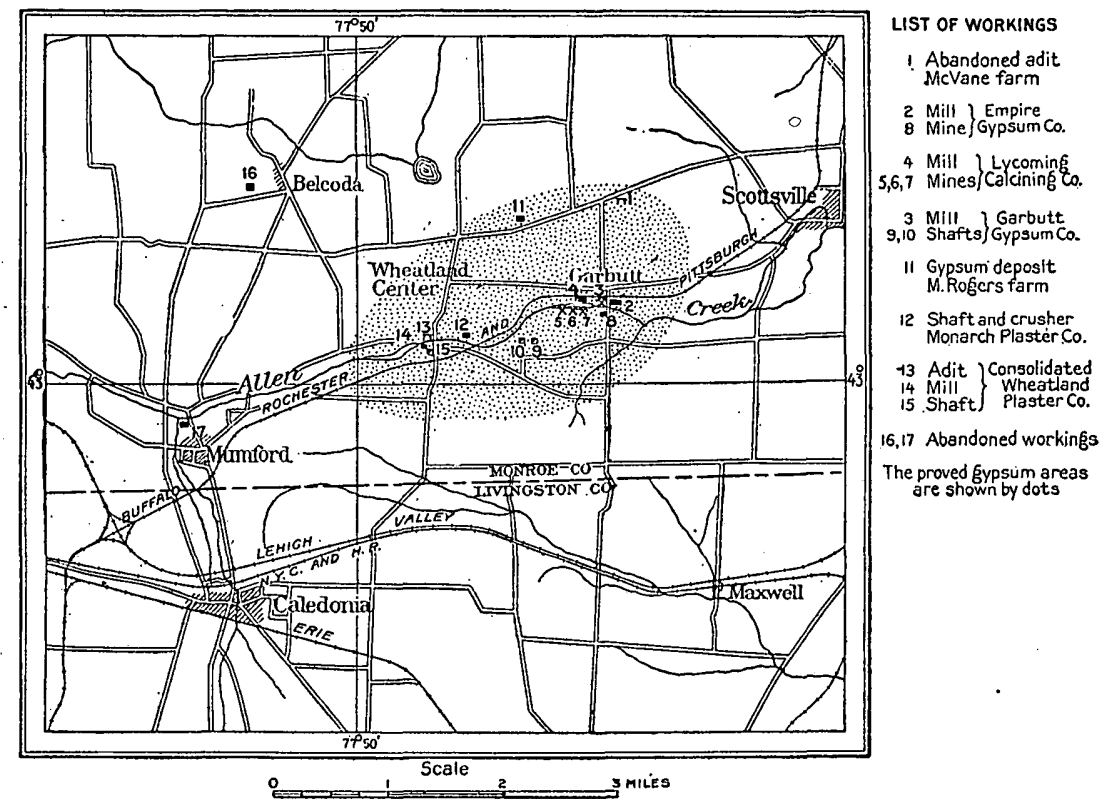

Frgure 45.-Map slowing Wheatland district, Monroe County, N. Y.

switch runs directly under the trestle from the Buffalo, Rochester \& Pittsburgh Railway.

Garbutt Gypsum Co.- This company, one of the oldest in the district, has a mill west of the Empire mill on the north bank of Allen Creek. The mines are located about a mile southwest of the mill, on the top of the south bank of the creek. In former days entrance was had to the gypsum bed by a tunnel driven into the north face of the hill, but this has been abandoned, and at present the bed is reached by two small shafts, 68 and 70 feet deep. The covering consists of 40 feet of soil and 22 feet of limestone, the gypsum layer being from 5 to 8 feet thick. The gypsum appears to be of remarkably good quality for the region and resembles the rock in Genesee and Erie counties. The purest, whitest layer occupies about 2 feet in the middle of the bed. This mine and mill have been idle several years. 
The rock was hauled by wagons more than a mile to the mill. The mill is equipped with one 15-ton kettle, one nipper and cracker, a burrstone mill for grinding gypsum, and a mixer.

Lycoming Calcining Co.-The mines of this company are located west of the Garbutt mill on the south bank of Allen Creek. Previous to 1900 the bed at this point was worked by means of a vertical shaft on the top of the bank, but when the property was acquired in 1900 by the present company a tunnel was driven into the creek bank. There are now three tunnels for working this bed of gypsum, which ranges from 6 to 7 feet in thickness.

The rock is a light-gray to brown gypsum with thin veins of satin spar running through it. The lower 2 feet are harder and of poorer quality. The mine has a good limestone roof, separated from the gypsum by a thin parting of shaly rock. The second "bottom" or layer of gypsum is 12 to 15 feet below the first and is separated from it by limestones. It appears to be of a grade equal to the upper rock. The mining operations have been conducted systematically, with pillars left every 21 feet. The mines are equipped with electric lights. Drilling is done with auger coal drills and blasting with low-grade dynamite. The whole face of gypsum is utilized, with no sorting, but care is taken to so arrange the cars that the poor and good grades alternate at the mill.

The cars are drawn up an incline by cable to the second floor of the mill and automatically dumped. After crushing, the material is sold. to Portland cement mills or converted into stuicco. Cummer rotary kilns are used instead of vertical kilns, the more usual type of calciner in the district.

Monarch Plaster Co.-The next mill in order is that of the Monarch Plaster Co., a little over a mile west along the Buffalo, Rochester \& Pittsburgh Railway. The mine and mill have been idle since 1910. The mine ency is a tunnel driven into the hill to the north. Drilling was done by auger electric drills and the mine was lighted by electricity. The gypsum bed is 6 feet thick, but owing to poor quality the lower 2 feet is left as a floor and only 4 feet of gypsum extracted in the rooms. The mine is dry and the roof solid, so that large rooms can be made, and open spaces 30 feet square are numerous. Mules were used for hauling. Six feet below the bottom rock is a second layer of gypsum, which is 6 feet in thickness, comprising 1 foot of exceptionally white gypsum. Nothing has as yet been done with this lower layer. The product of this company was

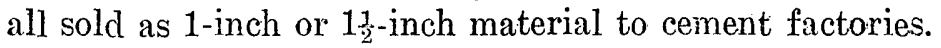

Consolidated Wheatland Plaster Co.-Halfway between Garbutt and Mumford, along Allen Creek, is the property of the Consolidated Wheatland Plaster Co. A tunnel driven from the north bank of the stream on a 6 -foot layer has been abandoned, and a shaft has 
been sunk at the mill. The shaft is 35 feet deep and reaches the same 6-foot layer that was mined by the Monarch Plaster Co. The thickness and character of the gypsum are the same as at the Monarch mine.

Possible occurrences of gypsum elsewhere in Monroe County.Aside from the localities described, the gypsum beds have not been much explored in the county. North of Allen Creek, pockety impure gypsum has been found at Beulah, on the Harman farm near Belcoda, and on the Rogers and McVane farms 1 mile north of Garbutt. In the Rogers farm the gypsum was found at a depth of 40 feet, being overlain by 27 feet of soil and 13 feet of limestone. On the McVane farm gypsum was at one time extracted from the hill by a tunnel, now abandoned. The farm of Mr. Skivington, north of Mumford, was explored for gypsum in 1912, but no further developments were undertaken, although the results were reported to be favorable. Gypsum was also encountered in a well on the farm of Mr. Clapp in North Rush. In. the region south of the outcrop gypsum has been encountered in wells at Mumford and Caledonia at 60 feet depth, and Mr. Jenkins, a well driller of Scottsville, says that an apparently good belt of gypsum runs from Wheatland to Maxwell, 4 miles southeast, and that it lies about 45 feet deep across the whole belt. He also says that gypsum was encountered in a well at the State industrial school.

GENESEE COUNTY.

Distribution and development.-The gypsum-bearing formation extends across the northern part of Genesee County. Its principal development is at Oakfield which now produces more gypsum than any other town in the State. Near the eastern boundary of Genesee County gypsum has been uncovered on the banks of Allen Creek, and at one time large quantities were quarried ngear Fort Hill.

Three miles northeast of Fort Hill, or midway between Fort Hill and South Byron, large amounts of gypsum were quarried about 1840.

The pioneer in the Oakfield district was Mr. Olmstead, who for some years previous to 1892 carried on a business in land plaster. In 1892 he installed a kettle, the first one in the State, and began the manufacture of calcined plaster. At present the industry at Oakfield is in control of two firms. (See fig. 4.6.)

United States Gypsum Co.-This company, which owns gypsum mills and mines in several States, entered the Oakfield district about 1903 and bought up or leased the properties of a number of the former companies. The company abandoned all but one of the many shafts, consolidated the mill equipment, and installed electric power. 
The present mines and mill are situated about $1 \frac{1}{2}$ miles west of Oakfield on the West Shore Railroad. The mine shaft is equipped with a two-compartment electric hoist. The rock is automatically dumped into large hoppers, is weighed, and then falls into a steellined storage bin from which it is loaded directly by chutes into large cars, which are drawn by a locomotive to the mill.

The mine has a capacity of about 1,000 tons of crude gypsum daily, a considerable part of which is shipped to cement factories and the trade. Rock entering the mill passes through a large horizontal cylindrical revolving drier and then goes by belt conveyer to crushers and mills. The pulverized material is raised by bucket conveyer to bins, which discharge to six calcining kettles and to two rotary kilns; both 67 feet long. The plaster of Paris or stucco is cooled and then raised to bins from which it goes to different parts of the mill. Some

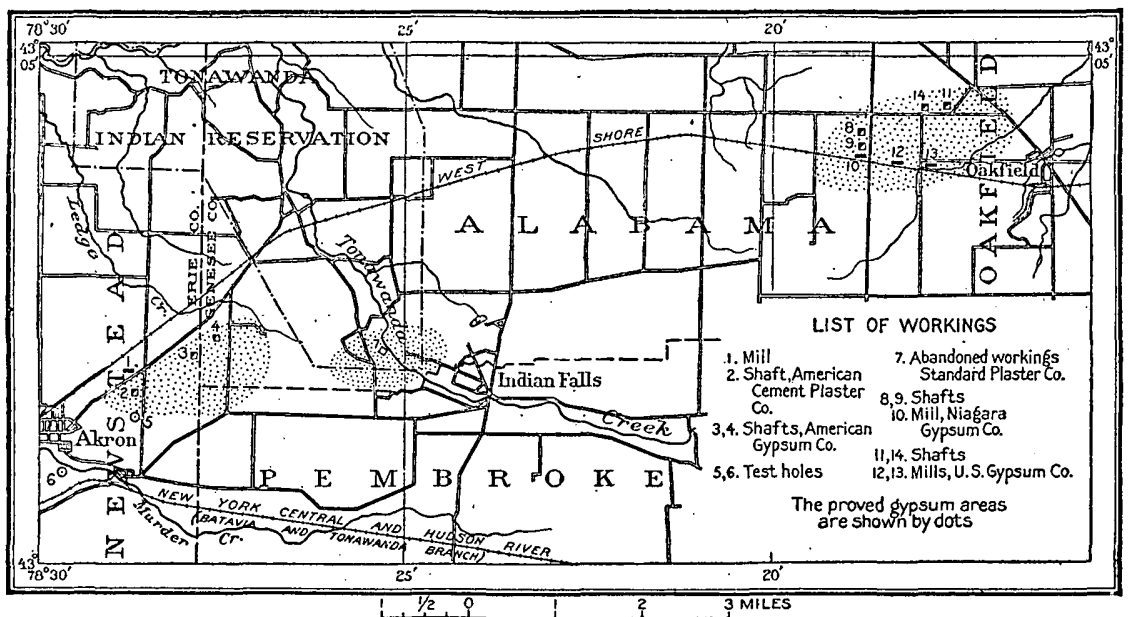

Figune 46.-Map showing Oakfield and Akron districts, Genesee and Erie counties, N. Y.

goes to the mixing room; where different brands of plaster are made by mixing with sand, hair, or wood fiber; some to the block shop, where hollow gypsum blocks are made; and some to the plaster-board mill. Plaster board one-quarter, three-eighths, and one-half inch thick is made in sheets 32 by 36 inches. Sheets of larger size are made also.

Niagarc Gypsum Co.-The mine and mill of this company are situated one-half mile west of the United States Gypsum Co.'s plant, or 2 miles west of Oalfield, on the West Shore Railroad. The mine is entered through a two-compartment shaft about 50 feet in depth. Electric power is used for drilling and mine traction, and an electric hoist raises the rock from the mine. At the mill the rock is crushed, elevated, cracked, and elevated again to the bins over the calciners. From the bins it passes into two large rotary Cummer calciners, each with a capacity of 15 tons an hour. The dust from the cal- 
ciners is collected in overhead bins and, together with the finished product from the calciners, is elevated and passes into the bricklined cooling bins. After remaining in these bins 24 hours the material is ground. It is then elevated and carried to the mixing room or to the board or block mill. In the mixing rooms several brands of plaster are made. This company makes 2-ply plaster board and hollow plaster blocks for interior partitions. The mill and mine are operated day and night and have a capacity of 500 tons for each 24 hours.

Other occurrences in Genesee County.-Eight miles west of Oakfield and 1 to 2 miles west of Indian Falls a 6-foot layer of gypsum is exposed along Tonawanda Creek. Above it lies an 8-foot layer of more impure and harder gypsum.

The deposits are included within the Tonawanda Indian Reservation. In 1901 the Standard Plaster Co. secured the mineral right to the whole tract and began mining. Tunnels were driven into the 6-foot layer. The rock mined was loaded on flat mine cars and pushed by hand to the tunnel entrance, where the good gypsum was loaded on cars and the waste rock thrown on the dump. From the mines the rock was carried by a railroad switch to the main line of the West Shore Railroad, near Alabama, the switch being about 4 miles long. The rock was then sent to Black Rock, Buffalo, where the company had a mill equipped with a gyratory crusher and screen, one Cummer calciner, one cooling bin, and five Sturtevant emery mills. The power was electric. The mines are now abandoned. Underground water and the presence of mud pockets are said to have been the main difficulties in the way of success.

The known gypsum beds of the Akron district begin 2 miles west of this locality. These will be discussed under Erie County.

\section{ERIE COUNTY.}

Distribution of the gypsum deposits.-Although gypsum beds of good quality no doubt occur below the Bertie limestone in Erie County, no definite information can be obtained of such deposits with the exception of those at Akron and those penetrated in the wells of the Buffalo Cement Co. at Buffalo.

The occurrence of gypsum at Buffalo was well established by the work of the Buffalo Cement Co. described by Ashburner.

The Buffalo Cement Co. drilled a series of wells near the Main Street crossing of the Belt Line in search for gas. Well No. 1 was drilled to a depth of 490 feet 6 inches with a diamond drill. Well No. 2 was drilled 6 feet from well No. 1 with a $5 \frac{5}{8}$-inch jump drill to a depth of 1,305 feet. The core of well No. 1 was placed in the cus- 
tody of the Buffalo Academy of Natural Sciences. The record of well No. 2 is given by Ashburner as follows:

Record of well No. 2 of Buffalo Cement Co. at Buffalo, N.Y. ${ }^{a}$

\begin{tabular}{|c|c|c|}
\hline & Thickness. & Depth. \\
\hline Shale and cement rock in thin streak & Feet. & Feet. \\
\hline Tolerably pure coment rock.......... & $\begin{array}{r}25 \\
5\end{array}$ & 30 \\
\hline Shale and cement rock in thin streaks.............. & & 43 \\
\hline Pure white gypsum ............... & & 47 \\
\hline 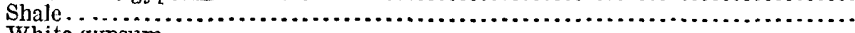 & & 49 \\
\hline 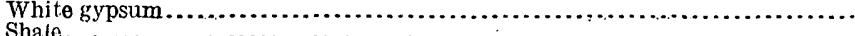 & 12 & 61 \\
\hline 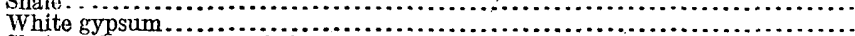 & & 62 \\
\hline Shalo and gypsum, mottled & $\begin{array}{l}4 \\
7\end{array}$ & 73 \\
\hline Drab shale with several layers of white gypsum, measuring 18 feet in a & 58 & 131 \\
\hline 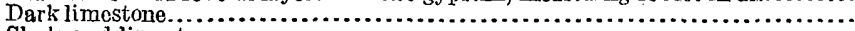 & 2 & 133 \\
\hline 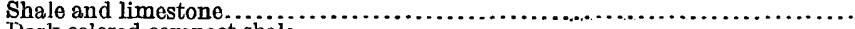 & 4 & 137 \\
\hline Dark-colored compact shale .................. & 3 & 140 \\
\hline Gypsium and shale, mottled and in streaks... & 580 & 720 \\
\hline 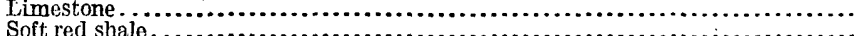 & $\begin{array}{r}5 \\
35\end{array}$ & 725 \\
\hline White solid quartzose sandstone, very har & 25 & 785 \\
\hline Soft red shale.............. & 520 & 1,305 \\
\hline
\end{tabular}

a Ashburner, C. A., Petroleum and natural gas in New Pork : Am. Inst. Min. Eng. Trans., vol. 16 , pp. $924-927,1888$.

A shaft 20 feet square was sunk on the premises later, for the purpose of determining the feasibility of mining the gypsum, but the rush of water through the gypsum layer at 43 to 47 feet was so strong that a pump with a capacity of 2,000 gallons a minute failed to make any impression upon it, and the attempt was abandoned.

Since then no further effort to exploit the gypsum has been made, though by reason of its quality and situation it seems to offer an attractive field, which would warrant more thorough investigation than has been given to it.

About 2 miles southwest of Akron a test hole was put down a few years ago, which encountered a bed of white rock. The locality of the hole is the Flint farm, near the crossing of the West Shore and New York Central (Batavia branch) railroads.

The Akron gypsum "basin," as it is locally termed, is situated northeast of the village of Akron or 20. miles east of Buffalo. The productive area lies south of the West Shore Railroad, with which connections are made by long: switches.

The boundaries of the workable bed or beds of gypsum have been rather well defined by the sinking of shafts and core-drill holes. The basin is 2 miles long and its greatest width is 1 mile. The deposit is pear shaped, and the small end lies just west of the American Cement Plaster Co.'s shaft and the large end east of the American Gypsum Co.'s plant.

The bed of gypsum as mined consists of a 4 to 5 foot bed of lightcolored crystalline or: granular gypsum. It is overlain by 25 to 50 
feet of thinly bedded impure limestones, and these in turn are rather heavily covered by a mantle of glacial clay ranging from a few feet up to 25 feet in thickness.

Two firms have operated mines and mills at Akron in recent years.

American Gypsum Co.-This company operates a large crushing plant and mines $2 \frac{1}{2}$ miles northeast of Akron on the boundary line between Genesee and Erie counties, the lands on which it owns mineral rights being situated on both sides of the line. The mine is entered by means of a shaft 60 feet deep. This shaft is divided into three compartments, one $\breve{\partial}$ by 8 feet for air passage and stairway; one 6 by 8 feet for passenger elevator; and one 6 by 8 feet accommodating the bucket elevator. Mining is carried on underground much as in coal mines, the most approved methods being employed to secure economy and safety. The gangways are carried 6 feet high and are wide enough to admit of using the 2 feet of barren rock taken from below tho gypsum bed for a supporting wall on either side of the gangway. The rooms are driven 24 feet wide by 300 feet long, and their height is simply the thickness of the vein, or 4 feet. Pillars 24 feet wide and alternately 40 or 60 feet long are left, each being separated by a 20 -foot crosscut. Good ventilation is afforded by the use of a 9-foot exhaust fan. Air drills are used. The air compressor also furnishes power for the pump at the bottom of the shaft.

The mine is lighted by electricity. At the foot of the shaft the mine cars are dumped into a steel hopper from which the rock is raised in a bucket elevator to the mill overhead. The elevator is 110 feet long, has 175 buckets, and travels 80 feet per minute. The rock is thus hoisted into the mill built directly over the shaft, and is discliarged into a crusher. After crushing it is screened and all material over 1 inch in size is reelevated to the crusher. The crushed rock is then ready for shipment, the whole product being sold crude to cement factories. The dust arising from the grinding is carried by suction through pipes into a series of long vertical cloth sacks, where the air escapes and the dust remains on the inner surface of the sack. At intervals the bags are shaken and the dust allowed to collect at the bottom. No use has been made of the dust, though it seems adapted for certain purposes by reason of its fineness and nearly. pure-white color.

All machinery in both mine and mill is driven by electric power from Niagara Falls. In 1909 a second shaft 64 feet deep had been sunk 1,420 feet west of the working shaft.

American Cement Plaster Co.-The mill of this company is situated 1 mile northeast of Alkron on the Bloomingdale road. The mine shaft is southeast of the mill and is connected with it by a narrowgage gravity railroad. Active operations were begun in the fall of 
1908. The mine is entered by a two-compartment shaft 84 feet deep. Drilling is done by compressed air. The mine is worked by a system that is based on the old method of extraction by means of radiating gangways which center at the shaft. Pillars are left 30 feet. apart and about 10 feet thick. The mine cars are pushed to the bottom of the shaft by hand. The gypsum bed as mined ranges from $2 \frac{1}{2}$ to 5 feet thick.

When first opened 4,000 gallons of water a minute were pumped from the shaft, and although the flow has been greatly reduced. the mine is quite wet. No forced ventilation is employed, a small airway on the east side of the shaft giving sufficient air. The mine cars brought to the bottom of the shaft are run directly on the platform of the hoist and are raised to the surface by a small drum hoist working in balance and driven by a steam engine. 'The cars. are raised to a level above the ground and are dumped either directly into 2-ton steel cars on a gravity track or are dumped on the reserve pile. These cars are run by gravity to the mill and arehauled back in a string by a horse. At the mill, which is just north. of the Bloomingdale road, the cars are hauled up an incline and dumped automatically into a jaw crusher. From this crusher the material passes directly to a cracker of the usual type, which reduces it to pieces the size of hickory nuts. It is then elevated and distributed to five 42 -inch French burrstones, where it is ground to a fine powder. It is then screened on a 60 -mesh brass shaking screen inclined at an angle of $45^{\circ}$, and all material above 60 mesh is returned and reground. Screw conveyers carry the ground material to three 10-ton kettles. The dust arising during calcining is caught. in steam-filled chambers and returned to the kettles. From the kettles the plaster is conveyed to a large storage bin holding 900 tons. Some of this 60 -mesh stucco is sold to outside companies for mixing, and some is reground on three 36-inch Munson burrstone mills, so that it is practically of 100 mesh and is thus sold for fine finishing plaster.' The plant is equipped with two five-compartment mixers and makes wall plasters with hair and wood fiber. The company manufactures its own supply of wood fiber, obtaining the wood, mostly poplar, willow, and basswood, from the neighboring farmers. The wood is shredded on an improved wood-fiber machine. The hair used is washed goats' hair and is purchased in bales. The sand is obtained from the company's pit situated close by the mill. The wood fiber made is mixed in the proportion of 1 ton of stucco to 30 pounds of wood fiber and 10 pounds of retarder. The wall plaster containing hair is mixed in the proportion of 1 ton of stucco to 3 pounds of hair and is then ready for the sand. Raw 
ground gypsum from the burrstones is also sold as land plaster to nurseries, experimental stations, and fertilizer firms. Power for the entire plant is fumished by, engines run with natural gas. The capacity of the mill is 300 tons of plaster a day.

\section{PHYSICAI AND CHEMICAL CHARACTER OF THE GYPSUM.}

Within the long stretch of Salina strata from Madison County to Erie County are included gypsum deposits of different physical and chemical characters. These variations are conditioned mainly by. the relative proportions and nature of impurities present and to a lesser extent by the different conditions in which the gypsum itself is found.

Though the deposits all belong to the general class of rock gypsum, from the descriptions of the individual deposits already given it is possible to distinguish two types that seem to be separate in their occurrence and may have originated under somewhat different conditions. The first of these types is represented by the dense firm gypsum in which the impurities are evenly distributed so as to give the appearance of a more or less homogeneous mass. This type comprises the usual rock gypsum, which forms the basis of the calcined plaster industry in New York and in most places elsewhere. It consists of a groundmass of finely divided gypsum fibers or elongated acicular crystals in felted arrangement, with a few Jarger individuals that stand out prominently by their brilliant cleavage surfaces (Pl. XXIV, A, p. 196). The other type is characterized by a loosely cemented aggregate of gypsum and shale, the two constituents being plainly discernible. The gypsum occurs usually in large crystals or crystal aggregates, which by themselves are transparent and quite free from impurities. The deposits of this type are built up of successive thin layers of the selenite and shale. When the mass is exposed to the weather the shale decomposes quickly and falls away from the gypsum, so that in outcrops it may have the semblance of a high-grade deposit. This type is known to the gypsum miners as "ashes," owing probably to the grayish color and powdery nature of the shale. It was quite extensively worked at one time for land plaster but is evidently unsuitable for calcination.

The chemical composition of the gypsum found in different sections of the Salina outcrop is shown by the accompanying detailed analyses of samples, which represent the run-of-mine gypsum, as now utilized, having been collected from the stock bins of the different mills. The analyses were made by G. E. Willcomb. 
4nalyses of gypsum from Erie, Genesce, Monroc; and Onondaga counties, $N . P$.

\begin{tabular}{|c|c|c|c|c|c|c|}
\hline 。 & 1 & 2 & 3 & 4 & 5 & 6 \\
\hline 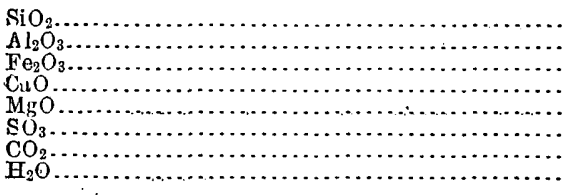 & $\begin{array}{r}0.51 \\
1.19 \\
.79 \\
30.62 \\
1.20 \\
43.59 \\
1.02 \\
20.52\end{array}$ & $\begin{array}{r}1.03 \\
.41 \\
1.27 \\
30.74 \\
2.01 \\
42.39 \\
2.20 \\
18.19\end{array}$ & $\begin{array}{r}0.40 \\
2.97 \\
.77 \\
30.76 \\
1.53 \\
43.78 \\
2.80 \\
17.53\end{array}$ & $\begin{array}{r}2.93 \\
1.92 \\
1.10 \\
26.27 \\
8.29 \\
33.83 \\
11.02 \\
14.87\end{array}$ & $\begin{array}{r}8.31 \\
4.53 \\
1.34 \\
21.50 \\
7.20 \\
30.47 \\
9.50 \\
14.53\end{array}$ & $\begin{array}{r}4.00 \\
1.74 \\
1.11 \\
29.36 \\
2.81 \\
35.79 \\
6.38 \\
17.93\end{array}$ \\
\hline Gypsum calculated.. & $\begin{array}{l}99.44 \\
93.74\end{array}$ & $\begin{array}{l}98.24 \\
91.27\end{array}$ & $\begin{array}{r}100.54 \\
94.26\end{array}$ & $\begin{array}{r}100.23 \\
7.2 .84\end{array}$ & $\begin{array}{l}97.38 \\
65.49\end{array}$ & $\begin{array}{l}99.12 \\
77.06 \\
\end{array}$ \\
\hline
\end{tabular}

1. Akron, Erie County.

2. Oakfield, Genesee County.

3. Oakfield, Genesee County.
4. Garbutt, Monroe County.
5. Lyndon, Onondaga County.
6. Lyndon, Onondaga County.

The following incomplete analyses are from the paper by Arthur L. Parsons, ${ }^{1}$ with the exception of the last one, which is taken from: a report by D. H. Newland: ${ }^{2}$

Incomplete analyses of gypsum from Monroe, Cayuga, Onondaga, and Madison counties, N. Y.

\begin{tabular}{|c|c|c|c|c|}
\hline$\cdot$ & $\begin{array}{l}\text { Gyp- } \\
\text { sum. }\end{array}$ & $\begin{array}{l}\text { Silica, } \\
\text { and in- } \\
\text { soluble } \\
\text { matter. }\end{array}$ & $\begin{array}{c}\text { Other } \\
\text { matter: }\end{array}$ & Remarks. \\
\hline 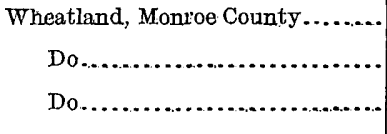 & $\begin{array}{l}82.5 \\
70.3 \\
94.03\end{array}$ & .............. & $\begin{array}{r}17.5 \\
\quad 5.97\end{array}$ & $\begin{array}{l}\text { "Other matter" includes } \mathrm{CaCO}_{3}, 1.75 \\
\text { MgCO } \\
\text { Analysis furnished by. Iroquois Portland } \\
\text { Cement Co. } \\
\text { Analysis furnished by Consolidated Wheat. } \\
\text { land Plaster Co. }\end{array}$ \\
\hline $\begin{array}{l}\text { Union Springs, Cayuga County ...... } \\
\text { Fayetteville, Onondaga County.... } \\
\text { Do........................... }\end{array}$ & $\begin{array}{l}74.09 \\
64.53 \\
73.92\end{array}$ & $\begin{array}{r}6.05 \\
11.17 \\
4.62\end{array}$ & $\begin{array}{l}19.86 \\
24.27 \\
21.44\end{array}$ & \\
\hline $\begin{array}{l}\text { Cottons, Madison County........... } \\
\text { Jamesville, Onondaga County ...... }\end{array}$ & $\begin{array}{l}82.66 \\
87.48\end{array}$ & 3.86 & $\begin{array}{r}13.48 \\
8.93\end{array}$ & $\begin{array}{l}\text { "Other matter" includes } \mathrm{Al}_{2} \mathrm{O}_{3}+\mathrm{Fe}_{2} \mathrm{O}_{3} \text {, } \\
\text { 1.84; } \mathrm{CaCO} \mathrm{CO}_{3}, 6.57 ; \mathrm{MgCO}, 5.07 . \\
\text { "Other matter" includes } \mathrm{Al}_{2} \mathrm{O}_{3}+\mathrm{Fe}_{2} \mathrm{O}_{3} \text {, } \\
\text { 2.92; } \mathrm{CaCO}_{3}, 3.33 ; \mathrm{MgCO}_{3}, 2.69 \text {. }\end{array}$ \\
\hline
\end{tabular}

The analyses indicate that the gypsum content of the rock ranges between the general limits of 64 or 65 per cent and 95 per cent. The grade apparently improves toward the western end of the section, in Genesee and Erie counties, where the average is above 90 per cent. The rock in this part is also the lightest in color and yields nearly white plaster:

The impurities of the roek are such as night be expected from the stratigraphic associations. The principal foreign ingredients are lime and magnesia carbonates, clay, and quartz. Most of the iron shown by the analyses is probably present in the clay. The high percentage of magnesia in the rock of the eastern section is a striking feature, since it appears to be greatly in excess of the proportions. found in dolomites. The presence of free carbonate is thus indicated.

\footnotetext{
1 New York State Geologist Twenty-third Ann. Rept., 1904.

2 The mining and quarry industry of New York State; report of operations and production during 1907 : New York State Mus. Bull. 120, p. 34, 1908.
} 


\section{FUTURE OF THE GYPSUIY INDUSTRY.}

The supply of gypsum available can not be calculated from the data at hand. Little exploration has been undertaken outside the areas mined, the resources of which within moderate distances of the outcrop have so far been ample to meet the demands. In no place have the deposits been followed for more than a mile from their northerly limit or under such cover that they could not be worked by vertical shafts 100 feet or less in depth.

On the assumption that the yield of gypsum to the acre is approximately 2,000 tons for each foot of thickness of the bed, the total production since the outset of mining operations in the State, about $9,000,000$ tons, represents the approximate equivalent of 125 acres of the thickest beds in central New York, and a little more than 1,000 acres of the average bed that is worked in the western counties. For a district that extends over 100 miles in length, the area thus represented seems rather insignificant.

A somewhat different aspect of the matter is presented, however, if the later period of production and development, covered by the growth of the calcining industry, is alone considered. Practically one-half of the total production of the State has been made in the last fifteen years, and the present annual production is more than 500,000 tons. Nearly all this material has been mined in the western part of the district, in Monroe, Genesee, and Erie counties, where the gypsum is more suitable for the manufacture of calcined plaster. In that section probably about 75 acres of gypsum land is worked out each year. If this production is continued for many years it will seriously affect the resources of rock along the outcrop and compel the extension of exploratory work to the south, down the dip of the beds. Just what conditions will be found in that direction can not be forecasted with certainty. It is safe to say, however, that the costs of mining will be measurably increased.

In general, at short distances from the outcrop the gypsum beds in the western area dip below the ridge or escarpment formed by the Onondaga limestone, and their depth increases rapidly to 300 feet or. more. So far as the writer is aware, little attention has been given to exploration south of this escarpment, and until some systematic work of that character has been carried out it is impossible to estimate the available supplies. Many gas and salt wells have been put down in this area, but their records apparently do not attempt any discrimination between anhydrite and gypsum. Careful examination of the material excavated from some of the salt shafts 10 or 15 miles or more to the south of the outcrop has shown that owing to the heavy overburden the deposit has the composition of anhydrite. 


\section{ORIGIN OF THE DEPOSITS.}

There is no doubt that the gypsum of the Salina formation has been deposited by evaporation of surface waters and is an integral part of the stratified succession. This view is advocated or tacitly implied in most descriptions of the New York gypsum deposits that have already been published, though it has not escaped criticism. The evidence in favor of this mode of origin to the exclusion of others may be summarized under the following heads: (1) Form and structure of deposits; (2) Associations of the gypsum; (3) Biologic conditions in Salina time.

(1) The occurrence of the gypsum in thin lenses which are of the same degree of continuity as the inclosing strata indicates an accumulation concordant with the salt, shales, and limestone of the Salina. The lenses, in most places at least, thin out very gradually; showing only moderate changes of thickness as they are traced from place to place and few irregularities not common to sediments in general. If the gypsum was formed by the reaction of acid waters upon limestone, variations in form like those found in replacement deposits of metallic minerals would be expected. The type of deposits in which the gypsum occurs as nodular masses with a thickness nearly equal to the horizontal dimensions, as figured by Hall and represented in Dana's "Manual of mineralogy," is certainly the exception and not the rule and is the result probably of solution of the larger masses by underground waters.

The undisturbed condition of the beds as generally observed is also against any theory of secondary deposition either by reaction upon limestone or by precipitation from ground waters. The change from limestone to gypsum involves an increase of 90 per cent in the volume, which would hardly occur without general disturbance of the adjacent strata. The beds, also, are not faulted or fractured so as to permit the easy circulation of waters in the vertical direction.

(2) The close relation of the gypsum to the salt deposits is such as would be expected from the evaporation of sea water. Though the fact that the salt underlies the main gypsum beds, whereas the reverse is the natural order, seems to controvert. this view, an explanation of the occurrence may be found without recourse to extraordinary conditions of evaporation and supply of the sea water. If the waters of that time held approximately the same relative proportions of salts in solution as the ocean of the present day, their evaporation would afford 1 part gypsum to more than 20 of salt. As gypsum occurs interbedded with the salt and probably distributed more or less through the Vernon shale below the salt, this relative amount may well be present in its normal order. The 
relations indicate, however, that the process of evaporation while the first gypsum and salt were laid down was subject to frequent vicissitudes from the influx of new supplies of sea water into the basins. After the salt had been precipitated by repeated evaporations the process was suspended for a time, during which the basins were probably invaded by land drainage and shales were accumulated in considerable thickness. A renewal of the early conditions with a fresh supply of sea water started the precipitation.of gypsum again, but this time the process was not continued long enough apparently to bring down salt, or if it was precipitated it was redissolved before the overlying strata were formed.

Both the salt and the main gypsum beds occur at the same respective horizons throughout their extent. The main gypsum beds are found only in the Camillus shale and are generally limited to the upper section. In the western part of the State they are capped 1 by limestone which shows no evidence of alteration by ground waters, and there are layers of unchanged limestone intercalated in the shale. There seems to be no adequate explanation for any selective action on the part of the limestone whereby certain beds were more prone to alteration than others.

(3) Variations in the character of the Salina strata are accompanied by marked fluctuations in the abundance of fossil remains. The preceding Niagara group is characterized by a fairly prolific and varied fauna which has, however, a peculiar development that is connected by paleontologists with changes of physical surroundings. The Pittsford shale at the base of the Salina contains a very different fauna that is characterized by eurypterids. Throughout the succeeding intervals represented by the Vernon shale, Syracuse salt, and Camillus shale, there is little or nothing to be found in the way of fossil remains, and only in the Bertie limestone, at the close of the Salina, do they reappear and are then represented by an assemblage related to that of the Pittsford shale. The lack of fossils in the gypsum beds may be explainable, perhaps, as the result of solution and breaking down of the strata by underground circulations, but this theory fails to account for their absence in the shales and unchanged limestones, which aggregate many hundreds of feet in thickness. This circumstance as well as the other facts regarding the fauna of Salina time becomes intelligible, however, when connected with the vicissitudes that life must encounter in sea waters of fluctuating salinity. 


\section{OHIO.}

By J. A. Bow NOCKer.

\section{IOCATTON AND THICKNESS OF DEPOSITS.}

For many years Ohio has been a large producer of gypsum and in 1918 ranked fourth among the States in quantity and also in value of gypsum produced. The extent of development and the growth of the industry are shown by the following figures: In 1885 the value of the gypsum produced was $\$ 27,652$; in 1895 it was $\$ 71,204$; in 1915 it was $\$ 772,520$; and in 1918 it was $\$ 1,239,649$.

The production in 1917 was 270,538 short tons, most of which was calcined and sold for wall plaster. In 1918 the production was only 199,456 short tons. Four companies were operating gypsum quarries and mills in Ohio in 1918.

Gypsum deposits underlie a broad area in Ohio but are restricted to one Silurian formation, the Monroe, which consists primarily of dolomitic limestone with interbedded layers of sandstone and in places of gypsum.

Although the only deposits of gypsum ever worked in Ohio are along the north and south shores of Sandusky Bay (Pl. XXV), Orton ${ }^{1}$ says :

At various other points gypsum is found in the outcrops of the [Monroe] formation, and notably in the vicinity of Sylvania, Lucas County, while in the deep wells recently drilled through northern and central Ohio, it is the exception to miss deposits of gypsum in the samples of drillings. The last case reported is 3 feet of pure fibrous gypsum from a depth of 150 feet at Upper Sandusky.

Orton reports gypsum also at different distances from 30 to 190 feet below the surface at Port Clinton, and it has since been found in a shaft on the Barnes farm at Locust Point, north of Oak Harbor. In a deep well drilled in 1886 at Sandusky, the driller reported 9 feet of gypsum at a depth of 272 feet and thinner beds "at many other points in the next 800 feet." Samples of drillings from wells in central and southeastern Ohio have not thus far disclosed gypsum, and Prosser states that he has not found this mineral in the outcrops of the Monroe formation in southern Ohio. Though it appears that the area underlain by gypsum is large, it seems probable that the

\footnotetext{
1 Orton, Edward, Gypsum or land plastẹr in Ohio: Obio Geol. Survey Rcpt., vol. 6, p. 697,1888 .
} 
t. 5

U. S. GEOLOGICAL SURVEY

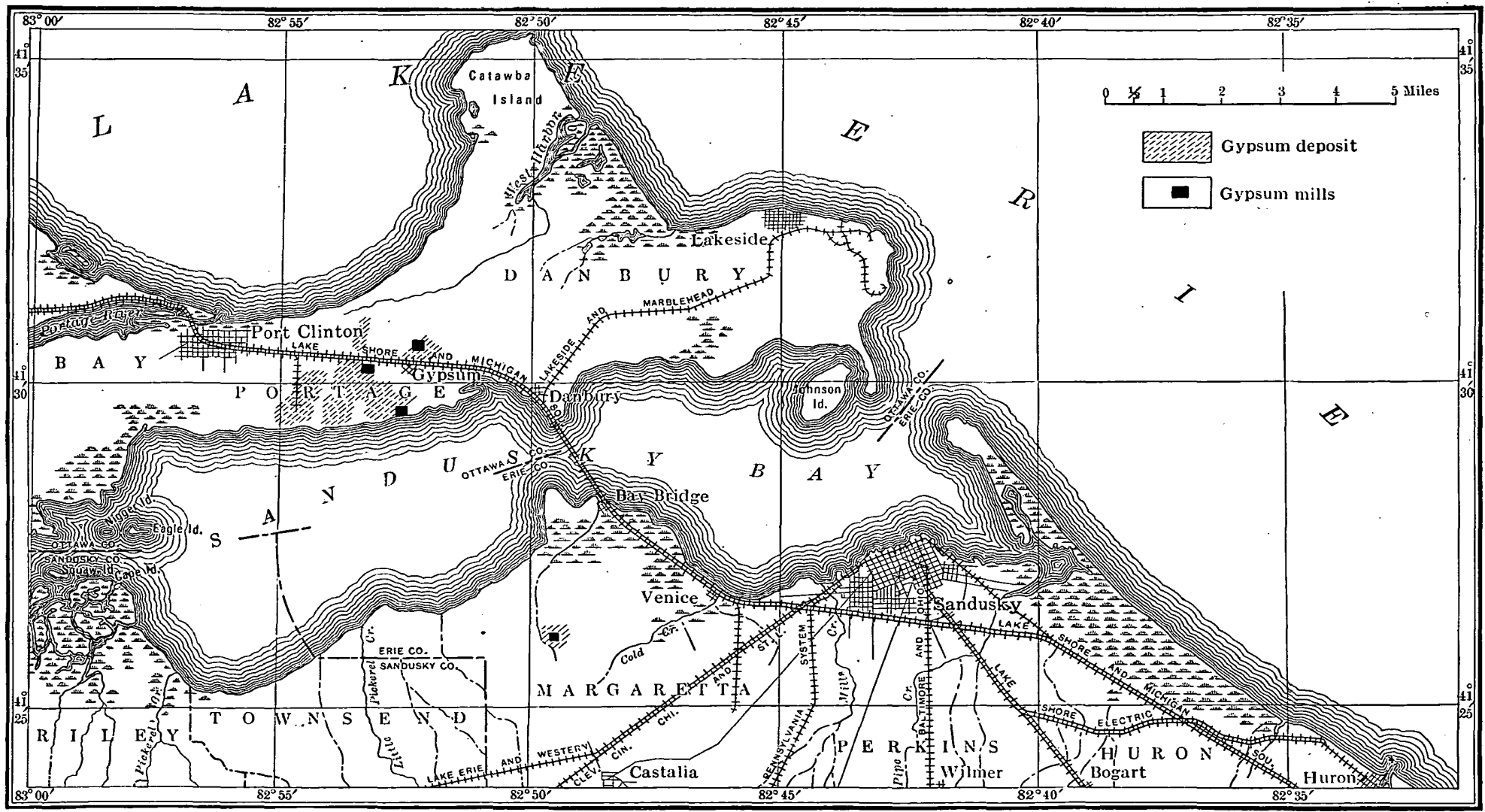

MAP SHOWING LOCATION OF GYPSUM DEPOSITS IN OHIO. 
deposit is too thin or at too great depth to be mined except along or near the lake shore west of Sandusky, and even there only two comparatively small areas have been actually tested. The following records show the succession of gypsum and limestone in this locality:

Section measired by Orton in old "plaster" quarry near shore of Sandusky Bay, 1: miles southuest of Gypsim, Ohid.

Drift clays (level of bay, $\&$ feet below surfice) $12-14$

Gray rock carrying land plaster

Blue shale.

Boulder bed cirrying gypsum in sepitrate masses em. bedded in shaly limestone.

Rlue limestone in thin and even courses____._. 1

Main plaster bed._. 7

Gray limestone in thin courses._. 1

I.owest plaster bed, variable_________ 5

Mixed limestone and plaster, bottom of quarry; water enters here in quantity.

About 1 mile due west of Gypsum the gypsum has been found at several places, and a test hole on the land of N. W. Payne shows the following section:

Record of test hole on land of $N$. W. Payne, 1 mile west of Gypsum, ohio.

\begin{tabular}{|c|c|}
\hline Glacial drift & \\
\hline Liniestone & $i$ \\
\hline Gypsim _............. & \\
\hline Limestone. & 1. \\
\hline Gypsum & i \\
\hline Limestone & 4 \\
\hline Gypsum & 2 \\
\hline Limestone & 2 \\
\hline Gypsum and limestone & 11 \\
\hline Limestoue & 2 \\
\hline Gypsum__n & 6 \\
\hline Limestone & 1 \\
\hline Gypsum & 1 . \\
\hline Limestone & \\
\hline Gypsuin & \\
\hline Limestone_-__- & \\
\hline
\end{tabular}

The bed 7 feet 2 inches thick that lies less than 10 feet below the glacial drift is quarried extensively in this ricinity. The 6-foot bet near the base of the test hole may be quarried if the upper bed ever. is exhausted. 
The following records also show the thickness of the bed near Gypsum :

Record of a core-drill hole on a farm about half a mile northoest of Gypsum, Ohio.

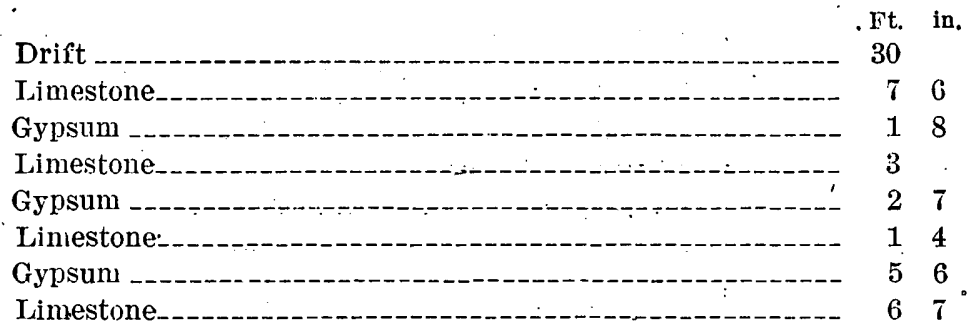

The following record of a drill hole south of Sandusky Bay on the Alfred Meggett farm, 3 miles northwest of Castalia, is furnished by S. C. Kelly:

Record of a drill hole 3 miles northuest of Castalia, Ohio.

\begin{tabular}{|c|c|}
\hline Glacial drift & \\
\hline Limestone & 12 \\
\hline White gypsum _. & 3 \\
\hline Gray gypsum & 17 \\
\hline White gypsum (mined) & 4 \\
\hline Limestone & 1 \\
\hline White gypsum (mined) & 7 \\
\hline Limestone-1- & \\
\hline hite gypsum & 3 \\
\hline
\end{tabular}

The deposit of gypsum which is shown in this record appears to be local, for one test on the Clara Meggett farm, which joins the Alfred Meggett farm on the north, found no gypsum, and the same is true on the Peter Altrater farm, which joins the Alfred. Meggett farm on the southeast. The beds mined are exceptionally thick at this place.

The sections given show the general succession and thickness of the gypsum beds. These features vary in short distances, and in some localities the beds can not be correlated with those shown in sections a short distance away. Within the space of a few rods gypsum may be reduced one-half in thickness and in places it is cut out entirely. The limestones make an excellent roof, and little or no timbering is necessary. Likewise the limestone makes a first-class floor, so that work is conducted under the maximum conditions of safety. The gypsum is fine grained and massive. Its color varies from snow-white to gray, and both kinds are calcined together. The process of manufacture is similar to that in other States and the product is used for like purposes. The market extends east into. Pennsylvania, west to Illinois, and south as far as Georgia. 


\section{HISTORY OF DEVELOPMENT.}

When gypsum was first discovered in Ohio is unknown, but it was probably about 1849, and the location was along the north shore of Sandusky Bay. Marsh \& Co., of Cincinnati, investigated the subject and later purchased the "plaster beds" located at Gypsum, near the present mill of the United States Gypsum Co. and built a mill at the foot of Wayne Street, Sandusky, where they made the gypsum into land plaster and plaster of Paris. In 1866 this mill was destroyed by fire but was rebuilt and operated until 1885. In 1872 Marsh \& Co. built a mill at Gypsum just across the tracks from the railroad station and operated it until 1885, when they erected " plant at the "plaster beds" and abandoned the mills at Sandusky and Gypsum.

Another pioneer firm was that of Lockwood \& Smith, who began work on land of Lockwood \& Boss, adjoining that of Marsh \& Co., and quarried the gypsum on a small scale. The principal business of both companies for a long time is said to have been supplying rock to a number of small gypsum mills in Ohio, New York, Pennsylvania, and Michigan. The plate-glass factories began calling for large supplies of gypsum, which of course stimulated the industry. About 1885 the Pittsburgh Plate Glass Co. made a contract with J. W. Lockwood to take gypsum from his property, and the rock was shipped by water to Cleveland, where it was distributed by rail to the different plants of this company. Later the plate-glass companies purchased the calcined gypsum, and that plan is followed by most of the companies at the present time.

Marsh \& Co. worked an open quarry until 1902, when underground mining began. This plant is still in operation, and since 1901 has been the property of the United States Gypsum Co. Formerly this company worked three beds of gypsum at the same time. The higher one was operated as a quarry, but the two lower beds were worked by underground methods. The upper bed has been worked out except a small area east of the old Marsh farm. The bed now mined lies about 50 feet below this horizon. Deeper drill holes made in this vicinity show that at about 100 feet below the surface calcium sulphate occurs in the anhydrous form.

On the shore of the bay, about 2 miles west of the plant of the United States Gypsum Co., there were formerly two mills. The Granite Hill Plaster Co. began work in 1889 and at first procured its rock from a quarry but in 1901 began underground mining. In 1902 this plant passed into the hands of the United States Gypsum Co. The Consumers Gypsum Co. began work in the same locality in 1902. About 1904 mining in the first plant had extended so near the bay that water entered freely and stopped the work. Two years 
later the adjacent plant was closed for the same reason. The bed of gypsum mined by these companies is reported to have ranged in thickness from 5 to 8 feet.

The American Gypsum Co. erected a plant about 1 mile west of Gypsum and began operations in January, 1907. In 1910 the Fishack Gypsum Co. built a mill half a mile northwest of Gypsum, and in 1914 it became the property of the American Cement Plaster Co. The last mill of this kind established in Ohio is the property of the Kelly Plaster Co. and is located about 3 miles north of Castalia, on the south side of Sandusky Bay. The company reports having had 40 acres tested with the core drill and in this manner has proved an adequate supply of the rock. This is the first and only mill built on the south side of the bay and hence marks a real extension of the field.

\section{DEVELOPMENT IN 1918.}

By R. W. STONE.

Gypsum was quarried and milled by four companies in 1918, three working on the north side of Sandusky Bay and one on the south side.

The American Cement Plaster Co. has a mine and mill half a mile north of Gypsum, a station on the Lake Shore \& Michigan Southern Railway. A bed of gypsum which lies 46 feet below the surface and runs very evenly about 6 feet thick is being worked by a slope. Cars are gathered by mules and hauled to the surface by a cable. The usual method of milling is followed, and the product is mainly wall plaster.

The American Gypsum Co.'s plant is 1 mile west of Gypsum on the south side of the Lake Shore \& Michigan Southern Railway. The mine, which is at the mill, is entered by a vertical shaft. Two gypsum beds are being worked. The upper bed, 34 feet below the surface, is 7 feet thick, and the lower one is 11 feet thick but includes a little hard shale or limestone. These two beds are separated by 8 to 10 feet of limestone, including a thin bed of gypsum. Practically all the mine haulage is by electric motor. This company is making gypsum tile as well as wall plaster.

The United States Gypsum Co.'s property is on the shore of Sandusky Bay, 1 mile south of Gypsum. . Old quarries along the shore on the upper bed are full of water. Part of this bed was mined from entries driven from the quarries. The present work is on a second bed 42 feet below the first. This lower bed is 10 to 15 feet thick and divided near the middle by 6 to 18 inches of limestone. The upper bench of this bed is gray mottled gypsum and the lower bench is for the most part pure white, though it contains some mottled rock. The white and gray rock are mixed in mining. 


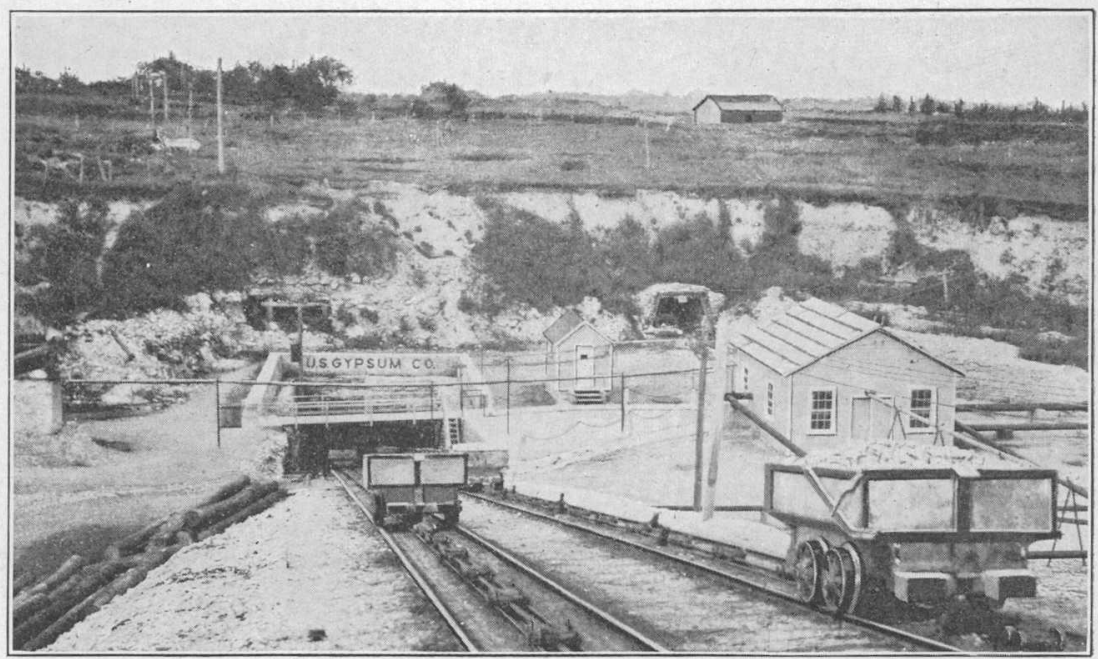

A. MINE OF UNITED STATES GYPSUM CO. AT GYPSUM, OHIO.

View shows abandoned workings on upper bed and incline to lower bed. Photograph by R. W. Stone.

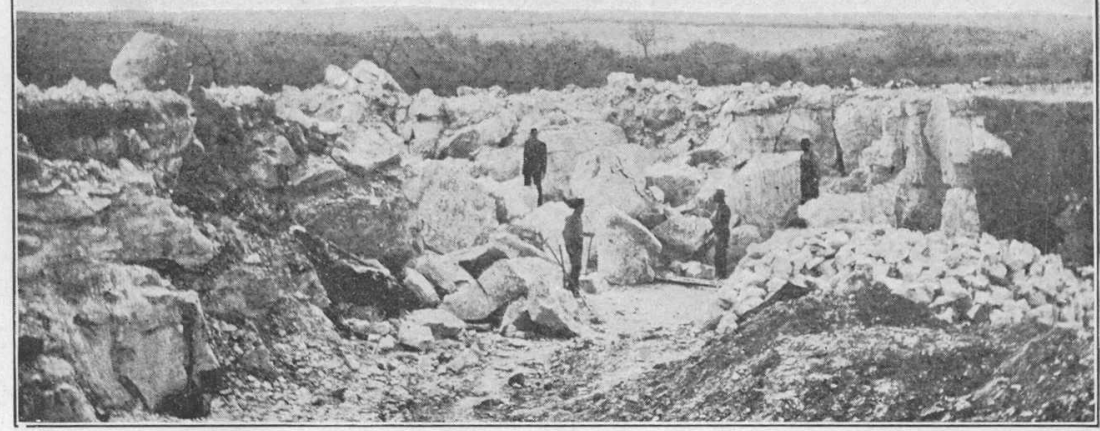

B. ROCK GYPSUM QUARRY OF AMERICAN CEMENT PLASTER CO. AT WATONGA, OKLA.

Photograph by E. F. Burchard. 
The cars are gathered by mules and moved up the slope to the top of the crusher house by an automatic rope haulage system. (See $\mathrm{Pl}$. XXVI, A.) The mill is at the mine, and is making gypsum plaster and tile.

The Kelly Plaster Co. is the only one on the south side of Sandusky Bay. The mine and mill are $2 \frac{1}{2}$ miles northwest of Castalia. The shaft, which is 73 feet deep, passes through more than 30 feet of gypsum, as shown in the record of a drill hole given on page 220. A bed of gray gypsum 17 feet thick is left, and 12 to 14 feet of white gypsum lying below it is mined. This white gypsum contains an irregular lenticular layer of shale or flinty rock 18 inches in maximum thickness, which has to be gobbed. The rock which is mined is very white and granular. A small quantity of alabaster has been found here but no selenite or satin spar. A $3 \frac{1}{2}$-foot bed of gypsum lying just below the floor of the mine is as yet untouched.

The mine has been opened so short a time that it is small. Haulage is by mules; electric and air drills are used. The product of the mill is sold both crude and calcined. 


\section{OKLAHOMA.}

By L. C. Sņ̣Der.

\section{CHARACTER AND EXTENT.}

The gypsum deposits of Oklahoma are in the western part of the State in the "Red Beds" area, which extends into Texas to the south and into Kansas to the north. The gypsum attains its maximum development in the portion of this area that lies in Oklahoma, where beds which reach a thickness of 60 feet can be traced for considerable distances. There are also large deposits of gypsite.

The gypsum occurs in different forms. Rock gypsum probably predominates, but the ledges grade into selenite gypsum, locally very coarsely crystalline. Veins of satin spar and selenite are abundant in the red clays near the heavy gypsum beds, and irregularly shaped concretions are found at horizons considerably below the heavy beds. The gypsite deposits are commonly on low-level lands or in valleys near the thick beds of rock or selenitic gypsum. Anhydrite is fairly abundant. It is present for the most part as irregular masses in the gypsum, but in some places forms definite bands or layers. In only a few places is the anhydrite sufficiently abundant to interfere with the utilization of the gypsum.

\section{GEOLOGIC RELATIONS.}

The gypsums of Oklahoma form a part of the great series of rocks which are generally known as the "Rèd Beds." The greater portion of the "Red Beds". in Oklahoma are of Permian age and all the gypsums occur in rocks of that age. ${ }^{1}$

The section of the Permian rocks, as worked out by Gould, ${ }^{2}$ is as follows:

\section{Section of the Permian rocks in Oklahoma.}

Quartermaster formation, soft, red sandstones with

arenaceous clays and shales
Greer formation, red clays, shales, and sandstones

Feet. with beds of gypsum and magnesium limestone or dolomite

Woodward formation:

Day Creek dolomite

Whitehorse sandstone

Dog Creek shales.

1 The age of the "Red Beds" is further discussed in Oklahoma Geol. Survey Bull. 11, pp. 107-114, 1213.

2 Gould, C. N., Geology and water resources of Oklahoma: U. S. Geol. Survey. WaterSupply Paper 148, pp. 34-77, 1905. 


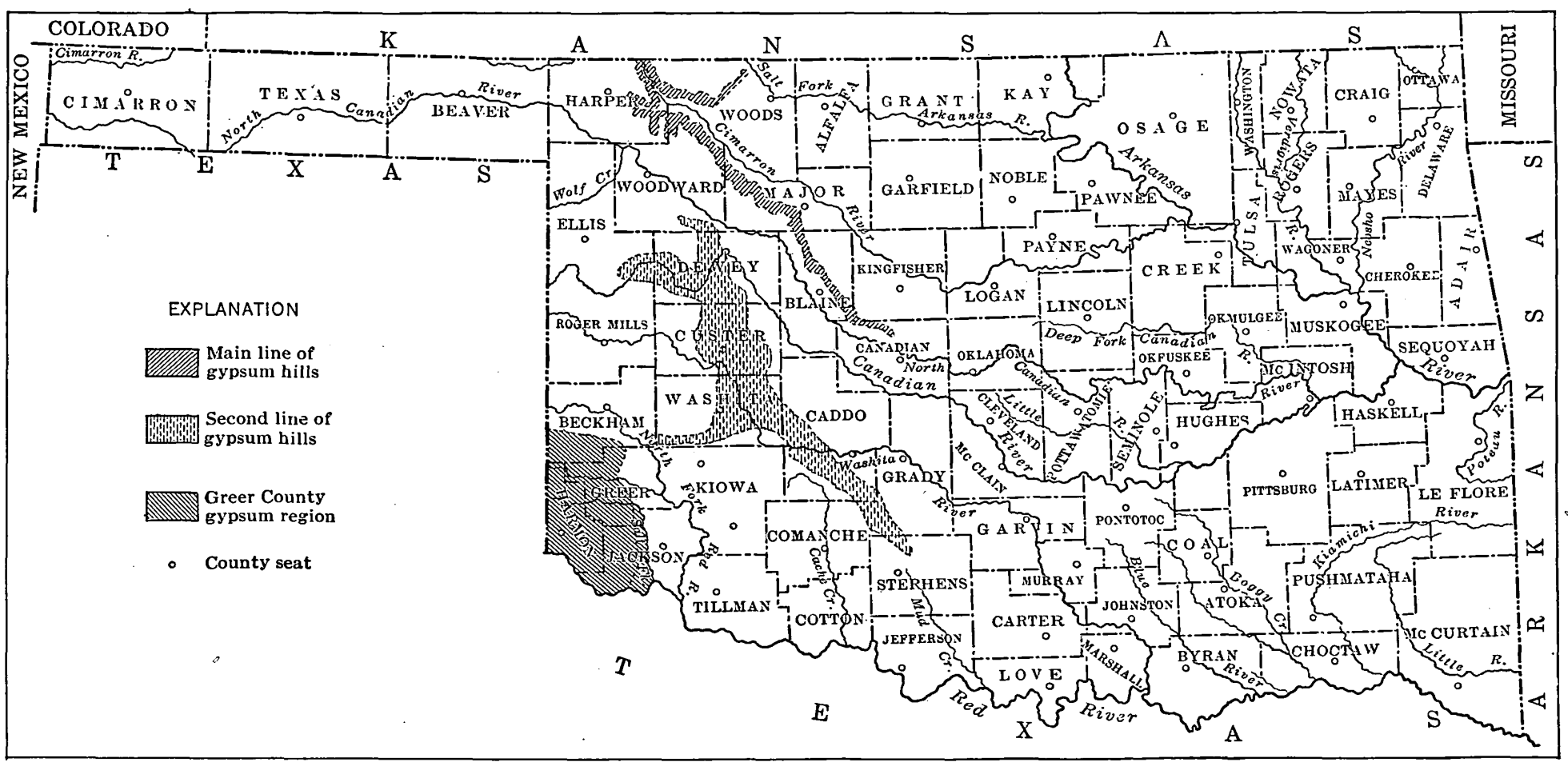

MAP SHOWING LOCATION OF GYPSUM DEPOSITS IN OKLAHOMA. 
Blaine formation, three gypsum members, the Fergu-

Feet. son, Medicine Lodge, and Shimer, with intervening. shales

$75-100$

Enid formation, red shales and clays with thin, lenticular red sandstones and bands of white sand_--- 1, 200-1, 500

Of these formations the Blaine and the Greer contain the grypsum deposits. The distribution and stratigraphy of these formations is given in some detail under the description of the localities.

\section{LOCALITIES.}

For convenience of discussion the gypsum deposits in Oklahoma are considered to occur in three areas-(1) the main line of gypsum hills, along Cimarron River, in the northwestern portion of the State; (2) the second line of gypsum hills, in the west-central portion; and (3) the southwestern gypsum hills, in the extreme southwestern portion. These areas are shown on the map (Pl. XXVII).

\section{MAIN LINE OF GYPSOM HILLS.}

\section{GYPSUM DEPOSITS.}

The main line of gypsum hills is produced by the outcrop of the Blaine formation, which consists of three beds of gypsum separated by red shales. Of the three beds the lowest one is known. as the Ferguson gypsum member; the middle as the Medicine Lodge gypsum member; and the uppermost as the Shimer gypsum member.

The line of hills enters Oklahoma from Kansas along the south side of Salt Fork of Arkansas River; then crosses Cimarron River near the Kansas line and extends southeast along the south side, gradually falling back from the river until the hills and the gypsum beds die out in Canadian County. The extreme southeastern extension of the hills lies nearer to the North Fork of Canadian River than to the Cimarron, but the escarpment faces the Cimarron.

Near the Kansas line, in Woods, Harper, and Woodward counties, the three gypsum beds are present, but the shales between them are thin, and the outcrop commonly gives the impression that there are only one or two beds. All three gypsums are entirely selenitic, the individual crystals reaching about 2 inches in dimension. This coarsely crystalline texture renders the beds porous and easily penetrated by water. Consequently the effects of solution are very marked. Sink holes and caverns are common, and in many places one or more of the beds is entirely removed at the surface and does not outcrop for considerable distances. As a result 
of solution the outcrops are very irregular and patchy. (See Pl. XXVIII, A.) The thickness of the Blaine formation in this vicinity is between 50 and 75 feet, of which half or more is of gypsum.

To the southeast, in Major County, the gypsum changes in character, becoming finer grained from northwest to southeast, so that at the Blaine County line the selenitic phase is almost entirely replaced by dense rock gypsum. With this change the effects of solution become less prominent and the outcrops of the three beds are much more distinct and regular.

The outcrop continues to the south and east across Blaine County with little change in the stratigraphy. The gypsum beds thin somewhat, and the intervening clays are a little thicker. The Medicine Lodge gypsum contains considerable anhydrite. Near the eastern boundary of Blaine County the gypsums thin and become lenticular, finally dying out in northern Canadian County, north of El Reno.

The nature of the Blaine formation is shown in the following sections, given in order from northwest to southeast:

Section on Yellowstone Creek $1 \frac{1}{2}$ miles southeast of Kingman, Woods County, Olkla.

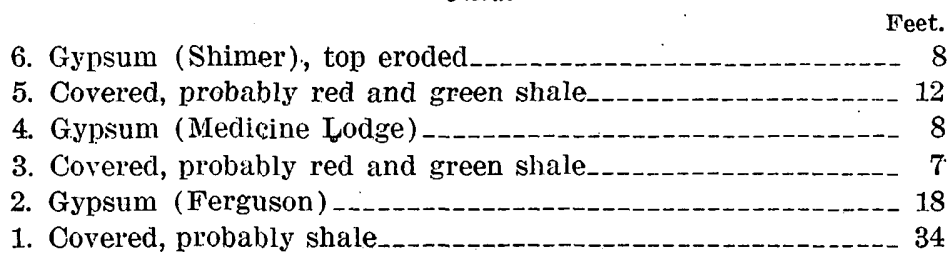

Nos. 2 to 6 , inclusive, make up the Blaine formation. All the gypsum is selenitic.

Section on West Barney Creek, Major County, Okla.

13. Gypsum (Shimer), top eroded_.r.

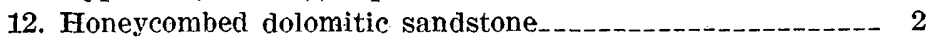

11. Covered, probably shale

10. Gypsum (Medicine Lodge) with about 6 inches of anhy-

drite near middle

9. Covered, probably shale____... 13

8. Gypsum (Ferguson)

7. Greenish dolomitic sandstone _.......-

6. Green sandy shale

5. Red shale with many thin bands of green shale and satin spar -_- mon 14

4. Selenitic sandstone

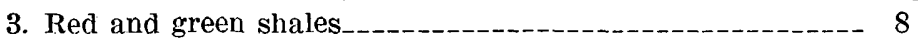

2. Shale and soft sandstone, red and green, cross-bedded,

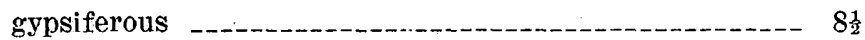

1. Covered, probably shale

Nos. 8 to 13, inclusive, make up the Blaine formation. 


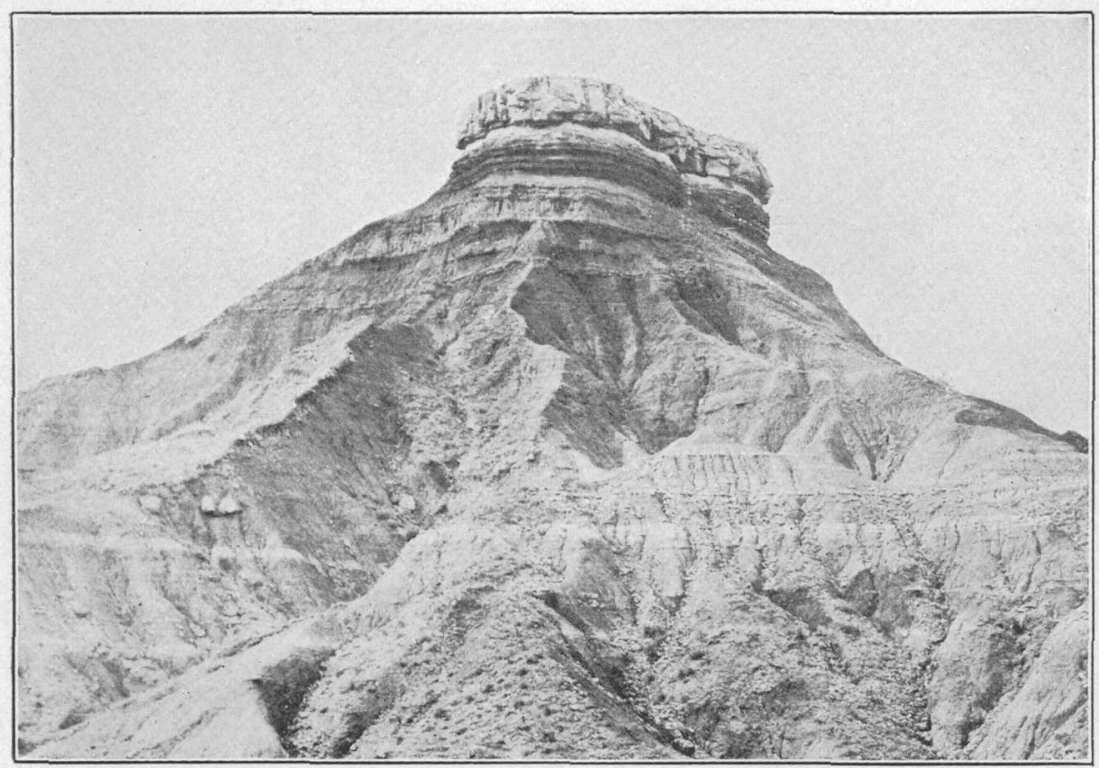

A. GLASS MOUNTAIN, WOODS COUNTY, OKLA., CAPPED WITH MASSIVE GYPSUM.

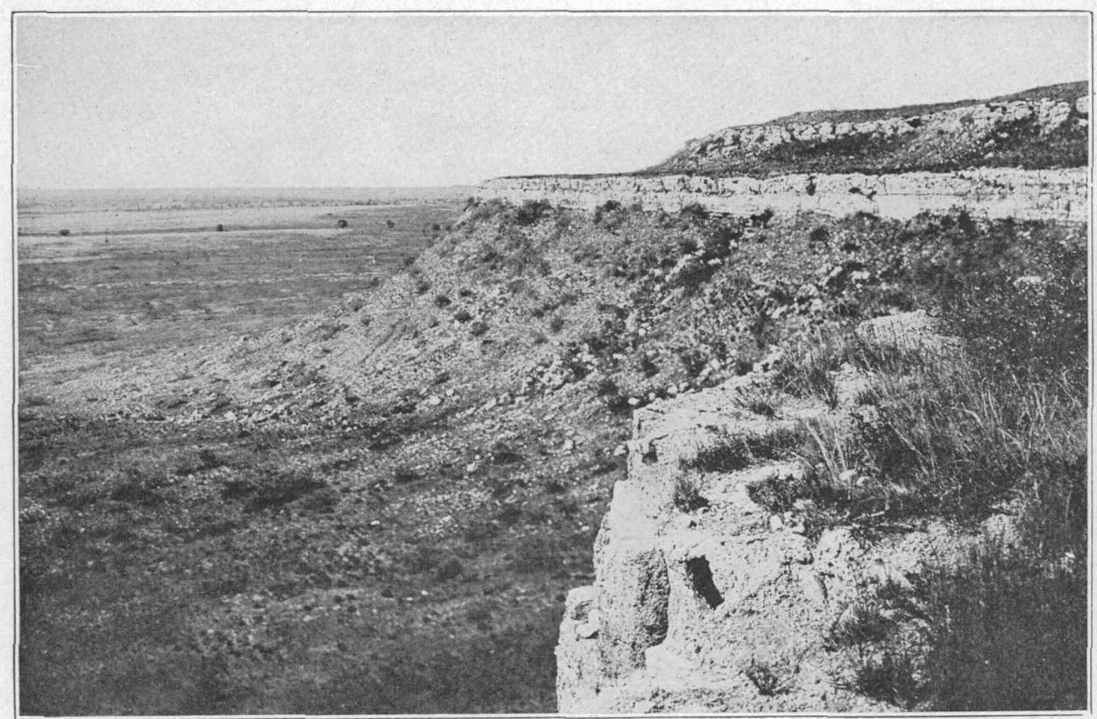

B. ESCARPMENT CAPPED WITH GYPSUM LEDGES, RED RIVER VALLEY, GREER COUNTY, OKLA. 
Section near Bickford, Blaine County, Olila.
6. Gypsum (Shimer), top eroler!- 14

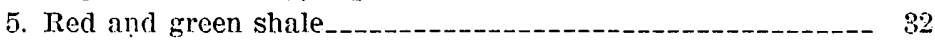
4. Gypsum (Medicine Lodge) :

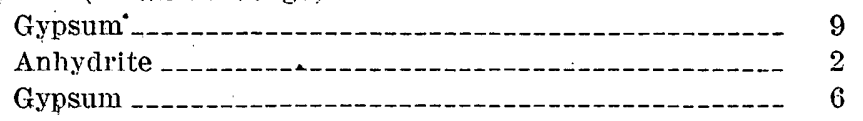

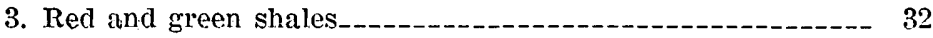
2. Gypsum (Ferguson) -
1. Red shales - -

Nos. 2 to 6 inclusive make up the Blaine formation. The gypsum is fine-grained rock gypsum, and the anhydrite division of the Medicine Lodge is quite constant in this vicinity.

Section 2 miles west of Altona and 1 mile vest of line between Blaine and Kingfisher counties, orkla.

7. Gypsum (Meet.

7. Gypsum (Medicine Lodge), top removed by erosion _......... 3

6. White dolomitic sandstone -_- 2

5. Red and green shales_____._. 16

4. Gypsum and anhydrite, with satin spar beneath

3. Red and green shale

2. Gypsum (Ferguson), selenitic

1. Red and green shale_-_-_-_- 21

The Shimer gypsum is absent in this region, but the dolomitic sandstone, which occurs beneath it to the northwest, is continued as a thick blue and white magnesian limestone, locally fossiliferous.

\section{GYPSITE DEPOSITS.}

Gypsite deposits are common along the first line of gypsum hills, but most of those so far known are very small. The only ones developed as yet are in Blaine County, north of Watonga. These beds in the aggregate cover more than 100 acres, and the gypsite averages 6 to 8 feet thick. The material has been utilized by mills at Watonga, Bickford, and Okeene.

\section{SECOND LINE OF GYPSUM HULS.}

GYPSUM DEPOSITS.

Although generally spoken of as a line of hills, the gypsum outcrops of this region do not form a single prominent escarpment, like the outcrop of the Blaine formation just described, but rather a series of low, rounded knolls and ridges. The gypsum beds are present in the lower part of the Greer formation. The rocks of this formation are principally soft clay shales, with some soft sandstones and lenticular masses of gypsum. Some of the lenses of gypsum are of considerable extent and thickness, but there are no welldefined beds which can be traced for many miles like those in the 
Blaine formation. The gypsum varies from fine-grained rock gypsum to coarsely selenitic gypsum, and from white to red and green in color.

The area here called the second line of gypsum hills includes parts of Dewey, Ellis, Roger Mills, Custer, Washita, Caddo, Comanche, Grady, and Stephens counties:

In the northern part of the area, in Dewey County, and in the small portions of Ellis and Roger Mills counties which contain gypsum, the beds are, for the most part, thin and lenticular. Though the total amount of gypsum present is great there is probably very little which can be considered as available under present conditions of transportation and markets. The only locality observed in these counties where conditions seem at all favorable for development is at Camargo, where a bed about 4 feet thick outcrops along the Wichita Falls \& Northwestern Railway.

The important deposits in this area are in the eastern portions of Custer and Washita counties. Beginning at Weatherford, in southeastern Custer County, and extending southward along Washita River, in Washita County, is an area that contains thick beds of gypsum. Near Weatherford the outcrops of beds which are as much as 50 feet in thickness and which would require very little stripping can be reached by short spurs from the Chicago, Rock Island \& Pacific Railway.

In eastern Washita County the gypsum occurs at two horizons, but the beds at both horizons are more or less lenticular. In many localities, however, beds 40 to 60 feet thick may be traced fon 1 or 2 miles. The gypsum is mostly massive rock gypsum, but selenitic gypsum is not uncommon. The lowest beds are hard and in places contain anhydrite. Several localities in this area can be reached by spurs, 2 to 4 miles in length, from the St. Louis-San. Francisco Railway. In the westward extension of the gypsum area in the southern part of the county three distinct ledges occur. These ledges range in thickness from 15 to 20 feet. The upper and lower ledges are massive rock gypsum, and the middle one contains anhydrite.

The deposits in Caddo, Comanche, and Grady counties are the southeastward extension of those in Washita County just described. The beds become thinner and more lenticular to the southeast, so that there are very few, if any, localities in these counties where the deposits of rock gypsum are commercially valuable.

\section{GYPSITE DEPOSITS.}

Important deposits of gypsite occur at Indianapolis, in Custer County, at Cement, in Caddo County, and at Rush Springs, in Grady County. The bed at Indianapolis is between 60 and 90 acres in 
extent and has a maximum thickness of 18 feet. This bed has not been developed. The beds at Cement originally covered about 40 acres and had a maximum thickness of about 12 feet. The gypsite from these beds was used in a plaster mill at Cement, which was burned in 1911. The greater part of the deposits has been used, and there is probably not enough material remaining to justify rebuilding the mill. The deposits at Rush Springs cover more than 50 acres and have an average thickness of about 8 feet. The material has been utilized for plaster at a large plant near Rush Springs.

\section{SOUTHWESTERN AREA.}

\section{GYPSUM DEPOSITS.}

The southwestern gypsum area lies in the extreme southwestern portion of the State, in Beckham, Greer, Jackson, and Harmon counties. The area is probably the southwestward continuation of the second line of gypsum hills, and the gypsum beds seem to lie at the same horizon as those to the east-that is, in the Greer formation. However, the beds form well-defined, continuous ledges, especially in the northern part of the area. The outcrop forms a steep escarpment, rising above a plain of red shales (see Pl. XXVIII, $B$ ), and is more like the outcrop of the gypșum beds of the Blaine formation, the first line of gypsum hills, than it is like- the eastern portion of the outcrop of the Greer formation, the second line of hills. The transition from the eastern portion of the outcrop of the Greer formation, in which the lenticular gypsum beds form low, rounded knobs, to the western portion, in which the well-defined gypsum beds form a steep escarpment, probably takes place in the belt along the south side of Washita County, where there are three beds which are continuous for a considerable distance.

In southern Beckham County, in northern Greer County, and in the northernmost township of Harmon County there are five distinct gypsum members in the Greer formation. From the base up these are the Chaney, Kiser, Haystack, Cedartop, and Collingsworth gypsum members.

The Chaney gypsum member in the western part of Greer County is a hard, massive layer 3 to 5 feet thick, generally white but locally gray or blue, and in places distinctly cross-bedded. To the east the bed thins and finally becomes only a gypsiferous band in the red shale.

The Kiser gypsum member is variable in character and thickness. Locally it is selenitic, but in other places it is quite shaly. The color is generally drab or bluish. The thickness ranges from 1 to 3 feet.

The Haystack gypsum member is massive, is white to gray, and ranges from 18 to 25 feet in thickness. Thin bands of gypsiferous 
sandstone occur locally. The bed is so jointed that it weathers into rectangular blocks, which in places cover the slopes for considerable distances below the outcrop of the bed.

The Cedartop gypsum member is a massive white gypsum 18 to 20 feet thick and very similar to the Haystack.

The Collingsworth gypsum member is of practically the same thickness as the Cedartop and very similar to it and to the Haystack gypsum. In many places its outcrop has been eroded.

These gypsum beds outcrop conspicuously on the north side of North Fork of Red River, in southeastern Beckham County, cross the river, and also the divides between North Fork and Elm Fork, and form a deep canyon in which Elm Fork flows eastward from the Texas line for about 13 miles.

Farther south the gypsum ledges lose their identity, and the southern portion of the area more nearly resembles the second line of gypsum hills. In southern Greer County the only notable outcrops are those on Salt Fork of Red River opposite Mangum. The greater part of Harmon County is very level, and exposures of gypsum are too rare to give an idea of the extent or thickness of the beds. Their presence is shown, however, in sink holes and in wells.

In western Jackson County the gypsums are more prominent than in southern Harmon County but much less so than along North and Elm forks of Red River. The stratigraphy is very irregular. The best exposures are on Horse Branch and Boggy Creek.

The following sections give the details of the stratigraphy in different parts of the southwestern gypsum area:

Section of bluff on north side of North Fork of Red River, 3 miles south of Carter, Beckham, County, Okla.

Greer formation:

Feet.

Rough, weathered, sandy dolomite capping the high hills

(Mangum dolomite nember).

Red and green gypsiferous shale___________ 24

Massive white gypsum (Collingsworth)

Red and green shale____._. 6

Massive white gypsum (Cedartop)

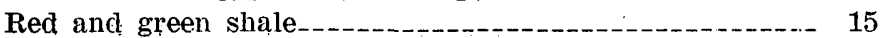

Massive white gypsum, in places containing thin ledges of sandstone (Haystack) _. 25

Reddish and green shale _._._._._. 24

Greenish gypsum layers and gypsiferous shale, becoming hard locally (Chaney)

Red and green gypsiferous shale from the base of the hill_ $\quad 30$. 
Section on Elm Fork at mouth of Hacliberry Creel, Grecr County, Olila.

Greer formation:

Feet.

Har:d cap rock, dolomite (Mangum) _._._._- 3

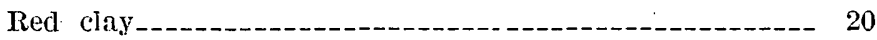

Massive white gypsum (Collingsworth) _._._-_._._._. 18

Red and blue clay _..._- 8

Massive white gypsum (Cedartop) --_-_-_-_-_-_-_-_- 20

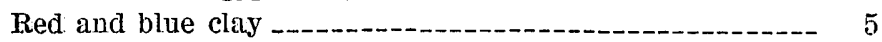

White gypsum separated into thin beds by sundy dolonite

(Haystack) -....-_-_-_.-- 18

Red and blue clay -_-_-_- 12

Bluish stratified gypsum (Kiser) -...-_-_-_-_-_-_-_ 4

Red and blue.clay _._._._._. 15

White and bluish gypsum (Chaney)

Red and blue clay -..-_- 8

Section of bhuff on Elm Fork in sec, 10, T. 6 N., R. 26 W., Harmon Comnt!), Okla.

Greer formation :

Dolomite (Mangum)

Red clay -...-_. 16

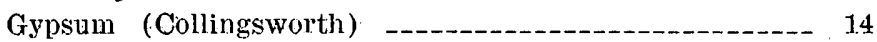

Red and blue clay

Gypsum (Cedartop) -

Red and blue clay-_-_- 5

Gypsum '(Haystack)

Red and blue clay $\dot{y}_{-}$

Grpsum (Kiser) -

Redi clay _-_._.

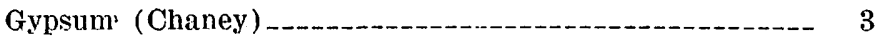

Gypsiferous red and blue clay -.......- 60

Section of bluff between Salt Forl and Horse Branch near Olustee, Jaclison County, Okla.

Hard dolomite, forming the cap of the hill

Red and blue clay _-_._- 1.2

Massive white gypsum _................ 8

Red clay with ledges of gypsum

Massive white gypsum _._._._._._._. 12

Red and blue clay ...-_-_-_....... 15

Red and blue soft shaly rock and gypsum _._......... 5

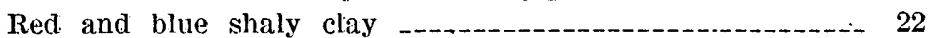

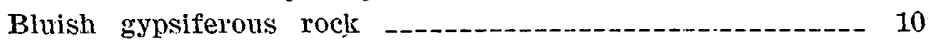

Red and blue clay -...- 8

Massive white gypsum _._._......... 3

Rerd clay slope from Horse Branch 
GYPSITE DEPOSITS.

No deposits of gypsite are known in Beckham County. In Harmon County only two small beds 3 to 6 feet thick, whose combined area is about 25 acres, are known. In Greer County, about 4 miles west of Willow, a station on the Wichita Falls \& Northwestern Railway, one of the Missouri, Kansas \& Texas lines, is a bed covering about 300 acres and ranging from 4 to 14 feet in thickness. This material seems to be an original deposit of very gypsiferous shale and fine sand rather than true gypsite. It is reported to have been tested and to have made good plaster.

The gypsite beds of Jackson County are among the most valuable in the State. They are of large extent and are well situated in regard to transportation. The largest bed known in the county covers an area of about 400 acres, just north of the town of Eldorado. The thickness of the gypsite ranges from 8 to 20 feet with little or no overburden. The Eldorado plant of the United States Gypsum. Co. is situated at the bed and is reached by a spur from the St. Louis-San Francisco Railway. The company owns this bed and also controls another bed in the same township. This second bed is about 140 acres in area and is 6 to 12 feet thick. The railroad passes near its east end. Several smaller beds having an aggregate area of 100 acres or more and thicknesses of 4 to 8 feet occur in the same portion of the county.

A gypsite bed approximately 376 acres in area lies 1 mile east of Duke, on the Wichita Falls \& Northwestern Railway. The gypsite is 6 to 8 feet in thickness, and its cover is 2 feet in greatest thickness. In considerable areas the gypsite lies at the surface. The gypsite is light gray near the surface but grades into pink and reddish-brown in the lower parts of the bed.

\section{ECONOIMIC - DEVELOPMENT.}

GENERAL CONDITION OF THE GYPSUM INDUSTRY.

The development of the gypsum industry in Oklahoma has been greatly retarded by poor transportation facilities, the high price of fuel, and the remoteness of important markets:

Though the resources of, gypsum are enormous, in only a comparatively few places are the deposits near enough to railroad lines to render them immediately available. However, sufficient quantities of gypsum are near enough to railroads to sustain an immense production for many years, and the lack of transportation is only a minor feature in retarding the growth of the industry.

None of the natural fuels occur in the gypsum area, and coal must be obtained from the fields of eastern Oklahoma or from Colorado and New Mexico. The fuel expense is necessarily high and 
makes the cost of the gypsum products much greater than in: regions more fortunately situated in respect to fuel supply.

By far the most important hindrance to the development of the industry, however, is the distance to the principal building centers. None of the cities near the deposits are large enough to provide markets for a large production. The freight rates to the cities of the Eastern and Central States are prohibitive, and in most of these cities the demand for gypsum products can be supplied from deposits much nearer than those in Oklahoma.

The great amount of building in Oklahoma following its admission as a State in 1907 furnished a good local market for plaster. Several mills were built to supply this demand. Since then some of the mills have been idle and others have made only small and intermittent production. Few, if any, have run to full capacity in the last few years.

\section{MIILLS AND QUARRIES.}

In 1915 there were nine mills operating or in condition to operate in Oklahoma-two at Watonga, and one each at Bickford, Darrow, Southard, Okeene, Alva, Eldorado, and Rush Springs.

The mill at Eldorado is in the southwestern gypsum area, the one at Rush Springs at the southeastern end of the second line of gypsum hills, and the others along the first line of gypsum hills. Five of the nine mills are in Blaine County. All the mills use the kettle process except the one near Darrow, which uses the Cumner rotary kiln or continuous process. Four mills operated in 1918.

The mill of the American Cement Plaster Co. at Watonga is located on the Chicago, Rock Island \& Pacific Railway. The capacity of the mill is about 200 tons of plaster each 24 hours. The rock gypsum is obtained from a quarry in the Medicine Lodge gypsum 7 miles northeast of the plant. The gypsum bed is 12 to 15 feet thick, and there is practically no anhydrite. (See Pl. XXVI, B.) The rock is crushed at the quarry and run into railroad cars in which it is conveyed to the mill. Gypsite is obtained from a large bed less than a mile distant from the rock quarry. The bed covers about 80 acres, and its maximum thickness is 8 feet. Not over half the deposit has been used. The principal products of the mill are different grades of wall plaster. A large part of the output is used at. the mill in the manufacture of partition blocks.

A plant which has been idle since 1912 is also located at Watonga. It was formerly operated by the Monarch Plaster Co., was sold to the Oriental Cement Plaster Co., and is now owned by the National Cement Plaster Co. It is equipped with the ordinary power plant, crushing and grinding machinery, and two 10-foot kettles. The 
quarry is nertheast of the plant, only a few rods from that of the American Cement Plaster Co., and gypsite was procured from the eastern portion of the bed utilized by that company.

The mill and quarry of the Roman Nose Gypsum Co. are located at Bickford, about 8 miles north of Watonga, on the Chicago, Rock Island \& Pacific Railway. The mill is at the foot of the escarpment of the gypsum beds of the Blaine formation, and only a short haul by wagon is necessary to transport the rock to the mill. The Medicine Lodge gypsum is quarried. The entire bed is about 15 feet thick, but the middle portion, about 3 feet in thickness, contains anhydrite. Only the 6-foot layer above the anhydrite has been used, but the lower portion: can be obtained easily by stripping the anhydrite. The mill has three 8-foot kettles for calcining. Power is furnished by a gas engine. Partition blocks and wall plasters were the principal products. This plant has been idle since 1914.

The Southwest Cement Plaster Co. had a mill with two 10-foot kettles at Okeene, on the St. Louis-San Francisco Railway. The rock gypsum was crushed at the quarry, $7 \frac{1}{2}$ miles southwest of Okeene, and hauled to the mill in railroad cars. The portion of the Medicine Lodge gypsum above the anhydrite wais quarried. Gypsite was taken from a bed near the quarry. This mill burned down in August, 1918.

The mill of the Oklahoma Gypsum Co, which is west of Darrow, on the St. Louis-San Francisco Railway, is idle. The quarry is in the Ferguson gypsum, which is 6 feet thick and very pure. The portion of the Medicine Lodge gypsum above the anhydrite is also available. It is 10 feet thick and requires little stripping.

The mill of the Oklahoma Plaster Co. at Alva, on the Chicago, Rock Island \& Pacific and Atchison, Topeka \& Santa Fe railways, has been torn down, and the company is out of business. The quarry is at Belva, in Woodward County, on the Atchison, Topeka \& Santa Fe Railway. The Ferguson gypsum, which in this locality is 25 feet thick and coarsely selenitic, was quarried.

The Southard plant of the United States Gypsum Co. is located at Southard, on the St. Louis-San Franciseo Railway. Two 10-foot kettles are used for calcining, and a 25-foot eircular kiln is used for making Keenes cement. Both the Shimer gypsum and the Medicine Lodge above the anhydrite have been quarried. The Shimer gypsum averages 17 feet thick in the quarries and is exceptionally pure. The stripping is generally less than 2 feet. The rock is hauled about one-fourth of a mile to the mill in wagons.

The Eldorado plant of the same company is located at Eldorado, in Jackson County, on the St. Louis-San Francisco Railway. The mill has four 10-foot kettles. Gypsite alone is used as the raw ma- 
terial. This is procured from a 400 -acre bed immediately north of the mill.

The mill of the Acme Cement Plaster Co. is at Acme, west of Rush Springs, in Grady County. Gypsite is used as the raw material. The mill is a modern fireproof concrete structure and has two 12-foot kettles, which are fired with fuel oil. This company quarries rock gypsum at Grady's Switch, near Cement, Caddo County, to supply Portland cement mills.

The Oklahoma Portland Cement Co. began to operate a mill at Primm in 1918 and sold its product crude.

In addition to the plants described others have been operated in the past. Plants at Cement and Marlow have been burned. These plants were succeeded by the plant at Rush Springs. The United. States Gypsum Co.'s mill at Okarche was abandoned in 1912 on account of the exhaustion of the gypsite beds and the difficulty of procuring a sufficient supply of rock gypsum. A small mill was operated at Peckham, in Kay County, several years ago but was removed when the small gypsite beds, from which the raw material was obtained, were exhausted. A 2-kettle mill still standing 4 miles west of Ferguson, in Blaine County, made a small production but has been idle for many years. On account of its distance from. the railroad there is no probability of its resuming operations. 


\section{OREGON.}

By R. W. Stone. ${ }^{t}$

\section{IOCATION AND CHARACTER.}

Gypsum in commercial quantity occurs in two localities in Oregon. One of these is at Gypsum, Baker County, and the other is in Crook County 30 miles east of Bend, in sec. 29, T. 18 S., R. 17 E. It is reported that the material in Crook County consists of crystals of gypsum mixed with clay, probably. gypsite, and that it has been used as a fertilizer. It lies at the surface without cover over many acres and can be dug with scraper or pick and shovel. A shaft 15 feet deep did not reach the bottom of the deposit.

Minor occurrences in Oregon have been reported from Grant County, in the John Day region; Jackson County, at the Alton or Baron mine, Ashland district; Josephine County, at the Alameda mine and Galice district (as a gangue mineral); and Wheeler County, at Bridge Creek. Nothing is known of the character or extent of the deposits at these places.

The only developed deposit of gypsum in Oregon is at Gypsum, near the middle point of the eastern boundary of the State, on a ridge that forms the divide between Burnt River and Snake River. Elongated lenses of rock gypsum occur on the ridge, but they have a limited geographic extent. A continuation of this deposit is reported to occur in the ridge on the opposite side of the river in Idaho. The gypsum lenses are from 10 to 40 feet thick. Some of the deposit is white crystalline gypsum of good quality, but part of it is rendered almost valueless by the inclusion of thin strata and films of a greenish chloritic mineral and by brecciation and inclusion of angular fragments of limestone and other rock. There is, therefore, a large percentage of waste in quarrying.

\section{GEOLOGIC RELATIONS.}

The lower portion of the ridge between Burnt River and Snake River is composed of a series of old lavas, largely rhyolitic in composition. Above these is a sedimentary series, in which the gypsum is interstratified. Thick beds of limestone and also shales, with intercalated strata of volcanic tuffs, occur in the series.

${ }^{1}$ Compiled from Lindgren, Waldemar, Gypsum deposits in Oregon: U. S. Geol. Survey Bull. 223, p. 111, 1904; Plaster mill of the Pacific Lime \& Gypsum Co., by staff correspondent, Pacific Builder and Engineer, July 5, 1913; and other sources. 


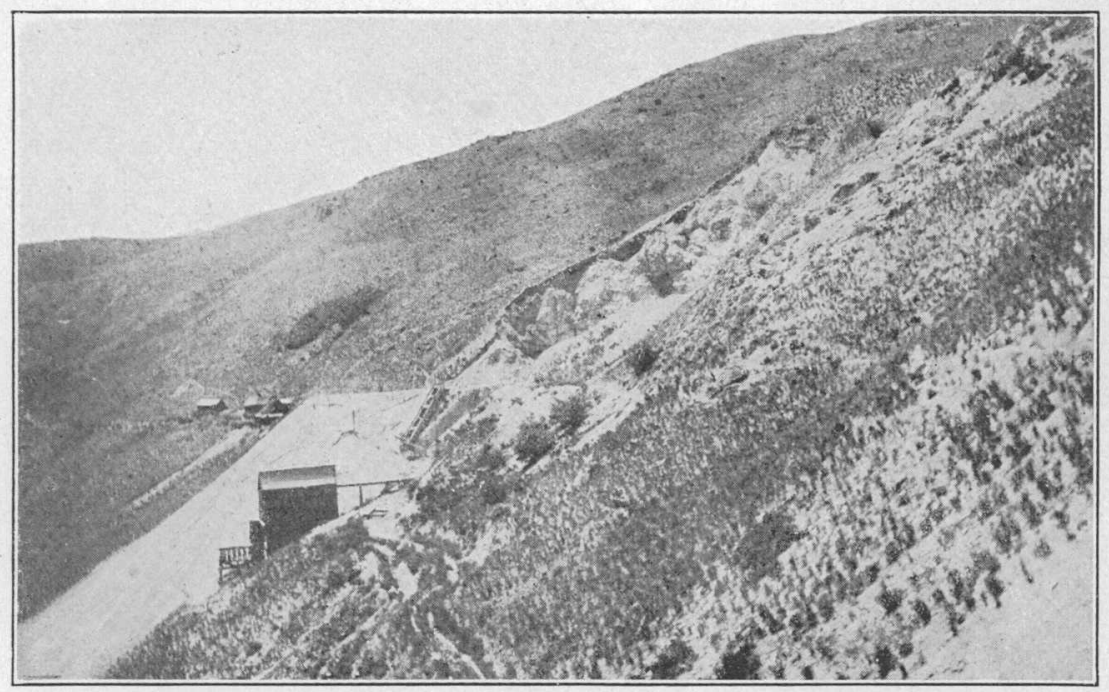

A. GYPSUM QUARRY AND LOADING PLATFORM OF AERIAL TRAMWAY, GYPSUM, OREG.

Photograph by E. F. Burchard.

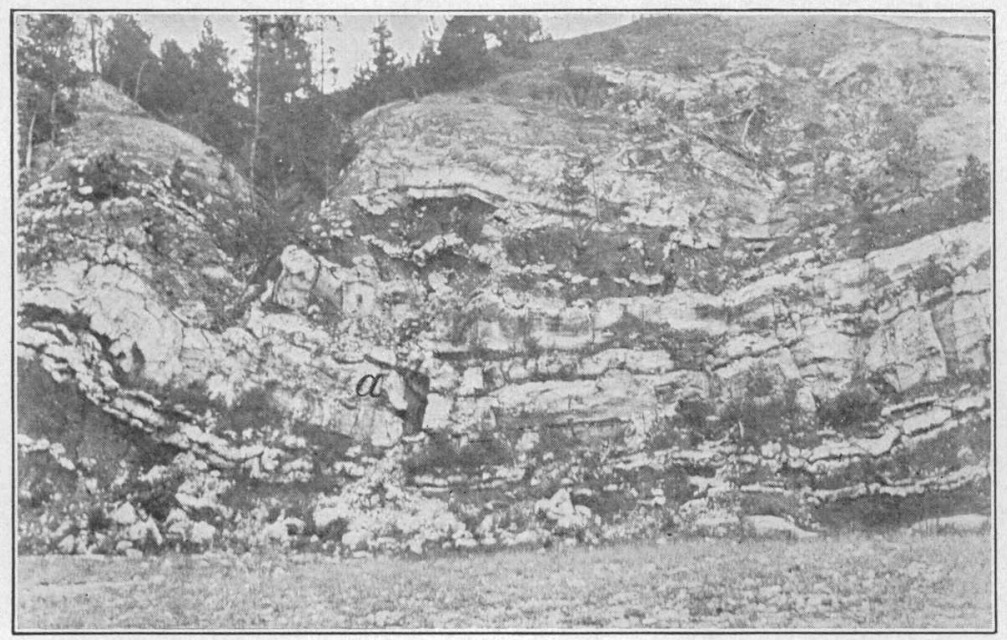

B. GYPSUM OUTCROP 4 MILES NORTHWEST OF MINNEKAHTA, S. DAK.

$a$, Location of mineral claim. Photograph by J. G. Hutton. 
The period to which the gypsum beds belong is probably early Miocene, as seems to be indicated by the geologic relation of the sedimentary beds of the region, but the evidence is not wholly clear.

\section{ECONOMIC DEVELOPMENT.}

Although the gypsum deposit on Snake River has been known for 40 years, it was long undeveloped. Remoteness from market probably retarded its use. The first development was not successful, for a mill erected in 1896 was burned the same year. Another plant was built and operated for some time. This was at Lime, a station on the line of the Oregon-Washington Railroad \& Navigation Co., 4 miles northwest of Huntington. The gypsum occurs about 200 feet below the summit of the ridge, 1,500 feet above and on the slope facing Snake River, and the deposit was reached from Lime by a winding road ascending the ridge. On account of the northwestward dip of the strata, development of the deposit was undertaken by means of tunnels. The elevation of the lower opening is approximately 3,900 feet above sea level. A tunnel 170 feet long, connecting with an upraise 100 feet long, exposed gypsum. rock of good quality 20 feet thick. This enterprise did not prove successful, however, although there was a market for gypsum products in Oregon, Washington, and southern Idaho, a territory to which it naturally was the source of supply.

Several years ago the Pacific Lime \& Gypsum Co. erected a plant at Gypsum, on the Oregon Short Line Railroad, about 5 miles northeast of Huntington, to use the same deposit as that worked from Lime. The mill is on the bank of Snake River and the quarry is on the ridge about 1,800 feet above it. (See Pl. XXIX, A.) Rock gypsum is brought from quarry to mill by a 6,100 -foot aerial tramway.

The gypsum is quarried by the open-bench system, and it is reported that a quarry face has been developed 250 feet wide and nearly 100 feet high. Dump cars, whose capacity is 1 cubic yard, convey the rock to bunkers at the outer edge of the quarry floor, where it is passed through a large jaw nipper and a gyratory crusher operated by electric motor. The rock thus broken to pass through a 1-inch ring runs by gravity into bins at the upper end of the aerial tramway. This conveyer operates under gravity with 36 buckets of 600 pounds capacity each. The weight of the loaded buckets going down is utilized to develop horsepower at the quarry for operating an air compressor and pneumatic tools.

From the storage bin at the lower end of the tramway a belt. conveyer takes the rock to the hopper of a horizontal rotary drier, where practically all the mechanically included moisture is driven 
off. This drier is 60 feet long, 8 feet in diameter, and oil fired. Steel bucket and screw conveyers take the hot rock to steel bins over the pulverizers. Air separators carry the pulverized gypsum, most of which will pass a 200-mesh sieve, to bins near the roof of the kettle room. Calcining is done in two 14-foot kettles of 20-ton capacity. Fuel oil is used for heating the kettles. From the concrete hot pits the stucco is taken by steel bucket and screw conveyers to bins on the upper floor of the mixing department. Mixing machines and valve baggers insure uniform preparation and weighing of the product. From each weigher a package conveyer delivers the bag to the car.

The main building of this plant is 525 feet long by 70 feet wide, has a steel frame, and is entirely covered with corrugated iron.

Electric power for driving all machinery at the plant is developed from fuel oil, which is stored in four 25,000-gallon cylindrical tanks. Most of the product of this plant is wall plaster and is sold in the Pacific Northwest. This Oregon deposit has been producing gypsum continuously for a number of years, with the exception of 1911-12, when no production was reported. It is now operated by the Acrne Cement Plaster Co., of St. Louis, Mo. 


\section{SOUTH DAKOTA.}

By J. G. HutTon.

\section{STRUCTURE AND STRATIGRAPHY.}

Beds of gypsum are exposed in the Black Hills in the western part of South Dakota. These mountains are on the boundary line between South Dakota and Wyoming, but much the larger portion of the area lies within South Dakota. Structurally the region is marked by an elliptical uplift about 125 miles long and 60 miles wide. The longer dimension lies nearly northwest and southeast. The rocks underlying the Great Plains in this area have been uplifted and eroded so that a complete section is exposed of all the strata from the Middle Cambrian to the Upper Cretaceous. The strata dip away from the central mass of crystalline rocks of preCambrian age. Owing to the domed structure of the region the formations outcrop in concentric belts. surrounding the central mass of pre-Cambrian rocks. The harder rocks everywhere present a rugged aspect, but the softer formations have a more subdued topography. The following general sections by Darton give the characteristics, range in thickness, and order of succession of the formations:

General section of Mesozoic and Paleozoic rocks in the northern Black Hills.

\begin{tabular}{|c|c|c|c|}
\hline Age. & Form & Principal characters. & Thickness. \\
\hline \multirow{4}{*}{ Cretaceous............ } & $\begin{array}{l}\text { Laramie (?) formation } b \\
\text { Fox Hills sandstone... } \\
\text { Pierre shale........... } \\
\text { Niobrara formation.... } \\
\text { Benton group: } \\
\text { Carlile shale.......... }\end{array}$ & 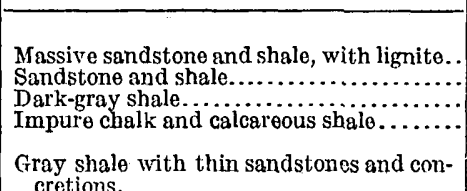 & \multirow{4}{*}{$\begin{array}{c}\text { Feet. } \\
2,500+ \\
250+ \\
1,200-1,400 \\
120-\frac{225}{} \\
600-800 \\
50-\quad 80 \\
900-1,150 \\
10-\quad 160 \\
10-\quad 100 \\
25-300\end{array}$} \\
\hline & $\begin{array}{l}\text { Greenhorn li } \\
\text { Graneros sha }\end{array}$ & $\begin{array}{l}\text { Impure slabby limestcne.................... } \\
\text { Dark shale with local sandstone in lower } \\
\text { part. }\end{array}$ & \\
\hline & $\begin{array}{l}\text { Dakota say } \\
\text { Fuson forn }\end{array}$ & $\begin{array}{l}\text { Gray to buff sandstone, mostly massive... } \\
\text { Shale, mostly massive, white to purple, } \\
\text { with sandstone layers. }\end{array}$ & \\
\hline & Lakota sa & $\begin{array}{l}\text { Buff sandstone, mostly hard, coarse, oross- } \\
\text { grained. }\end{array}$ & \\
\hline Crotaceous (?).. & Morrison formatic & $\begin{array}{l}\text { Massive shale, gray, greenish, maroon; } \\
\text { thin limestones. }\end{array}$ & $40-220$ \\
\hline Jurassic & Unkpapa sandsto & $\begin{array}{l}\text { Massive fine-grained sandstone, white, } \\
\text { butfe, }\end{array}$ & $5-150$ \\
\hline Jurassic.. & Sundance formation... & Gray shales, buff soft sandstone, reddish & $200-350$ \\
\hline $\begin{array}{l}\text { Triassic (?) ... } \\
\text { Carboniferous: }\end{array}$ & Spearfi & Red sandy shale with gypsum beds. & $450-695$ \\
\hline Permian & & & $\begin{array}{r}25- \\
60- \\
100\end{array}$ \\
\hline $\begin{array}{l}\text { Pennsylvanian-Mis- } \\
\text { sissippian (?.)c. }\end{array}$ & & $\begin{array}{l}\text { Sandstone, mainly white, buff, or red; } \\
\text { also limestone. }\end{array}$ & $350-600$ \\
\hline & & & $\begin{array}{r}100- \\
25-\end{array}$ \\
\hline Ord & e. & Massive buff limeston & $0 \tau \quad 100$ \\
\hline & Dea & $\begin{array}{l}\text { Brown sandstone, partly conglomeratic, } \\
\text { mostly massive; greenish gray sandy } \\
\text { shales, slabby dolomitic limestone, and } \\
\text { limestone conglomorate. }\end{array}$ & $200-500$ \\
\hline
\end{tabular}

a Darton, N. H., Genlogy and water resources of the northern portion of the Black Hills and adjoining regions in South Dakota and Wyoming: U. S. Geol. Survey Prof. Paper 65, p: 12, 1909.

$\delta$ Now referred to Lance formation.

$c$ Now referred to Pennsylvanian.

d Now referred to Upper Cambrian or Saratogan series. 
Gencral section of Mesozoic and Paleozoic rocks in the southern Black Hills. ${ }^{\circ}$

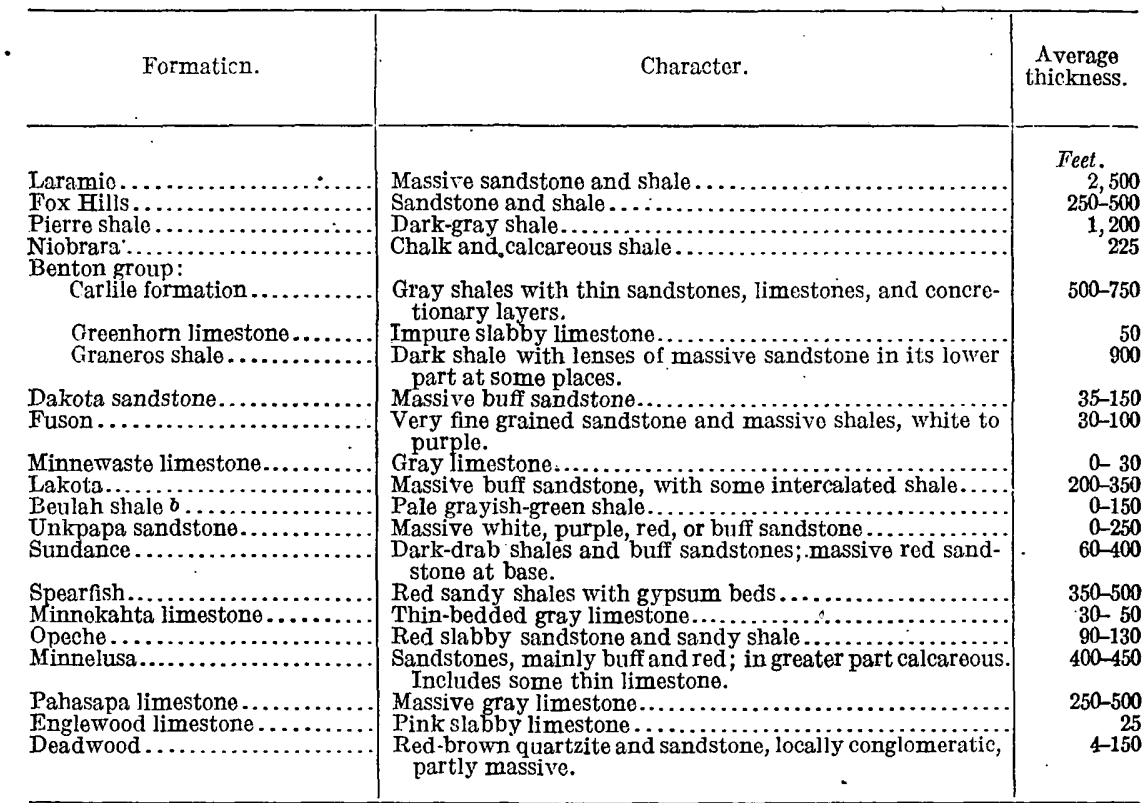

$a$ Darton, N. H., Preliminary dessription of the geology and water resources of the southern half of the Black Hills and adjoining regicns in South Dakota and Wyoming: U. S. Geol. Survey Twenty-first Ann. Rept., pt. 4, pp. 503-504, 1901.

$b$ Now known to bo the Morrison formation.

The Spearfish formation, in which the gypsum deposits occur, is of Triassic (?) age and consists of a red, sandy shale, ranging in thickness from 350 to 700 feet. The gypsum beds are present almost throughout the exposure of this formation in the Black Hills region. This formation has been called the "Red Beds," but it must not be confused with the red Jurassic sandstone or older Permian Opeche formation. Physiographically it is marked by an almost treeless valley extending entirely around the Black Hills uplift. The later formations in many places, capped by Cretaceous sandstone, form a steep escarpment facing the valley on its outward side, and the Minnekahta limestone dipping in most places somewhat steeply from the central mass of the hills forms its inner boundary. Rather low divides separate the basins of the streams which flow across the valley as they descend radially from the central area, but to the observer the valley appears continuous and without any notable interruption in its somewhat subdued relief. The area in which the Spearfish outcrops is known as the Red Valley, from the red color of the shale and the soil which has weathered from it. The distribution of the red beds in the Black Hills is shown in figure 47.

The Red Valley, in South Dakota, ranges in width from a few rods in Alabaugh Canyon, south of Hot Springs and on the west side of 


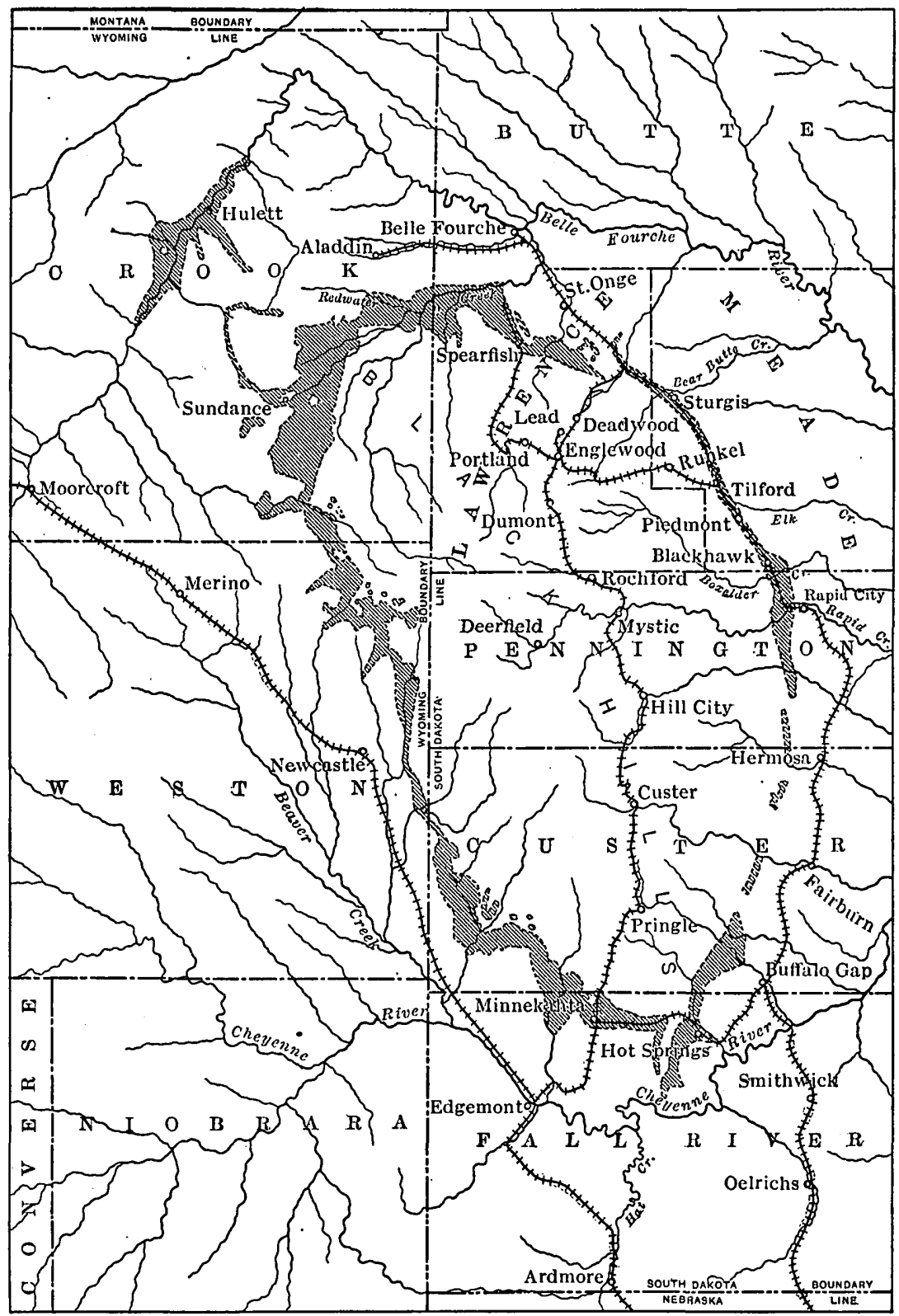

P $\quad \begin{array}{lllll}10 & 20 & 30 & 40 & 50 \mathrm{Miles}\end{array}$

Figure 47.-Map showing the area (shaded) that contains the gypsum-bearing folmation in the Black Hills, S. Dak. (After N. H. Darton.)

the Cascade anticline, to 3 miles in Martins Valley northeast of Hot Springs and to a similar width in Centennial Prairie between Whitewood and Spearfish. West of Minnekahta it is about 3 miles wide. 
The Red Valley landscape would be monotonous were it not for the outcrops of gypsum, which are indicated in many places by barren areas in the floor of the valley. At the summit of many cliffs and buttes the gypsum forms a conspicuous layer of snowy whiteness, or it has a banded appearance where more than one layer exists. (See Pl. XXX, A.) Along Centennial Prairie the gypsum outcrops for miles as snow-white bands in a bright-red background. (See Pl. XXXI, A.) A few miles northwest of Minnekahta, where trees are more abundant, the red, green, and white appear in marked contrast for several miles to the northwest.

At some points Red Valley is occupied by Tertiary deposits which cover the gypsum. This condition prevails west of Hermosa and Fairburn, and between Hermosa and Rapid City. The red beds are also covered somewhat in the area just west of Minnekahta. The places where the Spearfish formation is covered are shown as blank spaces on the map of the gypsum areas.

According to Darton ${ }^{1}$ the thickness of the Spearfish formation varies considerably from place to place. For example, along the east side of the Black Hills the thickness appears to be between 350 and 400 feet; in a deep well at Fort Meade, 695 feet; in Redwater Valley, near the mouth of Crow Creek, 680 feet; near Whitewood, 450 feet; in Alabaugh Canyon, 420 feet; west of Fanny Peak, 450 feet.

The gypsum occurs at different horizons in the Spearfish, and the thickness of the layers ranges from a fraction of an inch to 30 feet. There is some variation in the thickness of particular beds, although the principal beds are of nearly uniform thickness for long distances. In addition to the beds of gypsum there are secondary veins, which cut through the red shale in different directions. These veins have evidently been formed by water percolating from the adjoining beds and have been deposited in narrow fissures in the shale. There has been more or less solution in some of the thicker ledges, which give forth a hollow sound to the tread. In places there is folding or crumpling of layers, and the parting layers of red shale vary in thickness, having been squeezed out between the harder layers of gypsum. This condition is well illustrated in the region west of Minnekahta.

\section{IOCALITIES.}

WEST OF MINNEKAHTA.

Just west of Fanny Peak and across the Wyoming line a measurement made by Darton ${ }^{2}$ showed 450 feet or more of red beds which contain two thick beds of gypsum near the middle. The lower bed

${ }^{1}$ Darton, N. H., U. S. Geol. Survey Twenty-first Ann. Rept.; pt. 4, p. 517, 1901.

2 Idem, pp. 517-518. 


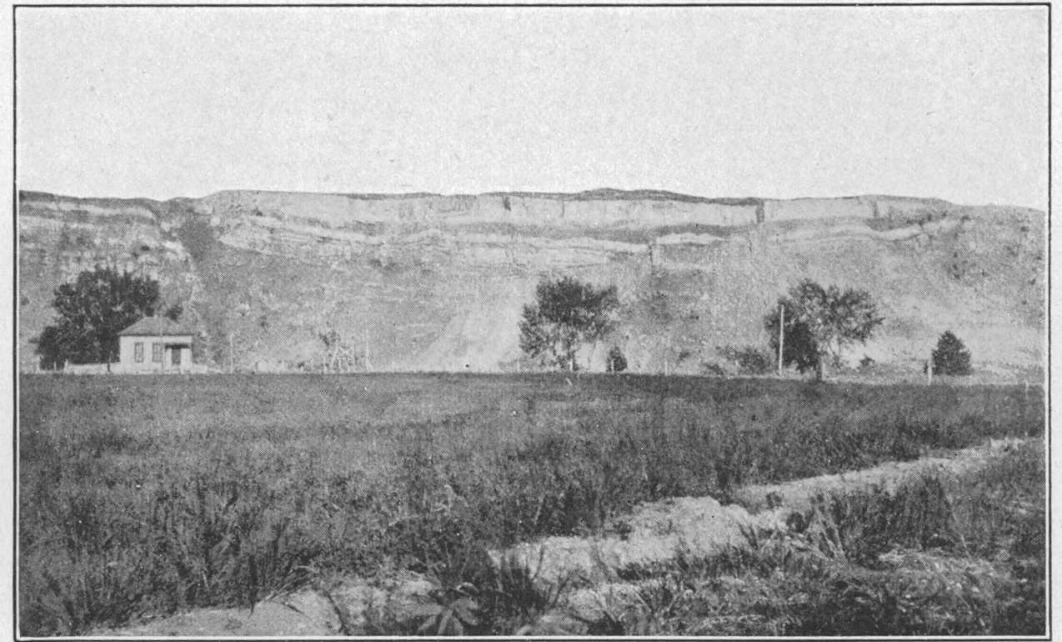

A. BLUFF SHOWING GYPSUM BED 1 MILE NORTHWEST OF HOT SPRINGS, S. DAK.

Photograph by N. H. Darton.

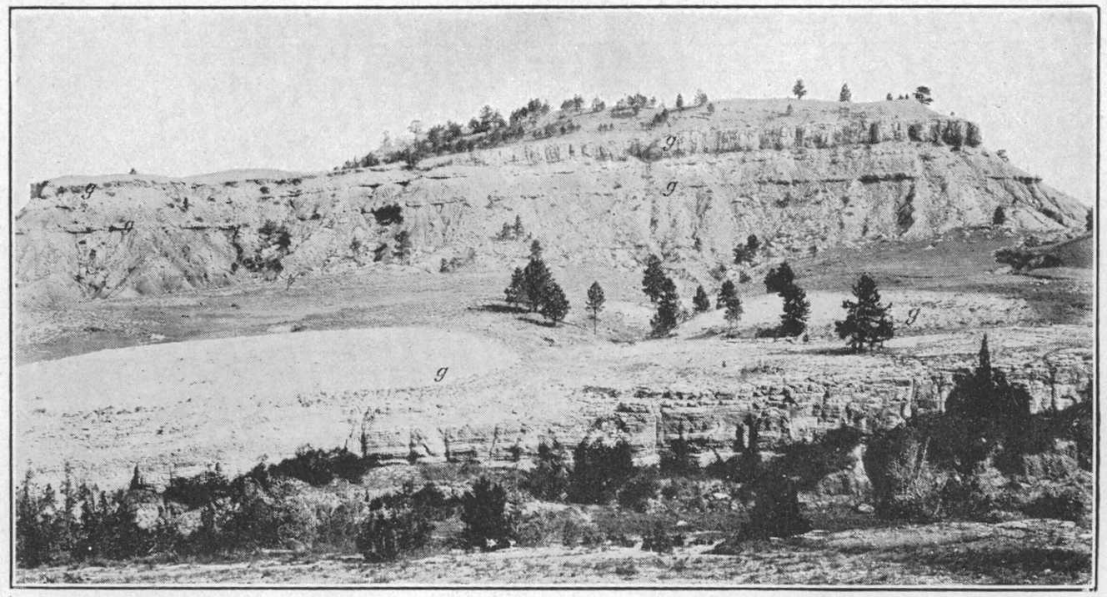

B. THREE GYPSUM BEDS IN HELL CANYON, 20 MILES SOUTHWEST OF CUSTER, S. DAK.

g, Gypsum. Photograph by N. H. Darton. 


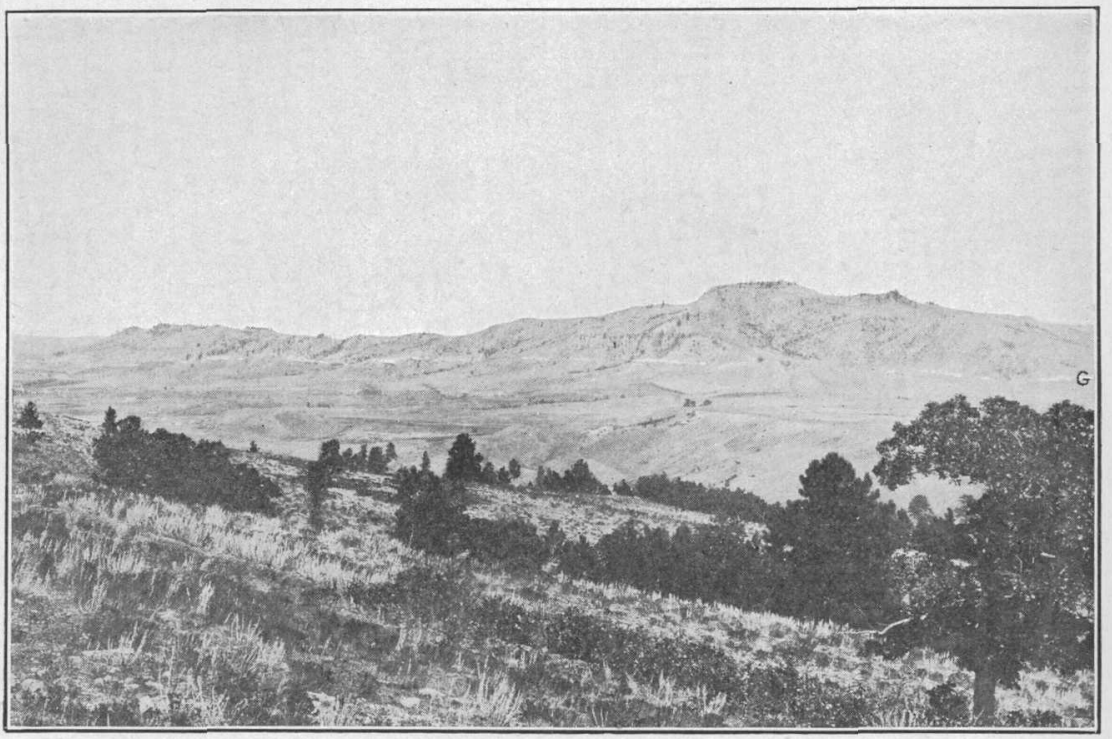

A. GYPSUM IN SPEARFISH FORMATION ON EAST SIDE OF SPEARFISH VALLEY, S. DAK.

G, Outcrop of gypsum bed. Photograph by N. H. Darton.

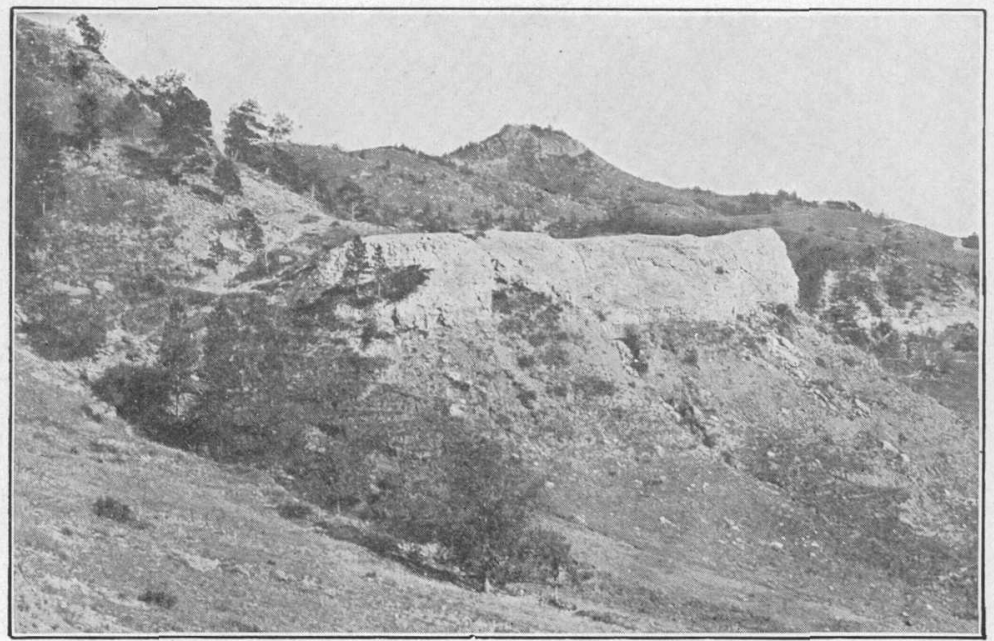

B. Close View of gypsum bed at SPEARFish, S. DAK.

Photograph by J. G. Hutton. 
of gypsum lies about 150 feet above the Minnekahta limestone. Above this bed are about 40 feet of red clays, a 2-foot bed of gypsum, 15 feet of red clays with two thin beds of gypsum near the top, a bed of gypsum which locally attains a thickness of 30 feet, and above it about 200 feet of red sandy shale, followed by the buff sandstone at the base of the Sundance formation.

About 5 miles northwest of Minnekahta, at the junction of an unnamed canyon with Bull Pen Creek, a tributary to Red Canyon Creek, the following section is exposed:

Section on Bull Pen Creek near Minnekahta, S. Dak.

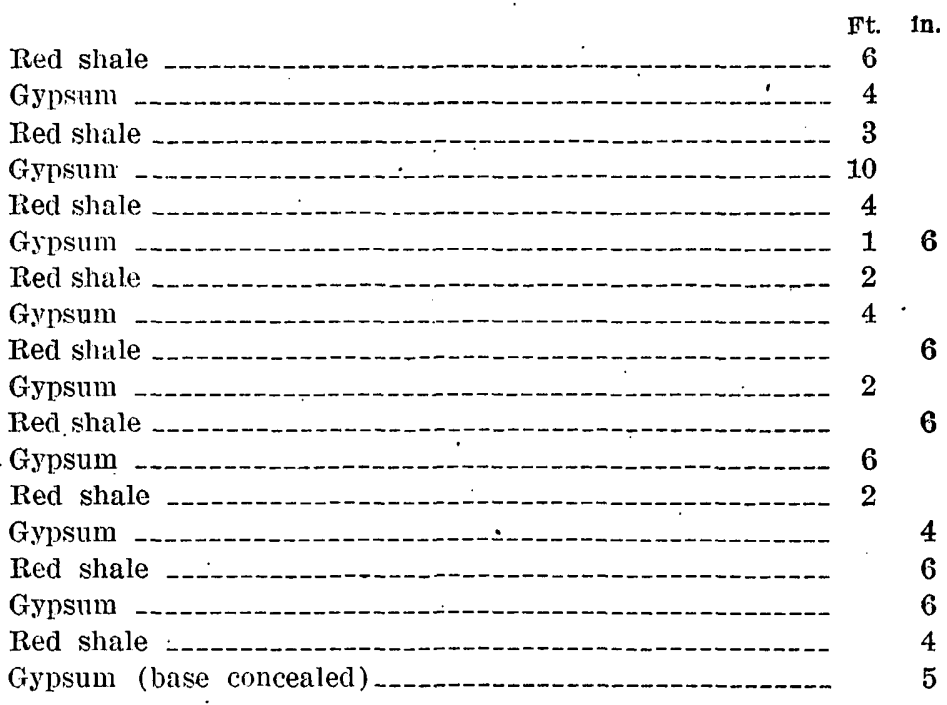

All the strata are somewhat folded, and the thickness of the layers differs greatly within short distances. The exposure at this locality is exceptionally fine. The gypsum is pure and, where not weathered, snow-white. A mineral claim has been established at this place, and at the point marked " $a$ " in Plate XXIX, $B$, work has been done in accordance with the local requirements applying to such claims. A number of other claims have been located in this vicinity and "assessment work" is being done. About 2 miles northwest of the locality described above there are fine exposures of gypsum. One divide about 65 feet in height is capped by a layer 8 to 10 feet thick. Higher ridges are capped by a layer of high-grade gypsum, which generally ranges from 8 to 10 feet thick but in places is about 20 feet thick. The lower bed ranges from greenish to brown in color, the individual laminae being commonly only a fraction of an inch in thickness. Northwest of this region, toward the Wyoming line, the Spearfish formation includes several beds of gypsum, notably near Hell Canyon, as shown in Plate XXX, $B$. 
MINNEKAHTA TO HOT SPRINGS.

Between Minnekahta and Hot Springs gypsum outcrops as far east as the vicinity of Erskine station, appearing at the surface in many places as dark-gray barren areas. At Erskine an effort has. been made to utilize the gypsum, but no work is being done at present. Near Erskine the Red Valley turns south along the Cascade anticline and is known as Alabaugh Canyon. Gypsum appears at. the surface and continues without perceptible variation into that portion of the valley which lies east of Minnekahta. Throughout the greater part of Alabaugh Canyon the beds dip steeply to the west and the Red Valley proper is in places only a few rods in width, the gypsum outcrop being inconspicuous. Darton ${ }^{1}$ reports a total thickness of red beds in this locality of 420 feet. The strata comprise at the base 150 feet of red beds and a bed of gypsum in places 20 feet in thickness, overlain by 250 feet of red beds containing a few thin layers of gypsum.

South of Cascade Springs the Red Valley passes around the south end of the Cascade anticline into a broader valley drained by Sheps Canyon. This region is deeply gullied and gypsum outcrops are common, giving rise to the characteristic gray barren areas. Thesegypsum beds apparently increase in thickness northward and are shown to their best advantage in the vicinity of Hot Springs. (See Pl. XXX, A.)

Darton's section ${ }^{2}$ on Cold Brook in the vicinity of Hot Springs: shows the following beds at the top:

\section{Section on Cold Brook near Hot Springs, S. Dak.}

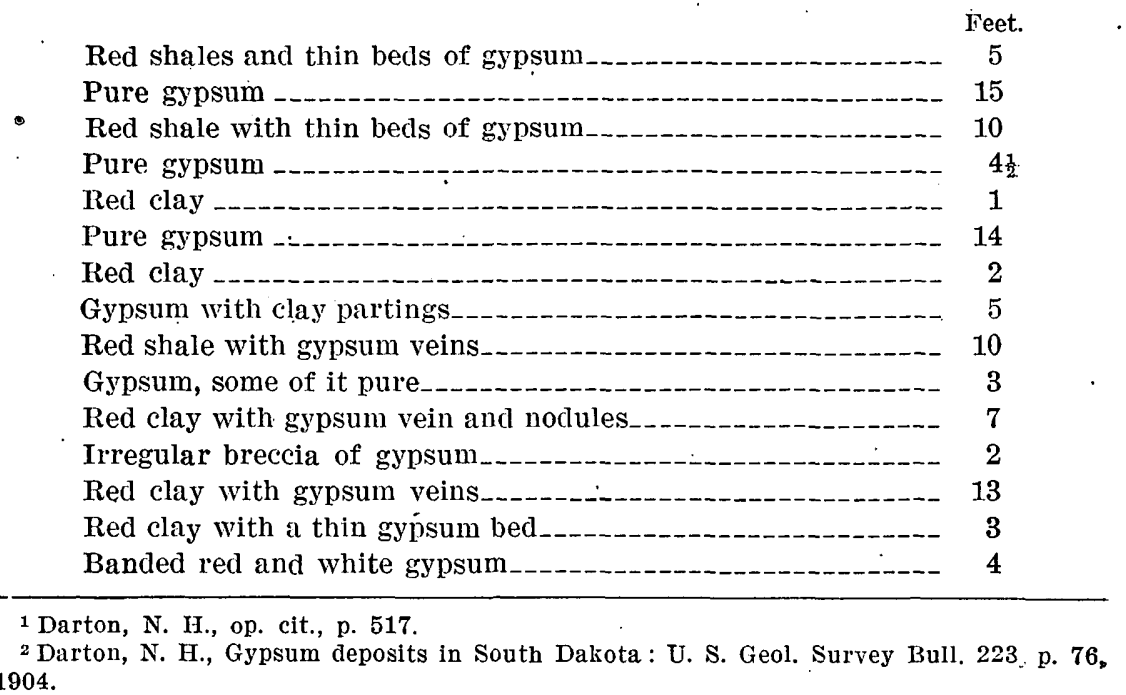


A gypsum mill was formerly operated at Hot Springs, but it was destroyed by fire several years ago and has never been rebuilt. The deposit from which gypsum was removed to supply the mill extends north along the left side of Cold Brook Canyon, and about 4 miles north of Hot Springs a layer of snow-white gypsum caps a bluff about 100 feet in height. This layer ranges from 6 to 10 feet or more in thickness and extends as a conspicuous band for a considerable distance along the valley. Below this bed are thinner layers of varying thickness, and near the base at some points a layer of harder shale with intercalated layers of gypsum appears. This layer attains a thickness of 20 feet in places but is not continuous. On the terrace on which the State Soldiers' Home is located is a butte capped with gypsum.

Northeast of Hot Springs the outcrop of red beds widens in the area known as Martins Valley. Gypsum is conspicuous in this vicinity, appearing in many places as new cliffs or'clay barren areas. West of Fairburn there is little gypsum, but west of Hermosa it. reaches a thickness of about 15 feet. Tertiary deposits cover the red beds in places in the region southwest of Hermosa and also between Hermosa and Rapid City.

RAPID CITY TO STURGIS.

Fine exposures of gypsum are seen a short distance northwest of Rapid City along the Chicago \& Northwestern Railway. TheUnited States Gypsum Co. operated a mill at this point from 1908 to 1915 , when the mill burned. The principal bed of gypsum ranges from 6 to 12 feet in thickness and is of good quality, although it is considerably broken.

The Rapid City Gypsum, Lime \& Portland Cement Co. has a plant 3 miles northwest of Rapid City, and though no gypsum products have been manufactured, borings on its property are said to show about 35 feet of gypsum in three beds of nearly equal thickness separated by layers of red shale.

From this point to Blackhawk gypsum is almost continuously exposed in small ridges.

At Blackhawk the Dakota Plaster Co. operated a plant which was for a number of years supplied from a bed of gypsum that ranges from 11 to 30 feet in thickness. This bed, like all the strata in this part of the Black Hills, dips east. The gypsum is said not to be broken up, as it is in some localities in this region. The mill was burned in the spring of 1916 but has been rebuilt and is using gypsite.

North of Blackhawk the valley widens, and gypsum appears on both sides of the railroad. North of Piedmont all the way. to Til- 
ford the ridges capped by gypsum are higher and more conspicuous than they are south of that place. At a creek about a mile south of Tilford the red shale is interbedded with layers of gypsum, none of which attains a thickness of more than 18 inches. Many veins a fraction of an inch in thickness appear in the stream cut immediately below the culvert under the railroad.

From Tilford to Sturgis the gypsum outcrops continue, and at Sturgis a bed about 10 feet thick appears. An outcrop along the railroad cut just west of the town shows marked variation in the thickness of the bed. The ruins of an old "stucco mill," destroyed by fire years ago, record an attempt to utilize the deposit at Sturgis. About $2 \frac{1}{2}$ miles west of Sturgis another gypsum mill was operated for a time, but only the foundation remains to mark its site.

STURGIS TO SPEARFISH.

From Sturgis to Whitewood gypsum outcrops are common. A short distance from Whitewood along the railroad leading to Deadwood there is a gypsum bed which attains a maximum thickness of about 10 feet but which becomes thinner toward the town of Whitewood. Very little gypsum is seen along the valley from Whitewood to a point beyond old Crook City, where the Red Valley widens out into Centennial Prairie.

Along the north side of Centennial Prairie, the name by which this portion of the Red Valley is known, from a point west of Whitewood to. Spearfish, gypsum appears as snow-white bands in the red shale. Where creeks cross the Red Valley the gypsum has been eroded or has been covered by alluvial deposits.

The following sections by Darton ${ }^{1}$ indicate the general character of the red beds and gypsum deposits in the vicinity of Spearfish:

Section of upper part of Spearfish formation in Redwater Valley, S. Dak.

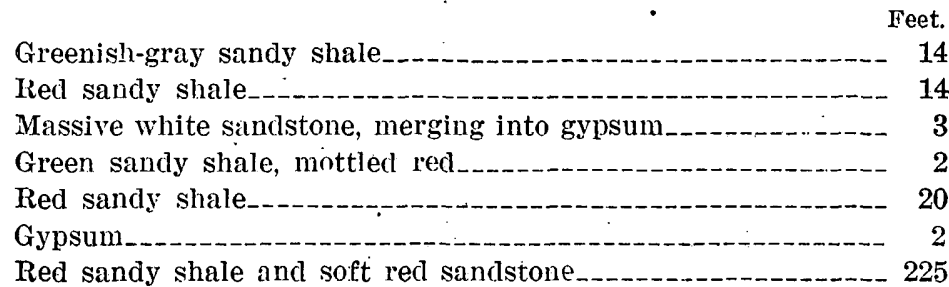

Below this are 395 feet of red sandy shale and soft sandstone, containing a 5 -foot bed of gypsum 120 feet above the base of the formation. In places the gypsum is in two or three beds, separated by thin bodies of red shale. Wast and northeast of Spearfish the upper beds increase in thickness, and one bed is 18 or 20 feet thick on the slopes near Lookout Peak.

\footnotetext{
1 Darton, N. H., Geology and water resources of the northern Black Hills and adjoining regions in South Dakota and Wyoming: U. S. Geol. Survey Prof. Paper 65, pp. 28-29, 1909.
} 


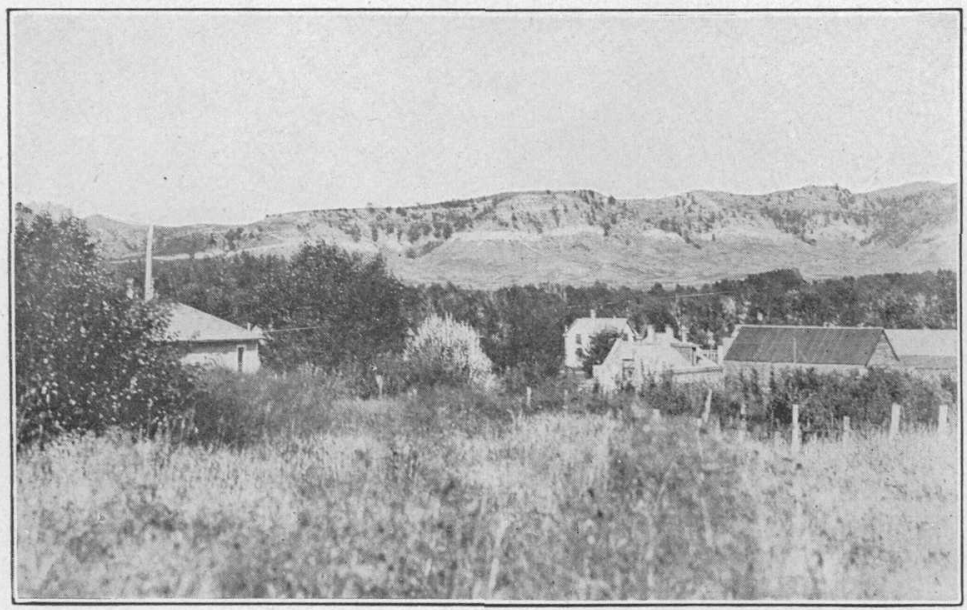

A. GYPSUM AT SPEARFISH, S. DAK.

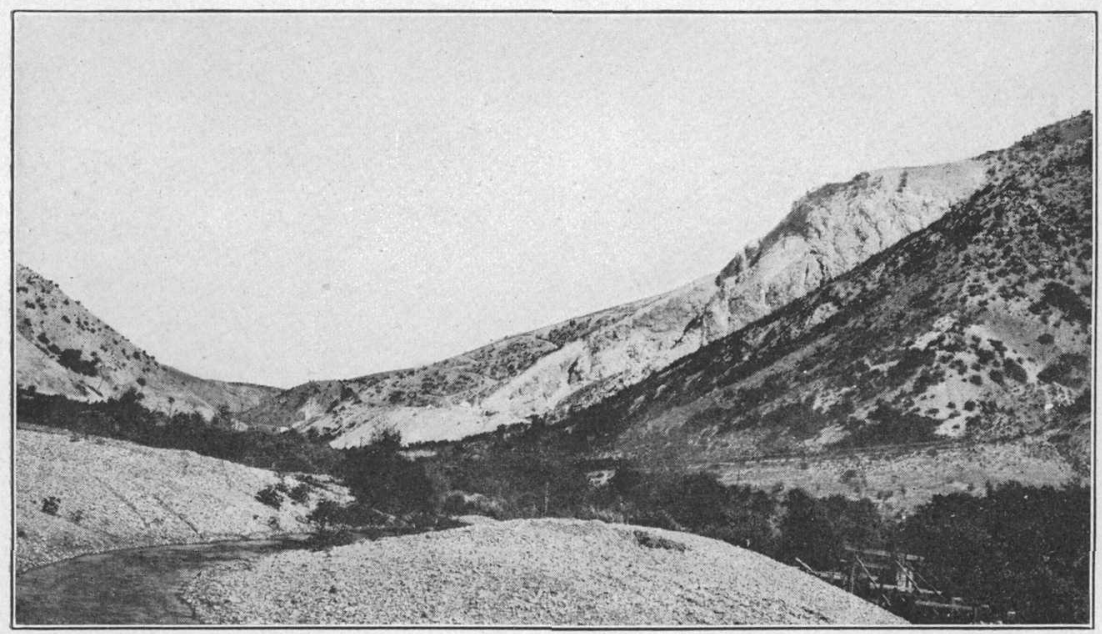

B. GYPSUM QUARRY 2 MILES EAST OF NEPHI, UTAH.

White rock rising 500 feet above valley is gypsum, and quarry extends to top. Mill is just beyond waste dump. Photograph by R. W. Stone. 
Section of upper beds of Spearfish formation cast of Spearfish, S. Dak.

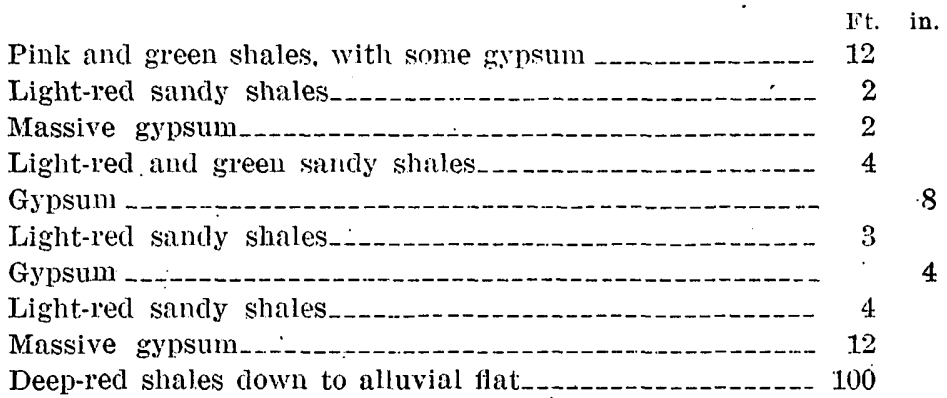

In the lower beds in this section there are several thin berls of gypsum, one of which renches a thickness of 2 feet on the northeast side of Lookout Peak.

Plates XXXI, $A$ and $B$, and XXXII, $A$, show the characteristic appearance of the gypsum at Spearfish.

A partial section by Richardson, ${ }^{1}$ which is quoted by Darton, ${ }^{2}$ is as follows:

Section of upper beds of Spearfish formation on east side of Lookont Peak, S. Dak.

Sundance formation.

Ft. in.

Massive white gypsum

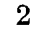

Clayey sandstone

Massive white gypsum

Red sandy shale, with a few green streaks_______._._._. 50

Gypsum on red and green clay

Chocolate-brown sandy. shale, a few gypsum veins_._...... 20

Red sandy shale under 1 inch of green clay_-_._-___._... 2

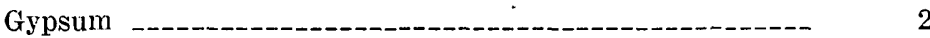

Red sandy shale, more massive below

Chocolate-brown sandy shale with streaks of green_._._._. 1.

Thin-bedded red sandy shale with specks of green_-_-_-_-- 10

Chocolate-brown sandy shale with many gypsum veins.

One of the gypsum beds in the upper part of the red beds has an average thickness of 12 feet in an area of several square miles in the region east and northeast of Spearfish, and a bed about 5 feet in thickness and 120 feet above the base of the red beds outcrops on the slopes adjoining the limestone ridge. northwest of Spearfish. The gypsum is nearly pure. ${ }^{3}$

Gypsum was once quarried about 4 miles north of Spearfish and was made into plaster in a mill located about half a mile farther north and operated by power obtained by diverting the water of Spearfish Creek. This plant has not been in operation for several years.

\footnotetext{
${ }^{1}$ Richardson, G. B., Upper Red Beds of the Black Fills: Jour. Geology, vol. 11, pp. 373-375, 1903.

a Darton, N. H., op. cit. (I'rof. Paper 65), p. 29.

${ }^{3}$ Darton, N. H., and O'Harra, C. C., U. S. Geol. Survey Geol. Atlas, Belle Fourche folio (No. 164), 1909.
} 


\section{CHEMICAL COMPOSITION OF SHALE AND GYPSUM OF SPEARFISH FORMATION.}

From estimates based on a microscopic examination and an analysis made by George Steiger, of the United States Geological Survey, Richardson ${ }^{1}$ gives the following mineral composition of the Spearfish shale:

Arineral composition of the shale of the Spearfish formation of South Dakota.

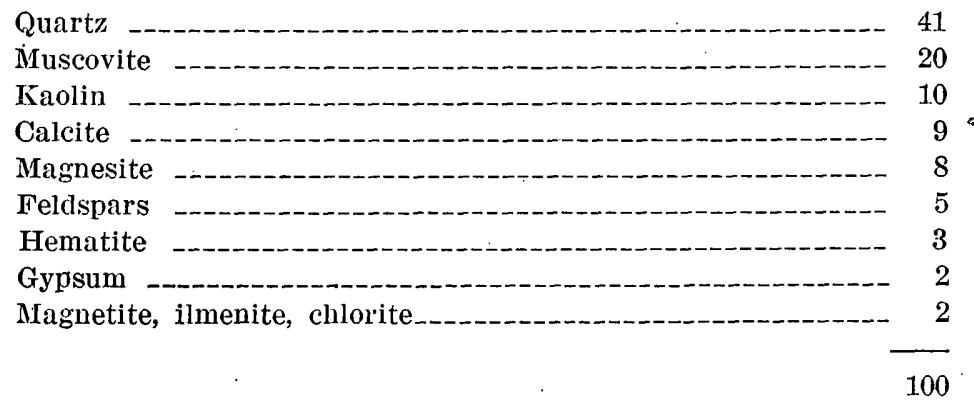

It was shown that the red color of the shale is due to an amorphous red pigment (anhydrous iron oxide) which irregularly coats and spots the minerals and is included in some of the quartz and kaolin.

Gypsum from a point near Cascade Springs, S. Dak., analyzed by George Steiger, of the United States Geological Survey, shows the following chemical composition:

\section{Analysis of gypsum from vicinity of Cascade Springs, S. Dak.}

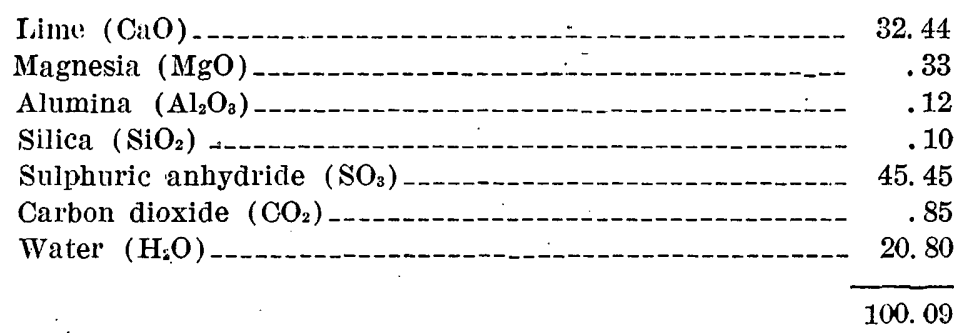

\section{ECONOMIC DEVELOPMENT.}

At present there are only two gypsum mills in operation in South Dakota. One of these mills is at Piedmont and is operated by the United States Gypsum Co. The mill which was started in 1908 at Rapid City and had a capacity of about 150 tons of plaster a day was burned in 1915. The new mill at Piedmont produces plaster and hollow building block from rock gypsum and gypsite dug at the

\footnotetext{
1 Richardson, G. B., op. cit., p. 380.

a Darton, N. H., Preliminary description of the geology and water resources of the southern half of the Black Hills and adjoining regions in South Dakota and Wyoming: U. S. Geol. Survey Twenty-first Ann. Rept., pt. 4, p. 585, 1901.
} 
plant. The other mill is at Blackhawk and is operated by the Dakota Plaster Co. It is owned by local stockholders and is capitalized at $\$ 150,000$. It has a capacity of about 200 tons a day and produces plaster exclusively, both for castings and common wall use. The original mill was burned in the spring of 1916 and the new. mill was in operation early in 1917.

The number of gypsum plants proposed or actually constructed. that have failed for one reason or another to pay a profit indicates a considerable loss of money in the gypsum business in this section. 'Two mills in the vicinity of Sturgis, one near Spearfish, one at Hot Springs, one near Erskine, one at Whitewood, and perhaps others are examples. The gypsum industry under present conditions in the Black Hills region appears not likely to be profitable to small operators without the advantage of thorough organization. There are extensive deposits of high-grade gypsum, which can be utilized to supply mills cheaply, so that the industry may be further developed as the population of the Northwest increases or when more favorable freight rates can be procured. 


\title{
TEXAS.
}

\author{
By R. W. STONE. ${ }^{2}$
}

\section{DISTRIBUTION.}

Gypsum deposits of great extent were discovered in Texas by expeditions sent out by the War Department in 1852 and 1855 . Northern Texas and the region between Pecos River and the Guadalupe Mountains were said to contain great bodies of the mineral. In the reports of the Geological Survey of Texas from 1889 to 1892 many observations were made on the gypsum deposits, especially by A. F. Cummins. Notwithstanding the early discovery, no adequate description of the gypsum deposits of Texas has been published. In this paper, the writer; without special field work, has drawn largely on other observers for the data and acknowledges the indebtedness.

Rock gypsum occurs in the areas shown in the accompanying map of Texas (fig. 48). Gypsite or gypsum earth is associated with the rock gypsum at some localities and is used at Acme. Gypsum crystals are abundant in a number of geologic formations in eastern Texas and are frequently mistaken for mica or assumed to be indications of valuable gypsum deposits. These individual crystals have no value, and thick beds of rock gypsum are so extensive in Texas that those distant from a railroad have no present commercial value. The principal gypsum-bearing areas are (1) in the north-central part of the State from Acme southward 150 miles to Colorado River; (2) in Hudspeth and Culberson counties, in Gypsum Plain and Malone Mountains; and (3) in southeast Texas.

\section{ECONOMIC DEVELOPMENT.}

Three plants are manufacturing gypsum products in Texas. Two are at Aome, near Quanah, Hardeman County, on the north border of the State. They are operated by the Acme Cement Plaster Co. and the American Cement Plaster Co. The third plant, owned by the Texas Cement Plaster Co., is at Plasterco, Fisher County, a few miles from the mine at Hamlin, which supplies the raw material. The total quantity of gypsum mined in Texas in 1918 was 157,388 short tons, and the value of gypsum products was $\$ 834,560$.

${ }^{1}$ Compiled from reports by C. L. Baker, B. F. Hill, G. B. Richardson, C. H. Wegemann W. E. Wrather, and others. 


\section{IOCAIITIES.}

NORTF-CENTRAL TEXAS.

CHARACTER AND GENERAL RELATIONS OF THE GYPSUM DEPOSTTS.

The largest area of gypsum deposits in Texas lies east of the foot of the Staked Plains, in the northern part of the State. The beds have a northeasterly strike and extend from Red River near Quanah to Colorado River in an irregular line, the sinuosities of

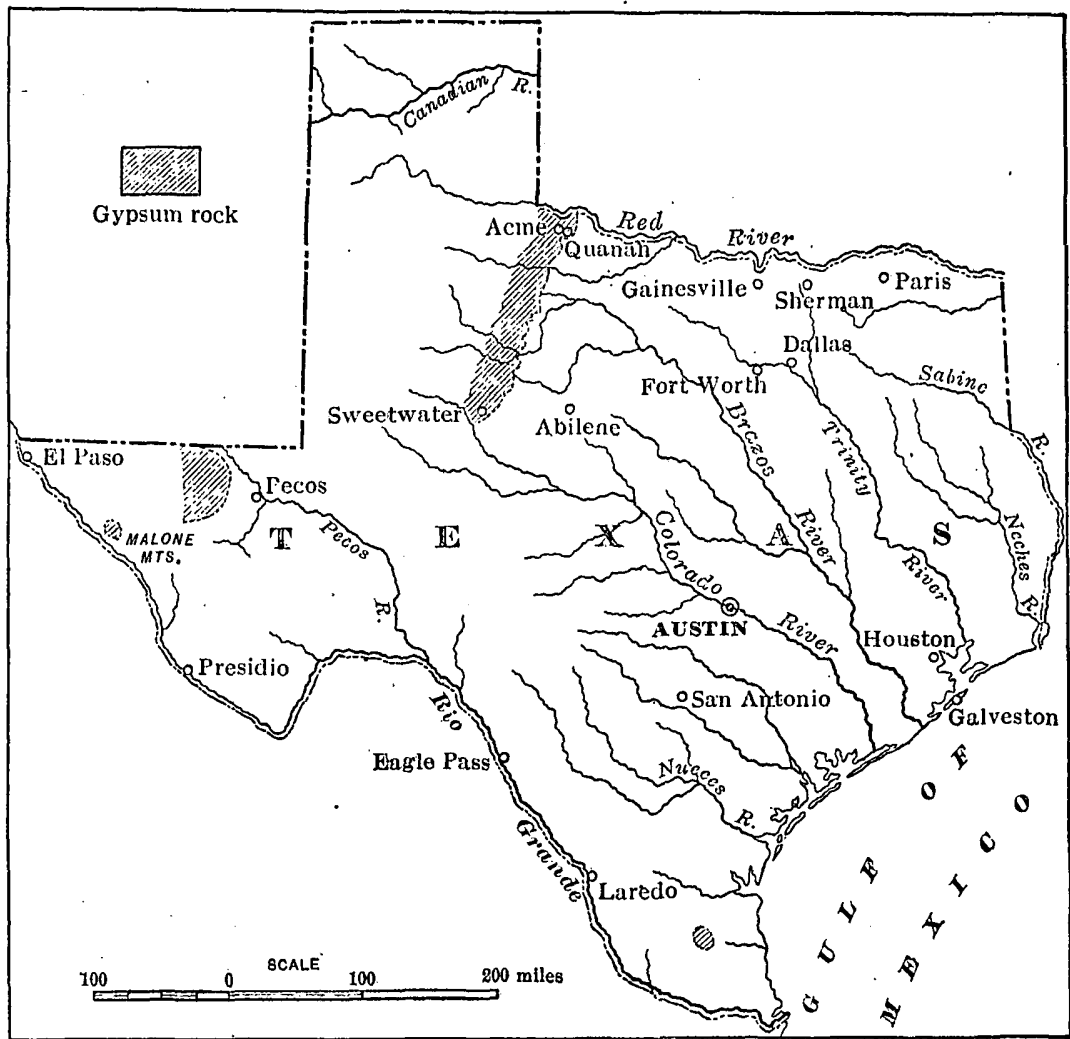

FIgUne 48.-Map of Texas showing location of principal deposits of rock gypsum.

which are produced by the valleys of the eastward-flowing streams. This belt of gypsum beds is from 20 to 50 miles wide, and is a continuation of the deposits in Oklahoma that occur in the Greer County region. The beds are of different thicknesses, ranging from a thin layer to 20 feet.

Near Acme, only a few miles south of the Oklahoma-Texas boundary, gypsum is being quarried and milled by the Acme Cement Plaster Co. and the American Cement Plaster Co. The Acme Co. makes Keene cement in one of its mills. The gypsum is exposed in nearly horizontal ledges along a narrow creek. It is closely associated with dolomite and occurs here in two beds, the lower 
one nearly 22 feet thick and lying 19 feet below a 10-foot bed. Gypsite also is used at Acme.

The rocks exposed at the surface in the vicinity of Quanah belong to the Clear Fork formation of the Permian series. ${ }^{1}$

About 11 miles southwest of Quanah and 7 miles south and a little west of Goodlet, in the "breaks" of Pease River, all the strata which reach the surface in the Quanah area are well exposed, the detailed rock section being as follows:

Section at wooded bluff half a mile west of the west line of sec. $28 \%$.

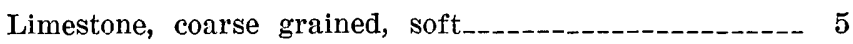

Shale, red and blue-_-_-_-_-_-_-_-_- 26

Gypsum, soft, granular.-_-.-_- 3

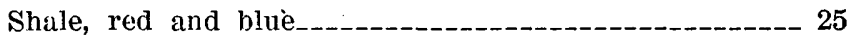

Gypsum, base soft, upper part hard, white

Limestone, fossiliferous__-_-_-_-_._- 8

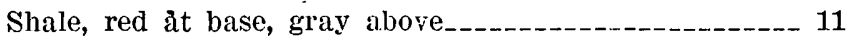

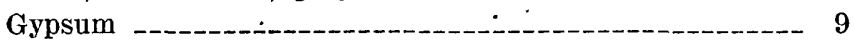

Shale, calcareous, gray, containing some thin limestone layers that weather white

Limestone, hard, light gray, weathering white; prominent over much of field._._._._._-_._- 3

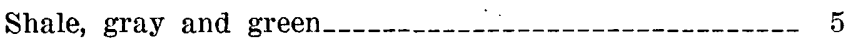

Gypsum, white and blue, hard

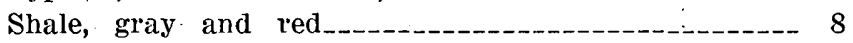

Limestone, white, fine grained, perforated with innumerable small holes about one-sixteenth of an inch in diameter

Shale, blue and greenish gray 4

Gypsum; soft and granular in lower part; hard, blue, tinted with red in upper part

Shale, red $-21$

Base not exposed.

In the section given above the bed of gypsum 21 feet thick appears to be the same as that which is mined at Acme.

The following sections from Mr. Cummins's report ${ }^{2}$ will give an idea of the quantity of gypsum to be found at certain localities and the mode of its occurrence:

Section at Kioula Peak, in the northeast part of Stonewall County, Tex., beginning at the bottom. Feet.

Gypsum -_-

Red clay

Gypsum -_. 20

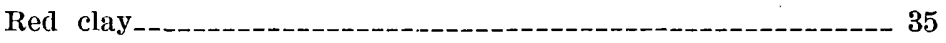

Gypsum

154

${ }^{1}$ Wegemann, C. H., A reconnaissance for oil near Quanah, Hardeman County: Tex.: U. S. Geol. Survey Bull. 621, p. 111, 1915.

2 Texas Geol. Survey Second Ann. Rept., p. 458, 1891. 


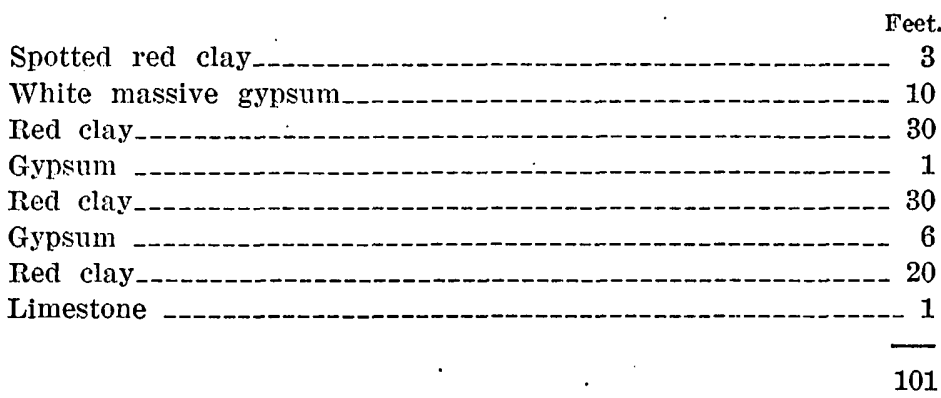

The following notes concerning localities south of Quanah are contributed by W. E. Wrather:

Along Double Mountain and Salt forks of Brazos River, west of Aspermont, Stonewall County, there is a bed of massive white gypsum ranging in thickness from 20 to 30 feet or more. Within a few hundred feet stratigraphically above it there are several other beds of pure gypsum from 2 to 12 feet thick, which are exposed in Double Mountain. The thick bed is exposed likewise along Sweetwater Creek, in Nolan County, where it is more than 20 feet thick, and outcrops of it or of another thick bed of gypsum are found for many miles north and south of these localities. The stratigraphic succession and number of gypsum beds in Haskell and Stonewall counties is shown in figure 49.

The principal beds of workable gypsum lie near the base of the Double Mountain formation. Observations made at perhaps a dozen widely separated localities along the outcrop of the Double Mountain beds in Texas show that the beds generally include a massive stratum of gypsum that is much thicker than other strata of gypsum either above or below it. This massive bed of gypsum, which is 20 to 30 feet or more thick, outcrops along Sweetwater Creek, in Nolan County, about 500 feet above the top of the dolomite exposed at Merkle, which immediately underlies the sandstone of Blowout Mountain and is taken as the base of the Double Mountain formation. Along the Double Mountain and Salt forks of Brazos Rivier the massive gypsum is about 250 feet above the dolomite and is of approximately the same thickness as along Sweetwater Creek.

At Medicine Mounds, in Hardeman County, the exact interval could not be accurately measured, though it is thought to be about 150 feet.

Until more detailed work has been done it can not be stated with certainty whether or not the massive gypsum represents a single continuous horizon. It seems probable, however, that it does not, for it has been observed that the beds thicken from north to south in the Double Mountain formation, which is in keeping with the in- 


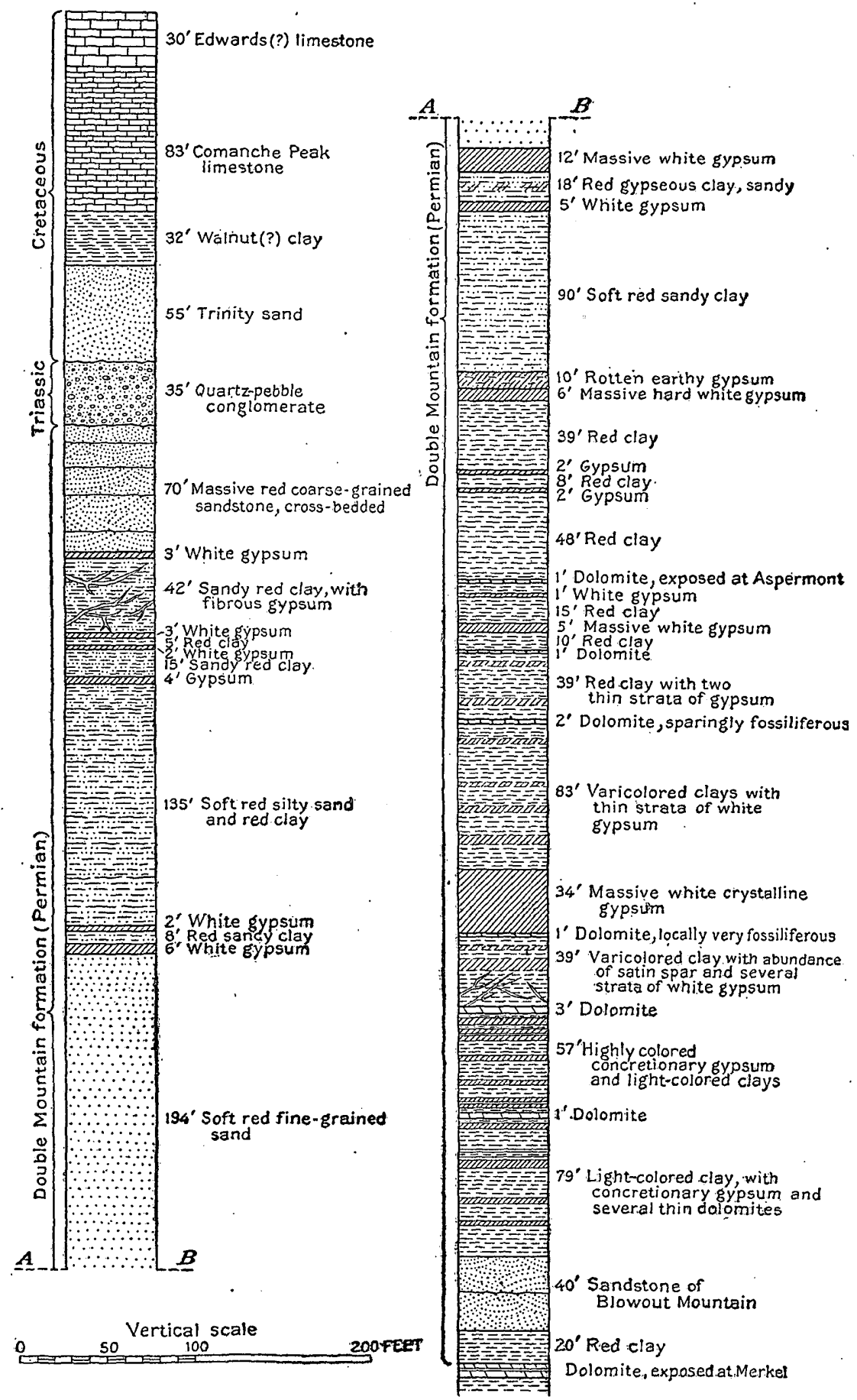

FigORE 49.-Columnar section showing strata exposed along Double Mountain Fork of Sirasos River from Flattop Mountain, Haskell County, to top of Double Mountain, Stonewall County, Tex. 
creasing interval from Red River southward between the main gypsum horizon and the dolomite described.

In places along the range of the Gyp Hills, which lie as a rule just west of the Kansas City, Mexico \& Orient Railroad, gypsite has been noted, though in the absence of any prospecting to determine the amount present it is impossible to draw any conclusion as to its commercial value. It is reasonable to assume, however, in view of the great amount of gypsum present, that tremendous quantities of gypsite will be found in this section when the demand for its utilization shall have arisen.

\section{GEOLOGIC RELATIONS OF THE GYPSUM BEDS.}

By W. E. Wraterer.

The gypsum-bearing beds of the north Texas Permian are the southward continuation of the Greer formation. ${ }^{1}$ These beds extend in a direction west of south from Red River near Quanah, in Hardeman County, for a distance of about 150 miles, to the valley of Colorado River, south of which they are covered by the Cretaceous deposits. They were included by Cummins in the Double Mountain formation of the Permian.

It seems that the Blaine formation, in which three of the important gypsum beds of Oklahoma are found, does not extend south of the Wichita Mountains. As observed above, the Greer formation, which overlies the Woodward formation in Oklahoma, can be traced far into Texas in continuous outcrop. On paleontologic evidence it appears that the time intervals represented in Oklahoma by the Enid, Blaine, and Woodward formations, which have a total thickness of over 2,000 feet, according to Gould's estimate, is represented in Texas by the Clear Fork formation alone. The thickness of the Clear Fork formation along Red River has never been accurately determined because of the prevailing soft character of the sediments, which weather down into a rolling plain, across which the thickness of beds can scarcely be computed. Along the Texas \& Pacific Railway, east of Sweetwater, 125. miles south of Red River, the thickness of the Clear Fork is not more than 750 feet. It seems, however, that there is a thinning of this formation from north to south.

Near the base of the Double Mountain formation in Texas a massive cross-bedded gray or red coarse-grained sandstone is found. On Blowout Mountain, southwest of Merkle, in Taylor County, this sandstone is over 100 feet thick. Its outcrop has not been traced continuously the entire distance southward from Red River to the Texas \& Pacific Railway, but it is reasonably certain that the sand-

1 Gould, C. N., Geology and water résources of Oklahoma: U. S. Geol. Survey WaterSupply. Paper 148, 1905. 
stone capping a prominent scarp at milepost 175 on the Fort Worth \& Denver City Railway, near the west edge of Wilbarger County, is the northward continuation of the sandstone of Blowout Mountain. It thickens from Red River southward from not more than 5 or 10 feet to over 100 feet in the area where it finally disappears under the Cretaceous in Taylor County.

Gypsum is found throughout the Double Mountain formation to the point of its disappearance under the Tertiary deposits of the Llano Estacado, though by far the most promising commercial deposits of gypsum occur in the lower portion of these beds. The upper beds of the Double Mountain formation have been traced by Cummins, Gould, and others through the valley of Canadian River, and have been found to connect with the Permian beds of eastern New Mexico. Near Red River gypsum is most prominently exposed in a stratigraphic interval of about 200 feet in the vicinity of Medicine Mounds, in southeastern Hardeman County. The beds which are quarried at Acme outcrop here, and the section is not dissimilar to that made by Wegemann in the breaks of Pease River, southwest of Quanah, though the main gypsum bed seems to be somewhat thicker.

The columnar section (fig. 49) was made along the Double Mountain Fork of Brazos River from the base of Flattop Mountain, in southwestern Haskell County, to the top of Double Mountains, in Stonewall County. It shows a total thickness of 1,170 feet of the Double Mountain formation, and this section probably falls nearly 1,000 feet short of representing the total thickness of the Double Mountain beds exposed east of the foot of the High Plains. It will be seen that thick beds of gypsum occur throughout the lower 600 feet of this section.

From the lithologic character of the beds it is evident that two divisions may be made in this section-a lower division, from 500 to 600 feet thick, in which varicolored clays relatively free from sand predominate, with thick beds of white massive gypsum and thin beds of fossiliferous dolomites; and an upper division that is marked by sands and sandy clays, which, where freshly exposed, are characteristically blotched with spherical greenish spots, ranging in diameter from that of a pinhead to one-half inch, supposedly due to the presence of iron in a ferrous state. This marking was aptly described by F. W. Cragin, who named similar beds in northern Oklahoma and Kansas, presumably of about the same age, the "polka-dot" beds. These sands are commonly cross-bedded and very massive, though they readily weather down into a soft, deep, sandy red soil, typical of this region. Southward they are more indurated, and around Sweetwater they outcrop in massive strata, a typical exposure occurring at Lake Trammel, south of that place. 
The two divisions that have been described are probably very nearly the equivalents of the Greer and Quartermaster formations of Oklahoma. If this is true, there is a corresponding thickening in these beds southward from Red River in the same or even a greater ratio than the thinning in the same direction in the Clear Fork beds. Gould estimates the thickness of the two divisions at not more than 500 feet in the eastern part of the Panhandle of Texas, near Red River, ${ }^{1}$ whereas the section given on Brazos River, 100 miles farther south, shows 1,170 feet, which is known to be considerably less than the total of the Double Mountain formation at this place.

\section{CULBERSON AND HODSPETH COUNTIES.}

In Culberson County east of the Guadalupe Mountains there is an area of gypsum approximately 50 miles in length and averaging 15 miles in width. ${ }^{2}$ At the State boundary it is 25 miles wide and it extends northward into New Mexico. This gypsum, known as the Castile gypsum, outcrops in Texas over 600 square miles. In a few places this great gypsum plain north of the Texas \& Pacific Railway and west of Pecos River is overlain by beds of later limestone and conglomerate. Good sections exposing 50 or 60 feet of gypsum are shown along Delaware Creek and Cottonwood Draw. Another exposure of the same beds is on the Southern Pacific Railroad east of Finlay, in Hudspeth (formerly part of El Paso) County. This deposit is now worked on a small scale.

The entire section of these Castile gypsum beds is from 300 to 500 feet thick, and the beds contain gypsum in a variety of forms and different degrees of purity. On the surface generally the gypsum is disintegrated and earthy. Besides the massive white granular variety there is grayish or dark gypsum, and in some places blue or red tints prevail. In places also thin strata of gypsum are highly impregnated with bitumen to such an extent that they have a sooty black color. The presence of these beds on the surface can often be detected on a hot day by the odor, which is noticeable for a distance of several yards. In purity the gypsum ranges from pure material to mixtures with sand, pebbles, sulphur, limestone, and other substances.

Locally selenite is abundant. Commonly the massive gypsum is considerably cracked and jointed, and in places there are many underground channels and caverns in it. All the streams and springs

${ }^{1}$ Gould, C. N., The geology and water resources of the castern portion of the Panhandle of Texas: U. S. Geol. Survey Water-Supply Paper 1.54, 1006.

2Richardson, G. B., Reconnaissance in trans-Pecos Texas: Texas Univ. Min. Survey Bull. 9, p. 22, 1904. 
within the gypsum plain are strongly impregnated with gypsum and many of them with salt and sulphur.

The exact geologic age of the Castile gypsum was for a long time undetermined, owing to the scarcity of determinative fossils, though from its association with Permian beds G. B. Richardson and others assumed it to be Permian. Later J. A. Udden presented evidence, based on the presence of minute fossils, principally Foraminifera, which he thought tended to show that the gypsum was of Cretaceous age. ${ }^{1}$ Subsequent observations made at the request of J. A. Udden, of the University of Texas, by Emil Böse and C. L. Baker, show conclusively that the formation is of Permian age. ${ }^{2}$

The locality mentioned above as being east of Finlay, in Hudspeth County, is in the Malone Mountains. It has the advantage of being situated near the Southern Pacific Railroad, and the outcrops are extensive and are favorable for working. J. A. Taff. ${ }^{3}$ in his paper describing this locality, says:

The Malone bed is so named because of the great development of gypsum it includes which occurs in the Malone Mountains. * * * The main gypsum field extends from the center of the mountain to the northwest end. $* * *$ The lowest rock exposed of the Malone Mountain horizon is a band of pale-yellow flaggy limestone. Above this limestone occurs the first horizon of white, fissile, granular gypsum, having a thickness of 45 feet. Succeding this gypsum there is $\mathbf{1 7 5}$ feet of massive blue granular limestone: $* * *$ Above this limestone comes a second horizon of gypsum of a thickness of 110 feet. It is the same, lithologically, as the first horizon, a stratified, nearly pure, friable, granular gypsum. It contains comparatively little earthy matter. On the east side of the southeast end of Malone Mountain there is a development of gypsum with a surface area of about 40 acres.

Gypsum is quarried in the Malone Mountains near Finlay for use in Portland cement made at El Paso.

F. W. Cragin and T. W. Stanton have studied these rocks and on paleontologic evidence refer them to the Jurassic. ${ }^{4}$

\section{SOUTHEASTERN TEXAS.}

\section{DEEPLY BURIED DEPOSITS.}

Great deposits of gypsum have been encountered in wells drilled for oil in southeastern Texas. At Spindletop, Jefferson County, 3 miles south of Beaumont, it is reported ${ }^{5}$ that a salt dome buried to a depth of 1,650 to 1,950 feet is covered by perhaps 600 feet of

${ }^{1}$ Udden, J. A., The age of the Castile gypsum and the Rustler Springs formation: Am. Jour. Sci., 4 th ser., vol. 40, pp. 151-156, 19,15.

2 Udden, J. A., letter of Feb. 6, 1917.

3 Taff, J. A., The Cretaceous deposits: Texas Geol. Survey Second Ann. Rept., pp. 721$722,1891$.

${ }^{1}$ U. S. Geol. Survey Bull. 266, 1905.

5 Harris, G. D., Oil and gas in Louisiana, with a brief summary of their occurrence in udjacent States: U. S. Geol. Survey Bull. 429, p. 24, 1910. 
gypsum. At High Island, Chambers County, 1 mile from the coast and halfway between Sabine Pass and Galveston, several wells record very thick deposits of gypsum. ${ }^{1}$ One well passed through 600 feet of gypsum extending from 600 to 1,200 feet below the surface, and another well passed through gypsum from 900 to 1,300 feet and then through rock salt to 2,600 feet, the bottom of the well. A well in Duval County passed through 300 feet of gypsum lying between 515 and 815 feet below the surface. Pumpings taken from the well when drilling in this bed show fragments of pure-white and gray finegrained gypsum and a considerable proportion of glassy selenite. These deposits are so deeply buried as to be commercially valueless so long as gypsum is abundant at the surface in other parts of the Southwest and the market is small.

\section{BROOKS COUNTY.}

By C. I. BAISER.

South of Falfurrias, at the terminus of the San Antonio \& Aransas Pass Railway, gypseous sand and selenite form a southwardfacing bluff 25 to 30 feet high, extending for several miles along the northern margin of a lake.

About 6 miles east of Falfurrias there is a mound called Loma Blanca which covers an area of probably 50 acres and has an elevation of approximately 75 to 100 feet above she level of the lake. Its northern side rises somewhat abruptly from a point near the water's edge and is covered with a soft gypseous sand that contains numerous blocks or boulders of selenite. About 6 miles south and a little west there is another mound of the same general form and height known as Alto Colorado, which is also said to consist of the same kind of gypsum.

The gypseous sand on Loma Blanca thins out toward the crest of the mound, and near the summit on the southern side a deposit of clear transparent selenite covers an area of several acres. The surface of this bare spot is rain pitted to a depth of 6 or 8 inches, and near the middle there is a cave or shaft about 36 feet deep.

The selenite exposed in the cleared portion of the Loma Blanca is in layers from 2 to 6 inches thick and is perfectly transparent. Blocks free from rain pitting can be obtained through which ordinary printed letters can be easily read. The thickness of the deposit is unknown, but it is over 1,000 feet. Recently the Producers Oil Co. drilled four wells to depths exceeding 1,000 feet and found practically the same material in each well throughout the whole depth. The deposit appears from the drilling records to be more or less cavernous. In two of the wells, which were approximately 500 feet 
apart, the drill passed through a cavity over 20 feet in depth. This cavern lies about 600 feet below the surface. Smaller cavities were found at different depths.

Mining of the gypsum deposits in Brooks County would not be difficult. They lie about 6 miles from the terminus of the San Antonio \& Aransas Pass Railway and 14 miles from Sarita on the St. Louis, Brownsville \& Mexico Railway. A branch of either line could easily be constructed to the mound. An open face of at least 60 feet may be obtained on any side of Loma Blanca.

The overlying gypseous sand is sufficiently pure to be used as land plaster, and much of it might be used in the manufacture of cement plaster and other structural materials. The main body of selenite is pure enough to be used for any purpose for which gypsum may be required.

OTHER LOCALITIES.

By B. F. Hrut.

The clays and marls of the Cretaceous system are gypsiferous in many places, though no deposits of economic importance have been found. Some of the occurrences of this nature are mentioned here, as the content of gypsum is important in its relation to the soils derived from the beds. The Del Rio clay normally contains large quantities of iron pyrites. Where it has been subjected to the process of weathering the oxidation of the pyrite has set free the sulphuric acid that it contains, and this in turn has combined with the lime in the clay to form gypsum. Crystals of selenite thus formed are often conspicuous in the outcrops. In the marls and clays of the Upper Cretaceous in the trans-Pecos region, especially in Brewster County, there are extensive beds containing selenite. In the Lower Cretaceous limestones, especially those of the Washita group in the neighborhood of the Terlingua mining district, extensive caves have been formed. Many of the caves have subsequently been filled with gypsum in a variety of forms, including massive gypsum, selenite, and satin spar.

In that portion of Texas lying'to the east of Brazos River there are numerous localities where the presence of gypsum has been noted. The geologic formations are of Tertiary and Quaternary age. R. A. F. Penrose, jr., and William Kennedy, in their reports on this region, note the presence of gypsum in some places in considerable quantities in the clays. In the Midway ("Wills Point") formation in particular, in Brazos Cointy, gypsum occurs chiefly in the form of selenite, some crystals of which are 6 inches long and have attracted considerable attention, although they are of no commercial importance. 


\section{UTAH.}

By R. W. Stone and C. T. Lupton.

\section{DISTRIBUTION.}

Commercial deposits of gypsum are abundant and widespread in central and southern Utah. Their distribution is shown on the map (fig. 50). Plaster mills have been operated at Nephi, Levan, and Sigurd, and plaster has been made by crude methods for local consumption at St. George and other places.

The known deposits of great extent are as follows: Juab County, near Nephi and Levan; Sanpete and Sevier counties, from Mayfield to Sigurd; Millard County, at White Mountain, near Fillmore; Emery County, east and south of Castle Dale: Wayne County, near Notom and in South Wash; Kane County, near Kanab; Grand County, between Grand River and La Sal Mountains; Iron County, southeast of Kanarraville; Washington County, several localities, particularly in the northeastern part of the county.

Several of these deposits are so far from a railroad or any market that there is no demand for their exploitation.

The gypsum area on the west flank of the San Rafael Swell is described by Mr. Lupton. Much of the information concerining other localities was obtained by Mr. Stone on a hasty reconnaissance of readily accessible gypsum localities which he made in August, 1916.

\section{IOCALITIES IN CENTRAL AND SOUTHERN UTAH.}

By R. W. STONe.

NEPHI, JUAB COUNTY.

The gypsum deposit at Nephi is at the mouth of the canyon of Salt Creek, 2 miles east of the railroad station (No. 1, fig. 50). It was discovered many years ago, before the town of Nephi was settled. A claim 600 by 1,500 feet was patented by John Hague and others in 1882 under the name of the Juab Plaster \& Mining Claim. During the next few years rock gypsum was quarried and calcined in sorghum pans, and the plaster was used locally and shipped to Salt Lake City. In 1888 Messers. Hyde, Hague, and Whitmore incorporated their company and erected a mill. Operations at this point continue to the present time, the property being owned and worked by the Nephi Plaster \& Manufacturing Co., W. L. Ellerbeck, president. 
The body of gypsum exposed in the south wall of Salt Creek (see Pl. XXXII, $B$, p. 246) extends from the track level, 5,450 feet above sea level, to 6,000 feet and the quarry face is more than 400 feet high. The quarry face, a great white scar on the mountain side, can
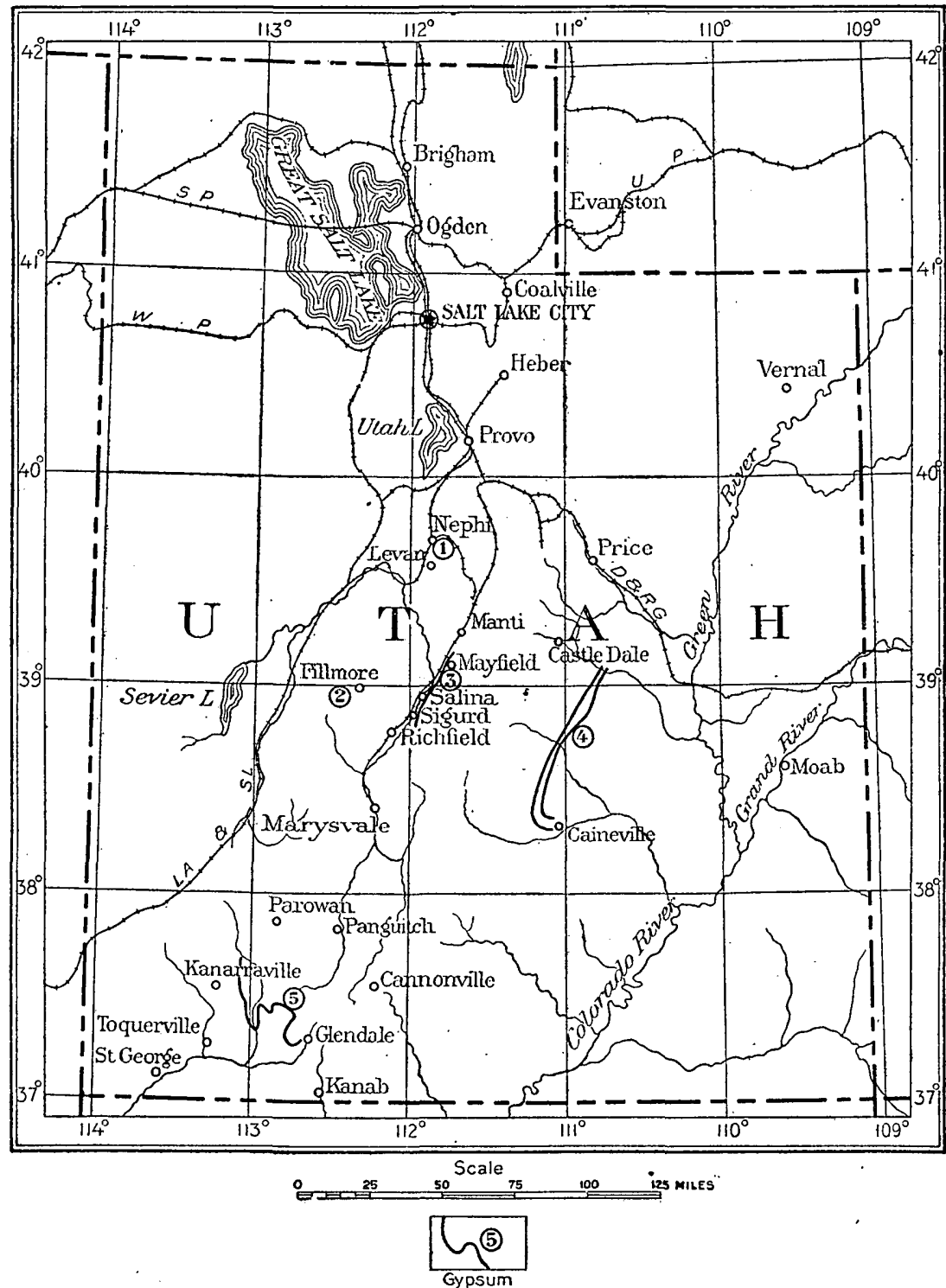

Numbers referred to in text

FIGURE 50.-Map showing distribution of principal gypsum deposits in vitah.

be seen from the railroad for several miles north of Nephi. Tho gypsum is 250 feet thick at the bottom of the quarry but widens above to 300 feet or more. Formerly the rock was taken out by quarrying, but the very high quarry face became dangerous, and a 
combination of quarrying, glory holes, and underground mining is now in use. A large shoulder of gypsum at the top of the quarry is being removed by shooting the rock into a glory hole which is tapped below by a tunnel that lies wholly in gypsum. In winter or inclement weather rock is mined in the tunnel. The gypsum is loaded in small steel mine cars, which are pushed by hand to the loading house at the top of a steeply inclined gravity tram. The loaded tram car, which carries the contents of three or four mine cars, in descending to the mill 400 feet below pulls up the empty car. The load is dumped automatically into a storage bin in the mill.

The present mill is of modern concrete and steel construction, made fire resistant with partitions of metal lath and gypsum plaster. From the storage bin the rock slides by chute to a nipper, from which it falls into a gyratory crusher. The "gravel" is elevated and run over Newaygo screens to steel storage bins, from which it is carried by screw conveyers to the kettles. The present equipment for calcining includes two 10-foot kettles and one 8-foot kettle. The. kettles dump direct to hot pits, from which the calcined plaster is elevated to Newaygo screens. After passing these screens it is pulverized in either a Raymond roller mill or a vertical burr mill. Three mixers are in use, one of them an especially designed tumbler mixer.

Water which is taken from Salt Creek 2 miles above the mill and conducted to it in a side-hill ditch has sufficient head at the turbine to make ample power.

The mill output includes land plaster, "gravel" for Portland cement mills, casting, finishing, hard wall, and dental plaster. Specially colored plaster for casting and for exterior and interior walls was prepared in large quantity in 1914 for building at the PanamaPacific International Exposition at San Francisco, and the PanamaCalifornia Exposition at San Diego. Keenes cement is made also in a specially designed kiln.

A branch line of the Denver \& Rio Grande Railroad passes the mill.

The geologic structure in the immediate vicinity of the Nephi gypsum deposit seems to be comparatively simple, for a ledge of shaly limestone about 100 yards west of the gypsum is easily traced up the hillside, its strike being N. $10^{\circ}$ E. and its $\operatorname{dip} 75^{\circ} \mathrm{W}$., and a similar ledge about one-fourth mile east of the deposit also ascends the hill, its strike ranging from N. $35^{\circ} \mathrm{F}$. to N. $15^{\circ} \mathrm{W}$, and its dip from $35^{\circ}$ to $50^{\circ} \mathrm{E}$. This ledge seems to be continuous to a point almost directly above the gypsum or 800 feet above the river, where it flattens. The western ledge, however, at an elevation of 50 feet above the top of the quarry seems to stop abruptly and red shale occurs in the line of strike. A ledge on which the tram is built on the east 
side of the gypsum appears to strike N. $55^{\circ} \mathrm{W}$. and dip $65^{\circ} \mathrm{W}$. under the gypsum, but it terminates 100 feet below the top of the quarry. (See fig. 51.)

Furthermore, the tunnel driven from the mill 250 feet through bedrock to the lower part of the quarry passes through shale in various attitudes, and the outcrop along the face of the hill between these two points shows complex structure. (See fig. 52.)

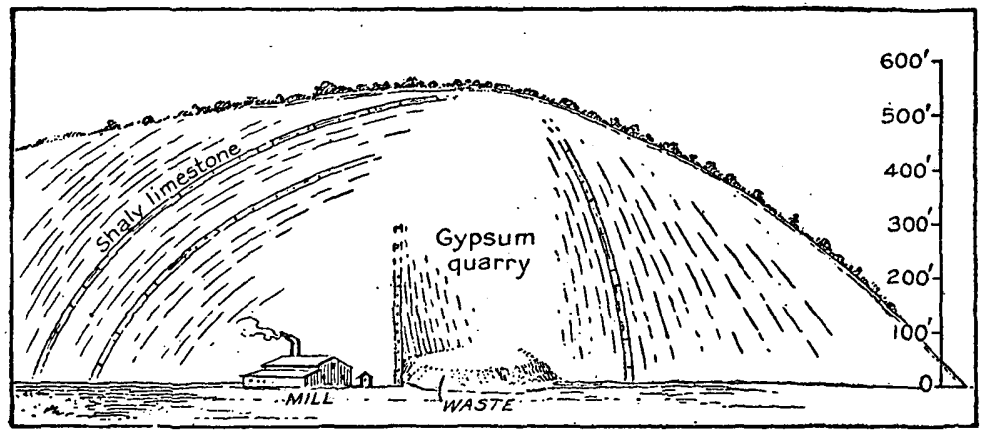

Figure 51.-Diagram showing geologic structure at gypsum quarry, Nephi, Utah.

The shale in the tunnel in contact with the gypsum appears to be conformable and to dip west at a high angle. In other words, there seems to be a conformable series from gray shaly limestone on the west through 200 feet of drab limy shale and through 250 feet of gypsum and a few feet of shale below it to a disturbed area on the east.

On the north side of the creek a limy ledge at the mouth of the valley strikes N. $20^{\circ} \mathrm{E}$. and dips $85^{\circ} \mathrm{W}$. On the hillside its

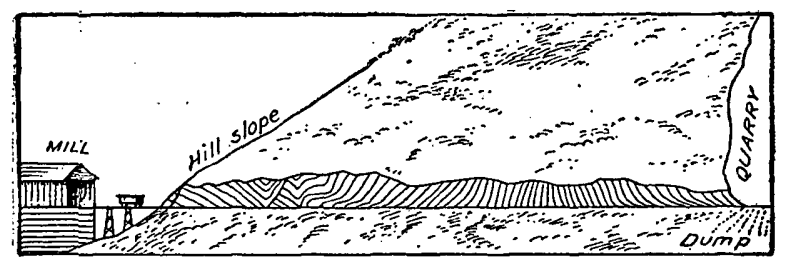

Figure 52.-Cross section of strata that lie between gypsum mill and quarry, Nephi, Utah.

strike changes to $\mathrm{N}$. $60^{\circ} \mathrm{E}$. and its dip to $55^{\circ} \mathrm{N}$. Opposite the - mill and 200 feet above it this ledge strikes N. $35^{\circ} \mathrm{E}$. and dips $45^{\circ} \mathrm{N}$. From the mill or quarry this ledge is seen to form part of a northward-plunging anticline. It is not regular, however, or at least there seems to be a displacement of about 150 feet by a small fault or very acute downfold near the top of the arch.

Gypsum is not found under this arch on the north side of the creek. Just above the upper ledge of limy shale that outlines the structure there is green and red shale. Half a mile farther east there are 


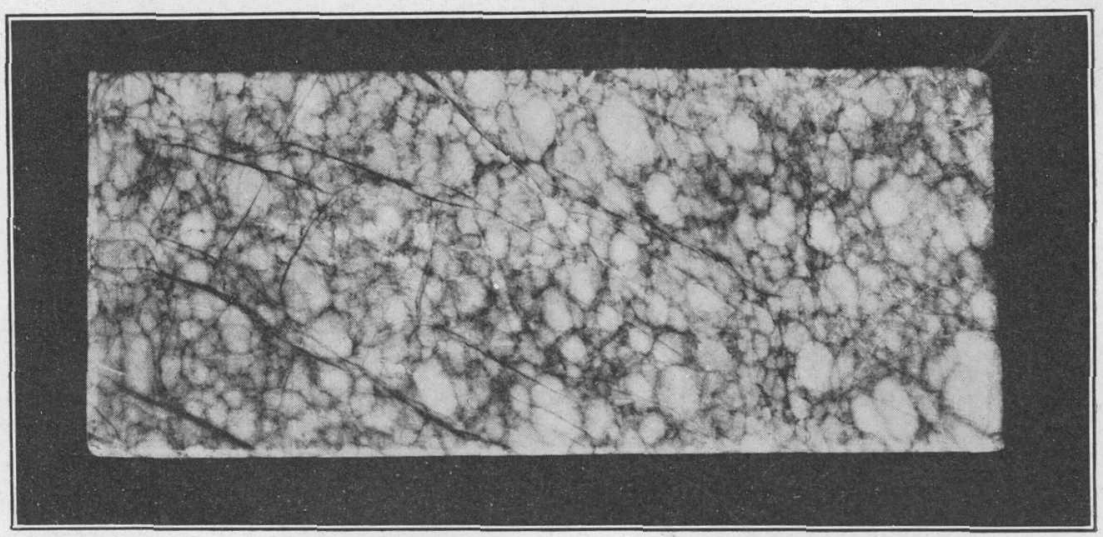

A. POLISHED BLOCK OF GYPSUM FROM NEPHI, UTAH, SHOWING MOTTLED CHARACTER OF THE ROCK.

One-third natural size.

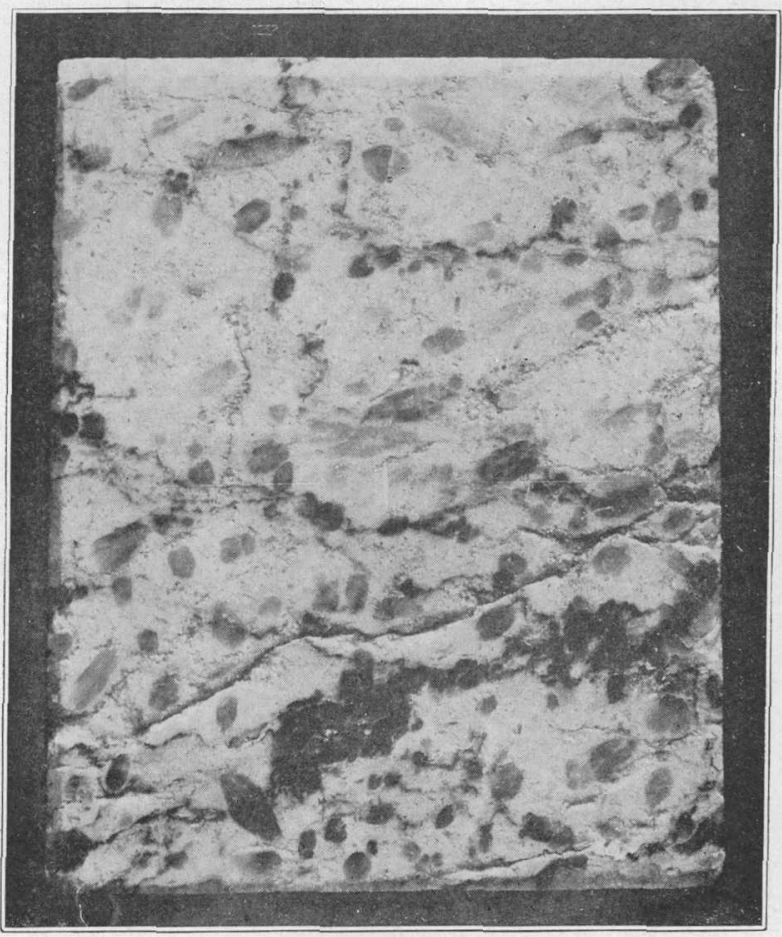

B. POLISHED BLOCK OF GYPSUM FROM NORTH HOLSTON, VA., SHOWING GRANULAR CHARACTER AND SELENITE PHENOCRYSTS. 


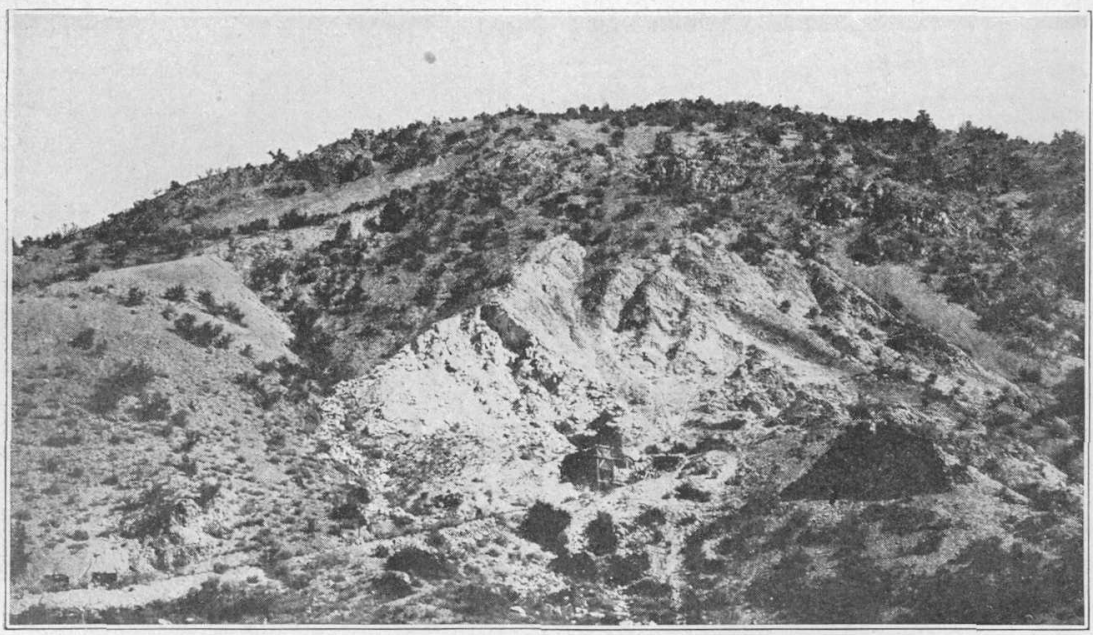

A. GYPSUM QUARRY 11/2 MILES EAST OF LEVAN, UTAH.

Photograph by R. W. Stone.

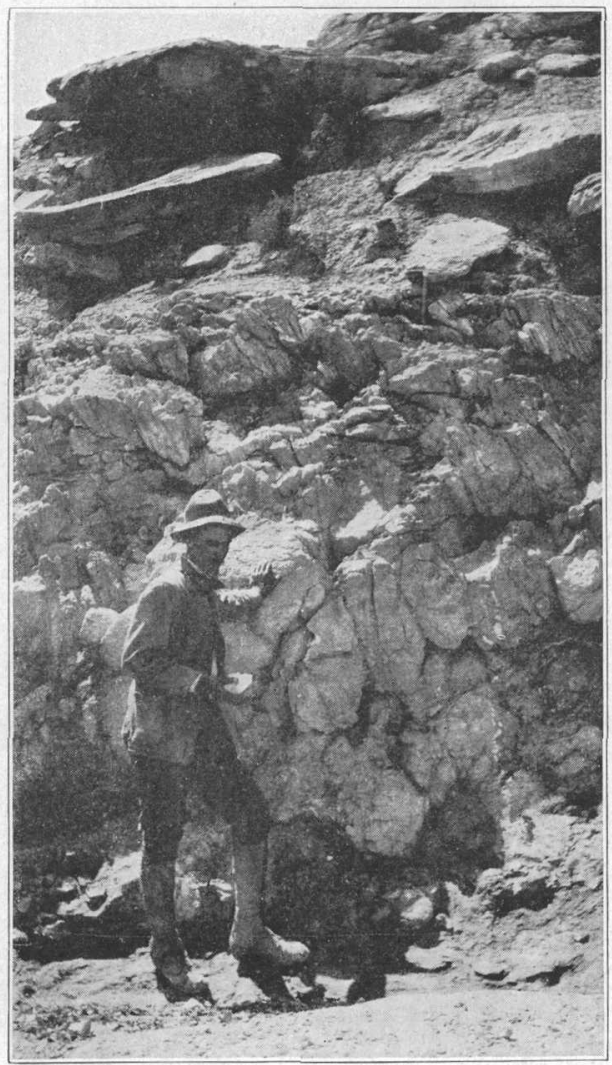

$\gamma$ 
several small ledges of gypsum and shale. If the gypsum is a regularly bedded deposit, as it appears to be, it would not show on the north side of the creek because of the sharply plunging anticline. The gypsum may be cut off at the top of the quarry by a fault, or there may be a very. sharp small fold here, which is represented on the north side of the creek by the dent near the top of the structural arch. No evidence was found of folding within the gypsum or to support the idea that it is a tightly compressed fold. It would seem to be either a chunky, abruptly terminated lens or a body cut off at one or both ends by a curving fault. Gypsum is reported to outcrop in a canyon 1 mile south and is found at a number of points between Nephi and Levan. Whether there is a continuous bed has not been determined.

The greater part of this deposit, including a thickness of 250 to 300 feet, is first-class plaster rock, massive and free from impurities; the remainder is somewhat fractured but usable, though on the margins it is interbedded with shale. Near the middle of the bed and high up in the quarry there is a block of anhydrite, which is easily recognized in mining and so avoided. Gypsum from the Nephi quarry, like that at Levan, is distinguishable from that of many other localities by its mottled light-brown color. The rock is dense and lusterless; its mottled character is shown in Plate XXXIII, $A$. Two analyses of the rock are given in the table on page 29.

The sedimentary origin of this deposit is shown by its bedded structure, which agrees with that of the country rock, by the interbedding of gypsum and shale, by the presence of calcium carbonate, magnesium carbonate, and small quantities of potassium and sodium salts, and by the occurrence of rock salt near by in the same sedimentary formation. It is probable that the gypsum was deposited from the water of an inland lake or lagoon. The geologic age of the gypsum is believed to be Jurassic, but this point has not been settled definitely for lack of paleontologic evidence. The red color of the overlying sedimentary formation is conspicuous and suggests that it belongs to the well-known "Red Beds" of the Western States. The Wheeler Survey mapped the rocks of this area as Jurassic and reported in their text that "the Jurassic rocks are everywhere found to be very gypsiferous, and in some places good workable beds of gypsum are seen. One of these beds occurs at Salt Creek, near Nephi." 2

LEVAN, JUAB COUNTY.

In the lower end of Levan Canyon there are several exposures of massive gypsum, the first one being $1 \frac{1}{2}$ miles east of the village of

${ }^{1}$ Howell, E. E., U. S. Geog. and Geol. Surveys W. 100th Mer., vol, 3, p. 264, 1875. 
Levan at the mill and quarry formerly operated by the Utah Consolidated Plaster Co. This property, now owned by J. H. Moyle, of Salt Lake City, has been idle for a number of years. The gypsum is exposed in the steep valley wall in a triangular outcrop about 200 feet high and 250 feet wide at the base. The gypsum is massive, mottled, light brown, like that at Nephi, and is thought by some to be a continuation of that deposit. Gypsim can not be traced continuously over the 11 miles between the two quarries, although it is said to occur at a number of places. Faulting complicates the problem, and the known change of color in the red beds from place to place at the same geologic horizon leaves correlation dependent on paleontologic evidence. Fossils, however, are very scarce in the strata closely related to these gypsum deposits. The disturbed and faulted character of the geologic structure at this quarry is shown in Plate XXXIV, $A$.

This deposit may be a short, thick lens bunched up by folding and faulting, but definite evidence as to its origin was not obtained. It is believed that the structure of this deposit is the same as that of the Nephi gypsum deposit.

Gypsum from the hillside quarry was dumped into a bin from which it was drawn into steel tram cars that moved by gravity down to the top of the mill. The 2-kettle mill is completely equipped, including Newaygo screen and sacker. Power was furnished by turbine, water being brought from the creek in a hillside ditch.

About one-fourth of a mile farther up the canyon there is a small body of gypsum in the north wall, and three-fourths of a mile above the mill there is a larger deposit, about 400 feet long at the base: and 250 to 300 feet high. Two 10 -foot adits in the base of this deposit show light-brown mottled gypsum. There is a small body of gypsum about 400 feet above the creek, on the south side of the canyon, at this point.

MANTI, SANPETE COUNTY.

According to Mr. O. Billings, of Manti, there is a flat-lying bed of gypsum 20 to 40 feet thick at the head of Manti Canyon, about 13 miles east of the town. The bed is said to be exposed for about. 4 miles. Gypsum is reported to be abundant in Lowrys Mountain in the Wasatch Plateau, east of Manti.

MAYFIELD, SANPETE COUNTY.

A band of light-colored rocks is very conspicuous on the east side of Sevier Valley from Mayfield nearly to Richfield (No. 3, fig. 50). This formation, which is believed to be of Jurassic age, carries beds of gypsum. 
Two miles northwest of Mayfield and only a few rods south of the road leading to Gunnison there is a bed of gypsum about 30 feet thick. It is exposed along a low ridge which trends N. $35^{\circ} \mathrm{E}$. The gypsum is massive white and mottled and is well exposed where a small wash cuts through it 150 yards from the road. The bed dips $50^{\circ} \mathrm{E}$. and is underlain by gray to buff shaly sandstone and overlain by 50 feet of paper-thin beds of gray sandy shale. This shale is overlain by red beds. The gypsum rests on an uneven surface at the one place examined; between the gypsum and the underlying regularly bedded strata there is a block of shaly sandstone, which lies with its bedding planes at a high angle to the contact.

The writer was informed at Mayfield that this ledge has been traced about 4 miles to the south. Whether it is exposed north of the Mayfield-Gunnison road was not determined, but the same formation was seen for several miles in that direction and is indicated on geologic maps as terminating west of Manti.

SALINA, SEVIER COUNTY.

An officer of the United States Forest Service, stationed at Salina, informed the writer that a ledge of gypsum that dips at a high angle is exposed an a ridge 3 miles east of Salina and extends north at least 3 miles to a small creek, where it has been quarried and burned. A rough stone kiln about 10 feet in diameter is used for making plaster. This ledge of gypsum was well exposed on the old twist road (now abandoned) in the northeast part of T. 21 S., R. $1 \mathrm{E}$.

It has been stated ${ }^{1}$ that gypsum was at one time quarried and ground in a small mill near Salina, but that active operations have been suspended. The writer made inquiry of several old residents of Salina regarding this statement and found them all in agreement that there never had been any kind of a gypsum mill near Salina. A small quantity of plaster is made intermittently by crude methods, as noted above.

SIGURD, SEVIER COUNTY.

The southernmost extensive exposure of gypsum in the 30 miles of nearly continuous outcrop of gypsum-bearing beds in Sevier Valley, and the only place in the valley where the rock is being utilized on a commercial scale, is at Sigurd. Two plants of the American Keene's Cement Co. and the Jumbo Plaster \& Cement Co. are quarrying rock gypsum and making plaster. The rock is quarried 2 miles northeast of the mills and hauled to them by wagon. It is reported locally that the gypsum was deposited as lenses, because

${ }^{1}$ U. S. Geol. Survey Bull. 223, p. 103, 1904. 
it is now found in small patches, tipping spurs, and capping knobs. An examination shows, however, that the original flat-lying beds have been upturned, faulted, and eroded. The seeming discontinuity is due to the outcrop between spurs being hidden by wash. At least three beds of gypsum are present. The lower one is 10 to 20 feet thick, the middle one 10 feet or less, and the upper bed appears to range from 20 to 50 feet in thickness. Both the upper and lower beds are quarried. Much of the rock is pure white finely granular gypsum, and some is light gray. Both white and gray rock are used. In some places the gypsum beds contain masses of coarse radiating selenite.

The gypsum beds outcrop around an anticline, which is several miles long, apparently terminating on the south near Glenwood and on the north about $2 \frac{1}{2}$ miles from Sigurd. The anticlinal structure is complicated by minor folds and faults.

W. P. Paine, manager of the Jumbo Plaster \& Cement Co., reports that abundant gypsum is exposed a few miles east on Lost Creek, where there are many acres of plaster rock with no overburden. The gypsum-bearing formation is gray: and limy shales, with here and there a small band of red beds, overlying the gypsum. Lithologically there is a close resemblance to the formation at Nephi.

The red shales and sandstones in which the gypsum beds occur were mapped by the geologists of the Wheeler Survey as Jurassic. ${ }^{1}$ The writer made a fruitless search for fossils and therefore has no new data concerning the age of the gypsum.

Beds of impure gypsum, unsuitable for plaster, occur in the same formation. One of these beds outcrops in the first small ridge east of the valley and along the road from the mills to the quarries.

The mills are operated by water power but have an auxiliary steam plant. One mill calcines pulverized gypsum in 10-foot kettles and the other burns lump gypsum in kilns.

White MOUNTAIN, MILLARD COUNTY.

About 8 miles west of Fillmore gypsum occurs in deposits of three types-gypsiferous clay, gypsum sand, and loose crystals (No. 2, fig. 50). The gypsiferous clay covers an oval area approximately 3 by 5 miles in extent. Gypsum sand dunes occur in two areas, one of them a mile long and a third of a mile wide, the other an irregular area approximately half a mile square. Mounds of loose small crystals cover an area about 2 miles long and half a mile wide. (See fig. 53.) The gypsum is believed to have been derived from the mountains on the east and to have been transported by streams, to the White Moun-

${ }^{1}$ U. S. Geog. Surveys W. 100 th Mer. Atlas Sheets 50 and 54. 
tain playa, where it was redeposited with detritus. This accounts for the gypsiferous clay. Desiccation of this deposit has formed small gypsum. crystals at the surface, which have been swept up by the wind and collected into dunes of gypsum sand, estimated to contain about 450,000 tons of pure gypsum.

It is well known that in late geologic time a considerable portion of Utah was submerged beneath a great lake. This lake was lowered by drainage over the rim and by desiccation until the bottom was exposed and the great Bonneville basin was divided into a number of separate basins. The existing lakes and playas occupy the bottoms of these basins. Concerning the origin of gypsum in the White Mountain playa, Gilbert has written as follows: ${ }^{1}$

In the southeastern angle of the Sevier Desert, there is a tract partially partitioned from the general plain by a series of coulees of basaltic lava extravasated during the Bonneville epoch. This contains several playas, marking localities where the drainage is checket but not completely imprisoned. The highest and most southerly of these differs from all the others in that its material is gypsum. It is probable that

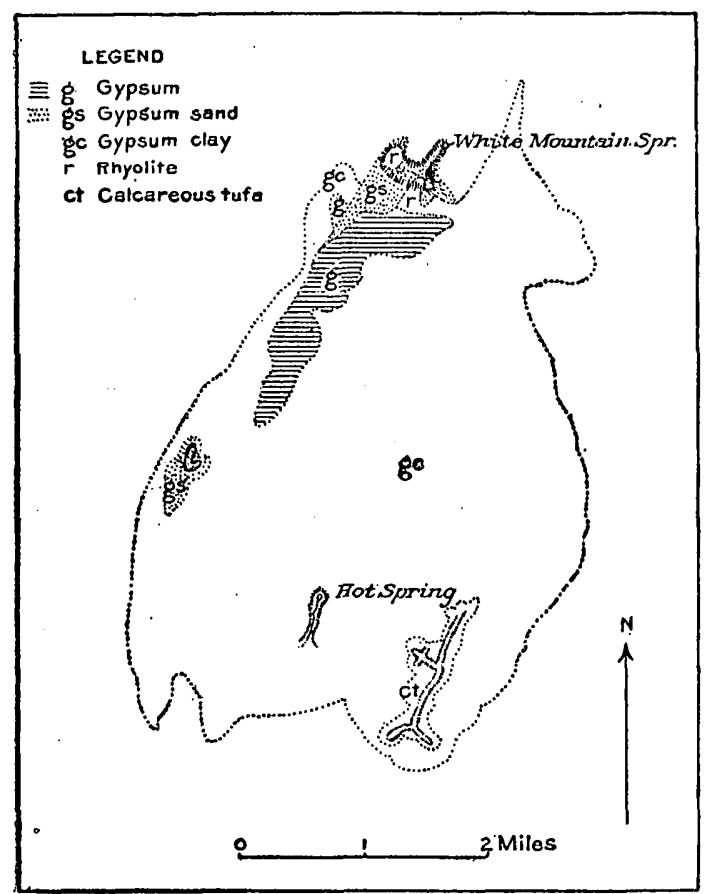

Figure 53.-Map showing extent of gypsum deposit at White Mountain, Utah. the deposit is independent

of any special chemical reaction and is due simply to discharge by evaporation of a mineral dissolved from the rocks. The streams whose waters occasionally flood the playa rise amongst strata of Jurassic and Triassic age, and such strata in the neighboring range are known to be highly gypsiferous. The heads of the streams were not examined. It was ascertained by digging in the playa that a portion of the deposit is amorphous and another portion crystalline. One phase of the precipitation results in the formation of small free crystals, which the wind sweeps from the surface of the playa and gathers into dunes. The dunes do not travel to a great distance but are arrested by a low rhyolitic butte near by, to which they have given the name of white Mountain. 
GEDAR City, IRON COUNTY, TO GLENDALE, KANE COUNTY.

In Iron, Washington, and Kane counties extensive deposits of gypsum have been noted in strata underlying coal beds. A bed of white rock gypsum more than 100 feet thick is recorded by Lee ${ }^{1}$ in Coal Creek canyon, east of Cedar City, Iron County. This bed is in red sedimentary rocks about 500 feet above a great thickness of red sandstone that makes a conspicuous clifi. In a report on the same area Richardson ${ }^{2}$ says that in a series of rocks composed of reddish and varicolored shale and sandstone of Jurassic age intercalated beds of white gypsum occur abundantly for many miles. $\mathrm{Mr}$. Richardson has furnished the following three sections from his unpublished notes (measurements were made with aneroid barometer) :

Section \& miles east of Kanarraville, Utah.

Feet.

Conglomerate

25

Sandstone, red-brown, and shale

Limestone, gray _-_._. 20

Gypsum, white _-_._._. 200

Limestone, massive, gray, including thin beds of gypsum_-_..- 500

About 200 feet below the top of this massive limestone there is a 25-foot bed of gypsum, and another bed, of unknown thickness, occurs near the base. This measurement, made with an aneroid, is part of a long section exposed southwest of the Union coal mine, in sec. 29, T. 37 S., R. 11 W. The 200 -foot gypsum bed is 7,300 to 7,500 feet above sea level and dips $15^{\circ}$ E. (No. 5, fig. 50).

Section $S$ miles southeast of Kanarraville, Utah.

$\begin{array}{lr}\text { Limestone, massive } & \text { Feet. } \\ \text { Gypsum - } & 25 \\ \text { Limestone, massive } & \end{array}$

The measurement was made in the SE. $\frac{1}{4}$ sec. 23, T. 38 S., R. 11 W., where the gypsum is 7,600 to 7,800 feet above sea level.

Section on North Fork of Virgin River.

Feet.

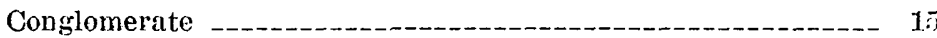

Sandstone, white, with streaks of red sandstone and shale_.. 1.50

Gypsum -...- 160

Limestone, massive _-_._.

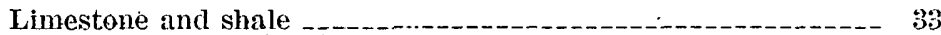

Sandstone, massive, scarlet.

1 Lee, W. T., The Iron County coal field, Ctah: U. S. Geol. Survey Bull. 316, p. 362, 1007.

i Richardson, G. B., Harwony, Colob, and Kanab coal field, Utah: U. S. Geol. Survey Bull. 341, p. 381, 1909. 
This section is exposed near Levi Walker's ranch, in sec. 34, T. 39 S., R. 9. W.

Mr. Richardson reports that gypsum in thick beds is common from Kanarraville southeast at least as far as the valley of Kanab Creek east of Glendale, Kane County. These great deposits are in the midst of a sparsely settled region remote from a railroad and source of demand, so that doubtless they will long be undeveloped.

The writer was informed by Mr. Dennet, of Rockville, that there is a thick bed of massive white gypsum near the Dennet homestead on Short Creek, in T. 39 S., R. 10 W. Others stated that gypsum is very abundant in thick beds near Mount Carmel, and Mr. Richardson's notes verify its occurrence in the valley of Muddy Creek at that place.

A large bed of gypsum is reported east of Toquerville in the valley just in front of the Hurricane fault. At La Verkin pure-white gypsum float is conspicuous in talus between the bridge over Virgin River and the warm sulphur spring in the river bank. The float up the canyon wall leads to a 12 -foot bed of massive white gypsum in the bank of the Hurricane irrigating ditch, about 300 feet above the river. On the opposite side of the river and half a mile farther upstream the La Verkin irrigating ditch is reported to cut through gypsum in several places, especially about onequarter of a mile above the 800 -foot tunnel by which the water is conducted from the canyon wall to the settlement. One of these gypsum ledges exposed by the ditch is said to be 30 feet high.

The road west from Hurricane that crosses the lava and fords Virgin River near the north line of T. 42 S., R. 14 W., zigzags through several low ridges of tilted green and red sedimentary strata on the west bank of the river. In these beds, along this crooked stretch of road called Purgatory, there is considerable gypsum, but the rock is so deeply weathered that it may not be noticed by the casual observer.

\section{ST. GRORGE, WASHINGTON COUNTY.}

In the midst of red beds on both sides of Virgin River near Bloomington, 5 miles south of St. George, there is a green shale series, which contains several beds of white gypsum of a sugary texture. This shale is believed to be the same formation as that at Purgatory, a locality on Virgin River 10 miles northeast of St. George. Therc has been no development or prospecting, and because of their soft weathered character the thickness of the individual gypsum beds could not be determined. There seem, however, to be several beds from 5 to 15 feet thick. The road from Bloomington through Curly Hollow to the Apex mine passes through these beds, as does also 
the road on the east side of the river from Bloomington to the Sullivan ranch. In Curly Hollow, west of Bloomington, some of the red beds exposed along the road appear to be gypsiferous shale, but close examination shows that they are composed of layers of gypsum one-half to 2 inches thick, with interlayers of shale a small fraction of an inch thick. Some of the gypsum layers are wavy, but those immediately. above and below them are not.

Several old residents at St. George agree that the best exposures of rock gypsum in thick beds near that town are in South Mountain, about 15 miles to the south, and in Quail Canyon, south of Mokaich Spring. Both of these localities are a few miles over the State line in Arizona and were not visited by the writer. The writer was told at St. George that gypsum is exposed abundantly and for a long way on the road from Gunlock up Santa Clara River.

The Mormon temple and tabernacle at St. George are notable examples of frontier plaster work. The writer saw the interior of the tabernacle, which is ornamented with molded plaster work in strong relief, and was told by Mr. T. B. Cottam, of St. George, how the plaster was made 40 years ago. At a locality several miles from town loose blocks of gypsum weighing 300 to 400 pounds were pried out with a crowbar. These blocks were broken with sledges and run through a horizontal burr mill, which reduced the rock to the size of acorns and corn. It was then cooked in a rectangular sheet-iron molasses pan, with constant stirring by hand. The plaster was drawn after the first settle.

SOUTH WASH, WAYNE AND GARFIELD COUNTIES.

The gypsum of this locality is better known than the locality itself, which is difficult of access. J. E. Talmage, of Salt Lake City, discovered huge geodes of selenite or crystallized gypsum in the deserts of Wayne and Garfield counties, and under the auspices of the Deseret Museum had 20 tons of these great crystals transported to Salt Lake City. They are now to be found in many museums in this and in foreign countries. The occurrence of the crystals has been described by Prof. Talmage as follows: ${ }^{1}$

Here and there along the gorges are outcrops of gypsum varying in degrees of purity, and seams of this material cut through the country rock in all directions. In places veins of satin spar, as thin as a sheet of note paper, or even an inch in thickness, can be traced for many hundreds of yards upon the surface of the ground in uninterrupted course, except for intersecting planes of the same material. On the walls of the ravines and canyons places are seen where spar veins cross and recross each other with bewildering profusion. ** * Gypsum in all varieties may be found within a short radius. Fibrous and scaly laminae,

\footnotetext{
1 Talmage, J. E., A remarkable occurrence of selenite: Science, vol. 21, pp. 85-87, 1893. Moses; A. J., One of the gypsum crystals from the cave at South Wash, Wayne County, Utah : Idem, pp. 230-231.
} 
plaster stone or rock gypsum in masses, lumps of pure alabaster, and fragments of selenite crystals are scattered along the washes and strewn upon the bench lanils.

The crystals occur in a cave, and this is inclosed by a thick shell forming a mound. This selenite mass seems to have been left exposed by the weathering of loosened friable sand and clay, of which the hill whereon the mound is situated is composed. *** Prisms of perfect form and varying in length from 1 to 5 feet and in weight from 10 to 100 pounds are of frequent occurrence. One of the most regular yet taken out is 4 feet long and the widest faces are 6 inches across. Cleaved slabs are obtainable 6 feet in length and $2 \frac{1}{2}$ feet in breadth. One of the longest perfect prisms yet obtained extends 51 inches, and from one of its faces 19 smaller crystals sprout. Twins are common, as are also compound terminations of very complicated structure.

In 1871 G. K. Gilbert (then geologist on the Wheeler Survey) described occurrences of rock gypsum seen by him in these counties as being so extensive that a person could walk in one direction for about 2 miles without stepping off of gypsum. Geologists of the Wheeler Survey mapped the sedimentary rocks of this region as Triassic, Jurassic, and Cretaceous. The age of the gypsum is uncertain and will remain so until detailed geologic field work is done in this region.

MOAB, GRAND COUNTY.

By F. L. HEss.

At the edge of the village of Moab, in the southern part of Grand County, there is a deposit of rock gypsum of unknown extent. Weathering has formed a dingy white spongy secondary deposit, about 40 feet thick, which hides the gypsum bed. Poor outcrops along Grand River suggest that the deposit is at least half a mile long; its thickness is unknown but probably is considerable. It is believed to be an interbedded deposit in rocks of Triassic age.

The spongy gypsum has been crushed and put on the road at Moab with good result. In fact, an outcrop of gypsum in this region may be recognized at once wherever a road crosses it, by the smooth, hard surface of the highway.

GYPSUM ALONG THE WEST FLANK OF THE SAN RAFAEL SWELL, UTAH. ${ }^{1}$

By C. T. Lup'ron.

\section{LOCATION AND EXTENT.}

The San Rafael Swell, along the west flank of which outcrop the gypsum deposits here described, is an irregular, somewhat elliptical

1 U. S. Geol. Survey Bull. 530, pp. 221-231, 1913.

$124567^{\circ}-20-1.8$ 
dome extending northeast and southwest in the east-central part of Utah, east of the Wasatch Plateau and west of Green River. (See Pl. XXXV.)

The San Rafael Swell is 60 to 80 miles long and 20 to 30 miles wide.

The gypsum-bearing rocks in this area outcrop in a belt ranging in width from a few hundred feet in the vicinity of Cedar Mountain or Red Plateau, at the north end of the area, to 3 or 4 miles near the center of the west flank, along the road leading from Emery eastward to the Globe copper mine.

The gypsum exposures can be most easily visited by leaving the Denver \& Rio Grande Railroad at Price, from which town a daily stage traverses approximately the entire length of Castle Valley to Emery, 63 miles to the southwest. At any of the towns between Price and Emery (Cleveland, Huntington, Castle Dale, and Ferron) conveyances may be obtained for a trip to the gypsum beds, which outcrop several miles to the east. Probably the most convenient point from which to visit the gypsum-bearing rocks is Cleveland, about 6 miles east of Huntington. A good road leads from Cleveland in a southeast direction to Buckhorn Flat, located directly south of Cedar Mountain or Red Plateau. At the east side of Buckhorn Flat the gypsum beds have been prospected and are reported to be well exposed. A good road has been built from Emery eastward across the outcrop of the gypsum to some copper prospects known as the Globe copper mine, on the west flank of the Swell. Next to the wagon road leading from Cleveland to Buckhorn Flat, this road would be the best one over which to haul the gypsum should it be mined.

Travel by rail may be terminated also at Salina, on the Rio Grande Western Railway, on the west side of the Wasatch Plateau, where conveyance can be obtained across this plateau to Emery, in Castle Valley. The gypsum exposures situated near the south end of the Swell in the vicinity of Caineville, and also those near the north end of the Water Pocket Flexure, near Notom post office, can be visited most easily by taking the stage from Salina to Loa, in Rabbit Valley, where conveyance can be obtained for the trip down Fremont River to Notom and Caineville.

\section{TOPOGRAPHY.}

The topography of the area is rugged. Mesas and buttelike forms cut from massive sandstone, approximately 800 feet thick, underlying the gypsum-bearing formation and outcropping east of it, are the most striking features. In many places the walls of these mesas, buttes, and scarps are almost vertical cliffs 300 feet or more high. The outcrop of this sandstone surrounds the central part of the 
Swell, which is locally known as Sinbad. The topography of the areas of gypsum-bearing rocks is in most places comparatively smooth, except along the streams, where badlands are common.

\section{GEOLOGY.}

The gypsum-bearing rocks are of Upper Jurassic age and are the approximate equivalent of the Flaming Gorge formation of Powell. ${ }^{1}$ They rest with apparent conformity on a massive cross-bedded sandstone, which is the Gray Cliff sandstone of Gilbert's Henry Mountains section, and is regarded as the same as the White Cliff sandstone (Upper Jurassic) of southern Utah and the Uinta Mountains. There are about 1,350 feet of strata, mainly reddish in color, with two gypsum-bearing: zones, one 200 feet below the top and the other 200 feet above the base. Between the two gypsum zones there is a series of red and gray sandstone and sandy shale about 950 feet thick. The beds thus described correspond closely with the Flaming Gorge formation described by Gilbert ${ }^{2}$ as occurring in the Henry Mountains region, a comparatively short distance south of the San Rafael Swell, where he determined the thickness to be approximately 1,200 feet.

The strata along the west flank of the Swell dip $3^{\circ}-8^{\circ}$ NW., but the strata along the east flank are in places much more steeply inclined, ranging from almost flat to approximately $70^{\circ} \mathrm{SE}$.

\section{GENERAL TEATURES OF THE GYPSUM DEPOSITS.}

The gypsum of this area is an interbedded deposit, precipitated in a shallow sea into which a large amount of sediment was carried, especially at the beginning and end of the gypsum-forming period. The greater part of the deposits take the form of alabaster. The gypsum of the upper zone has a reddish tint and is not quite so pure as the lower deposits, which are white. The gypsum of both zones is so compact and firm that it can be readily carved. The upper and lower portions of both gypsum belts in most places contain considerable sandstone and sandy shale interbedded with the gypsum. These impure portions probably will never be of value for mining, in view of the large amount of pure gypsum in the main parts of the beds.

At several places near the outcrop of the gypsum beds the overlying strata are contorted and deformed. This condition is probably

${ }^{1}$ Powell, J. W., Report on the geology of the eastern portion of the Uinta Mountains and a region of country adjacent thereto: U. S. Gcol. and Geog. Survey Terr., $2 d$ div., pp. $40,50,51,68,92,146,151-153,157,1876$.

2 Glibert, G. K., Geology of the Henry Mountains, Utah: U. S. Geog. and Geol. Survey Rocky Mtn. Region, p. 6, 1877. 
due to the removal of portions of the underlying gypsum in solution by ground water, and the consequent sinking of the covering strata. The lower beds are purer and thicker than the upper. Sections of the exposures examined, given below in the discussion of the gypsum at the different localities, illustrate this point. Very little selenite or crystalline gypsum was noted.

In most places the upper gypsum bed outcrops in the face of cliffs. This position is due to the character of the overlying and underlying rocks, which are in most places fairly resistant sandstone. The lower beds containing gypsum usually outcrop in a monoclinal valley in a broad belt, which corresponds closely to a true dip slope. The rocks that underlie the gypsum are harder than those stratigraphically above it, and, as the gypsum is comparatively soft, it is eroded with the softer sandstone and shales. East of Emery, along the Globe Copper Mine road, the lower gypsum bed outcrops for more than a mile on one of these dip slopes.

\section{LOCALITIES.}

\section{SOUTH OF CEDAR MOUNTAIN.}

A gypsum prospect directly south of Cedar Mountain or Red Plateau, at locality No. 1 (see Pl. XXXV), near an unused roadbed of the Denver \& Rio Grande Railroad, in the NW. $\frac{1}{4}$ SW. $\frac{1}{4}$ sec. 6, T. 19 S., R. 11 E. Salt Lake meridian, is a pit about 8 feet deep and 8 feet in diameter. Only unconsolidated conglomerate was to be seen in this pit, on account of caving. On the dump was a large amount of grayish-green sandy shale and some pieces of glistening porous gypsum. It is reported by Parlan McFarlane, of Cleveland, Utah, that the gypsum is at least 30 feet thick and that a number of claims have been staked and recorded in this locality. From the stratigraphic position of the prospect pit this is the lower gypsum horizon. It is quite probable that when the mining of gypsum is begun in the San Rafael region the first shipment will be made from this locality, as there is a fairly good road leading through Cleveland to the railroad at Price and also a fair road leading to Green River on the railroad to the southeast. The gypsum can be mined and moved to the railroad from this place at probably a smaller cost than from any other locality hereinafter described.

SAN RAFAEL VALLEY.

On the north side of San Rafael River, at the east end of Fullers Bottom, at locality No. 2 (see Pl. XXXV), the lower gypsum-bearing zone was examined and the following section was measured: 


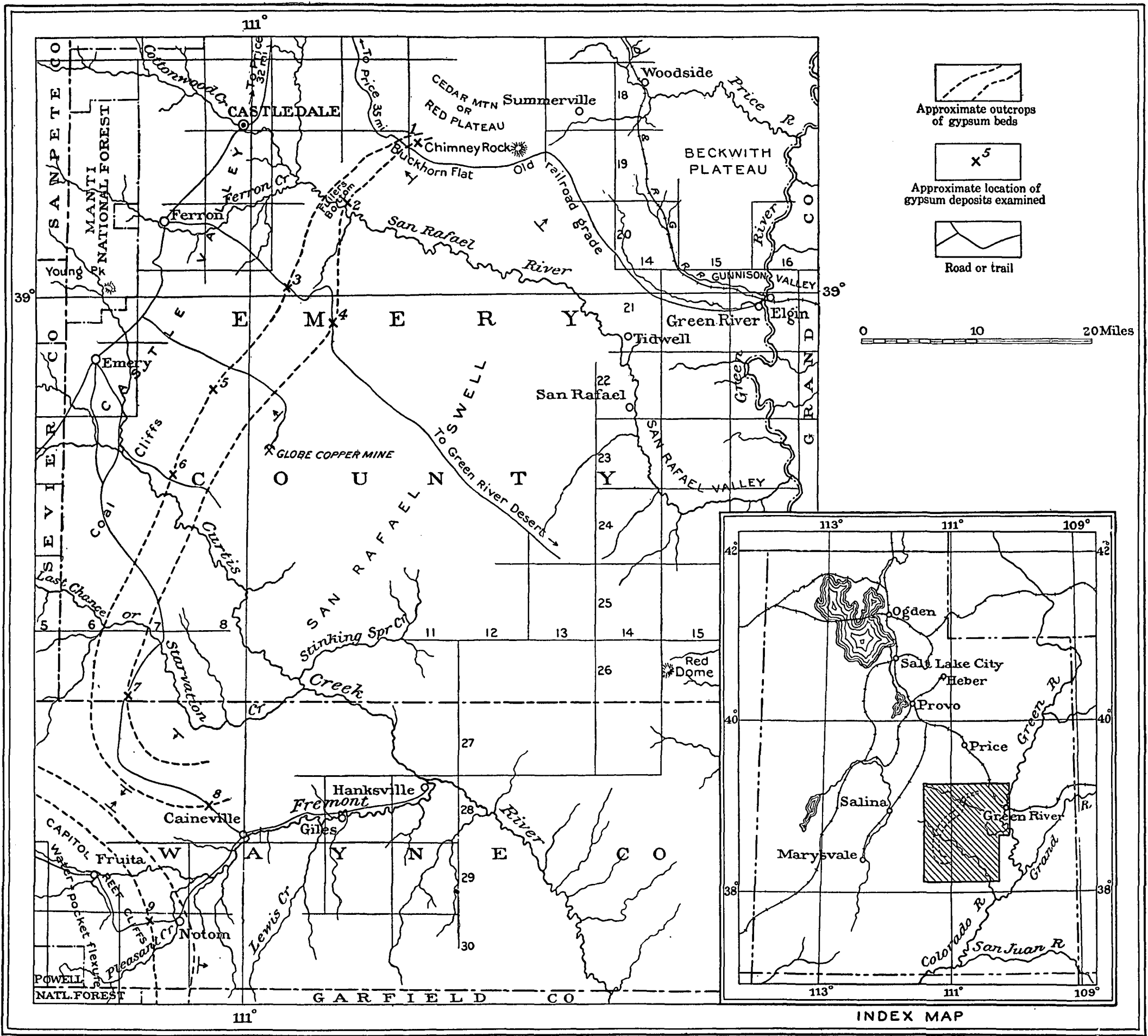

MAP SHOWING DISTRIBUTION OF GYPSUM DEPOSITS ON WEST FLANK OF SAN RAFAEL SWELL, UTAH. 
Section of gypsum-bearing rocks at the east end of Fullers Bottom along San Rafael River, Utah.

Sandistone, grayish, thin bedded, locally has a greenish tint. In many places these strata are much contorted and the Feet. strata at the outcrop have a wavy appearance......... $50+$ Gypsum, fairly pure, becoming less pure at top and base---- 30-35 Sandstone, reddish, contains thin veins of gypsum

Gypsum, very pure

Sandstone, reddish, contains thin veins of gypsum_......... 5

Sandstone, thin bedded, greenish gray-_--_-_-_-_-_-_-_ 12-15

Total gypsum $37-42$

The route from Castle Dale to this locality is down Cottonwood Creek and San Rafael River. The trip is easily made on horseback, but for wagon or buggy the road is very poor.

A sample of gypsum taken near the center of the upper bench at this locality was analyzed by J. G. Fairchild in the chemical laboratory of the United States Geological Survey, with the following result:

Partial analysis of gypsum from east end of Fullers Bottom along San Rafael River, Utah.

Lime $(\mathrm{CaO})$

Sulphur trioxide $\left(\mathrm{SO}_{3}\right)$

45.63

Water driven off at $300^{\circ} \mathrm{C}$

20.54

Chlorine $(\mathrm{Cl})$

.32

Iron oxide $\left(\mathrm{Fe}_{2} \mathrm{O}_{3}\right)$.

Trace.

This analysis shows an equivalent of 97.3 per cent of gypsum. Practically no anhydrite is present. The percentages of lime, sulphur trioxide, and water given in the analysis approach very closely those of pure gypsum, which contains 32.6 per cent of lime, 46.5 per cent of sulphur trioxide, and 20.9 per cent of water. A striking characteristic of this gypsum is the unusually large amount of chlorine it contains, which is about 10 times greater than that in the gypsum from Alabaster, Mich. (See analysis, p. 29.)

\section{HORN SILVER GULCH.}

In Horn Silver Gulch (No. 3, Pl. XXXV), approximately 10 miles southeast of Ferron along the wagon road leading from Ferron to Green River Desert, the upper gypsum-bearing rocks are well exposed. The thickness of the only bed of gypsum noted in this immediate region was measured across an outcrop on the south side of the gulch. (See Pl. XXXIV, B.) As noted in the general discussion of the gypsum, this bed has a slightly reddish tint and is much thinner than the beds at the lower horizon. The following section shows the character of the overlying and underlying rocks as well as the thickness of the gypsum at this place. 
Section of Iypsum-bearing rocks in Horn Silver Gulch about 10 miles southeast of Ferron, Utah.

Feet.

Sand and clay, gray, fine grained; sandstone, conglomerate at top

Sandstone, yellowish gray to brown; upper $1 \frac{1}{2}$ feet very hard and forms a ledge

Gypsum, very slightly reddish, comparatively pure; contains nodules of variegated chert

Sandstone and sandy shale, in places ripple marked, thin bedded; some very resistant beds 2 to 3 feet; mainly reddish in color with a few thin bands and streaks of greenish-gray fine-grained sandstone (base unexposed)

A' sample of the gypsum near the center of the bed was analyzed by J. G. Fairchild in the chemical laboratory of the United States Geological Survey, as follows:

Analysis of gypsum from Horn Silver Gulch, 10 miles southeast of Ferron, Utah.

Lime $(\mathrm{CaO})$

Sulphur trioxide $\left(\mathrm{SO}_{3}\right)$

Water driven off at $300^{\circ}$

Chlorine (Cl)

Iron oxide $\left(\mathrm{Fe}_{2} \mathrm{O}_{3}\right)$
32. 49

45.88

$20.5 \mathrm{~S}$

Trace.

This analysis shows an equivalent of 97.9 per cent of gypsum. Practically no anhydrite is present. The chlorine content is slightly more than that of the sample collected at locality No. 2 along San Rafael River.

\section{COLD WASH.}

In Cold Wash (No. 4, Pl. XXXV and fig. 50), 20 miles east of Emery, gypsum which belongs to the lower horizon outcrops along the road from Ferron to the Green River Desert. A detailed section measured a short distance northwest of Dripping Spring, on the west side of Cold Wash, is as follows:

Section of gypsum-bearing rocks on Cold Wash about 20 miles east of Emery, Utah.

Feet.

Sandstone, thin bedded, grayish in places, tints of red and green

Gypsum $35+$

Sandstone, greenish gray, thin bedded $60 \pm$

Shale and sandstone, reddish, thin bedded 18

Sandstone, yellowish brown, thin bedded _._._._.

Sandstone, yellowish brown. massive

Sandstone, maroon and yellowish buff. thin bedded_........ 15

Total gypsum 
In many places it is impossible to obtain an accurate measurement of the gypsum on account of its soluble character, the ground waters having dissolved part of the bed. At the locality above-mentioned conditions were such that it was impossible to determine whether the total thickness of the gypsum was seen.

Dripping Spring issues from thin-bedded sandstone about 40 feet below the base of the gypsum bed and naturally it carries a great amount of gypsum. The water, which is cold, has a bitter taste that is emphasized when the water is heated. The bitterness possibly is due to the presence of epsomite, the sulphate of magnesium.

\section{COLT GULCH.}

About 8 miles east of Emery, in an intermittent stream course known locally as Colt Gulch (No. 5, Pl. XXXV), the following section of the upper gypsum-bearing rock was measured:

Section of gypsum-bearing rocks in Colt Gulch, about 8 miles east of Emery,
$: \quad$ Utah.

Ft. in.

- Conglomerate, glay, fine grained; pebbles consist of chert and limestone, ranging from sand grains up to pebbles $\mathbf{3}$ inches in diameter; contains a few lenses of soft firiable sandstone

Sandstone, gray

Gypsum, sandstone, and limestone, with some red, gray, and white sandy shale $-166$

Gypsum, pinkish, impure, and very shaly at base, fairly pure at top; contains chert fragments. (This portion of the bed probably corresponds with the section measured at locality No: 3 in Horn Silver Gulch)

Shale, salmon red, in places greenish gray

Gypsum, almost pure white._. 10

Shale, reddish, sandy______-_ 1

Gypsum, somewhat impure

Clay shale, sandy, salmon-red__. 11 .

Total gypsum 36

This section, which was measured on the south side of Colt Gulch, shows that there is much more gypsum here than in the section measured 8 or 10 miles to the northeast, in Horn Silver Gulch.

\section{MUDDY CREEK.}

On the west side of Salt Wash, north of Muddy Creek (No. 6, Pl. $\mathrm{XXXV),} 15$ miles southeast of Emery and 6 to 8 miles south-south- 
west of Colt Gulch, a detailed section of the upper gypsum rocks was measured as follows:

Section of gypsum-bearing rocks on the west side of Salt Wash, north of MLuddy Creek, about 15 miles southeast of Emery, Utah.

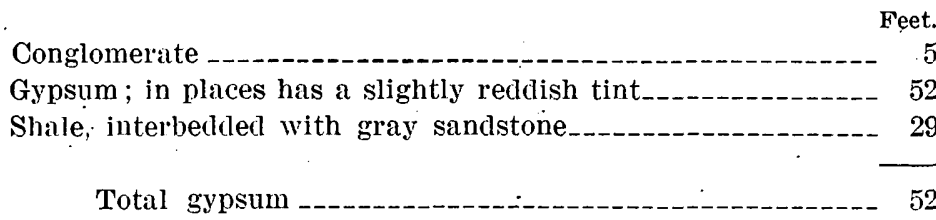

It is probable that the gypsum shown in this section may contain sandstone and shale partings, and portions of the bed may be somewhat impure, as the exposure was not good. The gypsum from this locality can be shipped with little difficulty, as an excellent road has been graded from Emery to a point a short distance east of the outcrop. At this locality the road, which follows an approximate dip slope of the strata, is on the gypsum for at least half a mile. Considerable deposits of quartz and gypsum sands cover the surface near the outcrop.

\section{IAST CHANCE CREEK.}

Very little is known regarding the details of the gypsum beds for a distance of 15 to 18 miles to the south from the locality last described. Sections of the gypsum were not measured, but the presence of the upper zone is assured by the "float" and the character of the water in Last Chance Creek where it is crossed by the wagon trail connecting Caineville and Emery, which is stratigraphically above the lower gypsum horizon. The water of this creek is so thoroughly saturated with gypsum and possibly some epsomite that it is practically unfit for the use of man or beast. A few miles south of Last Chance Creek, also known as Starvation Creek (No. 7, Pl. XXXV), a piece of gypsum "float" from the lower horizon was found near the Caineville-Emery wagon trail. The main bed was not seen, but the undulating, contorted character of the strata at this place suggested that as much gypsum lies a short distance beneath the surface as that measured at the exposure on San Rafael River (No. 2). A number of igneous sills and dikes were noted here and some of the pieces of gypsum suggest that it had been slightly metamorphosed by the heat from these intrusions.

\section{CAINEVILIE.}

About 3 miles northwest of Caineville post office, approximately in the center of T. 28 S., R. 8 E. Salt Lake meridian (No. 8, Pl. XXXV), the upper gypsum bed outcrops for 2 miles along the can- 
yon through which the Caineville-Emery wagon trail extends. The bed was not measured in detail but is approximately 8 feet thick and seemed to be very pure.

NOTOM.

Along the east flank of the Water Pocket Flexure, near the north side of T. 30 S., R. 7.E. Salt Lake meridian, about 2 miles west of Notom post office (No. 9, Pl. XXXV), a bed of gypsum undoubtedly representing the lower horizon is exposed near the wagon road extending from Fruita to Notom. This outcrop, the exact thickness of which was not measured, is about 75 feet stratigraphically above the massive cross-bedded sandstone to which Gilbert applied the name Gray Cliff. Although the horizon of the upper gypsum bed was crossed in the vicinity of Notom it was not seen at any place. It is probably present, however, as it outcrops a few miles to the north in the vicinity of Caineville.

\section{OTHER EXPOSURES.}

Along the road leading from Emery eastward to the Globe Copper mine both gypsum horizons were noted. The upper or pinkish bed has apparently the same thickness as that noted in Horn Silver Gulch. It was impossible to obtain a measurement of the lower bed, as it outcrops on an approximate dip slope for a distance of more than a mile. Gypsum deposits were not observed elsewhere along the west flank of the Swell, but the writer believes that the beds of both horizons are continuous from the north to the south end of the Swell and that they may some day be valuable should transportation become less expensive.

\section{CHARACTER OF THE GYPSUM.}

The gypsum of both horizons is comparatively pure. The lower bed, however, probably contains less impurity than the upper. The upper bed, in addition to the slight discoloration, contains numerous small chert nodules of various colors. These undoubtedly would cause some difficulty in the preparation of the gypsum for plaster of Paris. The lower deposits contain very little chert and are almost white. From these deposits gypsum which would make white plaster could probably be obtained. Certain portions of the upper pinkish bed, which is compact and fine grained, might be used as alabaster, giving a varied effect from the pure white. The lower bed could also be used in this way, as it is apparently as solid as the upper bed. The two analyses of samples taken in this area, together with the analyses of gypsum from other localities in the United States are given in the table on page 29. 
DEVELOPNENT.

Gypsum is not yet being mined in the San Rafael Swell. Except at the prospects south of Cedar Mountain or Red Plateau, the gypsum of this district has not been prospected. On account of the excellent natural exposures, however, prospecting is unnecessary, as in most places the entire thickness of the beds is well exposed. It is possible that small quantities of gypsum have been used by ranchers and others desiring plaster of Paris or land plaster, but the quantity removed from the field is insignificant. From the description given it is evident that the San Rafael Swell contains an enormous supply of gypsum, but probably no great quantity will be mined until better transportation facilities are available. It would be a comparatively easy matter to extend a railroad spur from either Green River or Price to these gypsum-bearing rocks. A railroad grade has been made through the northerm part of the San Rafael region connecting Green River'with Price; and although the road has never been used, it could be repaired with little labor and expense. As this grade crosses the gypsum beds in T. 19 S., R. 10 E., and as the gypsumbearing rocks occupy a monoclinal valley, a railroad spur eould be very easily projected through the center of the gypsum belt for its entire length. The raw product then could be mined and transported cheaply. Such a railroad would probably induce coal mining in the Cretaceous beds east and south of Emery along Muddy Creek and its tributaries.

Gypsum of the massive variety has a specific gravity of approximately 2.32. This is equivalent to about 145 pounds to the cubic foot. The following estimates are based on the considerations that the gypsum could be mined under cover to a distance of 2 miles from the outcrop; which, with the dip of $3^{\circ}$ to $5^{\circ}$, would carry the bed about 800 feet below the surface, and that the gypsum-bearing bedis are 60 miles in length on the west flank of the Swell. To be conservative, the upper bed is assumed to average 10 feet in thickness, and the lower beds to contain an average of 30 feet of gypsum. These assumed thicknesses probably represent 25 to 50 per cent less than the true average. On this basis the beds of gypsum on the west flank of the San Rafael Swell are estimated to contain $9,701,600,000$ tons $-2,425,400,000$ tons in the upper bed and 7,276,200,000 tons in the lower bed. 


\section{VIRGINIA.}

By G. W. STose.

\section{IOCATION.}

Large deposits of gypsum and salt occur in a district 20 miles long, extending northeastward from the village of Plasterco, Va., and lying in Washington and Smyth counties. Much of it is in or near the valley of North Fork of Holston River, and is accessible to railroad transportation by the Saltville branch of the Norfolk \& Western Railway, which joins the main line at Glade

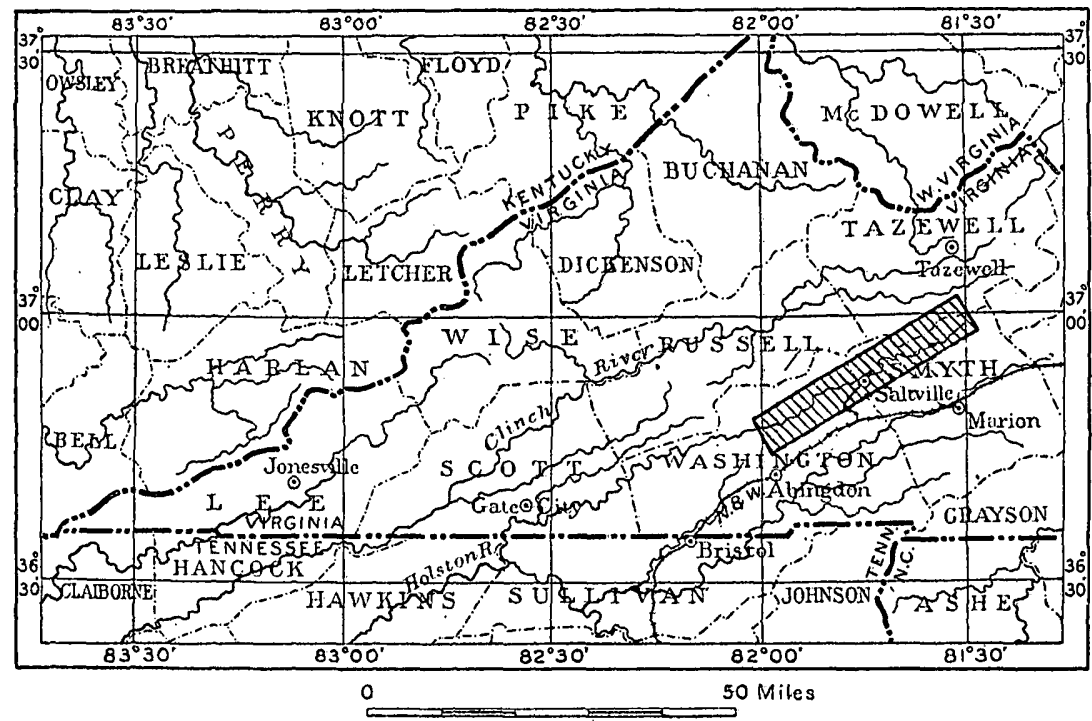

Fiave 54.-Index map of southwestern Virginla. The area described and mapped in this report is indicated by the shaded rectangle. Railroad connections for this arca only are shown.

Spring. The location of this area is shown in figure 54. The location of two gypsum plants now in operation and of several gypsum workings and prospects some of which at present are not commercially workable because of lack of transportation facilities, are shown on the geologic map in figure 55 .

\section{TOPOGRAPHY.}

The area represented on the map (fig. 55) comprises a mountain ridge 1,000 feet high, separating parallel valleys and rising above an adjacent deeply dissected plateau. The ridge, named Pine Mountain at the southwest and Brushy Mountain at the northeast, trends 


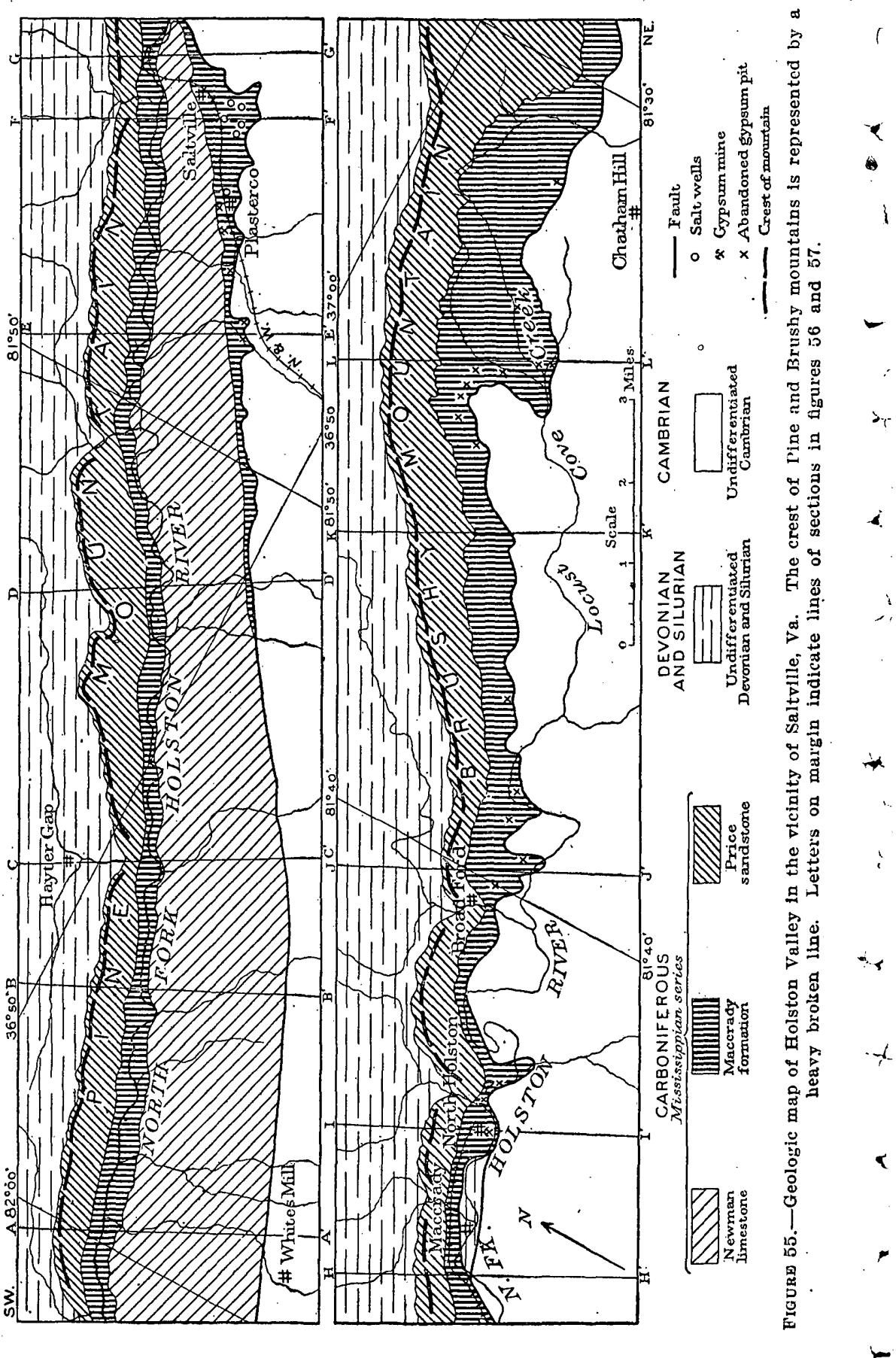


in general N. $70^{\circ} \mathrm{E}$, and its elevation ranges from 2,500 to 3,000 feet. It is cut nearly at right angles by several deep water gaps through which pass the waters from Clinch Mountain that drain into North Fork of Holston River, which flows southwestward. The plateau to the southeast ranges from 2,000 to 2,500 feet in altitude, and its surface is dissected into narrow transverse ridges and rounded hills.

\section{GEOLOGY.}

THE $\cdot$ ROCKS.

The rocks in which the gypsum occurs are of Milssissippian (lower Carboniferous) age. A generalized section of the Carboniferous rocks derived from several detailed sections in the vicinity of the mines is as follows:

Generalized scction of Carboniferous rocks in the vicinity of Saltville, $V a$.

Newmatn limestone:

Hard argillaceous limestone weathering to calcareous shale, including a few beds of crystalline limestone

Feet.

Red calcareous sandstone and coarse crinoidal $400+$ limestone, and $a$ few beds of argillaceous limestoné

Iight-blue laminated argillaceous limestone and calcareous shale, and a few thicker, purer, fossiliferous limestones

Massive gray and blue fossiliferous limestone, in part granular and crystalline, and containing some chert.

Maccrady formation:

Earthy limestone and dark-gray shale, weathering light gray to green and crumbly, abundantly fossiliferous

Grily calcareous sindstone and some shaly argillaceous or earthy limestone; harder fossiliferous simdstone at the top

Largely soft rocks, including shaly limestone and earthy sandstone, mostly concealed; apparently represented in places by red, green, and blue plastic clay, gypsum, and salt beds

Red sandy stale and red and gray shaly sandstone and in lower part soft light-buff shale, and thin black carbonaceous shale containing coal seamlets and plant remains 
Price sandstone:

Hard, irregular-bedded, rusty-gray sandstone, with Feet.

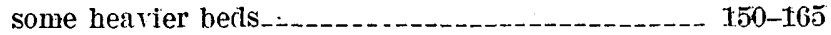

Iargely shaly sandstone, with a few harder bedis_-- 150-205

Massive gray to reddish-gray sandstone, thin-bedded

toward top, and fine conglomerate with scattered.

white quartz pebbles generally at base

$\frac{30-55}{380-425}$

Devonian rocks :

Thin-bedded sandstone and sandy shale conraining brachiopods of Chemung age, 536 feet.

Platy sandstone and slaty shale.

The Price sandstone is a hard, ridge-making rock which forms the ridge known as Pine Mountain and Brushy Mountain. The Maccrady formation consists of soft and easily disintegrated material that is generally deeply eroded and poorly exposed and therefore forms valleys. The best exposures of this formation occur in the valley of North Fork of Holston River from Maccrady southwest, although they are there largely covered by the terrace and floodplain deposits of that stream. The black shale and red sandy beds at the base are commonly exposed on the lower slopes of Pine Mountain, but the higher earthy limestones and shales of the formation are to be seen in few places. Northeast of Maccrady and southwest of Saltville red and olive to bluish plastic elays with gypsum occur in the midst of the Maccrady formation. The exact position in the formation of this clay and gypsum has not been fully established, because in the broad flats where the gypsum occurs only soft clay is seen and no key rocks outcrop. However, the gypsum seems to replace the middle earthy shales and sandstones, for to the northeast it lies above the lower red siliceous beds of the-formation, 120 feet or more thick, and at Saltville it lies below the sandstone that is 125 feet from the top.

The Newman limestone, although massive at the base, is composed largely of calcareous shales which weather readily to clay and soil. The formation forms high rounded hills.

The distribution of the rock is shown on the map (fig. 55).

\section{STRUCTURE.}

The rocks of the southeast side of the area shown on the map are part of a great mass of Cambrian dolomite and limestone which was thrust over the Carboniferous rocks on the northwest along a flat fault plane, as shown in the structure sections; (figs. 56 and 57). The Cambrian strata dip rather uniformly $30^{\circ}$ to $40^{\circ}$ SE., 

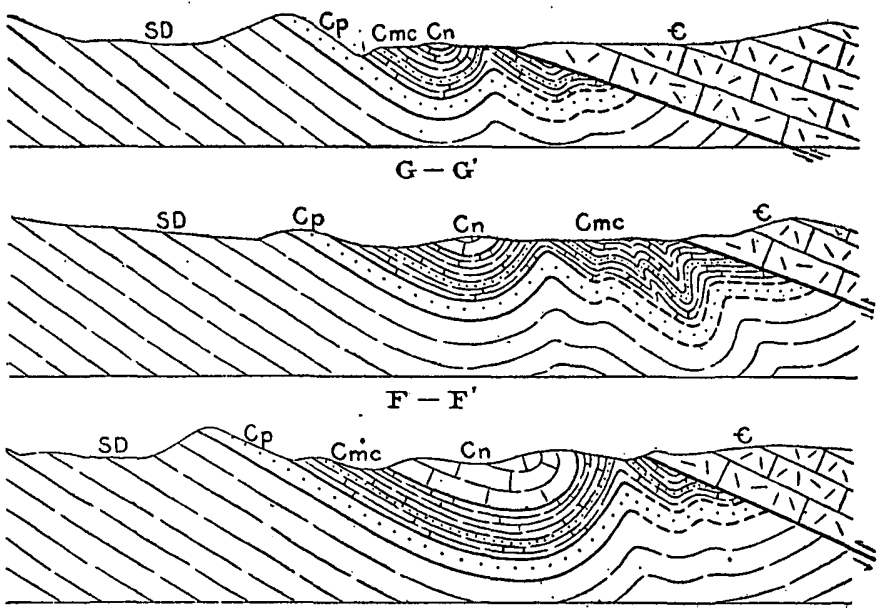

$\mathbf{E}-\mathbf{E}^{\prime}$
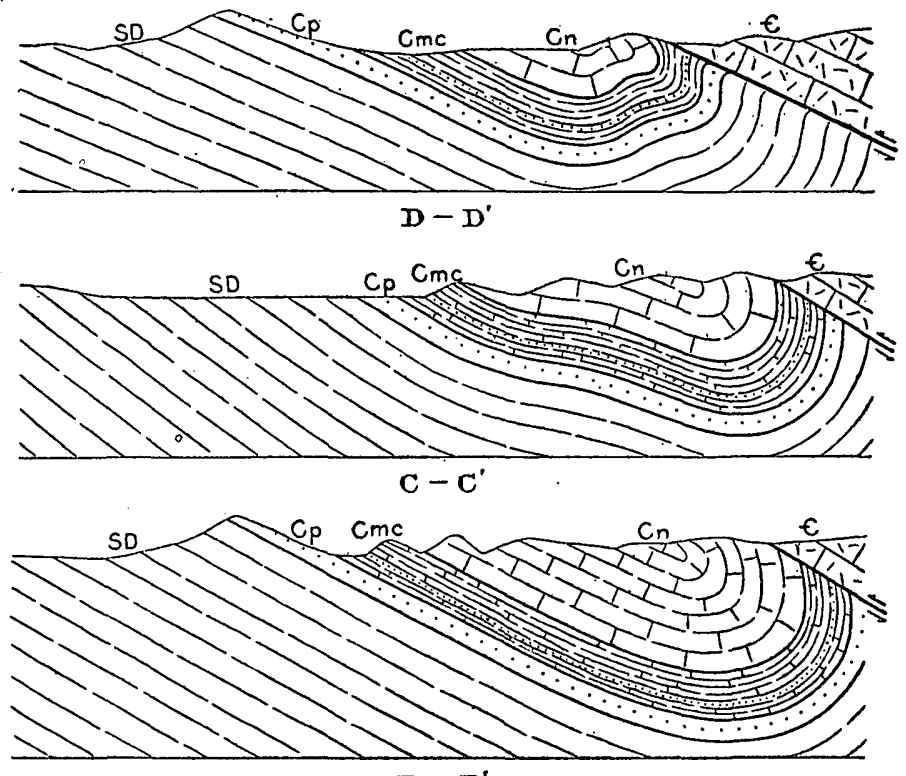

$\mathbf{B}-\mathbf{B}^{\prime}$

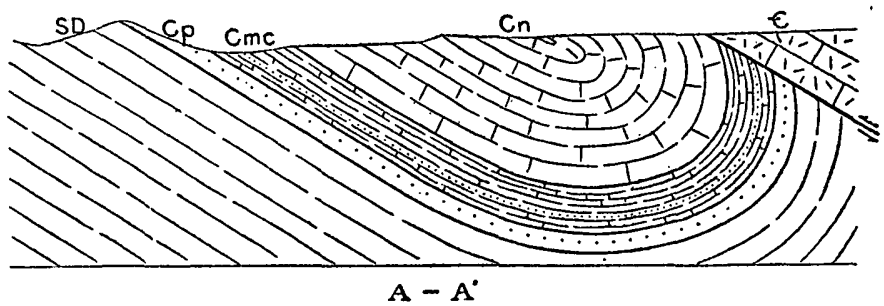

Figune 56.-Structure sections across Holston Valley, Va., along lines indicated by letters on the margins of geologic map (flg. 55). Cn, Newman limestone; Cmc, Mriccrady formation' $\mathrm{Cp}$, Price sandstone; $\mathrm{SD}$, undifferentiated Silurian and Devonian rocks; $€$, undifferentiated Cambrian rocks, mostly dolomite. Scale, double the scale of figure 55 . 
successively older Cambrian strata appearing at the northwest. Massive gray dolomite and magnesian limestone of Cambrian age is adjacent to the fault throughout most of its course in the mapped area. A still lower Cambrian formation of red argillaceous shale and sandstone is exposed over part of the area northeast of Broad Ford, apparently on the axis of an overturned anticline, the breaking of which may have commenced the overthrust faulting.

The rocks northwest of the fault, except those immediately adjacent to it, dip uniformly $25^{\circ}-40^{\circ} \mathrm{SE}$, and range from Carboniferous at the fault to lowest Silurian in Clinch Mountain, north-
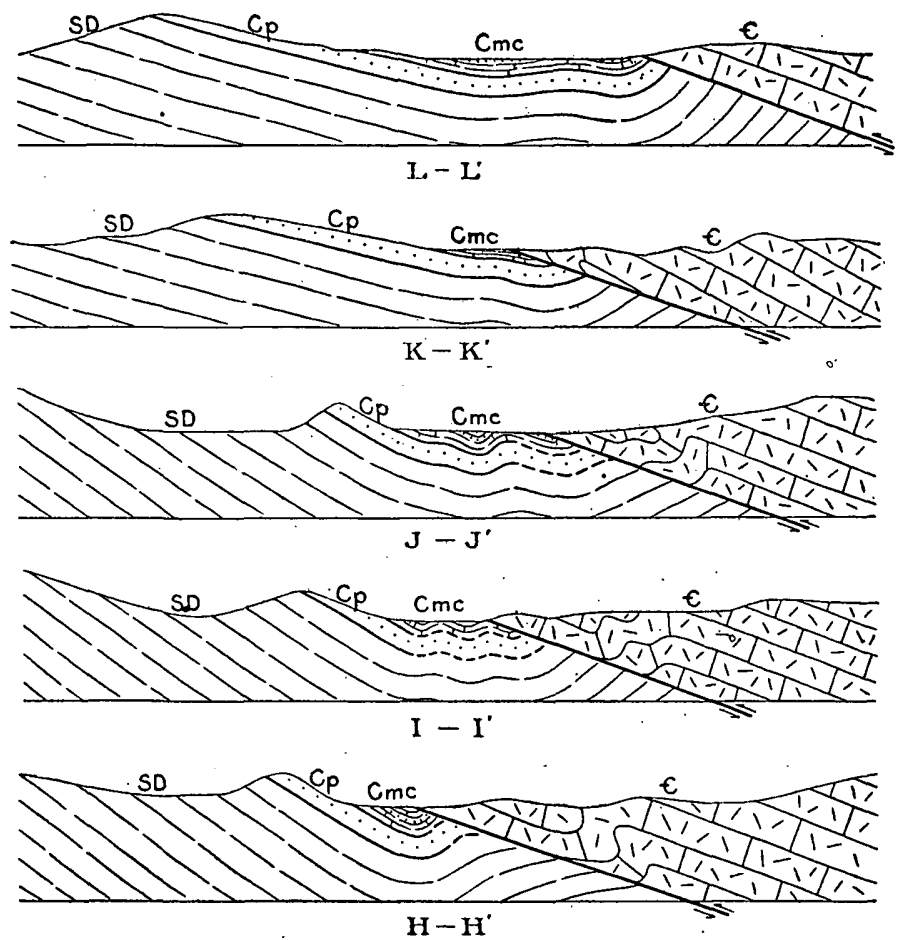

Ficiure 57.-Structure sections across Holston Valley, Va., along lines indicated by letters on the margins of the geologic map (fig. 55). Cn, Newman limestone; Cmc, Maccrady formation; Cp, Price sandstone; SD, undifferentiated Silurian and Devonian rocks; $€$, undifferentiated Cambrian rocks, mostly dolomite. Scale; double the scale of figure $\mathbf{5 5}$.

west of the area mapped. The soft Carboniferous rocks near the fault are bent into an overturned syncline. The sections in figures 56 and 57 show that the beds in the syncline gradually rise and the fold flattens and shallows from southwest to northeast. The Newman limestone, which has a thickness of about 2,000 feet in the most southern section, is gradually reduced in thickness by erosion in the shallowing syncline until northeast of Saltville it is entirely removed. The soft Maccrady formation which underlies the 
Newman outcrops along the southeast side of the syncline for only a few miles in the vicinity of Saltville and Plasterco, being faulted out in the southwestern part of the area. The observed dips on the south side of the syncline are mostly vertical.

The fault plane is exposed at several places in the area, dipping at angles ranging from $20^{\circ}$ to $60^{\circ} \mathrm{SE}$. The trace of the fault plane on the surface is very crooked in the northeastern part of the area, owing to the fact that the plane probably has a low southeast dip and is somewhat folded along the strike, so that erosion to the surface level has produced promontories of the overthrust rock at the downfolds and reentrants at the upfolds.

This fault is not a local or minor fault, for it has been traced southwestward in the Appalachians into the Rome fault, which has been proved to have a horizontal displacement of at least 5 miles in the vicinity of Rome, Ga.

It is concluded from a broad study of the structure that this fault of great magnitude and length did not originate in a broken fold but is of deeper-seated origin and is a shear plane that cuts diagonally across the strata to a great depth, the beds locally at the contact, however, being folded and crumpled by the friction and drag of the overriding mass. Thus the overridden Carboniferous beds on the northwest are bent into an overturned syncline from Saltville southwest and the overriding Cambrian beds on the southeast show an anticlinal structure in places.

\section{ORIGIN OF THE DEPOSITS.}

Explanations of the origin of these gypsum deposits published by W. B. Rogers, J. J. Stevenson, and E. C. Eckel were given by the author elsewhere, ${ }^{1}$ together with his own interpretation of the origin, which may be summed up as follows: The gypsum deposits of southwestern Virginia were probably derived from calcareous-argillaceous sediments which originally contained disseminated gypsum that was precipitated by the partial evaporation of sea water in a temporarily inclosed arm of the sea. The gypsum has since been concentrated in favorable layers in the same formation by underground waters which circulated chiefly along the fault contact between the Carboniferous and Cambrian rocks, dissolved the calcium carbonate from the adjacent earthy limestones, and segregated the gypsum in the more gypsiferous beds by chemical selection. Such transportation and concentration of gypsum are known to have taken place on a small scale in the satin spar veins in the adjacent clay, and

1 Stose, G. W., Geology of the salt and gypsum deposits of southwestern Virginia: U. S. Geol. Survey Bull. 530, pp. 232-255, 1913; Virginia Geol. Survey Bull. 8, pp. 51-73, 1913.

$124567^{\circ}-20-19$ 
the "domes:" of salt and gypsum in the Gulf States, if correctly interpreted by Harris and others, are examples of the process on a gigantic seale.

This conclusion seemed warranted because the gypsum deposits have so far been found only in soft shales of the Maccrady formation adjacent to the fault and descending southeastivard beneath the fault plane... Under this hypothesis the black rock in the gypsum is regarded not as a sedimentary layer but as the segregated insoluble impurities of the original deposit concentrated in ai concretionary ball-like form during the purification of the gypsum by recrystallization, and the alternating bands of pure and impure gypsum surrounding these rounded masses would represent a stage in the process of purification by this method. The thick layers of pure gypsum in the gypsum mines would be regarded not as original deposits of pure gypsum but as more or less gypsiferous beds that have been purified by the removal of lime by solution and of argillaceous matter by its concentration in the concretionary balls, and by the addition of gypsum derived from the disseminated particles in adjacent beds.

An alternative explanation of the origin of gypsum that will also account for the close association of the gypsum beds with the fault plane is that conditions favorable to the deposition of gypsum increased toward the southeast; that while marine conditions accompanied by deposition of fossiliferous limestone and clay prevailed on the northwest side of the area which is now the Saltville syncline, represented by the barren Maccrady formation along North Fork of Holston River southwest of Saltville, the southeast side of this area was occupied by an estuary or lagoon partly inclosed by a barrier and in this lagoon gypsum and red clay were being deposited, represented by the gypsum deposits southwest and northeast of Saltville. Under this hypothesis the western edge of the gypsum deposits is just being exposed, and the gypsum will be found to extend southeastward beneath the overthrust Cambrian dolomites, just as under the hypothesis of concentration along the fault zone. The thick beds of pure gypsum would thus be original deposits in which beds of argillaceous sediments had been so closely infolded that they appear as balls of black rock surrounded by bands of impure gypsum, the banding representing original sedimentation. The chief objection to this hypothesis is the abruptness of the change from thick marine sediments to equally thick nonmarine sediments, as displayed at Saltville and Maccrady, but this objection can be orercome by the assumption of extensive enrichment of the gypsum and salt beds by secondary concentration by circulating waters. A generalized record of one of the typical wells of the Mathieson Alkali Co. at Saltville is as follows: 
Generalized section of a well at Saltville, Va.

\begin{tabular}{|c|c|c|}
\hline & Thickness. & Depth. \\
\hline 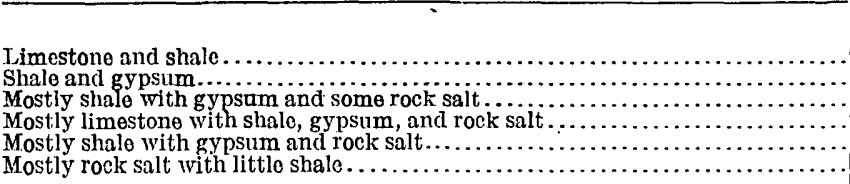 & \begin{tabular}{r|} 
Feet. \\
26 \\
195 \\
359 \\
215 \\
100 \\
197
\end{tabular} & $\begin{array}{r}\text { Feet. } \\
20 \\
221 \\
580 \\
795 \\
895 \\
1,092\end{array}$ \\
\hline
\end{tabular}

The section at the river cliff southwest of Maccrady is as follows:

Section of Maccrady formation rest of Maccrady, Fa.

Dark impure massive limestone (Newman).

- Feet.

Dark-gray to green crumbly fossiliferous shale and earthy gray limestones (upper part concealed)

Alternate thick earthy limestone, calcareous shale, and thin crystalline fossiliferous limestones

Massive-bedded bluish tough calcareous and argillaceous sandstone with fossiliferous calcareous layers___-_._-_._ 25

Gray sandstone, weathering brown-_-_-_-_-_-_-_-_-_- 5

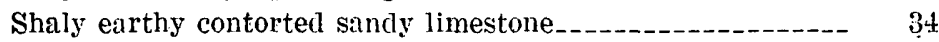

Hard thick-bedded bluish calcareous sandstone_-_._.-.-_-_ $\quad 20$

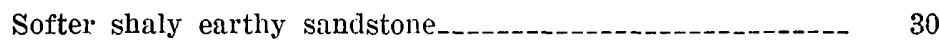

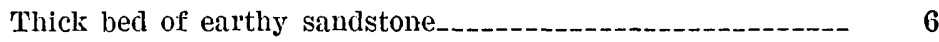

Hard impure limestone, with chert nodules

Thick soft earthy sandstone

Shaly earthy limestone

Thick-bedrded to shaly earthy sandstone-_-_-_-_-_-_-_-_---- 45

Covered, probably shaly earthy limestone and soft earthy sandstone

Covered, probably red siliceous shale at top (seen elsewhere) $\quad 26$

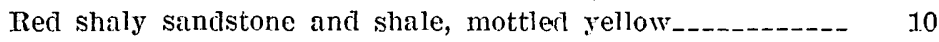

Red shale in part, rest covered

Red shaly sandstone, mottled yellow_-_-_-_-_-_-_-_-_-_-_ $\quad 7$

Shaly gray sandstone, with phosphatic fish plates.-.--_-_-- $\quad 10$

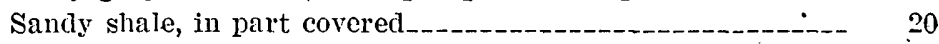

Soft shale, light buff to dark drab; light-gray fire clay with rootlets, leaves, and twigs at base_-_-_-_-_-_-_-_-_- 20

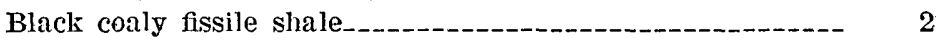

Slabby blue even-grained irregular-bedded sandstone, weather-
ing buff (top of Price sandstone).

It is not reasonable to believe that while several hundred feet of marine sediments were accumulating near Maccrady, nonmarine conditions prevailed a mile away, around Saltrille, where hundreds of feet of clay, gypsum, and salt were deposited. It is possible that a minor thrust fault cuts the section at a small ravine just southwest of Maccrady and passes southwestward along the belt of the Maccrady: formation, whereby the gypsum-bearing beds and the marine beds 
of the Maccrady formation, once much farther apart, were brought close together. The thickness and sequence of the middle portion of the Maccrady formation given in the preceding section would therefore be incorrect. The abrupt change in character of beds is more reasonably explained by assuming secondary concentration of the salt and gypsum.

\section{GYPSUIM INDUSTRY.}

EARLIER DEVELOPMENT.

In 1835 Rogers mentioned the great possibilities of this gypsum deposit as a source of fertilizer for the agricultural lands of Virginia. In 1836 he described these deposits as great detached masses of gypsum distributed along the Holston River belt for 40 miles. He reported that an almost solid mass of gypsum 25 feet deep, 50 feet long, and 15 feet wide was opened at McCall's quarry (probably one of the pits on the Robertson place), borings indicating that it ex-. tended to a depth of 100 feet, and stated that small openings had been made in the extensive exposures at the Buchanan banks in Walker Valley (Locust Cove), which indicated a great abundance of gypsum there.

Stevenson in 1885 reported extensive mining on the Robertson tract at the southwest end of the Saltville Valley, where some large masses close to the surface had at that time been worked out. $\mathrm{He}$ also reported that plaster had been dug for five years to a depth of 60 feet at Pierson's and under the limestone bluff south of the river on the Miller farm (at North Holston), in a deep shaft in the river bottom on the Taylor farm, and in a shaft north of the road on the same property ( 2 miles east of Broad Ford); and that extensive mining had been done by open pits and shafts on the Buchanan property, on Cove Creek, and in the small adjacent valley 3 miles west of Chatham.

Old caved-in pits where gypsum or "plaster," as it is commonly called, was mined from the surface in earlier days, are scattered along the belt of lowland from a point a mile west of Plasterco to the vicinity of Chatham Hill. Near Plasterco large pits, abandoned shafts, and caved-in ground mark the place where the Buena Vista Plaster Co. and the Robertsons formerly mined the gypsum and removed much of the available material close to the surface. Smaller openings were made by the same operators in the embayment about 1 mile to the southwest, but the deposits there have been only slightly explored. This tract is owned by the Buena Vista Plaster Co. and is at present leased to the United States Gypsum Co. In the broad flat at Saltville, where salt is extracted by the Mathieson Alkali Co., thick deposits of gypsum are reported in all the wells drilled for salt, and 
some beds at the surface were formerly mined for the manufacture of a kind of cement. The tract is owned by the Mathieson Alkali Co., which extracts brine but does not at present mine the gypsum.

At North Holston and in the embayment to the east several old gypsum pits on the Pierson and Miller farms were formerly worked for plaster but are now nearly obliterated. Several old pits are still visible near Broad Ford, most of them in the broad embayment to the east. One in the river bank on the Taylor farm, about a mile east of Broad Ford, still exposes gypsiferous shales beneath over-. thrust Cambrian dolomite. There are other pits on the Taylor farm and the adjacent Barnes place among the low hills north of the river. A large deposit was there opened by shaft and drifts but has long been abandoned and the workings filled with water.

Northeast of the Taylor farm the outcropping rocks continue to appear favorable for the occurrence of gypsum, but the exposed area of the Maccrady formation, which carries the gypsum, is narrow, and gypsum is not known to occur in quantity in the next 3 miles. Beyond to the northeast, however, on the Buchanan property, extensive deposits occur and were mined on a large scale. The gypsum was crushed in a mill on the property, which was in operation about 1907. The smaller pits have caved in, but some of the larger pits are full of water and are reported to be very deep. The embayment widens at this point and numerous pits are scattered over Locust Cove Creek bottom and adjacent small valleys. Several pits were worked north of Chatham Hill, and the crucle gypsum was crushed in a water-power mill on the river at Chatham Hill.

\section{PRESENT OPERATING MINES.}

Two gypsum companies are operating in the area at the present time. The United States Gypsum Co.; with offices in Chicago, has leased the Robertson tract from the Buena Vista Plaster Co. since 1909. This tract adjoins on the southwest the Mathieson Alkali Co.'s property at Saltville. The plant is located at Plasterco, in the narrow southwestward extension of the broad flat at Saltville. The workings are reached by two main shafts, which are reported to be over 200 feet deep. The two sets of workings seem to be in distinct bodies of gypsum. A third abandoned shaft leads to another mass of the deposit, and other isolated bodies have been located by drilling over the bottom land. Large shallow deposits of gypsum on the eastern edge of the tract directly adjoining the Mathieson property were previously worked out by surface openings and shallow drifts by the owners.

The gypsum in this mine seems to be in partly or wholly detached masses, some of great size, and not in continuous beds. The gypsum 
is mostly a white to gray granocrystalline rock inclosed in clay, the gray variety being streaked with fine dark argillaceous material. In the material on the dump of one of the abandoned shafts numerous small anhydrite crystals are scattered through the gypsum. The gypsum is brought to the surface by elevators and conveyed by tram cars to the mill, where it is roasted and pulverized for wall plaster and other purposes. Plaster bricks, tiles, and hollow blocks are also manufactured.

The Southern Gypsum Co.'s plant and office, which are at North Holston, are reached by the company's branch railroad from Saltville. The mine is located at an embayment of the lowland similar to that at Saltville, though not so large. The shaft to the mine in the lowland is connected by an aerial bucket tram with the main roasting and grinding plant at the railroad on the hillside to the north, where wall plaster and finishing plaster are made from the purer lump gypsum. A part of the crude product is ground directly at the lower mill near the shaft for Iand plaster, much of the gypsiferous clay being of the right mixture to be used in this way.

The bulk of the gypsum is granular and crystalline (see Pl. XXXIII, $B$, p. 264), like that at the United States Gypsum Co.'s plant. Some large sheets of selenite have been encountered, and small veinlets of satin spar are common in the associated clay. Some masses of anhydrite occur in the gypsum in the deeper workings. Some of the gypsum is finely banded with dark gypsum and in places fine dark argillaceous layers surround and merge into large rounded masses of black argillaceous material called "black rock." The banding of the gypsum suggests original bedding of the sediments, but some of it may have a different interpretation. (See p. 290.) The extent, thickness, and purity of the gypsum have been, carefully determined by numerous borings over the river bottom in the embayment, and it has been demonstrated by the company that the gypsum here occurs in thick beds of wide extent, although they vary greatly in thickness, being apparently lenticular.

The gypsum was formerly mined for land plaster in open cuts at outcrops along the river. It is now mined from a shaft in the bottom land from which run several levels along the strike of the beds and inclines down the dip toward the southeast to a maximum depth of 200 feet. Rooms 100 feet across and 50 feet high have been stoped out; large gypsum pillars are left to support the roof. 


\section{WYOMING.}

By R. W. Strone.

\section{CHARACTER AND EXTENT.}

'The workable gypsum deposits in Wyoming are confined to the Chugwater, Embar, and Spearfish formations ("Red Beds"). The Chugwater formation, the greater part of which is apparently represented by the Spearfish formation in the Black Hills, is presumably for the most part of Triassic age, although in some areas it includes beds of Permian and Pennsylvanian age. It is 600 to 1,600 feet thick and consists of soft massive red fine-grained sandstones, merging into red shales, and including extensive gypsum deposits and a few thin limestone beds. The formation as a whole is brilliant red, which renders it a conspicuous feature in most portions of the outcrop area. The gypsum beds lie from 15 to 120 feet below the top of the formation and near the bottom. The Chugwater in part overlies and in part is contemporaneous with and grades horizontally into the marine Embar formation. The Embar formation, which ranges in age from Pennsylvanian to early Triassic, consists of beds of gray, greenish, and yellowish shale, gypseous shale, and shaly limestone, including near their middle a persistent layer of nodular chert. The Embar rests on the Tensleep sandstone and is in part overlain and in part replaced by the lower red beds of the Chugwater formation. Where shaly its soft character, like that of the Chugwater formation, is commonly expressed by a valley.

The red beds (Chugwater formation), which are one of the most conspicuous geologic'features in the Rocky Mountain region, outcrop along the base of most of the mountain ranges in Wyoming and are exposed as the core of a number of secondary folds. The total length cf outcrop in the State in which there are one or more beds of gypsum over 4 feet thick is over 800 miles. Beds of gypsum 10 to 20 feet thick are common, and beds 30,40, and some even 60 feet thick extend for miles.

Gypsite occurs in a number of localities, particularly in the southern part of Albany County. This impure gypsum, or gypsum earth, is a secondary surficial deposit, usually occurring in depressions below rock gypsum. It is rarely more than a few acres in extent and as a rule is not more than 15 'feet thick. 
The outcrops of red beds known to be gypsum bearing are shown on the map (Pl. XXXVI), which was compiled by L. W. Trumbull, former State geologist of Wyoming.

\section{ECONOMIC DEVELOPMENT.}

Gypsum was first developed in Wyoming about 1890, at Red Buttes, on the Union Pacific Railroad, 9 miles south of Laramie. A small plant for the manufacture of plaster of Paris and wall plaster was erected, and this has since been in operation. The mill is located near the quarry. Below a thin cover of surface material there is a pure, almost white deposit of rock gypsum, which is worked to a depth of 15 feet. This depth, however, does not represent the entire thickness of gypsum.

Just south of the town of Laramie a very large bed of gypsite was discovered about 1895. A Kansas company purchased the ground. and erected a large plant, in 1896, which, after operating a few years, was then taken over by another company. This mill and another at the same place were making wall plaster from gypsite at Laramie in 1918.

The deposit at Laramie is covered with about a foot of soil, which is removed by means of plows and scrapers. Next below the overburden there is 9 feet of gypsite that is free from extraneous matter. It is plowed, taken up in wheeled scrapers, and hauled to the storehouse of the mill. The material as delivered by the scrapers is so pulverulent that it is cooked without being ground.

At Basin, Big Horn County, a small mill has been operating for several years on rock gypsum quarried on the Chicago, Burlington $\&$ Quincy Railroad 8 miles north of Greybull. The deposit here is massive gypsum with a few red shale layers which are discarded by hand picking after shooting off the solid. The rock is taken by rail to Basin, where it is broken in a gyratory crusher, pulverized between French burrstones, and calcined over a coal fire. Coal has. proved more economical than natural gas from wells in the vicinity.

A large part of the plaster made at Basin is molded into building blocks for exterior use. The appearance of buildings made of these blocks is pleasing, and the weather seems to have no bad effect on them. Blocks that have been in walls exposed to the weather for $\tau$ years show no checking. This is due to the aridity of the climate, the annual precipitation in this valley being only 5 inches, most of which falls during the warm months.

In a country where wood for building purposes is scarce the inexpensive plaster blocks can be sold. The mill at Basin supplies only the local market. 


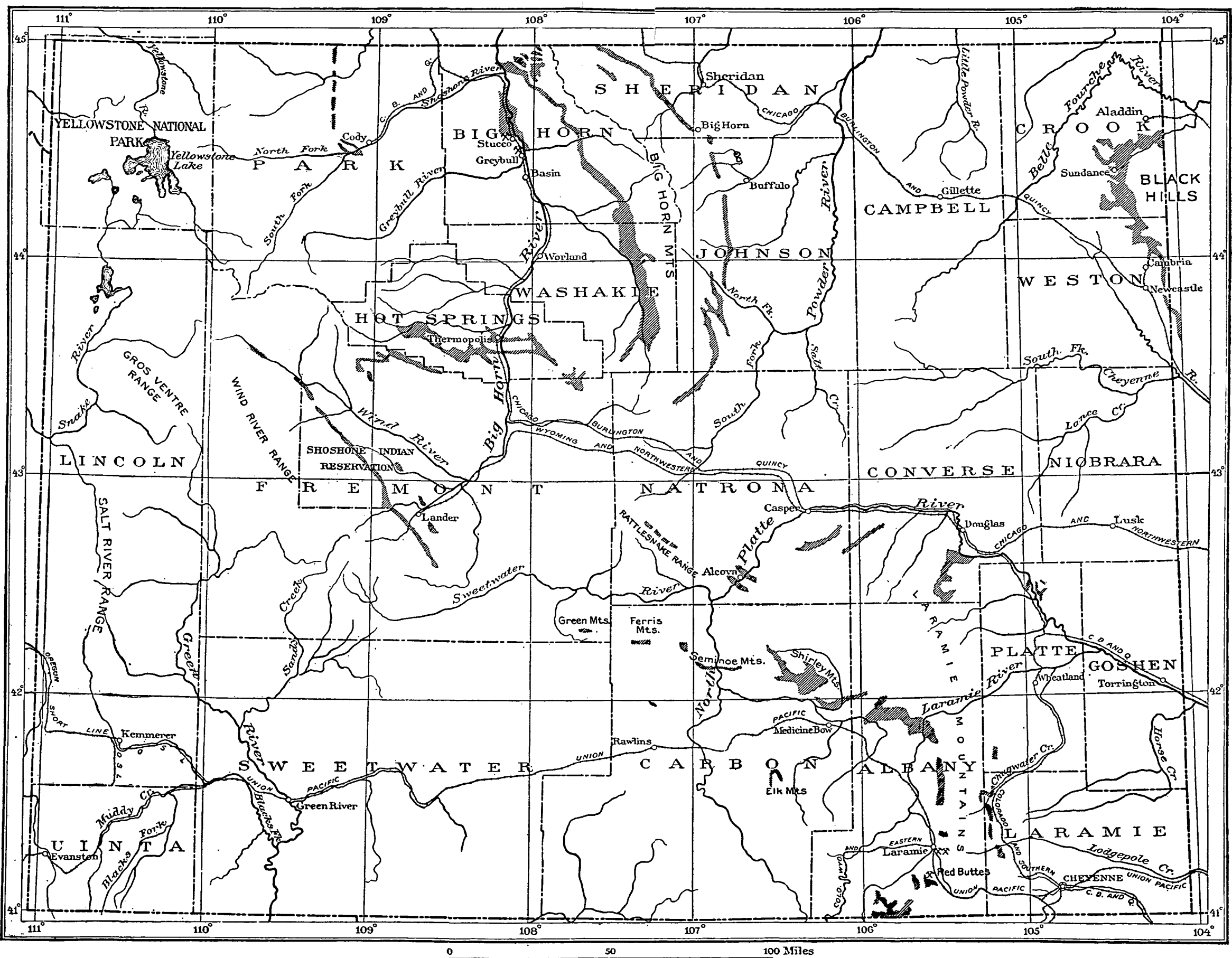

MAP OF WYOMING SHOWING AREAS KNOWN TO CONTAIN GYPSUM.

Shading indicates gypsum areas. Pick and hammer symbols indicates gypsum quarries. 
A small quantity of gypsum was quarried and calcined at Greybull in 1915 and made into building blocks, and in 1916 a new mill at Stucco, a few miles north of Greybull, began calcining local gypsum.

At Dayton, 16 miles west of Sheridan, a quarry has been opened and also one at Alcova, but these localities are too far from the railroads at present to warrant the erection of plants, except to supply the local demand.

The gypsum beds in Wyoming are so numerous and of such extent and purity that with proper facilities for transportation an enormous industry could be supplied.

\section{LOCALITIES.}

The following description of localities is compiled from the writings of N. H. Darton, C. A. Fisher, C. E. Jamison, C. T. Lupton, D. D. Condit, G. B. Richardson, C. E. Siebenthal, and L. W. Trumbull. Acknowledgment of the writer's indebtedness to these geologists is here made, and specific references to their work will be found in the following pages. The description begins with the gypsum in the Black Hills, follows the deposits in order across the northern part of the State, and thence southeast across the center of the State to the Colorado boundary.

\section{BLACK HILLS. 1}

Gypsum is abundant in the broad belt of red beds (in this area known as the Spearfish formation) encircling the Black Hills. The deposits on the east side of the Black Hills are described uncler the gypsum deposits in South Dakota (pp. 242-243).

East of Newcastle there are thick beds of gypsum in the lower portion of the Spearfish formation and a thick deposit at its top, which extends over a large area. The lower beds are 40 feet thick at some localities, and the upper bed is 30 feet thick. Extensive exposures of gypsum are found 5 miles southeast of Newcastle, a short distance northeast of the L A K ranch, in the middle of the formation, and gypsum beds underlie part of the alluvium in the valley of Stockade Beaver Creek for several miles north of the L A K ranch.

1 Darton, N. F., Preliminary description of the geology and water resources of the southern half of the Black Fills and adjoining regions in South Dakota and Wyoming: U. S. Geol. Survey Twenty-first Ann. Rept., pt. 4, p. 518, 1901. Geology and water resources of the northern portion of the Black Hills and adjoining regions in South Dakota and Wyoming: U. S. Geol. Survey Prof. Paper 65, 1909. U. S. Geol. Survey Geol. Atlas, Newcastle follo (No. 1.07), p. 9, 1904 ; idem, Aladdin folio (No. 128), p. 8, 1005.

Richardson, G. B., Upper Red Beds of the Black Hills: Jour. Geology, vol. 11, p. 373, 1903. 
In a deep bore hole at Cambria the Spearfish red beds were 492 feet thick, and the following subdivisions were recognized:

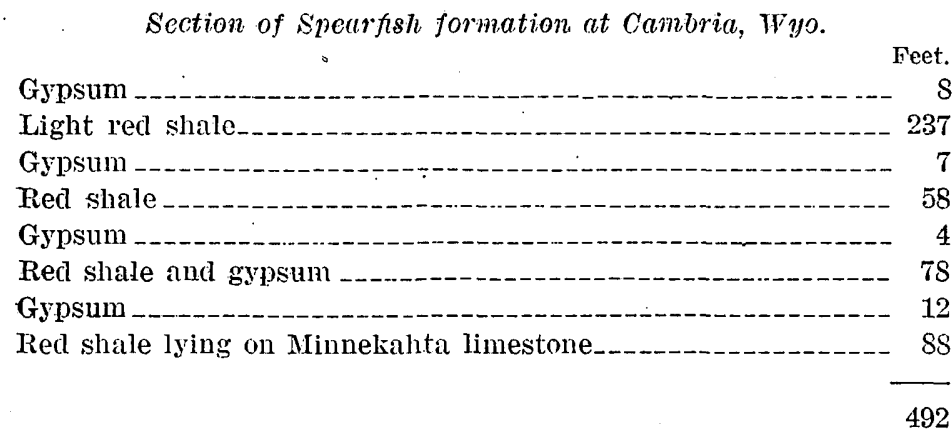

These deeply buried beds at Cambria need not be considered a future resource because of the extensive surface deposits near the main line of the railroad southeast of Newcastle.

In the valley 2 miles southeast of Mount Pisgah and 10 miles north of Newcastle there are extensive exposures of gypsum not far above the basal beds of the Spearfish formation, and on the north side of Mount Pisgah a 30 -foot bed at the top of the formation caps Red Butte, a prominent outlier 6 miles northeast of Cambria. A view of this thick bed capping Red Butte is shown in Plate XXXVII, $A$.

In Oil Creek valley, T. 47 N., R. 62 W., a massive white gypsum bed 25 feet thick is conspicuous. A few miles farther north gypsum beds extend partly around Inyankara and Strawberry mountains, and in the vicinity of Sundance exposures of them encircle Green Mountain and Gypsum Buttes. The main bed at these localities is about 5 feet thick.

A few miles south of Aladdin a gypsum bed which averages 15 feet thick outcrops continuously through Government and Redwater valleys. It occurs about 100 feet above the base of the Spearfish formation. Two miles northwest of Beulah, in Redwater Valley, there are two beds of massive white gypsum, one of them 2 feet and the other 4 feet in thickness.

Several thin beds of gypsum occur near the top of the Spearfish formation along Belle Fourche River northwest of the Black Hills, near Devils Tower, but their thickness in few places exceeds 2 feet.

The gypsum deposits on the west side of the Black Hills are relatively pure and if nearer to good markets would be valuable. 


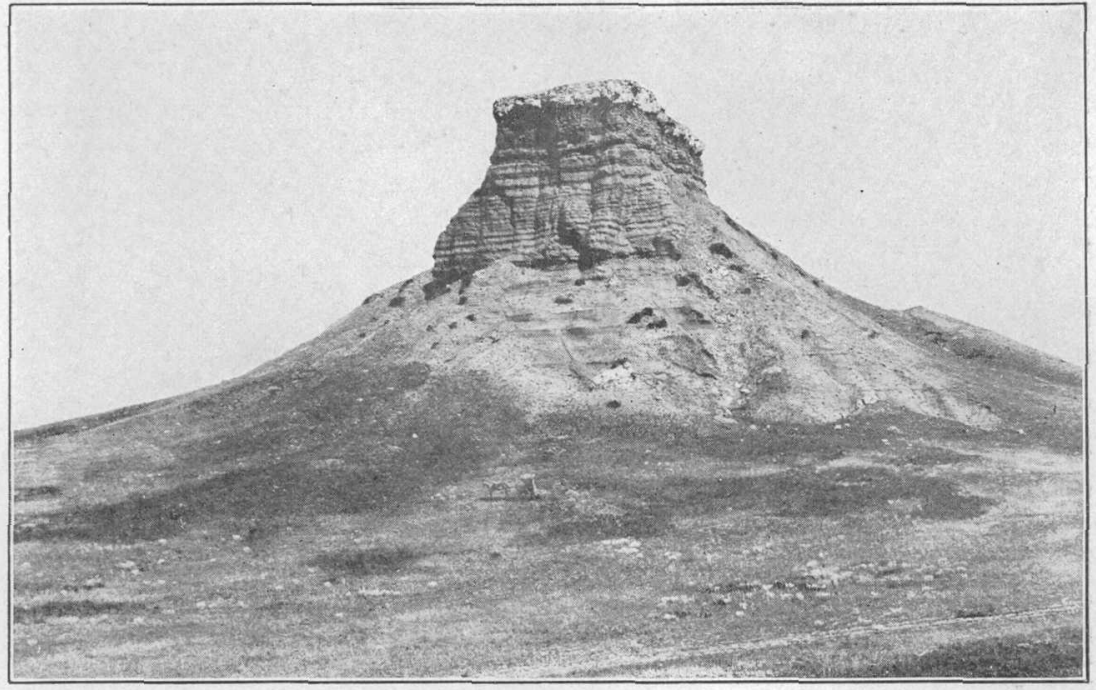

A. BUTTE OF RED BEDS OF SPEARFISH FORMATION CAPPED WITH A 30-FOOT BED OF GYPSUM EAST-NORTHEAST OF CAMBRIA, WYO.

Photograph by N. H. Darton.

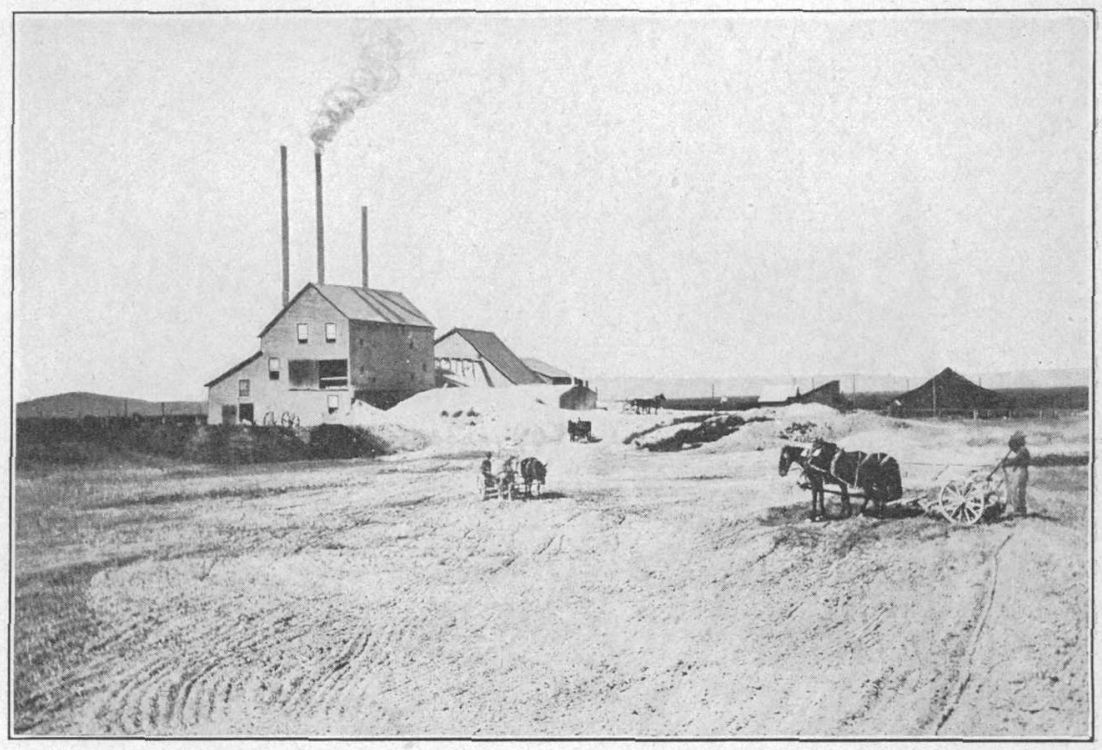

B. METHOD OF MINING GYPSITE, LARAMIE, WYO.

Photograph by E. F. Burchard. 


\section{BIG HORN MOUNTAINS. ${ }^{1}$}

\section{DISTRIBUTION.}

As red beds (Spearfish formation) encircle the Black Hills and form the Red Valley, so similar redl beds (Chugwater formation) surround the Big Horn Mountains, and by their softness make another though not so conspicuous red valley. The Chugwater formation extends along the base of the steeper portions of the slopes of the Big Horn Mountains. Along: the east side of the mountains, where the beds are nearly vertical, the outcrop is narrow, but on the western slope of the range the beds for the most part dip gently and accordingly have a wider and more conspicuous outcrop. On the east side the beds can be' traced, with few interruptions, from the Montana line across Sheridan and Johnson counties into $\mathrm{Na}$ trona County, a distance of 200 miles. On the west side of the mountains the red beds are almost continuously exposed for 175 miles from the Montana line to the southeastern part of Washakie County. Around the southern end of the Big Horn Mountains Eocene deposits conceal the older formations.

EAST SLOPE.

Sheridan County.--Information is meager concerning the gypsum beds in Sheridan County. Two beds 50 and 60 feet thick are exposed near Lodge Grass Creek, a few miles north of the State line in Montan: (p. 137), but according to Darton the principal gypsum bed in Sheridan County is near the base of the Chngwater formation and averages from 3 to 5 feet thick at most places. It outcrops almost continuously from Pass Creek to Little Goose Creek. A quarry was opened several years ago near Dayton, west of Sheridan, but it has not been operated and no information is at hand regarding the deposit at that place. Gypsum is well exposed on the head of Bearer Creek, a few miles southwest of Sheridan, and to the southeast as far as Big Horn.

Buffalo.-On the south fork of Rock Creek, which is tributary to Clear Creek at Buffalo, limestone is overlain by 200 feet of soft red sandstone containing much impure gypsum, and this is capped by a 20 -foot bed of pure gypsum. Near the head of Sand Creek sonthwest of Buffalo, where the beds are nearly vertical, there is over 100 feet of gypsum, some of it pure.

1 Darton, N. F., Geelogy of the Big Horn Mountains: U. S. Geol. Survey Prof. Paper: 51, 1906. J. S. Geol. Survey Geol. Atlas, Rald Mountain-Dayton folio (No. 141), p. 15, 1906.

Lupton, C. 'T., and Condit, D. D., Gypsum in the southern part of the Big Horn Mountains, Wyo.: U. S. Geol. Survey Bull. 640, pp. 139-157, 1916. 
The continuity of outcrop of the red beds is interrupted west of Buffalo by faulting and also where the beds cross the north forks of Powder River.

Crazy Woman Creek.-On Middle Fork of Crazy Woman Creek, in T. $47 \mathrm{~N}$., R. $83 \mathrm{~W}$., there are a number of beds of very fine textured white gypsum, which, with 14 thin partings, amounting to about 32 feet, make a total thickness of 125 feet. An analysis of gypsum from this locality is given in the table (p. 29).

Near Beaver Creek, a tributary of South Fork of Crazy Woman Creek, gypsum in beds 25 to 40 feet thick occurs locally near the top of the Chugwater formation, and exposures in a ravine show a large amount of gypsum in the Embar formation both above and below the purplish chert member.

On South Fork of Crazy Woman Creek the variable and discontinuous character of the gypsum beds is evident. Rock exposures along the main valley are not good, but it seems probable that gypsum is not present. Half a mile farther north, however, in T. $46 \mathrm{~N}$., R. $83 \mathrm{~W}$., there is about 90 feet of gypsum beds in the Embar formation. This thickness includes several shale layers, none of which is over $3 \frac{1}{2}$ feet thick.

Powder River.-On North Fork of Powder River, near the Webb ranch, in T. 45 N., R. $83 \mathrm{~W}$., there are beds of white and pink banded gypsum alternating with red shale which have a thickness of about 40 feet. This locality is northwest of Mayoworth and south of The Horn, a prominent projecting ridge on the front of the range. Near the Phillips ranch, on Red Creek, there is much gypsum along the base of the main mountain front and southward for several miles. The deposits are found to be discontinuous when traced along the outcrop. The gypsum beds are in the Embar formation, and those above the purplish chert member have a greater thickness than those below, being as much as 100 feet when the intercalated red shale layers are included.

In the vicinity of Barnum, in T. 43 N., R. 84 W., little gypsum is exposed, but the distorted attitude of the red shales supports the belief that gypsum beds probably of considerable thickness exist under the surface. If so they were once present and exposed at the surface but have been removed by solution. South of Barnum, along the valley of Buffalo Creek, there are numerous thick beds of gypsum. They are well exposed near Hole in the Wall, which is about 4 miles north of the Johnson-Natrona county line.

WEST SLOPE.

From the canyon of Big Horn River near the State line southeast along the west slope of the mountains to Shell Creek the outcrop of the Chugwater formation is narrow. Detailed information is not 
at hand regarding the gypsum. A bed several feet thick is reported near Cloverly, and it is said that gypsum from 10 to 15 feet thick is common along this side of the range. It is abundant south of Shell Creek as shown below.

Shell.-At the mouth of Shell Creek canyon, a few miles east of Shell, there is a bed of gypsum 12 feet thick. This may be the same as the bed near Cloverly and northward to the State line.

Hyattville.-On Paintrock Creek east of Hyattville there are several beds of gypsum, one 10 feet thick, in the Chugwater beds. At a point about 5 miles southeast of Hyattville and one-half mile west of the Hyattville-Tensleep road, gypsum occurs in seven beds, ranging in thickness from 1 foot 8 inches to 13 feet, with a total thickness of 43 feet of gypsum exposed in less than 60 feet of strata. Most of the gypsum at this place is pure white, but some of it is brownish gray and has a red stain. In this same neighborhood, near Zeisman's ranch, in sec. 34, T. 49 N., R. 89 W., gypsum beds 4 to 10 feet thick alternate with red shale probably belonging in the upper part of the Embar formation. Two analyses of gypsum from these places are given in the table (p. 29).

Tensleep.-The gypsum near the top of the Chugwater formation at a point about 2 miles northwest of Tensleep, on the north side of No Wood Creek, is thicker than at any other outcrop of the Chugwater beds here described. It is 74 feet thick, and the upper 20 feet is impure. Near Burke's ranch, on the north side of Tensleep Creek, two gypsum beds, 2 feet and 4 feet thick, occur in the midst of red shales in the lower part of the Embar formation, but the principal beds lie about 240 feet above the Tensleep sandstone. They consist of many layers interbedded with insignificant shale beds, the total thickness being about 90 feet, of which the shales constitute about 24 feet. The outcrops are stained reddish brown, but beneath the surface the gypsum is snowy white. The gypsum exposures in this vicinity in some respects rank among the most favorable deposits seen in the Big Horn Mountain region.

Bigtrails.-At the mouth of Buffalo Creek, a western tributary of No Wood Creek, the gypsum is in one bed 48 feet thick, lying 50 feet below the top of the Chugwater formation. It is mainly white and quite pure.

Redbank.-Near the base of the mountain, along the valley of Cherry Creek, about 2 miles southwest of Redbank, there is about 30 feet of gypsum with a few thin reddish shale layers in the Embar formation. Beneath this bed there are about eight gypsum beds, each 2 to 4 feet thick, scattered through an interval of 50 feet of red shale. The beds differ in thickness and disappear in a short distance along the outcrop, giving place to conglomeratic limestone, but a little farther along there appear other gypsum beds similarly stratified. 
$N_{o}$ Wood.-About 3 miles northeast of No Wood, where No Wood Creek enters the canyon, the upper portion of the Embar formation consists largely of massive white gypsum beds, many feet thick, with a few interbedded shale layers. About a mile southwest of the canyon the upper part of the formation shows almost no gypsum, but about $1 \frac{1}{2}$ miles sonthwest of No Wood the Embar again contains prominent gypsum beds. A thickness of 42 feet of gypsum with interbedded layers of red shale is exposed. This is the most southwesterly locality where gypsum beds of notable thickness were observed by Lupton ant Condit.

\section{BIG HORN BASIN. 1}

Gypsum occurs at a number of places in and around Big Horn Basin. Perhaps the most notable of these places, because the gypsum there is being utilized, is Sheep Mountain, a topographic eminence and structural anticline in the northern part of the basin, through which Big Horn River has cut a short canyon. Sheep Mountain is encircled by red beds carrying gypsum, which is quarried near Stucco and Greybull.

Stucco.-Gypsum is being quarried from the upper part of the Chugwater formation about one-half mile west of Stucco, a station on the Chicago, Burlington \& Quincy Railroad 8 miles northwest of GreybulI. The gypsum occurs in 8 beds which are 1 to 61 feet thick, a total of 26 feet of gypsum in 70 feet of strata. The rock is calcined in a mill completed in 1916 at Stucco. An analysis of the gypsum is given in the table on page 29 .

Greybull.-Gypsum at the top of the Chugwater formation is fairly well exposed near the south end of Sheep Mountain, about 2 miles north of Greybull, on the north side of Shell Creek. In all, 47 feet of gypsum is exposed in two beds, the upper one, which is 34 feet thick, is separated by 2 feet of shale from the lower one, which is 13 feet thick. The total amount may be greater, as the section is partly concealed. A few beds of gypsum 3 to 4 feet thick, in the Embar formation, are exposed along the southwest base of Sheep Mountain about 2 miles from the mouth of Shell Creek.

Cody.-Fisher reports the occurrence of an 8-foot bed of white massive gypsum 10 miles south of Cody in the upper part of the Morrison formation and a 30-foot bed of similar character 12 feet below the top of the Chugwater formation on Trail Creek a few miles northwest of Cody. A little farther northwest the red beds outcrop again and continue in a nearly straight course to the State

${ }^{1}$ Eupton, C. T., and Condit, D. D., Gypsum in the southern part of the Big Fiorn Mountains, Wyo.: .U. S. Geol. Survey Bull. 640, pp. 139-157, 1916.

Fisher, C. A., Mineral resonrces of the Big Horn Basin: U. S. Geol. Survey Bull. 285, p. 313, 1905. Geology and water resorrces of the Big Horn Basin, Wyo.: U. S. Geol. Survey Prof. Paper.53, p. 18, 1906. 
line. They are reported to contain gypsum, but the thickness of the deposits is not known. Along the east front of the Absaroka Range 500 to 600 feet of red sandstone is capped by 20 to 30 feet of white gypsum.

'Thermopolis.-Within a few miles north and west of Thermopolis' pure-white gypsum in beds 5 to 25 feet thick occurs 30 to 50 feet below the top of the Chugwater formation. About 9 miles east of Thermopolis, in the Red Spring anticline, there is a 16-foot bed of fairly pure gypsum near the top of the Embar formation, and in the upper part of the Chugwater formation there are two beds. The upper bed, 10 feet thick, lies about 33 feet above the lower bed, which is 42 feet thick. An analysis of gypsum from the north flank of Red Spring anticline is given in the table on page 29 .

OWL CREEK MOUNTAHS. ${ }^{1}$

The mountains in Hot Springs County sonth of Owl Creek are a westward continuation of the Bighorn Mountains. The structure is an uplift or fold with Paleozoic rocks exposed at the core. Chugwater red beds outcrop around the base of the mountains and contain a thick bed of gypsum. This bed, which is 100 feet below the top of the Chugwater and abore a prominent orange-colored sandstone, is 30 feet thick south of Embar and on Red Creek southwest of Thermopolis. It is very extensively exposed and 40 feet thick on the head of Muddy Creek in and near T. 7 N., R. 2 W.

\section{GROS VENTRE RANGE.}

It was stated in an earlier report ${ }^{2}$ that gypsum of excellent grade occurs in very thick beds at many places around the Gros Ventre Mountains. The writer has not traced the source of this information, but finds it controverted by recent geologic work. Eliot Blackwelder, who examined these mountains for the United States Geological Survey in 1910, asserts in an unpublished land-classification report that no important beds of gypsum have been found in the many excellent sections of the red beds along the north slope of the Gros Ventre Range. In his report on. T. 41 N., R. 113 W., Blackwelder says that "Very thin laminae of gypsum have been found in the lower part of the Chugwater formation in this tornship, but no layers more than a small fraction of an inch thick." He says further that because of the many excellent exposures of the rocks thick beds of gypsum would have been seen had they been present. He found no gypsum in T. 41 N., Rs. 115 and 116 W., which are at the west end of the range.

'Darton, N. H., Geology of the Owl Creek Mountains: 59th Cong., 1st sess., S. Doc. 210, p. $19,1906$.

${ }^{2}$ U. S. Geol. Survey Bull. 223, p. 84, 1904. 
SALT RIVEER RANGE.

The Salt River Range is in Lincoln County south of the Gros Ventre Range. Although it was stated in the earlier report ${ }^{1}$ that the red beds, which are extensively exposed in several north-south folds in this region, contain plentiful deposits of gypsum, inquiry of A. R. Schultz and G. R. Mansfield, geologists of the United States Geological Survey, who have worked in the area recently, elicited the information that gypsum was nowhere observed and, if present at all, must be in very thin and inconspicuous beds.

\section{WIND RIVER RANGE AND VICINITY. ${ }^{2}$}

Along the northeast slope of the Wind River Range for a distance of 100 miles the red beds are exposed almost continuously. No information is at hand as to the occurrence of gypsum other than that it is abundant and in thick beds. The red beds are exposed also in three areas along an anticline which passes east of Fort Washakie, Lander, and Dallas. The upper beds are pinkish and contain much gypsum.

Fort Washakie.-In the bank of Little Wind River, in sec. $34 ; \mathrm{T}$. $1 \mathrm{~N} .$, R. 1 W., there is a deposit of gypsum 61 feet thick. It consists of massive beds several feet thick, interlaminated with thin shale layers and all upturned at a high angle. Near by in the Sage Creek district gypsum beds range from 30 to 70 feet thick.

Lander.-Red beds, brought up and exposed by an anticlinal fold north and east of Lander, contain an abundance of gypsum, as shown by the beds 40 feet or more thick near the Lander Experiment Farm.

Hailey.-Unpublished notes made by a United States Geological Survey field party, under the direction of C. J. Hares, show that the red sandstone near the top of the Chugwater formation contains gypsum beds of various thicknesses near Hailey on Beaver Creek southeast of Lander. The maximum thickness about 2 miles west of Hailey is 12 feet. Southwest of Hailey, about 50 feet below the Sundance formation, there is 10 feet of white gypsum, with thin red shale partings.

\section{CENTRAL WYOMING. ${ }^{3}$}

Conant Creek.-It is reported that gypsum beds of sufficient thickness to be valuable for working outcrop for several miles around the end of an anticline on Conant Creek, a tributary of Muskrat Creek northeast of Lander. In view of the location of this deposit

${ }^{1}$ U. S. Geol. Survey Bull. 223, p. 84, 1904.

2 Jamison, C. E., Geology and mineral resources of a portion of Fremont County, Wyo.: Wyoming Univ. Bull. 2, ser. B, p. 84, 1911. Knight, W. C., Gypsum deposits in Wyoming: U. S. Geol. Survey Bull. 223, p. 84, 1904.

${ }^{3}$ Knight, W. C., op. cit., p. 83. 
and of the abundance of gypsum in Wyoming, the commercial importance of gypsum on Conant Creek, no matter how thick, is questioned.

Rattlesnake, Green, and Ferris mountains.-Gypsum has been reported in the slopes on the northeast side of the Rattlesnake Range, but no information is at hand regarding the thickness of the beds, except that no large deposits appear to be present. Gypsum beds are exposed in gulches and canyons along the southern base of Ferris Mountains and are reported in Green Mountains. All these localities are remote from any market and 25 miles or more from a railroad.

Alcova.-In the vicinity of Alcova, which is on North Platte River below the canyon and 30 miles above Casper, there is much gypsum in the lower part of the Chugwater formation. It is exposed in two areas, each 5 or 6 miles long, where a broad valley transverse to the river has been carved out of the Tertiary rocks. One area is at Alcova and the other 3 or 4 miles up the river at the mouth of the canyon.

\section{SOUTHEASTERN WYOMING. ${ }^{1}$}

Casper-Douglas area.-At the east end of Casper Mountain on Muddy Creek, in the upper part of the Chugwater formation, there is a 20 -foot limestone member which makes a prominent wall in the steep-dipping beds. In the sandstones overlying this limestone there is an 8-foot gypsum bed. Outcrops of the Chugwater are continuous to the east for a few miles to the area where Tertiary deposits cover the older formations south of Glenrock. South of Douglas the Chugwater is again uncovered, and its conspicuous red outcrop extends up Wagon Hound and Labonte creeks. On both these creeks there is consiclerable gypsum near the base of the formation.

Seminoe Mountains.-Red beds outcrop around the eastern end of the Seminoe Mountains and along the south side for about 20 miles. North Platte River has cut through the mountains about midway of their length, so that the exposures on the two sides of the river are of nearly equal length. There are many outcrops of gypsum beds of considerable thickness, but measurements of them have not been made.

'Darton, N. H., Paleozoic and Mesozoic of central Wyoming: Geol. Soc. America Bull., vol. 19 , pp. $403-470,1908$.

Darton, N. H., and Slebenthal, C. E., Geology and mineral resources of the Laramfe Basin, Wyo.: U. S. Geol. Survey Bull. 364, 1909.

Knight, W. C., Gypsum deposits in Wyoming: U. S. Geol. Survey Bull. 223, pp. 79-85, 1904.

Siebenthal, C. E., Gypsum deposits of the Laramie distrlct, Wyo.: U. S. Geol. Survey Bull. 285; pp. 404-405, 1906.

Trumbull, L. W., Cement plaster industry in Wyoming: Min. World, vol. 26, p. 387, 1907.

$124567^{\circ}-20-20$ 
Shirley Mountains and Freezeout Hills.-A range in the northeast part of Carbon County known as the Shirley Mountains is not over 10 miles long. Its eastward continuation, the Freezeout Hills, is a broad anticlinal arch about 15 miles long. Red beds are exposed around the Freezeout Hills and along the southwest base of the Shirley Mountains, the total length of outcrop being fully 30 miles. Gypsum is abundant in thick beds. The only measurenent is by Darton, who found a 30 -foot bed in the Freezeout Hills.

Rawlins.-Rawlins is at the southern end of an uplift about 15 miles long, on the east and southwest sides of which the Chugwater formation occurs. A fault on the northwest side of the uplift makes the encircling outcrop discontinuous. For many miles the gypsumbearing beds are concealed by later deposits, but at a point 12 miles north of Rawlins and on the southwestern slope of the uplift, where the beds dip steeply to the west, good gypsum has been found. The thickness of the gypsum is not known.

Medicine Bow.-The Chugwater formation is exposed for several miles in the valley of Little Medicine Bow River, north of the town of Medicine Bow. A section of the formation measured at the west end of Flat Top Mountain about 3 miles northeast of the mouth of Little Medicine Bow River, by C. F. Bowen, of the United States Geological Survey, and heretofore unpublished, is given below.

Section of Chuguter formation, T. 93 N., R. 79 W., Wyo.

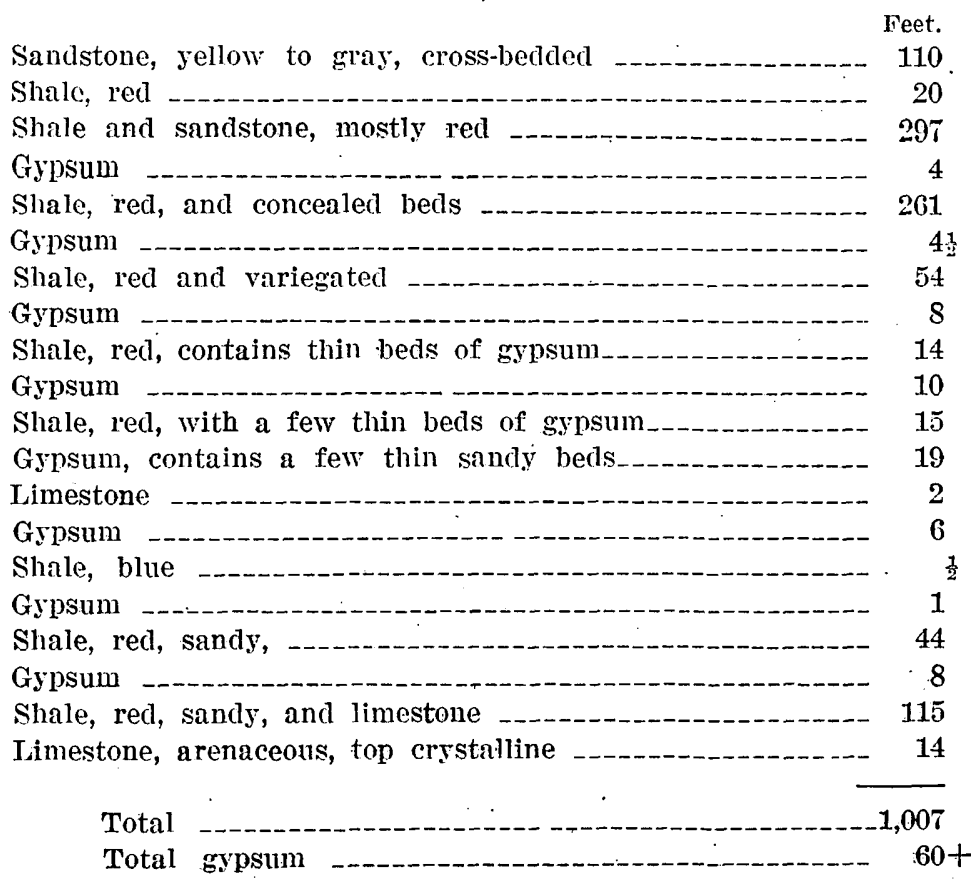


Elk Mountains.-Around the northern end of the Elk Mountains, a small group south of Hanna and at the northern extremity of the Medicine Bow Range, the Chugwater formation is exposed in a curring line. There are extensire beds of gypsum here, but to the south along the flank of the Medicine Bow Range the gypsum-bearing beds are concealed or obscured by mountain wash or by Tertiary deposits.

Laramie Basin.-About 12 miles east of Medicine Bow is the western extremity of a series of exposures of red beds which can be traced along the west slope of Laramie Mountains south to the Colorado line. Wherever the red beds are uncovered gypsum is found in workable thickness. The only development of gypsum deposits in the basin, however, is at Laramie and Red Buttes. Gypsite is used at Laramie and rock gypsum at Red Buttes.

Gypsite deposits are known at several places in the Laramie district. The principal one is that which is being worked just south of the city of Laramie. It has a depth of 9 feet and covers several hundred acres. The gypsite is dug with horse scrapers and goes directly to the calcining kettles without grinding or screening. (See Pl. XXXVII, B.) Other gypsite deposits in the vicinity are in secs. 3, 4, and SE. $\frac{1}{4}$ sec. 28 , T. 16 N., R. 73 W.; on Soldier Creek, 1 mile below and 2 miles above the site of Fort Saunders; NE. $\frac{1}{4}$ sec. 21, T. 14 N., R. $73 \mathrm{~W}$.; at the junction of Willow and Lone Tree creeks; and in secs. 33 and 34, T. 14 N., R. 74 W.

One mile east of Sportsmans Lake, in sec. 7, T. 13 N., R. 73 W., a bed of pure rock gypsum has been exposed to a depth of 4 or 5 feet in a small pit. The full thickness of the deposit has not been determined.

Red Mountain shows the greatest thickness of rock gypsum. in Laramie Basin. Just north of the Wyoming-Colorado line, in sec. 9, T. 12 N., R. '76 W., at the north base of Red Mountain, the following section was measured by C. E. Siebenthal:

Section at base of Red Mlountain, Albany County, Wyo.

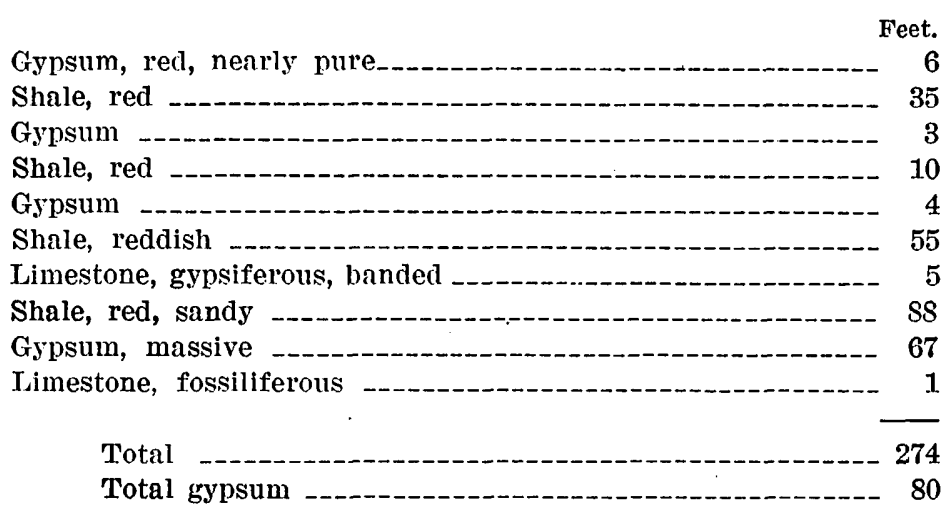


The bed of gypsum at the bottom of the section has a thickness of 30 feet or more along 5 miles of outcrop in the vicinity of the mountain, which is about 12 miles east of Wyocolo, a station on the Colorado, Wyoming \& Eastern Railway.

Rock gypsum does not outcrop in the immediate environs of Laramie but shows a thickness of 9 or 10 feet at the north base of a small hill in the SW. $\frac{1}{4}$ sec. 2, T. 16 N., R. 73 W. At Red Buttes it has been quarried for many years: 1 mile south of the station and made into plaster. Two beds are present, about 10 and 20 feet thick, and there is a gypsite deposit near the mill which also is used.

Laramie Mountains.-The Paleozoic and Mesozoic rocks on the east side of the Laramie Mountains dip to the east at high angles and were at one time covered with sediments of Tertiary age. Erosion has removed some of the cover and the old rocks are exposed in a few places along the west boundary of Laramie County. The red beds contain some gypsum, but so far as known not in notable quantity or thickness. 


\section{PART III. BIBLIOGRAPHY.}

The following bibliography contains the principal publications of interest as supplementary reading in connection with this report:

\section{GENERAL REFERENCES.}

\section{UNITED STATES.}

Adans, G. I., Gypsum deposits in the United States: U. S. Geol. Survey Bull. 223, 1904.

BURCHARD, E. F., The gypsum industry : U. S. Geol. Survey Mineral-Resources; 1909, pt. 2, 1910; idem, 1910, pt. 2, 1911; idem. 1911, pt. 2, 1912.

Joughlin, G. F., The gypsum industry in 1914 : U. S. Geol. Survey Mineral Resoụrces, 1914, pt. 2, 1915.

Srone, R. W., The gypsum industry: U. S. Geol. Survey Mineral Resources, 1912 , pt. 2 , 1913; irlem, 1913, pt. 2, 1914; idem, 1915, pt. 2, 1916; idem, 1916, pt. 2, 1917 ; idem, 1917, pt. 2, 1918; idem, 1918, pt. 2, 1919.

\section{CANADA.}

Bancex, L. W., and Elts, R. W., Lower Carboniferous belt of Alberta and Westmoreland counties, New Brunswick; Canada Geol. Survey Rept. for 187677, pp. 351-401, 1878.

Cole, L. H., Gypsum in Canada: Canada Dept. Mines, Mines Branch, Bull. 245, 256 pp., 1913.

Fletcher, H., Explorations and surveys in Cape Breton, Nova Scotia: Canada Geol. Survey Rept. for 1875-76, pp. 369-418, 1877.

Jennrson, W. F., Gypsum deposits of the maritime provinces: Canada Dept. Mines, Mines Branch, Bull. 84, 1911.

\section{TECHNOLOGY AND CHEMISTRY.}

Eckes, E. C., Cements, limes, and plasters, New York, John Wiley \& Sons, 1905. Hodgson, F. T., Mortar's, plaster's, stuccos, Chicago, F: J. Drake \& Co., 1906.

Hunt, T. S., Origin of gypsum, in Chemical and geological essays, ch. 8, 1875. Stone, R. W., Gypsum products, their preparation and use: Bur. Mines Tech. Paper 155,66 pp., 1917.

Wrtuer, F. A., Properties and uses of mineral gypsum: Appalachian Eng. Assoc. Trans., Bull. 33, 1909.

\section{REFERENCES BY STATES.}

ALASKA.

Burchard, E. F., Gypsum in Alaska: U. S. Geol. Survey Mineral Resources, 1913, pt. 2, p. 363, 1914.

Wright, C. W., Nommetallic mineral resources of southeastern Alaska: U. S. Geol. Survey Bull. 314, pp. 79-80, 1907. 


\section{ARIZONA.}

Blake, W. P., Gypsum deposits in Arizona: U. S. Geol. Survey Bull. 223, pp. 100-101, 1904

LEE, W. T., Geologic reconnaissance of a part of western Arizona: U. (S. Geol. Sturvey Bull. 352, p. 36, 1908.

ARKANSAS.

Hill, R. T., The Neozoic geology of southwestern Arkansas: Arkansas Geol. Survey, vol. 2, pp. 119, 241, 257, 1888.

\section{CALIFORNIA.}

AUburs, L. E., The structural and industrial materials of California: California State Min. Bur. Bull. 38, pp. 281-2Ss, 1906.

Bradley, W. W., Huguenin, E., Logan, C. A., and Waring, C. A., Mines and mineral resources of the counties of Monterey, San Benito, San Luis Obispo, Santa Barbara, Ventura, Calif.: California State Min. Bur. Bienn. Rept., 1915-16, pp. 44, 142, 167, 1917.

Crawford, J. J., Gypsum (localities in California) : California State Mineralogist Twelfth Ann. Rept. pp. 323-325, 1894.

State Mineralogist Thirteenth Ann. Rept., pp. 503-504, 1896.

Eakie, A. S., Minerals of California: California State Min. Bur. Bull. 67, pp. 184-186, 1914.

Fatrbanks, H. W., Gypsum deposits in California : U. S. Geol. Survey Bull. 223, pp. 119-123, 1904.

Grimstex, G. P., Gypsum and cement plaster industry in California : Eng. and Min. Jour., vol. 71, p. 724, 1901.

Harder, E. C., The gypsum deposits of the Palen Mountains, Riverside County, Calif.: U. S. Geol. Survey Bull. 430, pp. 407-416, 1910.

Hess, F. L., A reconnaissance of the gypsum deposits of California: U. S. Geol. Survey Bull. 413, 1910.

- Gypsum deposits near Cane Springs, Kern County, Calif.: U. S. Geol. Survey Bull. 430, pp. 417-418, 1910.

Sunk, Gordon, Gypsum in the Maria Mountains of California: Min. World, pp. 787-790, Apr. 15, 1911.

Waning, C. A., and Huguenin, E., Mines and mineral resources of Alpine, Inyo, and Mono counties, Calif. : California State Min. Bur. Bienn. Rept., 1915-16, pp. 81-82, 1917.

Watts, W. L., California State ${ }_{0}$ Min. Bur. Eleventh Ann. Rept., pp. 233-238, 1893.

The gas and petroleum yielding formations of the central valley of California: California State Min Bur. Bull. 3, pp. 35, 63, 1894.

\section{COLORADO.}

Burchard, E. F., Gypsum deposits in Eagle County, Colo.: U. S. Geol. Survey Bull. 470, pp. 354-365, 1911.

Butters, R. M., Permian or "Permo-Carboniferous" of the eastern foothills of the Rocky Mountains in Colorado: Colorado Geol. Survey Bull. 5, pt. 2, pp. 74, 82, 1913.

Gilbert, G. K., U. S. Geol. Survey Geol. Atlas, Pueblo folio (No. 36), p. 6, 1897. 
Lakes, A., Gypsum deposits in Colorido: U. S. Geol. Survey Bull. 223, pp. S6-S8, 1.904.

- Gypsum and clay in Colorado: Mines and Minerals, vol. 20, Dec., 1899.

LEE, H. A., Larimer County gypsum: Stone, vol. 21, pp. 35-37, 1900.

Peare, A. C., U. S. Geol. and Geog. Survey Terr. [Fighth] Ann. Rept., for 1.874, pp. $178-179,1876$.

Iiansome, F. L., Ore deposits of the Rico Mountains, Colo.: U. S. Geol. Survey Twenty-second Ann. Rept., pt. 2, pp. 273-280, 1901.

Siebenthal, C. E., Gypsum deposits of the Uncompahgre region, Colo.: U. S. Geol. Survey Bull. 285, pp. 401-403, 1906.

Spexcer, A. C., Geology of the Rico Mountains, Colo.: U. S. Geol. Survey Twenty-first Ann. Rept., pt. 2, pp. 48-54, 1900.

Spuri, J. E., Geology of Aspen mining district: U. S. Geol. Survey Mon. 31, pp. 239-241, 1898.

\section{FLORIDA.}

Day, D. T., Gypsum in Florida: U. S. Geol. Survey Twentieth Ann. Rept., pt. 6, pp. $662,663,1899$.

- Gypsum deposits in Florida: U. S. Geol. Survey Bull. 223, p. 48, 1904.

Stone, R. W., Gypsum in Florida: U. S. Geol. Survey Mineral Resources, 1918, pt. 2, pp. 293-296, 1919.

Florida gypsum deposit explorel: Rock Products, vol. 23, No. 2, pp. 30-31, 1920.

WILDER, F. A., Gypsum: Mineral Iudustry, 1917, p. 117, 1918.

IDAHO.

Purchard, E. F., Gypsum industry in 1910: U. S. Geol. Survey Mineral Resources, 1910 , pt. 2 , p. $727,1911$.

IOIVA.

Kax, G. F., A new gypsum deposit in Iowa: U. S. Geol. Survey Bull. 580, pp. 59-64, 1915.

Keyes, C. R., Gypsum deposits in Iowa: Iowa Geol. Survey Rept., vol. 3, pp. $257-304,1895$.

- Iow:a gypsum: Mineral Industry, vol. 4, pp. 379-396, 1896.

- Geological age of certain gypsum deposits [Kansas and Iowa]: Am. Geologist, vol. 30, pp. 99-102, 1902.

Wumper, F. A., Geology of Webster County, Iowa : Iowa Geol. Survey Ann Rept. for 1901, pp. 65-191, 1902.

- The age and origin of the gypsum of central Iowa: Jour. Geology, vol. 11. pp. 723-748, 1903.

- Gypsum deposits in Iowa : U. S. Geol. Survey Bull. 223, p1. 49-52, 1904.

\section{KANSAS.}

Batrex, E. H. S., Special report on gypsum and gypsum cement plasters : Kansas Univ. Geol. Survey Rept.,. vol. 5, 1899.

On the chemical composition of some Kansas gypsum rocks: Kansas Univ. Quart., vol. 6, pp. 29-34, 1897.

Cragrn, F. W., The Permian in Kansas: Colorado Coll. Studies, vol. 6, 1896.

Crane, W. R., Mining and milling of gypsum in Kansas: Eng. and Min. Jour., Nov. 9, 1901.

The gypsum plaster industry of Kansas: Eng. and Min. Jour., vol. 77, pp. $442-445,1904$. 
Grimsley, G. P., Special report on gypsum and gypsum cement plasters: Kansas Univ. Geol. Survey Rept., vol. 5, 1899.

-__-Gypsum deposits of Kansas : Geol. Soc. America Bull., vol. 8, pp. 227-240, 1897.

—_ Gypsum in Kansas : Kansas Univ. Quart., vol. 6, pp. 15-27, 1897.

Technology of gypsum; Mineral Industry, rol. 7; pp. 38s-394, 1899.

Gypsum deposits in Kansas: U. S. Geol. Survey Bull. 223; pp. 54-59, 1904.

Haworth, Erasnus, Mineral resources of Kansas for 1897: Kansas Univ. Geol. Survey Ann. Bull. pp. 59-65, 1898.

- Mineral resources of Kansas for 1898: Kansas Univ. Geol. Survey Ann. Bull., pp. 54-55, 1899.

HaY, Robert, A geological reconnaissance in southwestern Kansas: U. S. Geol.

Survey Bull. 57, pp. 22-24, 48, 1890.

Prosser, C. S., The upper Permian: Kansas Univ. Geol. Survey, vol.'2, pp. $55-95,1897$.

Sherwin, R. S., Theories of origin of gypsum: Kansas Acad. Sci. Trans., vol. 28 , pp. $85-88,1903$.

\section{LOUISIANA.}

Harris, G. D., The geology of Louisiana: Louisiana Geol. Survey Rept. for 1899, p. 137, 1899.

- Oil and gas in Louisiana: U. S. Geol. Survey Bull. 429, 1910.

\section{MICHIGAN.}

Gregory, W. M., Gypsum in Arenac and adjoining counties: Michigan Geol. Survey Ann. Rept. for 1901, pp. 15-18, 1902.

-__ The Alabaster area: Michigan Geol. Survey Rept., vol. 9, pt. 2, pp. 60-77, 1904.

C:Rimslex, G. P., Preliminary report on the gypsum deposits of Michigan: Michigan Geol. Survey Ann. Rept. for 1902, pp. 4-10, 1903.

The gypsum of Michigan and the plaster industry: Michigan Geol. Survey Rept., vol. 9, pt. 2, 246 pp., 1904.

Gypsum deposits in Michigan: U. S. Geol. Survey Bull. 223, pp. 45-47, 1904.

-_ A theory of origin for the Michigan gypsum deposits : Am. Geologist, vol. 34, pp. 378-3S7, 1904.

- Origin of gypsum, with special reference to the origin of the Michigan deposits: Kansas Acad. Sci. Trans., vol. 19, pp. 110-117, 1905.

\section{MONTANA.}

Freeman, O. W., Gypsum and lime industry in central Montana: Min. and Eng. World, vol. 45, pp. 663-664, 1916.

Rowc, J. P., Montana gypsum deposits: Am. Geologist, vol. 35, pp. 104-113, 1905.

- Montana gypsum deposits: Mines and Minerals, vol. 28, pp. 59-60, 1907. - Gypsum deposits of Montana: Eng. and Min. Jour., vol. 85, p. 1243, June 20, 1908.

WeEd, W. H., Economic value of hot springs and hot-springs deposits : U. S. Geol. Survey Bull. 260, pp. 598-604, 1905.

_ Gypsum deposits in Montana: U. S. Geol. Survey Bull. 223, pp. 74-75, 1904. 
NEVADA.

Jones, J. C., The origin of the anhydrite at the Ludwig mine, Lyon County, Nev. : Econ. Geology, vol. 7. pp. 400-402, 1912.

Loudernack, G. D., Some gypsum deposits of northwestern Nevada: Jour. Geology, vol. 11, p. 99, 1903 .

- Gypsum deposits in Nevada: U. S. Geol. Survey Bull. 223, pp. 112-118, 1904.

Rogers, A.'F., The occurrence and origin of gypsum and anhydrite at the Ludwig mine, Lyon Couniy, Nev.: Econ. Geology, vol. 7, pp. 185-189, 1912.

\section{NEW MEXICO.}

Brady, F. W., The white sands of New Mexico: Mines and Minerals, vol. 25, pp. $529-530,1905$.

Herrick, C. L., The geology of the white sands of New Mexico: Jour. Geology, vol. 8, pp. 112-128, 1900; New Mexico Univ. Hadley Lab. Bull., vol. 2, pt. 1, 1900 .

Lake Otero, an ancient salt-lake basin in southeastern New Mexico: Am. Geologist, vol. 34, pp. 174-189, 1904.

- Gypsum deposits in New Mexico: U. S. Geol. Survey Bull. 223, pp. 89-99, 1904.

MEINzer, O. E., Geology and water resources of Tularosa Basin, N. Mex.: U. S. Geol. Survey Water-Supply Paper 343 , pp. 69-71, 1915.

Neweld, F. H., The gypsum plains: U. S. Geol. Survey Twelfth Ann. Rept., pt. 2, pp. 281-282, 1891.

Shaler, M. K., Gypsum in northwestern New Mexico: U. S. Geol. Survey Bull. 315, pp. 260-266, 1907.

NEW YORK.

BECK, L. C.. Mineralogy of New York, pp. 61-67, 237-238, 1842.

Clarke, W. C., The gypsum industry in New York State: New Fork State Mus. Bull. 11, pp. 70-84, 1893.

Conrad, T., First annual report on the geological survey of the third district of New York, p. 179 (2d ed., p. 181), Albany, 1837.

Dana, J. D., Origin of gypsum deposits, in Manual of geology, p. 554, 1895.

Eckes, E. C., Gypsum deposits in New York: U. S. Geol. Survey Bull. 223, pp. 33-35, 1904.

HaLr, JAares, Geology of New York, pt. 4, pp. 421-457, 1843.

Hopkins, T. C., Mineral resources of Onondaga County: New York State Geologist Twenty-second Ann. Rept., pp. r109-1114, 1904; New York State Mus. Fifty-sixth Ann. Rept., vol. 1, pp. r109-r114, 1904.

Leighton, Henry, Gypsum deposits of New York: Yew York State Mus. Bull. 143, 94 pp., Oct. 1, 1910.

Lincols, D. F., Report on the structural and economic geology of. Seneca County, N. Y. : New York St:ate Geologist Fourteenth Ann. Rept., pp. 60-125, 1896.

Luther, D. D., The economic geology of Onondaga County, N. Y.: New York State Geologist Fifteenth Ann. Rept., vol. 1, pp. 238-303, 1897; also New York State Mus. Forty-ninth Ann. Rept., vol. 2, pp. 238-303, 1898.

The brine springs and salt wells of the State of New York: New York State Geolugist Sixteenth Aun. Rept., pp. 171-226, 1S90; New York State Mus. Fifteenth Ann. Rept., vol. 2, pp. 171-226, 1 \$99. 
Merrill, F. J. H., Salt and gypsum industries in New York State: New York State Mus. Bull. 11, 89 pl., 1893.

- Mineral resources of New York State: New York State Mus. Bull. 15, 1895 ; also New York State Mus. Forty-eighth Ann. Rept., vol. 1, pp. 359$595,1895$.

Newland, D. H., and Leighton, Henrs, Gypsum deposits of New Fork: New York State Mus. Bull. 143, 94 pp., 1910.

Newland, D. H., The mining and quarry industry of New York State; report of operations and production during 1904: New York State Mus. Bull. 93, pp. 930-932, 1905; idem, 1905 : Bull. 102, pp. 78-82, 1906 ; idem, 1906: Bull. 112, pp. $2 \bar{\imath}-29,1907$; idem, 1907 : Bull. 120 , pp. 31-34, 190S; idem, 190 S : Bull. 132, pp. 29-33, 1909; idem, 1909: Bull. 142, pp. 38-44, 1910; idem, 1910 : Bull. 151, pp. 30-33, 1911; idem, 1911: Bull. 161, pp. 34-36, 1912; idem, 1912 : Bull. 166, pp. 33-36, 1913; idem, 1913: Bull. 174, pp. 36-39, 1914; idem, 1914: Bull. 178, pp. 35-36, 1915; idem, 1915: Bull. 190, pp. 31-34, 1916; idem, 1916 : Director State Mus. Thirteenth Rept., pp. 263-265, 1917.

Parsons, A. I., Recent developments in the gypsum industry in New York State: New York State Geologist Twentieth Ann. Rept., pp. r177-1'183, 1902 ; New York State Mus. Fifty-fourth Ann. Rept., vol. 1, pp. r177-r183, 1902.

Notes on the gypsum industry of New York State: New York State Geologist Twenty-third Ann. Rept., pp. 89-157, 1904; New York State Mus. Fifty-seventh Ann. Rept., vol. 1, pp. 89-15T, 1905.

Pohlman, J., Cement rock and gypsum deposits in Buffalo: Am. Inst. Min. Eng. Trans., vol. 17, pp. 250-253, 1889.

Sarle, C. J., Economic geology of Momroe County, N. Y.: New York State Geologist Twenty-second Ann. Rept., pp. r75-r106, 1904; also New York State Mus. Fifty-sixth Ann. Rept., pp. r75-r·106, 1904.

Vanuxem, Lardner, Geology of New York, pt. 3, pp. 98-102, 1842.

Williams, S. G., Geological relations of the gypsum deposits in Cayuga County, N. Y.: Am. Jour. Sci., 3d ser., vol. 30, pp. 212-21s, 1885.

онIO.

Gidiber', G. K., Geology of West Sister Island: Ohio Geol. Survey, vol. 1,'pp. 589-590, 1873.

Orton, EDWand, Gypsum or land plaster in Ohio: Ohio Geol. Survey, rol. 6, pp. $696-702,1888$.

Pepper, S. V., Gypsum deposits in Ohio: U. S. Geol. Survey Bull. 223, pp. 3S-44, 1904.

\section{OKLAHOMA.}

Gound, C. N., Oklahoma gypsum: Oklahoma Dept. Geology Second Bienn. Rept., pp. 75-137, 1902.

- Gypsum deposits in Oklahoma: U. S. Geol. Survey Bull. 223, pp. 60-67, 1904

Extent and importance of Oklahoma gypsum deposits: Min. Sci., vol. 56, pp. 542-543, 1907, and pp. 583-584, 1907.

Geology and water resources of Oklahoma: U. S. Geol. Surver WaterSupply Paper 148, 1905.

Preliminary report on the structural materials of Oklahoma. Oklahoma Geol. Survey Bull. 5, pp. 98-113, 1911.

Snider, L. C., The gypsum and salt of Oklahoma: Oklahoma Geol. Survey Bull. 11, pp. 214, 1913.

Oklahoma gypsum deposits and industry: Eng. and Min. Jour., vol. 95. pp. 931-933, 1913. 
OREGON.

L.indgren, Waldemar, Gypsum deposits in Oregon: U. S. Geol. Survey Bull. 223, p. 111, 1904.

Anonymous, Plaster mill of the Pacific Lime \& Gypsum Co.: Pacific Builder and Engineer, July 5, 1913, pp. 3-4.

\section{SOUTH DAKOTA.}

Darton, N. H., Preliminary description of the geology and water resources of the southern half of the Black Hills and adjoining regions in South Dakota and Wyoming: U. S. Geol. Survey Twenty-first Ann. Rept., pt. 4, pp. 516-518, 584-585, 1901.

- Gypsum deposits in South Dakota: U. S. Geol. Survey Bull. 223, pp. 76-7S, 1904.

- Preliminary report on the geology and underground water resources of the central Great Plains: U. S. Geol. Survey Prof. Paper 32, p1. 392394, 1905.

RICHardson, G. B., Upper Red Beds of the Black Hills: Jour: Geology, vol. 11, pp. $365-393,1903$.

TEN NESSEE.

Safrord, J. M., Geology of Tennessee, p. 503, Nashville, 1869.

TEXAS.

ADams, G. I., Oil and gas fields of the western interior and northern Texas coal measures and of the Upper Cretaceous and Tertiary of the western Gulf coast: U. S. Geol. Survey Bull. 184, pp. 49-53, 1901.

Cummins, W. F., Geology of northwestern Texas: Texas. Geol. Survey Second Ann. Rept., pp. 455-459, 1891.

Goubd, C. N., Geology and water resources of Oklahoma: U. S. Geol. Survey Water-Supply Paper 154, 1906.

The geology and water resources of the western portion of the Panhandle of Texas: U. S. Geol. Surrey Water-Supply Paper 1.91, 1907.

Harris, G. D., Oil and gas in Louisiana, with a brief summary of their occurrence in adjacent States: U. S. Geol. Survey Bull. 429, 192 pp., 1910.

Hrrl, B. F., Gypsum deposits in Texas: U. S. Geol. Survey Bull. 223, pp. 68-73, 1904.

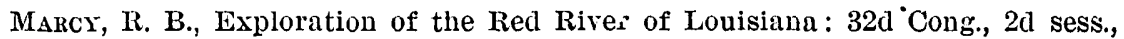
S. Ex. Doc. 54, pp. 52, 91, 171-174, 1853; 33d Cong., 1st sess., H. Ex. Doc. 15 , pp. 52, 91, 148-151, 1854 .

Richardson, G. B., Reconnaissance in trans-Pecos Texas: Texas. Univ. Min. Survey, vol. 9, pp. 43-44, 1904.

- Salt, gypsum, and petroleum in trans-Pecos Texas: U. S. Geol. Survey Bull. 260, pp. 573-585, 1905.

Simonds, F. W., The minerals and minerai localities of Texas: Texas Univ. Min. Survey, vol. 5, pp. 36-37, 1902.

Udden, J A., The deep boring at Spur: Texas Univ. Bull. 363, 1914.

\section{UTAH.}

Anonymous, The gypsum deposits and plants at Gypsum, near Nephi, Utah: Rock Products, vol. 10, p. 37, April, 1911.

Bơtweld, J. M., Gypsum deposits in Utah: U. S. Geol. Survey Bull. 223, pp. 102-110, 1904.

- Rock gypsum at Nephi, Utah: U. S. Geol. Survey Bull. 225, pp. 483-487, 1904.

Ginmert, G. K., Lake Bonneville: U. S. Geol. Survey Mon. 1, pp. 222-223, 1890. 
Lupron, C. T., Gypsum along the west flank of the San Rafael Swell, Utah:

U. S. Geol. Survey Bull. 530, pp. 221-231, 1913.

'iararage, J. E., A remarkable occurrence of selenite: Science, vol. 21, pp. 85-\$7, 1893.

\section{VIRGINIA.}

Boyd, C. R., Gypsum in southwestern Virginia: Resources of southwest Virginia, pp. 104-108, 1881.

LCKeI, E. C., Salt and gypsum deposits of southwestern Virginia: U. S. Geol. Survey Bull. 213, pp. 406-416, 1903.

_- Gypsum deposits in Virginia : U: S. Geol. Survey Bull. 223, pp. 36-37, 1904.

Stone, W. H., Gypsum plant in southwestern Virginia: Manufacturers Rec., pp. 51-52, Aug. 20, 1908.

Struenson, J. J., Notes on the geological structure of Tazewell, Russell, Wise, Smyth, and Washington counties of Virginia : Am. Philos. Soc. Proc., vol. 22, pp. 114-161, 1885.

Stose, G. W., Geology of the salt and gypsum deposits of southwestern Virginia : U. S. Geol. Survey Bull. 530, pp. 232-255, 1913.

\section{WYOMING.}

Branson, E. B., Origin of Red Beds of western Wyoming: Geol. Soc. America Bull., vol. 26, pp. 217-230, 1915.

Darton, N. H., Preliminary description of the geology and water resources of the southern half of the. Black Hills and adjoining regions in Sonth Dikota and Wyoming: U. S. Geol. Survey Twenty-first Ann. Rept., pt. 4, pp. 516-518, 584-585, 1901.

U. S. Geol. Survey Geol. Atlas, Newcastle folio (No. 107), p. 9, 1904.

- Preliminary report on the geology and underground water resonrces of the central Great Plains : U. S. Geol. Survey Prof. Paper 32, pp. 392-394, 1905.

- and O'H $128)$, p. 8, 1905.

- Geology of the Owl Creek Mountains: 59th Cong., 1st sess., S. Doc. 219, p. 19, 1906.

Paleozoic and Mesozoic of central Wyoming: Geol. Soc. America Bull., rol. 19 , pp. $403-470,1908$.

- and Siebenthal, C. E., Geology and mineral resources of the Laramie Basin, Wyo.: U. S. Geol. Survey Bull. 364, 1909.

Fisher, C. A., Mineral resources of the Big Horn Basin: U. S. Geol. Survey Bull. 285, p. 313, 1905.

- Geology and water resources of the Big Horn Basin, Wyo.: U. S. Geol. Survey Prof. Paper 53, p. 18, 1906.

JAmison, C. E., Geology and mineral resources of a portion of Fremont County, Wyo.: Wyoming Univ. Bull. 2, ser. B, p. 84, 1911.

KNight, W. C., Gypsum deposits in Wyoming: U. S. Geol. Survey Bull. 223, pp. 79-85, 1904.

Lupton, C. T., and Condrr, D. D., Gypsum in the southern part of the Big Horn Mountains, Wyo.: U. S. Geol. Survey Bull. 640, pp. 139-157, 1916.

Mouldy, R. B., and Slosson, E. E., The Laramie cement plaster: Wyoming Agr. Coll. Tenth Ann. Rept., 1900 .

Richardson, G. B., Upper Red Beds of the Black Hills: Jour. Geology, vol. 11, pp. 365-393, 1903.

Srebenthal, C. E., Gypsum deposits of the Laramie district, Wyo.: U. S. Geol. Survey Bull. 285, pp. 404-405, 1906.

Trumbule, L. W., Cement plaster industry in Wyoming: Min. World, vol. 26, p. $387,1907$. 


\section{INDEX.}

$\Delta$

Abbott \& Hickox, Page.

Absaroka Range, Wyo., deposit in-- 303

Acknowledgments for aid_...... 142, 297

Acme, Calif., deposits near.... 63

Acme, Okla., mill at_... 235

Acme, Tex., mills at_......... 250

Acme Cement Plaster Co., operations by _..._-

Age of deposits _..._. 26-27

Akron, N. Y., deposits at specimen from, plate showing-- 196

Alạbaster, Mich., alabaster at_... 124 deposit at, discovery of...... 129 quarrying at _..... 127

Alabaster, occurrence of _._._. 84 , $124,223,272-273,281$

properties of .......... 17

use of _...

Aladdin, Wyo., deposit near._... 298

Alamo Creek, Calif., deposits on:-- 84

Alamogordo, N. Mex., white sands near _............ 184-186

Alaska, bibliography of

deposit in ................ 47

mining in

Alcova, Wyo., deposits at and near_ 305 quarry at._._........... 297

Alpine Plaster Co., deposit worked by

Alteration, gypsum produced by $-22,25-26$

Altona, Okla., section near..... 227

Amboy, Calif., deposit in a lake bed at, plate showing _._- 77

deposits near -........ 81-82

American Cement Plaster Co., operations by _-- 211-213, 222, 233

quarry of, at Watonga, Okla., plate showing

American Gypsum Co., operations by

Analyses of gypsite $61,67,68,71,72,76,97$

Analyses of gypsum___ $27-29,74,82,99$, $182,186,214,248,277,278$ errors in _.......... 30-32

Ancho, N. Mex., deposits at_._._. 171

Anbydrite, alteration of, to gypsum $\quad 157$ occurrence of -._- 19-21, 93, 108-110, $150,152,154,156,167,224$ properties of

Antelope Valley, Calif., deposits in

Arden, Nev., deposit near._._. 155-158 geologic section at

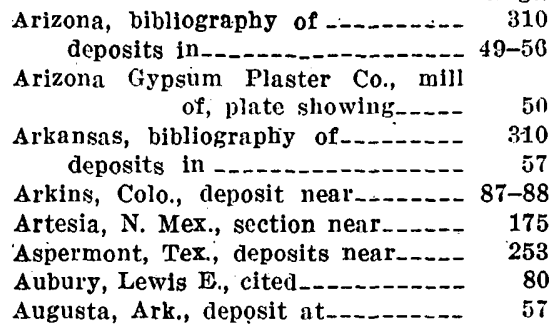

Arizona, bibliography of _... 310
deposits in

Arizona Gypsum Plaster Co., mill of, plate showing _... 50

Arkansas, bibliography of._._-_.-- 310

deposits in ....... 57

Arkins, Colo,, deposit near-_._-_ 87-88

Artesia, N. Mex., section near..... 175

Aspermont, Tex., deposits near._._ 253

Aubury, Lewis E., cited_._._._. 80

Augusta, Ark., deposit at_..... 57

Page.

Avawatz Mountains, Calif., deposits

in

B.

Bailey, E. H. S., Grimsley, G. P., and, cited_._._._. 111-120

Baker, C. L., on deposits in Brooks County, Tex _._._. 259-260

Bakersfleld, Calif., deposits near.-- 70-73 Banding in rock gypsum, plate showing

Bar hypothesis, Branson's, outline of

Barnum, Wyo., deposits near... 300

Basin, Wyo., milling at._._._._- 296

Bear Creek, Kans., natural bridge on

Bear Island, Fla., deposit on__._- 95-98 Eeaver Creek, Wyo., deposits on _ 299, 300 Beckham County, Okla., deposits in _..._. 229, 230

Belcoda, N. Y., deposits near.... 207

Belle Fourche River, Wyo., deposits on 298

Belle Isle, La., deposits at_........ 121

Bellevue, Mich., deposit at _._._.- 124

Belva, Okla., quarry at__._._._... 234

Benson, Ariz., deposits near._..- 50

Hertie limestone member of the Salina formation, nature and distribution of, in New York__._. 192 Best Bros, quarry, Kling, Kans_-_ 118, 120 gypsum bed in, plate showing-- 120 Beulah, N. Y., deposits at_..- 207 Beulah, Wyo., deposit near._..... 298 Beyer, S. W., analyses by Bibliography_._. 309-316 Bickford, Okla., quarry and mill at_ 234 section near.......................

Big Gypsum Valley, Colo., deposits in 94

Big Horn Basin, Wyo., deposits in_ $302-303$ 
Page.

Rig Horn Mountains, Wyo., deposits encircling _- $299-302$

Big Snowy Mountains, Mont., deposits encircling_____ $\quad 134$

Bigtrails, Wyo., deposit near._-_-

Ritterwater Valley, Calif., deposits in _......... 80

Black Hills, S. Dak., deposits in $-239-242$ sections in

I:lackhawk, S. Dak.; deposits near_- 245 mill at____ 249

Blake, Wr. P., cited________ 53, 54-55

Block, polished, of granular gypsum, from North Holston, Va., plate showing--polished, of mottled gypsum, from Nephi, Utah, plate showingshow Tex. sandstone

Blowout Mountain, Tex., sandstone of _-_--_--__- $253,255-256$

Blue Rapids, Kans., deposits near_ 112-113

Boards, gypsum plaster._._._... 43-44

Bowen, C. T., cited_______ 133, 136 section by 306

Powler, Mont, deposit near._._. 137

Bownockel, J. A., on deposits in

Ohio_._- 218-223

Branson, E. B., cited

Brawley, Calif., deposit west of _-_- 63

Brazos County, Tex., deposits in_-- 260

Brazos River, Double Mountain Fork of, deposits on _-_ 253-255

Salt Fork of, deposits on ____ 253

Brewster County, Tex., deposits in 260

Bridger, Mont., deposit near-_--_ 137

Brinkman, H. F., cited_____- 69-70

Buckskin, Nev., deposit near-_-_-- 154

Buena Vista Lake, Calif., deposit near----

Buffalo, N. $Y_{\text {, }}$ record of well at -210

Buffalo, Wyo., deposits near-_-- 299-300

Buffalo Cement Co., operations of $209-210$

Buffalo Creek, Wyo., deposits on_ 300, 301

Bull Pen Creek, S. Dak., section on _ 243

Burchard, E. F., on deposits in Alaska_

$47-48$

Furnt Island, Fla., deposit on _-_- 96-98

Butte capped with a bed of gypsum, near Cambria, Wyo., plate showing --_---

C.

Caballos Mountains, N. Mex., deposits in 172

Calneville, Utah, deposit near-_- 280-281

Calcasieu Parish, La., deposit in._- 121

Calcined gypsum, production of $-34,35-37$

Calcining, methods of _._-__-_ 39-40

Caledonia, N. Y., deposits at_-_- 207

Calhoun, F. H. H., cited__. 96,98

California, bibllography of _._. 310

deposits in__._. 19,58-86

southern, climate of $\ldots \ldots \ldots-\ldots 9-59$

map of, showing distribu-

tion of gypsum deposits
California Gypsum \& Mincral Co.,

Page. deposit worked by_-- 67-68

Cambria, Wyo., butte capped with gypsum near, plate showing

section at

Camillus, N. Y., quarry near__-_- 199

Camillus shale member of the Salina formation, nature and distribution of, in New York_-__-_-_-_- 192-193

Canada, bibliography on___._. 309

Cane Springs, Calif., deposits neal 73

Cantua Creek, Calif., deposits on_- 61

Cardiff giant, origin of

Carrizo Plain, Calif., deposits in_- 83 gypsite quarry on, plate showing $\quad 76$

Carter, Okla., section near__.... 230

Casper Mountain, Wyo., deposits near _-

Castaic, Calif, deposit near____- 75, 77

Castalla, Ohio, mine and mill near_- 222, 223

Castile gypsum, occurrence of, in Texas _._. 257-258

Cave Creek, Kans., deposit on_._._. 118

Cavern, Mont., deposit at_____ 136

Caverns, occurrence of, in Texas - 259-260

Cayuga Junction, N. Y., quarry and mill at_._._._._. 200-201

Cedar City, Utah, deposits near-_- 270

Cedar Mountain, Dtah, prospect south of

Cement, okla., deposit at -- 228-229, 235

Centennial Prairie, S. Dak., deposits in

Centerville, Iowa, deposit at____ 107-110 well at, record of._. 107

Cerro Blanco, N. Mex., gypsum capping, plate showing-- 179

Charley Canyon, Calif., deposit in $--\quad 75$

Chemistry of gypsum, bibliography of

Cherry Creek, Wyo., deposits on _._. 301

Chichagof Island, Alaska, deposit on_-n- 47

mining on $47-48$

Chugwater formation, Wyo., section of

Chupadera Mesa, N. Mex., deposits in

Cibola Pyramid, N. Mex., deposits in 107

Clifford Miller quarry, near Fayetteville, N. Y., bed in _ 196-197

Clockville, N. Y., deposit at

Cloudcroft, N. Mex., deposits near-169-170

Cloverly, Wyo., deposit near___._- 301

Clyde, N. Y., deposits at_._. 201

Coaldale, Colo., deposit worked at_- 91

Coalinga, Calif., deposit near, plate showing

deposits near

Cody, Wyo., deposits near-_._- 302-303

Cold Brook, s. Dak., section on---- 244

Cold Wash, Utah, deposit on ___- 278-279

section on 278 
Page. Deposits, localities of, in California, Page.

Colorado, bibliography of 310-311

deposits in, localities of - 19-20, 87-94 nature of _._._. 87

Colorado City, Colo., deposits worked near

Colorado Desert, Callf., deposits in

Colorado Springs, Colo., thick bed of gypsum at, plate showing -

Colt Gulch, Utah, section in

Composition of gypsum _..._._. 16, 27-29

Conant Creek, Wyo., deposits on-- 304-305

Consolidated Pacific Cement Plaster Co., deposit worked by

Consolidated Wheatland Plaster Co. mine and mill of, near Mumford, $\dot{N}$. Y $Y_{---}$206-207

Consumers Gypsum Co., operations by

Corona, Calif, deposits near

Cost of gypsum plaster._._._._._. 41-42

of plaster mills_._._._._._. 40-41

Cottonwood Creek, Callf., deposits on

Coyote Buttes, N. Mex;, deposits in_ 167 Cramer, Colo., deposit near._._. 90

Crazy Woman Creek, Middle and South forks of, Wyo., deposits on

Crystallization of gypsum_-_-_.-. 16,17

Crystals, impure, plate showing---- 18 occurrence and origin of, in Kansas _. _._. 118-119

Culberson County, Tex., deposit in

Culin, Frauk L., fr., cited___-_.-- 55 Cunmins, A. F., cited Custer, s. Dak., gypsum beds southwest of, plate showing-

\section{D.}

Darrow, Okla., quarry and mill near_ 234 Darton, N. H., cited......-_ 239, 246-247 on deposits in New Mexico.-- 161-186 Day, D. T., cited_._. 95 Dayton, Wyo., quarry at_..._._. 297, 299 Death Valley, Calif., deposits in _..- 82-83 Dehydration by grinding by intruded rock, results of -- 145-146 Deposition of gypsum, methods of -.- 21-26 Deposits, age of:_............. 26-27 efforescent, nature and distribution of, in California $-85-86$

formation of, by alteration_- $22,25-26$

by disintegration and mechanical reaccumulation _........... 22,26

by ground water... 21, 22, 23-25

by sea or lake water- 21-22, 22-23 interbedded, nature and distribution of, in California.

map showing - - 58

in Kansas, map showing-- $\mathbf{1 1 2}$

in New Mexico, map showing

in Ohio, map showing_-_-- 218

in Oklahoma, map showing - - -

in the United States, map showing -...-..-.--

In Wyoming, map showingon San Rafael Swell, Utah, map showing distribution of _.............-

perlodic-lake, nature and distribution of, in California..............

Sce also under Map and names of States.

De Queen, Ark., deposit at _...... $\quad 57$

Des Moines River, Iowa, deposit on_ 101$103,104-100$

Dickinson, W. O., analysis by _._. 28

Dimmit Lake, N. Mex., section at. 174-175

Domes, deposition of gypsum in _._ 2!-25

Double Mountain formation, Tex., deposits in

Douglas, Ariz., digging and calcining of gypsite at_._._.- 49-50

gypsite deposit at, plate showing -..... 50

manufacture of products at.-- 50

Douglas, Wyo., deposits near._.... 30.

Dudley, Calif., deposits near-_.__- 64-65

Duke, Okla., deposit near._..._._ 232

Dunes, formation of ....._._. 22, 26

Duran, N. Mex., deposit at______ 171

Duval County, Tex., deposits in_._. 259

E.

Eagle River, Colo., deposits on_--_ 92-93

East Paradox Valley, Colo., deposits in

Eaton Rapids, Mich., deposit at_--- 124

Fl Rito, N. Mex., thick bed of gypsum opposite, plate showing -

Eldorado, Okla., deposit near.--_- 232 mill at

Elm Fork, Okla., sections on._-_-_- 231 Elk Mountains, Wyo., deposits in _- 307 Emery, Utah, deposits near._._- 279, 281 Empire Gypsum Co., mining and milling by, at Garbutt N. $Y_{-}$

Fmpire Mountains, Ariz., deposit in - 52-53 Erosion of gypsum by rain, plate showing -..--..--.

F.

Fairchild, J. G., analyses by -- 29, 277, 278 Fairplay, Colo., deposits near._.. 92 Falfurrias, Tex., deposits near._-_ 259 Fayetteville, N. Y., quarries and mills near- 
Page.

Feldman, Ariz., deposits near.___- 55-56

Ferguson, Okla., mill at________- 235

F'erris Mountains, Wyo., deposits in 305

Ferron, Utah, gypsum bed in Horn Silver Gulch near, plate showing

265

Fillmore, Calif., deposit near...- 85

Fillmore, Utah, deposits neär_-_ 268-269

Finlay, Tex., quarry near._..... 258.

Fire Pulp Plaster Co., deposit worked by

Fishack Gypsum Co., operations by -- 222

Fisher, C. A., cited____._. 174-175

Florida, bibliography of _._._._. 311 deposits in

Forest Grove, Mont., deposit at_-_-- 134

Fort Apache Reservation, Ariz., deposit in

Fort Dodge, Iowa, deposit at 104-106 mining at _._. plate showing.-...-- 104 outcrop near, plate showing-_- 80

Fort Hill, N. Y., quarries near_-_- 207

Fort Washakie, Wyo., deposits near_ 304

Fcuntain Creek, Colo., deposits on - 89

Freeman, O. W., cited._._. 134

Freezeout Hills, Wyo., deposits in_-_- 306

French Point, Calif., alabaster on_-- $\quad 85$

Froeling, Henry, analysis by_._... 29

Fryingpan Creek, Colo., deposits on_ 92

Fuel, expense for, in Oklahoma_-_ 232-233

Fullers Bottom, Utah, section in

Future of production in New York_- 215

\section{G.}

Gallina, N. Mex., deposits néar__-_ 179-181 deposits near, plates showing

Galt, Nev., deposit near _... 158-159

Garbutt, N. Y., quarries and mills near_..........-._. 204-207

Garbutt Gypsum Co., mine and mill of, at Garbutt, N. Y - 205-206 $^{-}$

Garden of the Gods, Colo., deposits in

George, R. D., on deposits in Colorado__._._._._._._- 87-94

Gerlach, Nev., deposits near.... 150

Gies, W. J., analyses by _...... 28, 186

Gilbert, G. K., cited _._._. 89-90, 269

Glass Mountain, Okla., cap of massive gypsum on, plate showing

Glen Eyrie, Colo., deposit near.... 89

Glendale, Utah, deposits near.-.-_ 271

Goodman, Mont., thin deposit at. 132-133

Gould, C. N., cited_._._._. 224-225

Government Valley, Wyo., deposit in $\quad 298$

Grand . Rapids, Mich., mining and milling at_...-. 124-126

Grand River, Colo., deposits on _-__- 92, 93

Grandville, Mich., discovery at_... 129

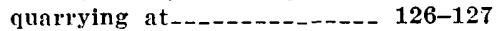

Granite Hill Plaster Co., operations of -
Granules in polished block of gypsum, plate showing---

Grapevine Canyon, N. Mex., deposits in

Greer County, Okla., deposits in _- 229-232 Green Mountain, Wyo., deposits encircling - 298

Green Mountains, Wyo., deposits in- 305

Greenacre ranch, Colo., deposits near 88

Greenhorn; Colo., deposit near.--- 90

Greybull, Wyo., deposits near_..._- 302

quarrying and milling at----- 297

Grimsley, G. P., and Bailey, E. H. S., cited......... 111-120

Grinding of gypsum, loss of water from-_. $30-32$

processes of -

Gros Ventre Range, Wyo., deposits not found in

Gross, Arthur, analysis by

Gunnison River, Colo., deposits on_- 93-94 Gyp Hills, Tex., gypsite in Gypsite, analyses of $61,63,67,68,71,72,76,97$ deposition of -.......- 21, 23-24 deposits of, in California_...-- 58-86 digging and calcining of -.---- 38-40 mining of, at Laramie, Wyo., plate showing -...-- 298

properties and occurrence of _-_ $\quad 17$ Gypsum, Colo., deposit near._._._ 93 Gypsum; Kans., deposit near__-_- 115-116 Gypsum, N. Y., quarries near_..._ 202 Gypsum, Ohio, mine at, plate show$\begin{array}{rr}\text { ing } & 222 \\ \text { sections near. } & \end{array}$

Gypsum, Oreg., deposit at_..._- 236 quarrying and milling at_..- 237-238 quarry and loading platform at, plate showing - 236

Gypsum, fibrous. See Satin spar.

Gypsum Buttes, Wyo., deposits encircling -._. 298

Gypsum Caryon, Calif., deposits in $\quad 77$ Gypsum Hills, Kans., deposits in - 117-118

H.

Hackberry Creek, Okla., section at mouth of -._._. 231

Fackberry Island, La., deposit on 121 Hailey, Wyo., deposits near____- 304 Hanover, Mont., deposit at._._- 135-136 Harmon County, Okla., deposits in_ 229-232 Hatcher, Carpenter \& Andrus, analysis by

Haworth, Erasmus, on deposits in Kansas _._._._._. 111-120

Hawthorne, Nev., deposit near._. 155 Heath, Mont., deposit at______ 134-135 Hell Canyon, S. Dak., three gypsum beds in, plate showing.

Henquenet cave, Kans., deposit exposed in

221 Hermosa, S. Dak., deposit near.-- 245 
Page.

Hermosa Creek, Colo., deposits on_Hess, F. L., on a deposit at Moab,

$$
\text { Utah }
$$

on deposits in California

High Island, Tex., deposits at Hilgard, E. W., cited

Hill, B. F., on deposits in Texas -

Holston River, North Fork of, Va. deposits on _._._._- 283-294

North Fork of, Va., structure of rocks on_._-_-_ 286-289

Hope, Kans., deposit at_._.... 115

Horn Silver Gulch, Utah, deposit

in _... 277-278

deposit in, plate showing _._._ 265

section in . 278

Hot Springs, S. Dak., deposits near._._. 244-245

gypsum bed in bluff near, plate showing -..--..--

Howard, Colo., deposits near._.- 91

Hudspeth County, Tex., deposit in - 257-258

Humboldt Range, Nev., deposits in - 146-149 geologic section in _._.

Hunters Hot Springs, Mont., deposit forming at _...... 138

Hutton, J. G., on deposits in South Dakota_._.

Hyattville, Wyo., deposits near._._ 301

\section{I.}

Idaho, bibliography of 311 deposits in 99-100

Imports, quantity and value of _.-_ $\quad 38$

Indian Falls, N..Y., deposit near

Indianapolis, Okla., deposit at _. 228-229

Information, sources of -

Inyankara Mountain, Wyo., deposits adjoining_-_-_-_-_- 298

Iowa, bibliography of _._._. 311 deposits in

\section{J.}

Jackson County, Okla., deposits in_ 229-232 Jamesville, N. Y., quarries and mills near._._._- 197-199

Jones, E. D., deposit worked by Jones, J. C., on deposits in Nevada_... $139-160$

K.

Kanarraville, Utah, sections near-- 270 Kansas, bibliography of_-_._._- 311-312 crystalline gypsum in, occurrence of -_. deposits in, geography of geology of - 112 localitles of _._. origin of 120

map of, showing localities of gypsum deposits and limits of the Permian series

quarrying and milling in 119-120
Kay, G. F., on deposits at Center-

ville, Iowa _...-..- 107-110

Keenes cement, production of Kelley Plaster Co,, operations by - 222, 223 Kern Lake, Calif., deposit near.-..- 71-73 Kettleman Plains, Calif., deposit in_ 73-75 Kibbey, Mont., deposits near._-_- 133 Klowa Peak, Tex., section at__._- 252

King City, Calif., bed of gypsum on mesa north of, plate showing -..-_.-_- 80

deposits near ...... 80

Kling, Kans., deposit at_._._. 118 bed in quarry at, plate showing- $\quad 120$

\section{L.}

L A K ranch, Wyo., deposit near_-_ 297

La Verkin, Utah, deposits near._._- 271

Labonte Creek, Wyo., deposits on _-. 305

Lamy, N. Mex., deposits near _._- 163, 173

Land, Ariz., deposit near..._._. 50-51

Land plaster, use of _._._._. 33,42

Lander, Wyo., deposits near._._- 304

Laramie, Wyo., milling of gypsite mining of gypsite, at, plate showing.

296

Laramie Mountains, Wyo., deposits in

Las Vegas, Nev., deposits near_-_- 159-160

Last Chance Creek, Utah, indications on 280

Lee, W. T., cited 51

Leighton, Henry, D. H. Newland and, on deposits in

New York__._._-_ 187-217

Levan, Utah, deposit at_..._._. 265-266 quarry near, plate showing--.- 265

Lime, Oreg., mill at._. 237

Little Fountain Creek, deposits on_ 89,91

Little Goose Creek, Wyo., deposit on_ . 299

Little Gypsum Valley, Colo., deposits in $\quad 94$

Little Medicine Bow River, Wyo., deposits on

Little Wind River, Wyo., deposit on

Localitles of gypsum deposits. See names of States.

Lockwood \& Smith, operations by ---

Lodge Grass Creek, Mont., deposit

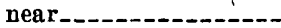

Lodge Grass Creek, Wyo., deposits near._._- 299

Loma Blanca, Tex., deposit in.-- 259-260

Lomo de las Cañas, N. Mex., deposits in_-_ 167

Lone Tree Creek, Wyo., deposit on_- 307

Lookout Peak, S. Dak., section on - 247

Los Cerillos, N. Mex., deposit near-- 177 outcrop near, plate showing -- 178

Lost Hills, Calif., deposits in._._. 65-67 mound of gypsum in, plate show-

ing 66

Louderback, G. D., cited__._- 147-148, 151 
Page.

312 deposits in

Loveland, Colo., gypsum quarry at, plate showing

Lovelock, Nev., deposits near._.- 146-149

Ludwig, Nev., deposit at___-_-_ 153-155 geologic section at.

153

Lupton, C. T., on deposits on the San Rafael Swell, Utah_ 273-282

Luxor Peak, Nev., deposits at the base of

Lycoming Calcining Co., mining and milling by, at Garbutt, N. $\mathbf{Y}$

Lyndon, N. Y., quarry near, plate showing

Lyon, Mont., deposit near

Lyons, N. Y., deposits at

150

206

196

138

201

M.

Maccrady, Va., section of the Màccrady formation near -

McKittrick, Calif., deposits near-.-McLure Valley, Calif., deposits in.- 64-65 McMillan, N. Mex., deposits at_-_- 176 Malone Mountains, Tex., deposits in_ Manlius, N. Y., quarries in

Mansfield, G. R., acknowledgment to-

Manti, Utah, deposit at

Map of area in Ohio, showing location of deposits.

Kansas, showing localities of deposits

New Mexico, showing localities of deposits

Oklahoma, showing localities of deposits

San Rafael Swell region, Utah, showing distribution of deposits in

southern California, showing dis tribution of deposits

the United States, showing localities which produce gypsum

Wyoming, showing areas known to contain gypsum

Maria Mountains, Calif., deposits in Maricopa, Calif., deposits near...--

Marsh \& Co., operations by

Martisco, N. Y., deposits near._-_.-

Massive gypsum. See Rock gypsum.

Maxwell, N. Y., deposit near._-__- 207

Mayfield, Utah, deposits near----- 266-267

Mayoworth, Wyo., deposits near.-. $\quad 300$

Mecca, Calif., deposits near._-_-_ 79

Medicine Bow, Wyo., deposits near.-

Medicine Bow Range, Wyo., deposits in

Medicine Lodge, Kans,, deposits near.

Meinzer, O. E., cited._-_._-_-

Mendota, Calif., deposits near._.-.-

Mesa del Yeso, N. Mex., deposits in and near
291

-70

176
258

199

99

266

218

112

162

224

276

58

34

296

8-79

70

221

199

306

307

117

186 59-61

167
Page.

Mesa Jumanes, N. Mex., deposits in $\quad 166$ Mesa Lucero, N. Mex., deposits in_-_ 164 section of

Messers Creek, Ark., deposit near.-- $\quad \mathbf{5 7}$

Metz, Calif., deposits near._._- 80

Michigan, bibliography of - 312 deposits in, development of -- 124-129 geology of - 122 nature and extent of - 20, 122-124

Midway, Calif., deposits near.... 70

Millegan, Mont., deposits near._-_- 131

Mill, gypsum, first built in the United States....... 101

Mills, plaster, arrangement and cost of --

Mining, methods of 38 methods of, plates showing-- 104, 298

Minnekahta, S. Dak., deposits west of _- 242-243

outcrop near, plate showing -.._ 236

Miser, H. D., on deposits in Arkansas _- 57

Mississippi, occurrence in

Mississippian rocks, deposits in

Moab, Utah, deposit at_____._. 273

Moapa, Nev., deposit near..._._. 159

Monarch Plaster Co., mine and mill of, at Garbutt, N. Y_- 206

Montana, bibliography of _....... 312 deposits in, age and distribution of - 131

localities of

Montezuma, N. Y., deposits near-_._ 200

Montpelier, Idaho, deposit near..._. 99

Morrison, Colo., deposits near._._. 88

Mottling in polished block of gypsum, plate showing _- 264

Mound House, Nev., deposits near - 150-153 Mount Carmel, Utah, deposits at_-- 271

Mount Pisgah, Wyo., deposits near_- 298

Muddy Creek, Utah, deposit near- 279-280

Mumford, N. Y., quarries and mills near -

Muttleberry Canyon, Nev., deposits near -

N.

Nacimiento uplift, N. Mex., deposit in _... 181-182

National Wall Plaster Co., quarry of, near Fayetteville, N. $\mathrm{Y}$ -

Nephi, Utah, deposit at, development of -

deposit at, geology of _..._-_ 263-265 quality of

polished block of gypsum from, plate showing quariy near, plate showing---- 246

Nevada, bibliography of 313 deposits in, development of_- 141-142 geology of localities of _._._..._- 20, 146-160 nature and distribution of:--_origin of 
Page.

New Mexico, bibliography of deposits in, distribution of, map showing - -

162 geology of localities of _..._ $20,161,163-186$ relations of generalized columnar section, showing _. 162

New York, bibliography of deposits in, geology of _-- 189-194, 196 localities of _._._____ 194-217 origin of _._. physical and chemical nature of _...... 213-214 gypsum resources in mining in, history of _._._._. 187-188 method of _.

Newark, N. Y., quarries near_-_-- 201-202 Newcastle, Wyo., deposits near._- 297-298

Newland, D. H., cited.

Newland, D. H., and Leighton, Henry, on deposits in New York 187-217

Niagara Gypsum Co., manufacturing by _... 208-209

No Wood Creek, Wyo., deposits on_ 301, 302 North Holston, Va., mining and milling at_................

polished block of gypsum from, plate showing -...-..-

North Rush, N. Y., deposit at

Notom, Utah, deposit near

\section{0.}

Oakfield, N. Y., operations in_-_- 207-209

O'Brine, D. B., analysis by

Ohio, bibllography of

deposits in, development of distribution of _..... 20, 218-220 localities of, map showing 218

oil Bubble mound, Calif., deposit in -

Oil Creek valley, Wyo., deposit in-

Oil lands, holding of, as gypsum claims -...-....

Ojal Valley, Calif., deposits in

Okarche, Okla., mill at._._.....-

Okeene, Okla, quarry near.....-

Oklahoma, bibliography of deposits in, development of _- 232-235 distribution and nature of _- 20 , 224, 225-232 geology of localities of, map showing _- 224

Olustee, Okla., section near _._.__ 231 Oregon, bibliography of

deposits in, development of _- 237-238 geology of _._. nature and occurrence of_ 236

Origin of the deposits. See under names of States.

Oro Grande, N. Mex., deposits near Oro Junta, Colo., deposit near...Orton, Edward, cited.

Oscuro, N, Mex., deposits near
Owl Canyon, Colo., deposit in Owl Creek Mountains, Wyo., deposits in. $P$.

Page. 88 303

Paintrock Creek, Wyo,, deposits on 301 Palen Mountains, Calif., deposits in 19,78 Palmdale, Callf., deposits near-_._- 75-77 deposits near, plates showing _- 76,77

Palmer, Chase, analyses by _.___ 28, 97

Palmyra, N. Y., deposits at..... 201

Panasoffkee, Fla., deposits near._.- 95-98

Paoli mine, location of .......... 59-61

Farsons, Arthur L., cited._._._._. 214

Pass Creek, Wyo., deposit on .... 299

Pease River, Tex., section on ...- 252

Pecos Valley, N. Mex., deposits in_ 173-176

Pedernal Peak, N. Mex., deposits near

Perry Park, Colo., deposits in_._._. 88-89 thick bed of gypsum in, plate showing

Phelps, N. Y., quarries near._..._. 202

Phillips Hills, N. Mex., deposits in.- 168

Piedmont, S. Dak., quarrying and milling at _._.

Pinos Wells, N. Mex., white sand near

Pittsford shale member of the Salina formation, nature and position of, in New York

Plaster, gypsum, preparation and cost of _gypsum, uses of

Plaster Bluff, Ark., deposit at__...- 57 gypsum bed at, plate slowing - $\quad 51$

Plaster boards, types and uses of _._ 43-44 Plaster Creek, Mich., discovery and development on -.. 128-129

Plaster of Paris, setting of - 40 Plasterco, Va., deposits near-_.._ 283-294

Plasterco, Tex., mill at______ 250

Point Aux Chenes, Mich., quarry at_ 129

Point Sal, Calif., deposits on _._- 84

Port Gibson, N. Y., deposits near- 202-203

Powder River, North Fork of, Wyo., deposits on 300

Prairie spring, N. Mex., deposits near. 168

Primm, Okla., mill at_... 235

Production of gypsum _..._... 33-37

Properties of gypsum

Pueblo, Colo., deposits near._..... 89-90

\section{Q.}

Quall Canyon, Ariz., deposit in ...- 51 Quanah, Tex., deposit near______ 251-253 Quarrying, methods of 38

R.
Rapid City, S. Dak, deposits near_ 245-246 Rattlesnake Range, Wyo., deposits 
Page.

Rawlins, Wyo., ‘deposits near____ .306

Red Butte, W Wo., 'deposit on

Red Buttes, W.yo., quarry and mill at quarrying at 307,308

Red Creek, W.yo., deposits on ___ 300

.Red Mountain, Wyo., deposits on _ 307-308 section on_____ 307

Red Plateau, Utah, prospect south of - 276

Red River, Okla., escarpment capped with gypsum ledges ion, plate showing

226

North Fork of, section on

Red Valley, S. Dak., deposits in _ $\mathbf{2 4 0 - 2 4 2}$

Redbank, Wyo., deposits near._._- 301

Redington, Ariz., deposit reported near.

Redwater Valley, S. Dak.-Wyo., deposit in

section in

298

246

Rehydration of ground gypsum

Rhodes farm, Kans., deposit at_-_- 116

Riceville, Mont, deposit at_____ 131-132

Richardson, G. B., cited_-_-_-_- 247, 248

Rico quadrangle, Colo., deposits in

Rincon Colorado, N. Mex., gypsum in north wall of, plate showing - -

Rio Chama, N. Mex., deposit on -- 179-181

Rio Gallina, N. Mex., deposits on-179-181

Rio Salado, N. Mex., deposits on -- 182-184

Roads, surfacing of, with gypsum_-- 2.73

Roaring Fork, Colo,, deposits on___ '92, 93

Rock Creek, South Fork of, Wyo,, deposit on

299

Rock gypsum, comparison of, with anhydrite _._._-_.-18

properties and occurrence of 17,19

Rockville, Utah, deposit near__-_ 271

Rogers, A. F., cited.

Rogers, G. S., cited___ 24-25

Rogers, W. B., cited... 292

Roman Nose Gypsum Co., quarrying and milling by

Roofing, tile and monolithic

Rosario siding, N. Mex., outcrop of gypsum near, plate showing ............

Roswell, N. Mex., section near Ruedi, Colo., deposit worked at

Rush Springs, Okla., deposit at_-.228-229 mill at 229,235

S.

Sacramento Mountains, N. Mex., deposits in

St. George, Utah, deposits near.- 271-272 making and use of plaster at_-- $\quad 272$

St. Ignace, Mich., quarry at

St. Ignace Peninsula, Mich., deposit on

St. Martin Islands, Mich., deposits on

St. Thomas, Nev, deposits near.-- 160
Salina, Utah, deposit at Page.

Salina formation, :geology of, in New York -..-- - 189,-194, 196

Salt Creek, Tex., section at_...___ 253

Salt River Range, Wyo., deposits not found in

Salt Wash, Utah, section on

Saltville, Va., deposits near._._- 283-294 generalized section of a well at_. 291

generalized section of Carboniferous rocks near_-- 285-286

San Andres Mountains, N. Mex., deposits in

San Jose.River, N. Mex., deposit on - 184 outcrop on, plate showing -_--- 184

San Miguel copper mine, N. Mex., section west of

San Pedro River, Ariz., deposits on. 54-56

San Rafael River, Utah, deposits on - $276-277$

San Rafael Swell, Utah, deposits on, access to

deposits on, development of

- general features of

geology :of _-__-______ 275

localities of....... $276-281$ map showing _._._- 276 quality of -

location of .........

topography of _..._._._._. 274-275

San Ysidro, N. Mex., cliffs of gypsum s o u t h w e st of, plate showing

Sand Creek, Wyo., deposit on__._- 299

Sands, white, analyses of --_-_-- 186 white, formation of occurence of -_-_-_-_- 81, 184-186 west of Tularosa, N. Mex., plate showing

Sandusky Bay, Ohio, deposits near- 218-220

Santa.Barbara Creek, Calif., deposits of alabaster on

Santa Catalina Range, Ariz., deposit in _-_._- 53-54

Santa Rita Mountains, Ariz., gypsum not known in

Satin spar, formation of

from a fissure in clay, plate showing - 17

occurrence of - 18 , $83,115,224,260,272-273$

properties of

Scandinavian Coal Co.'s hole, correlation of 108

Schaller, W. T., analyses by _._-_- 28, 182 Secondary deposit of spongy gypsum, plate showing.-

:Seepage of water, mound of gypsum deposited by, plate showing

Selenite, crystals of, plate showing- 16, 196 formation of phenocrysts of, plate showing_ 264 properties of 
Page.

Selenite, occurrence of $109,114,118-119,130,138,141$, $151,156,159-160,167,195,202$, $224,225,257,259,260,272-273$ split and bent, plate showing--transparency and inclpient cleavage of, plate showing

Seminoe Mountalns, Wyo., deposits in

Seneca River, N. Y., deposits on ---Senorito, N. Mex., deposit at_-_...-Serritas Mountains, Ariz., deposit reported in

Seven Rivers, N. Mex., section near Shale, deposition of, upon gypsum --

Shaler, M. K., cited__-_ 181-182

Shead, A. C., analyses by

Sheep Mountains, Wyo., deposits encircling

Shell, Wyo., deposit near._._._-_ 301

Shirley Mountains, Wyo., deposits in

Shoemaker, W. V.; cited_._._._._-

Siebenthal, C. E., cited

135

Sierra Fra Cristobal, N. Mex., deposits in

Sigurd, Utah, deposits near quarrying and milling at_--- 267, 268

Sinbad Valley, Colo., deposits in_._- 94

Smith, J. P., cited_____-_-_ 142-143

Smith, R. A., on deposits in Michigan_-

Smoky Hill River, Kans., gypsum crystals on ......-.

Snake River, Colo., occurrences on

Snake River, Idaho, deposit on_-_- 99-100

Snake River, Oreg., quarries and mills on -

Snider, L. C., on deposits in Oklahoma --_-_- 224-235

Soapstone Island, Fla., deposit on

Socorro, N. Mex., deposits east of _ 166-168

Soldier Creek, Wyo., deposits on_-_ 307

Solomon, Kans., deposits near._-_ 114-115

Solution, effects of, on rock gypsum, plate showing -..--..

South Dakota, bibllography of deposits in, development of _-- 248-249 geology of localities of

South Mountains, Ariz., deposit in-South Mountains, Calif., deposit in South Park, Colo,, deposits near.---

South Wash., Utah, crystalline deposit at _-_-

Southard; Okla., quarries and mill at --- 234

Spearfish, S. Dak., deposits near deposits near, plates showing - 243, 246 Spearfish formation, shale of, mineral composition of _-- 248

Spindletop, Tex., deposit at.--_-- 258-25y Sportsmans Lake, Wyo,, deposit near -..--.-.--
Spring Mountain Range, Nev., section of carboniferous bingta in

Springport, N. Y., deposits at_-_- 200 Spruce Creek, Colo., deposits on _-_ 93 Starke, N. Y., deposit in Steiger, George, analyses by

$68,76,82,248$

on Errors in the chemical analysis of gypsum____ 30-32

Stevenson, J. J., cited______._ 90, 292

Stockade Beaver Creek, Wyo., deposits on _. 297

Stone, R. W., Analyses of gypsum_-- 27-29 Arizona _-_._- 49-56 Florida__._. Gypsum industry, The._._...- 33-46 Idaho Introduction_._-_. 15-16

Irouisiana.

Mineralogy and geology of gypsum … 16-26

Mississippi _._. 130

Montana ........ 131-138

Ohio: Development in 1918_- 222-223

Oregon_-_-_.--_-_-_-_-_-- 236-238

Texas_-_._-

Wyoming-_-_-_-_-_-_ 295-308

Jones, J. C., and, Deposits in

southern Nevada

and Kay, G. F, Iowa_..... 101-110

and Lupton, C. T., Utah___-- 261-282

Smith, R. A., and, Michigan: Ec on omic development______

Stone City, Colo,, deposits near_... 89, 91 Stose, G. W., on deposits in Virginia...._._. 283-294

Strawberry Mountain, Wyo., deposits adjoining

Structure, banded, in massive gypsum, plate showing .-298

mottled, in massive gypsum, plates showing _._. 16,264

Stucco, Wyo., deposits near__._-_ 302 mill at_._._. 297

Sturgis, S. Dak., deposits nearl_-_ 246 Sullivan, E. C., analyses by _...- 60, 63, $67,71,72,74$

Sulphur City, La., deposits at__-_.- 121 Sunflower Valley, Calif., deposits in Suwanee, N. Mex., deposit near--_-- 184 Sweetwater Creek, Tex., deposits on_ 253 Swissvale, Colo., deposits near.... 91 -Sjracuse salt member of the Salina formation, nature and distribution of, in New York

T.

Table Mountain, Colo., deposits near Table Mountain, Nev., deposit at_..- $\quad 150$ Taff, J. A., cited._. 258 Talmage, J. E., cited.- 272-273 Technology, bibliography of _._._. 309 
. . Page.

Tennesses, bibliography of

Te_klec: $\because$ yo., deposits near_-_-_- 301

Texas, bibliography of

deposits in, development of._- 250, 251 distribution of $250,251-255,257-260$

geology of

Thermopolis, Wyo., deposits near.--- 303

Throopsville, N. Y., deposits near--- 200

Tijeras Canyon, N. Mex., deposit in _- 179

Tile, building, manufacture of _... $\quad \mathbf{5 0}$

building, uses of -._-_-_-_._- 44-45

Tilford, S. Dak., deposits near_-- 245-246

Tomey Creek, Calif., deposits near _- 59-61

Tonawanda Creek, N. Y., deposits on_ 209

Tonque Creek, N. Mex., deposit on - 177, 179

Toquerville, Utah, deposit near.... 271

Trail Creek, Mont., deposit on_..-- 138

Tree Creek, Mont., deposit on_..--- 133

Trinidad, Colo., deposits near._._- $\quad 89$

Tony, N. Mex., deposits at___._ 171

Tucson, Ariz., depósit reported near $\quad 53$

Tularosa, N..Mex., deposits near_-_- 169

Tulárosa Desert, N. Mex., white sands

in

Turkey Creek, Colo., deposits near-- 90-91

Turner, Mich., deposit at____._-_ 127

\section{U.}

Union Springs, N. Y., quarries near_

United States, map of, showing 10calities which produce gypsum -..-...--

United States Gypsum Co., mine of, at Gypsum, Ohio, plate showing -..-_-_-_--

operations by, in California

at Oakfield, N. Y._._- 207-208

at Gypsum, Ohio.- 221, 222-223

in Oklahoma........- 234-235

in Virginia

quarry of, at Alabaster, Mich., plate showing ...... 120

Uses of gypsum_._-_-__-_ 33-34, 42-45

Utah, bibliography of _....... 315-316 deposits in..........-. 21, 261-282

V.

Varieties of gypsum_-_-_-_-_-_-_ 17-18

Varney, N. Mex., deposits at_-_-_. 171 Vaughn, N. Mex., deposits near -- 170-171 Victor, N. Y., quarries near_-_-_- 202-203 Vinton, La., deposit near._._._. 121 Virgin River, Utah-Ariz.-Nev., deposits on

North Fork of, section on
Page.

Virginia, bibliography of -- 316 deposits in, development of _- 292-294 geology of location of origin of _ topography of _._-_._-_-_ 283-285

W.

Wagon Hound Creek, Wyo., deposits on

Water, determination of, in gypsum -

Water Pocket Flexure, Utah, deposit on

Watonga, Okla., gypsum quarry at, plate showing

mills at

West Humboldt Range. See Humboldt Range.

Wells, R. C., analyses by

West Barney Creek, Okla., section on 226

West Paradox Valley, Colo., deposits on

Wheatland, N. Y., quarries and mills in

Wheeler, W. C., analyses by Whetstone Mountains, Ariz., deposit reported in

White Mountain, Utah, deposits at_ 268-269 White sands. See Sands, white.

Whitewood, S. Dak., deposits near-- 246 Willcomb, G. E., analyses by -- 29, 213-214 Willow, okla., deposit near._._- 232 Willow Creek, Wyo., deposit on _._-- 307 Wind, gypsum carried by, plate showing - 185

Wind River Range, Wyo., deposits in

Wingate sandstone, gypsum on, plate showing._._. 179

Winn Parish, La., deposit in

Winslow, Ariz., deposits near._-_. 51-52 quarry near, plate showing.-- 51

Wrather, W. E., on geology of the gypsum beds of northcentral Texas_._-_- 255-257

Wyoming, bibliography of _._._. 316 deposits in, development of -- 296-297 geology of -_map of, showing areas known to contain gypsum -..--- 296

$\mathbf{Y}$.

Yellowstone Creek, Okla., section on 226 Yerington, Nev., deposit near._._- 155 